\title{
JÓZEF MATUSZEWSKI
}

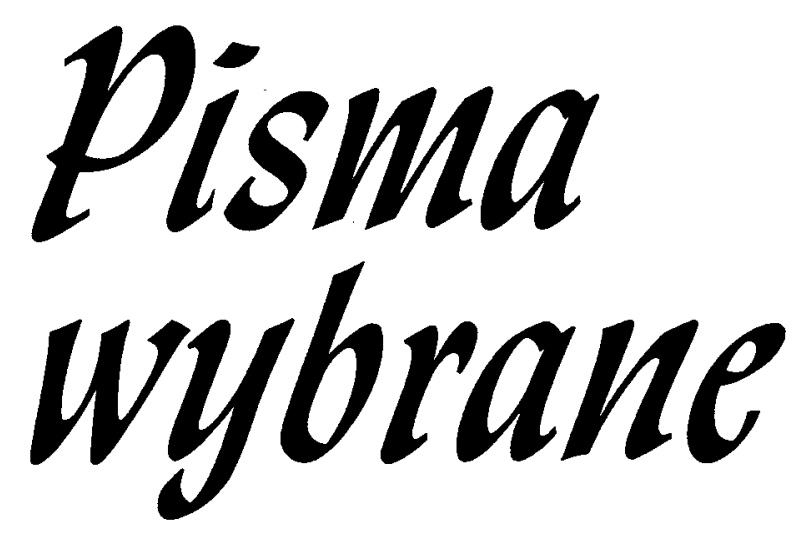

TOM II

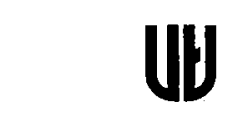

Wydawnictwo

Uniwersytetu Lódzkiego

Łódź 2000 
REDAKTOR WYDAWNICTWA UL

Hanna Wróblewska

REDAKTOR TECHNICZNY

Wieslawa Eubiech

KOREKTORZY

Anna Ciach, Aurelia Wendland

OKŁADKE PROJEKTOWAŁA

Barbara Grzejszczak

(C) Copyright by Józef Matuszewski, 2000

\footnotetext{
Wydawnictwo Uniwersytetu Lódzkiego 2000

Wydanie I. Nakład $100+40$ egz. Ark. wyd. 26,0

Ark. druk. 26,625. Papier kl. III, $80 \mathrm{~g}, 70 \times 100$

Zam. 16/3053/2000. Cena zł 50,-

Drukarnia Uniwersytetu Lódzkiego

90-236 Lódź, ul. Pomorska 143
}

ISBN $83-7171-331-2$ 


\section{Spis treści}

Problem konfiskaty dóbr szlacheckich $w$ dawnej Polsce ............. s

Iura Prutenorum . . . . . . . . . . . . . . . . . . . . . 11

Motywacja ignorancyjna $w$ dokumentach prawa niemieckiego . . . . . . . 25

Les manuscrits du coutumier pruthéne . . . . . . . . . . . . . 37

Czy handlowano chłopami w Rzeczypospolitej szlacheckiej? . . . . . . . . . . 43

Dyskusja nad Najstarszym Zwodem prawa polskiego . . . . . . . . . . . 47

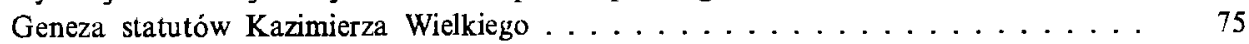

Liber baptistorum parafii Szubin $z$ lat $1736-1785 \ldots \ldots \ldots \ldots \ldots \ldots$. . . . . . . . 93

Rękojmia w rozumieniu Kodeksu Zobowiązań i rękojmia w dawnej polszczyźnie .. 115

Glówszczyzna chłopska i szlachecka . . . . . . . . . . . . . . . 133

Chłopska główszczyzna cywilna w Polsce . . . . . . . . . . . . . 143

Rodzic i rodziczka . . . . . . . . . . . . . . . . . . . . 185

Sprzedawalność urzędów w Polsce . . . . . . . . . . . . . . . 193

Gwarancje osobiste w Polsce przedrozbiorowej . . . . . . . . . . . . 259

La preuve en droit polonais du Moyen Âge et des Temps modernes . . . . . . . . 273

Recepcja prawa niemieckiego w Polsce i na Litwie . . . . . . . . . . . 277

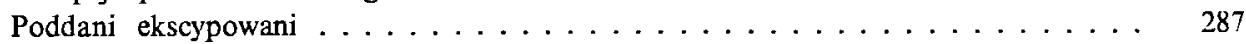

La proles illegitima et le ius terestre polonais . . . . . . . . . . . . . . . 297

Die angebliche Aufnahme des Sachsenspiegels Landrecht I 37 in das Polnische Land-

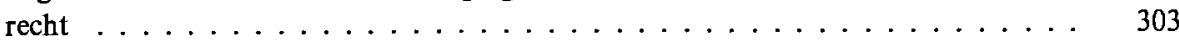

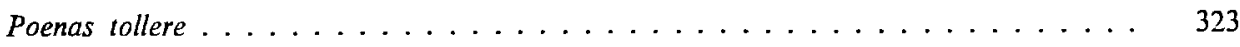

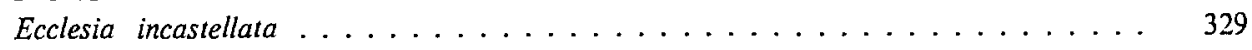

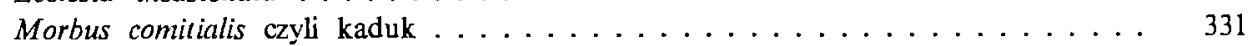

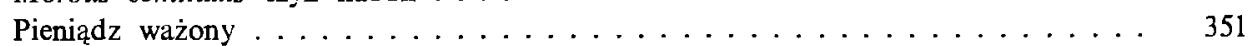

Kto to byt serbin? . . . . . . . . . . . . . . . . . 357

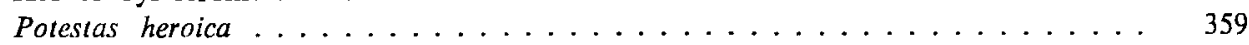

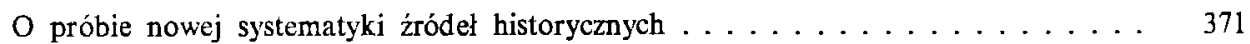

Terminologia rozpraw metodologicznych . . . . . . . . . . . . 395

o państwie i Państwie ....................... 403 


\section{Problem konfiskaty dóbr szlacheckich w dawnej Polsce*}

Wśród kar stosowanych w średniowieczu wyróżnia się tzw. kary rzeczowe czy też majątkowe'. Spośród nich na pierwsze miejsce wysuwa się konfiskata. Obejmowała ona cały majątek, bądź pewne tylko rzeczy²; dotyczyła ruchomości lub nieruchomości ${ }^{3}$. Na tym miejscu interesujemy się konfiskatą pełną, tą przede wszystkim, która obejmowała nieruchomości.

Surowość jej polegała nie tylko na tym, że pozbawiała skazanego całego majątku, że niszczyła go ekonomicznie. W ówczesnych warunkach pozbawienie jednostki podstawy ekonomicznej równalo się likwidacji politycznej. Toteż konfiskata nie jest pierwotnie karą samodzielna, lecz występuje wraz $\mathrm{z}$ innymi - kara śmierci, wygnaniem $\mathrm{i}$ infamia ${ }^{4}$. Stanowiła ona ich istotne uzupełnienie.

Konfiskata wybijała się swoją skutecznością. Skoro władca rozporządzal organami administracyjno-policyjnymi, które były bezsilne wobec niekarnych feudałów, tym samym nie był w stanie przeprowadzić wyroku śmierci przez siebie wydanego: delikwent mógł zawsze chronić się ucieczką. Wszakże nie mial możności zabrania z sobą majątku, na nim można było przeprowadzić egzekucje.

W życiu więc była to sankcja o wiele skuteczniejsza niż pozornie groźniejsza kara śmierci. Ten fakt sprawił, że na karę podstawową (pozbawienie życia) nie zwracano uwagi; jako mniej ważna odpadała, a utrzymywała się tylko konfiskata, która $w$ ten sposób przejmie rolę kary samodzielnej $j^{5}$. Przykładu na ten rozwój dostarcza nam sankcja za uchylanie się od służby wojskowej w pospolitym ruszeniu. Grozila za to kara śmierci

* Przedruk z materiałów VIII Powszechnego Zjazdu Historyków w Krakowie, 14-17 IX 1958. Referaty $i$ dyskusje, t. 7, Historia państwa i prawa, Warszawa 1959, s. 215-21.

${ }^{1}$ Pierwszego wyrażenia używa M. Handelsman $w$ dziele zatytułowanym Kara $w$ najdawniejszym prawie polskim, Warszawa 1908, s. 39, drugiego w Prawie karnym w statutach Kazimierza Wielkiego, Warszawa 1909, s. 144.

${ }^{2}$ M. Handelsman, Prawo karne, s. 150.

${ }^{3}$ P. Dąbkowski, Prawo prywatne polskie, t. 2, Lwów 1911, s. 201.

${ }^{4}$ M. Handelsman, Kara, s. 39, 80, 161, 249; tenże, Prawo karne, s. 148, 151.

5 Tenże, Kara, 80, 161. 
i konfiskata, wszakże w XV-XVI w. pierwsza jest tylko czczym frazesem, mimo że jeszcze dhugo powtarzano dawne rygory ${ }^{6}$.

Konfiskatę wymierzano za przestępstwa pospolite (furta i latrocinia), za przestępstwa na szkodę majątku państwowego (falszerstwo pieniędzy, zabójstwo servi camerae itd.), przestępstwa urzędnicze; przewiduje się ją też za nieprzestrzeganie pewnych zarządzeń monarchy $\mathrm{i}$ inne. Osobną grupę stanowią przestępstwa o charakterze politycznym, a więc zdrada księcia ${ }^{6 a}$; tutaj zaliczyć też trzeba odmowę służby wojskowej (felonia).

Dysponując taką sankcją jak konfiskata mienia, książę trzymal feudałów w posłuszeństwie, tym bardziej, gdy zważymy na nieprecyzyjność politycznych przestępstw. Tak długo przynajmniej, jak długo on sam będzie decydował, czy ktoś dopuścił się wobec niego zdrady. Tym zaś skuteczniejszym narzędziem była konfiskata $w$ walce $z$ przeciwnikami politycznymi, że rozciągała się nie tylko na jednostkę samego „zdrajcy”, lecz na cały klan, do którego ona należała, przede wszystkim zaś dotykała spadkobierców. Jeśli całe grupy występowały przeciwko wladcy, w calości spotykala je sankcja karna?. Konfiskata mienia pozwala na stosowanie jej nie tylko wobec feudalów świeckich, ale również w stosunku do duchowieństwa.

Decyzja o konfiskacie majątku mogla następować na mocy wyroku sądowego ${ }^{8}$. Takie orzeczenie wydawane w obecności asesorów nie wzbudzało poważniejszego protestu w spoleczeństwie. Ale dochodzić do niego mogło również bez formalnego postępowania sądowego. Konfiskatę mógl panujący zarządzić - jeśli nam wolno użyć terminologii anachronistycznej - w drodze postępowania administracyjnego. Nie znaczy to wszakże, żeby wszystkie konfiskaty ,administracyjne” zarządzone były nieprawne. Kutrzeba przyjmował, że pierwotnie ziemie nadawane były często rycerstwu nie dziedzicznie, lecz dożywotnio tylko, względnie później dziedzicznie, wszakże tylko w linii męskiej ${ }^{9}$. Z chwilą więc śmierci obdarowanego dokonany zabór majątku był prawnie uzasadniony.

Problem nadanych dóbr stawiany był nieraz przy zmianie panującego. Kazimierz Wielki nie uznawał zarówno nadań Głogowczyka, jak i Wacława ${ }^{10}$. Pamiętajmy też o występowaniu w świeckich stosunkach koncepcji kary znanej $\mathrm{w}$ prawie kanonicznym jako poenae latae sententiae. Po pewnych

${ }^{6}$ S. Kutrzeba, Materialy do dziejów pospolitego ruszenia z lat 1479 i 1509 , AHK, t. 9, Kraków 1902, s. 251.

M. Sczaniecki, Nadania, s. 29.

${ }^{7}$ Oczywiście zasady tej nie należy rozumiec zbyt rygorystycznie. Przytoczymy tu postanowienie przewidujące $\mathrm{w}$ razie popierania fures violentes i fures fraudulenti konfiskatę mienia $\mathrm{z}$ uszczerbkiem spadkobierców, nisi forte malitie ipsorum contrarii fuerint, KDWP 1, nr 95 (r. 1218).

M. Handelsman, Kara, 122-3, 162, 229, 250.

${ }^{9}$ S. Kutrzeba, Historia ustroju, wyd. 8, s. 56.

${ }^{10}$ K. Potkański, Sprawa restytucji, RAU, t. 39, 1900, s. 159, 167. 
przestępstwach konfiskata następowała bezpośrednio, ipso facto ${ }^{11}$; tym samym więc wyzucie z posiadania przez księcia było tylko prostą konsekwencją takiego stanu rzeczy. Ale niewątpliwie władca niejednokrotnie nadużywał swej władzy, konfiskował mienie bez żadnej podstawy, która by w oczach społeczeństwa mogła uchodzić za prawną. Tak postępowalo wielu panujących. $\mathrm{O}$ jednym z nich, Kazimierzu Wielkim, wiemy z monograficznych opracowań, jak częstych w tym względzie dokonywał ,pomylek", jak dokonywał zaborów minus iuste ${ }^{12}$. Król z żelazną ręką mógł sobie na to pozwolić. Nie była to jednak tylko wlaściwość jego rządów, robili to również inni. A gdy w zmienionych warunkach politycznych wymusza się u następcy restytucje, przeprowadza się je w sposób jak najmniej spełniający dezyderaty społeczeństwa $^{13}$.

Jest rzeczą oczywistą, że społeczeństwo niechętnym patrzy okiem na samowolę władcy. Ograniczenia arbitralnego postępowania księcia domagał się Kadlubek i inni. Powstają specjalne instytucje, które tępią ostrze konfiskaty: przemirze wojewodzińskie i ucieczka prawna (majątek wtedy pozostaje w ręku żony) ${ }^{14}$, dochodzenie ułaskawienia królewskiego ${ }^{15}$; książęta sami nieraz $w$ porozumieniach wzajemnych ograniczają prawo zaboru mienia bez wyroku sądowego ${ }^{16}$. Wreszcie spoleczeństwo reaguje na bezprawne postępowanie króla, organizując buntownicze konfederacje (Maćko z Borkowic). W ten sposób zostawia się coraz mniejszy zakres książęcej arbitralnej władzy, choć utrzymuje się ona dalej.

Wraz ze wzrostem znaczenia szlachty od drugiej połowy 14. w. zdobywa ona sobie przywilej po przywileju, by wreszcie od Wladyslawa Jagielly wymusić w r. 1422 akt czerwiński, którego $\S 3$ brzmi następująco: Item ut gratia uberiori consulentur a nobis, etiam nos fide et servitiis amplioribus prosequantur, promitimus, quod ex nunc et de cetero nunquam alicuius subditi regni nostri cuiuscunque dignitatis, eminentie, status aut gradus fuerit, bona hereditatia recipiemus, confiscabimus, recipi vel confiscari faciemus, nec se de eis per nos vel alios quoscunque homines intromittemus vel intromitti faciemus pro quibuscunque excessibus aut culpis, nisi prius super hoc precedat iudicium nostrorum, quos ad hoc deputaverimus, cum nostris prelatis, baronibus matura cognitio et sententia sequatur ${ }^{17}$.

${ }^{11}$ Tak jeszcze w statutach Kazimierza W., M. Handelsman, Kara, s. 123, Prawo karne, s. $148-149$.

12 K. Potkański, Jeszcze sprawa restytucji, RAU, t. 42, Kraków 1901, s. 46.

${ }_{13}$ Tenże, Sprawa restytucji, RAU, t. 39, Kraków 1900, s. 159.

${ }^{14}$ M. Handelsman, Prawo karne, s. 152.

is Ibidem, s. 205.

$16 \mathrm{~W}$ umowie między Henrykiem Brodatym a Wladysławem Laskonogim: occasionem quoque discordie precidere volens spopondi, quod homines mei homines suos omiss o iudicio vadiare nullatenus presumant, KDWP 1, $\mathrm{nr} 95$.

${ }^{17}$ J. W. Bandtkie, Jus Polonicum, s. 221-2. 
To postanowienie poszerzone o zasadę neminem captivabimus (charakterystyczne, że szlachta $w$ pierwszym rzędzie postarała się o zniesienie samowolnej konfiskaty!) powtórzone zostaje w późniejszych przywilejach szlacheckich (1430, 1454, 1496; na Mazowszu 1472). Utrzyma się też ono wraz z innymi wolnościami stanu szlacheckiego aż do zmierzchu Rzeczypospolitej. Reformatorski obóz Czartoryskich nie zawaha się go zabezpieczyć dla celów propagandowych.

Nie znaczy to, żeby zagadnienie konfiskat straciło odtąd na żywotności. Sankcja pozbawienia majątku zostaje utrzymana, wszakże ujęta w ścisłe szranki: wolno konfiskować mienie jedynie po przeprowadzeniu postępowania sądowego. Ale jakie sądy rozpatrują sprawy konfiskat nieruchomości?

Wiemy, że w okresie dzielnicowym sprawy o nieruchomości należały do samego księcia, i to zarówno $w$ sprawach spornych, jak i niespornych. $\mathrm{Z}$ pojawieniem się starostów zaczęli oni wyrokować $\mathrm{w}$ tym samym zakresie, co monarcha. Następnie atrybucje królewskie przejęły wiece, które wszakże w drugiej polowie 15. w. zanikły. Oprócz tego zwykłego sądownictwa król miał możność powoływania sądu komisarycznego. Zdajemy sobie sprawę $\mathrm{z}$ tego, że taki komisaryczny sąd ad hoc powolany przez monarchę niekoniecznie cechowala bezstronność. Tymczasem takim właśnie sądom zlecil rozpatrywanie spraw konfiskat przywilej czerwiński. Charakterystyczne przy tym, że w składzie jego przewiduje się prałatów i baronów, a więc sfery magnackie. Postanowienie to zresztą szło za dawniejszą praktyką, z tegoż samego elementu składały się sądy restytucyjne za Ludwika Węgierskiego ${ }^{18}$.

Mając sądownictwo w swym ręku, magnateria wykonuje je we własnym interesie - przydziela skonfiskowane szlachcie dobra sobie, chroni też ludzi swojego stanu ${ }^{19}$. Pole tarcia przenosi się więc teraz gdzie indziej, rodzi się konflikt między magnaterią a szlachtą. W tym sporze monarcha wydaje się już sprzymierzeńcem szlachty. Dlatego to akcentuje się, że król ma wyłączne prawo konfiskaty $(1422,1505,1563)^{20}$.

Szlachta walczy $\mathrm{z}$ kumulacją stanowisk starosty i sędziego ziemskiego, i doprowadza $z$ początkiem 16 . w. do widocznego upadku starosty ${ }^{21}$. Zaczyna się ograniczenie sądów komisarskich do coraz ściślejszych granic: od $1505 \mathrm{r}$. wolno im rozpatrywać jedynie spory o granice między dobrami królewskimi a szlacheckimi ${ }^{22}$. Sprawa konfiskat dostaje się przed sąd najwyższy - królewski odbywany na sejmie. We wszystkich ważniejszych

\footnotetext{
${ }^{18}$ K. Potkański, Sprawa, s. 159.

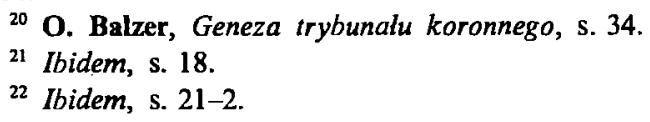

191509 r. sejm zarządził za nadużycie konfiskatę wszystkich dóbr byłego podskarbiego, Piotra Kurozwęckiego; za czasów bezkrólewia restytuowano mu dobra, F. Papée, Jan Olbracht, s. 204. 
sprawach musi się on liczyć z faktycznym wpływem senatu; od 1563-1578 r. wejdą w skład jego w charakterze asesorów również posłowie, przy czym o wyroku decyduje zasada większości głosów ${ }^{23}$.

Wyrazem walki szlachty z magnaterią jest też program egzekucji dóbr (analogiczny do czternastowiecznych restytucyj). Towarzyszy jej przepis, że sądownictwo w causae bonorum nullo iure ademptorum należeć będzie do sejmu (1563, 1564, 1565); postanawia się przy tym, że wyroki zapadłe w tych sprawach na sądach nadwornych będą nieważne. Postanowień tych w praktyce ściśle przestrzegano ${ }^{24}$. W ten sposób o konfiskacie mienia nieruchomego szlachty ostatecznie decydowała ona sama.

Sprawa konfiskaty dóbr posiada jeszcze swój aspekt ekonomiczny. Jeśli mienie królewskie kurczyło się w ciagu stuleci przez rozdawnictwo dóbr, to czy konfiskaty nie stanowią choć w części procesu równoważącego? Tak stawiano ten problem $w$ literaturze ${ }^{25}$. Wiemy, że pobór kar sądowych należał w części do wyrokującego sędziego; tak samo przedstawiała się sprawa $z$ konfiskatą; oprawca zabieral polowę majątku skazanego na śmierć złodzieja, reszta pozostawała żonie i dzieciom ${ }^{26}$. Statuty Kazimierzowskie postanawiały, że nieruchomości skonfiskowane przechodziły na rzecz skarbu, ruchomości zaś częściowo na rzecz baronów ${ }^{27}$. Praktyka jednak siegająca zamierzchłych czasów pokazuje, że władca przekazywał majątek skonfiskowany dalej $^{28}$, oczywiście swoim stronnikom. Statut z 1506 r. przewidywał, że dobra konfiskowane miały iść na rzecz zasłużonych ${ }^{29}$; w praktyce - obfitego materiału dostarczają źródła zajmujące się konfiskatami, które nastąpiły za niedopełnienie obowiązku pospolitego ruszenia - przyznawano je delatorowi. Wśród nich na pierwsze miejsce wybijali się dostojnicy, wojewodowie, kasztelanowie, starostowie, inni urzędnicy ziemscy $\mathrm{i}$ dworzanie ${ }^{30}$. Istnieją magnaci wprost polujący na dobra konfiskowane szlachty-dezerterów ${ }^{31}$. Szczególne korzyści z tego procederu ciągną wojewodowie ze względu na rolę, jaką odgrywali w organizacji pospolitego ruszenia ${ }^{32}$. Król więc nie

${ }^{23}$ Ibidem, s. 69. S. Kutrzeba, Historia ustroju, s. 356.

${ }^{24}$ O. Balzer, Geneza trybunalu, s. 62.

${ }^{25}$ K. Kolańczyk, Studia nad reliktami wspólnej wlasności, Poznań 1950, s. 171.

${ }^{26}$ W. Abraham, $O$ justycjariuszach, s. 25.

${ }^{27}$ P. Dąbkowski, Prawo pryw. p., t. 2, s. 201.

${ }^{28}$ M. Handelsman, Kara, s. 123.

${ }^{29}$ S. Kutrzeba, Materialy, s. 251.

${ }^{30}$ A. Borzemski, Sily zbrojne w woloskiej wojnie Jana Olbrachta, Lwów 1928, s. 26-7.

${ }^{31}$ A. Wyczański, $Z$ dziejów reform skarbowo-wojskowych za Zygmunta I. Próby relucji pospolitego ruszenia, PH, t. 43, Warszawa 1952, s. 291; Mikołaj Chełmski prowadzi procesy o dobra skonfiskowane z 36 osobami (przeważnie szlachta zagrodowa), A. Borzemski, op. c., s. 28, Jan Labancz otrzymuje dobra konfiskowane kilkunastu osób, S. Kutrzeba, Materialy, s. 368, nr 710; por. też przykład cytowany przez W. Pociechę, Bona, t. 2, s. 30.

${ }^{32}$ A. Wyczański, op. c., s. 302. 
dysponował majątkiem skonfiskowanym, lecz co najwyżej mial prawo wyboru między kilku donosicielami ${ }^{33}$.

Ponieważ król wystawiał dokument na dobra konfiskowane, o które obdarowany musial toczyć proces przed sądem komisarskim ${ }^{34}$, sprawa stawała się prywatnym sporem między tym, któremu dobra konfiskowano, a obdarzonym przywilejem przez króla. Miẹdzy tymi stronami dochodzić mogło do porozumienia ${ }^{35}$ i działo się to rzeczywiście w większości wypadków ${ }^{36}$. Tym samym nie skarb królewski się bogacił na konfiskatach, lecz feudałowie, a były to poważne wartości majątkowe; np. po klęsce bukowińskiej konfiskata objęła 370 pozycji 2400 osób $^{37}$.

Próbowano thumaczyć tę dziwaczną instytucję pewnym interesem monarchy: nie na niego spadało odium ${ }^{38}$. Ale rozwiązanie polskie wplywało ujemnie na skarbiec królewski zawsze pusty. Oczywiście nie należy twierdzić, że monarcha nigdy $z$ konfiskat nie skorzystał, i jemu się pewien udział dostawal ${ }^{39}$. Przypomnijmy też przepis obowiązujący na Litwie; według niego, nie mogły być przedmiotem nadawania dobra skonfiskowane zdrajcom ${ }^{40}$.

W literaturze zwracano uwagę na słabość polskiego prawa kaduka, jego niedorozwój $w$ porównaniu ze stosunkami w państwach sąsiednich ${ }^{41}$. Tę samą obserwację poczynić musimy co do konfiskaty. Zawodzila ona pod dwoma względami: zarówno jako środek terroru monarchy wobec feudalów, jak też jako sposób powiększenia majątku królewskiego. Bodin podkreślał $\mathrm{z}$ uznaniem, że w Polsce nie konfiskuje się dóbr skazańców, a nawet w razie dokonania konfiskaty zwraca się je dzieciom lub rodzinie ${ }^{42}$. Dla oceny władzy rządowej w Polsce podnieść trzeba ujemne następstwa ustroju, w którym rapacitas fisci stępiono do minimum. Tym to jeszcze więcej uderzające, że w lonie swoich majętności feudałowie skonfiskowali dominium utile swoich poddanych.

${ }^{33}$ A. Borzemski, op. c., s. 26.

${ }^{34}$ S. Kutrzeba, Materialy, s. 252.

${ }^{35}$ Ibidem, s. 254-5, A. Borzemski, op. c., s. 28; P. Dąbkowski, Ksiega alfabet., s. 37.

${ }^{36}$ A. Borzemski, op. c., s. 30.

${ }^{37}$ F. Papée, op. c., s. 154-5; o późniejszych ib., s. 165.

${ }^{38}$ A. Borzemski, op. c., s. 29.

${ }^{39}$ K. Potkański, Sprawa, s. 166, p. 1.

${ }^{40} \mathrm{P}$. Dąbkowski, Dobra rodowe $i$ nabyte $w$ prawie litewskim od XIV do XVI wieku, SHPP, t. 6, z. 5, Lwów 1916, s. 34.

${ }^{41}$ K. Kolańczyk, Studia, s. 297.

${ }^{42}$ S. Kot, Rzeczpospolita Polska w literaturze politycznej Zachodu, Kraków 1919, s. 58-9. 


\section{Iura Prutenorum*}

W. T. Paszuto, Pomiezanija. "Pomiezanskaja Prawda" kak istoriczeskij istocznik izuczenija obszczestwiennogo $i$ politiczeskogo stroja Pomiezanii XIII-XIV ww. Moskwa 1955, s. 184 +2 mapy +3 tabl.

Uczeni radzieccy od dłuższego czasu zajmują się wczesnofeudalnymi zwodami prawnymi krajów słowiańskich. Przypomnijmy ich prace nad Prawdą Ruską, uwieńczone epokową, dwutomową publikacją źródła dokonaną przez Instytut Historii Akademii Nauk ZSRR pod redakcją B. Griekowa (Moskwa 1940, 1947). Znane sq̨ studia B. Griekowa nad statutem winodolskim i polickim (1951). Wiemy też o badaniach tego uczonego nad najstarszym zwodem prawa polskiego, dotąd niestety nie opublikowanych, choć ogłoszenie tej pracy zapowiedział jej autor jeszcze za swego życia.

Młodsza generacja historyków radzieckich kontynuuje te tradycje, zwracając uwage na prawa sąsiadujących ze Slowianami ludów. Przed nami leży skromne rozmiarami, ale bogate treścią studium prof. Paszuty, zadedykowane pamięci Griekowa. Prof. Paszuto już od dhuższego czasu interesuje się tą problematyką, jak świadczy o tym artykuł wydrukowany w księdze pamiątkowej Griekowa'.

Jeśli nauka polska śledzi z zainteresowaniem prace nad prawodawstwami słowiańskimi, to i studium nad prawem pruskim budzi jej niemałe zainteresowanie ${ }^{2}$. Wiemy, że wplywy polskie na Prusy sięgaja bardzo dawnych czasów ${ }^{3}$. Co przy tym charakterystyczne, w Prusach doszło do recepcji prawa polskiego w 1249 r., która zresztą okazala się nietrwała. Stąd zrozumiałe duże analogie między Iura Prutenorum (= IP) a Najstarszym Zwodem prawa polskiego $(=\mathrm{NZ})$, wskazywane trafnie przez prof. Paszutę, podobieństwa zarówno instytucjonalne (starosta, komornik, odpowiedzialność pastucha), jak i wprost zapożyczenia terminologiczne (starosta, pustine,

* Przedruk z: Studia i Materialy do Dziejów Wielkopolski i Pomorza 1958, t. 4, z. 1, s. $425-35$.

'W. T. Paszuto, Nieskol'ko nabliudienij nad „Prusskoj Prawdoj”, Sbornik poswjaszczennyj

B. D. Griekowu, s. 112-6.

${ }^{2}$ Por. W. Hejnosz, rec. w. CPH, t. VIII, z. 2, s. 350-4.

${ }^{3}$ H. Lowmiański, Stosunki polsko-pruskie za pierwszych Piastów, PH, t. 41, 1950, s. 152-79. 
granice) $)^{4}$. Z calych Prus - jak stwierdza autor - najbardziej z Polską związana była Pomezania, mająca ożywione kontakty z ziemią chełmińską i zawiślańskim Pomorzem.

Nic więc dziwnego, że zajmując się problemem tak blisko związanym z zagadnieniami polskimi, korzystał autor z pomocy polskich historyków, czemu dał wyraz na kartach swego dziełka (s. 31). Nieodzowność współpracy historyków bratnich narodów, radzieckiego i polskiego - podkreślamy jak najsilniej. Niech uwagi, które tu pozwalamy sobie poczynić, będą wyrazem tej właśnie tendencji, by tak trudne badania porównawcze nad prawodawstwami slowiańskimi i narodów sąsiednich - prof. Paszuto ucieka się do analogii ruskich, polskich, litewskich - posuwać naprzód zbiorowym wysiłkiem wszystkich historyków słowiańskich.

Praca prof. Paszuty składa się z dwóch części, opracowania (s. 1-108) i publikacji samego tekstu IP (s. 109-78). Uzupełniają ją dwie mapki oraz kilka fotografii przedstawiających narzędzia pochodzące ze znalezisk pruskich, jak też sześć fragmentów drzwi gnieźnieńskich. Całość zamyka czterostronicowy indeks do tekstu (s. 79-182).

Tekst opublikowal autor dwukrotnie, dając nam oddzielnie redakcję wcześniejszą (s. 116-41) i późniejszą (s. 162-78). Pierwszą z nich zaopatrzył w warianty i równoległe tłumaczenie na język rosyjski $i^{5}$. Tą edytorską stroną dzieła prof. Paszuty zajmujemy się na innym miejscu ${ }^{6}$, tutaj kierujemy swą uwage na samo opracowanie zwodu pruskiego.

Sklada się ono z następujących rozdziałów: Wprowadzenie (kilka jego stronic należy treściowo do części wydawniczej), I. Gospodarstwo Pomezanii, II. Ustrój spoleczny, III. Prawo rzeczowe i spadkowe, IV. Zobowiązania i umowy, V. Walka klasowa, VI. Ustrój polityczny, VII. Sądownictwo. Zakończenie jednostronicowe zamyka rozważania autora słusznym stwierdzeniem, że „Pomezańska Prawda przedstawia sobą ważne źródło dla historyczno-porównawczych badań prawa zwyczajowego i feudalnego narodów Europy Wschodniej, w szczególności zaś nadbałtyckich, Polski i Rusi" (s. 108).

We wstępie prof. Paszuto daje krótki przegląd źródel do historii Pomezanii (Tacyt, Alfred, Gall-Anonim, umowa dzierzgońska, materiały archeologiczne), zestawia wszystkie informacje dla tych dziejów, powołuje się też na pewne prace polskie dotyczące Jaćwieży (Kamińskiego), wreszcie przechodzi do wyjaśnienia warunków politycznych, w których doszło do powstania omawianego zabytku. Zdaniem jego, feudalowie niemieccy korzystając z poparcia

${ }^{4}$ Balibyśmy się wszakże do polskich zapożyczeń zaliczać taki termin jak kemmerer pochodzenia lacińskiego, przy czym to słowo mogło przyjść równie bezpośrednio z Niemiec, jak pośrednio przez Polskę.

${ }^{5}$ Za tym wzorem, mającym zreszlą już starą tradycję, zamierzamy pójść przygotowując nowe wydanie najstarszego zwodu prawa polskiego.

${ }^{6}$ Studia Źródłoznawcze II, Poznań 1958, s. 192-5. 
papiestwa i cesarstwa dla zaatakowania Rusi, zajęli kraje przybałtyckie ${ }^{7}$. Szczęście długo im dopisywało, dopiero od granic ruskich odepchnął ich Aleksander Newski. Druga przeszkodę nie do pokonania dla Drang nach Osten stanowiła Litwa, która rychło skrystalizowała się w państwo wczesnofeudalne. Odpowiednio silnych organizmów ustrojowych nie zdołały natomiast stworzyć Estonia i Lotwa, dlatego padły pastwą inflanckiego zakonu. Jeśli mimo to zachowały one swe narodowe istnienie, to o tym zadecydowała pomoc Rusi. Opisując etapy podboju krzyżackiego w Prusach, stwierdza autor, że władza Zakonu opierała się na krwawej przemocy i masowej zagładzie ludności. Omówiwszy stosunki prusko-ruskie, przechodzi do samej Pomezanii. Iura Prutenorum zredagowano w momencie szczególnie trudnym dla Krzyżaków. Toczyli oni wówczas wojnę z Polską i Litwą, naprężone było również położenie $w$ Estonii. W tych warunkach, po zdławieniu krwawej wojny oswobodzicielskiej Prusów, feudałowie niemieccy zachowali w swym ustawodawstwie liczne normy zwyczajowego prawa pruskiego.

Pomijając pewne watpliwe wypowiedzi, które przytaczamy tu na odpowiedzialność autora, chcielibyśmy zastrzec się przeciwko dopatrywaniu się związku między sytuacją polityczną, jaka panowała w momencie spisania IP, a ich treścią. Pamiętajmy o daleko posuniętym indyferentyzmie ówczesnego państwa w wielu dziedzinach, które dzis̉ zalicza się do zasadniczych atrybucyj państwowych, między innymi także $w$ dziedzinie prawa. Następstwem tego była zwyczajowość prawa, ta zaś w państwach narodowo niejednolitych - a takim było państwo Zakonu Krzyżackiego - pociągała za sobą zasadę osobowości praw. Stąd to, wedhug IP, Prusacy odpowiadaja zgodnie z prawem pruskim (pomiezańskim), art. 24, 68; Niemcy - zgodnie $z$ prawem niemieckim, art. 27; Polacy - jak wiemy z NZ - zgodnie z prawem polskim ${ }^{8}$. Co prawda w momencie spisywania zwodu sprawa podległości prawnej danej jednostki nie zawsze była jasna, stwierdzamy wypadki wahań, jakim kto rządzi się prawem; stąd więc norma mówiąca o obowiązku dowodzenia swego prawa przy pomocy dokumentu, art. 68. Słyszymy też o przechodzeniu od jednego prawa do drugiego (od pruskiego do niemieckiego, art. 24, 117). Wszakże z przytoczonych faktów nie wysnuwalibyśmy jakichkolwiek wniosków o germanizacyjnych zakusach Krzyżaków w tej dziedzinie. $Z$ identycznymi zjawiskami spotykamy się wspólcześnie, np. w statutach Kazimierza Wielkiego, Król. art. 62, tymczasem polskiego władcy nikt o podobne zamierzenia nie posądzi.

\footnotetext{
${ }^{7}$ Passus ten wydaje się całkowitym anachronizmem. Również zbytnio współczesnym językiem dziennikarskim trąci zwrot określający św. Wojciecha katolickim agentem-kaznodzieją, s. 9 , p. 2 .

${ }^{8}$ Por. tez identyczną sytuację u Słowian zachodnich, którzy znaleźli się w organizmach państwowych niemieckich; opis jej w moim artykule pt. Artykuly slowiańskie Zwierciadla Saskiego, odb. z CHP, t. 1, 1948, s. 50. [Patrz: Pisma wybrane, t. I, s. 7-43].
} 
Nie bardzo wiemy, jaki byl stosunek tych różnych praw do siebie'. Jeśli autor zgodnie $\mathrm{z}$ dotychczasową literaturą utrzymuje, że Krzyżacy, pragnąc zjednać sobie górną warstwę ujarzmionego narodu pruskiego, nadali feudałom prawo chełmińskie, stanowiące uprzywilejowanie $w$ zestawieniu $\mathrm{z}$ prawem pruskim, w szczególności zaś z pomezańskim (s. 51), to zauważyć musimy, że nieprawne powoływanie się na prawo pomezańskie przy posługiwaniu się falsyfikatem (!), art. 68, świadczy o tym, że to właśnie prawo w pewnych warunkach przyznawało najwidoczniej jakąś szczególnie korzystną pozycję przed sądem. Podkreślmy przy tym jeszcze wysoką sankcję karną grożącą za tego rodzaju postępowanie (kara śmierci), a wówczas przestaniemy patrzeć na pomezańskie prawo jako na coś gorszego. Zajmując się już problemem osobowości praw pod rządami Krzyżaków, wspomnijmy o dwu artykułach, które zajmuja się konfliktem praw - art. 27 i 117.

Iura Prutenorum - jak zresztą tyle innych zwodów współczesnych - nie stanowią przemyślanej do końca kodyfikacji prawnej, stąd wynika ich niekompletność. Dlatego to uważamy za niecelowe usiłowania autora, by domysłami wyjaśnić, dlaczego ten czy ów artykuł pojawił się w spisie, dlaczego natomiast inne zagadnienie nie zostało poruszone (s. 72). Przyczyn, które sprawiły, że jakaś norma zwyczajowa została ujęta na piśmie, inna zaś została pominięta, nie jesteśmy w stanie dojść, wszelkie zakusy - poza jakimiś wyjątkami - pozostaną zawsze niepewne. Jeśli za autorem twierdzimy, że IP stanowią zwód prawny społeczeństwa rolniczego, to brak w nich norm poświęconych rzemiosłu miejskiemu nie może stanowić dostatecznego uzasadnienia dla tezy, że Zakon odsuwał Prusów od zajęcia się rzemiosłem (s. 37). Dla takiego twierdzenia trzeba znaleźć inne uzasadnienie źródłowe; przytoczone wyżej nie może uchodzić za wystarczające.

Nie zawsze podzielalibyśmy opinię prof. Paszuty w kwestii źródel, na które się powołuje. Stwierdzając znajomość pieniędzy u Prusów już przed podbojem krzyżackim - tezę tę uważamy za trafną w stu procentach - autor stara się ją dodatkowo wzmocnić. W takim wypadku oczekiwalibyśmy powolania się na wyniki badań archeologicznych, które stwierdziły w wykopaliskach monety itp. Tymczasem autor nieoczekiwanie powołuje się na rzeźby wykute na drzwiach gnieźnieńskich (s. 38). Podnieść tu chcemy stanowczo, że słynny ten zabytek mógłby stanowić źródło do historii Prusów wówczas tylko, gdyby zostal wykonany w Prusach przez miejscowych artystów. $Z$ takim zaś twierdzeniem dotąd nikt nie wystąpil. Tym samym więc zdobiące wydawnictwo reprodukcje tych drzwi (tabl. 4-9) znalazły się nie we właściwym miejscu.

Autor daje interesujące uzasadnienie swych badań nad instytucjami prawnymi. Dla niego nie stanowią one celu same w sobie, lecz mają shużyć

${ }^{9} \mathrm{O}$ możliwych wahaniach $w$ wypadku zbiegu praw por. CPH, t. VIII, z. 1, s. 77, p. 61. 
jako źródło do badania stosunków produkcyjnych (s. 56). Nie sądzimy, by autor potrafil uzasadnić swoje stanowisko, nawet stając na gruncie metodologii marksistowskiej.

Prof. Paszuto nazywa IP zabytkiem feudalno-kolonialnego prawa, wyłączającym większą liczbę norm prawa pruskiego. Opierając się na kryterium klasowego i politycznego nastawienia tego czy innego artykuhu, przy stałym uwzględnieniu warunków społeczno-ekonomicznych i politycznych jego powstania, rozróżnia trzy grupy norm: (1) odzwierciedlające pomezańskie prawo przedfeudalne; (2) odbijające prawo feudalne wytworzone w społeczeństwie pruskim; (3) po odjęciu tych artykułów zostają jako reszta normy i precedensy niemieckiego prawa feudalno-kolonialnego, któremu podporządkowano pomezańskie prawo przedfeudalne i wczesnofeudalne. Autor wskazuje przy tym, które artykuły należą do pierwszej grupy, które do drugiej i trzeciej (s. 30-1). Jeślibyśmy nawet zgodzili się na wydzielenie tych norm, które przez Niemców zostały wydane, co wynika bądź bezpośrednio $\mathrm{z}$ artykułu (art. 25: da der von Aldenborgk meister was), bądź też widać najwyraźniej $\mathrm{z}$ ich treści, że powstały dla ochrony interesów najeźdźcy, to nie wierzymy absolutnie w możność wyróżnienia przepisów prawnych pruskich przedfeudalnych i feudalnych. Przede wszystkim warunkiem, by podzial ten miał dla historyka jakieś znaczenie, byłoby określenie momentu chronologicznego, choćby $w$ postaci stulecia, w którym zdaniem autora kończy się jeden okres, a zaczyna drugi. W braku jego wspomniany podział, zresztą logiczny, pozostaje spekulacją pozahistoryczną. Co prawda autor zdaje sobie sprawę $\mathrm{z}$ jego przybliżoności, ale my nie możemy nawet dopatrzeć się jego celowości. W oparciu o wskazania klasyków marksizmuleninizmu pragnie prof. Paszuto wyłuskać z IP materiał charakteryzujący przejście stosunków patriarchalno-gminnych w feudalne. Ale czy tak stawiając kwestię, nie obracamy się w błędnym kole? Niewątpliwie Ruska Prawda zawiera elementy pozwalające dokładnie wyróżnić najdawniejsze partie zwodu od późniejszych dodatków. Wszakże nie widzimy ich ani w IP, ani też $w$ najstarszym zwodzie prawa polskiego. Dla przykładu przyjrzymy się niektórym artykułom IP i zastanówmy się, czy zakwalifikowanie ich przez autora do tej czy innej grupy nie nasuwa zastrzeżeń.

Dlaczego do pierwszej grupy (przedfeudalnej) zaliczać art. 123, chroniący chlopa idącego $\mathrm{z}$ pługiem $\mathrm{w}$ pole? Czy możemy wykluczyć ustanowienie takiego przepisu przez Krzyżaków? Postanowienie o mirze domowym znalazło się w grupie pierwszej (s. 41), natomiast obowiązek śladu, będący następstwem miru, w grupie drugiej. Tymczasem równocześnie obowiązek gonienia śladem nazywa się przeżytkiem! Czy może uchodzić za wystarczająco uzasadnione twierdzenie, że część art. 98, chroniąca prawo młodszego syna do dziedziczenia, sięga czasów patriarchalnych (s. 42)? W takim razie musimy domyślać się milczącego założenia, że w okresie patriarchalnym 
istniało dziedziczenie indywidualne nieruchomości. Dlaczego $\mathrm{z}$ dwóch artykułów dotyczących dochodzenia rzeczy skradzionej, art. 48 i 97, pierwszy ma pochodzić $\mathrm{z}$ okresu przed podbojem, drugi $-\mathrm{z}$ czasów krzyżackich (s. 62-3)? Sprawa wymagalaby w każdym razie bliższego uzasadnienia; to co autor pisze, $w$ zestawieniu $z$ tekstem IP nie ma bynajmniej mocy przekonywającej. Dlaczego art. 101 o przestępstwach komornika ma pochodzić z czasów krzyżackich? Sam autor stwierdza, że funkcje starszego w gminie wytworzyly się dawno i byly tylko wykorzystane przez aparat państwowy; nazwa sama, niewątpliwie obca, mogła śmiało przeniknąć do kraju Prusów niezależnie od Krzyżaków, jak to możemy stwierdzić dla stosunków polskich. $\mathrm{Z}$ dwóch artykułów dotyczących kradzieży, art. 65 i 72, pierwszy ma pochodzić $\mathrm{z}$ okresu przedfeudalnego, drugi $-\mathrm{z}$ następnego. Pierwszy grozi za kradzież utratą ucha, drugi - karą 3 grzywien. Według rozumienia prof. Paszuty, kara pieniężna jest późniejsza od kary cielesnej. Jest to, jak się zdaje, jedyny argument, którym posłużył się autor do oddzielnego zakwalifikowania chronologicznego obydwu artykułów. Tymczasem w literaturze naukowej panuje pogląd, że okrutne, bestialskie kary cielesne przybieraly na sile dopiero $\mathrm{z}$ wpływami niemieckimi. Ten pogląd stanowil podstawową tezę dziela M. Handelsmana ${ }^{10}$. Co więcej, autor sam utrzymuje, że Krzyżacy wprowadzili krwawe ustawodawstwo kolonialno-feudalne (s. 108). Przy rozpatrywaniu ostatnich artykułów nasuwa się jeszcze pytanie, czy kara pieniężna, a więc lagodniejsza $\mathrm{z}$ art. 72 , nie stanowi po prostu premii za przyznanie się winnego (leuckent er die dube, so mus er seyn entgehen selbsechste, bekennet er aber, so ist die busze drey marck). Gdyby ten domysł miał się okazać trafny, usunęłaby się wszelka podstawa klasyfikacji chronologicznej tych artykułów. Dodajmy jeszcze, że nawet artykuly zaliczone przez autora do trzeciej grupy, art. 11 i 101 uważa tylko za prawdopodobnie przez Krzyżaków wprowadzone (s. 60) ${ }^{11}$.

Z przytoczonych przykładowo bliżej rozpatrzonych artykułów widać, jak wątpliwe są tego rodzaju podziały przepisów prawnych na starsze i mlodsze. Tym bardziej, że prof. Paszuto w swym artykule nieco wcześniej opublikowanym inną przeprowadzil cezurę między normami pruskimi i niemieckimi ${ }^{12}$.

Zapoznając się z wnikliwym studium prof. Paszuty, nie oszczędzaliśmy sobie trudu zestawienia jego twierdzeń $z$ oryginalnym tekstem źródła. $Z$ przyjemnością musimy tu stwierdzić, że w większości wypadków analiza artykułów wydaje się poprawna. Wszakże $w$ rozumieniu kilku $z$ nich pozwalamy sobie mieć odmienne od autora zdanie. Ze względów praktycznych

\footnotetext{
${ }^{10}$ M. Handelsman, Prawo karne w statutach Kazimierza Wielkiego, Warszawa 1909, s. 144.

${ }^{11}$ Por. jeszcze niżej uwagi do art. 80.

${ }^{12}$ Por. artykuł cytowany w przyp. 1, s. 113.
} 
zastrzeżenia nasze ułożymy $w$ porządku cyfrowym kwestionowanych artykułów, by ułatwić dalszą kontrolę czytelnikowi. W razie omawiania równoczesnego kilku artykułów, pomieszczamy je wszystkie pod cyfrą najniższą.

Art. 2 świadczyć ma o tym, że patriarchalna wspólnota domowa straciła już dawną trwałość (s. 42, 56-7), ponieważ widoczne tu odrywanie się od wspólnoty. Nie wiemy, czy tego rodzaju pogląd da się utrzymać. Większe i mniejsze wspólnoty nie stanowią dwóch faz spolecznego rozwoju Prusów, ale dwa typy układów rodzinno-gospodarczych, obok siebie stale istniejących. Proces narastania wspólnoty i jej rozkładu dyktowały konkretne warunki życiowe.

$\mathrm{Ze}$ wspomnianego art. 2 łącznie $\mathrm{z}$ art. 32, 40, 70, wzmiankujących o mirze domowym, tworzy autor tezę o prawie rodziny do bezpieczeństwa. Jest to rzecz zbyt oczywista, by ją specjalnie podkreślać, albo też pod tym twierdzeniem ukrywa się myśl, która dla czytelnika nie jest wystarczająco jasna.

Art. 6. Autor zastanawia się nad wyrażeniem tego artykułu: mag sich nicht erholen, zadając sobie pytanie, czy zwrotu cytowanego nie należy zrozumieć w tym sensie, że danego świadka czekała większa kara niż normalna - pół grzywny (s. 101). Nie wydaje się ten domysł trafny. $\mathrm{Z}$ tekstu wynika, że świadek, który jest fellig po raz pierwszy i drugi, może sich erholen, tzn. ponownie wystąpić $w$ roli świadka, placąc $1 / 2$ grzywny kary. Atoli gdy jest fellig po raz trzeci, wówczas już więcej poprawić się nie może. Trzeci jego „potyczel” wpływa już materialnie na bieg procesu. Sądzimy, że należy rzecz rozumieć następująco: zeznanie świadka jest pewnego rodzaju sądem bożym: procedura toleruje dwa jego upadki w składaniu zeznań, upadek trzeci przesądza o niesłuszności bronionej przez świadka strony. Zauważmy, że surowsze rygory stosuje się przy zeznaniu samej strony; przegrywa ona sprawę już przy pierwszym potyczlu, albowiem po nieudanej przysiędze mag sich nicht erholen. Sprostujmy też twierdzenie, jakoby według tego artykulu strona placila pól grzywny za przysiegge w sprawie, którą przegrała. Wyraźnie mowa o karze płaconej przez świadka, który jest fellig.

Art. 11, 101. Artykuły oba mówiące o ,puścinie” przytoczono w związku z uwagami o pisemnej rejestracji praw dziedzicznych i sprzedaży własności dziedzicznej jako zjawisk, które mają starą datę. Nie widzimy tu jakiegoś związku rzeczowego między treścią artykułów a tezą autora.

Art. 12. Zdaniem autora, wielkie znaczenie w postępowaniu sądowym mial fakt, kto przysięga pierwszy (s. 102). Problem jest niewątpliwie źle postawiony, bowiem w średniowiecznej procedurze nie było $w$ ogóle takiej praktyki, by obie strony dopuszczano do przysięgi na tę samą okoliczność. Takie postępowanie byłoby niezgodne $z$ poczuciem religijnym. Zagadnienie 
leżało gdzie indziej, mianowicie w tym, kto był bliższy przysiędze, tzn. kogo dopuszczono do jej złożenia $\mathrm{z}$ równoczesnym odrzuceniem od przysięgi strony drugiej ${ }^{13}$. Rozumiemy dobrze wartość tego uprawnienia bliższości dowodowej. Równało się to złożeniu $w$ ręce korzystającego $z$ bliższości wyniku procesu: skoro się na przysięgę zdecydował, sprawę wygrywal. Tym wszakże zagadnieniem art. 12 się nie zajmuje, lecz chodzi w nim o to, do jakiego momentu wolno wystapić w procesie z przeciwroszczeniami, oczywiście celem żądania kompensacji. Okazuje się, że według prawa pruskiego, z pretensjami kompensacyjnymi wolno wystąpić aż do złożenia przez stronę przysięgi.

Art. 14. Można się zastanowić, czy dla charakterystyki życia rodzinnego jakiegoś społeczeństwa wolno się powoływać na przepisy kodeksu karnego. W jego świetle zawsze obraz wystąpi w jak najczarniejszych barwach, zupelnie nie odpowiadających rzeczywistości. Ta ostrożność wskazana też przy interpretacji art. 14 mówiącego o bratobójstwie. Nie ma chyba takiej grupy spolecznej, w której by do tego rodzaju zbrodni od czasu do czasu nie doszło, co wszakże nie daje żadnej podstawy do jakiegokolwiek uogólnienia.

Art. 17. Nie rozumiemy, dlaczego gebawersrecht miało pozostać poza granicami IP (s. 44), tym więcej, że autor trzy stronice poświęcił stanowisku prawnemu chłopów (s. 43-6). Co prawda pod wspomnianym terminem rozumie on prawo chłopów poddanych, ale czy rzeczywiście znajdujemy podstawę do twierdzenia, że IP regulowały życie osobiste chłopów swobodnych (s. 45)? Czy mnogie przepisy prawa karnego nie odnosily się do chlopów poddanych? Czy nie obejmowała ich szczególna ochrona rozciągająca się na chłopa idącego $z$ phugiem $w$ pole? Na s. 47 czytamy, że np. knecht $\mathrm{i}$ dienstbote byli biedakami, którzy popadli w zawisłość od pana, a więc stali się poddanymi. Dowiadujemy się, że byli oni bez prawa, a wynagrodzenie za wyrządzoną im szkodę należało się panu. Czy te wypowiedzi autora nie są charakterystyką gebawersrecht? Przytoczmy jeszcze wiadomości zastawione przez autora na s. 49.

Art. 21. Prof. Paszuto przyjmuje, że w razie posądzenia o pomoc w grabieży, przysięgę oczyszczającą składal pierwotnie oskarżony sam jeden, jak to podaje jeden $\mathrm{z}$ rękopisów IP. $\mathrm{Z}$ innych tymczasem manuskryptów wynika, że robil to samodwunast. Czy $w$ tych warunkach nie będzie trafniejszy domysl, że ten wyjątkowy rękopis jest $w$ interesującym nas miejscu błędny? Przy takim założeniu unikamy sprzeczności $\mathrm{z}$ innymi znanymi wypadkami przysięgi oczyszczającej. Zlagodzenie wymogu do

${ }^{13}$ Tak też trafnie interpretuje autor art. 101, mówiący o tym, że komornik samotrzeć jest bliższy dowodu niż chłop z dwunastu współprzysiężnikami, Nieskol'ko nabliudienij, s. 115. Tak rozumiemy też jego interpretację $w$ omawianym dziele, s. $69, \mathrm{z}$ tym jedynie zastrzeżeniem, że nie chodzi o świadków, lecz współprzysiężników komornika. 
przysięgi oczyszczającej samego tylko oskarżonego przy tak ciężkim przestępstwie na tle innych purgationes wydaje się wręcz nieprawdopodobne.

Art. 24. Czy z tego artykułu rzeczywiście wynika podporządkowanie prawa pruskiego prawu feudalno-kolonizacyjnemu Niemców? Przypomina on nam żywo analogiczne postanowienie statutów Kazimierza W., Król. art. 62, w których obcość narodowa wladcy nie wchodzi w rachubę.

Art. 25. Według autora, artykuł ten umyślnie został sformułowany warunkowo, jak to jest typowe dla ustawodawstwa klasy eksploatującej w tych wypadkach, gdy zajmuje się ono prawem klas pracujących (s. 44-5). Nie bardzo możemy uchwycić myśl tego zdania, wskutek czego boimy się $\mathrm{z}$ nią polemizować. Zauważyć wszakże musimy, że coniunctivus gebe nie występuje we wszystkich rękopisach, mianowicie w manuskrypcie H spotykamy formę gab er. Niejednokrotnie stwierdzamy też, że z trybem czasownika nie zawsze należy wiązać wnioski semantyczne, np. w NZ. Wreszcie nawet gdyby pójść za ścisłą, wa r un k ow ą interpretacją rozpatrywanego zdania, nie widzielibyśmy w nim podstawy do twierdzenia, że ustawa mistrza von Aldenborga zostawiała decyzje co do powinności wdów na rzecz państwa opinii czynników miejscowych. Według naszego rozumienia, artykul ten nie przewiduje żadnych warunków, lecz po prostu nadaje wdowom trzy lata wolnizny.

Art. 26. Zdaniem prof. Paszuty, obowiązek gonienia śladem byl w okresie spisywania zwodu przeżytkiem (s. 40-1). Być może, że jego stanowisko jest sluszne, ale bynajmniej nie wynika ono $\mathrm{z}$ art. 26 , który raczej służyć może za dowód, że instytucja ta była w Prusach w tym czasie w pełni swej żywotności.

Art. 28, 45, 84, 95, Anhang. Prof. Paszuto skłonny jest dawać pewnym postanowieniom omawianego zwodu interpretacje polityczną. Gdy konstatuje, że chłop idący na robotę lub wracający $z$ roboty pańskiej korzysta $\mathrm{z}$ podwójnej nawiązki, to wysnuwa $\mathrm{z}$ tego wniosek, jakoby w pierwszym okresie panowania Niemców pewna grupa ludzi miejscowych narażała się na groźbę pobicia ze strony sąsiadujących chłopów (s. 44, 87); czytamy też o gniewie własnego narodu za pójście na służbę Krzyżaków (s. 51); jedną z form walki politycznej Prusów z najeźdźcami była trucizna (s. 71, 92); autor wyróżnia grupę przestępstw przeciwko panującemu porządkowi (s. 92). Jesteśmy jak najdalej od myśli negowania walki politycznej Prusaków z Krzyżakami. Ale czy rzeczywiście wspomniane artykuły są jej wyrazem? Bójki między chłopami nie musiały wynikać koniecznie $\mathrm{z}$ niechęci do „sprzedawczyków". Interpretacja artykułów 45, 84, w sensie przestępstw przeciwko panującemu porządkowi (s. 69-70, 91), opiera się jedynie na słowie ubeltheter, któremu takie właśnie znaczenie autor przypisał.

Pamiętajmy, że Niemcy, będąc uprzywilejowani w zestawieniu z Prusakami, miedzy sobą nie są równi, art. 18; istnieją wśród nich possessionati, 
ogrodnicy i chłopi bez ogrodu (s. 54). Podnieśmy też za autorem, że główszczyzna swobodnego Prusaka równała się główszczyźnie Niemca ${ }^{14}$. Wydaje się przeto, że „narodowa" interpretacja wspomnianych artykułów nie jest uzasadniona. Co więcej, najjaskrawszy, zdawałoby się, przykład narodowej walki Prusaków z Krzyżakami, dostarczony nam przez anchang des preussens rechtens, a mówiący o truciu braci zakonnych, rozpoczyna się zdaniem die vergifftgebung unter denn preussen vor alters sehr gemein getrieben.

Uzupełnijmy powyższe zastrzeżenia jeszcze następującymi obserwacjami. Kary za przechowywanie złodzieja czy mordercy nie świadczą jeszcze o tym, by przestępca znajdował współczucie w narodzie (s. 70). Najwyżej - jak we współczesnych nam stosunkach - możemy powiedzieć, że istniały jednostki, które udzielały schronienia przestępcom; do tego stwierdzenia musi się ścisła interwencja ograniczyć. Teza, że nieodpowiedzialność gospodarza za nieświadome goszczenie u siebie przestępcy, art. 67, stanowi gwarancję, o którą postarali się Prusacy wobec daleko posuniętej samowoli władz krzyżackich, jest nieudowodniona. Zauważmy przy tym, że wspomniany art. 67 nie został zaliczony przez autora do grupy trzeciej, co więc świadczy o pewnej niekonsekwencji. Trudno mówić o jakiejś sprzeczności zasadniczej między społeczeństwem a władzą, skoro komornik powierza ochronę nad przestępcą członkom tego spoleczeństwa, art. 45. Obserwacja ta przekreśla wszystko, co autor powiedział o walce narodowej Prusaków z Krzyżakami. Co gorsza, wspomniany art. 45 według zestawienia prof. Paszuty należy do grupy trzeciej, do tej więc, którą według autora wprowadzili Krzyżacy! Nie zapominajmy również $o$ tym, że typowy reprezentant władzy lokalnej Krzyżaków, komornik, niejednokrotnie dopuszczal się wobec swych chlebodawców nadużyć, np. ukrywal przed nimi fakt kaduka, art. $101^{15}$.

Jeśli więc wielokrotnie ponawiane powstania pruskie świadczą o żywiołowej nienawiści odczuwanej przez tubylców do najeźdźców, jeśli terror stosowany wobec Prusów przez Zakon nie może ulegać żadnej wątpliwości, to musimy w każdym razie stwierdzić, że sprawy te nie znalazły odbicia w omawianym zwodzie prawnym. Instytucji podobnej do tej, jaka wprowadzili normandzcy najeźdźcy podbijając Anglię ${ }^{16}$, w Iura Prutenorum nie spotykamy.

Krótki ustęp o walce klasowej (s. 68-71) znajduje pełne oparcie w źródle, choć znowu nie wszystkie argumenty użyte przez autora są wystarczająco mocne. Trudno np. contumacitas Prusów thumaczyć stanowo-klasowymi

${ }^{14}$ Nieskol'ko nabliudienij, s. 113.

${ }^{15}$ Por. też niżej obserwacje przy art. 100.

${ }^{16}$ Chodzi nam tu o instytucje franc plege, tj. zbiorowej odpowiedzialności tubylców za bezpieczeństwo najeźdźców. Mianowicie w wypadku znalezienia trupa nieznanej osoby we wsi, płaciła wieś kare 46 grzywien, chyba że dowiodła, że denat był Anglikiem lub poddanym, por. F. Joüon des Longrais, Le droit criminel anglais au moyen âge (1066-1485), Rev. Hist. de dr. fr. étr., 1956. Franc plege zniesiono dopiero w 1340 r. 
podstawami prawnymi (s. 98). Niestawiennictwo w sądach jest rzeczą znaną także u członków uprzywilejowanej klasy feudałów. Klasowe uzasadnienie znajduje fakt podwyższenia główszczyzny dla chłopów będących w shużbie feudalów. Tym zagadnieniem $w$ związku $z \mathrm{NZ}$ zajmujemy się $w$ innym miejscu $^{17}$.

Art. 36, 67. Nie wiemy, na jakiej podstawie autor przyjął, że rodzina pruska posiadała charakter osoby prawnej. Fakt ten nie wynika bynajmniej $\mathrm{z}$ art. 36 i 67, które tego mają dowodzić.

Art. 46. Nie widzimy trudności w rozumieniu tego artykułu, tymczasem dopatruje się ich autor (s. 98).

Art. 49. Nie widzimy racyj, by w tym artykule dopatrywać się przymusu wyrzekania norm zwyczajowych (s. 48). Jego istnienie skłonni bylibyśmy uzasadnić względami fiskalnymi.

Art. 57, 69. Oba te artykuły zajmujące się granicami w przedstawieniu prof. Paszuty są zabarwione politycznie. Jego zdaniem, chodzi w nich o granice majątków zagarniętych przez Krzyżaków i ich administrację. Dlatego to miano ustalić tak wysoką karę, bo aż karę śmierci ${ }^{18}$. Zauważmy, że w tekście brak zupełnie wskazówki co do tego, o rozgraniczenie jakich ziem chodziło. A zatem teza autora, że mowa tam o ziemiach zagrabionych Prusakom przez najeźdźcę, jest tylko domysłem. Przyznajemy, że sama w sobie nie jest ona nieprawdopodobna. Ale źródło podkreśla silnie fakt, że chodzi o granice, wo die herschafft und die sachwalden machen eine grenitze und setzen; wysoka więc sankcja grożąca przestępcy wiąże się raczej z lekceważeniem wyraźnej decyzji władzy. Na podstawie tego artykułu nie możemy wyłączyć moźliwości, że nawet granica ustalona przez administrację państwową między dwoma majątkami pruskimi korzystała $\mathrm{z}$ takiej samej surowej ochrony prawnej. Tym samym wszakże pozbawiamy omawiany artykuł nacjonalistycznego zabarwienia. Tak samo niewłaściwa wydaje się interpretacja art. 69. W zwykłym sporze o granice, przy czym zwyczaj stoi na stanowisku bliższości dowodu tej osoby, do której należała gewere, autor dopatruje się jakiegoś konfliktu społecznego, w którym feudałowie pruscy zagarnąwszy cudzą ziemię i władając nią, znajdowali sobie bez trudu dwunastu wiarygodnych świadków (oczywiście po to, by dowodzić falszywie swoich praw). W rezultacie - w świetle wywodów autora - artykul ten ostrzem swym zwracal się przeciwko prostym ludziom pracy, Pomezanom ${ }^{19}$.

Art. 61. Wysokości główszczyzny dowodzi się świadkami lub dokumentem. $\mathrm{Z}$ tego artykułu autor wysunął wniosek o tym, że pismo u Prusów od

\footnotetext{
${ }^{17}$ Rzekome rycerstwo niższe w najstarszym zwodzie prawa polskiego, RH, r. 23, 1957.

${ }^{18}$ Takaż wypowiedż wcześniej w cytowanym w przyp. 1 artykule prof. Paszuty, s. 115.

19 Że chłopi zaorywali sobie wzajemnie miedze, o tym mówi wyraźnie art. 19 NZ.
} 
dawna znajdowało zastosowanie, co wydaje się za daleko idące. Podobnie nie możemy się zgodzić $\mathrm{z}$ rozumowaniem następującym.

Art. 68. mówi o fałszowaniu dokumentów w tym celu, by udowodnić podległość prawu pomezańskiemu. Autor tymczasem powołuje się na ten artykul, pisząc o dziedziczeniu testamentowym (s. 59).

Art. 77. Opierając się na tym artykule, stwierdza autor, że najem stanowił zwykłą droge zamiany w feudalną niewolę ( $w$ feodalnuju kabalu), po czym dodaje, że nieprzypadkowo w niektórych artykułach słudzy zbliżają się do nie wolników (cholop). Wolelibyśmy tego terminu nie używać dla okresu, z którego pochodzą IP.

Art. 78,79. Niesłusznie autor pisze o obowiązku stawiennictwa ciążącym rzekomo na obu stronach, winnym i poszkodowanym, pozwanym i powodzie (s. 97). Oddalenie powództwa w razie niestawiennictwa powoda, art. 79, nie jest karą; sędzia traktowal tego rodzaju zachowanie się strony jako milczące cofnięcie pozwu. $\mathrm{Z}$ art. 78 widać wyraźnie, jak państwo w sprawach karnych stara się uniemożliwić jednanie zainteresowanych. Skoro poszkodowany już raz zgłosil swoje roszczenia przed organem państwowym (komornikiem), nie może już od skargi odstąpić, lecz musi ją popierać przed sądem. Podobny wniosek wysnuć można $z$ art. 96. Obserwujemy zatem w IP fazę przejściową od dochodzenia prywatnego przestępstw do dochodzenia $\mathrm{z}$ urzędu.

Art. 80 stwierdza, że w razie zabójstwa bliźniąt, każde z nich należy uważać jako jednego człowieka. Autor zaliczył ten artykuł do swojej pierwszej grupy na podstawie domysłu stawionego na s. 88: „być może, że w przedfeudalnej przeszłości załatwiano to zagadnienie inaczej". Oczywiście nawet gdyby ten domysł mial się okazać trafny, nie możemy wyłączyć, że ten artykuł przynależy również do grupy drugiej. Ze swej strony rzucamy pytanie, czy nie chodzi w nim o dzieciobójstwo.

Art. 82. Prof. Paszuto stwierdza, że artykul ten, mówiąc o jednaniu i zakładzie, zawiera wiele niejasności; po czym pisze tak: nie wiemy, gdzie należy składać pieniądze, możliwe, że wręcza się je urzędnikom. Pod uczciwymi ludźmi należy się domyślać gminnej arystokracji (?), z jej grona wywodzą się gwaranci pokoju (?). Naruszający mir winien zwrócić pieniądze rękojmi dane na „przymerzenie”. Trzeba przypuścić, że suma zakładu w danym wypadku staje się dochodem państwowej władzy. Jeśli te domysły są trafne, to mamy podstawę widzieć w rozpatrzonym artykule świadectwo dobrze znanego $w$ innych prawach zjawiska podporządkowania państwu gminnych norm prawnych. Na nasz gust autor stanowczo za wiele stawił tu domysłów i to raczej nietrafnych.

Art. 99 stawia zasadę, że oskarżyciel posiadający naocznych świadków kradzieży, morderstwa lub zabójstwa, będzie dopuszczony do przeprowadzenia dowodu przed oskarżonym, proponującym przysięge oczyszczającą z 12 
współprzysiężnikami. Autor na tej podstawie pisze o stosunku świadków oskarżyciela do świadków oskarżonego: 7 świadków oskarżenia odpowiadalo swą wagą 12 współprzysiężnikom. Ten wniosek jest w całości bezprzedmiotowy.

Art. 100. Autor pisze o zbrojnym oporze przeciwko ciemiężycielom narodu (s. 70). My byśmy ujęli rzecz prozaiczniej: jeśli w czasie egzekucji egzekwowany stawia opór, a woźny (komornik) - jak się domyślamy - egzekucje przeprowadzal siła, przy czym doszło do ran lub pozbawienia życia, wtedy egzekutor nie odpowiada przed sądem.

Art. 112. Nie pisalibyśmy o ogrodniku (Gerthner), że był pozbawiony ziemi zupełnie, lecz że tylko jej mało posiadal, jak to zresztą autor sam stwierdza, mówiąc, że ogrodnik otrzymywal w użytkowanie ogród (s. 46).

Art. 114 mówi o odpowiedzialności rodziców za dziewięcioletnie dziecko, które utopiło inne dziecko. Wbrew autorowi nie widzimy tu żadnej trudności w kwestii odprzysiężenia się ojca: nie rozumiemy zupełnie wniosku autora o zależności decyzji sędziego od jego biegłości.

Art. 118 nazwany zostal przez prof. Paszutę bardzo niejasnym. Dopatruje się on $w$ tym artykule ochrony praw silnego, który zawładnął cudzym majątkiem; my tymczasem widzimy w nim oznaczenie terminu prekluzyjnego dla dochodzenia praw wynikających $\mathrm{z}$ retraktu rodowego. Wydaje się, że niewlaściwe rozumienie artykułu przez autora było następstwem niepotrzebnego wtrętu wsuniętego do tekstu rosyjskiego przez thumaczkę, co zagmatwało wyraźną myśl zwodu. Nadając tekstowi naszą interpretację, tym samym wypowiadamy się przeciwko tezie prof. Paszuty, jakoby Prusowie nie znali rodowego prawa skupu. Taki stan rzeczy byłby rzeczywiście dziwny, zważywszy że nie tylko sąsiednie kraje znają tę instytucję, lecz występuje ona chyba w całej ówczesnej Europie (pomijamy tu świat bizantyjski). Prostując wykladnię omawianego artykułu, pozbawiamy prawo pruskie rzekomej jego oryginalności w tym szczególe.

Art. 119 zajmuje się kwestią ponoszenia kosztów leczenia osoby poranionej, przy czym obowiązek ten ciąży na raniącym. Autor tymczasem na podstawie tego artykułu pisze o talionie przedfeudalnym (s. 84-5). Talionu dopatruje się on również w art. 124 (s. 86) i art. 54, choć w ostatnim ma to być talion naiznaku.

Art. 125. Nie zgadzamy się w zupelności z prof. Paszutą, gdy omawiając kary cielesne twierdzi, że prawo pruskie znało karę ucięcia ręki czy dwu palców. Jeśli na tezę mówiąca o stosowaniu kary szyi i obcięcia ucha autor powołuje się na artykuły, które wyraźnie wspominają o takich sankcjach, to przy karze ucięcia ręki czy palców cytuje się artykuły, w których porusza się kwestię sposobu zlożenia przysięgi czy to ręką, czy dwoma palcami. Oto jak uzasadnia autor swoje stanowisko: , Z Z k kadam y, że odpowiedzialność ręką i dwoma palcami pierwotnie także należała do kar wymierzanych na 
członkach ciała i dopiero później przemieniła się w przysięgę” (s. 94-5). Ten domysł wydaje się nam bardzo ryzykowny, osobiście uważamy go za wręcz nie do przyjęcia. Zacytowane wyżej zdanie autora opiera się $\mathrm{m}$. in. także na art. 125.

Tenże artykuł łącznie $\mathrm{z}$ art. 124 zajmuje się zagadnieniem wieloczynowego zbiegu przestępstw. Tak też, jak się wydaje, rozumie je autor (s. 93-9); na innym miejscu wszakże interpretacja jego idzie w innym kierunku (s. 95).

Uwagi poczynione wyżej nie mogą w niczym umniejszyć zasług prof. Paszuty położonych $w$ badaniach nad prawem pruskim. Sa one niezaprzeczalne. Opracowanie jego jest pierwszym systematycznym opisem instytucyj pruskich, mimo że od ogłoszenia zabytku przez Labanda upłynęło już niemal 100 lat (1866). Dzieło prof. Paszuty służyć będzie jako przewodnik po zwodzie pruskim, tym bardziej że publikacja Labandowska (jak zresztą i wydanie prof. Paszuty) nie zostało zaopatrzone w indeks. Na podkreślenie zasługują usiłowania autora, by zwód pruski rozpatrywać porównawczo. Nie bez racji stwierdza np., że niejasny art. 62 IP można zrozumieć w zestawieniu $\mathrm{z}$ art. $21 \mathrm{NZ}$ (s. 103).

Żałujemy, że autor nie zaopatrzył swej pracy w zestawienie artykułów przez siebie omówionych $\mathrm{z}$ wskazaniem stronic, na których to omówienie ma miejsce (tak jak to zrobił np. w swej pracy M. Handelsman ${ }^{20}$, ono by niewątpliwie ułatwiło czytelnikowi wykorzystanie bogatego dorobku autora. Stwierdźmy też pewne niedostatki bibliograficzne. Pisząc o prawie rycerskim w Polsce, prof. Paszuto powołuje się na Hubego (1874!) na s. 52, choć niewątpliwie nie obce mu są prace prof. $Z$. Wojciechowskiego poświęcone temu zagadnieniu. Zastanowić się też można nad celowością cytowania $\mathrm{w}$ tekście artykułów in extenso, $\mathrm{i}$ to jeszcze $\mathrm{w}$ thumaczeniu rosyjskim, zamiast jedynie miarodajnego oryginału niemieckiego, gdy czytelnika latwo odesłać do załączonego do wydawnictwa źródła ${ }^{21}$.

${ }^{20}$ M. Handelsman, Prawo karne, s. 221-2.

${ }^{21}$ Idąc za wzorem prof. Paszuty, wydaliśmy Iura Prutenorum, Tow. Naukowe w Toruniu, Fontes 53, Toruń 1963, zaopatrując je w równoległe thumaczenie polskie. Edycję poprzedza wstęp, uzupetnia przegląd zagadnien, tabela konkordacyjna oraz indeks pióra $\mathrm{H}$. Zawadzkiej. Ocenę tej publikacji dają H. Th(ieme), ZRG. GA, t. 80, 1963, s. 569-579, H. Lowmiański, Zapiski Hist., t. 29, 1964, s. 592-3, V. Prochazka, Pravně-historické studie, t. 10, 1964, Praha 1965, s. 246, K. Górski, Studia Źródłoznawcze, t. 10, 1965, s. 183. 


\section{Motywacja ignorancyjna w dokumentach prawa niemieckiego*}

Przykłady. Poglądy dotychczasowe. O klauzulach rezerwacyjnych i renuncjacyjnych w ogólności. Kwestia ignorantia iuris. Analiza klauzul ignorancyjnych. Występowanie rezerwacyj bez motywacji ignorancyjnej. Póżne pojawienie się motywacji ignorancyjnej. Pozostaje ona bez wartości dla oceny stosunków faktycznych.

W niektórych przywilejach zawierających nadania prawa niemieckiego wśród klauzul końcowych aktów pojawia się postanowienie o uchyleniu ujemnych następstw, jakie mogłyby wyniknąć dla wystawcy $z$ nieznajomości prawa niemieckiego. Dokumentów z podobnymi postanowieniami znaleźliśmy $45^{1}$. Ponieważ klauzula ignorancyjna jest ujęta dość stereotypowo, przytoczymy tylko trzy jej przykłady: najstarszy z 1294 r., najmłodszy z 1404 r. oraz wyjątkowy, bo od panującego pochodzący z 1362 r.; zestawienie wszystkich znanych nam wzmianek dajemy w przypisie ${ }^{2}$.

* Przedruk z: Studia historica w 35-lecie pracy naukowej Henryka Lowmiańskiego, Warszawa 1958 , s. $167-79$.

${ }^{1} \mathrm{Nie}$ przewertowaliśmy wszystkich kodeksów dyplomatycznych, lecz jedynie następujące: Kodeks dyplomatyczny Wielkopolski [dalej: KDWP], t. 1-5; Kodeks dyplomatyczny Małopolski [dalej: KDMP], t. 1-2; Kodeks dyplomatyczny Katedry Krakowskiej [dalej: KDKK], t. 1-2; Codex diplomaticus Poloniae [dalej: CDP], t. 1-2; Codex diplomaticus Silesiae [dalej: CDSil], t. 1-2; G. A. Tzschoppe und G. A. Stenzel, Urkundensammlung zur Geschichte des Ursprungs der Städte und der Einführung und Verbreitung deutscher Kolonisten und Rechte in Schlesien und der Ober-Lausitz, Hamburg 1832 [dalej: Tzschoppe-Stenzel], oraz B. Ulanowski, Dokumenty kujawskie i mazowieckie przeważnie z XIII wieku [dalej: DKM]. Nie sądzimy, by odkrycie dalszych jeszcze przykładów zmusiło do zmiany toku naszych wywodów. - Skróty wzorowane na H. F. Schmida, Die rechtlichen Grundlagen der Pfarrorganisation auf westslavischem Boden und ihre Entwicklung während des Mittelalters, Weimar 1938, s. XXIII-XXXVI. Uczony ten dał najpełniejsze zestawienie literatury $\mathrm{i}$ żódel z przemyślanym i konsekwentnie przeprowadzonym systemem skrótów.

${ }^{2}$ 1. Arcybiskupa gnieźnieńskiego z 1294 r. KDWP 2, nr 727; 2. Tegoż arcybiskupa z 1298 r., DKM 369, nr 17; 3. Biskupa poznańskiego z 1298 r., KDWP 2, nr 789; 4. Archidiakona whocławskiego z 1327 r., ibidem, nr 1077; 5. Arcybiskupa gnieźnieńskiego z 1330 r., ibidem, nr 1108; 6. Tegoż arcybiskupa z 1334 r., ibidem, nr 1139; 7. Tegoż arcybiskupa z 1341 r., KDWP 3, nr 2048; 8. Dziekana gnieźnieńskiego z 1345 r., ibidem, nr 1238; 9. Kapituły gnieźnieńskiej z 1351 r., ibidem, nr 1306; 10. Kapituły poznańskiej z 1355 r., ibidem, nr 1332 
Wzmianka 1. z 1294 r. Arcybiskup gnieźnieński Jakub nadaje wieś Bukownica niejakiemu Trzebiesławowi dla lokowania jej na prawie niemieckim. Wystawca omawia dość szczegółowo zagadnienie wolnizny, wymienia obowiązki chłopów po jej upływie oraz uprawnienia sołtysa, po czym pomieszcza następujące zastrzeżenie: „Et quoniam iura predicte civitatis Sroda sunt nobis incognita, protestamur, quod in prescriptis et aliis omnibus, que suorum commodum respiciunt dominorum, ad iura predicta volumus nos tenere".

Wzmianka 20. z 1362 r. Kazimierz Wielki nadaje dwom braciom Janowi i Mikolajowi, zwanym Gielnicow, prawo lokowania wsi Ropczyce na prawie magdeburskim w charakterze miasta. Monarcha, omówiwszy obowiązki mieszkańców lokowanej osady po uplynięciu wolnizny oraz uprawnienia jurysdykcyjne wójtów, postanawia: „Cum itaque iura Magdeburgensia nobis sunt prorsus incognita, omnia iura, que commodum et utilitatem eorum respiciunt, salva nobis et integra super omnia reservamus".

Wzmianka 45. z 1404 r. Arcybiskup gnieźnieński Mikołaj nadaje Janowi, murarzowi z Uniejowa, solectwo wsi Smólsko. Omówiwszy uprawnienia i obowiązki soltysa, wystawca dodaje: „Sed quia iura Theutonica [...] sunt nobis penitus ignota, ideo omnes honores et utilitates nostrum dominium concernantes pro nobis et nostris successoribus integraliter reservamus".

(prawdopodobnie ten akt miał na myśli M. Wiszniewski, Historia literatury polskiej, t. 2, Kraków 1840, s. 383; za nim M. F. Wladimirskij-Budanow, Niemieckoje prawo w Polsze i Litwie, S. Petersburg 1868, s. 30, p. 2); 11. Biskupa poznańskiego z 1357 r., DKWP 3, $\mathrm{nr} 1361 ; 12$. Archidiakona poznańskiego z 1357 r., ibidem, $\mathrm{nr} 1362 ; 13$. Dziekana poznańskiego z 1358 r., ibidem, nr 1384; 14. Arcybiskupa gnieźnieńskiego z 1359 r., ibidem, nr 1398; 15. Scholastyka gnieźnieńskiego z 1360 r., ibidem, nr 1428, przedruk $i b$. 5, nr 261; 16. Biskupa poznańskiego z 1360 r., ibidem, nr 1435; 17. Tegoż biskupa z 1360 r., ibidem, nr 1441; 18. Arcybiskupa gnieźnieńskiego z 1361 r., ibidem, nr 1456; 19. Kanonika gnieżnieńskiego z 1361 r., ibidem, nr 1459; 20. Kazimierza W. z 1362 r., KDMP 1, nr 266; 21. Biskupa poznańskiego z 1363 r., KDWP 3, nr 1498; 22. Prepozyta Kościelnej Wsi z 1363 r., ibidem, nr 1506; 23. Dziedzica Czepowa z 1364 r., ibidem, nr 1516; 24. Biskupa poznańskiego z 1364 r., ibidem, nr 1525; 25. Tegoż biskupa z 1364 r., ibidem, nr 1526; 26. Archidiakona poznańskiego z 1365 r., ibidem, nr 1543; 27. Komendatora zakonu św. Jana pod Poznaniem z 1366 r., ibidem, nr 1558; 28. Dziedzica Kunowa z 1366 r., ibidem, nr 1568; 29. Biskupa poznańskiego z 1367 r., ibidem, nr 1586; 30. Prepozyta gnieźnieńskiego z 1368 r., ibidem, nr 1604; 31. Biskupa poznańskiego z 1369 r., ibidem, nr 1614; 32. Tegoż biskupa z 1369 r., ibidem, nr 1615; 33. Prepozyta gnieźnieńskiego z 1370 r., ibidem, nr 1632; 34. Arcybiskupa gnieźnieńskiego z 1370 r., ibidem, nr 1633; 35. Biskupa poznańskiego z 1370 r. ibidem, nr 1638; 36. Prepozyta poznańskiego z 1376 r., ibidem, nr 1727; 37. Biskupa włocławskiego z 1379 r., DKM 264, nr 87; 38. Dziedzica Byszewa z 1383 r., KDWP 3, nr 1812; 39. Prepozyta gnieźnieńskiego z 1385 r., ibidem, nr 1834; 40. Arcybiskupa gnieźnieńskiego z 1385 r., ibidem, nr 1838; 41. Kapituły gnieźnieńskiej z 1390 r., ibidem, nr 1897 (cytują M. Wiszniewski i M. Wladymirskij-Budanow, $l$. c); 42. Kanonika poznańskiego z 1396 r., KDWP 3, nr 1972; 43. Klasztoru lubińskiego z 1400 r., ibidem, 5, nr 5; 44. Archidiakona poznańskiego z 1400 r., ibidem, $\mathrm{nr} 7$; 45. Arcybiskupa gnieźnieńskiego z 1404 r., ibidem, nr 62. 
Jak wiadomo, polemika o istotne znaczenie prawa niemieckiego toczy się od dłuższego czasu. Ze strony polskiej główne zasługi w jego wyjaśnieniu położył prof. K. Tymieniecki ${ }^{3}$, choć ze strony niemieckiej nie brak trzeźwych głosów zrywających $\mathrm{z}$ nacjonalistyczną postawą ${ }^{4}$. Jeśli jednak spory wśród uczonych w sprawach instytucji wygasłej już od setek lat są całkiem zrozumiałe, to zastanawiająca wydaje się nieznajomość prawa niemieckiego w okresie praktycznego stosowania tego prawa.

Przytoczone klauzule nie uszły uwagi badaczy dawniejszych. Pierwszy bodaj zajął się nimi M. Wiszniewski. „Cokolwiek bądź - pisze on - książęta nadawali prawo teutońskie nie tylko nie przewidując skutków jego dla siebie, lecz co większa nie wiedząc nawet, co wlaściwie udzielone prawo oznaczało; co nawet często otwarcie w dyplomach oznajmiano... Ta nawet wątpliwość dogadzała niekiedy biorącym przywilej, gdy przez to przywilej różnie nakręcać się i thumaczyć dawał. Kanclerze piszący nadania nie mogli się odwoływać do prawa magdeburskiego pisanego, bo go jeszcze nie było, albo jeśli już co dla pamięci spisano, nie było upowszechnione; bo jeszcze wówczas kunszt pisania był rzadki, a wyrocznie tajemnej mądrości więcej mialy powagi"'s.

Dostrzegł klauzulę również J. T. Lubomirski: „Kmiecie w swoim pośpiechu nie pozostawiają nawet dziedzicom dość czasu do poznania treści nowego prawa [niemieckiego], skutkiem tego ci ostatni nadając przywileje, wyznają, że nie są świadomi praw, jakimi obdarzają"6.

Problemowi omawianemu poświęcil też uwagę M. F. Wadimirskij-Budanow. Jego zdaniem, koloniści usiłowali zachować prawa rodzime, do których przywykli. Chcąc więc ich do siebie przyciągnąć, książęta nadawali im co do nich gwarancje. Tym samym wszakże nie zrzekali się własnej jurysdykcji. Nie równalo się to nadaniu autonomicznego ustroju sądownictwa i administracji, lecz tylko niższej jurysdykcji za przestępstwa nie pociągające za sobą kary śmierci. Tymczasem „,książęcy urzędnicy, wojewodowie i kasztelanowie nie mogli, jak to samo przez się jest jasne, zadośćuczynić takiemu zapotrzebowaniu kolonistów. Podobnie także i feudałowie dla tej samej przyczyny nie mogą bezpośrednio ciągnąć korzyści z darowanej im niższej jurysdykcji, to jest nie byli oni w stanie rozpatrywać występków według praw i obyczajów

\footnotetext{
${ }^{3}$ Ob. mój artykuł w Czasop. Prawno-Historycznym 2 (1949), s. 76 i nn., oraz K. Tymieniecki, Pisma wybrane, Warszawa 1956, s. 287.

"W. Maas, "Loi de Beaumont" und Ius Theutonicum, Vierteljahrschrift f. Sozial- u. Wirtschafısgeschichte, XXXII (Stuttgart 1939), s. 209-27. Trafne wydaje się określenie „europāisches Siedlungsrecht" użyte w Zeitschr. d. Savigny Stiftung f. Rechtsgeschichte 85 (1955), s. 309. Ob. też M. Bloch, La colonisation allemande en Pologne, Annales d'Hist. économique et sociale, 6 (1934), s. 593-8.

s M. Wiszniewski, op. cit., s. 383-4.

6 J. T. Lubomirski, Rolnicza ludność w Polsce, Bibl. Warsz. 20 (1861), s. 15.
} 
im nie znanych, o czym feudałowie wprost mówią czasami w wydanych przez siebie przywilejach (mówiq np., że miejskie prawo jest im całkiem nie znane). Jasne, że książę razem $\mathrm{z}$ feudałem winien był stworzyć w każdej kolonii nową formę administracji według niemieckiego prawa i mianować urzędnika obeznanego $\mathrm{z}$ niemieckimi zwyczajami prawnymi. Takie okoliczności posłużyły za podstawę do powszechnego ustanowienia $w$ koloniach (niemieckich) wójtów i sołtysów, i określiły pierwotną formę tego urządzenia"?.

Według E. Schmidta, nadanie prawa niemieckiego obejmowalo jedynie trzy zasady: (1) zwolnienie od wszelkich ciężarów prawa polskiego, (2) nadanie osobistej wolności, (3) możność uregulowania życia publicznego w pewnym stopniu samodzielnie. „So werden auch die Einzelbestimmungen und Unterscheidungen des Magdeburger oder Neumarkter Rechtes den Landesund Grundherren nicht näher bekannt gewesen sein, was sie übrigens auch bis tief in das 14. Jahrhundert hinein in ihren Urkunden öffentlich zugestanden. Auch dieser Unbekanntschaft der Fürsten mit dem deutschen Rechte ist es auch zu erklären, dass sie das doch nur auf städtische Verhältnisse zugeschnittene Magdeburger oder Neumarkter Recht auch an sehr zahlreiche Dörfer verliehen"8.

Powohując się na poprzedniego autora, stwierdza G. Schubart-Fikentscher, że prawo niemieckie było częstokroć użyte jako określenie zbiorowe w odróżnieniu od prawa miejscowego. „Ob man aber weiter sagen kann, dieser allgemeine Ausdruck sei gewählt, weil die slawischen Fürsten Einzelheiten bestimmter deutscher Stadtrechte nicht gekannt hätten, erscheint mir sehr zweifelhaft, zum mindesten für Schlesien. Denn hier ist schon früh erkennbar, wie bekannt einzelne Stadtrechte waren und eben deswegen unter ihrem Namen verliehen wurden".

Z tych przytoczonych wyimków widać, że poza ostatnią autorką reszta brała omawianą klauzulę za dowód niezbity nieznajomości prawa niemieckiego w Polsce. G. Schubart-Fikentscher ten pogląd wydaje się wątpliwy, przynajmniej co do Śląska. Jakiż więc jest rzeczywisty sens ignorancyjnej klauzuli?

Zauważmy, że występuje ona w końcowych postanowieniach dokumentów, zawierających postanowienia renuncjacyjne i rezerwacyjne. Przy umowach dwustronnych istnieje mianowicie obawa zarówno po stronie nabywającego prawo, jak i u zbywcy. Pierwszy niepokoi się o to, czy nabyte przezeń prawo przelane zostało $w$ całości, czy alienatorowi nie pozostały jeszcze jakieś uprawnienia, na mocy których mógłby ograniczać swobodę nabywcy.

${ }^{7}$ M. F. Wladymirskij-Budanow, op. cit., s. 30.

${ }^{8}$ E. Schmidt, Geschichte des Deutschtums in Lande Posen unter polnischer Herrschaft, Bromberg 1904, s. 126.

${ }^{9}$ G. Schubart-Fikentscher, Die Verbreitung der deutschen Stadtrechte in Osteuropa, Forschungen zum deutschen Recht, Bd. 4, H. 3, Weimar 1942, s. 153. 
Stąd też wymaga od zbywcy klauzuli renuncjacyjnych, szczegółowych $i$ generalnych. $Z$ drugiej strony zachodzi obawa, by nabywca uprawnienia nie rozumial nadania zbyt szeroko, $\mathrm{z}$ uszczerbkiem nadawcy, wobec czego ostatni pomieszcza klauzule rezerwacyjne.

Klauzulami tymi zajmowano się niejednokrotnie w literaturze ${ }^{10}$. Uważano je za przejaw reakcji zarówno przeciwko prawu rzymskiemu, jak i barbarzyńskiemu, ale także dopatrywano się w nich istotnego czynnika przeksztalcenia importowanego prawa, jego przystosowania do poglądów i stosunków miejscowych ${ }^{11}$; podnoszono również, że czasami shużyły one jedynie dla pokazania uczoności pisarza, który zbierał wszystkie ekscepcje znane rzymskiemu prawu i przytaczal je, choćby nie mialy żadnego związku z aktem prawnym, do którego je wlączal. Wskazywano na nie jako na dzieło kościoła, który je propagowal ${ }^{12}$. Stwierdzono, że dawały one wyraz przekonaniu, że umowa stoi przed przepisem prawnym ${ }^{13}$. Wreszcie podkreślano, jak to w prawie rzymskim obligacyjnym gromadzono je na korzyść dłużnika, $\mathrm{i}$ jak wierzyciele trzynastowieczni $\mathrm{z}$ trudnością tylko dopuszczali to uprzywilejowanie dhużnika nawet będącego $w$ złej wierze ${ }^{14}$. Rozwijały się one głównie w aktach prawa prywatnego, przede wszystkim gdy wystawcą byl duchowny ${ }^{15}$, ale nie wahano się posługiwać się nimi również $w$ aktach administracyjnych, mających zatem charakter publiczny, co zresztą w stosunkach średnowiecznych nie może razić.

Dwustronnymi umowami były $\mathrm{m}$. in. kontrakty lokacyjne prawa niemieckiego. Zawierał je wystawca przywileju, właściciel ziemski, z przedsiębiorcą lokacyjnym, zasadźcą, sołtysem czy wójtem. Spotykamy w tych kontraktach

${ }^{10}$ Por. o nich A. Giry, Manuel de diplomatique, Paris 1894, s. 557-8, 560-2, oraz K. Przybyłowski, Klauzula „rebus sic stantibus" w rozwoju historycznym. Pam. Hist.-Prawny III, (Lwów 1928), z. 1, s. 72, i tamże przyp. 1; A. de Boüard, Manuel de diplomatique française et pontificale, t. 1, Paris 1929 , s. 285 i nn. Ob. też artykuły cytowane w przypisach następnych. Sami zajmowaliśmy się niedawno klauzula zastrzegająca sądownictwo księcia w sprawach o causae hereditariae: Causae hereditariae klauzul immunitetowych, Czasop. Prawno-Historyczne VIII, (1956), s. 3-92 [Patrz: Pisma wybrane, t. I, s. 323-350]; wszakże to zastrzeżenie, jak się wydaje nie jest przejęte $\mathrm{z}$ rzymskiego prawa.

${ }^{11}$ E. Meynial, Des renonciations au moyen-âge et dans notre ancien droit. Nouvelle Revue historique de droit français et étranger, 24 (Paris 1900), s. 111, 113. Tezy te przypomina ostatnio E. Genzmer, Hugo von Trimberg und die Juristen. Studi in memoria di Paolo Koschaker, t. 1, Milano 1954, s. 326-7.

${ }_{12}$ A. Giry, op. cit., s. 560; tak też E. Genzmer, op. cit., s. 327, 332.

${ }^{13}$ E. Genzmer, op. cit., s. 332; J. Gillisen, L'apparition des renonciations aux exceptions de droit romain dans le droit flamand au XIIr siècle, Mélanges Fernand de Visscher, t. 3. Bruxelles 1950, s. 514.

14 J. Gillisen, op. cit., s. 515.

15 R. Feenstra, Zur Rezepzion in den Niederlanden. Studi in memoria di Paolo Koschaker, t. I, Milano 1954, s. 259. 
zastrzeżenia dla obydwu stron, na korzyść obdarzonych prawem niemieckim ${ }^{16}$, jak też i na rzecz feudała udzielającego przywileju ${ }^{17}$. $Z$ reguły jednak nie powohuja się wystawcy na nieznajomość prawa, a jeśli już o niej się mówi, to przewiduje się ją u obdarzonych przywilejem mieszczan. W takim zaś wypadku osiągający prawo niemieckie np. glogowianie mają się uciec po pouczenie do Wrocławia ${ }^{18}$. Ale przytoczone na początku klauzule nie o tego rodzaju ignorantia iuris mówią. Chodzi w nich o nieznajomość prawa u wystawcy przywileju ${ }^{19}$.

Ponieważ zwrot ignorantia iuris jest zapożyczony z prawa rzymskiego, przypominamy jego postanowienia $\mathrm{w}$ tym względzie. ,Regula est, iuris quidem ignorantiam cuique nocere, faci vero ignorantiam non nocere" 20 . Prawo rzymskie odróżnia zatem niewiedzę faktu i niewiedzę prawa. Druga jest szkodliwa, pierwsza ujmy nie przynosi ${ }^{21}$. Pomińmy tu już zagadnienie, czy do omawianych klauzul dają się w pełni zastosować normy rzymskie, czy rzeczywiście mamy $w$ nich do czynienia $\mathrm{z}$ ignorantia iuris, oraz czy normy prawa cywilnego wolno stosować w prawie administracyj-

${ }^{16} \mathrm{Np.}$ w przywileju ks. legnickiego, Bolesława III dla m. Hainau z r. 1332: ,„..omnia iura scripta et non scripta nostrorum civium Ligniczensium, videlicet iura Meydeburgensia et alia iura super modiis, mensuris, ulnis, molaribus [...] nec non metretis, quemadmodum hiidem cives nostri Ligniczenses habent pro nunc et habuerunt ex antiqua revolucione annorum plurimorum et sicuti in posterum habebunt ex parte nostri ipsius et nostrorum progenitorum ducum et principum Slesie ...", Tzschoppe-Stenzel, Urkundensammlung, s. 534, nr 142, ob. też KDMP 1, nr 278 (r. 1365).

17 „Insuper id nostri beneplaciti est, si scabini civitatis Svidenicensis aliis civitatibus et villis circa se situatis si quas earum dominus et princeps subordinaverit, que prius ius Magedeburgense non habuerunt, possint et valeant ius Magedeburgense et sentencias iuris a nobis datas ulterius distillare, dummodo sic ordinetur, quod iuri nostro, nobis et nostris sequacibus, per huiusmodi amministracionem ulteriorem nil derogetur", Txschoppe-Stenzel, op. cit., $\mathrm{nr} 180$ (r. 1363).

${ }^{18} \mathrm{~Np}$. Tzschoppe-Stenzel, op. cit., s. 594, nr 185, r. 1373.

1s Inne zagadnienie stanowi znowu nieznajomość prawa u wyrokującego kompletu sędziowskiego. Zasadą jest iura novit curia, wszakże $w$ procesach politycznych niejednokrotnie sędziowie nie widząc rozwiązania zgodnego i z prawem i z racją stanu oświadczają, że prawa nie znają. Przypominamy tu słynną deklarację sędziów polskich orzekających $w$ sprawie zapisu Kazimierza W. dla Kaźka słupskiego. Chcąc uchylić się od odpowiedzialności, stwierdzają, że orzeczenie ich odnosi się do ziemian, a nie do książąt „cum iura ducalia quoad hoc essent eis penitus ignota", Kronika Janka z Czarnkowa, MPH, II, s. 641. O tych kwestiach por. ostatnio K. Kolańczyk, Studia nad reliktami wspólnej wlasności ziemi w najdawniejszej Polsce, SHPP XX (1950), s. 2, s. 256-9. Wiemy oczywiście co myśleć o tego rodzaju wyrokach dyktowanych wzgledami politycznymi, zob. H. Mitteis, Politische Prozesse des früheren Mittelalters in Deutschland und Frankreich, Sitzungsberichte d. Heidelberg. Akad. d. Wiss. Philosp.-hist. K1. 1926-7 (Heidelberg 1927). Znamienne też, że w omówionym wypadku panowie rady testament-pergamin pocięli i zniszczyli, K. Potkański, Sprawa restytucji, Kraków 1900, s. 165.

${ }^{20}$ Paul. D. 22, 6. 9.

${ }^{21}$ F. C. Savigny, System des heutigen römischen Rechts, t. 3, Berlin 1840, s. $325 \mathrm{nn}$; H. Dernburg - P. Sokolowski, System d. römischen Rechts ${ }^{8}$, t. 1, Berlin 1911, s. 150-2; B. Windscheid, Lehrbuch des Pandektenrechts, t. 1, Düsseldorf $1867^{2}$, s. $186-8$. 
nym $^{22}$. Skoro pisarze średniowieczni uważali to za właściwe, nie pozostaje nam nic innego jak akceptować ich stanowisko. W tych warunkach przejdźmy do analizy klauzuli ignorancyjnej.

Rozkłada się ona następująco pomiędzy wystawców: na pierwszym miejscu stoi biskupstwo poznańskie (20 wypadków) ${ }^{\mathbf{2 3}}$, na drugim arcybiskupstwo gnieźnieńskie (16 - z tym jednak, że pierwszy i ostatni znany dokument dotyczy właśnie tego arcybiskupstwa), następnie po jednym - biskup włocławski, archidiakon włoclawski, klasztor lubiński, prepozyt Kościelnej Wsi, kościół św. Jana w Poznaniu, trzej rycerze wielkopolscy i jeden raz w przywileju Kazimierza W. dla wsi małopolskiej. W rezultacie więc na 45 wypadków 44 dotyczy dzielnicy wielkopolsko-kujawskiej, jeden tylko - Małopolski ${ }^{24}$. Co więcej, stwierdzić trzeba, że omawiana klauzula stanowi właściwość formularza wielkopolskich biskupstw. Charakterystyczne są daty pojawienia się klauzuli w dokumentach niebiskupich, w klasztornym w 1363 r., rycerskim w 1364 r. Stwierdzić zatem możemy, że formularz kancelaryj biskupich w paru wypadkach przeciekł do aktów innych wystawców, duchownych i świeckich; $z$ reguły jednak ani przywileje klasztorne, ani rycerskie tej klauzuli nie znają ${ }^{25}$.

Omawiana klauzula pojawia się w ,prywatnych" aktach lokacyjnych (44 razy na 45). Jedyny wyjątek stanowi akt Kazimierza W. Tym samym przywilej jego stanowi podwójne odstępstwo od reguły, stanowiąc jedyny dyplom małopolski z klauzulą ignorancyjną oraz jedyny akt władcy. Skąd ją zaczerpnął pisarz dokumentu, pleban czchowski, nie zdołaliśmy stwierdzić. Dodajmy, że dzięki wstawieniu tej klauzuli do dokumentu Kazimierza W.

${ }^{22} \mathrm{Na}$ curiosum to zwracał uwage E. Meynial, op. cit., s. 109.

${ }^{23}$ Zaznaczamy, że pod jedną pozycją sumujemy przywileje biskupów i kapituł.

${ }^{24} \mathrm{Jak}$ się wydaje, brak zupetnie podobnych klauzul dla Sląska. Wyrywkowe badanie kodeksów nie dało żadnych wyników pozytywnych, por. wyżej przyp. 1. Fakt wydania dużej masy aktów jedynie $w$ regestach uniemożliwia pehniejsze badania. Podnieść wszakże możemy, $\dot{z} \mathrm{e} w$ dotychczasowej literaturze - charakterystyczne jest milczenie na ten temat obszernego wstępu do wydawnictwa Tzschoppe-Stenzel, Urkundensammlung - nikt na podobną klauzulę śląską nie wskazał, nie cytuje żadnej autorka, która ostatnio sį̨ tym zagadnieniem zajmowała, mianowicie G. Schubart-Fikentscher, op. cit.

${ }^{25} \mathrm{Nie}$ chcemy obciążać balastem zbẹdnych przypisów, dlatego dajemy jedynie kilka przykładów: przywileje rycerskie: KDWP 2, nr 213, 1299 r., ib., nr 934, r. 1310; KDWP 3, nr 1393, r. 1358; magnackie: KDWP 2, nr 848, r. 1302; ib, nr 864, r. 1303; ib., nr 1170, r. 1330; klasztorne: KDWP 3, nr 1365, r. 1357; ib., nr 1524, r. 1364; ib., nr 1928, r. 1392. Również na Zachodzie klauzule renuncjacyjne są szczególną właściwością oficjałów biskupów. Władze świeckie stosują je czasowo później i rzadko tylko, ograniczając sį̨ niemal tylko do klauzul generalnych. E. Genzmer, op. cit., s. 329; J. Gillissen, op. cit., s. 516, 550 . Ostatni autor podkreśla, że nie wszystkie instytuty kościelne korzystaja $\mathrm{z}$ nich $\mathrm{w}$ równym stopniu, $i b$., s. 518. Wynik nasz potwierdza trafność przypuszczenia R. Taubenschlaga o pośrednictwie duchowieństwa $w$ przedostaniu się formularzy zachodnich do Polski, Formularze czynności prawno-prywatnych w Polsce XII $i$ XIII wieku, SHPP 12 (1930), z. 3, s. 58, 59. 
powstały $w$ jej rozumieniu pewne trudności. Stwierdziwszy, że klauzula ignorancyjna stanowi wlaściwość dokumentów prywatnych, musimy sprostować zdanie M. Wiszniewskiego, powtarzane przez późniejszych autorów, jakoby panujący przyznawali się do ignorancji prawa niemieckiego. Zanotujmy jeszcze, że w jednym z wypadków wymienia się aż dwu ,ignorantów". Mianowicie w akcie lokacyjnym odnoszącym się do wsi kapituły gnieźnieńskiej, wystawionym przez arcybiskupa gnieźnieńskiego Janisława, wystawca oświadcza, że prawa niemieckiego nie zna ani on sam, ani też kanonik Bogusław, do którego prebendy lokowana wieś należała.

Ignorancja najczęściej dotyczy ,iura civitatis Srzoda", rzadziej ,iura civitatis Maydburgensis" - 1357, 1358, 1362, 1363, 1365, 1366, 1369 i 1376 r., raz ,iura Maydburgensia vel Srzedensia" - 1400 r., dwukrotnie ,iura Culmensia" - 1359 i 1370 r., czasem ogólnie „iura Theutonicalia" - 1345, 1367 i 1404 r.

Powiedzieliśmy wyżej, że klauzula ignorancyjna należy do postanowień rezerwacyjnych. Czyje prawa one zastrzegają? $Z$ reguly prawa właścicieli prywatnych (dominorum villarum itp.), wyjątkowo - bo raz tylko - obok nich wymienia się „,domini terre utpote duces" - $1298 \mathrm{r}^{26} \mathrm{~W}$ kłopotliwej sytuacji stawia nas dokument Kazimierza W. z 1362 r. Użyty w nim zaimek „eorum" nie thumaczy się jasno, albowiem odnosić się może tylko do mieszczan i soltysów. Drugi wszakże zaimek rezerwuje prawa dla "nobis" - wystawcy, a więc króla. Te trudności interpretacyjne wykazują, jak obca była wtłoczona tu klauzula pisarzowi, tak że nie potrafił jej właściwie spożytkować. Rezerwacje dotyczą nie tylko wystawcy przywileju, ale częstokroć również jego następców, ,salva nobis et nostris successoribus", lub też - co na jedno wychodzi - „salva dominio ville”, czy wyraźniej jeszcze „salva et integra dominis villarum predictarum, qui pro tempore fuerint" $-1370 \mathrm{r}$.

Jakie prawa zastrzega się w klauzuli? Powiedzieliśmy wyżej, że klauzula rezerwacyjna pojawia się $w$ dyplomach lokacyjnych po omówieniu szczególowym praw i obowiązków kolonistów i sołtysa. Zamyka więc ona stojącą przed nią grupe postanowień, z którymi jest jak najściślej związana. Od tej zasady znaleźliśmy tylko parę wyjątków, np. akty z 1366, 1383 i 1400 r., z których widać, że pisarz zapomnial pomieścić wcześniej pewne przepisy, wobec czego położył je po wspomnianej klauzuli. Wymieniwszy dokładnie obowiązki osadników należne zgodnie z prawem średzkim, pisarze niektórych dokumentów trafnie zaznaczają, że chodzi o ,alia iura Novi Fori" nie wymienione $w$ tekście, $\mathrm{z}$ lat 1366, 1383, 1385. Chodzi zaś o tę grupę uprawnień, które dotycza "commodum, honorem, dominium et utlilitatem", „commodum et utilitatem", „commodum (commoditatem) et honorem",

${ }^{26} \mathrm{DKM}$, s. 369, nr 17, r. 1298; zob. J. Matuszewski, Immunitet ekonomiczny w dobrach kościola w Polsce do roku 1381, Poznań 1932, s. 324, przyp. 5. 
„utilitatem, commodum et honorem", „omnes honores et utilitates”, „omnia iura et servicia”, „omnes et singulos honores”, „servitia et utilitates" oczywiście feudałów. Niektóre przywileje wychodzą poza te ogólniki, dodając jeszcze dalsze postanowienia: „quod salvum sit nobis idem ius Theutonicum Novi Fori [...] in solucionibus, exactionibus et serviciis, que racione iuris vel consuetudinis competunt vel competere poterunt in futurum" - 1298 r., ,que consueverunt in villis episcopatus Poznaniensis circumiacentibus observari" - 1357 r., ,iura dominium nostrum concernentia iuxta modum aliarum villarum nostrarum in predicto districtu Wolboriensi locatarum" - 1379 r., „omnia iura, utilitates, labores et honores, prout in aliis nostris villis capituli fieri est consuetum" - 1400 r. Przyjrzyjmy się jeszcze szczegółowym postanowieniom dorzuconym po klauzuli ignorancyjnej: „et eciam ipsi kmenthones tres in anno arare nobis tenebuntur" - $1366 \mathrm{r}$; $w$ drugim akcie $\mathrm{z}$ tegoż roku wymienia się obowiązki wojskowe sołtysa i chłopów. Niemniej wymowne są postanowienia występujące tuż przed klauzulą ignorancyjną: „,ceterum omnia alia iura et servicia seu soluciones, prout cetere ville nostre Theutonicales, eodem iure locate, faciunt, nobis solvere et exhibere teneantur" (oba akty z 1364 r.). Zestawione w tak dużej liczbie teksty nie pozostawiają żadnej wątpliwości co do intencji klauzuli. Chodzi w niej o to, by szczegółowe postanowienia kontraktu lokacyjnego nie stały się przeszkodą dla innych jeszcze roszczeń wlaściciela ziemskiego, nie pomieszczonych w akcie.

Klauzule rezerwacyjne występują także w dokumentach, w których nie podaje się motywacji $w$ postaci ignorancji prawa, np. $w$ akcie biskupa poznańskiego z 1310 r. czytamy: ,et nihilominus omnia iura et servicia alia, que nunc sunt in villis Theutonicalibus, et que excrescent in posterum, nobis et nostris successoribus, exhibebunt, que alii exhibent et exhibere debent suis dominis in iure Theutonico constituti" ${ }^{27}$. Takie zastrzeżenia są dość licznie reprezentowane ${ }^{28}$, występują również $\mathrm{w}$ przywilejach biskupstwa krakowskiego $^{29}$, co więcej - również wśród aktów panujących ${ }^{30}$. Wśród ostatnich

${ }^{27}$ KDWP 2, nr 935; podobnie ibidem, nr 1029 (1322 r.), 1168 (1337 r.), 1104 (r. 1329).

${ }^{28}$ Zacytujmy jeszcze przywilej prepozyta trzemeszeńskiego z r. 1357: , in aliis consuetudinibus iuris Theutunici memoratus scoltetus et incole pretacte hereditatis teneant se ad ius Novi Fori. quod Srzedske vulgariter nominatur", KDWP 3, nr 1353. Zob. też podobnie KDMP 1, nr 125 (r. 1295); KDWP 3, nr 1315 (r. 1352); ib. 2, nr 1029 (r. 1322); KDKK 2, nr 244 (r. 1328); nr 246 (r. 1331); KDWP 2, nr 1168 (1337 r.); KDMP 1, nr 222 (1347 r.); DKM, s. 266, nr 88 (r. 1379); charakterystyczna jest też klauzula rezerwacyjna biskupstwa krakowskiego z 1334 r. ,protestamur insuper, quod omnia et singula iura et beneficia, que ius predictum Sredense seu Noviforense contingunt, pro nobis in posterum reservamus", KDKK 2, $\mathrm{nr} 249$ (1334 r.); podobnie w wielu innych przywilejach tegoż biskupstwa, czasem bez czasownika "reservamus".

${ }^{29}$ KDKK 1, nr 180 (1340 r.); 182 (1347 r.); 230 (1363 r.).

${ }^{30} \mathrm{~Np}$. KDWP 2, nr 627 (1288 r.); 799 (1298 r.); 970 (1314 r.). 
klauzula rezerwacyjna przybiera nawet ustalone brzmienie „iuribus tamen regalibus in omnibus semper salvis" ${ }^{\prime 31}$. Przytoczymy wreszcie tak charakterystyczną rezerwacje aktu z 1345 r. ujętą niemal tak samo jak klauzule ignorancyjne, jednak bez tej właśnie motywacji ignorancyjnej: „alia eciam iura Sredensia, que commodum et utilitatem respiciunt dominorum, reservo integra atque salva, et secundum quod aliarum villarum capituli Gneznesis ecclesie dominis eorum servicia exhibebunt, ita prefatus scoltetus michi et meis successoribus exhibebit ${ }^{\prime 32}$.

Zwróćmy uwagę na jeszcze jeden szczegól, że nawet w kancelariach, w których używa się motywacji ignorancyjnej dość często, a więc w aktach biskupów wielkopolskich, spotykamy w niemałej liczbie akty prawa niemieckiego, bez uzasadnienia rezerwacji nieświadomością prawa ${ }^{33}$.

Podkreślmy jeszcze, że motywacja ignorancyjna pojawia się dopiero z końcem XIII w., po czym występuje dość regularnie przez całe stulecie XIV w., by wreszcie zaniknąć - sądząc na podstawie przejrzanych kodeksów - $\mathrm{z}$ początkiem wieku XV.

Jeśli $w$ momencie pojawienia się prawa niemieckiego $w$ Polsce jego przepisy mogły być w Polsce nie znane, to dla XIV i XV w. ta ewentualność nie może być brana $w$ rachubę. Podkreślmy jeszcze dla uwydatnienia słuszności naszego stanowiska fakt, że pisarze pomieszczają ignorancyjną motywację przy odnawianiu przywileju lokacyjnego sołtysowi (1385 r.) albo przy sprzedaży sołectwa we wsi, w której prawo niemieckie dotąd obowiq̨zywało, nowym sołtysom (1376 r.).

Widzimy zatem, że klauzula rezerwacyjna jest właściwością powszechną przywilejów prawa niemieckiego. Ona to umożliwi w przyszłości wprowadzanie ciąglych ograniczeń ludności zarówno wiejskiej, jak i miejskiej, przy ciągłym powoływaniu się na prawo niemieckie, które w ten sposób nabiera znamion pojęcia tak rozciągliwego, że mieści się w nim wszystko: zarówno stosunkowo wolne miasta królewskie, jak i miasta prywatne uciskane niemal jak wieś pańszczyźniana ${ }^{34}$.

Motywacja uzasadniająca rezerwację ignorancyjną prawa właściwa jest tylko pewnym kancelariom duchownym, z których formularza najwidoczniej

${ }^{31}$ KDKK 2, nr 348 (r. 1388); 360, 435, 453, 558 (1415 r.); KDMP 1, nr 301 (r. 1369); 328, KDWP 5, nr 117 (r. 1407), 317 (1420 r.). Przytoczmy tak charakterystyczna klauzule łącząca prawo rycerskie z prawem niemieckim: „Expiratis his annis (wolnizny) idem ius in eadem villa habebimus, quod alii principes in villis militalibus eodem iure locatis habere consueverunt, iure tamen Theutonicali in eadem villa semper permanente", KDWP 2, $\mathrm{nr} 627$ (r. 1288); zob. też ibidem, $\mathrm{nr} 970$ (1314 r.).

${ }^{32}$ KDWP 2, nr 1239 (1345 r.).

${ }^{33}$ Akty biskupa poznańskiego: KDWP 2, nr 755 (1296 r.); 757, 762, 1136, 1139; 3, nr 1531, 1752, 1915; 5, nr 134 (1408), arcybiskupa gnieźnieńskiego: KDWP 2, nr 1152 (1335); 3, $\mathrm{nr} 1698,2016 ; 5, \mathrm{nr} 118,126$.

${ }^{34}$ J. Mazurkiewicz, Jurydyki lubelskie, SHPP, ser. 2, t. V (Wrocław 1956), s. 64. 
w paru przypadkach korzystały osoby świeckie. Duchowni notariusze zaczerpnąwszy znajomości prawa rzymskiego ${ }^{35}$, tę wiedzę pragnęli zużytkować na co dzień, popisać się niejako nią w wygotowanych przez siebie aktach. Jeśli cytuje się nieraz klauzule $\mathrm{z}$ prawa rzymskiego nie pozostające $w$ żadnym związku $\mathrm{z}$ aktem $^{36}$, to logiczne, choć prawniczo slabe uzasadnienie rezerwacyjnej klauzuli nieznajomością prawa wydawać się musiało dla średniowiecznego umysłu świetnym chwytem. Będąc pozostalością powierzchownych studiów prawniczych, motywacja ignorancyjna nie odbija jakichś stosunków rzeczywistych, nie nadaje się przeto do wysnuwania jakichkolwiek wniosków faktycznych o stanie znajomości prawa niemieckiego w Polsce ${ }^{37}$. Równie ona bezbarwna i beztreściowa, jak tyle innych zwrotów zaczerpniętych $\mathrm{z}$ prawa rzymskiego czy pisma św. „Es sind dies alles überflüssige, oft unpassende Beiwerke gesuchter Eleganz" - powtórzmy za niemieckim badaczem ${ }^{38}$. Ale $w$ każdym razie omawiana klauzula jest wyraźnym dowodem „recepcji” rzymskich pojęc prawnych w Polsce.

Błąd popełniony przez dawniejszych badaczy, od $\mathbf{M}$. Wiszniewskiego począwszy, należy do tej samej kategorii omyłek, co „ścisła” interpretacja exceptio non numeratae pecuniae, prowadząca do wniosków najoczywiściej fałszywych ${ }^{39}$. $\mathrm{Z}$ wyrażeń zapożyczonych $\mathrm{z}$ prawa rzymskiego niebezpieczną

${ }^{35}$ Por. O. Stobbe, Geschichte der deutschen Rechtsquellen, t. 1, Leipzig 1860, s. 47.

${ }^{36}$ A. Giry, op. cil., s. 560-2.

${ }^{37} \mathrm{Nie}$ wiążemy jej ze zwrotem pojawiajacym się $w$ dwu pierwszych przywilejach $z$ motywacja ignorancyjna, mianowicie $w$ przywilejach arcybiskupa gnieźnieńskiego Jakuba z $1294 \mathrm{r}$. i 1298 r. Brzmi on w nich następująco: „,hereditatem ecclesie nostre, dictam Bukownicza [...] iure novo, quod est confectum in Sroda scilicet vel unde ius illud noscitur processisse, dedimus ad locandum", KDWP 2, nr 727, wzglednie: ,iure novo, quod est et servatur in Srzoda Slezie vel unde ius illud processit", DKM, s. 369, nr 17.

${ }^{38}$ O. Stobbe, op. cit., s. 649.

${ }^{39}$ Por. nasz Immunitet ekonomiczny, s. 157, przyp. 6, ze s. 156. O znaczeniu tej ekscepcji zob. w czasach starożytnych H. Monnier, Etudes de droit byzantin, Nouvelle RHDFE, t. 24 (1900), s. 172-4; o jej stosowaniu w średniowieczu zob. E. Meynial, op. cit., gdzie osobny rozdzial zatytulowany: De la renonciation à l'exception non numeratae pecuniae, s. 128-42; por. też A. de Boüard, op. cit., s. 289; H. Keller, Zur Geschichte der „Exceptio non numeratae pecuniae". Studi in onore di S. Riccobono, t. 2, Palermo 1936, s. 283-323; E Genzmer, Hugo von Trimberg, s. 324; J. Gillissen, op. cit., s. 522-7. Ostatni badacz stwierdza, że wspomnianą ekscepcję stosowano nie tylko dla pożyczki, ale również w wypadku sprzedaży i wszelkich innych kontraktów, na mocy których winna jedna strona wręczyć drugiej pewną sumę pieniężną, s. 526. Znaczenie tej klauzuli w prawie rzymskim zasadza się na regule, że wlasność nie przechodzi na nabywcę, zanim nie zapłaci ceny lub nie zadowoli sprzedawcy; aż do tego momentu zatem przyshuguje więc sprzedawcy rei vindicatio, R. Feenstra, Inst. 2, 1, 41 et les origines de la ,revendication" du vendeur non payé. Mélanges Fernard de Visscher, t. 3, Bruxelles 1950 , s. 456. Występowanie ekscepcji non numeratae pecuniae w Polsce przesądza w sensie pozytywnym pytanie stawiane z górą pól wieku temu przez E. Meyniale, czy w innych krajach - poza Francja - wraz z zaznajamianiem się z kodyfikacją justyniańską aplikowano w aktach jej postanowienia nie wnikając bliżej $w$ ich wlaściwe znaczenie, op. cit., s. 110, 
jest rzecza wysnuwanie konkluzyj o kulturze prawnej spoleczeństwa, w którym to zapożyczenie się pojawia; wysnuwanie $\mathrm{z}$ nich wniosków o stosunkach faktycznych jest wręcz niedopuszczalne.

przyp. 1. Takąż potakująca odpowiedź dla Niemiec i Flandrii daje E. Genzmer: „Sie (Renuntiationem) sind nicht nur ein in gewissem Umfange gemeineuropäische Phänomen, sondern auch ein nahezu gleichzeitiges", Hugo von Trimberg, s. 326, przyp. 3. - Pozostaje jeszcze do napisania monografia, która by omówiła szczegółowo ekscepcję non numeratae pecuniae w stosunkach polskich, datę jej pojawienia się u nas oraz stwierdzenia, czy ona ostatecznie przyjęła się w polskim prawie. Przykłady omówionej tu ekscepcji daje R. Taubenschlag, Formularze, s. 21, 43, 56. 


\section{Les manuscrits du coutumier pruthène*}

Dans les dépouilles laissées par le collectionneur d'antiquités d'Elbing, le marchand drapier Grübnau, un autre collectionneur, pharmacien de profession, H. F. Neumann, découvrit, en 1825, un manuscrit provenant du début du $\mathrm{XV}^{\mathrm{e}}$ siècle'. On nomma ce manuscrit par la suite, Codex Neumannianus. Il comprenait les quatre pièces suivantes, rédigées toutes en allemand:

1. Le droit de Lübeck, destiné à la ville d'Elbing;

2. Le coutumier pruthène;

3. Le coutumier polonais;

4. Le vocabulaire allemano-pruthène $e^{2}$.

On se figure aisément la portée de cette découverte, que son contenu démontre. Le manuscrit en question constituait le seul spécimen du coutumier polonais et du vocabulaire allemanopruthène. Bien que le coutumier polonais ne soit pas le premier dans le monde slave - la Pravda Ruska le précède de beaucoup - il appartient cependant aux plus anciens de cette partie de l'Europe. Le vocabulaire mentionné renferme huit cents mots pruthènes environ; il constitue, par conséquent, le plus grand et le plus ancien recueil d'une langue indo-européenne entièrement éteinte. Les linguistes l'apprécient donc à juste titre. Nous verrons que la seconde partie, contenant le droit du même peuple pruthène, représentait, elle aussi, une copie de haute valeur.

Le nouveau propriétaire du codex envisageait, lui-même, la publication de tous ces monuments juridiques et linguistiques. Aussi refusait-il à d'autres l'accès du manuscrit. Ce n'est qu'au moment de sa mort qu'il permit au comte Adam Sierakowski de copier le coutumier polonais qui fut, par la

* Przedruk z: Étude d'histoire du droit privé offertes á Pierre Petot, Paris 1959, s. 1-6.

${ }^{1}$ M. Töppen, Erinnerungen an F. Neumann, Altpreussische Monatschrift, t. 6, Königsberg, 1869 , p. 336 et suiv.; du même: Die Elbinger Geschichtsschreiber und Geschichtsforscher in kritischer Ubersicht vorgeführl, Zeitschrift des Westpreussichen Geschichtsvereins, H. 32, Dantzig, 1893, pp. 188-93.

${ }^{2}$ E. Volckmann, Das älteste geschriebene polnische Rechtsdenkmal, Elbing-Stettin, 1869, p. 2; M. Winawer, Najdawniejsze prawo zwyczajowe polskie (le plus ancien coutumier polonais), Warszawa, 1900, p. 2; A. Bezzenberger et W. Simon, Das Elbinger deutsch-preussische Vokabular, Königsberg i. Pr., 1897, p. 1. 
suite, édité en $1868^{3}$; mais, encore en 1866 , en publiant les Iura Prutenorum, Paul Laband écrivait: huius codicis usus, precibus meis neglectis, mihi a possesore negatus est ${ }^{4}$.

Par conséquent, pour son édition, Laband dut se contenter des six manuscrits suivants:

1. W de 1433;

2. $\mathrm{S}$ du $\mathrm{XVI}^{\mathrm{e}}$ siècle;

3. $\mathrm{R}$ de 1561 ;

4. O de 1593;

5. $\mathrm{H}_{1}$ du XVII ${ }^{\mathrm{e}}$ siècle;

6. $\mathrm{H}_{2}$.

Parmi ces manuscrits, l'éditeur distinguait deux rédactions différentes: une systématique et l'autre non systématique. La seconde rédaction, représentée à cette époque par le seul manuscrit $\mathrm{S}$, comportait 127 articles; la première, représentée par les autres, ne contenait que 102 articles.

Laband n'ignorait point l'existence de trois autres manuscrits, notamment de celui de Neumann qu'il avait pourvu du chiffre 7 et que nous marquons de la lettre $\mathrm{N}$ :

7. $\mathrm{N}$ du $X V^{\mathrm{e}}$ siècle, ainsi que de deux autres, mentionnés dans un ouvrage ancien intitulé Erläuterung Preussens. Il savait également que ces derniers appartenaient au groupe systématique ${ }^{5}$.

En 1869, E. Volckmann, dans l'introduction à sa publication du plus ancien coutumier polonais, nota que le texte $\mathrm{N}$ comptait 86 articles $^{6}$; mais il doutait toujours de la souche à laquelle celui-ci appartenait.

En 1874, apparut une nouvelle publication du coutumier pruthène. Cette fois, il fut édité par W. Pierson d'après un manuscrit de Gotha':

8. G de 1588-1592.

Le manuscrit utilisé par lui appartenait au groupe non systématique. Aussi cette souche voyait-elle doubler le nombre de ses représentants. Enregistrons que Pierson ignorait totalement la publication antérieure de Laband $^{8}$.

${ }^{3}$ Vetera Iuris Polonici Monumenta, t. 2, Krakow, 1870. Cependant le tirage à part contenant le coutumier polonais fut divulgué parmi les savants en 1868 .

4 Iura Prutenorum saeculo XIV condita, nunc primum e libris manuscriptis ed., P. Laband, Regimonti Pr., 1866, p. 4.

${ }^{5}$ Nous renvoyons a la publication citée dans la note précédente, notamment à son court préambule en latin, pp. 3-6.

'Cr. supra, n. 2.

${ }^{7}$ W. Pierson, Aus einem Collektaneenbuche Kaspar Hennenbergers, Zeitschrift für preussische Geschichte und Landeskune, Jahrg. 10, 1873, pp. 56-64, Jahrg. 11, 1874, pp. 28-32, 357-64.

${ }^{8}$ Cf. note précédente, Jahrg. 10, p. 56. 
Depuis lors, personne ne s'est occupé du droit pruthène. Les éditions mentionnées n'ont engendré aucun travail analytique. Ce n'est qu'en 1955 que le savant soviétique, M. W. T. Paszuto, consacra une étude à ce monument. Non content de l'analyse détaillée, il trouva utile la réimpression du texte établi par Laband: une réédition, appuyée sur l'étude de tous les manuscrits, n'était guère réalisable dans les conditions d'après-guerre. Il y ajouta une traduction en russe et, au surplus, il y annexa un nouveau texte de la rédaction systématique, en s'appuyant sur une copie dactylographiée exécutée pour un professeur lithuanien, P. J. Pakarklis, décédé depuis. Cet exemplaire appartient au groupe systématique ${ }^{9}$. La copie fut probablement faite d'apres un des manuscrits mentionné dans l'introduction de P. Laband, notamment:

9. $\mathrm{P}$ du $\mathrm{XVI}^{\mathrm{e}}$ siècle.

$\mathrm{Au}$ total, on connaissait neuf manuscrits du droit pruthène. Malheureusement, la guerre n'a pas épargné ces textes. A l'heure actuelle, le sort des manuscrits de Königsberg (W, S, R, O) est complètement inconnu. Des deux que détenait la bibliothèque de Gdansk $\left(\mathrm{H}_{1}, \mathrm{H}_{2}\right)$, l'un $\left(\mathrm{H}_{2}\right)$ est perdu. Le Codex Neumannianus s'est égaré aussi ${ }^{10}$. Son manuscrit du droit pruthène était le seul qu'aucun des imprimés n'eût pris en considération; sa perte est d'autant plus regrettable. Néanmoins, si grave qu'elle soit, elle est compensée, dans une certaine mesure, par une copie écrite d'apres ce manuscrit de la main de son propriétaire, Neumann. Pour l'édition envisagée, celui-ci arait transcrit le texte du coutumier en question et avait noté les variantes des autres manuscrits. Ses travaux préparatoires semblaient sans importance lors de la publication de Laband. Ils reprennent, a l'heure actuelle, après les ravages de la guerre, la valeur d'un document, d'autant plus que nous savons combien Neumann était consciencieux ${ }^{11}$. Après son décès, tous ses papiers furent déposés aux archives municipales d'Elbing. Ils se trouvent, actuellement, aux archives départementales de Gdansk; bien que leur inventaire ne soit pas encore achevé, on a réussi à trouver le cahier de Neumann renfermant la copie des Iura Prutenorum ${ }^{12}$.

L'étude de cette copie tardive nous l'a fait apparaître comme la plus intéressante de toutes. Tout d'abord, constatons-nous, elle est rédigée en

9 W.-T. Paszuto, Pomiezanija, "Pomiezanskaja Prawda» kak istoriczeskij istocznik izuczenija obszczestwiennogo i politiczeskogo stroja Pomiezanii XIII-XIV ww. (La Poméranie. Le coutumier poméranien comme source historique servant à l'étude des institutions sociales et politiques de la Poméranie des XIII-XIVe siècles), Moskwa, 1955, p. 184.

${ }^{10} \mathrm{Cr}$. Revue historique de droit français et étranger, 1957, p. 452.

11 Ses travaux manuscrits sont qualifiés pleinement utilisables par E. Carstenn, Die Elbinger Handschriften des lübischen Rechts, Zeitschrift des Westpreussischen Geschichtsvereins, H. 72, Dantzig, 1935, p. 143.

12 Cote ancienne: Rep. H, nr 49, fasc. 1 . 
un allemand beaucoup plus ancien que celui des autres. C'est donc le plus ancien spécimen du coutumier qui se soit conservé. Il mérite, par conséquent, une attention particulière. Deuxièmement, il appartient au groupe non systématique, comme les manuscrits $\mathrm{S}$ et $\mathrm{G}$, mais il ne contient que 86 articles. C'est donc l'exemplaire le plus court que nous connaissions. Si l'on compare ses 86 articles avec ceux du manuscrit $S$, on constate qu'ils sont exactement les mêmes; seule la répartition des articles du manuscrit $\mathbf{N}$ diffère de celle du manuscrit $S$, d'ailleurs insensiblement. Notamment lesdits 86 articles du manuscrit $\mathrm{N}$ correspondent strictement aux 82 premiers articles du manuscrit $S$.

$\grave{A}$ juger d'après toutes ces observations, il devient évident que le manuscrit $\mathrm{N}$, négligé jusqu'a présent, constitue la plus ancienne rédaction, remontant, peut-être, a son état initial. Pour bien déterminer l'époque approximative de sa mise par écrit, remémorons-nous quelques éléments, établis avec précision par Laband, lors de sa publication de 1866.

La rédaction systématique - maintient celui-ci - est postérieure à la rédaction non systématique. C'est pourquoi il l'a prise pour base de sa publication. Laband a remarqué, non sans justesse, que dans la rédaction systématique les particules relatives à un même sujet suivent exactement l'ordre numérique de la rédaction non systématique. Il s'ensuit que le rédacteur, désirant systématiser le coutumier, réunissait les articles consacrés au même problème pour les copier ensuite selon le schéma voulu. Mais, pendant ces remaniements, le texte ne subissait aucun changement. Le travail se limitait ainsi a un aménagement selon un ordre logique ${ }^{13}$. Ce raisonnement de Laband ne paraît pas appeler de réserves.

L'arrangement logique, effectué, en tout cas, avant 1433 (à cette date remonte le plus ancien manuscrit de la rédaction systématique, manuscrit $W$ ), présume l'existence d'un manuscrit non systématique, composé du même nombre d'articles, c'est-à-dire de 102. L'ayant constaté, Laband prétendit reconnaître en celui-ci l'antiquissima pars, donc le coutumier initial. $\grave{A}$ cet égard, le manuscrit $\mathrm{N}$ apporte un élément nouveau. Il démontre qu’à un moment donné le coutumier pruthène ne comprenait que 86 articles. Était-ce le contenu de la rédaction primitive?

Nous ne sommes pas à même de le démontrer, mais ce n'est pas improbable. Toujours est-il que, si le coutumier primitif ne se recoupe pas entièrement avec le manuscrit $\mathrm{N}$, ce dernier, certes, est le plus proche de l'original. Ceci dit, nous parvenons à établir l'arbre généralogique des manuscrits comme suit:

Bien qu'en général le tableau de Laband soit maintenu, il subit un certain remaniement qui, par ailleurs, n'est pas négligeable.

13 P. Laband, Lura Prutenorum, p. 5. 
Nous savons que la première rédaction des Iura Prutenorum fut faite en l'an 1340; cette date est insérée au texte du coutumier et rien ne nous autorise à lui refuser notre crédit. D'autre part, nous n'ignorons pas non plus que la plus ancienne rédaction systématique fut faite en 1433. Entre ces deux dates, par conséquent, s'intercale au moins une rédaction élargie non systématique de 102 articles. $\mathrm{Si}$ le manuscrit $\mathrm{N}$ excédait par son contenu l'original, une rédaction de plus entrerait en ligne de compte. Quatre rédactions, en moins de cent ans, ne paraissent pas improbables.

Or.

1340

$\mathrm{N}$

86 art.

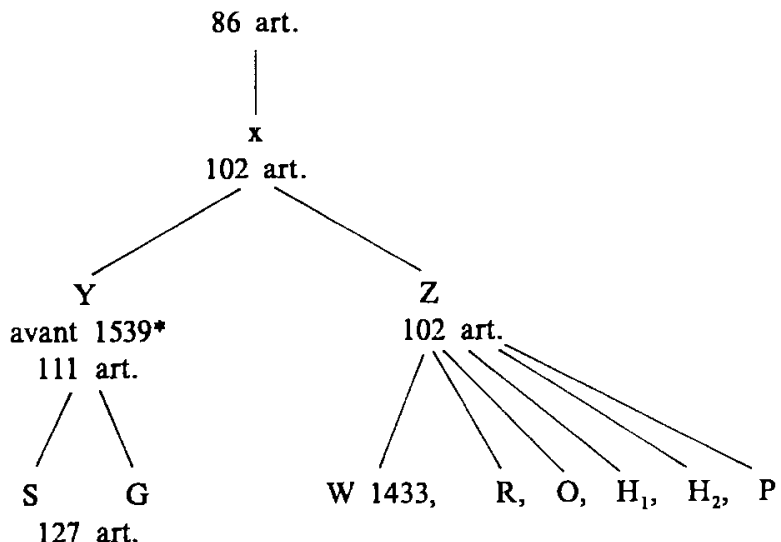

* Dans le manuscrit S, cette date suit l'article 111, P. Laband, Iura Prutenorum, p. 4.

La rédaction systématique, une fois faite, ne supportait plus d'être complétée, par des articles postérieurs. Depuis son apparition en 1433 et jusqu'au XVII ${ }^{c}$ siècle, elle ne subit aucune transformation. La rédaction non systématique, par contre, montre un développement continu. Elle passe par cinq ou, au moins, quatre stades intermédiaires, qui se laissent aisément suivre à travers les manuscrits conservés. Rédigée en 1340 et composée de 86 articles au plus, la coutume atteint l'apogée de son développement apres 1539 avec le manuscrit contenant 127 articles.

Nous avons relevé plus haut la conformité exacte des manuscrits $\mathrm{N}$ et S. Cependant, il ne faut pas passer sous silence quelques menus détails indiquant d'une façon évidente des retouches postérieures: 


\section{$\mathrm{N}$}

Art. 29

Werden lute gewunt, dy von iren heren rechte geen, das sal men ozweveldig richten.
$\mathrm{S}$

Art. 28

Il ne semble pas que la différence soit uniquement de style.

Tout ce que nous venons de recueillir sur les manuscrits du droit pruthène attire l'attention sur le manuscrit $\mathrm{N}$. Bien qu'il fut le plus ancien, il est resté jusqu'a présent, par un concours de circonstances défavorables, en dehors de toute investigation scientifique. Aucun des éditeurs des Iura Prutenorum ne l'a pris en considération. Cette erreur, cependant, ne paraît pas irréparable. Bien que nous le connaissions, à l'heure actuelle, par une copie tardive du XIX ${ }^{e}$ siècle, ce manuscrit doit être considéré comme le principal et comme celui qui reflète, sinon la rédaction primitive, au mois la plus proche de l'original. C'est pourquoi il doit servir de base à la prochaine publication. 


\section{Czy handlowano chlopami w Rzeczypospolitej szlacheckiej?*}

Odpowiedź twierdzącą na postawione w tytule pytanie dał J. Deresiewicz, w oparciu o zestawiony obfity material źródłowy [1]. Opublikował on mianowicie 747 aktów „transakcyj” chłopami, które mają dowodzić jego tezy. Ponieważ partia ogłoszona drukiem jest tylko częścią zgromadzonych przezeń dokumentów, dotyczących Wielkopolski (ogólna liczba dochodzi do 3000) - zjawisko handlu chłopami należy zdaniem wydawcy uznać za masowe. Tym samym Deresiewicz przeciwstawia się poglądowi dawniejszemu, panującemu w nauce, reprezentowanemu m. in. przez Rutkorwskiego, zdaniem którego handel chłopami zachodzil sporadycznie. Nowa rewolucyjna teza wymaga skrupulatnego rozpatrzenia i kontroli.

Wydawca podzielił opublikowane akty na kilka grup: donacje, sprzedaże, zamiany, zastawy; znajdujemy też kilkadziesiąt aktów, które do żadnej z powyższych kategoryj nie należą; stwórzmy z nich grupe „innych". W liczbach wygląda to następująco:

\begin{tabular}{lr} 
- donacje & 526 \\
- sprzedaze & 58 \\
- zamiany & 35 \\
- zastawy & 46 \\
- inne & 82 \\
\hline razem & 747
\end{tabular}

Uderzająca jest cyfra donacyj. Darowizny nie stanowią normalnego przejawu życia gospodarczego. Jeśli zatem one posiadają tak zdecydowaną przewagę, będziemy patrzeć dość sceptycznie na charakter handlowy tych transakcyj.

Co prawda Deresiewicz odróżnia w grupie donacyj darmowe i odpłatne; ostatnie zbliżają się bardzo do sprzedaży. Takich odpłatnych donacyj

* Przedruk z: Sprawozdania Wrockawskiego Towarzystwa Naukowego 1960, 15 A, s. 71-4.

[1] Transakcje chlopami w Rzeczypospolitej Szlacheckiej (w. XVI-XVIII), wyboru dokonał i do druku przygotował J. Deresiewicz, Warszawa 1959, s. XLVI-743. 
naliczyliśmy 98. Ale i po tej korekcie (nie całkiem uzasadnionej) cyfra donacyj jest poważna, bo wynosi 428 wobec 156 sprzedaży i donacyj odplatnych.

$Z$ transakcyj chłopami Deresiewicz wyłączyl sprzedaże nieruchomości feudalnych, a więc całych wsi wraz z zamieszkałymi w nich chłopami. I to niewątpliwie słusznie. Uwzględnił wszakże takie sprzedaże chłopów z gruntem, w których alienowany chłop przechodzil wraz ze swoim gospodarstwem $\mathrm{z}$ jednego państwa do innego, sąsiedniego (s. VIII). Podobnie postępuje $z$ dzierżawcami. Takie rozwiązanie nie wydaje się nam słuszne. Nie bardzo też bylibyśmy skłonni brać w rachubę operacyj czasowych, lecz ograniczylibyśmy się do transakcyj wieczystych i na nie też zwrócimy uwagę szczególną.

Nie bez znaczenia pozostanie analiza formul. Formula jest jednolita we wszystkich aktach - darmowych $\mathrm{i}$ odpłatnych. Brzmi ona najczęściej tak: dedit, donavit, inscripsit et in perpetuum resignavit, prout quidem dat, donat, inscribit et in perpetuum resignat actu praesenti (nr 157), czy po polsku: „zupełnie daje, ustępuję, daruję i rezygnuję" (nr 138). Czasem w formulce rezygnacyjnej pojawi się termin vendo (nr 179), czy po polsku ,zaprzedaje" ( $\mathrm{nr}$ 439). Ale słusznie Deresiewicz zauważa, że nie można $\mathrm{z}$ ostatnimi określeniami wiązać odmiennej kwalifikacji prawnej.

W takim razie dla odróżnienia aktów darmowych i odplatnych pomocną nam będzie cena. Jeśli ona się pojawi - akt jest sprzedażą; w braku jej - darowizną. Zdumiewająca jest liczba aktów, które pomijają kwestię ceny milczeniem. Ale $-\mathrm{z}$ drugiej strony - teksty wskazujące wyraźnie na charakter darmowy są całkiem wyjątkowe. W każdym razie dziwny to handel, w którym sprzedawca nie zwraca uwagi na ekwiwalent pieniężny.

W dużej grupie aktów czytamy o jakimś zadośćuczynieniu. Ta satisfactio nie musi jednak być ceną za chlopa, jak tego wyraźnie dowodzi akt nr 603 .

Przy handlu jakimkolwiek towarem, ludzkim czy innym, oczekiwać należy związku ceny $z$ wartością ekonomiczną sprzedawanego obiektu. Tej zależności bynajmniej nie zauważamy. Uiszcza się cenę ad mentem legis. Równa się ona taxa capitis, a ta wynosi 120 grzywien za chłopa, 60 grzywien za chłopkę ( $z$ wariantami lokalnymi). Ustalona $w$ tym wymiarze konstytucja z $1631 \mathrm{r}$. utrzymała się główszczyzna plebejska bez zmian aż do rozbiorów. Zmiany w wartości pieniądza spowodowane katastrofami politycznymi i gospodarczymi, jak ,potop", nie odbiły się zupełnie na cenie chłopa. Wnosimy więc, że taxa capitis nie jest ceną. Nie znajdziemy chyba drugiego takiego towaru, który by przez z górą 150 lat nie uległ wahaniom cen.

Cena za chłopa równająca się główszczyźnie ulegała ciągłej obniżce na skutek dewaluacji pieniądza. Pod koniec Rzeczypospolitej nie przedstawiała ona większego znaczenia. Weźmy jeszcze przy tym pod uwage fakt, że w ,cene” wchodzil chłop cum uxore, liberis, pecoribus, pecudibus, supellectili domestica ac rebus eorum omnibus (nr 39). 
Dla przyjęcia charakteru handlowego transakcyj chłopami ważne jest stwierdzenie roli chłopów w tych transakcjach: byli oni biernym przedmiotem handlu, czy też transakcje wynikały na skutek postępowania chłopów. W szeregu wypadków "handel" był następstwem małżeństwa. W myśl kościelnej zasady nierozdzielności małżonków, bądź nupturient, bądź nupturientka zmienić musieli pana.

O wiele częściej jeszcze dochodzilo do transakcyj w następstwie zbiegostwa kmieci: stanowią one 1/5 wszystkich drukowanych aktów. Szczególnie interesującą grupe stanowią transakcje chłopami, którzy zbiegli do nabywcy. Co więcej, częstokroć dochodzi do alienacji zbiegłych poddanych po daremnych usiłowaniach rewindykacyjnych. Powód przeszedł wszystkie instancje, aż do Trybunału włącznie. Na nic wyroki się nie zdały, wobec tego strony uciekają się do transakcji.

Oba przytoczone wypadki, małżeństwa i zbiegostwa, rzucają mocny cień na handlowość transakcyj chłopami. Przedmiot ich, chłop, jest w obydwu wypadkach jak najbardziej aktywny. Tymczasem, jak stwierdza Deresiewicz, było to zjawisko masowe.

Niejednokrotnie inne kroki poczynione przez chłopa doprowadzały do transakcyj: zaciągnięcie długu, popelnione przestępstwa.

Wyżej stwierdziliśmy, że istnieje wspólna formula dla rozporządzeń różnej treści, darmowych i odpłatnych. Akty przytaczane niżej wykażą, że pod tymi samymi formulami kryją się czynności prawne, nie będące ani sprzedażą, ani donacją; oddanie przez pana na służbę (np. nr 86, 142) czy wręcz pójście na służbę chłopa, aprobowane ex post przez jego pana ( $\mathrm{nr}$ 264). Oddanie dziecka na wychowanie $\mathrm{z}$ równoczesną rezygnacją $\mathrm{z}$ praw matczynych $\mathrm{z}$ powodu niemożności utrzymania ( $\mathrm{nr} 719$ ), $\mathrm{z}$ całą pewnością nie jest również transakcją handlową.

Do transakcyj chłopami zaliczył wydawca dyspozycje o różnej treści prawnej. Stąd wielka masa aktów, które w swej publikacji zgromadzil. W oparciu o nie postawił Deresiewicz tezę masowości handlu chłopami. Przedstawiona wyżej analiza na podobne uogólnienia nie pozwala.

Transakcje zestawione świadczą o ciągłej, żywiołowej migracji chłopów $\mathrm{z}$ jednego państwa-seniorii do drugiego. Wobec niej szlachta była bezsilna. Skrępowanie prawne ruchu ludności nie dawało poważniejszych rezultatów. Przemieszczanie się chłopów z jednych państw do drugich wymagało uregulowania prawnego. Jego forma są transakcje. Przy ich pomocy przenosi się subditatus, subditio, subditatura. To jest istotna treść tych aktów. Nie mogą one zatem stanowić podstawy twierdzenia, jakoby handel chłopami w dawnej Rzeczypospolitej był zjawiskiem masowym. 


\title{
Dyskusja nad Najstarszym Zwodem prawa polskiego*
}

\author{
La seule attitude raisonnable, la seule qui ne déçoive \\ pas, c'est la recherche de l'erreur et non pas la recherche \\ de la vérité. Le reste - pures divagations. \\ Roger Martin du Gard
}

1. Recenzje. 2. Wydanie. 3. Thumaczenie. 4. Objaśnienia. 5. Wstęp do wydawnictwa. 6. Codex Neumannianus. 7. Nazwa opublikowanego zbiorku. 8. Charakter i cel zbiorku. 9. Narodowość autora. 10. Zawód i wykształcenie autora NZ. 11. Miejsce powstania zwodu - partia negatywna. 12. Miejsce powstania zwodu - partia pozytywna. 13. Czas redakcji zabytku - partia negatywna. 14. Czas redakcji zabytku - partia afirmalywna. 15. Uwagi o metodzie dyskusji i o tonie w niej panującym.

\section{Recenzje}

Wydawca znajduje się w wyjątkowo szczęśliwym położeniu: spotkał się z żywym odzewem ze strony kolegów badaczy oddanych studiom nad dawnym prawem polskim. Świadczą o tym recenzje, które ukazały się niedawno, czy ukazują równocześnie: S. Russockiego i K. Buczka na łamach „Kwartalnika Historycznego", J. Adamusa i A. Vetulaniego w niniejszym tomie Czasopisma ${ }^{1}$. Za uwagi przez nich poczynione, nawet najbardziej polemiczne, jestem im niezmiernie wdzięczny i składam serdeczne podziękowanie. Niektóre akceptuję w całości, z innymi natomiast trudno mi się zgodzić. Chęcią zajęcia własnego stanowiska i uzasadnienia go tłumaczy się napisanie niniejszego artykułu.

* Przedruk z: Czasopismo Prawno-Historyczne 1960, t. 12, z. 2, s. 233-260. Por. B. Griekow, Polskaja Prawda, opyı iznoszenija obszczestwiennogo i politiczeskogo stroja Polszi XIII w. po polskoj prawdie (,kniga prawa"), [w:] Izbrannyje trudi, t. 1, Moskwa 1957, s. 265-442.

${ }^{1}$ S. Russocki, KH 66, $\mathrm{nr} 4,1959$, s. 1266-1269; K. Buczek, $O$ najdawniejszym spisie prawa polskiego, KH 67, nr 1, 1960, s. 161-169; J. Adamus, niniejszy tom CPH, s. $189 \mathrm{nn}$. oraz A. Vetulani, Nowe wydanie niemieckiego zwodu prawa polskiego, ibidem, s. 195. Dla uniknięcia masy odsyłaczy cytujemy dalej powołane wyżej artykuły w tekście, podając jedynie paginę; przy moim nazwisku podana stronica odnosi się do wstępu towarzyszącego publikacji NZ. 


\section{Wydanie}

$\mathrm{Na}$ ogół wydanie tekstu wywołało najmniej zastrzeżeń, czy wręcz spotkało się z uznaniem. Staranność jego podkreślają Adamus i Vetulani, metodę wydania uważa w pełni za zadowalająca Vetulani. Zalety podziału na rozdziały i ustępy wykazują: Russocki, Adamus, Vetulani. Vetulani zarzuca, że za Volckmannem nie uwydatniono wyrazów i ustępów zaznaczonych $w$ oryginale rubrą. Ale czy szczegól ten istotnie taki decydujący, skoro pójście za nim przez Volckmanna doprowadziło do podziału wyraźnie niepraktycznego i rzeczowo nieuzasadnionego? Russocki podkreśla wprowadzenie nowej, własnej interpunkcji. Vetulani domaga się $w$ tekście (jak zresztą $\mathrm{i}$ we wstępie) żywej paginy. Postulat ten wydaje się jak najbardziej słuszny. Przylączamy się do tego apelu pod adresem przyszlego wydawcy.

\section{Tlumaczenie}

I ta robota spotkała się z ocena pozytywna. Thumaczenie ,całkowicie samodzielne" - pisze Russocki, stwierdza przy tym ,wysoki stopień dokładności i precyzji, znacznie wyższy niż u ... poprzedników"; ,przekład bezsprzecznie lepszy” - konstatuje Buczek; przekład „ulepszony” (Adamus); „staranny”, „,cenny" (Vetulani). Te wypowiedzi zresztą nie są bezkrytyczne, bowiem ci sami badacze zgłaszają zastrzeżenia co do oddania niektórych zwrotów czy wyrazów. Sami też wypowiadaliśmy zastrzeżenia co do wartości thumaczenia (ustęp 57). Ponieważ rzecz ta wiąże się ściśle $\mathrm{z}$ interpretacją tekstu, celem pracy już dokonanej, jak i tej, którą zamierzamy wykonać w przyszłości, wobec tego zajmujemy w stosunku do tych uwag wlasne stanowisko.

Vorrede, w. 89. Vetulani proponuje zastąpić thumaczenie sver - ciężki przez poważny (tak jak Grekow). Propozycja bardzo ponętna.

w. 91: zo hat doch beharren - jednakowoż oglosil on; Buczek niesłusznie twierdzi, że cytowane zdanie nie zostało przethumaczone. Inna rzecz, że przez niedopatrzenie jakieś słowa oglosil on postawiono w nawiasie.

art. $4^{8}$ (i wielokrotnie, por. indeks) herre - tłumaczyliśmy czasem książe, czasem pan. Kwestionuje to Vetulani, i może słusznie, ale sami podnosiliśmy co do przekładu tego rzeczownika zastrzeżenia (s. 156, p. 9). Pragniemy zatem podkreślić, że ksiqżę był lakże panem, jak to stwierdza średniowieczny gramatyk, autor Kroniki wielkopolskiej².

art. $4^{13}, 15^{25}, 29^{2}$ : scheffer - szafarz, rzqdca; Buczek proponuje ujednolicenie, niewątpliwie słusznie, ale sensu to nie przeinaczyło.

art. $6^{5}, 2^{13}:$ gut - majatek, i to zarówno, gdy chodzi o gospodarstwo chlopskie, jak i rycerskie, kwestionuje Buczek, ale sam nie daje własnej propozycji; thumaczyć przez dobro? Ale to substantivum defectivum, nie można urobić dlań miejscownika, który właśnie jest potrzebny.

${ }^{2}$ J. Matuszewski, O państwie i Państwie, CPH, t. X, z. 2, 1958, s. 79. (Patrz tutaj s. 405). 
art. $10^{2}$ : von dem gemordeten manne; zarzut Buczka, jakoby zostało przełożone przez utopil polega na nieporozumieniu, w thumaczeniu wyraźnie czytamy o zabójstwie człowieka.

art. 122: kamere - mieszkanie; zdaniem Buczka ma być komora ksiqżęca. Rzeczywiście termin chyba stosowniejszy, bo dający szersze możliwości wykładni.

art. 123: houbtnot - ciężkie przestẹstwo; kwestionuje Russocki, wydaje mu się trafniejsze thumaczenie Helcla (glówny gwall), s. 1268.

art. 127: wer stylt in eynes mannes clette, her zy ritter adir gebuer - kto kradnie $w$ czyimś domu, czy to bedzie rycerz czy chlop; Buczek twierdzi, że chodzi tu o rycerza czy chłopa jako okradzionego. To zdanie jesteśmy skłonni podzielić; daliśmy temu wyraz w przyp. 24 na s. 178. Zaznaczyliśmy wszakże, że interpretacja gramatyczna skłania do wykładni podanej $\mathrm{w}$ thumaczeniu.

art. $13^{7}, 11^{4}, 20^{3}, 22^{4}, 25^{10}$ : willekür, gewillekoret - wola, ustanowiono, co kwestionuje Buczek; nasze thumaczenie podtrzymujemy, willekür jest terminem wieloznacznym, w thumaczeniu zaś szukamy nie słownych pendant, lecz odpowiedników ad sensum. Czyż powoływać tu znane wilkierze, których odpowiednikiem polskim będzie nie co innego, jak ustawa czy statut miejski?

art. 15: lantstrose - droga ksiqż̨ca; thmaczenie uważa za nieodpowiednie Buczek, proponując droga publiczna. Widocznie nie zauważył naszego dość długiego ekskursu pomieszczonego na s. 186 , przyp. 31 .

art. 15: Vrede - pokój; zdaniem Buczka winno być mir. Czy to nie to samo? Termin pokój wprowadziliśmy z pełną świadomością, ponieważ rzeczownik mir we współczesnej polszczyźnie nabrał znaczenia całkiem odrębnego, a substantivum pokój jest pełnym odpowiednikiem niemieckiego vrede.

art. 15: opuszczono w thumaczeniu abir - zarzuca trafnie Buczek. Dodać więc należy po słowie jeśli - zaś.

art. $15^{10}$ : rillermeszig man - czlowiek równy rycerzowi; uważa za trafne Russocki, s. 1268.

art. 15 $5^{11}$ : unde dem, dez gerichte ist; oddano przez sqdownictwo zamiast sqd (Buczek); racja tylko formalna, sens zwrotu taki, jak podano w thmaczeniu.

art. 15 ${ }^{18}$ : wirt eyn ritter geslagyn - jeśli uderzy sie rycerza; tlumaczenie kwestionuje Buczek, nie wiemy wszakże, czy mu chodzi o użycie strony zwrotnej zamiast biernej (unikaliśmy jej zgodnie $z$ duchem języka polskiego, który tej strony nie lubi), czy też o thumaczenie uderzy, pobije, przy czym obstajemy, skoro źródlo odróżnia totslag oraz slagen ane totslag.

art. 155: denne opuszczono w thumaczeniu (Buczek); dodać należy wówczas.

art. $15^{27}$ : daz her den doch obir trank uzge - ze on wtedy poszedl dla trunku; nie rozumiemy, co Buczek kwestionuje.

art. $17^{1},{ }^{4}, 28^{2}$ : juncvrawe, maget, dirne - dziewczyna (z dodatkiem z rycerskiego stanu, wiejska); przy swoim thumaczeniu obstajemy.

art. 172: Alzo - tak samo; kwestionuje Buczek, swoje thumaczenie podtrzymujemy.

art. $17^{6}$ : tochter - dziewczę; winno być córka - domaga się słusznie Buczek.

art. 18 $8^{1-2}$ : czendener - dziesiętnik; winno być dziesięcinnik - pisze trafnie Buczek. Dla tego staropolskiego wyrazu domaga się on słusznie praw obywatelstwa.

art. 202: nu abir - co prawda teraz; kwestionuje Buczek, niejasny dla nas zarzut.

art. $21^{\text {s: }}$ unde hat her keine tochter gelozen - jeśli zaś on zostawil córkę. Moje thumaczenie zgodne $\mathrm{z}$ dotychczasową tradycja interpretacyjna zakwestionował Adamus, a za nim Russocki, proponując: jeśli nie zostawil żadnej córki $i^{3}$. Nowa propozycja wydaje się jak najbardziej niesłuszna. Wyraz kein w znaczeniu nowoczesnym ein jesl pospolity w ówczesnej niemczyźnie. Zakładać więc, że użyto go w znaczeniu dzisiejszym, a przy takiej interpretacji

${ }^{3}$ J. Adamus, $O$ prawie dziedziczenia nieruchomości przez kobiety $w$ najdawniejszym prawie polskim, CPH, t. XI, z. 1, 1959, s. 137; S. Russocki, o. c., s. 1269. 
przyjmować, że „dalsza... częsć tekstu musi być albo zniekształcona, albo zawiera lukę myślową" (Russocki, s. 1269), albo też na podstawie takiej ryzykownej interpretacji stawiać przypuszczenie, „że pod panowaniem Krzyżaków przepis ten posiadał większe znaczenie praktyczne niż pod panowaniem Piastów, dlatego też widziałbym $w$ tym artykule już raczej dodatki czy uzupemienia powstałe pod panowaniem krzyżackim. Wobec tego artykuł ów Księgi Elbląskiej niekoniecznie dowodzi czegoś dla oryginalnego prawa polskiego, a w żadnym wypadku nie dowodzi, by kobiety wedle niego nie dziedziczyły nieruchomości"4, wydaje się nam dość ryzykowne czy nawet wręcz karkołomne. Wobec tego podtrzymujemy w tym szczególe swe thumaczenie.

art. 2214: probist - proboszcz; ma być prepozyt - twierdzi Vetulani. Słowa te o wspólnej etymologii niejednokrotnie używane są promiscue (mówimy o prepozycie czy proboszczu kapitulnym). W konkretnym wypadku propozycja Vetulaniego raczej słuszna, bo chodzi o prepozyta jakiegoś konwentu, jakby to wynikało z pozycji po opacie, a nie o proboszcza parafialnego, który kryje się chyba pod terminem pfaffe.

art. 23': entwerten - odpowiadać; Buczek wytyka pominięcie słowa $\mathrm{w}$ thmaczeniu, co jest zarzutem niesłusznym.

art. $23^{10-12}, 28^{1},{ }^{3}, 29^{5-6}$ : eigene lute, eigen man thumaczono $\mathrm{z}$ reguły jako poddany, raz tylko jako wlaśni ludzie. Kwestionuje Buczek, domagając się wprowadzenia określenia chlopów niewolnych (przypisańców). Nasze thumaczenie kwestionuje też Vetulani. Prof. Buczek obiecuje zając się problemem w osobnej pracy, zaczekajmy więc na jego drukowane wywody. Słowa poddany używamy jako odpowiednika łacińskiego servus, mieszczącego w sobie nieskończenie obfitą skalę średniowiecznej zależności chłopskiej, od takiej, która równa się niemal niewolnictwu, do takiej, k tóra omal dorównuje stanowisku chłopa wolnego. To skłoniło nas do tego, żeby i schalk oddać przez poddany. Przeglądając podczas lektury recenzji prof. Buczka cytowane wyżej artykuły, stwierdziliśmy jedno niedopatrzenie własne $\mathrm{w}$ thumaczeniu, na które krytycy nie zwrócili uwagi, ale które tu korygujemy. W art. $23^{12}$ ein man der eigen hette - czlowiek, który ma poddanych, należy thumaczyć przez czlowiek, który ma wlasność (ziemskq), podobnie jak to zrobiliśmy w art. $23^{11}$.

art. $23^{14}, 29^{2}$ : gezessen - osiadli, zamieszkuje; kwestionuje Buczek, ale to bardzo bliskie sobie synonimy.

art. $24^{10}$ : prister - ksiqdz; powinno być duchowny - twierdzi Vetulani. Raczej wolelibyśmy już $\mathrm{w}$ to miejsce kaplana. Ale nie chcemy sprzeczać się o to, który z tych synonimów jest tu lepszy.

art. $26^{4}$ : uf eynes andirn dorfes marke - na obszarze innej wsi; uważa za poprawne (wbrew odrębnemu thumaczeniu Grekowa) Russocki, s. 1268.

art. 274: obir den czwn - poprzez plot; ma być ponad plot - domaga się Vetulani. Zdaje się, że myślimy w tym wypadku o jednym $\mathrm{i}$ tym samym: gałęzie drzewa znalazły się nad powierzchnią należącą do sąsiada.

art. 291: von des landesherren wegen - $w$ interesie ksiecia; Vetulani proponuje z ramienia ksiecia, w sprawach ksiecia; sens wydaje się identyczny.

art. $29^{2},{ }^{4},{ }^{6}$ : houf - dwór, podwórzec, co kwestionuje Buczek; adróżnienie świadomie wprowadzone zgodnie $\mathrm{z}$ dwojakim znaczeniem tego słowa $\mathrm{w}$ języku niemieckim.

art. $29^{6}$ : zemeliche - podobnie; nie wiemy, dla jakich racji kwestionuje Buczek. Przyznajemy, że formę przymiotnikową oryginału oddaliśmy przysłówkiem. Tak daleko, sądzimy, sięga licentia traductoris.

\footnotetext{
4 J. Adamus, o. c., s. 139.
} 
Dodajmy jeszcze, że Buczek żąda, bym podal, czym się moje tłumaczenie różni od poprzednich. Ale taki dezyderat równa się postulatowi napisania osobnej rozprawy, co nie jest zadaniem wydawcys.

\section{Objaśnienia}

Obszerniejszych przypisów rzeczowych domaga się Vetulani; Buczek pragnąlby objaśnień staropolskich terminów prawniczych (s. 169), ale spełnienie tych dezyderatów - to znów powiększenie rozmiarów dziełka. Nasze stanowisko jest inne: chcielibyśmy, by źródło mówiło w pierwszym rzędzie samo, rolę swoją komentatora pragnęlibyśmy usunąć $w$ cień, by nie przysłaniać historykowi źródła. Stąd to ograniczyliśmy komentarz do nieodzownego, jak nam się wydawało, minimum.

Vetulani domaga się indeksu do przekładu. Postulat wydaje się nam niesłuszny. Indeksować należy źródło oryginalne, a nie jego thumaczenie. Tekst zaś niemiecki zindeksowany został w sposób pełny. Stąd znowu wydaje się niezrozumiały zarzut Adamusa o braku indeksu rzeczowego.

\section{Wstęp do wydawnictwa}

Ani wydanie źródła, ani thumaczenie nie wzbudziło tylu i takich zastrzeżeń, jak dodany przez nas wstęp, obejmujący 123 stronice. Vetulani nazywa go niedostatkiem naszego wydawnictwa (s. 202). Z niepokojem myśli o tym, że na metodzie pracy, zastosowanej w naszym wstępie, wzorować się będą młodzi adepci nauki historycznoprawnej (s. 203). Tymczasem poruszyliśmy w nim zagadnienia, które według starego zwyczaju podaje się we wstępach: opisaliśmy kodeks, w którym mieściło się źródło, zajęliśmy się nazwą, miejscem, czasem powstania i autorem zwodu, wreszcie przedstawiliśmy zasady edytorskie i zasady przekładu. Nasze domysły co do genezy źródla, przejęte zresztą od dawniejszych autorów, uznane zostały przez niektórych krytyków za blędne do gruntu. Nie pozostaje nam więc nic innego, jak ponownie się tej sprawie przyjrzeć i rozpatrzeć hipotezy naszych adwersarzy. Wpierw wszakże przypatrzmy się dwom określeniom, przez nas używanym, a zakwestionowanym przez krytyków: Codex Neumannianus [CN] oraz „Najstarszy Zwód” [NZ].

${ }^{5}$ Pominęliśmy rozbieżności tłumaczenia Grekowa. Oba przekłady (Grekowa i nasze) są przedmiotem analizy jednego z uczniów prof. Vetulaniego (s. 201, przyp. 14). 


\section{Codex Neumannianus}

Pierwsze określenie, chyba z przyczyn patriotycznych, zaczepia Vetulani (s. 202). Nie sądzimy, by to był argument wystarczający. Raz wprowadzone do literatury naukowej określenie, naszym zdaniem, o ile nie ma jakichś zasadniczych zastrzeżeń, winno być uszanowane. Taki, wydaje się, jest właśnie casus nazwy kodeksu. Prof. Vetulani co prawda zarzuca Neumannowi - i słusznie - że ukrywał posiadany egzemplarz przed okiem naukowców. Ale robił to, ponieważ sam chciał rzecz wydać, a tylko przeliczył się ze swoimi siłami i zamiaru swego zrealizować nie zdołal. Jedna wszakże rzecz jest pewna: jemu zawdzięczamy zachowanie kodeksu. I ta zasługa górować musi nad słabościami ludzkimi historyka-amatora. Przez ten czyn Fryderyk Neumann tak się zasłużył nauce w ogóle, polskiej historii prawa w szczególności, że z całą racją jego nazwisko figuruje jako określenie omawianego rękopisu. I stąd to bez wahań kontynuujemy określenie wprowadzone niemal sto lat temu przez niemieckich historyków.

\section{Nazwa opublikowanego zbiorku}

Ponieważ nie było ustalonej nazwy zabytku - pomnik sam tytułu nie posiada - usiłowaliśmy stworzyć taką, która, będąc sztuczną, wykaże przynajmniej tę zaletę, iż dokładnie precyzuje zawartość zbiorku i jego charakter, „prawną treść pomnika” - jak tego żądał kiedyś prof. Vetulani ${ }^{6}$. Nazwaliśmy go więc Najstarszym Zwodem prawa polskiego (NZ) ${ }^{7}$, co prof. Adamus nazywa określeniem zapewne najodpowiedniejszym. Prof. Vetulani woli swój określnik - Prawo Polaków. Ale czy on rzeczywiście góruje nad naszym? Polemizowaliśmy $\mathrm{z}$ nim na ten temat (s. 11), lecz prof. Vetulani $\mathrm{w}$ ogóle nie rozprawia się $\mathrm{z}$ naszą argumentacją, traktując ją per non est. Rozpatrzmy więc jeszcze raz tę sprawę. Może to nie tyle ważne dla samego tytułu dziełka, ile charakterystyczne dla metody argumentacyjnej prof. Vetulaniego.

Nazwa lansowana przez prof. Vetulaniego jest sztuczna, równie jak nasza. Prof. Vetulani - wprowadzając ją - wzorowal się na tytule nadanym przez Labanda zbiorkowi prawa pruskiego, tzw. Iura Prutenorum. Ale - podkreślaliśmy - w Prusach innego zabytku prawa zwyczajowego nie mamy, takie określenie jest więc niedwuznaczne, nie wywołuje przeto

${ }^{6}$ A. Vetulani, Niemiecki spis polskiego prawa zwyczajowego, CPH, t. V, 1953, s. 185.

${ }^{7}$ Niezrozumiały wydaje się nam zarzut prof. Vetulaniego, jakobyśmy nie zaproponowali dla pomnika żadnej nazwy, s. 203, przyp. 19. 
sprzeciwu. Natomiast dla polskiego pomnika prawnego określnik wprowadzony przez prof. Vetulaniego jest za mało precyzyjny. To, co czytamy u prof. Vetulaniego o rzekomej różnicy między Prawem Polskim a Prawem Polaków ${ }^{8}$, nie wytrzymuje krytyki. Pamiętajmy też, że Laband dał zbiorkowi pruskiemu tytuł laciński w okresie, gdy jeszcze wstępy do wydawnictw pisano po lacinie. Tak już $w$ drugiej połowie $X X$ w. nie postępujemy. Trudno też dla zabytku polskiego, pisanego po niemiecku, wprowadzać tytuł laciński - Iura Polonorum?. Toteż prof. Vetulani woli używać raczej tłumaczenia tego łacińskiego tytułu, ale - to niekonsekwencja, na którą wskazywaliśmy już dawniej (s. 10, p. 25) - oddaje je przez Prawo Polaków, zatem w liczbie pojedynczej. Czy nie lepiej porzucić taką kalkę dziewiętnastowiecznej laciny? Prof. Vetulani spostrzega jej ułomność, skoro pisze: „Zdaję sobie sprawę, że nazwa Prawo Polaków może budzić wątpliwości przez swe ogólnikowe określenie"10. Te wątpliwości twórcy nazwy podzielalissmy $\mathrm{i}$ podzielamy $\mathrm{w}$ całej pełni. Określenie nasze jest $\mathrm{o}$ wiele bogatsze $w$ treść, nie wywoluje dwuznaczności tak niepożądanej $w$ terminologii naukowej. Pokazuje ono, że to spis prywatny prawa zwyczajowego, co $\mathrm{z}$ tytułu prof. Vetulaniego zupełnie nie wynika. Jedyne ryzyko - to oznaczenie superlatywem najstarszy; ale to ryzyko bierzemy $\mathrm{z}$ całym spokojem na siebie $\mathrm{z}$ racji, które wyłuszczyliśmy we wstępie do naszego wydawnictwa. Nazwa przez nas wprowadzona nie jest zresztą tak niezręczna, skoro używa jej prof. Vetulani w tytule swego artykułu polemicznego, brzmiącym Nowe wydanie niemieckiego zwodu prawa polskiego, a i w tekście prof. Vetulani stosuje identyczne określenie (s. 219, 220, 227). Zauważmy też, że Buczek uważa za trafniejsze określenie spis, ale jest ono niewątpliwie mniej techniczne niż zwód. Zresztą Buczek systematycznie posługuje się wprowadzonym przez nas skrótem (NZ), co świadczy dobitnie o tym, jak ta innowacja jest praktyczna.

\section{Charakter i cel zbiorku}

We wstępie do wydawnictwa zreferowaliśmy dawniejsze poglądy (s. 105-106), które zgodnie (poza prawdopodobnie Volckmannem) opowiadały się za tym, że NZ był pracą prywatną. Do tej opinii przyłączyliśmy się również. Idzie też za nią prof. Buczek („praca o charakterze amatorskim i nieoficjalnym", s. 167). Urzędowego charakteru dopatruje się chyba prof. Vetulani w związku ze swą koncepcją śląską zwodu.

\footnotetext{
A. Vetulani, Niemiecki spis, s. 185.

9 Zastrzeżenia Vetulaniego, ibidem, s. 185.

${ }^{10}$ Ibidem, s. 185.
} 
O praktycznym przeznaczeniu zbiorku pisaliśmy też poprzednio (s. 106). Takież przekonanie wypowiada też prof. Vetulani, natomiast przeciwstawia się mu stanowczo prof. Buczek. Trudno się do jego stanowiska przychylić.

\section{Narodowość autora}

Dla sprawy miejsca powstania zwodu w argumentacji prof. Vetulaniego istotną rolę odgrywa narodowość autora. Przyznajemy, że ten rodzaj „dowodu" nie jest dla nas bardzo przekonywający. Wszakże, chcąc śledzić drogę, jaką się snuje myśl badawcza prof. Vetulaniego, zajmijmy się nim również przed rozstrzygnięciem innych niewiadomych. Dawniej prof. Vetulani przyjmowal, że autorem zwodu był Niemiec, dobrze znający stosunki polskie. Teraz sprzeciwia się temu domysłowi stanowczo ${ }^{11}$; nic nie wskazuje na to, że autor Prawa Polskiego był Niemcem (s. 228). Ta nowa hipoteza jego spotkała się ze zdecydowanym oporem krytyki: przeciwstawia się jej mocno Buczek (s. 167), choć $\mathrm{z}$ drugiej strony niemieckości autora nie uważa za udowodnioną Russocki (s. 1267). Przyjrzyjmy się wywodom prof. Vetulaniego bliżej. Uczony ten, nie mogąc sobie poradzić $\mathrm{z}$ językiem zabytku, pisanym - wiemy - w ost-mittel-deutsch (znajomość jego każe założyć, że autorem był Niemiec), znalazł rozwiązanie dość zręczne: autorem zwodu jest Polak pochodzenia niemieckiego, $\mathrm{z}$ obojga rodziców Niemców, bądź z matki - Niemki czy ojca - Niemca, po prostu... Volksdeutsch. Jakie sq przesłanki tej hipotezy? Patriotyzm, przejawiający się rzekomo w Vorrede, która według Vetulaniego jest ,apologią niepodległości Polski”. Myśmy tymczasem dopatrywali się $w$ niej, jak i w tekście zabytku, bezstronności autora-Niemca, referującego obiektywnie zagadnienie stosunków polsko-cesarskich. Ten nuance interpretacyjny wydaje się zatem zbyt subiektywny, by na nim coś budować.

Prof. Vetulani naturalnie zdawał sobie sprawę $\mathrm{z}$ względności tego argumentu, dlatego posłużył się dodatkowym elementem, któremu obiektywizmu nie odmówi nikt: danymi statystycznymi. Zauważył on mianowicie, że w Vorrede poświẹcił autor Niemcom 3 wiersze, Polakom zaś - 13; tak postąpić mógł tylko Polak. Nie sądzimy, by ilość wierszy we wstępie mogła być pewnym wskaźnikiem dla określenia narodowości autora. Przy zwięzłości Vorrede nie sposób stwierdzić, co skłoniło jej autora do takiego wlaśnie, a nie innego ujęcia i przedstawienia rzeczy. Wszakże skoro prof. Vetulani posługuje się tą metodą „statystyczną", zastosujmy ją i my konsekwentnie. Najwięcej wierszy poświęcil autor Żydom (29), dalej Rzymianom (21), Grekom (lącznie z Rzymianami (22)). NZ został zatem zredagowany przez

${ }^{11}$ Ibidem, s. 180 i n.; na tę rozbieżność zwrócil już uwagę S. Russocki o. c., s. 1267, przyp. 5. 
Żyda! Naturalnie, dalecy jesteśmy od tego poglądu, staramy się jedynie argumentacje prof. Vetulaniego doprowadzić ad absurdum, wykazać jej niezasadność. A może jednak metoda statystyczna prawidłowo stosowana da się rzeczywiście zużytkować w badaniach nad narodowością autora? Może nie należy jej odrzucać bezwzględnie? Uprzytomnijmy sobie jeszcze raz sytuację. Autor poświęcił 29 wierszy Żydom, 21 Rzymianom, 22 Grekom łącznie z Rzymianami, 13 Polakom, a 3 jedynie Niemcom. Skoro pisal swe dzielko dla Niemców - a co do tego faktu prof. Vetulani jest $z$ nami zgodny - to przypomnial im wszystko, co wydawało mu się niezbędne z dziejów powszechnych dla „ustawienia" zabytku. O Niemcach pisal najmniej, bo oni zarówno dla Niemca-autora, jak i Niemca-odbiorcy nie stanowili takiej niewiadomej, jak inne ludy. Konkludujemy: uważamy za ryzykowne wysuwanie wniosków o narodowości autora $\mathrm{z}$ ilości wierszy poświęconych poszczególnym narodom $\mathrm{w}$ Vorrede. Jeśli zaś to kryterium zastosujemy konsekwentnie, obraca się ono przeciwko hipotezie prof. Vetulaniego: prowadzi bowiem do wniosku, że autorem NZ był Niemiec.

Prof. Vetulani nie zadowala się przedstawioną argumentacją, z której rzekomo ma wynikać to, że redaktorem NZ był... Volksdeutsch. Idzie on znacznie dalej - wskazuje niemal palcem, kto nim był. Wśród jego kandydatów do autorstwa NZ spotykamy Jakuba ze Skaryszewa i Stefana Polaka. Pierwszy, Małopolanin z pochodzenia, ale związany ze Sląskiem, de hospitibus parentibus extitit oriundus. Zatem „, rodziców nie-Polaków, z a p e w n e niemieckiego pochodzenia” (s. 229), „czyż nie mógł być autorem czy inspiratorem Prawa Polaków, aby pospieszyć z pomocą Krzyżakom"? Oczywiście, mógł. Drugi - Stephanus Polonus, o rodzicach którego nie wiemy nic, wszakże istnieją ślady jego śląskiego pochodzenia. O nim to prof. Vetulani wypowiada się następująco: „Obojętne, czy był on Niemcem z języka czy Polakiem z krwi i kości, w każdym razie mógl znać doskonale język niemiecki", „więc chyba bez trudu mó gl napisać Prawo Polaków" (s. 231). I tu zgoda na to: mógł. „Obok tych dwu wymienionych, z pewnością bylo więcej wśród wyższego kleru polskiego, których stać było na zredagowanie w poprawnej niemczyźnie zwodu polskiego prawa zwyczajowego na użytek duchownych i świeckich władz w państwie krzyżackim" (s. 231). Tego tak całkiem pewni nie jesteśmy, ale w całości nie wykluczamy i tej możliwości również. Zapytamy jednak, czy praca historyka polega na wyszukiwaniu możliwości, czy wskazanie na nie ma zastąpić już nie dowód, ale uprawdopodobnienie gloszonej tezy?

W rozumowaniu prof. Vetulaniego stwierdzić musimy dwa dalsze bardzo poważne niedociągnięcia. Z faktów, że na Śląsku godności kapitulne piastowali Niemcy z pochodzenia i duchowni urodzeni w Polsce $\mathrm{z}$ małżeństw mieszanych czy $\mathrm{z}$ obojga rodziców przybyłych do Polski z zagranicy (s. 228), że Wroclawianie studiowali za granicą, że włączono ich do capella papieskiej 
(s. 228), nie wolno nam wysnuwać żadnego wniosku co do śląskiego pochodzenia zabytku.

Stając na gruncie teorii prof. Vetulaniego, tzn. zakładając, że autorem NZ był jakiś... Volksdeutsch, nie możemy wyłączyć możliwości, że ludzie o takich samych kwalifikacjach żyli również w państwie krzyżackim! Przyjęcie możliwości śląskiej bynajmniej nie wyklucza pruskiej. Teoria śląska przy wszystkich wysilkach prof. Vetulaniego, nie stała się bynajmniej prawdopodobniejsza od krzyżackiej.

$\mathrm{Na}$ zakończenie uwag o narodowości autora $\mathrm{NZ}$ poczyńmy jeszcze następujące spostrzeżenia. Niełatwo jest stwierdzić na podstawie tekstu, czy autor czuł po polsku, czy po niemiecku. Być może zagadnienie to jest po prostu anachronizmem, dlatego pojawiły się interpretacje wzajemnie wykluczające się, prof. Vetulaniego i nasza (do niej przylącza się Buczek). Że poczucie narodowe $w$ średniowieczu istniało, to jest rzeczą niewątpliwą, ale że nie było również jasnej świadomości narodowej jak w XIX w., to także pewnik. Autor NZ nie zalicza się sam do jednej czy drugiej strony. Pisze o Polakach i polskich prawach, o Niemcach i niemieckich instytucjach w formie obiektywnej, nigdy nie używa zaimka nasz, mój. Czytelnik NZ znajduje się w o wiele gorszym położeniu niż badacz korzystający z Ksiegi Henrykowskiej, gdzie prepozyt-Polak odpowiada niemieckiemu opatowi na jego wątpliwości co do możliwości retraktu iure Polonico: ...quod aput at tavos nostros et patres ex antiquo statutum est [...]. Sed forte vos, Theuthonici, non plene intelligitis (Lib. 1,8). W takiej sytuacji zostawmy to zagadnienie na uboczu, nie zawiera ono bowiem żadnego elementu, który by nas zbliżal do rozstrzygnięcia podstawowej kwestii, gdzie zwód zredagowano. Ograniczmy się przy tym do stwierdzenia, którego dotąd nie kwestionuje nikt: autor $\mathrm{NZ}$ władal perfekt językiem niemieckim.

\section{Zawód i wyksztalcenie autora NZ}

Prof. Vetulani już w dawniejszym swym artykule wyrażal domysł, że autorem NZ byl duchowny i to wyższych stopni ${ }^{12}$ (za nim idzie Buczek, s. 266). Tę tezę pominęliśmy milczeniem w naszym wstępie, nie chcąc toczyć polemiki i tak już nadmiernej z domysłami, które nie wydawały się nam wystarczająco ugruntowane. Nie uważamy bowiem za dowód jego stanu duchownego tych wszystkich informacyj, które prof. Vetulani zestawil w swoim artykule. Ponieważ prof. Vetulani ponownie występuje ze swą teza, zmusza nas do analizy swojej argumentacji. Informacje o płaceniu

\footnotetext{
${ }^{12}$ A. Vetulani, Niemiecki spis, s. 189.
} 
świętopietrza, przepisy o zżęciu zboża bez wezwania dziesięcinnika, wzmianka o jawieniu się wyższego duchowieństwa przed sądem świeckim w sprawach chłopów poddanych nie wydają się wystarczające dla uzasadnienia stawionego domysłu. Prof. Vetulani za decydujące uważa pomieszczenie modlitw w brzmieniu łacińskim. Wszakże nie da się $\mathrm{z}$ całą pewnością wylączyć, że mógl je otrzymać od jednego z kapłanów czynnych przy sądach bożych. Skrótowa formuła końcowa modlitw, na którą prof. Vetulani zwraca uwagę, jest argumentem dla wykształcenia czytelnika NZ, a nie dla jego twórcy; to samo z faktem niewymienienia, o które psalmy chodzi w ordaliach. Całość argumentacji prof. Vetulaniego ograniczyła się zatem do tego, że wydaje się bardziej prawdopodobne, iż autor zaczerpnął modlitwy z benedykcjonału biskupiego. Zdanie: „,..zapewne sam tekst powstał na życzenie duchowieństwa czynnego na obszarze państwa zakonnego"13, którego nie widzimy powodu zwalczać, nie zawiera $w$ sobie nic, co by przemawiało za tym, ze autorem byl duchowny.

W dawniejszym artykule prof. Vetulani potrąca też o zagadnienie wykształcenia autora, co rozbudowuje w ostatniej polemice. Pisze o jego wiedzy teologicznej ze względu na znajomość Starego Testamentu, o wykształceniu prawniczym zarówno w prawie kanonicznym, jak i rzymskim (s. 229).

Pierwsze twierdzenie jest ryzykowne. Ogólnikowe wiadomości z Biblii nie mogą służyć za dowód teologicznych studiów. Teza o znajomości prawa kanonicznego i rzymskiego jest na pierwszy rzut oka frapująca, ale trzeba jej wpierw dowieść, dotąd bowiem nikt nie wykazal elementów czy to romanistycznych, czy to kanonistycznych w Zwodzie. I nie wydaje się, by to bylo łatwe: autor bowiem $\mathrm{z}$ pewnością nie powstrzymałby się od popisania swą znajomością choćby terminologii rzymskiej, tego zaś w tekście nie zauważamy wcale. Podnosimy więc wątpliwość co do powyższego założenia, a tymczasem odgrywa ono $w$ rozumowaniu prof. Vetulaniego dużą rolę. Przyjąwszy je, stwierdza on co następuje: „...takich wykształconych jednostek było w połowie wieku XIII, w okresie rozwoju kulturalnego Polski, którego dotąd nie doceniamy, z pewnością sporo. Sądzę, że wystarczy, jeśli wskażę na dwóch, którzy spelniali w nadmiarze warunki, jakie z pewnością posiadał redaktor Prawa Polaków" (s. 229). Mają być nimi wspomniani wyżej Jakub ze Skaryszewa i Stefan Polak. Nam ich wykształcenie teologiczne, a przede wszystkim rzymsko-kanoniczne, wręcz nie pozwala dopatrywać się w nich autorów zwodu (rzeczywiście - jak się wyraża prof. Vetulani - spełniają oni warunki „w nadmiarze'). Zresztą poczynić wolno jeszcze następującą uwage, stając nawet na gruncie zalożeń prof. Vetulaniego: takich teologów i prawników nie brakło też w państwie krzyżackim!

13 Ibidem, s. 190. 


\section{Miejsce powstania zwodu - partia negatywna}

Nie znamy ani miejsca, ani czasu redakcji zabytku. Skoro oba te zagadnienia musimy rozwiązać stawiając hipotezy, wypada się zastanowić, która hipotezę stawić wpierw - co do miejsca czy co do czasu redakcji. Ta kolejność bowiem może nie pozostać bez wpływu na rozwiązanie drugiej niewiadomej. Sądziliśmy, że na pierwszym miejscu trzeba rozstrzygnąć kwestię miejsca; prof. Vetulani postąpił odwrotnie. Oczywiście, moglibyśmy wypróbować obie ewentualności i rozpatrzyć, do jakich dojdziemy wyników, gdy najpierw rozwiążemy niewiadomą terytorialną, a potem chronologiczną; następnie rozważyć, co nam da kolejność odwrotna.

Ponieważ źródło o miejscu redakcji zachowuje milczenie zupełne, badacze zestawiają rozmaite pośrednie argumenty, które przemawiać mają za krzyżacką, jak większość, czy za śląską genezą zabytku, jak chce prof. Vetulani, czy wreszcie za polską (lecz nie śląska), jak przyjmuje prof. Buczek. Rzecz sama $w$ sobie ciekawa $z$ punktu widzenia metodycznego. Jak wiemy, w $C N$ znalazły się cztery pomniki: dwa $\mathrm{z}$ nich niewątpliwie powstały pod panowaniem Krzyżaków, Iura Prutenorum i słowniczek niemiecko-pruski. Trzeci - prawo lubeckie dla Elbląga, zredagowany został w Lubece, choć adresatem tej pracy było miasto krzyżackie. Problem więc rysuje się taki: czy domniemywać, że NZ zredagowano w państwie krzyżackim, jak Iura Prutenorum i słowniczek, czy też, że powstal on poza ziemiami zakonnymi, jak prawo lubeckie, a jedynie przeznaczony został dla Krzyżaków. Prof. Vetulani opowiada się za ewentualnością drugą. Rozpatrzmy jego argumenty.

1. „W treści pomnika nie ma najmniejszej, pośredniej czy bezpośredniej wzmianki, która pozwalałaby lączyć jego powstanie z ziemiami świeżo opanowanymi przez Krzyżaków. Jest to rzecz notoryczna i nie ma potrzeby nad nią się zatrzymywać" (s. 214). Zgoda, stąd te nasze wątpliwości co do miejsca powstania zabytku. Gdyby taka wzmianka najmniejsza, pośrednia czy bezpośrednia, istniała, nie toczylibyśmy sporu. Ale - i to musimy silnie podkreślić - nie ma też najmniejszej poszlaki w źródle, by lączyć je ze Śląskiem. $Z$ milczenia źródła nie wynika nic ani dla naszej tezy, ani dla supozycji prof. Vetulaniego. Argumentum e silentio nie wolno przeto prof. Vetulaniemu wykorzystywać dla siebie.

2. Szereg informacyj podanych przez NZ nie ma najmniejszego praktycznego znaczenia dla sędziego krzyżackiego - twierdzi prof. Vetulani. Wstrzymujemy się na razie od analizy przepisów, rzekomo nie mających żadnego praktycznego znaczenia dla ,połowy XIII w., nie mówiąc już o wieku XIV" (s. 214). Stańmy na gruncie teorii prof. Vetulaniego: Legat papieski dokonuje na Śląsku redakcji miejscowego, śląskiego prawa dla K rzyżaków, by mogli je nadać Prusom. Ładnym ich obdarzył zbiorkiem, 
tyle w nim przepisów bez praktycznego znaczenia! Co dziwniejsza, w świetle tej teorii Krzyżacy mimo to rozciągnęli go na ludność tubylczą; zbiorek taki, jaki jest, znalazł praktyczne zastosowanie w państwie krzyżackim. Nieudolność tej argumentacji jest więc rażąca.

Rozpatrzmy obecnie te ustępy, które - zdaniem prof. Vetulaniego - nie mogły mieć praktycznego znaczenia dla sędziego krzyżackiego. Są to: artykuł o służbie dla księcia, o pozwie książęcym itd. Okazuje się, że prof. Vetulani zestawil te przepisy NZ, w których występuje termin Landesherr. Skoro thumaczymy je przez ksiqże, a w państwie krzyżackim księcia nie było, zatem... Wszakże thumaczenie jest rzeczą dość konwencjonalną, co zresztą prof. Vetulani najsłuszniej podkreśla. Sami też wskazywaliśmy na to, że trafniej byłoby oddać termin wspomniany przez wladce (s. 156, przyp. 9), a wtedy zastrzeżenia prof. Vetulaniego upadną i calkiem już bezprzedmiotowe stanie się retoryczne pytanie, którym prof. Vetulani zakończył swój dowód drugi: „Dlaczegoż natomiast nie ma w zwodzie żadnej wzmianki o specjalnej ochronie prawnej panów i władców krzyżackich?"14

3. W trzecim punkcie sięga prof. Vetulani do innej broni. Przez argumentację przedstawioną $\mathrm{w}$ nim przebija się próba wykazania nam nie dość rozwiniętych uczuć patriotycznych ${ }^{15}$. $Z$ tym zarzutem dość osobistej natury nie chcielibyśmy polemizować ze względów zasadniczych. Zauważmy wszakże, że z nie dość rozwiniętych u nas uczuć patriotycznych nie wynika jeszcze, żeby NZ powstał na Śląsku, a to pragnie prof. Vetulani wykazać. W tej argumentacji brak jakiegoś związku wynikania. Prof. Vetulani zarzuca nam, że nie doceniamy inteligencji Polaków żyjących w XIII w. Takiego zdania tymczasem nie wypowiedzieliśmy. Jeśli w myśl naszej teorii autorem zwodu jest jakiś niemiecki funkcjonariusz zakonny, który, pracując dłuższy czas wśród Polaków w wymiarze sprawiedliwości, zapoznał się dobrze $\mathrm{z}$ urządzeniami polskimi i trafnie je ujął na piśmie, to $\mathrm{z}$ niej nie wynika bynajmniej, byśmy twierdzili, że Polak w identycznych warunkach (tzn. przebywający $w$ środowisku niemieckim i pełniący funkcje sądowe nad Niemcami) nie mógł się doskonale zapoznać z wlaściwościami sądownictwa niemieckiego i je spisać, czy nawet zręcznie zestawić z urządzeniami polskimi. Rozważenie tej ewentualności nie było dla naszej teorii potrzebne, nie rozpatrywaliśmy jej przeto; ale też nie jest potrzebne i dla doktryny prof. Vetulaniego. O co więc spór? Prof. Vetulani pisze: „....urzędnik krzyżacki redagujący zwód prawa polskiego na użytek swych kolegów nie miał możności tak doskonale $\mathrm{i}$ wszechstronnie zaznajomić się z jego zasadami [tzn. prawa polskiego]. Nie dlatego, że był Niemcem, lecz dlatego, że był

${ }^{14}$ To samo odpowiemy na zarzuty prof. Buczka (s. 157) z tym jeszcze, że ostatni sam używa terminu władca.

${ }^{15}$ Por. poczynione wyżej w ustępie 6 uwagi co do określenia Codex Neumannianus. 
urzędnikiem krzyżackim, bratem zakonnym" (s. 214). Nie rozumiemy, dlaczego zakładać brak inteligencji u zakonnego brata. Zresztą prof. Vetulani odstępuje prędko od tego przekonania, bo pisze niżej: „Zarówno Niemcy mogli poznać dobrze zasady prawa polskiego, jak i wykształceni Polacy zasady prawa niemieckiego" (s. 215). Na to piszemy się również. Dalszy argument prof. Vetulaniego: „...wydaje mi się bardzo mało prawdopodobne, aby w państwie krzyżackim, mieczem budującym swe hupieskie państwo, istniał urzędnik, który interesował się historią pewnych urządzeń polskich czy stosunkami obyczajowymi" nie nadaje się do polemiki. Przesłanka podana jest zbyt ogólna, aby cokolwiek wysnuwać z niej dla genezy NZ.

4. Dla prof. Vetulaniego wydaje się niemożliwe do przyjęcia, „aby po roku 1309 , lecz przed 1320 mógl działać urzędnik krzyżacki [...], który by w swym dziele nie dal wyrazu klasowemu i politycznemu negatywnemu stosunkowi do chłopskiej ludności polskiej i do sąsiednich książąt polskich" (s. 215). „Zważywszy tedy na rodzący się od drugiej połowy XIII w. ostry konflikt między zakonem a książętami polskimi, moment ten wprost wyklucza możność dopatrywania się autora zbioru między urzędnikami krzyżackimi" (s. 216). Pamiętajmy, że Krzyżacy w ugodzie kiszporskiej zgodzili się na przejęcie przez Prusów prawa polskiego, że później ci sami Prusowie pod ich panowaniem wrócili do swego prawa pruskiego, że wrogości wobec książąt polskich tak generalnie nie okazywali nawet $w$ drugiej polowie XIII w., jak to wykazała już J. Karwasińska ${ }^{16}$, a ostatnio podkreśla H. Chlopocka, że sam Lokietek aż do 1308 r. był do nich przychylnie nastawiony ${ }^{17}$. Co gorsza, ta cała argumentacja nie chwyta nie tylko dla XIII i XIV w., ale także dla momentu, w którym pracowal Holcwesscher. Mimo że to okres Grunwaldu, dzielko zostało starannie skopiowane!

5. Z argumentem, opierającym się na art. $28 \mathrm{NZ}$, mówiącym o ucieczce chłopa do innej ziemi polskiej albo niemieckiej, walczyliśmy już dawniej ${ }^{18}$. Wszystkie swoje dotychczasowe zastrzeżenia podtrzymujemy. Podkreślamy tu dodatkowo jedną rażącą niekonsekwencję wywodów prof. Vetulaniego. Ze zdania wstępu stwierdzającego, że Polacy byli $d y$ Dutschin zcu nokbuer, wynika dla niego, że „,autor pochodził z ziemi (polskiej) bezpośrednio s ąsiadującej z Niemcami”, a więc ze Śląska. Tymczasem w umowie kiszporskiej, stanowiącej tak ważki element dla teorii prof. Vetulaniego, czytamy - passus zresztą cytowany przez prof. Vetulaniego - że Prusacy przyjmuja legem mundanam [...] Polonorum, vicin or um suorum. Tymi sąsiadami w świetle wywodów prof. Vetulaniego są... Ślązacy.

\footnotetext{
${ }^{16}$ J. Karwasińska, Sqsiedztwo kujawsko-krzyżackie 1235-1343, Warszawa 1927-1929.

${ }^{17}$ H. Chłopocka, Tradycja o Pomorzu Gdańskim w zeznaniach świadków na procesach polsko-krzyzackich w XIV i XV wieku, RH 25, 1959, s. 75.

${ }_{18}$ J. Matuszewski, $W$ sprawie slaskiego pochodzenia najstarszego spisu prawa polskiego, CPH, t. V, 1953, s. 203.
} 
6. „Jak można wythumaczyć, że tuż przed rokiem 1320, w państwie krzyżackim, w zwodzie redagowanym przez krzyżackiego urzędnika dla sędziów krzyżackich, mógł znaleźć się przepis, że za zabitego na polu albo na drodze eynen dutschen man, den heysen dy Polen gast, gildet her [...] mit $X X X$ marken. Nie chodzi tutaj o to, że za zabicie Niemca miano placić taką samą główszczyznę, jak za każdego innego chłopa polskiego, lecz przede wszystkim, czy Polacy pod krzyżackim panowaniem niemieckich kolonistów sprowadzanych i popieranych przez władze mogli nazywać "gośćmi», a krzyżacki urzędnik mial jakikolwiek powód, aby wiadomość o tym przekazać swym kolegom" (s. 217)? Nam się to wszystko wydaje możliwe, jeśli tylko pozbędziemy się podświadomych bodźców, działających na nas, Polaków, żyjących pod wrażeniem Hakaty czy hitleryzmu, bodźców, które uznać musimy za anachroniczne dla momentu redakcji NZ. Wiemy bowiem, że mniej więcej współcześnie Polacy jakąś warstwę Polaków nazywali gośćmi i nikt im tego nie brał za złe, ani dopatrywal się braku uczuć patriotycznych ${ }^{19}$.

Odrzucić musimy również inne dowody prof. Vetulaniego: Ucieczka do miast, w których panuje prawo niemieckie - w XIV w. czy choćby w drugiej połowie XIII w. w rachubę wchodzi z całą pewnością nie tylko Śląsk. Autor $\mathrm{NZ}$ orientuje się $\mathrm{w}$ odmienności przepisów prawnych $\mathrm{w}$ poszczególnych opolach - zarzuca prof. Vetulani, ale czy sądzić, że cała ziemia chełmińska stanowila jedno opole? ( $w 1953$ r. prof. Vetulani był mniej stanowczy ${ }^{20}$ ). Pewne argumenty ująl prof. Vetulani tak lakonicznie, że nie rozumiemy ich dobrze, jak np. twierdzenie, że „Pomorze nie (wchodzi w rachubę) ze względu na jego polityczną odrębność".

W doktrynie prof. Vetulaniego jeden problem nie został wcale rozważony, a budzi on wątpliwości wyjątkowe. Według niej, Krzyżacy recypowali dla Prusów w 1249 r. polskie prawo śląskie. W myśl zasady osobowości praw, o której mówiliśmy we wstępie, Krzyżacy tolerowali wobec ludności polskiej tubylczej prawo miejscowe polskie - prawo ziemi chełmińskiej. W $1261 \mathrm{r}$. Prusacy wrócili do swego prawa pruskiego. $Z$ tego więc wynikałoby, że śląskie prawo $w$ państwie krzyżackim wygasło. Tymczasem prof. Vetulani przyjmuje, że NZ (a więc polskie prawo ze Śląska według jego domysłu) obowiązywało polską ludność zakonnego państwa. W hipotezie prof. Vetulaniego pokazuje się więc duża luka: kiedy śląskie prawo zostało przez Krzyżaków narzucone tubylczej ludności polskiej. Sam fakt zresztą wydaje się wręcz nieprawdopodobny. Zakładać przyjęcie dobrowolne, zwyczajowe,

${ }^{19}$ Że $w$ terminie hospes nie tkwiło nic ujemnego wynika $\mathrm{z}$ faktu następującego: szlachta oczyszczała się iuxta iura hospitalia, w. Semkowicz, Nagana $i$ oczyszczenie szlachectwa w Polsce $X I V$ i $X V$ w., SHPP, t. I, z. 1, Lwów 1899, s. 20.

${ }^{20}$ A. Vetulani, Najstarszy spis, s. 192. Por. też w tym duchu trafne uwagi J. Adamusa, O prawie dziedziczenia, s. 134, 137. 
prawa śląskiego przez Polaków krzyżackich za pośrednictwem Prusaków, którzy prawem polskim rządzili się co najwyżej 12 lat, nie odważy się chyba nikt.

Co prawda, w ostatnim artykule prof. Vetulani przedstawia rzecz trochę inaczej: NZ powstał w związku z przejęciem zobowiązania przez Krzyżaków, że ludność polska będzie się rządzila prawem polskim i w związku z ugodą kiszporską (s. 208). Przy tym jednak, powołując się na zasadę osobowości prawa, przyjmuje, że dla krzyżackich Polaków przeniesiono prawo śląskie. Te sprawy są ważne, skoro, jak pisze prof. Vetulani, „istniały u nas dzielnicowe partykularyzmy prawne" (s. 212). Dorzućmy jeszcze, że prof. Vetulani skłaniałby się do przypuszczenia, że ta redakcja, którą miał legat papieski, była może inna od przekazu, którym dziś dysponujemy (s. 222).

Prof. Vetulani tezę o śląskim pochodzeniu NZ nazwal w $1953 \mathrm{r}$. hipotezą roboczą ${ }^{21}$. Po upływie siedmiu lat, bez żadnych nowych, decydujących argumentów przedzierzgnęla się ona $w$ jego umyśle w pewnik. Przeciwko tej metamorfozie protestujemy stanowczo. Pozostaje ona wciąż hipotezą i to - na nasze wyczucie, a dołącza się do naszego stanowiska prof. Buczek - wysoce nieprawdopodobną, czy nawet niemożliwą.

Śląska hipoteza posiada jeszcze jeden dotkliwie słaby punkt: związana jest ściśle $\mathrm{z}$ hipotetyczną datą powstania, $\mathrm{z}$ rokiem 1249. Jest ona więc hipotezą drugiego stopnia; wywróci się zatem automatycznie, skoro tylko wykażemy nieprawdopodobieństwo chronologiczne konstrukcji.

Proweniencji krzyżackiej naszego zabytku przeciwstawia się również prof. Buczek. Rozpatrzmy z kolei jego argumenty.

1. Codex Neumannianus nie jest zespołem naturalnym; powstal z a pe w ne „w sposób czysto mechaniczny i przypadkowy przez zebranie w nim pism o różnej zgoła proweniencji" (s. 162). W przytoczonym zdaniu polączono wypowiedzi, z których za słuszną uznamy tylko jedną. Zgadzamy się mianowicie $\mathrm{z}$ różną proweniencją czterech zabytków wchodzących $\mathrm{w}$ skład $\mathrm{CN}$ : nigdzie też nie daliśmy wyrazu myśli, by były one dziełem jednego autora. Ale $\mathrm{z}$ tego nie wynika bynajmniej, by zespól powstal przypadkowo: myśl przewodnia całości jest nazbyt wyraźna; pisaliśmy o tym we wstępie (s. 39-41). Dalecy też jesteśmy od twierdzenia, jakoby to był ,na wpół urzędowy zbiór" (por. wyżej ustęp 8): z tego wszakże znowu nie wynika, by nim nie posługiwano się w sądach (s. 109). Za tym przemawia - tak przynajmniej przyjmuje się $w$ literaturze dotychczasowej $i$ do tej opinii przylączyliśmy się (s. 41) - glosa, której treści niestety nie znamy.

A jakiż wniosek naprawdę zasadny można wysnuć z obserwacji, że $\mathrm{CN}$ nie zachował się w większej liczbie egzemplarzy? Jak niewiele brakowało, żeby

\footnotetext{
${ }^{21}$ A. Vetulani, Najstarszy spis, s. 194.
} 
nawet ten jeden egzemplarz się nie uchował! Racje, dla których pewne partie CN zachowały się w większej liczbie (prawo lubeckie i Iura Prutenorum) rozpatrywaliśmy we wstępie (s. 109-110).

2. „Analiza treści tego zabytku nie tylko nie potwierdza tezy o jego krzyżackiej proweniencji, lecz zdecydowanie jej się sprzeciwia" (s. 162); „...nie ma tu najlżejszego nawet śladu instytucji krzyżackich, nie wyłączając urzędu komtura" (s. 162). Zgoda; obserwacja nad wyraz trafna. Ale czy wniosek uzasadniony? Przecież w Iura Prutenorum, których krzyżackiemu pochodzeniu nikt nie ośmieli się przeczyć, również nie ma mowy o komturze!

3. „Wspomniane w NZ urządzenia odnoszą się jak najwidoczniej do ustroju Polski dzielnicowej" (s. 162). I znowu na to zgoda; nie zapominajmy wszakże o tym, że autor NZ wyraźnie zapowiada swą chęć przedstawienia współczesnego sobie prawa polskiego i $z$ tej zapowiedzi wywiązuje się całkiem nieźle, porównując czasami urządzenia polskie z niemieckimi.

4. Że zabytek nie powstał w kraju krzyżackim ,dowodzi tego n i eo d pa rci e wzmianka o opłacaniu przez Polaków świętopietrza. W Ziemi Chełmińskiej bowiem nie ściągano go od 1255 r., a na Pomorzu Gdańskim przestano ściągać zaraz po zajęciu tego kraju przez Krzyżaków [...] Mamy tu zatem niezaprzeczalny dowód, ze NZ nie powstał, wbrew twierdzeniu J. Matuszewskiego, pod rządami krzyżackimi" (s. 163). Znowu nie widzimy tu związku wynikania między powolanymi faktami a wnioskiem. Osoba mieszkająca nie tylko pod panowaniem krzyżackim, ale gdziekolwiek indziej poza granicami państwa polskiego mogła snadnie pisać o zobowiazaniach Polski wobec papiestwa, cesarstwa itp., występujących w takiej czy innej formie, choćby one nie pokrywały się ze zobowiązaniami państwa krzyżackiego. Gdybyż to autor NZ napisal: „z naszego kraju płaci się świętopietrze”, wtedy - i tylko wtedy - rozumowanie prof. Buczka uchodziłoby niewątpliwie za uzasadnione.

\section{Miejsce powstania zwodu - partia pozytywna}

Staraliśmy się wykazać nikłość argumentów profesorów Buczka i Vetulaniego. Wszakże nie chcemy się zadowalać negacją, choćby nawet miała się ona okazać udana. $Z$ tego tytulu spotkał już nas raz zarzut ze strony prof. Adamusa (s. 142). Przejdźmy więc do poszlak, które przemawiają za krzyżacką genezą zabytku; zebral je w dużej mierze Helcel. Zestawmy na początek jeszcze raz obserwacje, na które godzą się wszyscy: 1. Rękopis znaleziony został w Elblągu, a więc na terytorium należącym niegdyś do państwa krzyżackiego; 2. Zabytek znajduje się wśród innych pruskich zabytków prawnych; 3. Zredagowany został w języku niemieckim, a przy 
tym w dialekcie, którego używali władcy państwa zakonnego; 4. Zabytek obowiązywal w państwie krzyżackim (zgodność istnieje tu między nami i prof. Vetulanim, natomiast prof. Buczek jest mniej zdecydowany, choć też przyjmuje, że sporządzono go ,nie bez myśli o praktycznych celach" (s. 167). Oczywiste jest, że przytoczone okoliczności nie stanowią jeszcze dowodu, by $\mathrm{NZ}$ zredagowano $\mathrm{w}$ państwie krzyżackim. W tych samych bowiem warunkach znajdujące się prawo lubeckie dla Elbląga zostało stworzone poza granicami państwa krzyżackiego. Stoi zatem przed nami dylemat następujący: czy stawiając hipotezę co do miejsca redakcji $\mathrm{NZ}$, pójść za analogią lubecką, lub też za analogią dwóch innych zbiorków, które weszly w skład $\mathrm{CN}$, a których geneza krzyżacka jest niewątpliwa? Analogia $\mathrm{z}$ prawem lubeckim wydaje się dość slaba. Prawo miejskie ówczesne miało $w$ dużym stopniu charakter międzynarodowy - $\mathrm{i}$ to zarówno prawo lubeckie, jak i prawo magdeburskie. Przejęcie prawa lubeckiego przez Elbląg nie stanowi jakiejś anomalii na owe czasy, wręcz przeciwnie: jest zjawiskiem zwykłym, właściwym miastom leżącym na pohudniowym brzegu Bałtyku. W innych rejonach konstatujemy podobnie zwycięski pochód praw magdeburskiego, chelmińskiego itp. Znajdujemy na to dziesiątki czy nawet setki przykładów. Podobnej recepcji masowej praw ziemskich nie znamy wcale. Przejęcie prawa polskiego przez Prusów stanowi jakiś jaskrawy wyjątek; nie wiemy zresztą, czy ono faktycznie się dokonało, skoro w 12 lat później Prusowie posługują się już swoim narodowym prawem.

Powiedzieliśmy, że prawo lubeckie jest importem $\mathrm{z}$ zewnątrz. Znamy datę dokładną, kiedy zawędrowało ono z Lubeki do Elbląga - rok 1240. Rękopis pierwszego egzemplarza zachował się do dziś dnia i obecnie znajduje się w WAP Gdańsk. Był on napisany po łacinie. Prędko pojawiaja się jego thumaczenia niemieckie; ze względu na potrzeby miast lokowanych na prawie lubeckim, posługujących się niederdeutsch, w tym dialekcie te thumaczenia początkowo ujęto. W pierwszych latach XIV w., a może nawet w końcu XIII w., powstaje nowa redakcja prawa lubeckiego, tłumaczenie na język środkowo-niemiecki. Ten język świadczy o tym, że przekładu dokonano na użytek Zakonu, którego kancelaria posługiwała się tym językiem. Wszystkie późniejsze rękopisy elbląskie prawa lubeckiego, między innymi $\mathrm{i}$ ten, który jest zawarty w Codex Neumannianus, już ten dialekt zachowują. Jeśli więc utrzymywaliśmy, że dwa zabytki zawarte w CN są krzyżackiego pochodzenia, a trzeci pozakrzyżackiego, to braliśmy daleką genezę ostatniego. Konkretny egzemplarz lubeckiego prawa w języku „krzyżackim" również na terenie krzyżackim powstał. Czy w tych warunkach nie jest ryzykowne dopatrywać się importu jednej cząstki ze Śląska? Skoro wszystkie trzy rękopisy są zabytkami z państwa krzyźackiego, czyż duże prawdopodobieństwo nie przemawia za tym, żeby i czwartemu, tzn. NZ, takąż krzyżacką genezę przypisać? 
Prof. Vetulani powołuje się na analogį prawa górniczego. Rzeczywiście Krzyżacy recypują śląskie prawo górnicze, ale i co do tego szczegółu znowu możemy powiedzieć, że i to charakter międzynarodowy tego prawa rzuca się w oczy. A Śląsk to niewątpliwie najbliższy dla Krzyżaków rejon, w którym są góry.

Pewne dane przemawiają również za krzyżackim rozwiązaniem. Wiemy, że uznali oni wobec rycerzy ius Polonicum militare (1233 r.), że w państwie krzyżackim spisywano ludowe prawa tubylcze (Iura Prutenorum), że spisywano je również $w$ języku niemieckim i to takim samym jak język NZ. Skoro Krzyżacy utrzymywali prawo polskie wobec rycerstwa, skoro zgadzali się na obowiązywanie prawa pruskiego wśród Prusów, wydaje się całkiem naturalne, że i prawo polskie wobec miejscowych Polaków było respektowane. Zresztą na tym samym stanowisku stoi i prof. Vetulani. W tych wszystkich szczególach, które tu zestawiliśmy, nie znajdujemy żadnego elementu, który by przeciw krzyżackiej genezie przemawiał.

Zważmy jeszcze na obserwacje poczynione dawniej, dopatrujące się pokrewieństwa przepisów prawnych, znanych NZ, z prawem mazowieckim, a nie $\mathrm{z}$ grupą śląsko-małopolską. Prof. Vetulani sam podkreślal kiedyś konieczność badania różnic dzielnicowych ${ }^{22}, \mathrm{z}$ jego strony więc należało oczekiwać dowodu pokrewieństwa $\mathrm{z}$ grupą śląską, a tej pracy nawet nie zapoczątkował.

Dodajmy jeszcze, że nie bardzo rozumiemy tę całą argumentację, która chce wykluczyć krzyżackość zabytku na tej podstawie, że NZ mógl powstać choć nie na Śląsku, to w każdym razie w Polsce (Buczek, s. 162-163). Ziemia Chelmińska czy Pomorze spełniają wszelkie warunki polskiego kraju; tylko że tereny te znalazly się stosunkowo niedawno pod niemiecką okupacją.

Rozpatrując krzyżacką i śląską hipotezę, zauważyć musimy pod jednym względem niższość hipotezy śląskiej. Opiera się ona na całym komplecie hipotez, od chronologicznej począwszy, z których każda $\mathrm{z}$ osobna wydaje się nieprawdopodobna. Do tylu niekonsekwencji, które staraliśmy się wykazać, dorzućmy jeszcze jedną: jak można przyjmować, że legat papieski, który potępia szereg zwyczajów prawnych obowiązujących w Polsce - stwierdzil to prof. Vetulani ${ }^{23}$ - transplantuje sądy boże do państwa zakonnego?

Prof. Vetulani stwierdzał kiedyś, że opinio communis opowiada się za genezą krzyżacką zabytku ${ }^{24}$, że „wniosek taki [tzn. jego o śląskim pochodzeniu] na pierwszy rzut oka może wydawać się zbyt ryzykowny ${ }^{25}$. Nam się wydaje taki również po gruntownym przemyśleniu. Za śląskim pochodzeniem nie przemawia nic.

\footnotetext{
${ }^{22}$ Ibidem.

${ }^{23}$ Ibidem.

24 Ibidem, s. 188.

${ }^{25}$ Ibidem, s. 193
} 
Opowiadając się za dawną hipotezą Helcla o redakcji NZ w państwie krzyżackim, nie twierdzimy, że ją udowodniliśmy, jak to czyni prof. Vetulani co do swej hipotezy śląskiej. Staraliśmy się jedynie wykazać jej duże prawdopodobieństwo i na tym się nasza rola kończy.

Dodajmy wreszcie, że prof. Adamus zauważa, iż ,pewne prawdopodobieństwo przemawiać raczej się wydaje za tradycyjna hipoteza" (s. 191). Przy tym zastanawia się nawet nad tym, czy spisane w NZ prawo „stanowi pomnik dawnego oryginalnego prawa polskiego, a nie może jakieś prawo już dość gruntownie zmienione przez Krzyżaków"26.

Skoro historycy nie potrafią żadnego decydującego argumentu przytoczyć za taką czy inną proweniencją zabytku, zapytajmy, co na temat tak dyskutowany mówią językoznawcy ${ }^{27}$. Niestety badania dotychczasowe nie doprowadziły w tym względzie do jakiegoś stanowczego wyniku ${ }^{28}$.

\section{Czas redakcji zabytku - partia negatywna}

Trzynastowieczność zabytku jest hipotetyczna ${ }^{29}$, związek zaś z rokiem 1249 wręcz lekkomyślny. Prof. Vetulani nie był dawniej tak jego pewny ${ }^{30}$. Że wpadı na ten pomysł dwudziestoletni dr Sierakowski, to tlumaczy się łatwo jego wiekiem. Prof. Vetulani nie wyłącza teraz możliwości jeszcze wcześniejszej redakcji pomnika (s. 223). W tej pustce źródłowej, gdy chodzi o rozwój życia prawnego u Prusów i w państwie krzyżackim, jedna data jest pewna - rok umowy kiszporskiej. Ale to jeszcze nie podstawa do łączenia $\mathrm{z}$ nią genezy $\mathrm{NZ}$.

Za trzynastowieczna proweniencją zabytku ma przemawiać antyczność instytucji. Sa one bowiem starsze od statutów Kazimierza Wielkiego. Na s. 138.

${ }^{26}$ J. Adamus, O prawie dziedziczenia nieruchomości przez kobiety, CPH, t. XI, z. 1, 1959,

${ }^{27}$ Sprostujmy przy tej okazji omyłkę, jaka zakradła się do niektórych recenzji, jakoby NZ był spisany w języku staroniemieckim, jest to tymczasem język średnioniemiecki (milteldeutsch, a nie altdeutsch).

${ }^{28}$ Oto opinia wypowiedziana przez dr Halinę Zawadzką w pracy znanej nam z maszynopisu: „Das ÄPRdm (NZ) gehört ohne Zweifel der ostmitteldeutschen Kanzleisprache an, wofür in der vorliegenden Arbeit Beweise angeführt werden..., s. XXVI... Auf Grund der hier gebotenen orthographischen und historisch-phonetischen Analyse kann jedoch das Entstehungsgebiet nicht näher bestimmt werden. Um dies zu ermilteln, müsste eine Reihe anderer, aus dem ganzen omd. Gebiet stammender Handschriften herangezogen werden, wobei vor allem Urkunden des Deutschen Ordens und der Kanzleisprache Schlesiens von ausschlaggebender Bedeutung zu sein scheinen, s. XXVII".

${ }^{29} \mathrm{Na}$ jakimś nieporozumieniu polega zdanie prof. Adamusa, jakobym redakcję NZ odnosił do początku XV w. (s. 192). W tym momencie skopiowano Codex Neumannianus (s. 45).

${ }^{30}$ A. Vetulani, Niemiecki spis, s. 184. 
to godzimy się niewątpliwie, cóż wszakże $\mathrm{z}$ tego wynika? Czy nie dopiero w tychże statutach znosi się odpowiedzialność w wypadku, gdy quacunque morte casuali vel inopinata contigerit aliquem de hac migrare luce, puta de arbore cadendo videlicet vel in aqua mergendo, S.n., art. 59. Czy zatem aż do lat sześćdziesiątych XIV w. ${ }^{31}$ nie obowiązywał starodawny przepis, który zresztą znalazł również odzwierciedlenie w art. $10 \mathrm{NZ}$ : jeśli się ktoś utopi, zo ledt der herre adir der richter dy gegenote. Dy mus bewysen, wer in irtrenkit hat? Czy więc rzeczywiście błędna jest moja koncepcja, jakoby antyczne przepisy mogly obowiązywać w wieku XIV, jak mi to zarzuca prof. Vetulani? W ogóle, dodajmy, datowanie oparte na argumencie antyczności instytucji jest metodycznie dość ryzykowne. Urządzenia raz wprowadzone utrzymują się siłą bezwładności dhugo, przeżywają warunki, w których powstały, wskutek czego wystąpić moga w źródłach nawet paręset lat po ich zjawieniu się. Dawniejsza teoria poczytywała retrakt ex iure gentilicio za relikt $\mathrm{z}$ okresu rodowego!

Jeśli kwestionujemy antyczność instytucyj jako podstawę datacji źródła prawnego $-z$ jednej strony, to $-\mathrm{z}$ drugiej - wydaje się nam mocny argument powolania się na instytucje nowe, poświadczone przez badany zabytek. Do takich zaliczylibyśmy za prof. Buczkiem (s. 165) praktykę stosowania pisma w postępowaniu sądowym. Według NZ, oskarżyciel wyraża zgodę na świadków proponowanych przez oskarżonego: welchin her abir libet, den heyset der richter schreyben, art $5^{2}$. Istnieje też człowiek, der dy geczuge scribit, któremu należy się przepisana przez zwyczaj taksa w wysokości 6 fenigów art. $5^{3}$. Jak wiemy, najstarsza wzmianka polska o tabulae iudicii pochodzi z $1322 \mathrm{r} \cdot{ }^{32}$ Mówi ona o tym, że wpisywano w nie terminy pozwów. NZ donosi natomiast o notowaniu pisemnym imion świadków. Czy rzeczywiście taką praktykę wolno nam cofnać do połowy XIII w. w stosunkach ziemskich? Co prawda prof. Vetulani przyjmuje, że o szerszym zastosowaniu pisma w procesie ziemskim można mówić już w polowie XIII w. (s. 212, p. 35), ale czy teza taka da się utrzymać, skoro oparciem dla niej są jedynie teksty mówiące o citacio per litteram? Problem w każdym razie wymaga bliższego rozpatrzenia.

Dla prof. Vetulaniego argumentem mocnym, przemawiającym za trzynastowiecznością zabytku, jest kara kamienowania, grożąca według NZ zdrajcom. Czy kara ta jest rzeczywiście niemożliwa z początkiem XIV w.? Zaglądamy do najnowszej pracy poświęconej karom - powołuje się też na nią prof. Vetulani - i stwierdzamy, że na cały okres piastowski posiadamy tylko dwie

${ }^{31}$ S. Roman, Z badań nad statutem wielkopolskim Kazimierza Wielkiego, [w:] Opuscula Casimiro Tymieniecki septuagenario dedicata, Poznań 1959, s. 239 i n.

${ }^{32}$ S. Kutrzeba, Historia źródel dawnego prawa polskiego, t. I, Lwów-Warszawa-Kraków, b. d., s. 130 . 
wzmianki o kamienowaniu, u Galla i w $\mathrm{NZ}^{33}$. Jak przy tak szczuplym zasobie informacji budować coś pewnego? Czy zabytek postawimy na polowę XIII stulecia, czy na początek wieku XIV, będzie to zawsze przykład poza Gallem jedyny. Czyż więc ,rzecz dziwna”, żeśmy tego elementu nie zużytkowali?

Prof. Vetulaniego razi występowanie sądów bożych w zakonnym państwie w wieku XIX. Wszakże zabytek świadczy niedwuznacznie o zanikaniu tych sądów, o uchylaniu się duchowieństwa od nich. Czyż tu właśnie nie dopatrywać się wpływów ustawodawstwa kościelnego, które zrazu zakazywało duchowieństwu jedynie uczestnictwa przy ordaliach, ale nie tykało samej instytucji? Gdyby więc NZ informowal, że biskupi czy jakaś inna ecclesiastica persona brała sama udział $\mathrm{w}$ pojedynku, to wydawałoby się nam na początek XIV w. rażące, ale kiedy dawała się zastąpić swemu poddanemu (podobnie zresztą postępuje książz̨), nie widzimy w tym argumentu po myśli prof. Vetulaniego. W przypisie swego cennego artykułu prof. Vetulani stwierdza $-z$ powolaniem się na inną własną publikację - że biskupi polscy już w końcu XII w. mieli wątpliwości co do ujemnych następstw, czekających duchownego za udział w sądach bożych (s. 206, p. 27). Ale wiemy też, jak długo przepisy prawa powszechnego o viri uxorati nie byly respektowane w polskiej prowincji kościelnej! Przypomnijmy wreszcie ponownie, że na sąsiadującym z Prusami Mazowszu ordalia utrzymały się do końca XIV w. (s. 75).

Żaden zatem $z$ przedstawionych przez prof. Vetulaniego dowodów nie jest $w$ stanie zbić hipotezy o powstaniu NZ w początku XIV w. To wszystko, co mogło dziać się w połowie XIII w., a tym bardziej w latach siedemdziesiątych-osiemdziesiątych tegoż stulecia, moglo mieć miejsce również w pierwszym dwudziestoleciu wieku następnego.

Ale prof. Vetulani w ostatnim artykule wytacza nowe działo, pisząc: „,...wydaje mi się, że do dawnych argumentów wysuwanych na uzasadnienie trzynastowiecznego pochodzenia Prawa Polskiego jestem obecnie $w$ stanie dorzucić jeszcze jeden. Wzmacnia on moją hipotezę o powstaniu naszego pomnika w polowie wieku XIII". Dostarcza go pismo Innocentego IV z 1253 r. do legata Opizona. Uzasadniono w nim świętopietrze tak samo jak w NZ.

Otóż niewątpliwie byłby to argument datacyjny o wyjątkowym, przekonywającym znaczeniu, gdyby... Od razu przyznalibyśmy prof. Vetulaniemu rację, przestalibyśmy bronić późniejszej genezy zabytku, staralibyśmy się ułożyć historię pomnika tak, by okoliczności jego powstania dostosować do

${ }^{33}$ H. Grajewski, Kara śmierci w prawie polskim do polowy XIV wieku, Warszawa 1956, s. 204-206. Za pierwszą wzmiankę poczytywał informację NZ M. Handelsman, Kara w najdawniejszym prawie polskim, Warszawa 1907, s. 160. 
tej niewątpliwej daty. Prof. Vetulani wszakże zawodzi nas w swej argumentacji zupełnie, nie wykazuje bowiem bynajmniej, że NZ powstal przed wspomnianym pismem papieskim, bez tego zaś cała teza wisi w próżni. Jeśli bowiem NZ zredagowano po tej dacie, to pole dla wszelakiego rodzaju hipotez otwarte. Prof. Vetulani ustala zależność tekstową obu zabytków, ale ona nie wystarcza dla datacji; trzeba jeszcze stwierdzić kierunek tej zależności. Prof. Vetulani powołuje pismo Jakuba Świnki z 1285 r. o podobnej argumentacji. Gdyby ono nie było datowane, czyżby $z$ tego należało wnosić, że powstało przed aktem z 1253 r.? Co więcej, prof. Vetulaniemu wydaje się, „że przy sformułowaniu niniejszego pisma Jakub Świnka mógł mieć w swym ręku odpis pisma książąt wysłanego do Innocentego IV, względnie odpis pisma papieskiego, skierowanego do legata papieskiego Opizona z 1253 r." (s. 211, p. 33). A czyż tych pism nie mógł mieć w ręku redaktor NZ? Jak długo zatem prof. Vetulani nie udowodni nam starszeństwa NZ od pisma z $1253 \mathrm{r}$., nie będziemy mogli poshugiwać się ostatnim aktem jako elementem datacyjnym, tym bardziej że prof. Vetulani wykazał nam tekstową zależność tych aktów (s. 211, 223-224)!

To, co prof. Vetulani doczepia do swej argumentacji, mianowicie wywody o kanonizacji św. Stanislawa, pominiemy już milczeniem. Co tu kanonizacja ma do rzeczy? Z Żywotu św. Stanisława ma być - zdaniem prof. Vetulaniego - zaczerpnięta myśl przemienionej wielkości (s. 228). Cóż jednak bardziej pospolitego jak megalomania narodowa. Przeprowadzanie filiacji na podstawie wzmianek o niej wydaje się nam rzeczą ryzykowną.

Rozważmy jeszcze jedno zagadnienie: co jest prawdopodobniejsze - oparcie się dokumentu o zbiorek prawniczy, czy oparcie się tego zbiorku o dokument? Opowiedzielibyśmy się raczej za ewentualnością drugą. Ale załóżmy - by śledzić tok rozumowania prof. Vetulaniego - że istotnie pismo z $1253 \mathrm{r}$. opiera się na NZ. Nie przyjmiemy - jak się wydaje - ewentualności, że kancelaria papieska wzorowała się na NZ, lecz założymy raczej, że zrobili to książęta polscy w swym piśmie obediencyjnym. Jakże to pogodzić $\mathrm{z}$ innymi założeniami doktryny śląskiej? Legat papieski, znajdując się w drodze do Krzyżaków, sporządza na Śląsku dość szczegółowy spis prawa zwyczajowego. Dowiadują się o tym książęta polscy, dokonują z niemieckiego tekstu dosłownych zapożyczeń i układaja na tej podstawie lacińskie pismo do papieża. Co więcej, jak to wszystko pomieścić w czasie? Wyrażaliśmy dawniej wątpliwości co do faktu, by legat niejako na kolanie dokonal redakcji śląskiego prawa zwyczajowego w języku niemieckim. Tymczasem $\mathrm{w}$ świetle rozpatrywanych tu wywodów tyle jeszcze było czasu, że fakt ten zdołano zakomunikować polskim książętom i ci zdążyli przysłać notariusza, który skopiowal sobie argumentację NZ.

Prof. Vetulani zapytuje: „Jaki interes miał urzędnik krzyżacki, rzekomy autor zbioru, aby ją [tzn. doktrynę wiążąca świętopietrze $\mathrm{z}$ przyjęciem 
chrześcijaństwa] przekazywać do wiadomości innym krzyżackim urzędnikom" (s. 212, przyp. 34)? Odpowiedzi na to dać nie potrafimy.

W polemice dawniejszej $\mathrm{z}$ prof. Vetulanim żartowaliśmy sobie $\mathrm{z}$ jego argumentu, jak to Krzyżacy odczuwali potrzebę spisania polskiego prawa zwyczajowego, i jak ta potrzeba w pewnym momencie stała się dla nich paląca. Ku naszemu zdziwieniu nasz oponent ten argument potrzeby „palącej” podtrzymuje. Czy on wszakże nie jest zbyt subiektywny? Jak udowodnić, że „paląca" potrzeba odnośnie do prawa polskiego powstała już w połowie XIII w., a taka sama „paląca” potrzeba co do prawa Prusów powstała dopiero w 1340 r.? Przez 90 lat zatem w stosunku do ludności tubylczej, która stanowiła trzon państwa krzyżackiego, w stosunku do Prusów, mieszkających w masie, potrzeba zatrzymała się w stadium ,niepalącym"?

Te swoje spostrzeżenia o „palących” i ,niepalących” potrzebach zaopatrzył prof. Vetulani w uwage, która ma pogrążyć mnie zupełnie; oto ona: „Wbrew całemu nowoczesnemu kierunkowi naukowemu, rozwiniętemu szczególnie we Francji, który w sposób naukowo bardzo płodny łączy powstanie pomników prawnych $\mathrm{z}$ rodzącymi się nowymi potrzebami i doktrynami, woli stanąć [Matuszewski] na stanowisku agnostycznym" (s. 222). Tak rzeczywiście, wolę agnostycyzm od „naukowej” argumentacji, której próbkę dostarczył nam prof. Vetulani.

Prof. Vetulani szydzi z mojej argumentacji o zbieżności (dodajmy częściowej) polskiej doktryny dworskiej o stosunku Polski do cesarstwa z poglądem, reprezentowanym przez $\mathrm{NZ}$, oraz $\mathrm{z}$ posłużenia się argumentem „królestwa polskiego". Pierwszy fakt wykazuje zgodność „,wiszącą w powietrzu" - pisze prof. Vetulani, drugi - jego zdaniem - jest „,zupelnie chybiony”. Wszakże równocześnie stwierdza: „,..otóż oba powyższe argumenty (o bardzo wątpliwej wartości) mog ły b y być użyte jako wskaźniki do określenia ostatecznej daty, przed którą zwód nasz musia powstać". Właśnie tak zużytkowałem przytoczone argumenty (s. 90-94).

Prof. Vetulani ciągnie dalej tak: „Ale czy prof. Matuszewski ma jakieś argumenty, które $\mathrm{każa} w \mathrm{ykluczyć}$ wiek XIII, jako epoke powstania Prawa Polaków oraz każą przyj áć wiek XIV, jako czas jego spisania"? $\mathrm{Na}$ to odpowiemy łatwo: Czy prof. Vetulani dysponuje jakimś elementem, który każe wykluczyć wiek XIV jako epokę redakcji NZ? Czyż ponownie mamy przypominać zdanie Helcla (s. 78) i konkluzję naszą, wysnutą $z$ analizy jego argumentacji (s. 80)?

$\mathrm{Na}$ drugie pytanie odpowiemy afirmatywnie, zwracając uwage na moment pominięty przez prof. Vetulaniego - moment, którego wszakże pozostawić bez uwzględnienia nie można: argument lingwistyczny. Podkreśliliśmy już dawniej jego wage (s. 79); zanim jednak przejdziemy doń, rozpatrzmy jeszcze argumentację prof. Buczka, który wypowiada się za drugą połową XIII w., najchętniej za latami 1270-1280. 
Stwierdźmy od razu, że sposób argumentacji, dość chaotyczny, budzi poważne zastrzeżenia. Krytyk zestawia razem szereg instytucji, mających przemawiać za trzynastowieczną genezą NZ. Takie zgrupowanie argumentów - przyznajemy - dla przekonania mniej krytycznego czytelnika zawiedzie, gdy każdy $z$ tych argumentów zanalizujemy $z$ osobna.

Trudno przyjąć dość niejasną argumentację o królewskości polskiej istniejącej rzekomo już w latach 1295-1319. Że zrównanie kupców w główszczyźnie z rycerstwem przystaje wyłącznie do XIII w., udowodni nam autor dopiero w zapowiedzianym przez siebie artykule; na jego ukazanie się musimy więc czekać. Zaś wszystko to, co wspomniany uczony pisze o komorniku, pozostaje bez wartości, gdy zważymy, że w Iura Prutenorum, zabytku w każdym razie późniejszym niż NZ, taż instytucja występuje niejednokrotnie. Jakiż walor przekonywający ma dowód kupna dziewcząt, skoro wspomniany badacz daje w przypisie przykład identycznego kupna z XV w.!

Prof. Buczek zresztą zdaje sobie sprawę $\mathrm{z}$ względności swych tez, skoro zgrupowawszy tyle dowodów, przemawiających rzekomo za wiekiem XIII, dodaje: „...można wprawdzie utrzymywać, że zawarte w NZ wskazówki pośrednie dadzą się odnieść od biedy, czy nawet równie dobrze do początków XIV w." (s. 164).

\section{Czas redakcji zabytku - partia afirmatywna}

Badania jezykowe, nie doprowadzone jeszcze do końca, pozwalają już dziś na stawienie pewnych domysłów: wydaje się, że pomnik powstał w początku XIV w.; zwyczaje ortograficzne, jakie wykazuje NZ, pojawiają się z początkiem tego stulecia; te same obserwacje nie pozwalają przenieść redakcji zabytku do drugiej połowy XIV w. ${ }^{34}$

${ }^{34}$ Oto dosłowny cytat $\mathrm{z}$ nie drukowanej pracy dr H. Zawadzkiej: „Es lässt sich also, was das orthographische Bild anbetriff, nichts absolut Sicheres sagen. Diese Schlüsse, die hinsichtlich der Entstehungszeit des ÄPRdm (NZ) auf Grund orthographischer Merkmale gezogen werden, sind nur hypothetische Feststellungen, die auf einer breiteren Vergleichsebene untersucht, vielleicht festgelegt werden könnten.

Das Denkmal scheint aus dem Anfang des 14. Jhs zu stammen. Darauf weisen folgende Tatsachen: die Doppelschreibung ee, die Verwendung des Zeichens $y$ sowohl für den Vokal (im Wechsel mit $i$ ) als auch für den Konsonanten, die Verwendung des $w$ als Bestandteil des Diphtongs, wo $w$ als Laut etymologisch nicht begründet ist, ausserdem die Schreibung $w$ für $u$, die Bezeichnung der Affrikata mit $c z$, die Schreibung $c z$ im Wortanlaut, die Doppelschreibung ssch - alles dies sind Schreibgewohnheiten, die seit dem 14. Jh. in Handschriften und Urkunden auftreten und die auch im ÄPRdm aufzuweisen sind. Andererseits konnte das Denkmal nicht später als in der ersten Hälfte des 14. Jhs. niedergeschrieben werden, wenn wir als Beweis solche Eigenheiten heranziehen, wie das sporadische Auftreten des $h$ als 
Rozpatrzmy się wreszcie w historii polskich „zwierciadel” prawnych.

Zauważmy od razu, że pojawiają się one nie przed końcem XV w. $\mathrm{z}$ jednym wyjątkiem: na terytorium łęczyckim ułożono u schyłku XIV w. mały zbiorek złożony z 14 artykułów, znany z dziełka późniejszego, zatytułowanego Constitutiones Lancicienses, a ulożonego w początku XV w. Z XV stulecia pochodzą też prawdopodobnie Consuetudines terrae Mazoviae oraz Consuetudines terrae de processu iudiciario et terminorum observatione, wcielone do pierwszego statutu mazowieckiego z $1532 \mathrm{r}$.

Malopolskie Artykuly sqdowe, jak wykazal w swym cennym studium prof. Vetulani, pochodzą z ostatniej ćwierci XV w. (1469-1493), Consuetudines terrae Cracoviensis - z początku XVI w. (przed 1506 r.). Ostatnie pozostają zresztą w związku $\mathrm{z}$ redakcją oficjalną zwodów, przewidzianą przez kanclerza Łaskiego i nakazaną przez Aleksandra I.

Tak więc w stosunkach polskich zwody prawne powstają w świetle źródeł najwcześniej w końcu XV w. Co ważne przy tym, wszystkie ujęte są po lacinie. Przyjmować w tych warunkach redakcję polski ego zwodu po niemiecku w Polsce w polowie XIII w., a więc 150 lat wcześniej, wydaje się bardzo ryzykowne. Do takiej hipotezy musimy się odnieść jak najbardziej sceptycznie. Jeszcze jaskrawiej rzuci się w oczy ta wyjątkowość, gdy „ustawimy” NZ na tle europejskiego rozwoju zbiorów prawnych.

Przypomnijmy najważniejsze jego daty. We Francji (poza źródłami kanonicznymi i dziełami zagranicznymi prawa feudalnego, jak Libri feudorum i Assises de Jérusalem) w XIII w. notujemy kilka zwodów. Szereg ich rozpoczyna powstały okolo 1200 r.: Le Très-Ancien Coutumier de Normandie, po nim idzie Summa de legibus Normandiae i Conseil à un ami Piotra z Fontaines (1254-1258). Nieco później ukazuje się Livre de Jostice et Plet (ok. 1270 r.). Établissements de Saint-Louis (1272-1273) i po roku 1283 arcydzieło tego rodzaju literatury francuskiej, Coutumes de Beauvaisis. W XIV w. liczba ich wzrasta. W wieku XV ich redakcja oficjalna zostala przepisana przez ordonans z Montilz-les-Tours z $1454 \mathrm{r}$.

W Niemczech najgłośniejsze dzieło - Sachsenspiegel, ukazuje się około 1220-1235; następne - Spiegel der deutschen Leute (1235-1275), zostało niedokończone, a zrewidowane przez autora Schwabenspiegel z lat 1274-1275.

Längezeichen, das Fehlen der Verdoppelung für $s$, die nur in einem Beleg vorhandene Schreibung th, den willkürlichen Wechsel $u / v$ für Vokal und Konsonant, die Schreibung $c z$ im Anlaut des Wortes, die vereinzelte Schreibung $n n, l l, r r$.

Diese orthographischen Merkmale können aber nicht die einzige Grundlage für eine endgültige Datierung des Denkmals sein, da wir über die Vorlage Holcwesschers zu wenig wissen. Der Beginn des 14. Jhs. könnte als Entstehungsdatum der Handschrift angenommen werden, wenn wir wüssten, dass Holcwesscher das Original selbst benutzt hat. Wäre es jedoch nur eine ältere Abschrift, so dürfen wir im Hinblick auf das Original keine Schlüsse ziehen, wenn wir nur das orthographische Bild der Quelle als Beweis heranziehen", Die Sprache des ältesten polnischen Rechtsdenkmals (Orthographie, Laute), s. XXIII-XXIV. 
W Czechach z XIII w. nie mamy żadnego zwodu. Z pierwszej połowy XIV w. pochodzi dzieło Piotra Rosenberga; jego część pierwsza dotycząca procesu sięga, jak się wydaje, XIII w.; drugie dzieło czternastowieczne to Ordo iudicii terrae.

Co prawda $\mathrm{z}$ terenu słowiańskiego posiadamy znacznie wcześniejszy zwód - Prawdę Ruską; jej początków dopatrują się badacze już w XI w. Z tym wczesnym rozwojem Rusi nie można jednak porównywać stosunków polskich. Przy tym, co ważne, Prawda Ruska nie została zredagowana w języku niemieckim!

W tych warunkach skłonni jesteśmy przesunąć datę redakcji NZ na datę możliwie najpóźniejszą ante quem, na taki moment, któremu nie sprzeciwia się nic, a który przy tym jest w pełnej zgodzie z językiem $\mathrm{zabytku}$, na okres, który nie jest zbyt oddalony od innego podobnego zabytku prawa zwyczajowego lửności tubylczej w państwie krzyżackim, Iura Prutenorum, powstałego w swej redakcji pierwotnej w $1340 \mathrm{r}$.

Data ta, co ciekawe, nie tylko zbliżona jest do chwili spisania Iura Prutenorum, lecz zgadza się również z czasem powstania innych zabytków, wchodzących w skład Codex Neumannianus: prawo lubeckie w wersji ostmitteldeutsch - około 1300 r., słowniczek niemiecko-pruski - z początku XIV w., czy nawet $z$ końca XIII w. Przy tym, co znowu istotne, datowanie tych zabytków nastąpiło niezależnie, dokonali go badacze, którzy nie zajmowali się wcale NZ - uczeni, którzy reprezentowali odrębne gałęzie wiedzy.

Datując redakcję NZ na ante $1320 \mathrm{r}$, zdajemy sobie sprawę z tego, że jest to hipoteza; ze względu na argumenty przedstawione wyżej, wydaje się ona najbardziej prawdopodobna. Chętnie ustąpimy przed doktryną lepiej zbudowaną. Hipoteza o powstaniu NZ na Śląsku w 1240 r., zawierająca wewnętrzne sprzeczności, wydaje się nam wręcz nieprawdopodobna ${ }^{35}$.

${ }^{35}$ Zaprotestować musimy stanowczo przeciwko zbyt afirmatywnym wypowiedziom prof. Vetulaniego w rodzaju: ,ponieważ okazuje się, że Prawo Polaków powstało poza obszarem krzyżackim, że nie wyszło spod pióra krzyżackiego urzędnika"; „tym samym, skoro wykluczone jest, jak wykazałem, pochodzenie zasad tego prawa z ziemi polskiej opanowanej przez Krzyżaków"; „wobec przeprowadzenia przeze mnie dowodu, że Prawo Polaków nie mogło powstać w wieku XIV”; „wiemy już, że państwo krzyżackie nie było ojczyzną autora zwodu". Otóż nie, nie, stanowczo nie. Prof. Vetulani niczego nie dowiódł, niczego nie wykazał, niczego nie wykluczył; stawił odrębną od mojej hipotezę - co mu wolno, ale zapomniał w wigorze polemiki, że jego hipoteza pozostaje hipotezą od pierwszej do ostatniej strony i taka pozostanie aź do dostarczenia dowodu; tego zaś dotąd prof. Vetulani nie przedstawił. Naprawdę zatem wszystko ogranicza się do zdania, które prof. Vetulani nieoględnie w swym tekście pomieścil: „dzisiaj jeszcze jestem głębiej przekonany niż w 1953 r.” (s. 222). Ale to głębokie przekonanie prof. Vetulaniego o jego infallibile magisterium nie starczy za dowód. 


\section{Uwagi o metodzie dyskusji}

Chcąc zbić nasz domysl, prof. Vetulani - podkreślam to, bo wymóg jest wręcz frapujący - żąda ode mnie dow od u n e gat y w ne g o: ,[Matuszewski] nie podal jednakże żadnego argumentu, który przemawialby za tym, że w związku $z$ tymi wypadkami (tzn. ugoda kiszporską) nie mógl powstać nasz pomnik" (s. 208). To jest prawda. Ja rzeczywiście nie dowodzę, że $\mathrm{NZ}$ nie mógł powstać w 1249 r. Dezyderat prof. Vetulaniego thumaczymy sobie latwo: znakomity mediewista, znawca szczególny średniowiecznego procesu, prof. Vetulani tak się jego zasadami przejąl, że wziął na serio przeprowadzane $w$ średniowieczu dowody negatywne. Przy takim znakomitym wczuciu się $w$ atmosferę epoki nie bez racji zarzuca mi przeto ,podejście wadliwe" (s. 208). Żyjąc w XX w., nie dopuszczam bowiem myśli, jakoby negativa były probanda... 


\section{Geneza statutów Kazimierza Wielkiego*}

(Na marginesie pracy S. Romana, Geneza statutów Kazimierza Wielkiego. Studium źródloznawcze, Kraków 1961).

1. Teksty podstawowe i wzajemne stosunki trzech układów statutu małopolskiego. 2. Części składowe statutów Kazimierzowskich. 3. Chronologia. 4. Zależność statutu małopolskiego od wielkopolskiego. 5. Zakres terytorialny. 6. Inne stwierdzenia. 7. Działalność ustawodawcza Kazimierza Wielkiego.

„Prawo pisane nowa rzecz jest; dopiero od Wielkiego Kazimierza nastało, i to go bardzo mały był początek"'. Ta wypowiedź szesnastowiecznego pisarza ujmuje trafnie stanowisko statutów Kazimierzowskich w dziejach polskiego prawa. Pokrywa się ono zresztą w dużej mierze ze zdaniem Janka z Czarnkowa, według którego wspomniany król zwyczaje prawne in scriptis redegit ${ }^{2}$. Historyk zajmujący się początkami jakiejś instytucji dawnej zdaje sobie sprawę $\mathrm{z}$ trudności, jakie piętrzą się przed badaczem początków pisanego prawa w Polsce. A to wlaśnie podstawowa problematyka, jakiej poświęcił swe piękne dzieło prof. S. Roman.

Literatura dla tego zagadnienia jest bardzo mnoga, a niezwykle sporna. Tezy wysuwane przez uczonych są ze sobą diametralnie sprzeczne. Jedni uważają statuty za twór Kazimierzowski, inni cofaja je do Władysława Łokietka, do synodu łęczyckiego czy nawet do... Popiela; a i Ludwik Węgierski nie zostal pominięty w szeregu monarchów, którym usiłuje się to dzieło przypisać. Także i pod innymi względami trudno mówić o zgodności poglądów. Te sprawy omawia autor Genezy w zwięzłym i treściwym rozdziale II $^{3}$. Tytuly rozdziałów III-IV unaoczniają nam, że monografia jest studium par excellence źródłoznawczym ${ }^{4}$. Takie wszakże prace - wiemy - muszą leżeć u podstaw wszelkich badań historycznych. Zestawmy wyniki

* Przedruk z: Czasopismo Prawno-Historyczne 1962, t. 14, z. 2, s. 195-213.

${ }^{1}$ L. Górnicki, Droga do zupelnej wolności, wyd. R. Pollak, t. 2, Warszawa 1961, s. 527.

${ }^{2} \mathrm{MPH}$, t. 2, s. 624 .

${ }^{3}$ Rozdział pierwszy poświęcił autor historii publikacji tekstów.

${ }^{4}$ Zaznaczył to autor w podtytule; tak też zakreśla swój temat we wstępie, s. 5; zob. też s. 190. 
omawianej monografii, wyniki, które - jak się wydaje - stanowią trwały dorobek nauki; wskażmy też na słabsze zdaniem recenzenta miejsca przedstawionej konstrukcji.

\section{Teksty podstawowe i wzajemne stosunki trzech ukladów statutu malopolskiego}

Rękopisy dzieli autor na trzy grupy: dzielnicowe samodzielne, statuty połączone małopolsko-wielkopolskie oraz dygesta małopolsko-wielkopolskie. Układ alfabetyczny oraz drobne fragmenty wypadają $\mathrm{z}$ rozważań nad genezą w ogóle: drugie - ze względu na swą fragmentaryczność, pierwsze ze względu na późny czas powstania, jak i na pochodzenie wtórne od innych rękopisów. Wszystkie trzy grupy są reprezentowane przez rękopisy sobie współczesne, poza wyjątkowo wczesnym O1. Znaczy to, że od lat dwudziestych XV w. kopiuje się wszystkie redakcje równocześnie, i to aż do końca tegoż stulecia - to jest do momentu pojawienia się pierwszych statutów drukowanych, choć pewien typ (układ A według systematyki Klodzińskiego) bierze zdecydowana przewage nad innymi.

Grupa III jest pochodna od grupy II, ta zaś powstała $z$ grupy I. Dla rozważań nad genezą statutów wchodzi zatem w rachubę jedynie grupa pierwsza.

Istnieją dwa samodzielne statuty dzielnicowe - wielkopolski i małopolski. Pierwszy jest reprezentowany przez jeden jedyny rękopis $z$ końca XV w., - Sierakowski 3. Ponieważ jest on niekompletny, oprzeć się trzeba na innym rękopisie, Królewieckim, w którym zajmuje on artykuły 108-153. Posłużenie się tą namiastką jest tym bardziej uzasadnione, że rękopis Królewiecki jest jednym z najstarszych i najstaranniejszych manuskryptów $(49,116)$.

Lepsza jest sytuacja, gdy chodzi o reprezentantów statutu malopolskiego. Jest ich bowiem czterech: Bandtkie 4 (1480). Częstochowski (1423), Ossolińskich 1 (1400) oraz Petersburski 3 (1463). Z tych podstawowych rękopisów odpada Pt3, ponieważ jest defektowny. Dla analizy zostają zatem $\mathrm{B} 4, \mathrm{Cz}$ i $\mathrm{O} 1$.

Spośród nich na pierwsze miejsce wysuwa się B4 o 59 artykułach. Prawda, jest to manuskrypt późny, bo pochodzący z 1480 r. Wszakże w Pt5 zachował się rejestr rubryk zwanych Statuta Cracoviensia, pochodzący z około 1390 r., zawierający w identycznej jak w B4 kolejności identyczne rubryki aż do art. 24. Tym samym co najpóźniej do tego momentu wolno nam odnieść powstanie redakcji B4 w pierwszym jej członie. Z B4 wywodzi się Cz o 105 artykułach; z niego, z kolei, O1 o 106 artykułach. Do wniosku tego doszedł autor przeprowadziwszy analize grup tematycznych i systematyki tekstów oraz przestudiowawszy powiązania układu z treścią poszczególnych artykułów. Subtelne rozumowanie S. Romana wydaje się nie do podważenia; 
rozpatrzenie $\mathrm{i}$ unicestwienie argumentów $\mathrm{O}$. Balzera w pełni przekonywające, tak że próby ostatniego badacza wysunięcia jako rękopisu podstawowego manuskryptu Ol uznać trzeba za chybione ${ }^{5}$. Rezultatem tej analizy ${ }^{6}$ jest wyłączenie $z$ rozważań nad genezą statutów rękopisu O1. Rehabilitacja B4 wydaje się osiągnięciem kapitalnym. W dyskusji trwającej z górą wiek nad hierarchią rękopisów statutów - jedni badacze podkreślali wagę B4 (Bandtkie, Lelewel, Hube, Helcel, Ulanowski, Piekosiński, Kutrzeba, Kaczmarczyk), inni go deprecjonowali (Stadnicki, Taubenschlag, Balzer, Vetulani) - Roman przechyla szalę na korzyść tezy pierwszej. I to już chyba ostatecznie.

W rezultacie wywodów $S$. Romana na placu boju pozostały rękopisy: $\mathrm{Sk} 3$ wraz z $\mathrm{Kr}$ jako jego namiastka, B4 i $\mathrm{Cz}$.

\section{Części skladowe statutów Kazimierzowskich}

Że statuty w postaci znanej nam dzisiaj nie są czymś jeđnolitym, o tym wiadomo od dawna. Przekonanie to podziela $w$ omawianym studium S. Roman. Wyróżnia on siedem partyj.

W masie, która uchodziła za statut wielkopolski, wyróżnić należy dwie grupy artykułów: główny trzon statutu, stanowiący w aktualnym stanie badań niepodzielną calość, wraz $\mathrm{z}$ przedmową, $\mathrm{Kr}$ art. 108-141 (s. 118-120), oraz tak zwane przez S. Kutrzebę petit a, Kr art. 142-151. Określenie to nie jest odpowiednie, albowiem są to materiały przygotowawcze do statutu czy statutów (s. 126-127, 183); wszakże tę nieścisłą nazwę autor zatrzymuje (s. 127). Pierwsza partia stanowi właściwy statut wielkopolski, druga jest członem odrębnym, powstalym później (s. 118). Teza ta - jak wiemy - nie nowa, nie wywołuje sprzeciwu. Argumenty podpierające ją (odrębne sformułowanie artykulów i różna ich stylizacja) wydają się mocne. S. Roman występuje wszakże z dalszą supozycją. Ponieważ petita zachowały się tylko w rękopisach statutów połączonych, malopolsko-wielkopolskich, w rachubę brać należy dwie możliwości ich połączenia ze statutami: dodano je do statutu wielkopolskiego jeszcze przed polączeniem go ze statutem małopolskim, albo też dorzucono je dopiero po scaleniu statutu małopolskiego $\mathrm{z}$ wielkopolskim (Patrz schemat na s. 78).

Obie możliwości przyjąć można $\mathrm{z}$ równym uzasadnieniem - stwierdza S. Roman (s. 132). Sam jednak opowiada się za ewentualnością drugą. Petita, jego zdaniem, są dopiero dodatkiem do statutu połączonego, małopolsko-wielkopolskiego; do statutu wielkopolskiego nie należały nigdy.

${ }^{5}$ Zarzut skierowany pod adresem 0 . Balzera jest o tyle nieuzasadniony, że jego dzielo o statutach ukazało się jako opus posthumum. Jakąż mamy gwarancję, że znakomity badacz podzielał wyrażone w nim poglądy do końca, skoro nie zdecydował się sam na jego publikacje?

6 Autor wykazal też niezasadność podziału Taubenschlaga na edykty i dekrety (72-3). 
1

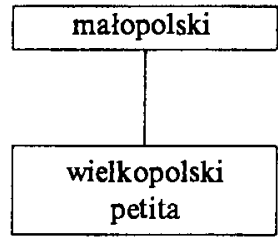

2

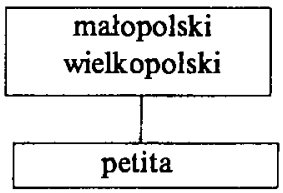

Przyjrzyjmy się uzasadnieniu tej tezy.

$\mathrm{Z}$ treści petitów wynika, że są one nie wielkopolskie, lecz że mają charakter ogólnopolski, wykazują wyraźne tendencje unifikacyjne i centralistyczne (s. 131-132). Stwierdzenia te akceptujemy w pełni. Wszakże ich charakter ogólnopolski nie wyklucza dołączenia ich do statutu wielkopolskiego (s. 136), podobnie jak ogólnopolskie prohemium statutu dzielnicowego nie przeszkadza nikomu, żeby ono zaliczyć do statutu dzielnicowego, małopolskiego. A skoro petita byly ogólnopolskie, odnosily się więc tym samym i do Wielkopolski. Wydaje się więc całkiem naturalne i celowe, że któryś z redaktorów ogólnopolskie przepisy dołączył do dzielnicowego statutu wielkopolskiego.

Przypuszczalne miejsce powstania petitów - Małopolska - nie może również stanowić kontrargumentu. Intensywny udział w redakcji petitów bral król - twierdzi S. Roman. Kazimierz Wielki był królem Polski, a nie królem krakowskim. Mial na swoim dworze i Wielkopolan, choćby Janka z Czarnkowa (o możliwości jego udziału w ustawodawstwie pisze autor na s. 197); przy ich współpracy dorzucenie nowych przepisów moglo się snadnie dokonać. Jest możliwe, że petitów żaden wiec wielkopolski nie recypował, ale $\mathrm{z}$ tego nie wynika bynajmniej, by rękopiśmiennie nie zostały one złączone dla tego właśnie celu z statutem wielkopolskim. Zresztą także inicjatywa prywatna jakiegoś urzędnika królewskiej kancelarii nie da się wyłączyć.

Do argumentów, przedstawionych wyżej, o mocy - jak się zdaje - nie absolutnej, S. Roman dorzucil dalszy, umocowując swoją tezę od strony źródłoznawczej: petita „, s samym tylko statutem wielkopolskim w znanych nam tekstach ani razu nie występuja" (s. 132, 137). Taki dowód, negatywny, nie jest z swej istoty mocny. Co więcej, można się zastanowić, czy jest on w ogóle dopuszczalny. Mediewiście, skromnemu w swych wymaganiach, wystarczyłoby niewiele rękopisów, odpowiadających stawionemu tu warunkowi; ale nawet on nie może zejść w żadnym wypadku poniżej jednego przykładu. Tymczasem tutaj $w$ takiej właśnie znajdujemy się sytuacji. Jedyny samodzielny rękopis wielkopolski, Sk3, zawiera tylko 28 artykułów; dla naszego zagadnienia zatem zużytkować się nie da, brakują mu bowiem końcowe artykuły! A nie wiemy, ,jaka była dalsza zawartość jego wzoru" - pisze S. Roman (s. 116). Przypomnijmy, że zdaniem A. Kłodzińskiego, petita we wzorze Sk3 się znajdowały. 
Liczba artykułów statutu wielkopolskiego

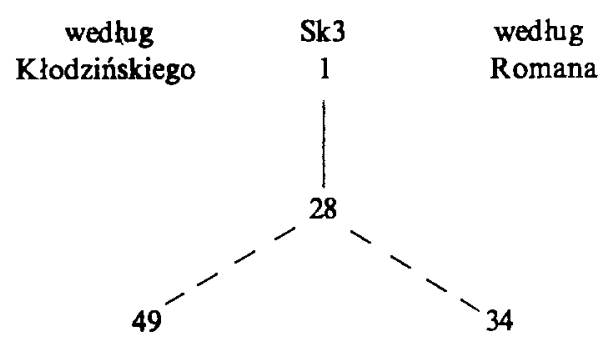

Zacytowane wyżej zdanie Romana jest niewątpliwie prawdziwe. Ale w konkretnej konstelacji źródłowej stanowi ono mimowolną pułapkę na czytelnika, który gotów mniemać, że egzemplarze statutu wielkopolskiego bez petitów rzeczywiście istnieją. S. Roman zresztą sam nie wyzwolił się widocznie $z$ nurtujących go wątpliwości, skoro pisze, że nie wiemy, czy przyczyną niewystępowania petitów ze statutem wielkopolskim w ani jednym wypadku nie jest tylko okoliczność, że poza niekompletnym Sk3 statut wielkopolski $w$ izolowanej postaci nie dochowal się do naszych czasów (s. 132), przy czym zaznacza, że nie zachował się ani jeden pełny przekaz statutu wielkopolskiego, który by nie zawierał owej grupy statutów (s. 126).

Jeśli więc mimo tego zastrzeżenia S. Roman posłużył się przedstawiona argumentacja, postapił tak, zdając sobie dobrze sprawę $\mathrm{z}$ tego, że twierdzenie jego o braku związku między petitami a statutem wielkopolskim mógłby obalić jeden jedyny rękopis, zawierający izolowany statut wielkopolski w rozmiarach 44 artykułów. Skrzętnie notuje więc, że takiego rękopisu nie ma, co jest niewątpliwa prawda. Ale argumentem byłoby dopiero istnienie samodzielnego statutu dzielnicowego dla Wielkopolski bez petitów. Takiego zaś dotąd nie znamy.

Ze względu na wagę problemu rozpatramy się jeszcze raz szczególowo w przekazach rękopiśmiennych statutu wielkopolskiego. Obok jedynej samodzielnej redakcji niepełnej, Sk3, zawieraja go zwody połączone, małopolsko-wielkopolskie grupy A tablic Kłodzińskiego. Poza tym w pewien szczególny, swoisty sposób przekazały go rękopisy Działyńskich II i Pulawski I $(1441$ r.) oraz thumaczenie Świętosława (1449 r.). Jeśli ostatni rękopis, zawierający thumaczenie polskie statutów, siłą rzeczy odpaść musi z rozważań nad genezą statutów; jeśli sytuacja jest podobna $\mathrm{z}$ D2 i P1, zawierającymi przejątki ze statutu warckiego, to czyż można je pominąć w rozważaniach nad istnieniem osobnego statutu wielkopolskiego? Czy te trzy rękopisy upoważniałyby historyka do stawienia tezy o wydaniu osobnego statutu dla Wielkopolski, nawet gdyby nie zachował się Sk3? Czyż wiele brakowało, by $\mathrm{i}$ ten jedyny egzemplarz się nie dochowar? A jeśliby dać odpowiedź potakująca na stawione wyżej pytanie, to czy w nich nie należy szukać 
rozstrzygnięcia dylematu: petita stanowily część składową statutu wielkopolskiego, czy też wcielone zostały dopiero do gotowej już komplikacji małopolsko-wielkopolskiej?

Uprzytomnijmy sobie zawartość tych trzech rękopisów: zawierają one statut małopolsko-wielkopolski w ukladzie dygestowym (grupa B Kłodzińskiego), do której dopisano statut wielkopolski wraz z petitami. Należy rozwiązać zagadnienie następujące: skąd dwaj kopiści i tłumacz zaczerpnęli statut wielkopolski po raz drugi? S. Roman stwierdza, że Świętosław korzystal zapewne $\mathrm{z}$ rozpowszechnionych wówczas dygestów i z redakcji statutów połączonych; statutu wielkopolskiego w postaci oryginalnej i izolowanej od innych tekstów w ręku nie miał (s. 137, przyp. 255). Pewna wydaje się rzecz, że Świętosław mial w ręku dygesta, skoro z nich dokonal thumaczenia. Ale na czym oparte twierdzenie Romana, że tenże thumacz zaczerpnął statut wielkopolski ze statutu połączonego? Dlaczegoż $\mathrm{w}$ takim razie nie przethumaczyl od razu calego statutu w wersji szerszej? To samo pytanie można skierować pod adresem kopistów D2 i P1. Dlaczego oni, mając pod ręką zwód pelny małopolsko-wielkopolski oraz uklad dygestowy, kopiowali najpierw dygesta, by potem $\mathrm{z}$ rękopisu typu $\mathrm{A}$ dodać jeszcze czlon wielkopolski? Takie postępowanie wydaje się co najmniej dziwne. Zalożenie Romana nie jest zresztą jedynie możliwe. Rękopisy izolowanego statutu wielkopolskiego istnieć musiały $w$ polowie XV w., skoro jeszcze z końca tego stulecia jeden jedyny się zachowal, Sk3. Podnieśmy, że S. Roman, zastanawiając się nad genezą grupy III statutów (dygestowej), liczy się $\mathrm{z}$ ewentualnością jej powstania bądź z grupy II (statutów połączonych małopolsko-wielkopolskich), bądź z dwu samodzielnych statutów dzielnicowych - małopolskiego typu $\mathrm{Cz}$ i izolowanego wielkopolskiego (s. 48 i ib. przyp. 13). $\mathrm{Na}$ innym miejscu wyraża domysl, że osobno krążyly rękopisy statutu wielkopolskiego (s. 197), osobno statutu małopolskiego w dwu układach: $\mathrm{Cz}$ i O1 (s. 197). Jeśli dla powyższych rozważań wychodzi to na jedno, to dla naszego dylematu sprawa jest dość ważka. Analiza dokładna (być może, S. Roman tę pracę już wykonał, a tylko nie przedstawił jej wyników w swym dziele ${ }^{7}$ ) jest $\mathrm{w}$ stanie wyświetlić sprawę. A więc albo potwierdzi domysł Romana, albo go obali. W drugim wypadku runie teza, jakoby petita nie stanowily nigdy przynależności statutu wielkopolskiego; w pierwszym nie stanie się ona o jotę mocniejsza. Nie przeprowadzając tu wspomnianej analizy, notujemy tymczasem dwa sposoby reakcji na powtarzające się z konieczności artykuły statutu wielkopolskiego. Kopiści D2 i P1 przepisywali mechanicznie najpierw artykuły wielkopolskie $\mathrm{z}$ ukladu dygestowego, następnie z układu całkowitego; przy takim postępowaniu niektóre artykuly wielko-

${ }^{7}$ Stwierdził np. identyczność Świętosł. z B 2, gdy chodzi o ekstrawaganty wspólne, s. 133, przyp. 237. 
polskie występują w nich dwukrotnie. Natomiast Świętosław dobrze się orientował, że stanowiłoby to zbędne dublowanie ciężkiej pracy thumacza. Dlatego to, natknąwszy się na ten sam artykul, zachował $w$ drugim razie jego numeracje kolejną, ale tekst zastapil odsyłaczami w rodzaju: to tez $j u \dot{z}$ wyżej poloziono pod rubrykq (art. 13), lub po lacinie: positum est in primo libro de citacionibus (art. 6).

Pewne wątpliwości co do przynależności petitów nasuną się jeszcze przy omawianiu chronologii poszczególnych członów statutów. Ale już przedstawione zastrzeżenia w pewnym stopniu podważają domysł Romana. Może jednak argumentacja S. Kutrzeby, którą zbija S. Roman (s. 126-128), nie jest tak całkiem pozbawiona racji? Może $w$ niej tkwi rzeczywiście jakaś poszlaka wielkopolskości petitów?

Podkreślmy jeszcze, że petita sq obramowane przepisami wielkopolskimi, statutem wielkopolskim i ekstrawagantem art. 152, opisującym praktykę stosowaną w Wielkopolsce (s. 132). Przy czym ekstrawagant ten (wraz z następnym) znajduje się we wszystkich rękopisach (s. 133), co świadczy o wczesnym jego włączeniu do zwodu. Do tych uwag pragniemy się na razie ograniczyć.

Dwuczłonowość statutu małopolskiego, reprezentowanego przez B4 wynika ewidentnie $\mathrm{z}$ powtórzenia $\mathrm{w}$ obydwu partiach tej samej systematyki. Pierwsza partia obejmowała 24.5 artykułów wraz z przedmową. Jest to statut wiślicki, stanowiący jedną całość.

Zwód dopełniający dołączono do statutu wiślickiego w sposób mechaniczny, $\mathrm{z}$ zatarciem odrębności jednego i drugiego, a to przez usunięcie części zakończenia statutu wiślickiego, w szczególności daty, i zamiany reszty zakończenia na zwyczajny artykuł (93). Nie należy sądzić, by zwód dopełniający wiódł samodzielny żywot; powstał jako uzupełnienie części pierwszej i dla tej części.

Prejudykaty nie są rzeczywistymi wyrokami; odrywają się one od historycznie stwierdzalnych wypadków i dążą do uogólniania (100), co wskazuje wyraźnie na ich charakter jako wzoru (98); są więc wytworami już pewnej pracy koncepcyjnej, oderwanej w znacznym stopniu od konkretnych wydarzeń (103); raczej fikcyjne (102), otrzymały szatę prejudykatowych wyroków sądowych (103) po to, by służyć jako pouczenie dla sędziego (100); jedynie znaczna mniejszość (sześć wypadków, s. 98; dziesięć wypadków, s. 99) stanowi rzeczywiście rozstrzygnięcie konkretnego sporu; mogły się one wywodzić z odpowiedzi sądu wyższego (101). Cytowane wypowiedzi Romana nawiązują do znanego artykułu Winiarza, którego stanowisko autor uznał,

${ }^{8}$ Por. tu s. 46, przyp. 6. Dokładna analiza winna też rozpatrzyć źródła Sk 3.1 tu bowiem nie mamy pewności bezwzględnej, że kopista nie korzystał z wzoru grupy A, przy czym z przyczyn, których dziś nie znamy, przepisał tylko partię drugą. 
konkludując, że prejudykaty są teoretycznym wyjaśnieniem norm obowiązującego prawa zwyczajowego (101).

Prejudykaty opracowane zostaly $w$ ramach systemu $\mathrm{Cz}$, poza tym układem jako całość nie istniały, nie mogły tworzyć osobnego, specjalnego dzieła (106). Idąc za zdaniem Winiarza, sądzi Roman, że zostały one ułożone $\mathrm{w}$ celu włączenia do statutów $\mathrm{w}$ miejscach $\mathrm{z}$ góry określonych (108). Jeden prejudykat zbliża się do ekstrawagantów (O1 53), jeden ekstrawagant zbliża się do prejudykatów ( $\mathrm{Cz} 22$ ) (s. 102, przyp. 122).

Ekstrawaganty były luźnymi ustawami lub niewielkimi grupami ustaw, powstałymi po ogłoszeniu statutów dzielnicowych i po ułożeniu zwodu dopełniającego. Nie tworzyły nigdy choćby częściowej całości (113).

Ekstrawaganty wspólne dołączono do zwodu statutów nierównocześnie, już po scaleniu statutu małopolskiego $\mathrm{z}$ wielkopolskim i po dodaniu petitów. Tylko dwa $\mathrm{z}$ nich figurują we wszystkich rękopisach (Kr 152-153), inne występują tylko w niektórych kodeksach (F1 155-156, O3 D3 141, 151, 169).

\section{Chronologia}

Wyróżniwszy siedem elementów skladowych statutów, S. Roman zastanawia się nad czasem ich powstania. W literaturze istniał spór już co do $\mathrm{chronologii} \mathrm{względnej.} \mathrm{Jedni} \mathrm{historycy} \mathrm{uznawali} \mathrm{statut} \mathrm{wielkopolski}$ za starszy od małopolskiego (Lelewel, Helcel, Taubenschlag), inni dopatrywali się starszeństwa statutu małopolskiego (Hube, Ulanowski, Kaczmarczyk). Układ chronologiczny poszczególnych elementów według S. Romana ${ }^{9}$ przedstawia zestawienie:
1. Proh. w. + statut wielkopolski
2. Proh. m. + statut wiślicki
3. Petita
4. Zwód dopełniający
5. Prejudykaty
6. Ekstrawaganty
7. Ekstrawaganty wspólne

${ }^{9}$ Podwójną ramką oznaczamy dziela ustawodawcze, pojedynczą - te człony statutów, które, zdaniem Romana, stanowily niegdyś osobną całość. 
Najstarszą częścią jest statut wielkopolski (s. 180). Za jego starszeństwem w stosunku do statutu wiślickiego przemawia zarówno forma zewnętrzna, jak i porównanie konkretnych artykułów statutu wiślickiego z artykułami statutu wielkopolskiego (B4 8 zredagowano po $\mathrm{Kr} 122, \mathrm{~B} 411$ - po $\mathrm{Kr}$ 139; B4 5 - po $\mathrm{Kr} 115 ; \mathrm{B} 415$ - po $\mathrm{Kr} 116$; B4 19 - po $\mathrm{Kr} 127$; s. 164-167). Petita powstały przed zwodem dopełniającym, albowiem niektóre ich postanowienia programowe zostały w dopełnieniach zrealizowane (B4 48 - po $\mathrm{Kr} 151$; B4 47 - po $\mathrm{Kr} 148$; s. 183-185); między tymi dwiema partiami statutów istnieje jawna zależność (s. 185). Petita sformułowano niedługo po wydaniu statutu wiślickiego, a może raczej przy okazji jego opracowania (s. 186). Zwód dopełniający jest niewątpliwie późniejszy od statutu wiślickiego i stanowi jego uzupełnienie, choć niektóre z jego artykułów mogły pochodzić z czasów wcześniejszych (s. 176-179). Prejudykaty i ekstrawaganty mogły powstać równocześnie (s. 114, 180-182). Ekstrawaganty wspólne są z całą pewnością członem ostatnim (s. 182).

Zestawmy te wyniki $\mathrm{z}$ zasobem rękopiśmiennym:

\begin{tabular}{l|l} 
Sk3 & 1 \\
$\mathrm{~B} 4$ & $2+4$ \\
$\mathrm{Cz}\left[\begin{array}{l}\mathrm{B} 4 \\
- \text { Prej. } \\
\mathrm{E}\end{array}\right.$ & $2+4+5+6$ \\
$\mathrm{Cz}+\mathrm{Wlkp.*}$ & $2+4+5+6+1$ \\
$\mathrm{Kr}\left[\begin{array}{l}\text { Cz } \\
- \text { Wlkp. } \\
- \text { Petita } \\
\text { E com. }\end{array}\right.$ & $2+4+5+6+1+3+7$ \\
* Etap tekstowo nie poświadczony.
\end{tabular}

Uderza w tym zestawieniu późny moment włączenia petitów do korpusu statutów. Brak ich w statucie wielkopolskim jest zrozumiały w świetle doktryny Romana; według niej, nie figurowały one w pierwotnym układzie statutu wielkopolskiego (s. 118). Spożytkował je autor zwodu dopelniającego, skoro - jak widzieliśmy wyżej - niektóre jego artykuły są inspirowane przez petita; nie zwrócił wszakże na nie uwagi ani kompilator $\mathrm{Cz}$, ani układacz pierwszej redakcji statutów połączonych. Dopiero do połączonych objątków, małopolskiego i wielkopolskiego, przyczepiono petita. Wyjaśnienie podane przez Romana, jakoby petita „sformulowane jeszcze przed zwodem dopełniającym czekały w kancelarii królewskiej na pomyślny moment, by otrzymać 
kształt i autorytet ustawy" (s. 194), stanowi domysł, który nawet trudno uprawdopodobnić.

Przy obecnym stanie rękopisów nie można ustalić ch ronolog i i bezw z ględ n e j wszystkich elementów składowych statutów. Najdokładniej jeszcze da się to zrobić ze statutem wielkopolskim. Ten trzon najstarszy (tzn. prohemium +34 artykuły) powstał między $1356 / 57$ a marcem $1362 \mathrm{r}$. Datę tę ustalił S. Roman już dawniej. Swoje wywody powtarza niemal dosłownie w omawianej monografii. Jeśli terminus a quo nie budzi jakichś zastrzeżeń, to cała argumentacja, zmierzająca do uzasadnienia terminu ad quem, niewątpliwie bardzo pomysłowa (s. 151-154), nie wydaje się przekonywająca.

Punktem wyjścia jest dla autora data podana w statucie wielkopolskim, Kr 116; ustawa, wprowadzając nowe terminy dawności dla dziedzin kupionych czy zastawionych ( 8 bądź 30 lat), postanawia, że lata biec mają od dnia 11 marca 1347 r. Teoretycznie biorąc, istnieją trzy moźliwości ustalenia terminu, od którego zaczyna biec przedawnienie: ustawodawca bierze za punkt wyjściowy bądź datę wcześniejszą aniżeli rok wydania ustawy, bądź moment samego wydania normy, lub też termin późniejszy aniżeli publikacja ustawy. Roman wyklucza pierwszą ewentualność, bo przy niej naruszono by „prawa nabyte osób zainteresowanych, których preskrypcja rozpoczęla się według norm dawniejszych" (s. 152). Odrzuca też vacatio legis, ponieważ odwleczenie takie "trudno by bylo - wobec dhugiego terminu preskrypcji (8 bądź 30 lat) - czymkolwiek uzasadnić" (s. 152). Podana data jest zatem momentem wydania normy o przedawnieniu. Wszakże nie w tym roku wydano caly statut wielkopolski lecz jedynie sam przepis o przedawnieniu. Zredagowany około lat sześćdziesiątych XIV w. statut wielkopolski, wcielił mającą już kilkanaście lat normę wraz $\mathrm{z}$ datą jej wydania do korpusu statutów. Tu źródło od wieków trwającej omyłki, jakoby Kazimierz W. wydal (wielkopolski) statut w 1347 r. (s. 152).

Przeciw takiemu hipotetycznemu przebiegowi ustawodawstwa Kazimierzowego nie będziemy wysuwać zastrzeżeń. $Z$ trzech możliwości, o których piszemy wyżej, wybrał S. Roman - jak sądzimy - najprawdopodobniejszą. Wątpliwości budzi natomiast dalszy ciąg rozumowania opierający się o interpretację niezmiernie rygorystyczną, którą niełatwo odnieść do wieku czternastego. Zanalizujemy więc ją szczegółowo.

W 1347 r. wprowadza Kazimierz Wielki dwa okresy przedawnienia: jeden dla sprzedaży nieruchomości (8 lat), drugi dla zastawów dziedzin (30 lat). Obie te innowacje, jak należy sądzić, służyły interesom indywidualnej własności panów. Ale w takim razie wymagały one odmiennego uregulowania okresów przedawnienia, dokonania operacyj, które biegły w kierunku wręcz odwrotnym: prawo retraktu krewnych (o nie chodzi w wypadku sprzedaży - jak przyjmuje trafnie S. Roman (s. 140)), poprzednio ograniczone nawet 
do jednego pokolenia ${ }^{10}$, należało czasowo skrócić, prawo wykupu zastawu - przedłużyć. Tymczasem S. Roman mniema, że w obu wypadkach terminy przedawnienia wydłużono, że dawniej retrakt krewnych był zapewne krótszy (s. 153 i $i b$. przyp. 39). Sprostowanie to pozostaje zresztą bez znaczenia dla określenia daty ante quem statutu wielkopolskiego.

Dawność przy zastawie przedłużono $\mathrm{z} 15$ lat na lat 30 - zakłada Roman. Znowu nie widzimy racyj, by $\mathrm{z}$ tym domysłem walczyć. Ale gdzież tu podstawa do określenia daty ante quem statutu wielkopolskiego? Rachuba prosta: $1347+15=1362$. W roku 1347 wydano nową ustawę o preskrypcji; nie mogła ona mieć zastosowania do zastawów ustanowionych przed tą datą; zastawy, korzystające $\mathrm{z}$ dawnej, krótszej preskrypcji wygasały w $1362 \mathrm{r}$. Wydając statut w latach sześćdziesiątych, ustawodawca zdawal sobie sprawę $\mathrm{z}$ istnienia zastawów powstalych przed 11 marca $1347 \mathrm{r}$., dla których obowiązywała preskrypcja piętnastoletnia. Po roku 1362 takich zastawów już nie było. Statut wielkopolski wydany zostal zatem ante 1362 r. (s. 153)!

Ustawa z 1347 r., wprowadzając nowy termin przedawnienia, nie dotyczyła spraw dawnych w myśl zasady lex retro non agit, tzn. nie odnosiła się do dóbr, które zastawcy utracili z mocy poprzednio obowiązującej prekluzji piętnastoletniej. Pod tym względem nasze stanowisko pokrywa się z tym, jakie zajmuje S. Roman. Wątpliwości natomiast nasuwa domysł, że nowa norma nie rozciągała się na zastawy ustanowione w okresie między 1332-1347 r. Nie wolno było naruszać praw nabytych osób zainteresowanych - pisze S. Roman (s. 151, 152). Czy jednak aplikowanie takiej zasady, jako najsłuszniejszej dla okresu powstawania BGB, wolno odnieść do wieku czternastego? Czy tak wykładać należy dotyczący tej samej materii przedawnień B4 25: ...cum omnes constituciones et statuta legem imponant rebus et negociis futuris et non preteritis, volumus, ut omnes nostre constituciones [...] non respiciant preterita, sed tantummodo presencia et futura? Nie sądzimy też, by zbyt silnym argumentem za interpretacją S. Romana mogło być brzmienie art. 5 statutu ks. Ziemowita z 1377 r.: Item si quis hominum suam hereditatem alicui pro pecuniis aut pro quibuscunque rebus obligaverit || a tempore constitutionis hodierne || illa obligatio ad triginta annos integre durabit ${ }^{11}$. Wykładnia tego artykułu podana przez S. Romana (s. 145) spornego problemu nie porusza. Uzależniona ona tymczasem jest od tego, czy wyrażenie pomieszczone między kreseczkami złączymy z pierwszym, czy drugim członem zdania. A już z pewnością przedstawionego wyżej poglądu S. Romana nie podzielal piętnastowieczny autor systematycznego układu; ująl on bowiem treść omawianego przepisu statutu następująco: Statutum non est institutum super preteritis rebus, sed super presentibus et futuris negociis, ideo in iudicio nemo secundum usum preteritum iudicetur, quod derogaret statuto ${ }^{12}$.

10 Por. nasze uwagi pomieszczone w Aqua abrenuntiationis, CPH, t. 4, 1952, s. 184 przyp. 1; s. 189 , przyp. 32, i s. 201, przyp. 3, oraz podanz tamże literaturę. [Niniejszy art. zamieszczony w Pismach wybranych, t. I].

1 SPPP, t. 1, s. 270; cytat u S. Romana, s. 145.

12 AKP, t. 5, Kraków 1897, s. 130. 
W pierwszym zdaniu autor oddaje myśl statutu niemal tymi samymi słowy; w dalej idącym objaśnieniu zdradził wyraźnie swój pogląd: od chwili zaprowadzenia nowej normy, nią winny kierować się sądy, a nie dawną: równałoby się to bowiem derogowaniu ustawy! Dodajmy, że S. Roman ten tekst cytuje (s. 68), co więcej, poczytuje interpretację piętnastowiecznego układacza za trafną (s. 68, 89)! Sądzimy, że autorom statutów czternastowiecznych, równie jak wykładaczowi ze stulecia następnego, obca była subtelność prawnicza, na której buduje całą swą konstrukcję S. Roman. Tym samym więc odpada wszelka podstawa do tej rachunkowej operacji, którą przedstawiono wyżej ${ }^{13}$.

Elegantia prawnicza, której piękny przykład daje S. Roman, tak cenna i nie bez znaczenia praktycznego dla czasów dzisiejszych, napotyka na jeszcze jeden szkopul: czasokres trzydziestoletniej preskrypcji wprowadzony w 1347 r. nie wszędzie był respektowany i po wydaniu statutu wielkopolskiego w latach sześćdziesiątych. Zwyczajowo stosowano w sądach dawną prekluzję piętnastoletnią. Stąd aktualność ponowienia przepisu w statucie warckim (s. 152).

Autor przyjmuje, że statut wielkopolski był pierwotnie zaopatrzony w datę, która znikła dopiero w dalszych redakcjach (s. 146). Podobnie było i ze statutem wiślickim, w którym data znajdowała się, jak należy przypuszczać, po art. 25a; znikła ona przez połączenie tego artykułu $\mathrm{z}$ dalszymi (s. 92). Momentu jego ogłoszenia nie da się więc dziś dokładnie ustalić. Taka sama jest sytuacja $\mathrm{z}$ innymi częściami składowymi statutów. W każdym razie statut wiślicki, petita zwód dopełniający oraz większość prejudykatów $\mathrm{i}$ ekstrawagantów pochodzi $\mathrm{z}$ czasów Kazimierza Wielkiego (a więc ante 1370). Zwód małopolski - układ $\mathrm{Cz}$ - i połączony, małopolsko-wielkopolski, powstały w najbliższych latach po 1370 r. Ekstrawaganty wspólne są późniejszego pochodzenia, niektóre $\mathrm{z}$ nich mogą pochodzić nawet z XV w.

\begin{tabular}{|l|l|}
\hline $\begin{array}{l}\text { Statut wielkop. post } 1357 \\
\text { Statut wiślicki } \\
\text { Petita } \\
\text { Zwód dopemiający }\end{array}$ & za życia Kazimierza W. \\
\hline $\begin{array}{l}\text { Prejudykaty } \\
\text { Ekstrawaganty }\end{array}$ & $\begin{array}{l}\text { w większości za życia } \\
\text { Kazimierza W. }\end{array}$ \\
\hline $\begin{array}{l}\text { Cz } \\
\text { Małop.-wielkop. (układ A) }\end{array}$ & najbliższe lata po 1370 \\
\hline Ekstrawaganty wspólne & póżniej, nawet w XV w. \\
\hline
\end{tabular}

${ }^{13} \mathrm{Na}$ temat daty statutów Kazimierza W. prowadził autor tych słów dyskusję z B. Lesińskim. Przyznaje otwarcie, że nie jest w stanie dziś wyróżnić własnego wkładu od sugestii współrozmówcy. 
I ta tabelka stwarza jakąś niepokojącą sytuację, gdy chodzi o petita. Ułożone za Kazimierza Wielkiego, z jego udziałem, sporządzone w królewskiej kancelarii, leżały na boku, czekając na śmierć swego duchowego ojca. I dopiero po jego zgonie wcielono je do zbiorku statutowego! Czy nie jest prawdopodobniejsza hipoteza, nawiązująca w części do koncepcji Hubego, przyjmująca narastanie oddzielne zarówno statutu wielkopolskiego, jak i statutu małopolskiego, a dopiero potem złączenie ich w jedną całość, do której przyczepiono ekstrawaganty wspólne? Wówczas mielibyśmy do czynienia z następującym rozwojem tekstów:

I

Statut wielkop. $\quad 34$

Petita

10

Ekstrawaganty*

art. $152-153 \quad 2$

46

II

Statut wiślicki

24.5

Zwód dopełniający 34.5

Prejudykaty 25

Ekstrawaganty 22

106

III

Statut wielkop. $\mathrm{z}$ uzupełnieniami 46

Statut wiślicki $\mathrm{z}$ uzupełnieniami 106

152

IV

Statuty wielkop. i małop. z uzupełnieniami 152

Ekstrawaganty wspólne

* Wielkopolskiego pochodzenia jest $z$ całą pewnością tylko art. 152 (s. 132, 136). Ze wzgledu na występowanie obu artykułów we wszystkich rękopisach, traktujemy drugi łącznie $z$ pierwszym. 


\section{Zależność statutu malopolskiego od wielkopolskiego}

Między statutem wielkopolskim a małopolskim istnieje wyraźna zależność - jak to stwierdzał kiedyś Helcel. Układ statutu wiślickiego jest mniej więcej taki jak statutu wielkopolskiego w jego pierwotnym kształcie (34 artykułów) (s. 120). Co więcej, dwa artykuły są wspólne obu kodyfikacjom (Król. 111 i 132 odpowiadają B4 7 i 6, s. 118-119). S. Roman rozważa ewentualność, w której redaktorzy ich mogli oprzeć się na wspólnym wzorze, co by thumaczyło podobieństwo (s. 121-122, 163, 172). Wspólne artykuły swą treścią nie dają oparcia przemawiającego za ich wielkopolskim czy małopolskim pochodzeniem. Prawda, ich arengi przypominaja bardziej statut małopolski, ale i w statucie wielkopolskim czasami one też się pojawiaja (s. 163). Zważywszy wszakże na fakt starszeństwa kodyfikacji wielkopolskiej, nie możemy mieć co do tego faktu wątpliwości, że redaktor statutu wiślickiego czytal statut wielkopolski, a nie na odwrót (s. 168, 172). Zależność zatem jest jednokierunkowa: statut wielkopolski wpłynął na redakcję statutu małopolskiego; wpływ ten szedł tak daleko, że autor drugiego statutu przejąl dosłownie dwa artykuły od swego poprzednika.

\section{Zakres terytorialny}

Spór o statuty rozciągał się także na kwestię zakresu terytorialnego ich obowiązywania. Jedni badacze, od Dhugosza począwszy, przyjmowali istnienie statutu ogólnopolskiego (Helcel, Balzer, Kłodziński ${ }^{14}$ ); drudzy utrzymywali, że istniały jedynie statuty dzielnicowe (Hube, Kutrzeba). Roman przychyla się do stanowiska drugiego. Statut wielkopolski ma wyraźny charakter dzielnicowy. Dzielnicowy jest też statut wiślicki, choć ten jego charakter nie jest już tak widoczny jak w pierwszym (s. 92, 120). Przedmowa jego ma charakter ogólnopolski (s. 173). Taki sam rys wykazują wstępy do poszczególnych artykułów małopolskich (s. 174-175). Statut wiślicki był zatem zalążkiem prawa ogólnopolskiego, miał stanowić krok do wprowadzenia prawa wspólnego dla calego królestwa (s. 175). Dzielnicowy był również zwód dopełniający (s. 95). Chociaż był w zasadzie zbiorkiem partykularnym ustaw małopolskich, pomieszczono $w$ nim - jak się zdaje - także przepisy ogólnopolskie, a w każdym razie starano się wszystkim artykułom nadać taką formę, by wyglądały one jak statut powszechny (s. 178). Być może, te artykuły o charakterze powszechnym pomieszczono przez rozmyślną nieuwage (s. 193). „Była to przeto kontynuacja polityki widocznej już w statucie wiślickim" (s. 178). W petitach występuja idee o charakterze

14 AKP, t. 2, s. LIII. 
ogólnopolskim (s. 132), nie były one charakteru wyraźnie wielkopolskiego (s. 128). Prejudykaty są $z$ całą pewnością pochodzenia małopolskiego (s. 111-112). Ekstrawaganty są $w$ zasadzie małopolskie, choć mogły się znaleźć wśród nich przepisy ogólnopolskie (s. 114). Artykuły zawarte w $\mathrm{Cz}$ są w zasadzie pochodzenia małopolskiego (s. 114).

Statutu powszechnego Kazimierz W. nie oglosil nigdy (s. 186-187, 193). Ale istniały tendencje ogólnopolskie, przejawiające się w statucie wis̉lickim, zwodzie dopełniającym, ekstrawagantach i petitach. Istniały nawet poszczególne artykuły o charakterze powszechnym (s. 186-187). Statut wiślicki tylko z pozoru jest małopolski, w istocie rzeczy miała to byc ustawa dla wszystkich prowincyj (s. 192). S. Roman zastanawia się nad tym, jak by wyglądał statut powszechny, gdyby swoje zamierzenia Kazimierz W. zdołał zrealizować (s. 193). Dążenie do stworzenia statutu ogólnopolskiego znalazło wyraz w stworzeniu zwodu małopolsko-wielkopolskiego (s. 194). Była to namiastka statutu powszechnego (s. 194). Jeśli pracy unifikacyjnej za życia Kazimierza W. nie ukończono, to przyczyną tego była niespodziewana śmierć monarchy (s. 196).

\section{Inne stwierdzenia}

Statuty były robotą jakiegoś duchownego; świadczy o tym układ kodyfikacyj, jak i wyraźna zależność stylistyczna od źródel prawa kanonicznego. Przypuszczalnym autorem był arcybiskup Jarosław Bogoria (s. 190). Statut wielkopolski ma charakter spisu prawa zwyczajowego $\mathrm{z}$ niewielkq liczba norm stanowionych (s. 147, 190). Natomiast statut wiślicki zdradza tendencje reformatorskie (za Hubem) (s. 139, 171-172). Miejscem wydania statutu malopolskiego byla Wiślica. Jak dotąd, nie jest poważnie uprawdopodobnione, by statut wielkopolski ogłoszono w Piotrkowie (s. 123).

Tyle cennych wyników zawiera interesująca praca S. Romana. Podkreślmy jej nowatorski charakter: wprowadza ona badania na nowe tory, takie, po których nie poruszał się dotąd nikt. Czytelnik odkłada ją z żalem, zapoznawszy się $\mathrm{z}$ jej przebogatą treścią. Obok tylu zagadnień postawionych i rozwiązanych, autor dotyka w sposób wnikliwy problemu działalności ustawodawczej Kazimierza Wielkiego.

\section{Działalność ustawodawcza Kazimierza Wielkiego}

Zwód typu $\mathrm{Cz}$ czy $\mathrm{O} 1$ nie otrzymal nigdy sankcji ustawodawczej (s. 114-115). To nie był statut ani kodyfikacja, czy zbiór urzędowy (s. 115), choć byl powszechnie używany w praktyce urzędowej, przede wszystkim 
zapewne w sądzie królewskim (s. 115). Ustawodawczą sankcję otrzymały jedynie dwa człony: statut wielkopolski (34 art.) (s. 120) i statut wiślicki (24,5 artykulów) (s. 90). Jedynie one są normami o pełnej mocy obowiązującej (s. 138).

Zwód dopełniający mógl być dziełem prywatnego autora (s. 95); będąc w zasadzie pracą prywatną, oficjalnego charakteru zapewne nie miał (s. 92). Artykuły jego nie tworzyły nigdy jednolitego statutu ogłoszonego jako całość. Zapadły one niewątpliwie na wiecu czy wiecach, ale jedne pochodzą od monarchy, drugie od monarchy i baronów, inne wreszcie tylko od baronów (s. 94-95). Może zestawił je któryś z sekretarzy królewskich, „,któremu polecono zebrać dla celów urzędowej praktyki istniejące luźne konstytucje lub ich częściowe zwody i dołączyć je do statutu wiślickiego dla jego uzupełnienia i uaktualnienia, bez zmiany wszakże ich charakteru" (s. 95, 96). Ten zbiór prywatny związany był z kancelarią królewską, stąd cieszył się wielkim autorytetem (s. 95). Samodzielnego żywota nie wiódł nigdy, powstał jako uzupełnienie części pierwszej (statutu wiślickiego) i dla tej czéści. Był zbiorkiem autentycznych ustaw, ale jako całość nie był ustawą.

Nieprzekonywające są wywody S. Kutrzeby, jakoby petita wyszły od niektórych czynników społecznych (duchowieństwa) (s. 128). Nie pochodzą też wprost od monarchy (s. 141), nie otrzymały z całą pewnością sankcji królewskiej jako ustawa (s. 126); mają więc charakter nieobowiązujący bez sankcji królewskiej, stąd były bez mocy prawnej ${ }^{15}$. Ten charakter nieobowiązujący artykułów Król. 142-151 uważa autor za udowodniony (s. 124-125). Powstały one wszakże za wiedzą czy na polecenie króla (s. 183). Można być pewnym, że w zredagowaniu ich niemala byla rola samego Kazimierza W., przy czym on sam albo współdziałał w ich opracowaniu lub w dyskusji nad nimi, albo ich ułożenie nastąpiło na jego polecenie, bądź przynajmniej za jego wiedzą. Za tym przemawia - jak się zdaje - fakt, że nie zawahano się owych niekompletnych i niedojrzałych jeszcze przepisów włączyć do obowiązujących statutów (dodajmy: po zgonie monarchy - według twierdzenia S. Romana). Wszystko wskazuje na to, że dołączenie petitów do statutów było akcją zupełnie świadomą. Chociaż artykuły te oficjalnej sankcji ustawodawczej nie otrzymały, to przecież były wynikiem myśli i starań monarchy, co w pewnym stopniu mogło skompensować ich ustawodawcze braki (s. 131). Na przełomie XIV i XV w., kiedy wytwarzały się dygesta, musiano jeszcze w kancelarii królewskiej mieć jakieś wiadomości o pochodzeniu petitów, i zapewne zawahano by się przed ich zużytkowaniem, gdyby nie przemawiały za nimi jakieś specjalne racje (s. 126). Ale pierwotnie pomnik ten nie był przeznaczony do publikacji, lecz miał służyć jedynie w formie wskazówek na przyszłość (s. 192).

${ }^{15}$ Tak też już w artykule S. Romana, Dygesta malopolsko-wielkopolskie a dążenia do unifikacji prawa polskiego na przelomie $X I V i X V$ w., CPH, t. 10, z. 2, 1958, s. 123. 
Co do prejudykatów sądzi autor, że chybiona jest próba przypisywania im charakteru ustawodawczego na tej podstawie, że weszły w skład statutu małopolskiego i wraz $\mathrm{z}$ nim mogły otrzymać sankcję królewską (s. 110). Byly one przeważnie sfingowane, przypisane królowi, ale od niego nie pochodzily. Jak petita, tak i prejudykaty nie mialy w zasadzie ustawodawczego charakteru (s. 138). Ale czy nie miały żadnej zgoła mocy obowiązującej? „Wahałbym się stawić sprawę tak ostro" - pisze autor (s. 110). Prejudykaty nie wprowadzały żadnej nowej zasady prawnej (przynajmniej $16 \mathrm{z} \mathrm{nich})^{16}$, nie zmieniały obowiązującego prawa, nawet nie kusiły się o jego nową interpretacje, nie wymagały też osobnej sankcji ustawodawczej (s. 110). W zasadzie jest to praca prywatnego prawnika. Prawdopodobnie powstały w kancelarii królewskiej i dla celów urzẹdowych (s. 111); mają charakter do pewnego stopnia półurzędowy. Niemożliwe jest, by powstały bez wyraźnej urzędowej zachęty (s. 111).

Nic nie wskazuje na to, żeby ekstrawaganty tworzyly specjalny statut opublikowany przez króla. Dodano je do B4, czerpiąc material $\mathrm{z}$ luźnych konstytucyj lub $\mathrm{z}$ niewielkich ich zbiorków (s. 113-114). Włączyl je do statutu małopolskiego zapewne jakiś cieszący się autorytetem jurysta w celach urzędowej praktyki (s. 114).

Dopełnienia, ekstrawaganty małopolskie i ekstrawaganty wspólne zachowały się w zespolach, które jako takie sankcji ustawodawczej nie otrzymały (s. 138). Okoliczność ta wszakże nie pozbawiała ich mocy obowiązującej; w ich skład wciągnięto bowiem luźne, pojedyncze ustawy lub drobne grupy ustaw, a więc normy, $\mathrm{z}$ których każda $\mathrm{z}$ natury rzeczy posiadala sama dla siebie moc obowiązującą (s. 138).

Luźne artykuły powstały $\mathrm{z}$ uchwał różnych zjazdów; czasem opierały się zapewne na rozporządzeniach lub poleceniach królewskich, wydawanych w innych okazjach, na sądach, w radzie itp. Niekiedy może nawet stanowią one sformułowania istniejącego zwyczaju (s. 138-139). Zarówno statut wielkopolski, jak i wiślicki powstały „przynajmniej w części nie inaczej, jak przez odpowiednią selekcję dawniejszych materiałów prawnych, pomnożonych o nowe normy i ujętych przez ustawodawcę w zaokrągloną całość" (s. 139).

Zwód malopolski jako całość nie otrzymal sankcji ustawodawczej, nie był ani statutem, ani kodyfikacją czy zbiorem urzędowym. Był powszechnie stosowany $w$ urzędowej praktyce, przede wszystkim zapewne w sądzie królewskim (s. 115).

Umyślnie zestawiliśmy w komplecie wypowiedzi autora na temat charakteru prawnego norm, zawartych w tzw. statutach Kazimierza Wielkiego.

${ }^{16}$ Autor przypuszcza, że prejudykaty, dla których Winiarz nie mógł znaleźć odpowiednich zasad $w$ samym statucie ani $w$ prawie zwyczajowym, opierały się również na zasadach prawa zwyczajowego, dzisiaj nam nieznanych. 
Nie sądzimy, by mogły one zadowolić badacza. Nie bardzo rozumiemy, co nazwać wolno sankcją oficjalną; nie wiemy też, co znaczy określenie ,artykuły z ustawodawczymi brakami”. Czy mamy stwarzać sobie pojęcie jakiegoś ustawodawczego alembiku średniowiecznego, po którego przejściu projekt nabiera pełnej mocy stanowionej? Jak wyróżnić normy charakteru urzędowego od reguł o charakterze pólurzędowym? Dlaczego charakter półurzędowy mają mieć przepisy, które „powstały w kancelarii królewskiej i dla celów urzędowych"? Co to za ustawy, które nie zostały wydane przez samego monarchę (s. 141)?

Jesteśmy zwolennikami modernizacji języka w stylu Guglielma Ferrera. Ale musi ona mieć pewne granice. Sądzimy, że w naszym wypadku trzeba się oderwać od koncepcji ustawy nam współczesnej, wydanej przez legislatora, ujętej na piśmie, obowiązującej od ściśle określonego momentu, gdy projekt przejdzie wszystkie fazy przewidziane przez konstytucję, aż do chwili, gdy zostanie formalnie skasowana. Trzeba zgodzić się $\mathrm{z}$ tym, że ustawa mogla być wydana przez monarchę ustnie; że była zawsze czasowa, stąd konieczność odnawiania jej, jeśli miała trwać dhużej, w przeciwnym razie ludzie o niej zapomną ${ }^{17}$; że do jej ważności trzeba zgody zainteresowanych, że traciła moc obowiązującą non usu, jak też i ze śmiercią swego twórcy, chyba że nowy monarcha ją zatwierdzi; że nieprzestrzeganie ustawy zarówno przez króla, jak i poddanych uzasadniala dostatecznie zmiana warunków, w których do jej wydania doszło ${ }^{18}$, że - wreszcie - wątpliwe się wydaje, by władca mógl pójść przeciwko zwyczajowi - taka akcja $\mathrm{z}$ góry skazana byla na niepowodzenie; statuty kazimierzowskie są tego najlepszym dowodem.

$\mathrm{S}$. Roman pomieścil $w$ dhugim przypisie nader trafne uwagi na temat obowiązywania ustaw (s. 124-125). Ale - oczywista - nie zajął się działalnością normodawczą Kazimierza W. Jego zamierzeniem było rozpatrzeć przekazy rękopiśmienne statutów. $Z$ tego zadania wywiązal się znakomicie. Rzadko, niestety, pojawia się równie gruntowne studium o nieodpartej wprost sile przekonywania. Dodatkowego waloru pracy dopatrywalibyśmy się w tym, że pobudza czytelnika do dalszych dociekań. Lektura dzieła S. Romana uwidacznia dotkliwą lukę $w$ naszych badaniach; brak nam monografii, poświęconej władzy ustawodawczej (czy może lepiej: normodawczej) monarchii piastowskiej.

\footnotetext{
${ }^{17}$ Por. tu s. 151.

18 Stąd możliwość pojawiania się w krótkim odstępie czasu sprzecznych ze sobą norm prawnych.
} 


\section{Liber baptisatorum parafii Szubin $\mathrm{z}$ lat 1736-1785*}

I. Przełomowa data 1772. II. Najstarsze metryki szubińskie. II. Liber baptisatorum z lat 1736-1780. IV. Liber baptisatorum od 1780 r. V. Treść zapisów chrztów. VI. Ocena liber baptisatorum jako źródła do badań demograficznych. VII. Inne księgi metrykalne parafii szubińskiej z końca XVIII w.

\section{Przelomowa data 1772}

Księgi dusz utrzymywały się długo jedynie jako rejestry kościelne ${ }^{1}$. $\mathrm{Z}$ tego nie wynika bynajmniej, by $\mathrm{z}$ nich nie czerpano czasami dla celów świeckich, np. dla przeprowadzenia dowodu poddaństwa ${ }^{2}$, wszakże zdarzało się to jedynie sporadycznie. Jest zaś rzeczą charakterystyczną, że nie przywiązywało do nich wagi państwo. Nie tylko nie prowadziło ono wlasnych statystyk, ale nie potrafilo wykorzystać na swoje potrzeby notowań kościelnych.

Co prawda konstytucja z 1764 r. domagała się od wszystkich ordynariuszy, by nakazali proboszczom corocznie zaraz po Nowym Roku metryki baptisatorum swoich respective kościolów per oblatam ad acta proprii districtus podawać, a kancelarie grodzkie nie miały od tej oblaty pobierać żadnej opłaty. Wszakże działo się to $\mathrm{w}$ trosce, jak $w$ wielu miejscach przez zaniedbanie wpisowania $w$ ksiegach parafialnych upieszczony klejnot szlachectwa naszego niebezpiecznej podlega skazie. Również tytul tego przepisu: $O o b$ latowaniu metryk szlacheckich $w$ wlasnym grodzie $e^{3}$ prowadzi do wniosku, że chodziło w tej konstytucji jedynie o potomstwo szlacheckie, a nie o wszystkie

* Przedruk z: Studia i Materiały do Dziejów Wielkopolski i Pomorza 1962, t. 7, z. 2, s. 199-220.

1 Por. Spis ludności parafii Szubin z 1766 r., wyd. J. Matuszewski, Studia i Materiały do Dziejów Wielkopolski i Pomorza, t. VI, z. 1, 1960, s. 356-357.

${ }^{2}$ Transakcje chlopami w Rzeczypospolitej szlacheckiej, wyd. J. Deresiewicz, Warszawa 1959, nr 63, 649. W razie potrzeby fałszowano też metryki chrztu: J. Michalski, Studia nad reformq sqdownictwa $i$ prawa sqdowego $w$ XVIII w., cz. 1, Wrocław 1958, s. 48, przyp. 116.

3 Volumina Legum, t. VII, s. 68. 
dusze urodzone $w$ parafii. Zapewne odbiciem tego nakazu było zarządzenie biskupa poznańskiego, Młodziejowskiego z 5 III 1779 r., nakazujące zapisywać oddzielnie chrzty dzieci szlacheckich ${ }^{4}$. Znowu zatem wspomniana konstytucja miała na oku nie cele statystyczne, lecz genealogiczne.

Pomijamy już zagadnienie jej zgodności czy sprzeczności z przepisami kościelnymi.

Państwo, nie interesując się notowaniami ruchu czy stanu ludności, nie interweniowało $w$ ogóle $w$ sprawy sposobu przeprowadzania rejestracji. Urząd kościelny, parafia, prowadził je zgodnie z poleceniami kościelnymi, choć nie zawsze respektował je $w$ pełni ${ }^{5}$. Ten stan rzeczy utrzymal się w Polsce do pierwszego rozbioru. Państwo pruskie objęło od razu swoimi zainteresowaniami rejestry parafialne. Studium Liber baptisatorum (LB) parafii szubińskiej, która w 1773 r. została zagarnięta przez Prusy ${ }^{6}$, pozwala na uchwycenie przelomowego momentu, jaki dla ksiąg parafialnych okręgu noteckiego stanowi przejście spod jednego zwierzchnictwa (polskiego) pod drugie (pruskie). Potwierdza ono w pelni trafność wypowiedzi A. C. Holschego: „In Westpreussen und also auch im Netzedistrikt wurde gleich nach der Besitznehmung alles auf preussischen Fuss eingerichtet"?.

\section{Najstarsze metryki szubińskie}

Zachowany LB parafii Szubin obejmuje lata 1736-1785. Nie jest to wszakże pierwsza księga chrztów prowadzona w tej parafii, jak to wynika z protokołu wizytacji z 15 X 1699 r., gdzie czytamy: ...metrica baptisatorum,

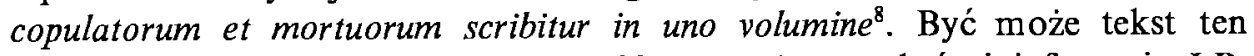
ma na myśli tę samą księgę, vetus liber metrices, o której informuje LB,

${ }^{4}$ Encyklopedia kościelna, t. XXI, 1896, s. 365. Nie bardzo więc bylibyśmy skłonni podpisać się pod twierdzeniem, jakoby konwokacja z 1764 r. nadała metrykom charakter ksiąg publicznych, R. Rajkowski, Zmiana nazwiska, Warszawa 1955, s. 15.

${ }^{5}$ Mirandum autem et dolendum maxime est, in re penitus necessaria, parochos nimis quam negligenter versari. Inveniuntur enim longe plures, qui descriptionem parochiarum, animarumque notitiam omnium non habeant [synod hucki w 1621 r.], Decretales summorum pontificum pro Regno Poloniae et constitutiones synodorum provincialium et dioecesanarum Regni eiusdem ad summam collectae, Poznań 1869, s. 303.

${ }^{6}$ Por. M. Bär, Westpreussen unter Friedrich dem Grossen, t. I: Publikationen aus den K. Preussischen Staatsarchiven, t. 83, Leipzig 1909, s. 49. Hołd złożony został nowemu władcy 22 V 1775 r. przez dzierżawcę dóbr szubińskich - Jakuba Trąmpczyńskiego, i burmistrza Szubina - Albrechta Glowackiego, ibidem, t. II, s. 773.

${ }^{7}$ A. C. Holsche, Der Netzedistrikt, ein Beitrag zur Länder- und Völkerkunde mit statistischen Nachrichten, Königsberg 1793, s. 73.

${ }^{8}$ Archiwum Archidiecezjalne w Gnieźnie, Acta Visitationum, Acta Consist. Gnes., E 6, Visit., f. 421 (1696-1699). 
a która zawierała zapisy do ostatnich dni października 1736 r. Ponieważ wówczas zapelniła się, założono od listopada tegoż roku nową metrykę̧, stara księga wszakże zaginęla ${ }^{10}$.

\section{Liber baptisatorum $\mathrm{z}$ lat $\mathbf{1 7 3 6 - 1 7 8 0}$}

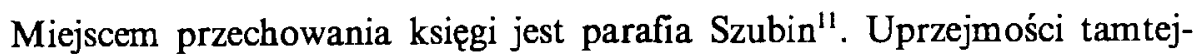
szego księdza proboszcza Namysłowskiego zawdzięczamy możliwość jej skrupulatnej analizy. Jest to księga papierowa, formatu $19 \times 29 \mathrm{~cm}$, oprawiona w półskórek. Zewnętrzna strona oprawy zawiera napis: Katholische Kirche, Altburgund, Kreis Altburgund. Poniżej znajduje się nalepka z napisem: Altburgund (Szubin). Liber baptisatorum 1736-1785. Na grzbiecie okladziny figurują słowa: Altburgund - Szubin, Kr. Schubin 1736-1785, oraz poniżej nalepka $z$ cyfrą porządkową woluminu: 2 . Wklejka na wewnętrznej stronie okładziny wykazuje ważniejsze zapiski znajdujące się $w$ tej ksiażce.

Księga jest paginowana, zawiera 331 stron. Na karcie tytułowej widnieje napis: Liber metrices baptisatorum ecclesiae Szubinensis anno Domini 1736 in annum 1737 comparatus, poniżej zaś kilka cyfr napisanych w $1845 \mathrm{r}$. Zapisy chrztów ciągną się do s. 321 . Wyjątkowe są wtręty innej treści. I tak na s. 116 i górnej ćwiartce s. 117 znajduje się Pro memoria praesentium et futurorum, gdzie zanotowano wiadomości o misjach, o nawróceniach, o wprowadzeniu Confraternitas Sanctissimi Nominis Iesu, o odpustach, w końcu o sepultura ossium; mianowicie $\mathrm{z}$ dawnego ossarium przewieziono na dwóch wozach kości ad tumulum amplum in caemeterio $S$. Margarithae preparatum. Zapisu tego dokonano 19 III 1756 r. Na s. 175-176 wpisano inwentarz pod tytułem: Anno Domini $1767^{m o}$, die 28 mensis maii. Inventarium Suppellectilis ecclesiae parochialis Szubinensis in visitatione generali conscriptum, po czym idzie Decretum reformationis (s. 176-177). Ostatnie dwa wpisy zostały podpisane przez wizytatora - kanonika Wyczałkowskiego.

$\mathrm{Na}$ s. 323-325 figuruje Inventarium ecclesiae parochialis Szubinensis; na s. 325 - Libri ecclesiae oraz Inventarium domus plebanalis. Sporządzono go z okazji przekazania po zmarlym proboszczu szubińskim - Wojciechu

9 Vetus liber metrices completus est et clausus anno 1736, ultimis diebus mensis octobris. Hic incipit a novembri determinium anni currentis habiturus, s. 3.

${ }^{10}$ Nie bardzo więc respektowano przepisy synodalne: liber vero baptisatorum habeatur sub diligenti custodia, sitque decens ac bene compactus [synod płocki 1733], Decretales, t. II, ed. Z. Chodyński et E. Likowski, Poznań 1882, s. 440.

${ }^{11} \mathrm{~W}$ archidiecezji gnieźnieńskiej jeszcze nie zgromadzono starych, nieaktualnych ksiąg parafialnych $w$ archiwum archidiecezjalnym. Podkreślamy, że obowiązek odsyłania ksiąg metrykalnych czy też kopii po upływie roku do kancelarii biskupiej nakładały przedrozbiorowe synody diecezjalne, Decretales, t. II, s. 441; Encyklopedia kościelna, t. XXI (1896), s. 365. 
Szczepańskim, nowemu - Stanisławowi Żarnowieckiemu; podpisali: proboszcz z Samoklęsk i dziekan lekiński, Józef Kasprowicz, oraz proboszcz z Szaradowa, Jan Gruzmacher, jako egzekutorowie i nowy proboszcz. W końcu widnieje notka wizytatora z 6 XII 1791 r. Na s. 328-329: Konnotacja lask cudownych przez protekcje Najšwiętszej Boga Rodzicy Marii przed jej obrazem w kaplicy kosiciola szubińskiego doznanych; na s. 330: krótki spis utensyliów kościelnych, rozciągający się na 6 linij; na s. 331-332: Connotatio personarum ad fidem catholicam conversarum; jest ich $\mathrm{z}$ górą trzydzieści (pierwszy zapis datowany pochodzi z 1741 r., ostatni z 1775 r.).

Wlaściwy rejestr chrztów rozpoczyna inwokacja: In nomine Sanctissimae Trinitatis. Amen, po czym idzie tekst następujący: Primam huius libri occupat faciem nobilissima ab origine suo propago, potem cala prawie stronica zawiera wzniosłe myśli. U samego dołu pierwszej stronicy dokonano zapisu następującego: Illustrissimi Mathias a Mycielno Mycielski et Veronica de Konarzewskie Mycielska, castellani Calissienses, legitimi coniuges, obtulerunt ad inscribendum in metrices natorum filium suum, nomine Stanislaum Philippum Nerium, bini nominis, extra regnum ... [dwa wyrazy zatarte i ciąg dalszy na stronicy następnej] bino eiusque arce, ditionis Brandenburgicae, sub tempus incursionis Saxonum et Moschorum, partes serenissimi Augusti III promoventium, feliciter ortum; cuius ceremoniales actus sacramentum baptismi procedentes et subsequentes eum remotiori tempori relinquuntur. Patrini in particulari actu ad formam baptismi assistentes connotantur, scilicet admodum reverendus Iosephus Jarczewski congregationis S. Philippi Nerii presbyter, et generosa domina Constantia Grzybowska. Baptisavit autem illustris et admodum reverendus Adalbertus Wyrwiński, canonicus collegiatae Samotuliensis, die 18 martii 1735.

Anno autem Domini 1743 die 14 novembris ceremoniales actus adcomplevit illustris reverendus Adalbertus Szczepański, canonicus in arce S. Georgii Gnesnensis, assistentibus pro patrinis illustri et magnifico Francisco Radzewski, succamerario Posnaniensi, cum illustri Teressia Skoroszewska, castellana Premetensi.

Anno vero Domini 1736 die 19 iunii ego Adalbertus Szczepański collegiatae Samotuliensis cantor, parochus Szubinensis, baptisavi infantem nomine Ioannem Nepomucenium, illustrissimorum Mathiae Mycielski et Veronica de Konarzewskie, castellanorum Calissiensium, legitimorum coniugum, filium levantibus de sacro fonte patrinis: magnifico domino Augustino Dzialyński, capitaneo Naclensi, cum illustri et magnifica domina Teressia de Mycielskie Skoroszewska, castellana Premetensi, magnifico domino Martino Dzialyński cum magnifica domina Catharina Cielecka, capitanea Powidzensi.

Anno domini 1737 , die vero $6^{\text {ta }}$ ianuarii ego idem, quam commendarius protunc ecclesiae Rynarzeviensis, baptisavi infantulam nomine Victoriam, generosorum Sebastiani et Marianne de Gostkowskie Chodoreskich, legitimorum 
coniugum, filiam, levantibus de sacro fonte patrinis: generoso domino Remigiano Gostkowski et generosa Teressia Zdzychowska, virgine.

Cytowane zapisy „feudalne” wypełniaja pierwsze dwie stronice rękopisu. Stronica trzecia rozpoczyna się interesującą notatką, którą wykorzystaliśmy wyżej ${ }^{12}$. Dalej idzie tytul: November anni 1736 oraz zapisy chrztów według dość jednolitego schematu, którego podajemy kilka pierwszych przykładów:

$[1]^{13}$ Admodum reverendus dominus Aegidius Graczewski, vicarius Szubinensis, baptisavit infantulam Catharinam, laboriosorum Stanislai et Reginae, famulorum vulgo parobkow, coniugum legitimorum, filiam, cuius patrini fuerunt: Stanislaus Pawelczak et Catharina, virgo, omnes de Pinsko.

[2] Idem, qui supra, baptisavit Hedvigim, laboriosorum Stephani Mizgala et Reginae, semicmethonum, coniugum legitimorum, filiam, cuius patrini fuerunt: Andreas Cholewczak et Catharina, virgo, omnes de villa Pinsko.

[3] Idem, qui supra, baptisavit infantem Andream, laboriosorum Petri et Agnetis Koziolek, inquilinorum de Wolwark, legitimorum coniugum, filiam, cuius patrini fuerunt: Tomas Palicki et Anna Butorowiczowa, cives Szubinenses.

Podane trzy chrzty kończą zapisy $\mathrm{z}$ listopada. Następnie pod nowym tytułem miesięcznym stwierdzono brak chrztów: December vacat, po czym dano nowy tytuł: Annus Domini 1737 i poniżej: Ianuarius. Oto dwa zapisy styczniowe:

[4] Admodum reverendus dominus Adamus Lipiewski, parochus Szaradoviensis, de consensu loci ordinarii baptisavit infantem Antonium, famatorum Adami et Annae Durczyńskich, legitimorum coniugum, civium Szubinensium, filium, levantibus de sacro fonte patrinis: admodum reverendo domino Egidio Graczewski et generosa Ludwika Baykowska, virgine.

[5] Ego Adalbertus Szczepański, curatus Szubinensis, baptisavi infantulam, Agnetem Teressiam, famatorum Alberti et Constantiae Sulkowskich, incolarum Szubinensium, legitimorum coniugum, filiam, levantibus de sacro fonte patrinis: admodum reverendo Aegidio Graczewski et generosa Teressia Żegocianka. virgine aulica.

Pod następnym tytułem miesięcznym: Februarius idą dalsze zapisy. I w ten sposób wypelniono całą księge do 1780 r., wysuwając jako tytuly annus Domini i miesiąc ${ }^{14}$. Dla porównania podajemy jeszcze jeden z końcowych zapisów, z 1780 r.: Anno, ut supra, die 2-da ianuarii. Ego Valentinus Brykczyński baptisavi infantulam nomine Agnetem, natam hacce die, hora 4-ta

12 Por. przyp. 9.

${ }^{13}$ Cylry porządkowej chrztów brak w oryginale, choć to przepisywało ustawodawstwo kościelne: ...utque iidem numeri apponantur singulis baptisatis eo ordine, quo describuntur, inchoando a primo baptisato ineunte anno ad ultimum, qui annum claudet, Decretales, t. II, s. 440.

14 Wzory w Spisie ludności parafii Szubin, s. 385-386. 
mane ex laboriosis Francisca et Catharina Przestworkow, legitimis coniugibus, catholicis. Patrini fuerunt: laboriosus Mathias Koziolek cum Catharina Adamczanka de Pinsko. Tekst zatem stal się nieco szczegółowszy.

Obok tekstu pojawiają się w księdze zapisy marginalne. Przy każdej pozycji chrztu podaje się na marginesie zewnętrznym, cyfrą arabską dzień miesiąca oraz nazwę wsi wchodzącej w skład parafii szubińskiej, w której dziecko się urodziło, a więc przy zapisie 1. 18 Pińsk, przy 2. - 24 Pinsk, przy 3. -29 Wolwark itd., tzn. że chrzty odbyly się w listopadzie w dniach 18,24 i 29 , a dzieci pochodzily ze wsi Pinsk, Wolwark itd. ${ }^{15} \mathrm{~W}$ pewnych partiach ksiegi te noty marginalne zostały przy oprawie obcięte. W innych znowu (s. 15-109) nie zawieraja one daty dziennej, albo tylko wyjątkowo (s. 36), ograniczając się jedynie do miejscowości urodzenia. Daty dzienne pojawiają się znowu na s. 110-238, po czym zanikają (s. 239-262), choć sporadycznie pojawiają się i tam. Stwierdziliśmy wyżej, że noty marginalne pomieszczone zostały na marginesie zewnętrznym stronic, a więc na kartce recto po stronie prawej, na kartce verso po stronie lewej. Na kilku stronicach wszakże (ostatnie cztery zapisy s. 109 oraz s. 110-115, 117-119) pisarz zajął oba marginesy, notując na lewej miejscowość, na prawym datę miesięczną. Marginesy na tych stronicach oddzielone zostaly od tekstu grubymi kreskami. Zanotujmy jeszcze, że jeden $\mathrm{z}$ zapisujących księży nie pisal dat na marginesie, lecz pod każdym zapisem: die 4 praesentis [mensis], anno, ut supra (s. 47).

Do marginesowych zapisów miejscowości piszący widocznie przywiązywał wage, skoro popełniwszy omyłkę dokonal poprawki (Pinsko na Szubin, s. 169).

W momencie zaprowadzenia omawianego LB przewidziano go wylącznie na zapisy chrztów. Jeden raz wszakże zanotowano fakt zgonu dwuipółletniego dziecka; dostrzegłszy omyłkę, pisarz zapis ten przekreślił (październik $1778 \mathrm{r}$., s. 251). Ten zapis świadczy o tym, że równocześnie prowadzono w parafii księge zgonów, która się nie zachowała.

Dla pełności opisu dodajmy, że pisarze niejednokrotnie podkreślali nazwisko chrzczonego, np. s. 204 i n., 230; działo się to jednak rzadko. Natomiast cała szubińska księga chrztów zawiera ślady pozostawione na niej przez archiwistów czy szperaczy. W swych badaniach genealogicznych interesowali się występującymi w LB nazwiskami rodziców dziecka, dlatego podkreślali je olówkiem od s. 77 niebieskim, czasem czerwonym.

W LB znajduje się między stronicami oprawionymi kilkanaście wklejek w postaci luźnych pasków, w ilości do trzech na jednej stronie (trzy między s. 246-247, dwie między s. 258-259, jedna między s. 256-257, 232-233, 244-245, 206-207, 202-203, 190-191). Zawierają one zapisy chrztów, chrzest

\footnotetext{
${ }^{15}$ Wzór ibidem.
} 
$\mathrm{z}$ wody Mycielskiego (15 V $1771 \mathrm{r}$.), z zaznaczeniem: baptisavi infantem ex aqua, necessitate, s. 206-207, chrzest dziecka nieślubnego, s. 190-191 (1769 r.). Wklejka między stroną 218-219 zawiera pięć zapisów chrztów, z których jeden przekreślono. Na prawej górnej ćwiartce tejże wklejki zapisano jakieś obliczenia rachunkowe oraz stwierdzono probatio calami. Niektóre wklejki sporządzono znacznie później niż otaczający je tekst, np. pod 1775 r. (między s. 232-233) wciągnięto zapis z 1803 r. Z tego roku pochodząca wklejka między s. 246-247 jest odpisem metryki chrztu, sporządzonym dla zainteresowanego, a niedoręczonym mu, bądź jego kopią. Wklejka między s. 266-267 informuje o wydaniu metryki w $1804 \mathrm{r}$. Wklejona kartka z 1803 r. podaje fakt urodzenia się dziecka w dniu 21 XII 1775 r.

Księgi parafialne podlegaly periodycznej kontroli: produkowano je mianowicie dwa razy do roku na zjazdach dekanackich, co oznaczano w tekście słowami w rodzaju: productum in congregatione decanali Vangrowiec, die 25 octobris. Mathias Groblinski, dec. et par. Vangr. m.pp., s. 9; lego et approbavi diligentiam in congregatione decanali ad ecclesiam Zunensem die 12 maii. Mathias Grobliński, decanus Leknensis, parochus Vangrovecensis mpp., s. $11^{16}$.

\section{Liber baptisatorum od 1780 r.}

Przedstawiony wyżej opis dotyczy rejestru, który można nazwać polskim. Zagarnięcie Szubina wraz z całym Netzedistrikt w 1773 r. nie wywarlo wplywu na sposób rejestracji chrztów aż do $1780 \mathrm{r} .{ }^{17}$ Ostatni zapis, według dawnej polskiej modły sporządzono w dniu 27 X 1780 r. (s. 262) Na s. 263 pojawia się tekst następujący: Tabellae seu metrices baptizatorum iuxta ordinem serenissimi Regiminis Borussiae descriptae ab anno 1780 die $1^{\text {ma }}$ ianuarii. W rzeczywistości też od następnej stronicy następują zapisy według schematu pruskiego, s. 264-32018. Schemat ten rozciąga się równocześnie na dwie stronice. Wygląda on tak:

${ }^{16}$ Por. Spis, s. 386, z nota produkcyjną z 1766 r.

${ }^{17} \mathrm{Na}$ Sląsku od chwili zawładnięcia nim przez Prusy kładzie się akcent na statystykę ludnościową, wprowadzając w każdym mieście coroczny Seelenregister, S. Golachowski, Opole w roku 1787, Przegląd Zachodni 1952, nr 1-2, s. 107. W samych Prusach tradycje statystyki demograficznej są znacznie starsze; narodziny ich wiąże się z ciężkim okresem wojny trzydziestoletniej, T. Ladogórski, Generalne tabele, s. 7. Fryderyk II rozbudował statystykę do rozmiarów nieznanych żadnemu państwu w XVIII w., choć długo wyniki jej nie są ścisłe, ibidem, s. 9-10.

${ }^{18} \mathrm{~W}$ zaborze austriackim wygląd zewnętrzny metryk zmienia się zupetnie $\mathrm{z}$ rokiem 1784 , kiedy to $z$ nakazu władz zaprowadzono nowe księgi, J. Widajewicz, Nazwiska i przezwiska ludowe, Pam. Hist.-Prawny, t. I, z. 3, Lwów 1925, s. 3. 


\begin{tabular}{|l|l|l|l|l|l|l|l|l|}
\hline $\begin{array}{l}\text { Nomina } \\
\text { parochia- } \\
\text { rum }\end{array}$ & \multicolumn{3}{|c|}{ Numerus omnium } & $\begin{array}{l}\text { Specificatio omnium baptisato- } \\
\text { rum ab anno 1780. Die prima }\end{array}$ & $\begin{array}{l}\text { Annotatio an } \\
\text { gemini nati, } \\
\text { an aliquid } \\
\text { monstrosi vel } \\
\text { singulare circa } \\
\text { partum evenerit }\end{array}$ \\
& & & & & &
\end{tabular}

Ponieważ zapisy polskie kończą się w październiku 1780 r., natomiast schemat pruski wchodził $w$ życie od 1 stycznia tego roku, wynika $z$ tego, że dopiero pod koniec października $1780 \mathrm{r}$. zaczęto w parafii szubińskiej stosować się do rozporządzeń władz pruskich ${ }^{19}$, przy czym na system pruski przerobiono dotychczasowe zapisy od 1 stycznia począwszy ${ }^{20}$. Ten fakt umożliwia nam porównanie obydwu sposobów zapisów. Okazuje się przy tym, że zapis polski mniej więcej pokrywa się z zapisem pruskim w rubryce Specificatio, z tym jednak, że w ostatnim ujmuje się go regularnie w formie obiektywnej ${ }^{21}$. Charakterystycznym novum dla systemu pruskiego jest stworzenie rubryk dla celów statystycznych.

19 Dowodzą tego założone w tym roku księgi sslubów i zgonów, ob. niżej s. 113. Niesłusznie więc artykuł pomieszczony w Encyklopedii kościelnej przyjmuje, że rząd pruski zaczął interweniować w te sprawy dopiero w 1794 r., t. XXI, s. 365.

${ }^{20}$ Może pouczające będzie przytoczenie utyskiwań, nadesłanych w tym względzie z Berlina w osobnym Circulare z 15 IV 1779 r. an alle Inspectores: Bei den letztern Jahres-Listen der Getrauten, Gebornen- und Gestorbenen ist bemerkt worden: 1. dass diese Listen nicht überall nach einer übereinstimmenden Form angefertigt werden ohnerachtet Wir das allhier in der Realschule käuflich zu habende Schema zur allgemeinen Vorschrift gegeben haben. 2. dass die unter den Gestorbenen mitbegriffene unzeitig und totgeborene Kinder nicht allemal unter den Geborenen mitgezählt seien, als welches die grosse Anzahl der Verstorbenen gegen die Gebohrnen vermuten lässt. Wir wollen Euch und die unter euch stehende Prediger demnach wiederholt gnädigst erinnern, dass sämmtliche sowohl Pfarr-als Inspections-Listen nach obgedachtem Schema überall, wo es noch nicht geschehen, gefertigt werden müssen. Ad 2. aber wird, um die Anfertiger der Listen desto aufmerksamer zu machen, eine eigene Colonne wegen der Totgebohrnen in dem nächsten Abdruck zugesetzt werden. Dzieci urodzone nieżywe należy liczyć zarówno po stronie urodzeń i zgonów. W miejscowościach oddalonych od miast, gdzie nie ma władz, w razie wystąpienia chorób epidemicznych kaznodzieje mają o tym donieść pisemnie Landratowi albo Kriegs-Domänen-Kammer, 1776 r., szp. 19-22; ob. też ibidem, szp. 47. Jak widać więc, rząd pruski wykorzystuje duszpasterzy dla celów państwowych, zlecając im funkcje statystyczne. Interesuje się też wysokością iura stolae (1771 r., t. V, s. 298 i późniejsze), wyznacza taryfę maksymalną za metryki chrztu, ślubów i zgonów na 6 groszy (1777 r., s. 406).

${ }^{21}$ Szczegółowe informacje nie tylko o dacie chrztu, lecz także o dacie urodzenia, a nawet godzinie urodzenia podawał już wówczas zapis polski. Tak się przedstawia rzecz z pierwszą metryką z 1780 r., ale w drugiej godzina urodzenia pojawia się tylko w rejestrze pruskim. Wydaje się zresztą, że jest ona wymyślona przez piszącego, skoro jej nie było $w$ zapisie polskim, a tekst według schematu pruskiego sporządzono po 8 miesiącach! Widocznie ksiądz 
Rubryki te przewidziane są dla cech notowanych już dawniej: płci oraz ślubnego pochodzenia. Obok nich pojawia się pozycja nowa, tak charakterystyczna dla pruskiej monarchii: status militaris ${ }^{22}$. Nowy zapis dziecka powiększa równocześnie cyfry: zbiorczą, płci, ślubności; sumy wszakże nie zawsze są poprawne.

Chociaż przejęcie systemu pruskiego nastąpiło dopiero w 1780 r., nowe władze zainteresowały się już wcześniej kościelną rejestracją ludności. Wyraźny ślad tego znalazł się w LB. Mianowicie w połowie s. 245 pomieszczono notatkę: ad hunc locum tabella descripta et remissa. Pochodzi ona z 1777 r., sporządzono zaś ją między październikiem a listopadem. W następnych latach pojawia się ona regularnie przy tej samej dacie; kontynuuje się też ją po wprowadzeniu systemu pruskiego. Jeszcze w 1782 r. sumowanie liczb zostaje zamknięte na koniec października; od początku listopada do końca roku kalendarzowego idzie nowy ciąg cyfr. Podobne w 1783 r., z tym jednak, że kolejność cyfr nie została porzucona $\mathrm{z}$ nowym rokiem kalendarzowym. Rejestrator parafialny układa zatem swe tabele według kościelnego roku statystycznego, sięgającego widocznie od 1 listopada do 31 października roku następnego ${ }^{23}$. Zestawione fakty wykazują, że pruski rząd już w cztery lata po zajęciu okręgu nadnoteckiego, tj. od 1777 r., żądał od parafii rocznych zastawień liczbowych ${ }^{24}$. Wszakże nawet po przestawieniu zapisów na modłę pruską, metryki pozostały w dalszym ciągu księgami kościelnymi. Stąd to produkuje się je na zjazdach dekanalnych (np. $29 \times 1780$ r.).

postąpił tak, chcąc uczynić zadość wymogom władz pruskich. Także nazwisko celebransa zostało podane $\mathrm{w}$ zapisie pruskim niezgodne $\mathrm{z}$ zapisem polskim. I tu oczywista omyłka przepisującego, który nie czytał uważnie rejestru polskiego, a wiedział, kto w tym czasie był proboszczem.

${ }^{22} \mathrm{~W}$ Prusach stan wojskowy wprowadzono do metryk już dawniej, T. Ladogórski, Generalne tabele, 1954, s. 8; W. Dziewulski, Rozwój Dzierżoniowa do poczqtków XIX w., PZ 1954, nr 11-12, s. 494.

${ }^{23}$ Zauważmy, że w 1790 r. nowa numeracja urodzeń idzie już od 22 września. Sporządzanie tabel według kalendarza kościelnego utrzyma się do końca XVIII w., O. Behre, Geschichte der Statistik in Brandenburg-Preussen bis zur Gründung des Königlichen Statistischen Bureaus, Berlin 1905, s. 146.

${ }^{24}$ W Prusach już od 1720 r. obowiązywal nakaz Consignation urodzeń, zgonów i ślubów do Królewca; schemat zestawień ustalono w 1747 r. W. H. Beckher, Preussische Kirchenregistratur oder kurzer Auszug königlich-preussischer Edicten und Verordnungen, welche in Kirchen- und Schulsachen in dem Königreich Preussen publiciert werden, Königsberg u. Leipzig 1769, s. 84-85. O tych listach populacyjnych por. też K. G. Haupt, Handbuch über die Religions-, geistlichen und Unterrichts-Angelegenheiten im Königreiche Preussen, t. III, Quedlinburg und Leipzig 1823, s. 107-108, oraz T. Ladogórski, Ocena, s. 59. 


\section{Treść zapisów chrztów}

Zgodnie z zarządzeniami wladz kościelnych w metryce chrztu notuje się następujące dane ${ }^{25}$ :

1. Data chrztu. $Z$ reguly ogranicza się ona do daty dziennej; czasem pojawia się i dzień urodzenia, i godzina urodzenia; dzieje się to zwłaszcza w końcowych zapisach polskich. Od czasów pruskiej rejestracji data urodzenia występuje regularnie.

2. Imię, nazwisko, stanowisko w hierarchii kościelnej celebransa.

3. Wskazówka, że udzielono chrztu dziecku (infans, infantula, puella) lub osobie dojrzałej (vir adultus, s. 123).

4. Imie, względnie imiona dziecka.

5. Określenie płci dziecka (filius, filia).

6. Liczba noworodków.

7. Imiona i nazwisko rodziców dziecka wraz z określeniem wskazującym na ich pozycje klasową (illustrissimi, illustres, generosi, famati, laboriosi, semicmethones $\mathrm{i}$ in.).

8. Miejsce zamieszkania rodziców $-\mathrm{z}$ reguły pokrywa się ono $\mathrm{z}$ miejscem urodzenia dziecka; odstępstwa od tej reguly notuje się szczegółowo.

9. Stwierdzenie urodzenia dziecka ślubnego lub nieślubnego.

10. Imiona i nazwiska rodziców chrzestnych $\mathrm{z}$ wskazaniem ich miejsca zamieszkania, ewentualnie $\mathrm{z}$ bliżej determinującym ich określeniem klasowym.

11. Ponieważ notowano chrzty wszystkich chrześcijan, katolików i niekatolików, ten fakt znalazl wyraz w postaci określeń: cath[olicus], acath[olicus].

Zanalizujmy, w jakim stopniu schemat ten realizowano. To umożliwi nam stwierdzenie stopnia wiarygodności źródla dla zamierzonych zestawień statystyczno-demograficznych.

${ }^{25}$ Pastoralis Maciejoviana daje wskazówkę następującą: Quorum omnium nomina et cognomina ipsemet sacerdos manu sua describat in libro baptisatorum in hunc modum: anno 1607 die 15 octobris ego $N$., plebanus aut vicarius ecclesiae parochialis $N$., baptisavi $N$., filium $N$. et $N$., coniugum legitimorum; patrini fuerunt $N$. et $N$., Decretales, t. II, s. 441 . Z powyższym pokrywa się w dużym stopniu przepis statutu płockiego z $1733 \mathrm{r}$.: Ipsemet parochus vel vicarius, qui ex illis baptisaverit, propria manu describat nomina et cognomina patris et matris infantis baptisati, nec non patrini ac matrinae, diemque et annum collati baptismi hoc modo: Die, mense, anno, ego $N$., parochus ecclesiae $N$. , baptisavi $N$. , filium $N N$., legitimorum coniugum, natum die: patrini fuerunt NN. Quodsi partus illegitimus fuerit, scribatur: baptisavi $N$., ex incertis parentibus natum etc., nisi parentes ipsi partum pro suo agnoscant velintque nominatim exprimi, ibidem, t. II, s. 441. Ostatni przepis różni się od poprzedniego nie tylko tym, że przewiduje wypadki nieślubnego urodzenia dziecka - różnica raczej formalna, bo przepis Maciejowskiego, przewidujący stwierdzenie ślubnego pochodzenia, implikuje tym samym i sytuację odmienną - ale i wymogiem notowania daty urodzenia. 
Ad 1. Zgodnie $\mathrm{z}$ katolickim poglądem, nativitas następowała nie $\mathrm{z}$ chwilą przyjścia na świat dziecka, lecz z momentem chrztu ${ }^{26}$. Dlatego to właśnie notowania kościelne interesują się tą datą. $\mathrm{Na}$ nią też wskazuje przepis Maciejowskiego. Mimo to LB, jako namiastka księgi urodzeń, nie sprawi nam większego zawodu. Dziecko bowiem chrzci się bądź w dniu urodzenia, die, qua natus, s. 43, 48, 51, eodem die natum (13 XI 1768 r.), bądź co najwyżej w parę dni po urodzeniu ${ }^{27}$. Ustawodawstwo kościelne pilnowało tego, by odstęp czasu między urodzeniem a chrztem nie był zbyt dlugi: najwyżej w ciągu ośmiu dni (statut lucki z 1607 r., poznański z 1689 r., kijowski z 1762 r.) - ne diutius octavo ab ortu infantis die baptismus differatur ${ }^{28}$. Jak stwierdziliśmy wyżej, czasem piszący zanotowal i datę dzienną urodzenia. Od chwili wprowadzenia schematu pruskiego LB staje się równocześnie liber natorum, skoro data urodzenia jest stale podawana przed datą chrztu.

Ad 2. Chrztu udzielal zawsze ksiądz katolicki, nawet gdy chodziło o chrzest dziecka akatolika. $Z$ reguly sakramentu udziela proboszcz lub wikariusz parafii szubińskiej. W kilku, bardzo nielicznych wypadkach, celebransem był ksiądz obcy. Wówczas zaznaczano ten fakt w LB: de consensu loci curati ${ }^{29}$, de licentia (s. 206), ex consensu loci prepositi (s. 255). $O b$ mortis periculum udzielały chrztu także osoby świeckie. One wszakże zapisów nie dokonywały nigdy. Nawet $w$ takich wypadkach sporządzał je duchowny ${ }^{30}$.

Ad 4 i 5. Imię dziecka podaje się konsekwentnie. Czasami nadawano dwa imiona, zwlaszcza gdy chodzi o chrzty feudałów. Jest to zawsze imię świętego katolickiego, zgodnie $\mathrm{z}$ zaleceniami kościelnymi ${ }^{31}$.

${ }^{26}$ Stąd to catalogus baptisatorum nazywal sie też libri vitae, Encyklopedia kościelna Nowodworskiego, t. X (1878), s. 512-513; Podręczna encyklopedia kościelna, t. XXVII-XXVIII (1911), s. 32.

${ }^{27}$ Oto zestawienie dokonane tytułem przykładu:

$\begin{array}{rlll}\text { data urodzenia } & \text { data chrztu } & \text { data urodzenia } & \text { data chrztu } \\ 24 \text { V } & 26 \text { V } 1755 & 28 \text { VI } & 6 \text { VII } 1766 \\ 4 \text { VII } & 5 \text { VII } & 24 \text { VII } & 26 \text { VII } \\ 2 \text { VI } & 6 \text { VI } & 11 \text { VIII } & 12 \text { VIII } \\ 18 \text { III } & 22 \text { III } 1766 & 16 \text { VIII } & 21 \text { VIII } \\ 8 \text { VI } & 10 \text { VI } & 25 \text { VIII } & 28 \text { VIII } \\ 19 \text { VI } & 24 \text { VI } & 24 \text { III } & 27 \text { III } 1769 \\ 17 \text { VI } & 22 \text { VI } & & \end{array}$

$17 \mathrm{VI} 22 \mathrm{VI}$

${ }_{28}$ Decretales, t. Il, s. 437. Jedynie w czasie Wielkiego Tygodnia można było odłożyć chrzest dzieci zdrowych do Wielkiej Soboty, statut włocławski z 1568 r., ibidem.

${ }^{29}$ Por. Spis, s. 385.

${ }^{30}$ Przykłady w punkcie 13.

${ }^{31}$ Decretales, t. II, s. 440. 
Już nadane imię pozwala stwierdzić płeć dziecka, upewnia zaś nas co do tej danej określnik filius czy filia albo ich odpowiedniki. Wyjątkowo tylko nie da się wywnioskować płci $\mathrm{z}$ zapisu. Dzieje się to zwłaszcza przy noworodku nieżywym, infans non vivus (s. 256), czy słabowitym, chrzczonym in extrema necessitate aqua simplici immediate ante ipsam expirationem, kiedy to nie nadawano nawet imienia: et nullum nomen impositum, quia hoc fieri festinatio in eiusmodi casu necessaria prohibuit (s. 132) ${ }^{32}$, ani nie zapisywano określeń filius czy filia. W trzech wypadkach nie zapisano imienia od razu, lecz piszący zostawił wolne miejsce dla uzupełnienia tej danej, czego jednak nie zrobil $w$ dwu wypadkach (1746 r., s. 52; 27 III 1769 r.), w trzecim dokonano uzupełnienia innym atramentem (s. 192).

Ad 6. Przyjście na świat jednego dziecka, zjawisko najpospolitsze, nie wymagało osobnego zaznaczenia. Natomiast notowano fakt urodzenia sie bliźniąt, gemini (7 II 1767 r.) czy trojaczków, tres unius partus (s. 27, 1742 r.).

Ad 7. Nazwisko rodziców pojawia się regularnie, z rzadkimi bardzo odstępstwami. I tak w 1746 r. (s. 52) podano tylko imiona rodziców z zostawieniem luki na nazwisko. Czyżby go nie nosili? Zaznaczmy, że chodziło tu o osobę niskiej kondycji, operarius ${ }^{33}$. Nie notowano natomiast zawodu ojca ${ }^{34}$. Czasami pomieszczano funkcję zaszczytną rodzica, filius scabinorum (s. 49).

Ad 8. Informacja o miejscu zamieszkania rodziców pojawia się również regularnie. Szczegół ten był ważny z punktu widzenia kościelnego, ponieważ przepisy synodalne zakazywały chrztów dzieci $\mathrm{z}$ cudzej parafii ${ }^{35}$, toteż normalnie zapisy dotyczą parafian szubińskich. Jeśli ktoś osiedlił się niedawno

${ }^{32}$ Podobnie z dzieckiem immaturo utero natum [...] a me, suprascripto, simplici aqua propter imminens periculum mortis baptisatum; qui et mortus, s. 48 (1746), oraz baptisavi infantem in extremo vitae periculo positum, s. 45 (1745 r.).

${ }^{33}$ J. Widajewicz, stwierdzając w czterech wypadkach brak nazwisk rodziców, sądzỉ, że nie mieli go wcale, Nazwiska i przezwiska, s. 6, przyp. 9.

${ }^{34}$ Por. Spis, s. 387.

${ }^{35}$ Nemini parochorum liceat baptisare subditum alterius parochiae sub poena quinque marcarum proprio parocho applicandarum. Si autem probetur, eum fraudulenter omisisse nomen parochiae vel etiam nomen baptisati false annotasse vel absolute libro metrices talem baptismum non inseruisse, poena dupli vel aliis arbitrariis veniet puniendus. Quodsi vero de licentia proprii parchochi vel etiam in casu necessitatis sine licentia alienus parochus aliquem baptisaverit, tunc hic baptismi sic collati notitiam, eadem vel subsequenti die statim transmittet proprio parocho, quae $a b$ utroque libris baptisatorum inseratur, Decretales, t. II, s. 440 (Plocensis 1733 r., Culmensis 1745 r.). Przepisy kościelne miały jeszcze dalszy cel na oku: que descriptio id quoque commodum afferre poterit, ut parochiae incertae seu controversae facilius distingui atque in ordinem redigi possint, dum constiterit, quae loca finitimi parochi sibi vindicent et ascribant, ibidem, t. I, s. 303; por. też Spis, s. 396, przyp. 68. 
w parafii, piszący nie omieszkał tego zaznaczyć: $8 \mathrm{~V} 1768 \mathrm{r}$. urodził się Stanisław e nobili Francisca Antonina Woyciechowska, domicilium suum in hac parochia brevi tempore ante partum constituente. $\mathrm{Z}$ nieszubińskich parafian chrzczono najczęściej dzieci $\mathrm{z}$ parafii rynarzewskiej, słupskiej i samoklęskiej ${ }^{36}$. Naruszając kompetencję terytorialną, celebrans uzasadniał ten krok koniecznością spowodowaną nieobecnością proboszcza właściwego, ex necessitate ob absentiam proprii curatoris orta (4 III 1766 r., 30 I 1753 r.), zaszłą z powodu jego zgonu (s. 32, 1744 r.; 14 I 1753) ${ }^{37}$; czasem uzasadnienie ograniczało się do niebezpieczeństwa utraty życia przez dziecko, in periculo mortis (s. 78,1750 r.). W jednym wypadku obok wskazania na nieobecność proboszcza dodano: et ob imbecillitatem infantis (s. 23, 1744 r.). O wlaściwości parafialnej decyduje przynależność parafialna rodziców, a nie miejsce urodzenia dziecka. Mimo więc urodzenia w Szubinie, zapis podkreśla, że dziecko przynależy do parafii slupskiej (25 III 1766 r.). Charakterystyczna jest też następująca wskazówka: NB. Huius filii parentes oriundi de civitate Szubin et non nisi ad tempus commorantes in prefata villa reversuri ad propria (s. 34, 1744 r.). Jeden raz zapisujacy dorzucil: cuius metrica adscribenda ad proprium parochum transmissa (s. 166, 1766 r. $)^{38}$. Tu chyba źródło wklejek, o których pisaliśmy wyżej. Wszystko to świadczy o pewnym ladzie, panującym $w$ lonie kościelnej administracji.

Ad 9. Nigdy nie pominięto w zapisach cechy ważnej dla prawa kanonicznego, ślubnego czy nieślubnego pochodzenia. W pierwszym wypadku przy nazwisku rodziców pisarz notuje: legitimorum coniugum. W razie wątpliwości co do tego faktu przeprowadza się dowód ze świadków; w 1742 r. ochrzczono Marianne famatorum Laurentii Cichocki, absentis et Hedvigis, pro tunc existentis in hoc oppido et parentis, seque habere maritum praefatum, sed alibi morantem, testibus comprobantis, quatenus iuxta narrata coniugum legitimorum filiam, s. 24 . Przy dzieciach nieślubnych zaznacza się: thori illegitimi (s. 32, 34), matris illegitime (s. 67), spurius (s. 67), parentis ignoti (s. 42), ignotorum ac illegitimorum coniugum (s. 110). $\mathrm{Z}$ konieczności więc zapisy dzieci nieślubnych sq̨ niekompletne: brak nazwiska i imienia matki (s. 32, 64), jest tylko imię matki bez nazwiska (s. 34, 82, 89), choć czasem podano zarówno imię, jak i nazwisko: parentis ignoti, matris Agnetis Niedoroślanka, thori illegitimi (s. 42). Wyjątkowo i przy dziecku nieślubnym podawano bliższe szczegóły o obojgu rodzicach: ex Dorothea, ancilla, et Thoma, famulo, personis solutis et vagis, catholicis ( $13 \mathrm{~V} 1767 \mathrm{r}$.); infantem [...] thori illegitimi ex Hedviga Groszkówna, virgine corrupta, et famato, ut fertur, Valentino Lewandowski,

${ }^{36} \mathrm{Z}$ parafii rynarzewskiej naliczyliśmy 10 wypadków, z parafii słupskiej 5 , z samoklęskiej 3.

${ }^{37} \mathrm{~W}$ tym wypadku podano nazwisko zmarłego proboszcza - Jan Lipiński.

${ }^{38}$ Por. Spis, s. 385. 
oppidano Szubinense, adultero (27 II 1769 r.). Ex illegitimo thoro wywodziła się Konstancja Sulkowska, ochrzczona 19 V 1760 r.; jej ojcem był nobilis adolescens Martinus Sulkowski, matką zaś generosa Franciszka Kuberska. Nazwisko zatem otrzymało dziecko po nieślubnym ojcu! Nieraz chodzi o wlóczęgów: ex femina ignota, nomine Anna, quam alio proficiscentem partus in hac parochia occupavit (25 XI 1767 r.); Marianna, mająca dziecko, była córką Michała Rybskiego advenae mendicantis (s. 34).

Ad 10. Zgodnie $z$ wymogami kościelnymi ${ }^{39}$, rodzice chrzestni występują przy wszystkich zapisach. Może ich nie być $w$ razie chrztu $\mathrm{z}$ wody in periculo mortis, cuius nulli patrini fuerunt (s. 132, 1759 r.). W wypadku takim występowała jako matka chrzestna akuszerka, solum obstetrix levavit infantem (s. 48, 1746 r.). Czasem w zapisie pozostawiano lukę na nazwisko rodziców chrzestnych; nie wypełniono jej wszakże, gdy dziecko po kilku dniach zmarło, nie było więc potrzeby uzupełnienia zapisu (25 XI 1772 r.). Czasem występowały dwie pary rodziców chrzestnych, patrini oraz coassistentes (5 II 1764 r., 23 II 1764 r.). Było to regułą w wypadku rozbicia chrztu na dwa akty: wówczas figurują patrini ad actum privatum oraz assistentes seu patrini ceremoniarum (s. 43,1745 r.). Jak wiemy, rozłożenie chrztu na dwa akty było zwykłe przy chrztach feudałów.

Występujący rodzice chrzestni wzbogacają naszą wiedzę o mieszkańcach parafii, nieraz bowiem dowiadujemy się o ich zawodzie, zwlaszcza gdy jest on niecodzienny: honesta Anna, propinatrix Szubin (s. 49, 1746 r.); honestus Offman, chirurgus aulicus (s. 33, 1743 r.); generosus Stelcel [?] medicinae doctor, exteras nationes peragrans (14 V 1766 r.) generosus Martinus Szalrzycki, vexillifer militaris, in Szubin commorans (dwukrotnie: 19 IV 1769 r. oraz 16 VII 1769 r.); 19 III 1778 r. występuje w roli ojca chrzestnego perillustris reverendissimus dominus Casimirus Czyżogorski, canonicus cathedralis Livoniensis, tum collegiatae Szamotuliensis et praepositus Szubinensis. Signum temporis: od 1775 r. pojawiają się w charakterze ojców chrzestnych milites Prutenorum (19 III, 2 VII, 4 VIII 1775 r., 13 I 1776 r.). Dane o rodzicach chrzestnych i rodzicach dziecka świadczą o pewnym współżyciu różnych klas ze sobą: gdy 14 VII 1769 r. chrzczono Bonawenturę Czaplewskiego, ex nobilibus, rodzicami chrzestnymi byli wspomniany wyżej generosus Martinus Szalrzycki, vexillifer militaris, et famata Rosalia Lewandowska, oppidana Szubinensis; przy chrzcie dziecka nobilów Miąskowskich (był on oeconomus de Pinsko) rodzicami chrzestnymi byli mieszczanie (10 IX 1769 r.), u spectabilis Mathaeus Reyman, scholae rector, rodzicami chrzestnymi byli kanonik

${ }^{39}$ Przepisy o rodzicach chrzestnych podają Decretales, t. II, s. 438 . Od funkcji tej wykluczeni byli według Pastoralis Maciejowiana: infideles, haeretici, schismatici, excommunicati, monachi, ibidem, s. 437. 
gnieźnieński i dziekan lekiński, Wojciech Szczepański, oraz generosa Eleonora Chrzanowska, oeconomisa Szubinensis (28 II 1757 r.); u szubińskiego chirurga funkcję rodziców chrzestnych pełnili: laboriosus Sebastian Baran de Lachowo et honesta Anna - propinatrix Szubinensis (s. 49, 1746 r.). Należy podkreślić, że specjalnie godnych rodziców chrzestnych dobierano dla dzieci nieślubnych: wikary szubiński, Jan Gruzmacher, późniejszy proboszcz szaradowski, oraz magnifica ac generosa domina, Teresia Krzyżanowska (s. 82, 1751 r.). Prawdopodobnie tą drogą chciano zapewnić dziecku szczególną opiekę. Niektórzy rodzice chrzestni występuja w tym charakterze wielokrotnie. Pod tym kątem widzenia zbadaliśmy jedynie lata $1764,1765,1766$, przy czym okazało się, że niektóre osoby pełnią rolę ojca czy matki chrzestnej cztery, pięć czy sześć razy. Wojciech Głowacki był 11 razy ojcem chrzestnym, a już rekord ustaliła Helena Glowacka, która w podanych latach była 23 razy matką chrzestną!

Ad 11. Stwierdziliśmy już dawniej, że ksiądz katolicki traktował jako swoje dusze chrześcijan niekatolików ${ }^{40}$. Z LB okazuje się nadto, że on także chrzcil dzieci akatolików (w naszym wypadku ewangelików) ${ }^{41}$, mimo to pozostawały one acatholici! Te dane w zapisie notuje się starannie ${ }^{42}$. Nawet $\mathrm{z}$ obcej parafii (rynarzewskiej) przynoszą honesti acatholici do chrztu córeczkę ${ }^{43}$. Zapis stwierdza przy tym, że zrobili to in casu necessitatis et in absentia illustris curati, przy czym chodziło niewątpliwie o tamtejszego katolickiego proboszcza ${ }^{44}$.

Jeden tylko wynotowaliśmy wypadek małżeństwa mieszanego; rodzicami chrzczonego dziecka byli: Iacobus Berent, cath., textor, lutherana uxor (s. 39, 1744 r. $)^{45}$. Zdarza się też, że wśród rodziców chrzestnych ojciec był katolikiem, matka acatholica (s. 27, 1741 r.).

Zaznaczmy, że osobne ewangelickie księgi kościelne datują się dopiero od $1795 \mathrm{r}^{46}$

${ }^{40}$ Por. Spis, s. 381.

${ }^{41}$ Podkreśla się to już w literaturze od dawna, M. Beheim-Schwarzbach, Der Netzedistrikt in seinem Bestande zur Zeit der ersten Teilung Polens, Zeitschrift der Hist. Gesellschaft f.d. Provinz Posen, t. VII, 1892, s. 249; A. Lattermann, Einführung in die deutsche Sippenforschung in Polen und dem preussischen Osten, Poznań 1938, s. 18-19, 78. Przyczyną tego była mała liczba duchownych ewangelickich; jeszcze w 1788 r. było ich w okręgu nadnoteckim tylko 36 , M. Beheim-Schwarzbach, 0 . c., s. 246.

${ }^{42}$ Raz wyraźnie: omnes una cum parientibus infantis acatholici, s. 23, $1742 \mathrm{r}$.

4321 VII 1754 r., s. 105; podobnie 16 IX 1763 r., s. 170.

44 Drugi przypadek chrzlu akatolika in defectu parochi Rynarzeviensis defuncti, s. 32, 1744 r.; podobnie z Samoklęsk akatolika in absentia loci ordinarii, s. 76, $1750 \mathrm{r}$.

is Takiego faktu nie zna wszakże Status Animarum.

${ }^{46}$ A. Lattermann, Einführung, s. 83. Dielko M. Meyera, Die Kirchenbücher im Regierungsbezirk Bromberg, Jahrbuch d. Hist. Gesellschaft $f$. d. Netzedistrikt zu Bromberg 1898, zawiera zestawienie ksiąg ewangelickich, ponieważ konsystorz poznański i gnieźnieński nie odpowiedziały na kwestionariusz, s. 11. 
Takie dane zawierają regularnie zapisy chrztów. Nieraz występują jeszcze jakieś dane szczególne.

Mówiliśmy wyżej o podawanym nieraz zawodzie rodziców chrzestnych. Czasem podaje się także zawód rodziców dziecka, w rodzaju famulantes (28 XI 1756 r.). Najczęściej ma to miejsce, gdy chodzi o jakieś zajęcie niecodzienne: honestorum Ioannis Hetzegoff et Mariannae artis chirurgicae coniugum legitimorum (s. 49, 1746 r.), a zwłaszcza żebracze ${ }^{47}$ : filiam mendicantium transeuntium (bez nazwiska rodziców s. 47, 1746 r.), córka laboriosorum Stanislai et Mariannae Chudzikowskich mendicantium (s. 67, 1749 r.), dwukrotnie chrzczą dzieci mendicantes Szczypiorowie (s. 42, 1745 r.; s. 61, 1747 r.). Zauważmy, że nie podkreśla się żadnej z funkcji miejskich czy wiejskich (burmistrza, radnych, sołtysów).

W wyjątkowych wypadkach zapis informuje nas o akuszerce, mianowicie wtedy tylko, gdy dokonala ona chrztu $\mathrm{z}$ wody. Jedna $\mathrm{z}$ nich, Apolonia Kamecka, występuje jako obstetrix probata (s. 170, 18 IX 1766 r.). Znaczenie tego wyrażenia wyjaśniają nam wizytacje kościelne, w czasie których badano, czy akuszerka jest wystarczająco przygotowana do udzielania chrztu in necessitate ${ }^{48}$. Chodziło zatem nie o kwalifikacje $\mathrm{z}$ punktu widzenia sanitarnego, lecz o umiejętność dopełnienia czynności liturgicznej ${ }^{49}$. Co do niej zaś nasuwały się nieraz wątpliwości: Idem qui supra baptisavi infantem nomine Annam sub condicione, eo quod ab obstetrice baptisatus fuerat in periculo, dubium tamen fuerat de valore baptismi (29 V 1759 r.).

Oprócz regularnych wyżej scharakteryzowanych zapisów pojawiają się zapisy skreślone (s. 159), przy czym zaznaczono nihil deest, lub niepelne ${ }^{50}$. Istnieją także zapisy, które wyraźnie odbijają od innych, mianowicie gdy chodzi o chrzty feudałów i chrzty osób dorosłych, przede wszystkim Żydów.

Wyżej stwierdziliśmy, że pierwsze dwie stronice księgi zarezerwowano dla nobilissima propago Mycielskich oraz innych wielkich ludzi Szubina i okolicy. Po ich zapelnieniu dalsze zapisy chrztów znalazły się wśród zapisów zwykłych śmiertelnych, ale wyróżniają się od nich przez rozbicie

${ }^{47}$ Por. Spis, s. 387.

48 Obstetrices de administrando in casu necessitatis baptismi bene instructae reperiuntur, podaje wizytacja z 1766 r., Archiwum Archidiecezjalne w Gnieźnie, Acta Visit. E 18, s. 616; podobnie zresztą $w$ wizytacjach poznańskich, np. z 1781 r., Archiwum Archidiecezjalne w Poznaniu, Acta Visitationum, r. 34, f. 10, 191 v.

49 Zaznaczmy, że w Prusach składały akuszerki egzamin na fakultecie medycznym w Królewcu już od 1715 r., W. H. Beckher, Preussische Kirchenregistratur, s. 56.

${ }^{\text {so }}$ Piszący zostawił wolne miejsce, które najwidoczniej zamierzał później wypełnić, czego jednak nie zrobił. Tak na s. 204 rozpoczął trzykrotnie wpis, dał duże światło na trzy zapisy, z tym, że dwukrotnie stwierdził vacat, dwukrotnie zaś zapisał na marginesie określenie miejscowości, Wolwark; uzupehienie tekstu wszakże nie nastąpiło. 
chrztu na dwa akty ${ }^{51}$ : particularis actus ad formam baptismi ${ }^{52}$ i ceremoniales, kiedy to kapłan complevit ceremonias baptismi (s. 43) ${ }^{53}$. Odstęp między nimi mógł być paromiesięczny. Na przykład wobec dziecka Krzyżanowskich, chrzczonego $23 \mathrm{~V}$ (s. 18), dokonano uzupełniających ceremonii w listopadzie ${ }^{54}$, lub krótszy (25 i 27 V 1745 r.). Mogło się zdarzyć, że drugiego aktu nie dopełniono, czego nie omieszkano zaznaczyć: omissis propter legitimam rationem caeremoniis (s. 36-37, 1744 r. $)^{55}$.

Dhugością tekstu wyróżnia się również zapis chrztu Żyda, co świadczy o wadze, jaką przywiązywano do takiego sukcesu duszpasterskiego. Charakterystyczne jest przy tym, że Izaaka Manaszewicza nie chrzcil miejscowy proboszcz, lecz kcyński, że podano jego zawód (mercaturam exercentem), miejsce urodzenia (Przemęt), fakt żądania zmiany nazwiska na "katolickie” - Michal Nowacki, że w uroczystości chrztu brali udzial aliquot sacerdotes. Rodzicami chrzestnymi neofity byli: kanonik Rolniecki i szlachetna Krzyżanowska. Przy czym jeszcze hic actus ceremonialis baptismi peragebatur in die dedicationis ecclesiae Szubinensis (21 VIII 1757 r., s. 123). 13 II 1758 r. ochrzczony został adolescens cathehumenus, ex iudaismo conversus, cui nomen impositum et cognomen Notecki Paulus; chrztu udzielał znowu ksiądz obcy, rodzicami chrzestnymi byli: proboszcz kolegiaty szamotulskiej, Wyrwiński, oraz Marianna Swinarska. 6 I 1774 r. ochrzczono Żyda, Jakuba Lewka, ex iudaismo ad fidem christianam aspirantem, - dum adhuc in errore versabatur. Przy chrzcie otrzymal on imię Gaspar i nazwisko Lewkowicz; rodzicami chrzestnymi byli: dzierżawca Szubina, Trąmpczyński, oraz właścicielka Kołaczkowa, Grabska.

Zapisy chrztów wypełniają zgodnie $\mathrm{z}$ omówionym schematem całą księgę. Czasem wszakże piszący nie oparł się pokusie zanotowania innych jeszcze wiadomości: o matce - post editum foetum statim emortuae (s. 61, 1748 r.); o dziecku - hic infans statim mortuus (22 XI 1772 r.); hic infans post aliquot dies mortuus (25 XI 1772); o urodzeniu nieżywym dziecka - cuius manus ex utero - bat ${ }^{56}$, ergo sub conditione utrum vivus, baptizabatur (26 VI 1779 r., s. 256); o fakcie, że urodzone dziecię jest pogrobowcem (posthumus, s. 38, 1744 r.) Wreszcie o szczególnie interesujących wydarzeniach

${ }^{51}$ Zwróciliśmy na to uwage dawniej, Spis, s. 382, przyp. 52.

\$2 Także zwrot: baptisavit privatim, ceremoniae differuntur, s. 28, 1743 r.

${ }^{53}$ Przyklad podany wyżej, s. 96.

54 Tak samo $z$ dziećmi wlaścicieli Szubina, Mycielskich (lipiec 1738 r.), gubernatores in bonis Szubin Chrzanowskich i in. (s. 38, 1744 r.; s. 41,1744 r.; s. 43,1745 r.).

ss Wyróżnienie się feudałów w metryce chrztów zaznacza się także, liczbą imion, których nadaje się trzy, s. 38, 1744 r., s. 41 , a także innym brzmieniem imienia: dziewczęta "chamskie" otrzymując za patronkę Marię, noszą imię Marianny, córeczka administratora Szubina jest Marią (s. 157, 1763 r.); wreszcie imionami dość niepospolitymi, jak w ostatnim wypadku: Teofila, Ludwika, Barbara. Rzecz wymagałaby, oczywiście, szczególowego zbadania.

${ }^{56}$ Począlek słowa sklejony $z$ kartką sq̨siadująca. 
lokalnych, jak pożar, który 26 IX $1744 \mathrm{r}$. w ciągu godziny integrum fere oppidum in favillam redegerit. Spłonęly przy tym 63 domy cum universa fere supellectili incolarum ac duobus horreis, segete plenis (s. 40).

\section{Ocena liber baptisatorum jako źródla do badań demograficznych}

Wyżej rozpatrzyliśmy pytanie, czy LB, będący rejestrem chrztów, zastąpić może księge urodzeń. Odpowiedź wypadła pozytywnie: urodzenia i chrzty niemal się pokrywają; zresztą od pewnego momentu zapisy podaja konsekwentnie datę urodzenia. Wszakże zważywszy na to, że księgi kościelne prowadzono nieraz bardzo pobieżnie ${ }^{57}$, musimy rozpatrzyć zagadnienie dalsze: czy notowano wszystkie chrzty? Niełatwo je z calą pewnością rozstrzygnąć. Jeśli bowiem spośród osób wystẹpujących w Status Animarum tylko $37 \%$ zdołano skonfrontować z zapisami LB, to czyż możliwe jest, by aż tak olbrzymia część uszla rejestracji? Czy ten brak koniecznej, wydawałoby się, koincydencji nie jest następstwem płynności nazwisk ${ }^{58}$, która pociąga za sobą tak duże luki konfrontacyjne? Zważmy nadto, że notowano chrzty dokonywane simplici aqua, noworodków umierających tuż po urodzeniu, że zapisywano nawet wypadki urodzeń martwych. To wszystko skłania nas do nieodmawiania zaufania księdze chrztów. Być może, że nie zawiera ona chrztów w stu procentach, ale raczej do tego stanu się zbliża.

Nie mogąc stwierdzić niedoborów, musimy skonstatować, że LB grzeszy $\mathrm{z}$ naszego punktu widzenia nadmiarem. Omawialiśmy wyżej wypadki chrztów dorosłych Żydów. Obok tego zdarzają się wypadki przyjmowania chrztów przez ewangelików: perillustris Rzekaczewski [...] absolvit [...] Luteranos ab haeresi (chodzi o parę małżonków, s. 19); ochrzciła się Anna Billert, vidua lutherana, olim scholae magistri in Schottland uxor (s. 126); żona Hoffmana, który był prosceniorum operator, lutherana abiuravit haeresim (s. 126); luteranin przyjął też chrzest 29 I 1757 r. Do tego zestawienia należy dodać listę nawróceń, powołaną wyżej ${ }^{59}$. Nadmiar ten wszakże nie przedstawia dla badacza żadnych niebezpieczeństw; w zestawieniach statystycznych zostanie po prostu nie uwzględniony.

Stwierdziliśmy wyżej zapisy chrztów nieparafian. I takie dzieci łatwo wyłączyć. Należy wszakże liczyć się z możliwością, że i dzieci parafian

${ }^{57}$ Por. sankcje grożące kapłanom za niedbałe prowadzenie ksiąg Decretales, t. II, s. 441. Ibidem w cap. 32, zatytulowanym: Quales debeant esse libri metrices et qua diligentia servandi?, postawiono wymóg ut omnes eorum pagine notentur numerorum serie, prout conspicitur in libris typo impressis, ibidem, s. 440. Por. też Wyczawski, o. c., s. 95, 151.

sB Por. Spis, s. 388-390.

59 Por. wyżej, s. 95-96. 
szubińskich mogły być w nagłej konieczności chrzczone gdzie indziej. Co prawda, istnialy nakazy kościelne przysyłania wypisów takich chrztów właściwym parafiom. Czy jednak zawsze czyniono im zadość?o

A jak się przedstawiała „kancelaria” parafialna? Zapisów nie zawsze dokonywal ten ksiądz, który udzielał chrztu, przynajmniej gdy chodziło o księży miejscowych, proboszcza i wikarego. Stąd to ujmowano je raz w formie subiektywnej (ego baptisavi), to znowu w formie obiektywnej (baptisavit). Proboszcz tak sumienny, jakim był ks. Żarnowiecki, rzadko tylko swoim czytelnym kaligraficznym pismem dawał znać na lamach LB o swojej egzystencji; zapisy za niego sporządzal ks. wikary Cybort ${ }^{61}$, chociaż proboszcz z całą pewnością chrztów udziela ${ }^{62}$. Natomiast ksiądz zamiejscowy, który udzielał chrztu w kościele szubińskim, sam dokonywal zapisu ${ }^{63}$.

Zapisu nie dokonywano od razu po chrzcie, przynajmniej nie zawsze albo nawet nie tego samego dnia, jak tego wymagało ustawodawstwo kościelne ${ }^{64}$. Rejestrujący chrzest w 1742 r. (s. 25) zanotowal imiona dziecka i rodziców, nazwiska ich wszakże już nie pamiętal, przeto zostawił nań lukę, po czym podal rodziców chrzestnych $\mathrm{z}$ uwagą: ...dies determinari non potest, mense vero augusto, ante diem tamen 24-tam eiusdem, anno ut supra. Tylko przy takim zapisie niewspółczesnym z aktem mogło dojść do dwukrotnej rejestracji tego samego chrztu. Tak się rzecz przedstawia z Magdaleną Kapicką, zarejestrowaną pod 22 i 25 VI 1766 r. (s. 168). Zgodne są bowiem zarówno imię chrzczonego dziecka, jak i imiona rodziców, rodziców chrzestnych oraz data urodzenia. Za odstępstwem od zasady natychmiastowej rejestracji przemawia też omówiona wyżej luka co do rodziców chrzestnych ${ }^{65}$.

Aktu chrztu dokonywano $\mathrm{z}$ reguły $\mathrm{w}$ kościele. Poświadczaja to zapisy, wedlug których ob imminentis mortis periculum chrzci się dziecko w domu,

${ }^{60}$ Por. wyżej, s. 104-105.

${ }^{61}$ LB, s. 166; ob. fotokopię, Spis, s. 385.

${ }^{62}$ Pierwszego chrztu udzieli! ks. Żarnowiecki 25 XI 1765 r., pierwszego własnoręcznego zapisu dokonał 25 I 1766 r. Takie postępowanie było niezgodne $z$ nakazami synodów, jak cytowany wyżej z 1733 r., według którego ipsemet parochus vel vicarius, qui ex illis baptisaverit, propria manu describat, Decretales, t. II, s. 441; por. też Podreczna encyklopedia kościelna, t. XXVII-XXVIII, s. 32; przypomnijmy też zakazy kościelne, by przy prowadzeniu metryk posługiwać się stużbą czy nauczycielami (1641 r.), Encyklopedia kościelna Nowodworskiego, t. XIV (1881), s. 227.

${ }^{63} \mathrm{~Np}$. na s. 9-10 pojawia się ręka ojca Jacentego, karmelity strictae observantiae, przy czym tekst nieco różni sį od zwykłych zapisów (podana data dzienna i roczna); w końcu zapisu czytamy: Ita testor idem qui supra map. Por. też początek zapisu innego karmelity, na fotokopii, Spis, s. 385. W LB snadnie zatem śledzić można ręce piszących proboszczów i wikariuszy.

${ }^{64}$...ut ista parochi iuxta formulam titualis Romani accurate statimque - si fieri potestdescribant, nunquam vero ultra diem hoc facere differant, Decretales, t. II, s. 441.

${ }^{65}$ Por. wyżej, s. 106. 
jednakże skoro tylko stan zdrowia dziecka na to pozwala, uzupełnienie ceremonii odbywa się w kościele ${ }^{66}$.

Brak w źródle wskazówek o miejscu przechowywania ksiąg. Skądinąd wiemy, że nie było tu jakiejś reguły jednolitej. Trzymano je w zakrystii lub na probostwie ${ }^{67}$. Analiza pisma pokazuje, że piszący nie tylko posługiwali się innym piórem, lecz także innym atramentem. Różnica inkaustów zaznacza się bardzo dobitnie na s. 236-237, 240-242. Zapisów zatem widocznie nie dokonywano $w$ jednym miejscu, lecz notujący zapisy zabieral księge do siebie, by ją wypelnić w domu. Wszakże zarówno proboszcz, jak i wikary mieszkali niedaleko kościola ${ }^{68}$, stąd księga wielkich wędrówek nie odbywala.

Zestawione tu informacje świadczą o dość prymitywnej organizacji kancelarii parafialnej. To jednak nie wpływa na oslabienie naszego zaufania do powstałych $w$ niej ksiąg. Podnieśmy bowiem, że poczynione tu usterki są wręcz wyjątkowe; należy się przeto zastrzec, by na ich podstawie nie wytworzyć sobie obrazu fałszywego. $Z$ reguly - takie wrażenie odnosi czytelnik LB - zapisy stanowią dokumentację historyczną pierwszorzędnej wagi. Szczegółowe daty podawane w każdym wypadku - a jest ich niemało, liczba danych zapisu sięga w krańcowych wypadkach 13 - każą zakładać, że rejestracji dokonywano rzeczywiście statim. Można więc z calym spokojem przystąpić na ich podstawie do analizy materiału demograficznego. Jeśli technika zapisów nie wzbudza poważniejszych zastrzeżeń, to w przekonaniu o wartości rejestru umocni nas zestawienie urodzeń, śledzone przez kilka dziesiątków lat. Stosunek płci wydaje się prawidłowy, liczba urodzeń wykazuje powolny, ale stały wzrost.

Badacz zagadnień ludnościowych Szubina w okresie przed pierwszym rozbiorem operuje więc dwoma źródłami dotyczącymi ruchu ludności (Liber Baptisatorum) i jej stanu (Animarum Status). Oba uzupełniają się w pewien sposób. A ponieważ zawierają informacje wiarygodne, szczegółowa analiza dostarczy nam cennych wyników, tym wartościowszych, że wyprzedzają o jakieś trzy dziesiątki lat zestawienia statystyczne robione przez władze polskie in extremis.

${ }^{66} \mathrm{~W}$ domu chrztu dokonuje akuszerka, s. 170, 1766 r., lub inna osoba świecka (famata Helene Holewińska, civis Szubienensis) lub ksiądz (7 II 1767 r.).

${ }^{67}$ Oto informacje zebrane $\mathrm{z}$ diecezji poznańskiej: Libros istos metrices reverendus parochus in sacristia conservat, wizytacja z 1777 r., f. 93 v (Gnin); libri circa admodum reverendum praepositum conservantur, ibidem, f. 113 (Komorowo); libri metrices [...] conservanturque in armario intra residentiam plebanalem sito, ibidem, f. $154 \times$ (Opalenica).

${ }^{68}$ Plebania dzisiejsza znajduje się tuż obok kościoła, nie wiemy jednak, czy na tym samym miejscu co domus plebanalis wspomniany w SA, skoro wedhg wizytacji z $1766 \mathrm{r}$. istniały dwa domy plebańskie: jeden stary zbudowany w 1610 r., drugi, późniejszy, s. 609. Niedaleko też musiała się znajdować domuncula vicarialis wyslępująca także w tej samej wizytacji jako domus pro vicario, s. 609-610. 


\section{Inne księgi metrykalne parafii szubińskiej z końca XVIII w.}

Obok ksiąg chrztów prowadzono w Szubinie współcześnie rejestry ślubów i zgonów, jak o tym informuje protokół wizytacji z $1766 \mathrm{r}^{69}$ Jednakże nie dochowały się one do naszych czasów. Parafia szubińska może się chlubić kompletem metryk od lat osiemdziesiątych tegoż stulecia. Dla wieku osiemnastego w rachubę wchodzą:

1. Liber copula tor um. Nosi ona na okładce napis: Liber copulatorum 1780-1821. Wewnątrz podano tytul: Copulatorum liber metrices, iuxta ordinem Regiminis Borussiae comparatus, anno Domini 1780.

2. Liber mortuorum. Księgę zgonów oprawiono w sztywną okładkę, na której położono napis: Liber mortuorum ab anno 1780 ad 1807. Wewnętrzny tytuł wygląda następująco: Liber metrices mortuorum, iuxta ordinem et mandatum Regiminis Borussiae conscriptus, anno Domini 1780. Od drugiego końca tej księgi prowadzono zgony innowierców: Specificatio dissidentium mortuorum, incepta ab anno $1785^{\text {to }}$.

3. Liber baptisatorum. Druga księga chrztów założona została w 1785 r.: Liber baptisatorum ab anno 1785 ad 1806.

Wszystkie te księgi znajdują się w kancelarii parafii szubińskiej, gdzie przechowuje się je $\mathrm{z}$ dużą pieczołowitością.

${ }^{69}$ Libros metrices baptisatorum, copulatorum et mortuorum, diligenter connotatos, exhibuit parochus, s. 615 . 



\title{
Rękojmia w rozumieniu Kodeksu Zobowiązań i rękojmia w dawnej polszczyźnie*
}

\author{
Mowa nasza jest pod opiekq prawa i strażq pokoleń. \\ Kto swoja mowe lekceważy, ten jest cudzoziemcem na \\ wlasnej ziemi, ten nie ma ducha przodków, ten oddziela \\ mowe narodu od mowy nauk. \\ Tadeusz Czacki
}

Artykuł niniejszy nie daje analizy instytucyj prawnych, współczesnej i przedrozbiorowej. Nie ma na celu porównawczego studium $z$ dziedziny prawa obligatoryjnego. Przedmiot jego, w intencjach autora, jest o wiele węższy: terminologiczna strona zagadnienia. Badania nad językiem prawnym i prawniczym ${ }^{1}$ leżą u nas odlogiem zupełnie. Ani kodyfikacje międzywojenne, ani prace kodyfikacyjne ostatniej doby nie wywolały dyskusji językowej ${ }^{2}$. Bez echa pozostaly głosy zachęcające do studiowania języka ustaw i kodeksów ${ }^{3}$. A uprzytomnijmy sobie, dla przeciwstawienia, jaką lawinę artykułów wywołal projekt BGB $^{4}$ i sama kodyfikacja po jej publikacji ${ }^{5}$. Podobnych wypowiedzi o języku polskich ustaw daremnie szukać w literaturze.

* Przedruk z: Czasopismo Prawno-Historyczne 1963, t. 15, z. 1, s. 203-222. Por. S. Urbańczyk w: Język Polski 1964, t. 44, s. 178

I Rozróżnienie B. Wróblewskiego, Język prawny i prawniczy, Kraków 1948, s. 51 i n., 136 i n.

${ }^{2}$ Por. artykul pt. O szerszq dyskusje $w$ zwiqzku z pracami kodyfikacyjnymi, PiP, t. XI, 1956, cz. 1, s. 417-21.

${ }^{3}$ E. Bautro, Idea lingwistyki $i$ semantyki prawniczej, Lwów 1935, s. 19.

${ }^{4}$ E. J. Becker, System und Sprache des Entwurfes eines BGB für das Deutsche Reich, Berlin u. Leipzig 1888; L. Fuld, Die deutsche Sprache und das BGB, Gegenwart, t. 34, 1888, s. 44; A. Keller, Der Entwurf eines $B G B$ für das deutsche Reich, Zeitschr. des allgemeinen deutschen Sprachwesens 1888, s. 81-6, 99-104; 1893, s. 94-6; L. Poldschmidt, Kritische Erörterungen zum Entwurf, 1889; Thudickum, Juristendeutsch, Hirths Annalen 1892, s. 126-36; W. Gensel, Die Sprache des Entwurfs - Eine Kritik, zugleich eine Mahnung an alle deutsche Juristen; tenże, Unsere Juristensprache, Unsere neue Gesetzessprache, Leipzig 1911.

${ }^{5}$ J. Erler, Die Sprache des neuen BGB, Berlin 1896; G. von Klaeden, Das Latein im Rechte, Stillehre für Juristen, Frankfurt a. O. 1896; Altsmann, Zum Sprachgebrauch des BGB, Deutsche Juristenzeitung, R. 3, 1898, s. 405-6; O. Müller, Begriffsbestimmungen aus dem BGB, Deutsche Juristenzeitung 1898, s. 463-7. Zestawienie bibliografii podaje wstęp do tłumaczenia urzędowego BGB z $1923 \mathrm{r}$. 
A jak się przedstawia nasz język prawniczy? Czy jest on wystarczająco precyzyjny, a równocześnie przystępny i zrozumiały dla szerokich warstw społeczeństwa? Zagadnienia dzisiaj tym ważniejsze, że społeczeństwo nasze nie tylko żyje według obowiązujących norm prawnych, ale samo je stosuje, biorąc $w$ szerokiej mierze udział $w$ orzecznictwie, dzięki instytucji sądów ławniczych: samo też uczestniczy w dyskusjach nad projektami ustaw.

$Z$ wagi problemu języka prawnego zdawano sobie doskonale sprawę już w poprzednich pokoleniach. W. A. Maciejowski pomieścil w swej wielkiej, a niewątpliwie przedwczesnej i dlatego bezwartościowej syntezie ${ }^{6}$ osobny rozdzial, któremu dał tytul: Język prawny $i$ technika. Ograniczył się wszakże w nim do uwag tak ogólnikowych, że czytelnik dzisiejszy nie wyciągnie $\mathrm{z}$ nich żadnego pożytku. J. Lelewel na wygnaniu w Brukseli napisal w 1850 r. rzecz zatytulowaną Wyrazy prawne, poprzedzającą Slownik 87 wyrazów prawa magdeburskiego $o^{8}$. Upstrzona dziwactwami etymologicznymi nie przedstawia i ta rozprawka żadnej wartości.

R. Hube zwrócił uwagę na studia Jagića, który badał pomniki prawne tylko ze stanowiska językowego. Podkreślil przy tym polski historyk wartość takich studiów dla wywodów historycznoprawnych'. Z wagi problemu słownictwa prawnego zdawal sobie też sprawę doskonale O. Balzer. Domagal się on ulożenia dwóch słowników terminologii prawniczej - współczesnego i historycznego ${ }^{10}$. Dobitnie też podkreślił $w$ tej mierze swe stanowisko L. Finkel. W „spisie głównych przedmiotów" swej epokowej Bibliografii podal on hasło „terminologia prawa" ${ }^{11}$. Ze wspomnianej Bibliografii widać

${ }^{6}$ W. A. Maciejowskiego gromił już W. Dutkiewicx, Uwagi nad dzielem „Prawo polskie prywatne" przez Piotra Burzyńskiego, Warszawa 1873, s. 82; niezwykle zaś surowo ocenil O. Balzer, por. CPH, t. XII, z. 1, 1960, s. 287, przyp. 1. Co prawda ostatnio W. Sobociński nazywa go autorem dzieła na miarę nauki światowej (Prace nad historycznym slownikiem czeskiej terminologii prawnej (HiSP) a polska leksykografia prawna, CPH, t. XI, z. 1, s. 159); przychylilibyśmy się wszakże do opinii dawniejszych.

${ }^{7}$ W. A. Maciejowski, Historia prawodawstw slowiańskich, t. 1, Warszawa-Lipsk 1832, s. 216-9.

${ }^{8}$ J. Lelewel, Polska wieków średnich, t. IV, Poznań 1851, s. 199-231.

${ }^{9}$ R. Hube, Poglad na nowsze prace okolo wyjánienia historii praw Slowian poludniowych, Biblioteka Warszawska 1872 , t. IV, s. 188.

${ }^{10}$ O. Balzer, $W$ sprawie slownika wyrazów prawa polskiego, Studia nad Prawem Polskim, Poznań 1889, s. 1-15; tenże, O slowniku wyrazów prawa polskiego, Przegląd Literacki, dod. do tyg. Kraj, Petersburg 1887/8, t. VII, nr 52; tenże, O potrzebie slownika wyrazów prawa polskiego $i$ ich metodzie, Przegląd Sądowy i Administr., R. 12, Lwów 1887, s. 632-3. Balzer wystapił ze swoim projektem na pierwszym zjeździe prawników i ekonomistów polskich w Krakowie; na tenże zjazd zgłosił też referat $\mathbf{K}$. Dunin, $W$ kwestii slownika prawnego polskiego, Przegląd Sądowy i Administr., R. 12, s. 743-4. Referat Balzera spotkał się z entuzjastycznym przyjęciem (Dunin nie był obecny na zjeździe). Sprawę słownika powierzono Komisji Prawniczej PAU, A. Suligowski, Pierwszy zjazd prawników i ekonomistów polskich $i$ jego znaczenie, odb. z Ateneum, Warszawa 1887, s. 4-5.

${ }^{11}$ L. Finkel, Bibliografía historii polskiej, cz. 1, Lwów 1891, s. LV. 
wszakże dobitnie, że studiów $w$ tej dziedzinie brak było naonczas zupełnie. W miejscu, do którego Finkel odesłal, figuruje jedna tylko pozycja, a mianowicie wspomniany wyżej artykuł programowy O. Balzera ${ }^{12}$. Nie jest to tymczasem studium języka prawnego. W okresie międzywojennym zajmowal się problematyką prawnojęzykowa E. Bautro ${ }^{13}$.

Niedawne stosunkowo dzieło B. Wróblewskiego opisuje język prawniczy w ogólności, a nie polski język prawniczy ${ }^{14}$. Znamienny przy tym jest dla autora tego fakt, że ilustruje swoje wywody dłuższymi cytatami obcojęzycznymi ${ }^{15} . \mathrm{Z}$ ostatniej doby możemy powolać wartościowe artykuły J. Wróblewskiego i F. Studnickiego ${ }^{16}$.

$\mathrm{W}$ sumie zatem polski dorobek naukowy $\mathrm{w}$ tej dziedzinie okazuje się skromny ${ }^{17}$.

Względy praktyczne doprowadzily do powstania specjalnego rodzaju literatury, którą nazwać można poprawnościową. Wskazuje ona, jakiego stylu, jakich terminów powinni prawnicy używać, jakich zaś określeń unikać. W wielkiej pracy o stylach $w$ języku polskim krótki ustęp poświęcił językowi urzędowemu K. Brodziński ${ }^{18}$. Masę artykułów poprawnościowych pomieścil „Poradnik Językowy” od chwili swego założenia ${ }^{19}$, aż po ostatnie lata ${ }^{20}$. Większą pracę $\mathrm{z}$ tego zakresu stanowi J. Morelowskiego studium $O$ stylu urzędowym ${ }^{21}$. Wzmiankujemy wreszcie cenny artykuł poznańskiego uczonego $Z$. Lisowskiego ${ }^{21 a}$.

12 Obok niego figurują tam Pisańskiego De lingua Polonica iurisconsulto Prussico utilissima, 1763, (Rozprawka uzasadnia tezę podaną $w$ tytule. Znamy ją z thumaczenia pomieszczonego w wypisach: Ludzie Oświecenia w jezzyku $i$ stylu, t. 2, 1958, s. 547-53), oraz H. Rzewuskiego, O dawnych i teraźniejszych prawach polskich slów kilka przez Autora Listopada, Kraków 1855; rzecz ta wszakże nie zajmuje się językiem prawniczym, jest ona co najwyżej $z$ naszego punktu widzenia nieużyteczną gawędą.

13 E. Bautro, Idea lingwistyki i semantyki prawniczej, Lwów 1935.

14 Por. na ten temat uwagi W. Sobocińskiego, o. c., s. 174, przyp. 24.

15 B. Wróblewski, Język prawny..., s. 183-184.

16 J. Wróblewski, Wykladnia prawa a terminologia prawna, PiP, 1956, cz. 1, s. 843-65; tenże, Jezyk prawny a teoria dogmatyki prawa, PiP, t. XIII, z. 1, 1958, s. 57-68; F. Studnicki, O dogmatyce prawa, $\mathrm{PiP}, \mathrm{t}$. XII, cZ. 2, 1957, s. 114-25.

17 Stwierdza to J. Wróblewski, Jezyk prawny a teoria, s. 57.

18 K. Brodziński, Pisma, t. V, wyd. J. I. Kraszewski, Poznań 1873, s. 208-12.

19 Jak powstal tzw. jezzyk ,galicyjski", Poradnik Językowy, t. I, nr 3, Kraków 1901, s. 33-7; J. Morelowski, O stylu urzędowym, Por. Język, t. III, 1903, s. 107-10; S. Kecker, o jezyku w korenspondencji handlowej, Por. Język, t. III, 1903, s. 139-42; C. Świerczewski, $O$ jezyk polski w korenspondencji handlowej, Por. Język, t. V, 1905, s. 54-7; R. Zawiliński, Urzędowe psucie jezzyka, Por. Język, R. 21, 1925, s. 121-2.

20 J. Liberman, O poprawny jezyk aktów prawnych, Por. Język, 1955, s. 32-4.

${ }^{21}$ J. Morelowski, O stylu urzedowym i terminologii prawniczej, Czasop. Prawne i Ekonom., t. IV, Kraków 1903, s. 461-93.

${ }^{21 a}$ Z. Lisowski, Kilka uwag o jezyku polskich ustaw cywilnych, Przegląd Notarialny, t. II, 1948 , s. $192-206$. 
Zapotrzebowaniu spolecznemu na wiedzę prawniczą, łatwo dostępną dla niewykształconego ogółu, shużyły w Rzeczypospolitej przedrozbiorowej układy alfabetyczne. Okazały się one nieodzowne i później. Prędko też zorientowano się $w$ ich znaczeniu dla nauki. Te dwa bodźce, praktyczny i naukowy, uwidaczniają się równocześnie, a nierównomiernie przy wszystkich pracach słownikowych XIX i XX w. Słowniki stanowiły wdzięczne pole dla wysiłku jednostek, przekraczały jednak ich możliwości, gdy stawiały sobie za cel osiągnięcie szersze. Dla tego celu tworzono zatem ciała kolegialne.

Jednym z pierwszych byl komitet wiedeński, który już w 1849 r. zajął się ułożeniem terminologii prawnej dla wszystkich słowiańskich narodowości Austr̃ii ${ }^{22}$.

W latach sześćdziesiątych ubiegłego stulecia zawiązał się w Towarzystwie Naukowym Krakowskim komitet terminologii prawnej. Nie doprowadzil on jednak do powstania słownika. Tymczasem język polski stal się zrazu częściowo obowiązujący w sądach i urzędach; niebawem od 5 VI 1869 r., nabrał charakteru urzędowego w całej Galicji ${ }^{23}$. Stąd zrozumiałe powodzenie prac słownikowych prywatnych. W 1861 r. ukazała się Terminologia J. Mosera i J. Wyrobisza; w 1862 r. szczególnie przydatny Niemiecko-polski slownik wyrazów prawa i administracji Majera; z 1870 r. datuje się S. Madejskiego Niemiecko-polski slownik prawny cywilny ${ }^{24}$.

Również we Lwowie działała osobna komisja terminologiczna, w której skład wchodzili m. in. Malecki, Kalina, Bobrzyński, Balzer ${ }^{25}$. W Krakowie kwestię terminologii prawnej porusza w 1887 r. prof. Kasparek w Towarzystwie Prawniczym ${ }^{26}$. Te wszystkie zamierzenia nie zostały uwieńczone rezultatem. Sprawa słownika prawnego, który by uwzględnił terminologię najnowszych czasów, jest stale aktualna - pisze w 1903 r. J. Morelowski ${ }^{27}$.

Dużo uwag pojawia się $\mathrm{z}$ okazji thumaczeń oryginalnych ustaw austriackich na język polski ${ }^{28}$, obfitują w nie także recenzje ${ }^{29}$.

Wyżej wspomnieliśmy o programie prac słownikowych, stawionym przez O. Balzera. Ponieważ apelu nie zrealizowano, wystąpi $z$ nim ponownie

${ }^{22}$ W. Sobociński, o. c., s. 167.

${ }^{23}$ J. Morelowski, $O$ stylu urzędowym..., s. 474-5.

${ }^{24}$ J. Moser - J. Wyrobisx, Terminologia prawno-polityczna w jezyku niemieckim i polskim wypracowana do podręcznego użytku, Kraków 1861; drugie wydanie słownika Majera ukazało się w 1874 r. w redakcji Bojarskiego; planowano wydanie trzecie.

${ }^{25}$ J. Morelowski, $O$ stylu urzędowym..., s. 476, 478 przyp. 2, 491 przyp. 1. O pracach tej komisji informuje periodycznie Przegląd Prawa i Administracji.

${ }^{26}$ J. Morelowski, O stylu urzędowym..., s. 478.

${ }^{27}$ Ibidem, s. 491.

${ }^{28}$ K. K., Rozbiór dwóch przekladów nowej procedury karnej, Kraków 1874; Sitowski, W sprawie ujednostajnienia terminologii polskiej, Przegląd Prawa i Administracji, R. 22, Lwów 1897 , s. $647-57$.

${ }^{29}$ Przegląd Prawa i Administracji, R. 21, 1896, s. 159-61; R. 22, 1897, s. 421-4, 580-4; R. 30,1905 , s. $503-6$. 
K. Kadlec ${ }^{30}$. Z okresu międzywojennego zanotujmy publikację częściowych materiałów, zebranych przez Sterzyńskiego, Ślaskiego i Riabinina ${ }^{31}$.

W sumie zatem nie doprowadzono do stworzenia dzieła w rodzaju Deutsches Rechtswörterbuch ${ }^{32}$, tak że historyk prawa zmuszony jest uciekać się do ogólnych słowników językowych starszych oraz tych, które niedawno zaczęły się ukazywać ${ }^{33}$.

Zaznaczmy jeszcze, że dla badań historycznoprawnych ushuge analogiczną do słowników oddaja indeksy załączone do dzieł historycznoprawnych; od Maciejowskiego począwszy, poprzez Kucharskiego, Burzyńskiego, Dąbkowskiego, skończywszy na wielkiej syntezie Polskiej Akademii Nauk ${ }^{34}$. Na szczególną zaś uwage zasługują indeksy do żródeł prawnych. Wymienianie ich zajęłoby zbyt dużo miejsca. Ograniczymy się przeto do przypomnienia epokowego indeksu dokonanego przez O. Balzera do Corpus Iuris Polonici oraz do zestawienia dolączonego do niedawnego wydawnictwa polskich rot sadowych Kuraszkiewicza-Wolffa ${ }^{35}$.

$\mathrm{Na}$ zakończenie tych uwag wzmiankujemy publikację W. Sobocińskiego. Choć poświęcona pracom leksykograficznym czeskim, zawiera wiele interesujących materiałów dla polskiej twórczości słownikowej ${ }^{36}$.

${ }^{30}$ K. Kadlec, O potrebé historyckých glosárú slovanských, [w:] Ksiega Pam. ku czci O. Balzera, t. II, Lwów 1925, s. 1-11.

${ }^{31}$ T. Sterzyński, $Z$ dziejów jezzyka wojskowego. Slownictwo administracyjne wojska Królestwa Polskiego 1815-1830 r., Warszawa 1922; B. Slaski, Materialy do polskiego slownika prawniczego, Kępno 1931; J. Riabinin, Materialy do lubelskiego slownika aktowego, Lublin 1934.

${ }^{32}$ Stwierdza to ostatnio W. Sobociński, $O$ historii sqdownictwa $w$ Polsce magnackiej $X V I I I$ w., CPH, t. XIII, z. 1, s. 157.

${ }^{33}$ Slownik staropolski, t. I, Warszawa 1953-1955; Slownik laciny średniowiecznej w Polsce, Wrocław-Kraków-Warszawa, red. M. Pezia, L. I, 1953-1958; Materiały do stownika polszczyzny XVI w., znajdujące się w Seminarium Języka Polskiego w Poznaniu - czerpaliśmy z nich pełna ręką dzięki uprzejmości jego kierownika, prof. W. Kuraszkiewicza.

${ }^{34}$ W. A. Maciejowski, Historia prawadawstw; A. Kucharski, Najdawniejsze pomniki prawodawstwa slowiańskiego, Warszawa 1838; P. Burzyński, Prawo polskie prywatne, Kraków 1867-1871; P. Dąbkowski, Prawo prywatne polskie, t. I-II, Lwów 1910-1911. Wzmiankujemy też ○ układzie alfabetycznym, w jakim ułożył swą cytowaną wyżej (przyp. 6) recenzję W. Dutkiewicz (Uwagi..., s. 3, 12-24), oraz P. Dąbkowskiego, Ksiega alfabetyczna dawnego prawa prywatnego polskiego (Lwów 1932), która jest przetransponowaniem jego Zarysu na układ alfabetyczny; pracą tą nawiązał P. Dąbkowski do tradycji analogicznych robót przedrozbiorowych. Instytucje prawne czasów najdawniejszych uwzględnia ostalnio Slownik starożytności slowiańskich, t. I, Wrocław-Warszawa-Kraków 1961-1962; Historia państwa i prawa Polski do r. 1795, t. I-II (J. Bardach, Z. Kaczmarczyk, B. Leśnodorski).

${ }^{35}$ Corpus Iuris Polonici, t. III, ed. O. Balzer, Kraków 1906; W. Kuraszkiewicz, A. Wolff, Zapiski $i$ roty polskie XV $i$ XVI wieku z ksiag sqdowych ziemi warszawskiej, Kraków 1950; takiegoż indeksu należy oczekiwać w wydawnictwie Kowalewicz-Kuraszkiewicz, Wielkopolskie roty sqdowe XIV-XV wieku, t. I: Roty poznańskie, Poznań-Wrocław 1959, t. II: Roty pyzdrskie, 1960, po ukazaniu się tomu trzeciego.

${ }^{36}$ W. Sobociński, Prace nad historycznym slownikiem czeskiej terminologii prawnej; od czasu tej publikacji pojawiły się nowe studia, np. E. Michálek, $K$ slovni zásobĕ a právni terminologii kních devaterých, Prävněhistorické studie, t. VII, Praha 1961, s. 303-14. 


\section{Rękojmia kodeksu zobowiązań}

Nie wnikając głębiej w istotę rękojmi k. z. ${ }^{1}$, ograniczymy się do stwierdzenia, że treścią jej jest odpowiedzialność sprzedawcy za wady prawne i fizyczne zbytego przedmiotu².

Terminologia występująca w k. z. nie jest jednolita. Ustawa używa paru określeń na oznaczenie tej instytucji. Wyrażenia ,rękojmia za wady prawne i fizyczne" lub „rękojmia za wady prawne” i „rękojmia za wady fizyczne” występują $z$ reguly $w$ nagłówkach rozdziałów i oddziałów k. z. (tyt. 6, rozdz. 4). W poszczególnych artykułach dodatek ,za wady prawne” jest nieczęsty (art. 316, 319, 488). Jest to oczywiste, gdy ustawa wymienia konkretną wadę, za którą sprzedawca nie ponosi rękojmi: „sprzedawca nieruchomości nie jest obowiązany do rękojmi za publiczno-prawne ciężary i ograniczenia" (art. 311). Ale i w innych wypadkach zazwyczaj spotykamy wyrażenia zwięźlejsze: obowiq̨zek rękojmi (art. 307, 318), lub po prostu rękojmia (art. 207, $306 \S 1-2,313,319 \S 1-2$ ).

Określenia najkrótsze, złożone $\mathrm{z}$ jednego tylko terminu rękojmia, pojawiają się tam, gdzie w zdaniu jako orzecznik występuje imiesłów o b o w i ą z a n y: „sprzedawca obowiązany jest do rękojmi” (art. 306 \& 1-2), ,d dhużnik [...] obowiązany jest do rękojmi” (art. 207), „sprzedawca nieruchomości nie jest obowiązany do rękojmi” (art. 311). Użycie iniesłowu „obowiązany” wyklucza - rzecz oczywista - zastosowanie w tym samym zdaniu substantivum „obowiązek” (rękojmi). Widać to najwyraźniej z zestawienia art. 306, który mówi o zobowiązaniu do rękojmi z idącym po nim art. 307, według którego „sprzedawca jest zwolniony od obowiązku rękojmi”. Czasem wszakże i bez wspomnianego orzecznika ,obowiązany" występuje skrótowe wyrażenie: „sprzedawca zwolniony będzie od rękojmi”" (art. 314), „stosuje się przepisy o rękojmi przy sprzedaży" (art. 488, 624).

Zatem określeń rzeczownikowych omawianej instytucji prawnej znamy w k. z. trzy: rękojmia za wady prawne, fizyczne, obowiązek rękojmi i rękojmia. Niewątpliwie sens ich jest identyczny. Niepotrzebnie więc wprowadziła ustawa rzeczownik obowiązek (rękojmi), gdy nadanie np. art. 307 brzmienia zwartszego: ,sprzedawca jest zwolniony od rękojmi” (podobnie $\mathrm{z}$ art. 314) nie zmieni w niczym jego treści.

${ }^{1}$ Robia to ze znawstwem S. Domański, Instytucje kodeksu zobowiqzań, Część szczególowa, Warszawa 1938-1939, s. 38-93, 155-8, i R. Longchamps de Bérier, Zobowiqzania, wyd. 3, Poznań 1948, s. 26, 154, 333, 452-6, 466-7, 489, 491-2, 506.

${ }^{2}$ Rękojmia znajduje zastosowanie także przy innych kontraktach, tzw. kaufähnliche Geschäfte: umowa o dzieło, art. 488; zamiana, art. 353; darowizna, art. 361; najem, art. 373; ugoda, art. 624. I te artykuly zostały wzięte pod uwagę w naszej analizie, choć w toku dalszych wywodów, dla uproszczenia, będziemy mówili tylko o odpowiedzialności sprzedawcy. 
Obowiązek powstający dla sprzedawcy $\mathrm{z}$ rękojmi określa ustawa czasownikiem odpowiadać: „sprzedawca wierzytelności odpowiada za wypłacalność dłużnika” (art. $312 \S 1$ ); ,przy sprzedaży papierów wartościowych sprzedawca od powiada" (art. 312 § 2); ,sprzedawca nieruchomości [...] odpowiada za obszar" (art. 320); "sprzedawca nie odpowiada" (art. 322); „sprzedawca od p ow i a d a tylko za wady glówne” (art. $333 \S 1$, art. 361). Jest rzeczą zastanawiającą, dlaczego ustawa nie posłużyła się formami językowymi - czasownikową i rzeczownikową, utworzonymi od jednego rdzenia, a więc dlaczego nie stworzyła naturalnej, wydawałoby się, pary: rękojmia - ręczy, lub też: odpowiada - odpowiedzialność. A może nie obcy jej termin odpowiedzialność w tym właśnie znaczeniu?

Przejrzyjmy jeszcze raz k. z. pod tym kątem widzenia. Słowa odpowiedzialność używa ustawa w paru znaczeniach ${ }^{3}$. Nie będziemy ich bliżej analizować, a skierujemy swą uwage na artykuł $312 \S 1$ : ,sprzedawca wierzytelności odpowiada za wypłacalność dhużnika w chwili przelewu tylko o tyle, o ile taką odpowiedzialność na siebie przyjąl". Już na pierwszy rzut oka skłonni bylibyśmy przyjąć, że w tym paragrafie odpowiedzialność postawiono zamiast rękojmi. Wszakże interpretator wychodzić musi $w$ pierwszej linii $z$ założenia, że ustawa, stosując inny termin aniżeli w pozostałych wypadkach, robi to celowo, że świadomie go wprowadza, by zaznaczyć pewną dystynkcję. Za taką moźliwością jednak nielatwo się wypowiedzieć, gdy zważymy:

1. Rozpatrywany artykuł znajduje się $w$ rozdziale IV, zatytułowanym Rękojmia za wady prawne i fizyczne, w oddziale 2, o nagłówku: Rękojmia za wady prawne. Ustawodawca niewypłacalność dhuznika traktuje jako wadę prawną, której wykluczenie w osobnym artykule wydawało mu się konieczne, podobnie jak w artykule poprzednim (art. 311) wykluczenie odpowiedzialności sprzedawcy ,za publiczno-prawne ciężary i ograniczenia, którym nieruchomość podlega". Zarówno w pierwszym, jak i drugim artykule zajmuje się ustawa takimi wadami, za które nie można sprzedawcy pociągać do odpowiedzialności.

2. Przeciwko takiej wykładni prowadzi też interpretacja filologiczna. Wiemy już, że odpowiednikiem czasownikowym rękojmi jest odpowiadać. Verbum to $w$ analizowanym artykule również występuje. Przyjąć, że odpowiedzialność znaczy tu co innego niż odpowiadać tegoż samego artykułu, równałoby się posądzeniu ustawodawcy o skrajne niedbalstwo terminologiczne.

3. Wreszcie - i ta obserwacja musi mieć znaczenie decydujące - że chodzi tu istotnie o rękojmię $w$ rozumieniu $k$. z., naprowadza nas na to $\S 2$ omawianego art. 312, który jest uzupełnieniem $\S 1$. Zajmuje się on również sprzedażą wierzytelności, $\mathrm{z}$ tą różnicą, że dotyczy wierzytelności

\footnotetext{
${ }^{3}$ Prof. W. Ludwiczak naliczył ich cztery.
} 
ujętych w formę papierów wartościowych. Gdy te dwa paragrafy zestawimy z sobą ( $\$ 1:$ „Sprzedawca wierzytelności odpowiada za wypłacalność dłużnika tylko o tyle...”, i § 2: „Przy sprzedaży papierów wartościowych sprzedawca odpowiada $\mathrm{z}$ tytułu rękojmi...), jest rzeczą zupełnie pewną, że oba wypadki odpowiadania sq̨ identyczne, że więc i substantiwa, odpowiedzialność z $§ 1$ i rękojmia $z \$ 2$ pokrywają się $w$ zupełności. Tak też ujmuje rzecz

\section{R. Longchamps de Bérier ${ }^{4}$.}

Dlaczego w takim razie ustawodawca wprowadzil dalsze określenie na instytucję zwaną przez siebie $\mathrm{z}$ reguły rękojmią? Wyjaśnienie nasuwa się tylko jedno: ze względów estetycznych. Nie chcial widocznie w dwu po sobie następujących zdaniach jednego artykułu użyć dwukrotnie słowa rękojmia, zastąpił je więc w $\S 1$ terminem, który sam się narzucał jako pendant czasownika odpowiadać; jest nim substantivum odpowiedzialność. Ale w takiej sytuacji, gdy ustawa wprowadza dwa terminy na jedno pojęcie, $\mathrm{z}$ punktu widzenia precyzji prawniczej ${ }^{5}$ trudno poczytać takie rozwiązanie za najlepsze. Przyznajemy zresztą, że zastąpienie rękojmi przez odpowiedzialność jest wyjątkowe. W rezultacie jest to wszakże określenie czwarte. Zachęceni tym wynikiem kontynuujmy analizę terminologiczną k. z. w interesującym nas szczególe.

W art. 308 położyła ustawa rzeczownik odpowiedzialność obok rękojmi: „Strony mogą przez umowę odpowiedzialność z tytułu rękojmi rozszerzyć, ograniczyć lub wyłączyć. Jednakże wylączenie lub ograniczenie odpowiedzialności z tytułu rękojmi jest nieważne...". Jeśli dla ustawodawcy rękojmia = odpowiedzialność za wady prawne i fizyczne, to zwrot powyższy należy poczytać za określenie tautologiczne, znaczy to bowiem tyle, co powiedzenie: odpowiedzialność z tytułu odpowiedzialności za wady prawne i fizyczne. Nie ratuje go bynajmniej połączenie tych dwóch rzeczowników trzecim: „z tytułu”. A już w art. 559 kumulowanie substantiwów doszło do szczytu. Mówiąc o wkładzie wspólnika do spółki innych rzeczy niż pieniądze, postanawia ustawa, że stosuje się odpowiednio przepisy już to o sprzedaży, już to o najmie, m. in. „do jego obowiązku [...] odpowiedzialności $\mathrm{z}$ tytułu rękojmi"'. A zatem i obowiązek, i odpowiedzialność, i tytuł, i rękojmia.

Nie trzeba być purystą językowym, żeby się na podobne wyrażenie nie zgodzić. Tym bardziej że do cytowanego konglomeratu należy jeszcze dodać domyślne „za wady prawne i fizyczne”. Reguła Godąba: „ani jednego

4. Longchamps de Bérier, o. c., s. 465-6.

${ }^{5}$ O jej konieczności K. Brodziński przy okazji omawiania języka urzędowego, Pisma, t. V, s. 208. O wymogach stylu ustawowego por. też S. Goląb, Przed projektem polskiego kodeksu cywilnego, Czasopismo Prawne i Ekonom., t. XVIII, nr 1, Kraków 1920, s. 16.

'Tekst bez wypuszczenia wygląda tak: „Do jego obowiązku świadczenia, odpowiedzialności z tytułu rękojmi i ponoszenia niebezpieczeństwa stosuje się...". Nasze uwagi nawiązują do wypowiedzi Z. Lisowskiego, Kilka uwag..., s. 194. 
niepotrzebnego słowa"7 $\mathrm{z}$ pewnością nie znalazła tu posłuchu. Zamiast by jedna nazwa techniczna (rękojmia) zaoszczędzila nam wielu słów, jak tego życzył sobie Ihering ${ }^{8}$, w k. z. wiele słów określa jedną instytucję.

A czyż o jotę zmienilby się sens powołanego art. 308 , gdyby mu nadać brzmienie następujące: „Strony moga przez umowę rękojmię rozszerzyć, ograniczyć lub wylączyć. Jednakże wyłączenie lub ograniczenie rękojmi jest nieważne...”. Albo gdyby art. 559 ujęto następująco: „Do jego obowiązku świadczenia, rękojmi i ponoszenia niebezpieczeństwa stosuje się...”.

Wyżej stwierdziliśmy, że w k. z. wbrew, jak się wydaje, zamierzeniu autora, wkradła się do tekstu para: odpowiada - odpowiedzialność. Ale dlaczego nie ma pary drugiej, rękojmia - ręczy? Skoro ustawa nie waha się używać substantivum rękojmia, dlaczego $\mathrm{z}$ równą racją nie wprowadza odpowiednika czasownikowego: sprzedawca r ęc zy za wady fizyczne i prawne. Tego nie ośmielila się zrobić; nie pozwoliło widocznie na to poczucie językowe. Compositum tego słowa: poręczyć, znalazło zastosowanie dla instytucji, której lacińskim odpowiednikiem jest fideiussio (tyt. 17, art. 625 i n.).

Zbierzmy osiągnięte wyniki: termin rękojmia posiada $w \mathrm{k}$. $\mathrm{z}$. jedno znaczenie: występuje on bądź samoistnie, bądź z uzupełniającym go rzeczownikiem obowiązek (rękojmi), bądź z bliżej precyzującym go dodatkiem (rękojmia) za wady prawne i fizyczne; synoninem jego jest $w$ jednym wypadku odpowiedzialność, ustawa używa czasem zwrotu odpowiedzialność $\mathrm{z}$ tytulu rękojmi, raz to trio substantywowe zamieniło się $\mathrm{w}$ kwartet: obowiązek odpowiedzialności z tytułu rękojmi; odpowiednikiem werbalnym rękojmi jest odpowiadać, nigdy ręczyć; określnik poręczenie oznacza instytucję, która $\mathrm{z}$ rękojmią k. z. nie ma nic wspólnego!

Omówiona terminologia $\mathrm{k}$. z. występuje $w$ ustawach, które odsylaja do rękojmi k. z. (np. dekret o prawie spadkowym z 8 X 1946 r., Dz. U. nr 60, poz. 328 , art. 68 ); przede wszystkim zaś stosuje się ją w literaturze komentującej k. z. aż do ostatnich dni'.

Przeprowadzona analiza wykazała, że wprowadzenie osobnego terminu rękojmia na oznaczenie odpowiedzialności za wady prawne i fizyczne nie dało pożądanego rezultatu:

1) słowo to $w$ języku polskim jest $w$ tym znaczeniu widocznie na tyle niejasne, że potrzebuje uzupelnień: za wady prawne, za wady fizyczne;

2) na tyle niezręczne, że na to samo pojęcie ustawa wprowadza dwa określenia: substantywne i werbalne, $\mathrm{z}$ różnych rdzeni: rękojmia - odpowiadać;

3) na tyle niecharakterystyczne, że nie wyklucza używanego powszechnie i zasadnie innego rzeczownika: odpowiedzialność, przed którym sam ustawodawca się nie uchronil;

${ }^{7}$ S. Goląb, l. c.

${ }^{8}$ Por. B. Wróblewski, Jezzyk prawny i prawniczy..., s. 88.

9 „Prawo do rękojmi za istnienie przelanej wierzytelności", J. Fabian, Przelew bankowy między jednostkami gospodarki uspolecznionej, RPES 1961, z. 2, s. 62. 
4) na tyle niewystarczające, że praktyka, jak zresztą i autor k. z., niejednokrotnie używają konglomeratu słów: obowiązek rękojmi, odpowiedzialność z tytułu rękojmi, który trudno uznać za udany.

Dlaczegoż ustawodawca raz wprowadziwszy określnik rękojmia na oznaczenie odpowiedzialności za wady prawne i fizyczne, nie zadowala się nim, ale $\mathrm{z}$ reguly dodaje objaśniające go bliżej substantiva? Racja wydaje się prosta: rękojmia w języku potocznym posiada widocznie znaczenie tak różne od przyjettego w k. z., że zachodziła uzasadniona obawa nieporozumienia między autorem ustawy a jej czytelnikem. Sam fakt użycia dwóch złożeń, tak bliskich, bo utworzonych $\mathrm{z}$ jednego tematu: rękojmia, poreczenie, $w$ różnych znaczeniach stanowi już wystarczające ostrzeżenie. Być może też, że w innych, współcześnie obowiązujących ustawach substantivum rękojmia występuje $w$ innym znaczeniu, czy $w$ innych znaczeniach; licząc się z nimi, ustawodawca bronil siebie i czytelnika przed niewlaściwymi skojarzeniami, i dlatego, by uniknąć omyłki, podkreślił, choć to dla czytelnika k. z. nie może ulegać wątpliwości, że chodzi mu o ten właśnie, a nie inny sens rękojmi - odpowiedzialności za wady prawne i fizyczne.

Zanim poznamy pełną ewolucję semantyczną rękojmi, stwierdźmy, że ten określnik k. z. nie stanowi novum w polskim języku prawniczym okresu miedzywojennego. Z 1916 r. datuje się praca Romana Longchamps de Bérier, zatytułowana Rekojmia $z$ powodu wad i braków a obowiqzek świadczenia. Studium $z$ austriackiego prawa cywilnego ${ }^{10}$. W przypisku do pierwszego zdania tej monografii autor zaznacza, że $w$ dalszym ciągu pracy używać będzie wyrazu rękojmia bez dodatku na oznaczenie rękojmi z powodu wad i braków ${ }^{11}$.

Konstatujemy zatem tożsamość terminologii k. z. i Romana Longchamps ${ }^{12}$. Ta zbieżność nie zadziwi nas, skoro ten uczony, obok Ernesta Tilla, był głównym referentem i wspóltwórcą kodeksu zobowiązań ${ }^{13}$. Zauważmy, że $i$ trzej dalsi czlonkowie komitetu pięciu (Allerrhand, Doliński, Stefko) ${ }^{14}$ działali we Lwowie. Zaznaczmy wszakże, że takiego samego terminu używał również $\mathrm{i}$ kontrprojekt ${ }^{15}$, którego autor pochodzil $\mathrm{z}$ b. zaboru rosyjskiego. Czyżby rękojmia w tym sensie stanowiła określenie ogólnopolskie, właściwe językowi wszystkich dzielnic polskich? Czyżby dlatego nie wywoływała $\mathrm{z}$ niczyjej strony protestu, choć $w$ komisji kodyfikacyjnej znaleźli się reprezentanci z paru zaborów? ${ }^{16}$

${ }^{10}$ Archiwum Naukowe, dział I, t. VIII, z. 1, Lwów 1916.

11 Ibidem, s. 1, przyp. 1.

${ }^{12} \mathrm{Z}$ tą różnicą, że braki (Sachmangel) zastąpiono wadami fizycznymi.

${ }^{13}$ L. Domański, System kodeksu zobowiqzań, Warszawa 1934, s. 8-9; J. Górski, Wstẹp do Zobowiqzań $R$. Longchampsa de Bérier, wyd. 3, s. V.

${ }^{14}$ E. Till, Polskie prawo zobowiqzań. Projekt wstępny z motywami, Lwów 1923, s. 1.

${ }^{15}$ L. Domański, Lwów 1923, s. 1.

${ }^{16}$ Skład komisji kodyfikacyjnej podaje jej publikacja: Komisja Kodyfikacyjna, t. I, z. 1, s. $8-10$; z. 2. 


\section{Rękojmia w terminologii staropolskiej}

W prawnej polszczyźnie przedrozbiorowej terminy utworzone od słowa ręka występują dość często; podobnie zresztą jak w innych językach. Pozostaje to $\mathrm{w}$ zwiazku $\mathrm{z}$ rolą, jaka przypadła temu organowi człowieka w dawnej symbolice prawnej. Stąd to zarówno rzymska manus, jak i germańska hand tylekroć pojawiają się w rozmaitych kontekstach prawniczych ${ }^{1}$. W tych warunkach zrozumiałe kalki jezzykowe obrazowych wypowiedzi: manus fidelis $=$ wierna ręka ${ }^{2}$, manus mortua $=$ zmarła ręka, manus potens $=$ mocna ręka ${ }^{3}$, jak $\mathrm{i}$ różne desygnaty analogicznych tworów językowych, np. rzym. mancipium, pol. rękojmia, czy wreszcie i specyficzne wyrażenia, właściwe tylko jednemu językowi ${ }^{4}$.

W polszczyźnie mamy następujące wyrazy omawianego rodzaju: rękojmia, rękojemstwo ${ }^{5}$, rękobraniny ${ }^{6}$, wierna ręka, poręka, zaręczyny, zrękowiny, (po)rękawiczne i odpowiednie formacje werbalne: ręczyć, poręczyć, zaręczyć, obręczyć, wyręczyć, czy pochodne od nich substantiva dewerbatywne: ręczenie, zaręczenie, poręczenie. Nie zapominajmy też, że w języku polskim występują określenia, w których temat ręka nie pojawia się, z którym wszakże związana jest myśl udziału ręki w czynności ${ }^{7}$.

Zdaniem A. Brücknera, prastare rękojmia znaczy „,poręka” i ,poręczyciel ${ }^{8}$, a więc zarówno nomen agentis, jak i nomen actionis, albo - by użyć terminologii lacińskiej - i fideiussio, i fideiussor. Tymczasem P. Dąbkowski, który rękojemstwu w dawnym prawie polskim poświęcił osobne studium, termin rękojmia stosuje konsekwentnie jako nomen agentis ${ }^{9}$. Co więcej, nie

${ }^{1}$ Por. Real-Encyklopädie der classischen Altertumswissenschaft, t. XIV, 1930, hasła: manus, manumissio, manus iniectio; J. Grimm, Deutsche Rechtsaltertümer, t. I-II, Leipzig 1899, indeks sub verbo hand i pochodne; K. v. Amira, Grundriss des germanischen Rechts, Strassburg 1913, indeks; C. v. Schwerin, Rechtsarchäologie, t. I, Berlin 1943, s. 36, 65-6; E. v. Künnsberg, Rechtliche Volkskunde, Halle 1936, s. 94.

${ }^{2}$ Ob. P. Dąbkowski, Wierna ręka czyli poklad, SHPP, t. III, z. 2, Lwów 1909, s. 19.

${ }^{3}$ Corpus Iuris Polonici, t. III, indeks.

${ }^{4} \mathrm{~Np}$. Hand wahre Hand.

${ }^{s}$ P. Dąbkowski, Ręojemstwo w prawie polskim średniowiecznym, Lwów 1904; tenże, Prawo prywatne..., t. II, s. 381-99.

6. J. Riabinin, Materialy do lubelskiego slownika aktowego, Lublin 1934, s. 44.

${ }^{7}$ Nająć od jąć, oznacza ujmowanie ręką osoby slugi (J. Bardach, Historia państwa i prawa, t. I, s. 318 , przyp. 97).

${ }^{8}$ SEJP, s. 458.

9 „Tym zabezpieczeniem mogła być os oba, czyli rłkojmia”, Prawo prywatne..., t. II, s. 382; Rẹkojemstwo..., s. 42-3; Zarys..., s. 306-10. 
przytacza innych określeń staropolskich, które byłyby jego synonimami ${ }^{10}$. Odpowiednikiem lacińskim jest fideiussor.

Jako określnika dla nomen actionis używa Dąbkowski stale substantivum rękojemstwo. W terminologii dawnej obok rękojemstwa używano jeszcze określeń: poręka, rękowanie, rękojemskie uprzezpieczenie ${ }^{11}$, zakład ${ }^{12}$, ślub, ślubienie ${ }^{13}$. Lacińskimi odpowiednikami byly: fideiussoria, caucio fideiussoria, caucio fideiussorialis, rzadko fideiussio, fideiussorium, wyjątkowo fideiusseatoria ${ }^{14}$.

O czynności samej mówiono ręczyć, obręczyć, przyręczyć, poręczyć, $\mathrm{w}$ wielkopolskich tekstach: wgwesić ( $\mathrm{z}$ niem. vergewissern), rzec komu ${ }^{15}$, ślubić ${ }^{16}$. Po lacinie: fideiubere, profideiubere, superfideiubere, fideiussorie se obligare, caucionari fideiussoria, fideiussaliter promittere, stare. Sprawić, że ktoś poręczył, określano: wręczyć kogoś ${ }^{17}$, in fideiussoriam caucionem introducere, intromittere, inducere, obligare. Dłużnik wierzycielowi rękojmię daje, dat, assignat, ponit, in caucionem fideiussoriam involvit. Wierzyciel rękojmię bierze, recipit, uzyskuje, acquirit. Dłużnik rękojmię wybawia, ponit, supportat, expedit, liberat, exbrigat de fideiussoria. Wierzyciel rękojmię spuszcza, wypuszcza ${ }^{18}$.

Taka jest terminologia naszych źródeł; polska i lacińska - według badań P. Dąbkowskiego. Czyżby więc wielki językoznawca uległ omyłce? Przejrzyjmy jeszcze raz źródła, ograniczając się zresztą do spornego tylko terminu rękojmia. Najstarszych zapisów tego substantivum dostarcza nam roty przysiąg:

1398 r. - jako Mikołaj wyprawił o odzienie swego rękojmię, ocz gi był wręczy1 ${ }^{19}$;

1399 r. - jako wiemy i świadczymy, eże cokoli rękojmia Imram ręczył za Sułka ${ }^{20}$;

1400 r. - jako moj rękojmia nie mial stawiać wołów $w^{21}$;

1400 r. - swego rękojmię wyprawi122;

${ }^{10} \mathrm{~W}$ thumaczeniu statutu dla Ormian z 1601 r. występuje termin poręcznik, Corpus Iuris Polonici, t. III, s. 533.

"P. Dąbkowski, Rękojemstwo..., s. 42-3. Termin „,poręka” pojawia się już w średniowieczu, choć występuje rzadziej.

12 Ibidem, s. 48 (z powołaniem Lindego).

13 Ibidem, s. 49.

14 Zestawienie Dąbkowskiego uzupełnić możemy wyrażeniem vadium fideiussorium, AKP, t. VIII, s. 92, nr 367, czy vadimonium, B. Erzepki, Przyczynki..., s. 84.

${ }^{15}$ P. Dąbkowski, Rekojemstwo..., s. 42-3.

16 Ibidem, s. 49.

17 Ibidem, s. 46.

18 Ibidem, s. 47.

19 J. v. Lekszycki, Die ältesten grosspolnischen Grodbücher, t. I, Leipzig 1887, nr 2740.

${ }^{20}$ SPPP, t. VIII, nr 9490.

${ }^{21}$ J. v. Lekszycki, $o$. c., t. II, Leipzig 1889 , nr 900.

${ }^{22}$ R. Hube, Zbiór rot przysiqg sqdowych poznańskich, kościaniskich, kaliskich, sieradzkich piotrkowskich $i$ dobrzyńskich z końca XIV i pierwszych lat wieku XV, Warszwa 1888, s. 109. 
1403 r. - jako Szczepan nie wziął z Wojciecha zapłaty, ale z jego rękojmi ${ }^{23}$; 1418 r. - jako przytem byli, mieli być rękojmiami za te pieniądze ${ }^{24}$;

1426 r. - o tę droge, o którą Warsz Jana Konarskiego, rękojmię Rafałowskiego pozwat ${ }^{25}$;

1422 r. - o to ja był rękojmia, iże jej dosyć uczyniła ${ }^{26}$;

1456 r. - jakom ja [...] innego rękojmiego wstawić mia2 ${ }^{27}$;

1461 r. - jam podług zmowy byłem w Sochaczewie przed prawem, a oni nie byli ani iściec, ani rękojmie ${ }^{28}$;

1482 r. - Andrzej Gorczewski, rękojmia za urząd ziemski²;

1490 r. - iże Jakub nie miał nagabać Grzegorza z Sokołowa, rękojmiego księdza.... ${ }^{30}$.

Zestawione teksty, zaczerpnięte $\mathrm{z}$ rot przysiąg, sięgające od końca XIV w. do schyłku w. XV, dają odpowiedź niedwuznaczną: rękojmia = fideiussor. Liczbę przykładów można snadnie powiększyćc ${ }^{31}$. Podkreślmy jeszcze, że teksty pochodzą z Wielkopolski, Małopolski, Sieradzkiego i Mazowsza ${ }^{32}$.

Nie inaczej używają terminu rękojmia tłumaczenia statutów Kazimierzowskich.

Art. 101. O rękojemstwie. Rękojmia twierdząc [...] ku doświadczeniu ma być dopuszczon ${ }^{33}$.

Art. 95. ...aczby o pieniądze, alibo o konie, alibo o którekolwiek rzeczy insze zyskane spolne rękojmie ułożyli, o ich upominaniu i pozywaniu o to pamięć uczynili, mimo wszystko rekojemstwo alibo zastawą.... ${ }^{34}$

Art. 4. ...że gdy niektory o pieniężny albo inszych rzeczy dług rękojmią był, a gdy iściec slowie pierwszy dłużnik niektórą cząstkę swemu pożyczcy

${ }^{23}$ Piek., nr 603. Skróty tytułów zaczerpnięto z wykazu, pomieszczonego w Slowniku staropolskim, t. I, s. XIV-XXXI.

${ }_{24}^{4}$ Ksiegi sqdowe brzesko-kujawskie (1418-1424), Teki A. Pawińskiego, t. VII, wyd. J. K. Kochanowski, Warszawa 1905, nr 284; por. też ihidem, nr 91, 326, 1817.

${ }^{25}$ J. Baudouin de Courtenay, Roty przysiqg $z$ archiwum radomskiego, MPKJ, t. II, Kraków 1903, s. 304.

${ }^{26}$ Prace Filologiczne, t. VIII, s. 17.

${ }^{27}$ W. Kuraszkiewicz-A. Wolff, o. c., nr 1001 .

${ }^{28}$ Ibidem, $\mathrm{nr} 146$.

${ }^{29}$ Ibidem, nr 1531

${ }^{30}$ Ibidem, nr 1644

${ }_{31}$ Dla ulatwienia kontroli podajemy zestawienie miejsc, w których pojawia sį̨ omawiane substantivum: SPPP, t. VIII, nr 7056; Piek. nr 54, 168, 646, 1094, 1409; K. Malkowski, Przeglqd najdawniejszych zabytków języka polskiego, Warszawa 1872, s. 117, 118; AKP, t. VIIl, s. 141 , nr 767, 138, nr 735, 166 nr 1053; MPKJ, t. II, s. 298; Ks. Maz., nr 2389; SKJ, t. III, s. 189 , nr 22 , s. $194, \mathrm{nr} 64$.

${ }^{32}$ Przypomnijmy, że po roku $1446 \mathrm{w}$ księgach poznańskich obserwujemy zupełny zanik rot polskich (Kowalewicz-Kuraszkiewicz, o. c., s. 10).

${ }^{33}$ Stosł. AKP, t. III, s. 245.

${ }^{34}$ Ibidem, s. 277. 
zapłacił procz oczywistości tegoto rękojmi, tegdy w tem uczynku ten isty rekojmia od tegoto rękojemstwa bywał wyzwolon [...] ustawiamy, że jakoli procz oczywistości i procz wiedzenia swego rękojmi ten isty dlużnik swemu pożyczcy za niektórą cząstkę tegoto dlugu dosyć by uczynil, a wżdy ten isty rękojmia ku zapłaceniu ostatku tegoto długu dla swego rekojemstwa jest obowiązan ${ }^{35}$.

Art. 102. Jan pożyczył Piotrowi dziesięć grzywien i wziął po niem za nie rękojmię Wawrzyńca. Potem Piotr Janowi zapłacił pieniądze krom rękojmi, a potem Piotr Warzyńca pozwał o rękojemstwo ${ }^{36}$.

Również z $1437 \mathrm{r}$. pochodzący słowniczek podaje jako równoważnik fideiussor rękojmię ${ }^{37}$. W thumaczeniu z 1528 r. statutu dla Ormian per possessionatos fideiussores oddano: „przez osiadłe rękojmie"38.

Excepta i zwyczaje województwa mazowieckiego roku 1576 pod tytułem o zgwalceniu rękojmiów pomieściły tekst następujący: „Jeśliby kto rękojmie albo posły, które zowią selce, posłane do siebie w rzeczach kmiecych $\mathrm{i}$ innych wedle prawa potrzebnych urzędu ziemskiego [...] dotykając się, to jest ręcząc abo aresztując bydło, konie, stado, abo którekolwiek inne ruchome rzeczy, abo o złożenie dnia ku uczynieniu sprawiedliwości z poddanymi abo z sługami, abo jakie insze rękojemstwo którychkolwiek, jakichkolwiek rzeczy abo praw, przywilejów czyniąc, zgwałcil abo ubił..."39. W wiejskiej księdze sądowej Trześniowa występuje „rękome Matzec"40.

W Groickiego Porzqdku sqdów [...] prawa magdeburskiego spotykamy passus następujący: ,...złoczyńce sędzia na rękojemstwo nie ma dawać, bo gdyby go na rękojmię dawal, srogość prawa nad nim ustaje, gdy rękojmia głową płaci, jeśli złoczyńca zbieży" ${ }^{41}$. Podobne zastosowanie rękojmi w Artykulach prawa magdeburskiego... z $1500 \mathrm{r}^{42}$

Od XVI w. w badaniach nad słownictwem pomocne są słowniki, których szereg rozpoczyna znakomity Mączyński ${ }^{43}$. Vas ,rękojmia, a zwłaszcza

35 Ibidem, s. 327.

${ }^{36}$ Dział I AKP, t. III, s. 206.

${ }^{37}$ Catalogus codicum manuscriptorum Bibliothecae Universitatis Jagellonicae Cracoviensis, wyd. W. Wisłocki, Cracoviae 1877-1881, nr 228, s. 87.

${ }^{38}$ Corpus luris Polonici, t. III, s. 533.

39 Vol. Leg., t. II, f. 946.

${ }^{40}$ H. Polaczkówna, Najstarsza ksiega sq̨dowa wsi Trześniowa 1419-1609, Lwów 1923, nr 932; ob. też ibidem, nr 1371, 1372.

${ }^{41}$ Cytat u Lindego.

${ }^{42}$ Artykuly prawa magdeburskiego z rẹkopisu okolo roku 1500, wyd. A. Kalina, RA Wydz. Filolog., t. VII, 1880, s. 227-318.

${ }^{43}$ I. Mączyński, Lexicon Latino-polonicum ex optimis latinae linguae scriptoribus concinnatum, Regiomonti Borussiae 1564. O autorze słownika por. H. Barycz, Jan Mączyński, leksykograf polski XVI w., Reformacja w Polsce, R. 3, Warszawa 1924, s. 218-55, oraz W. Kuraszkiewicz, Wyrazy polskie w slowniku lacińsko-polskim Jana Mącyńskiego, cz. 1, Wrocław-Warszawa-Kraków 1962, s. 5-31. 
w rzeczy o głowę idącej" (476 a/3); inventor aliquando pro fideiussore „rękojmia, przyrzecznik za kogo" (483 a/43); vadimonium mortis accipere „rękojmię przyjąć za jednego, na śmierć skazanego, że go na pewny czas ma stawić (476 a/29); praedes, satisdatores, locupletes pro re, de qua lis est apud iudicem, ne, qui tenet diffidens, causae possessionem deteriorem faciat, alias sequestratores „rękojmie, którzy do rozprawienia sprawy niektórej zapisują się na swym imieniu za tego, którego się rzecz na sądzie toczy" (318 d/54); satisdo „,ubezpieczam, zapisuję się, rękojmia albo przyrzecznika stawiam" (93 a/22); praes, sponsor „rękojmia, przyrzecznik za kogo" (318 d/44); sponsor "obiecnik, przyrzecznik, rękojmia, ten zwłaszcza, który co komu dobrym słowem obiecuje, zmawia z kim i postanawia" (410 a/24); fideiubeo ,ślubuję, ręczę, przyrzekam, zastępuje kogo, bierzę to na się"; hic fideiussor ,rękojmia zastępca” (126 a/32).

W takim samym znaczeniu używa substantivum rękojmia Ambrosius Calepinus $^{44}$, Baltazar Andrzej Fontana ${ }^{45}$. Grzegorz Cnapius daje takie odpowiedniki lacińskie rękojmi - zaręcznika: vas, praes, interventor pro fideiussore, manceps, adpromissor, sponsor pro aliquo, fideiussor, auctor secundus, expromissor, rękojmia abo zaręczniki komu daję, zaręczam się kim, zaręczniki daję, że kogo w dekrecie sądowym zastąpię; rękojmię abo zaręczniki od kogo biorę, zaręczniki od kogo biorę, że mię w dekrecie sądowym drugi zastąpi $^{46}$. W takimże sensie używa terminu rękojmia Konstanty Szyrwid ${ }^{47}$, M. C. G. Eberlein ${ }^{48}$, M. A. Trotz ${ }^{49}$. Ale w końcu XVIII w. uchodzi już za wyraz dawny, zaniedbany ${ }^{49 a}$.

Obraz zatem otrzymujemy jasny: rękojmia oznacza osobę. Tak zresztą przedstawia się rzecz i w języku czeskim: ruka, rukojmĕ, „bürge” - stwierdza Miklosich $^{50}$; rukojmě, ručitel mask - konstatuje V. Machek ${ }^{51}$.

44 Dictionarium undecim linguarum, Bazylea 1590; dział polski opracował P. Mączyński, H. Oesterreicher, Nieco o dziale polskim w jedenastojęzycznym slowniku Kalepina z r. 1590, Prace polonistyczne ofiar. J. Losiowi, Warszawa 1927, s. 467; tamże niezwykle pozytywna ocena tegoż słownika, s. 473.

45 Dictionarium quatuor linguarum, Gedani 1613, s. 744, 931, 1052-53, oraz w niepaginowanej części polsko-łacińskiej.

46 Thesaurus polono-latino-graecus, Cracoviae 1643; identycznie wydania późniejsze, np. z 1741 r. Knapski powołuje się na następujących prawników: Tucholczyka, Groickiego, Herburta, Sarnickiego, Szczerbica, Januszowskiego, Smigleckiego; J. Puzynina, O metodzie leksykograficznej w ,"Thesaurusie" Knapskiego, Poradnik Językowy 1956, s. 175.

47 Dictionarium trium linguarum, Vilnae 1713.

48 Entwurf eines polnischen Wörter-Buchs, Breslau 1763.

49 Nouveau dictionnaire français, allemand et polonais, wyd. 1, Leipzig 1771.

${ }^{49 a}$ I. Wlodek, Slownik wyrazów dawnych $i$ zaniedbanych, Rzym 1780 (cytuję za: Ludzie Oświecenia o jezyku i stylu, t. 3, 1957).

so Etymologisches Wörterbuch der slavischen Sprachen, Wien 1886, s. 276.

s1 Etymologický slovnik jazyka českého a slovenského, Praha 1957. 
W tym układzie semantycznym następuje w pewnym momencie zakłócenie, któremu zdecydowany wyraz daje S. B. Linde: 1. Rękojmia „obowiązek, obietnica stawienia się za kogo u sądu, vadimonium"; 2 . Rękojmia, -iego m. „zaręcznik, ręczyciel, poręcznik, zabezpieczający daną obietnicę z obowiązkiem dopełnienia jej przez się w przypadku nieuiszczającego się dłużnika"s2. Wcześniejszy przykład takiej konfuzji daje nam M. L. Danet ${ }^{53}$. Staje się ona też prędko powszechna. Dają jej wyraz słowniki M. A. Troca ${ }^{54}$, I. Krasickiego ${ }^{55}$, J. S. Bandtkiego ${ }^{56}$. Następuje ona również w języku prawników: ,rękojmię, czyli fideiussią za drugiego czyniący" - pisze Andrzej Zamojski w 1778 r. ${ }^{57}$; „poręka albo rękojmia jest zabezpieczenie danej przez drugiego obietnicy $\mathrm{z}$ dopełnieniem jej przez siebie w przypadku nieuiszczenia się dłużnika" - wyraża się Józef Januszkiewicz ${ }^{38}$. Porękę z rękojmią mieszał też Ostrowski, później Czacki ${ }^{59}$.

To nowe znaczenie: rękojmia fideiussio wypiera w ciągu XIX w. dawne: rękojmia fideiussor. W tym już sensie używa terminu Maciejowski ${ }^{60}$, a Slownik warszawski substantivum rękojmia jako nomen agentis opatrzył krzyżykiem, podkreślając $w$ ten sposób, że to wyraz staropolski. Ten stan rzeczy poświadczają też późniejsze słowniki ${ }^{61}$. Utrzymuje się on też $w$ poczuciu językowym dzisiejszym.

Rozbiór nasz doprowadził do wyniku następującego: w staropolszczyźnie rękojmia służy wyłącznie jako nomen agentis. Charakterystyczna przy tym jest nie tylko niezmienność terminologii aż po wiek XVIII, ale i fakt, że jest ona wspólna wszystkim dzielnicom; jest ona zatem ogólnopolska. Godne podkreślenia, że reguła rękojmia $=$ fideiussor nie napotkała żadnego wyjątku, a liczba źródeł, którą wzięliśmy w rachubę, była wystarczająco duża, by uchodzić za reprezentatywną. W konflikcie zatem opinii A. Brücknera i P. Dąbkowskiego przyznać należy rację ostatniemu ${ }^{62}$.

${ }^{52}$ Cytat wedhug wydania drugiego z 1859 r.; wydanie pierwsze w latach 1807-1814.

${ }^{53}$ Nouveau grand dictionnaire de francois, latin et polonois, Varsovie 1743.

s4 Nowy dykcjonarz to jest mownik polsko-niemiecko-francuski, Lipsk 1779.

ss I. Krasicki, Zbiór potrzebniejszych wiadomości porzqdkiem alfabetu ulożonych, t. I, Warszawa-Lwów 1781 , s. 293.

${ }^{56}$ Slownik dokladny jezyka polskiego i niemieckiego, Breslau 1806.

${ }^{57}$ Zbiór praw sqdowych przez eks-kanclerza Andrzeja ordynata Zamojskiego ulożony, wyd. W. Dutkiewicz, Warszawa 1874, cz. 2, art. XXXVI $\$ 6$ oraz $\S 9$.

${ }^{58}$ Myśli do prospekı rozdzialu VII-go ksiegi I-ej o kontrakıach i zapisach, art. 9, wyd. S. Borowski, Kodeks Stanislawa Augusta, s. 171.

${ }^{59}$ P. Dąbkowski, Rekojemstwo..., s. 43, przyp. 12.

${ }^{60}$ Ibidem, s. 11.

${ }^{61}$ M. Arct, Slownik staropolski, t. I, opr. A. Krasnowolski, Warszawa 1914; tenże, Slownik ilustrowany jezyka polskiego, 1929.

${ }^{62}$ Por. cierpkie uwagi językoznawców o Slowniku etymologicznym Brücknera: K. Nitsch, Ze wspomnień językoznawcy, Kraków 1960, s. 252; W. Doroszewski, Etymologia w pracach Brücknera, Poradnik Językowy 1954, z. 2, s. 11-6. Dodajmy, że identyczne do Dąbkowskiego stanowisko zajął J. Los, Gramatyka polska, cz. II: Slowotwórstwo, Lwów-Warszawa-Kraków 1925 , s. $116,144$. 
Najpóźniej przed polową XVIII w. ${ }^{63}$ pojawia się inne znaczenie terminu; rękojmia staje się nomen actionis. Dokonało się przeniesienie pojęcia konkretnego na oderwane. Ono wypiera szybko sens dawny, by w XIX w. zapanować wyłącznie.

W czasie gdy slowo rękojmia było nomen agentis, język posiadal dla nomen actionis inne wyrazy. Zestawił je kiedyś $\mathbf{P}$. Dąbkowski ${ }^{64} . \mathrm{Z}$ nich najczęstszym było rękojemstwo. Występuje ono pospolicie w rotach przysiąg ${ }^{65}$, w tłumaczeniu Statutów kazimierzowskich ${ }^{66}$, w wiejskiej księdze sądowej Trześniowa ${ }^{67}$, w rozmaitych słownikach ${ }^{68}$, w ustawodawstwie szesnastowiecznym $^{69}$, w kompediach ${ }^{70}$. Mączyński ${ }^{71}$ i Knapius powołują ten termin często. Niewątpliwie występują $w$ tym samym znaczeniu także inne rzeczowniki: obręczenie $^{72}$, zaręczenie ${ }^{73}$, ale rękojemstwo znajduje zastosowanie najpowszechniejsze. Slusznie zatem może być traktowane za P. Dąbkowskim, jako terminus technicus dawnego slownictwa prawnego. Zasadnie więc poshugują się nim historycy, omawiając polskie instytucje chłopskie ${ }^{74}$. W końcu XVIII w. uchodzi już wszakże za wyraz dawny i zaniedbany (I. Whodek).

${ }^{63}$ Zdaniem P. Dąbkowskiego, konfuzja średniowiecznego słownictwa technicznego nastąpiła pod koniec Rzeczypospolitej (Rękojemstwo..., s. 43). Sądzimy, że zjawisko to należy cofnąć o jedno stulecie. Zwrócić bowiem trzeba na to uwage, że dzięki sile inercji słowniki moga notować zmiany sematyczne $z$ pewnym opóźnieniem. Rzecz wymagałaby w każdym razie żmudnych badań dodatkowych.

${ }^{64}$ Por. wyżej s. 126.

${ }^{65}$ Leksz., t. II, nr 2180, 2392; SPPP, t. VIII, nr 6902; Piek., nr 644, 946, 1181; R. Hube, Zbiór..., s. 113; Teki Pawińskiego, t. VII, nr 91, 293, 1414, 3466; AKP, t. VIII, s. 45, nr 18, 19 , s. 144 , nr 791, s. 150 , nr 841 , s. 156, nr 906, s. 53, nr 81; Ks. Maz., t. III, nr 1480; SPPP, t. II, nr 3267; SKJ, t. III, s. 188, nr 20; Czers., s. LXXXVII; Maz., t. I, nr 231a, i dalsze wg indeksu.

${ }_{66}$ Stosl., art. 42 (s. 296), art. 4 (s. 323).

${ }^{67}$ H. Polaczkówna, Najstarsza ksiega..., nr 371.

* Slowniczek lacińsko-polski wyrazów prawa magdeburskiego z wieku $X V$, wyd. Z. Celichowski; Slownik Bartlomieja z Bydgoszczy (1532 r.), s. 18; B. Erzepki, Przyczynki do średniowiecznego slownictwa polskiego. I: Glosy polskie wpisane do lacinsko-niemieckiego slownika (Vocabularius ex quo) drukowanego w roku 1490, Roczn. TPN Pozn., t. 34, Poznań 1908, s. 84.

os Vol. Leg., t. II, f. 640, 697.

70 J. Tarnowski, Ustawy prawa ziemskiego polskiego dla pamięci lepszej krótko i porzqdnie $z$ statutów $i$ z konstytucyj zebrane 1578, wyd. Turowskiego, Kraków 1858, s. 54-5.

${ }_{71} 36 \mathrm{c} / 31,36 \mathrm{c} / 37,36 \mathrm{c} / 35,93 \mathrm{a} / 26,126 \mathrm{a} / 34,410 \mathrm{a} / 29,476 \mathrm{a} / 5,476 \mathrm{a} / 24$.

72 Slownik Bartlomieja z Bydgoszczy, s. 18.

${ }^{73}$ J. Tarnowski, o. c., s. 54-5.

${ }_{74}$ T. Czacki, O litewskich i polskich prawach, t. II, Kraków 1861, s. 216-7; P. Dąbkowski, Rękojemstwo..., s. 101; K. Tymieniecki, Procesy twórcze formowania sie spoleczeństwa polskiego $w$ wiekach średnich, Warszawa 1921, s. 246; A. Sucheni-Grabowska, Zapomniany przywilej o rekojemstwie kmiecym, $\mathrm{PH}$, t. 44, s. 169-80. O. Balzer, robił zarzut R. Hubemu, że używał wyrazu poreka, omawiając czternastowieczne prawo polskie, a nie rzeczownika rękojemstwo, $\mathrm{KH}$, t. I, s. 475. W sprawie rękojemstwa chłopów por. też P. Burzyński, Prawo polskie prywalne, t. 1, Kraków 1867, s. 426. 
Od XVIII w. funkcję rękojemstwa przejął rzeczownik rękojmia. Ale obok rękojmi używa się w tym stuleciu również innych terminów: poręka ${ }^{75}$, ręczenie $^{76}$.

Gdy substantivum rękojmia zmieniło swe znaczenie, pojawiły się w jego miejsce określniki: poręcznik ${ }^{77}$, czasami dawniej używany, łaciński fideiussor, któremu nadano nawet deklinację polską ${ }^{78}$, zaręczający ${ }^{79}$, czy wreszcie ręczyciel, poręczyciel, niezbyt udały twór najnowszych czasów, jak go określa P. Dąbkowski ${ }^{80}$.

Nie naszą rzeczą wyjaśnienie przyczyn tego przesunięcia znaczenia. Jak sądzimy, stało się to $\mathrm{z}$ tej racji, że formant $-a$ dla rzeczowników męskich stał się wcześnie nieproduktywny ${ }^{81}$, wskutek czego zbladła jego wyrazistość semantyczna. Oczywista, że zmiana znaczenia pociągnęła za sobą zmianę rodzaju: ten rękojmia przeszedł w tę rękojmię. Likwidacja męskich rzeczowników kończących się na $a$ czy przesuwanie ich do innych grup rzeczowników jest zjawiskiem szerszym.

Śledząc ewolucję znaczeń rękojmi od fideiussor do fideiussio, nie sprecyzowaliśmy bliżej zakresu znaczeniowego tego terminu, tego oczywiście, które mu przypisywali prawnicy. W języku lacińskim fideiussor est sponsor, qui pro alio aliquid promittit (Forcellini). Wedhug definicji osiemnastowiecznej, fideiussor zobowiązuje się „być w odpowiedzi za drugiego" ". Takie też znaczenie przydają określeniu zestawione przez nas wyżej konteksty dawniejsze. W rezultacie więc - nawiązujemy do nauki K. v. Amiry o Schuld i Haftung - rękojemstwo należy do kategorii odpowiedzialności (Haftung) za cudzy dług. Tymczasem rękojmia k. z. jest odpowiedzialnością sprzedawcy za dług własny, kategorii Schuld. Jeśli dotąd zbadališmy, jak rękojmia fideiussor przeszedı w rękojmię fideiussio i określiliśmy w przybliżeniu moment tego przesunięcia znaczenia, to $w$ dalszej analizie należy stwierdzić, kiedy rękojmia $=$ odpowiedzialność za cudzy dlug przeszła $\mathrm{w}$ odpowiedzialność za wady prawne i fizyczne, oraz wyjaśnić, jak do tego doszło. Dla prawnika zagadnienie to jest niewątpliwie bardziej pasjonujące. Analiza zaś jego, jesteśmy tego pewni, wyjaśni te wszystkie wątpliwości terminologiczne, które nasunęło nam studium rękojmi $\mathrm{k}$. $\mathrm{z}$.

${ }^{75}$ S. Borowski, Kodeks Stanislawa Augusta, s. 118, 207, 250, 260.

${ }^{76}$ Ibidem, s. 228.

77 Ibidem, s. 118.

${ }_{78}$ Zbiór Zamojskiego, cz. II, art. XXXVI, § 7-8.

79 Ibidem, \& 11, 13.

${ }^{80}$ P. Dąbkowski, Rekojemstwo..., s. 43; autor ten widzi tu nie tylko przykład marnotrawnego nieposzanowania pamiątek przeszłości, ale i zlego gustu (Prawo prywatne..., t. I, s. 53-4). Wcześniej już O. Balzer wytykał R. Hubemu używanie poręczyciela zamiast rękojmi czy rękojemcy, KH, t. 1, s. 475.

${ }^{81}$ Zaznaczmy wszakże, że jeszcze Knapski przez analogię do rękojmia tworzy rzeczownik świadomia, J. Puzynina, Neologizmy Grzegorza Knapskiego, Poradnik Językowy 1955, s. 91.

${ }^{82}$ I. Krasicki, Zbiór..., s. 293. 


\section{Glówszczyzna chlopska i szlachecka*}

Główszczyzna była instytucją dobrze znaną społeczeństwom średniowiecznym. W granice imperium rzymskiego wniosły ją plemiona germańskie ${ }^{1}$. Ale nie stanowiła ona bynajmniej jakiejś wlaściwości szczególnej urządzeń germańskich. Nieobca byla również Słowianom ${ }^{2}$, jak i innym ludom kontynentu europejskiego, czy poza $\mathrm{nim}^{3}$. Oczywiście znało ją także prawo polskie ${ }^{4}$.

Główszczyzna stanowila karę kompozycyjną ${ }^{5}$. Zapłata jej chroniła życie zabójcy, zastępowała odwet $w$ postaci zemsty krwawej. ${ }^{6}$. Oczywista więc, że nie uiszczano jej, gdy przestępca poniósł śmierć7.

* Przedruk z: Kwartalnik Historyczny 1964, t. 71, z. 1, s. 17-26.

1 E. Chénon, Histoire générale du droit français public et privé dès origines à 1815 , t. I, Paris 1926, s. 265-6; R. Schröder - E. Künssberg, Lehrbuch der deutschen Rechtsgeschichte, wyd. 7, Berlin-Leipzig 1932, s. 86-7, 373-377; M. Handelsman, Prawo karne w Statutach Kazimierza Wielkiego, Warszawa 1909, s. 203.

${ }^{2}$ K. Kadlec, O prawie karnym u Slowian zachodnich, Enc. AU, Kraków 1913, s. $117 \mathrm{nn}$.; I. Czomow, Krwawa zemsta u Slowian, [Pam. Hist.-Pr., t. 7, z. 6] Lwów 1929, s. 9 nn.; K. Tymieniecki, Spoleczeństwo Slowian lechickich, Lwów 1928, s. 37-8.

${ }^{3}$ K. Koranyi, Powszechna historia państwa i prawa, t. I, Warszawa 1962, s. 92; J. Klima, Prava Hammurabiego, Warszawa 1957, s. 290-1.

${ }^{4}$ Por. literature powolywaną niżej.

s Wydaje się, że jest ona pochodzenia przedpaństwowego, por. J. Bardach, [w:] Historia państwa $i$ prawa Polski do polowy XV wieku, t. I, Warszawa 1957, s. 80 nn.; A. Vetulani, Przemiany $w$ urzqdzeniach $i$ życiu prawnym spoleczeństw w poczqtkach państwa polskiego, [w:] Poczqtki państwa polskiego, red. K. Tymieniecki i in., t. 2, Poznań 1962, s. 183.

${ }^{6}$ Chénon, op. cit., s. 263-4; R. Taubenschlag, Pravo karne [Studia nad Hist. Prawa Pol., t. 14, z. 3] Lwów 1934, s. 52. Poglądy średniowieczne na rolę kary zestawia Handelsman, Prawo karne, s. 103-5; M. Winawer, Najdawniejsze prawo zwyczajowe polskie, Warszawa 1900, s. 169-70; Bardach, op. cit., s. $80 \mathrm{nn}$. Cenne wywody na ten temat zawiera R. His, Das Strafrecht des deutschen Mittelalters, 1. 1. Leipzig 1920, s. 367-74.

${ }^{7}$ St. Kutrzeba, Mężobójstwo w prawie polskim XVI stulecia, Czasop. Prawne i Ekonom., 25. Kraków 1929, s. 273-4; następowało to nawet wówczas choćby zgonu nie spowodowała akcja odwetowa; por. też St. Kutrzeba, Dawne polskie prawo sqqdowe w zarysie, wyd. 2, Lwów-Warszawa-Kraków 1927, s. 41. 
Charakterystyczna dla średniowiecza nierówność prawna musiała znaleźć odbicie także w dziedzinie prawa karnego. Występowala ona zapewne już w okresie rodowo-plemiennym ${ }^{8}$. Wywarła swój wplyw na wysokość główszczyzny. Teoretycznie biorąc, można by ją obliczać, biorąc za podstawę wartość głowy zabójcy. (Zabójstwo - wiemy - grozilo odwetem, morderca wykupywał więc swoją głowę od śmierci, płacąc kwotę, której warta była jego głowa, ocalona przez tę kompozycję). Ten system - zdawałoby się logiczny - nie znajdowal nigdzie zastosowania? ${ }^{9}$ Przeciwstawiala mu się bowiem tendencja zapewnienia wyższej ochrony prawnej tym grupom osób, które uchodziły za społecznie ważniejsze, którym też państwo zapewniało ochronę specjalną (urzędnicy świeccy, duchowni, drużynnicy) ${ }^{10}$. Do takich należało też niewątpliwie rycerstwo, $\mathrm{z}$ którego wytworzyła się później szlachta.

Stąd też powszechnie brano pod uwagę szkodę, jaka powstawała wskutek zabójstwa dla rodziny (rodu) denata, zatem wartość głowy zabitego. Tak było $w$ państwie frankijskim ${ }^{11}$, to samo stanowisko zajmowało też prawo polskie ${ }^{12}$. Główszczyzna była oplatą za poczyniony uszczerbek - pisze R. Hube ${ }^{13}$ - wyrównaniem krzywdy ekonomicznej ${ }^{14}$, odszkodowaniem, zadośćuczynieniem, satysfakcją ${ }^{15}$, zadośćuczynieniem o podłożu prawnoprywatnym $^{16}$, zadośćuczynieniem pieniężnym (solutio, plat ${ }^{17}$. Aspekt odszkodowawczy wziąl więc zdecydowanie górę nad wykupem, cywilność kompozycji nad jej charakterem karnym. Pomimo tego wyraźnie ekonomicznego charakteru, główszczyznę zalicza się - słusznie - do instytucji prawa karnego.

${ }^{8}$ Vetulani, Przemiany, s. 184.

${ }^{9}$ Nie znano go też w okresie panowania zasady osobowości praw w państwie frankońskim; prawda, aplikowano początkowo prawo oskarżonego, nawet gdy chodziło o ustalenie wergeldu; Chénon, op. cit., s. 125, ale $z$ tego nie wolno jeszcze wysnuwać wniosku, jakoby główszczyzna zabójcy była miarodajna.

10 Vetulani, Przemiany, s. 178, ob. też RH, t. 23, 1957, s. 153.

11 Chénon, op. cit., s. 266, 347-52.

12 Stan przestępcy mógł jednak mieć znaczenie da wymiaru zadośćuczynienia, J. Rafacz, Dawne prawo sqdowe polskie w zarysie, Warszawa 1936, s. 454-5.

${ }^{13}$ R. Hube, Sqdy, ich praktyka i stosunki prawne spoleczeństwa w Polsce ku schylkowi 14 wieku, Warszawa 1886, s. 240, 243.

${ }^{14}$ M. Handelsman, Kara w najdawniejszym prawie polskim, Warszawa 1907, s. 85.

${ }^{15}$ Handelsman, Prawo karne, s. 138-9; tenże, Kara, s. 84; Kutrzeba, Mężobójstwo, s. 273.

${ }^{16} \mathrm{~K}$. Dobrowolski, Wróżda $i$ pojednanie $w$ sqdownictwie polskich wsi beskidowych XVI i XVII wieku [Studia nad Hist. Prawa Pol., t. 8, z. 4]. Lwów 1924, s. 24.

${ }^{17}$ St. Kutrzeha, Mężobójstwo w prawie polskim XIV i XV w., RAU. WH-F, 1. 50. Kraków 1907, s. 130; tenże, Dawne polskie prawo, s. 39. 
Wysokość główszczyzny zależała od przynależności stanowej ${ }^{18}$. Stąd dla stosunków wiejskich zasadniczy był podział na główszczyznę rycerską (szlachecką) i chłopską (plebejską) ${ }^{19}$. Co więcej, w średniowieczu w lonie klasy feudalnej wyróżnia się dwie, nawet trzy warstwy ${ }^{20}$. Dystynkcję taką przeprowadzal zarówno akt z $1252 \mathrm{r}^{21}$, jak zwłaszcza statut małopolski Kazimierza Wielkiego ${ }^{22}$. Zanikła ona $w$ końcu średniowiecza ${ }^{23}$, w czasach nowożytnych zróżnicowanie to $\mathrm{w}$ łonie warstwy feudalnej więcej nie wystąpiło $^{24}$. Zasada równości szlacheckiej znajduje w ten sposób swój wyraz i w prawie karnym.

Średniowiecze znało nadto inne różnice $w$ główszczyznach, mianowicie regionalne ${ }^{25}$. Świadczy o tym porównanie taryfy aktu z $1252 \mathrm{r}^{26}$ ze znaną nam $\mathrm{z}$ Najstarszego Zwodu prawa polskiego ${ }^{27}$, jak wreszcie - $\mathrm{i}$ to $\mathrm{w}$ sposób dobitny - Statuty Kazimierzowskie: podają one inną taryfę dla Wielkopolski, inną dla Małopolski ${ }^{28}$, równie odrębną dla rycerstwa, jak i chłopów. Wielkopolska główszczyzna rycerska wynosiła 30, małopolska - 60 grzywien; chłopska taryfa w Małopolsce - 10, w Wielkopolsce - 6, później 9 grzywien ${ }^{29}$.

${ }^{18}$ R. Hube, Ustawodawstwo Kazimierza Wielkiego, Warszawa 1881, s. 201; Kutrzeba, Mężobójstwo, RAU, s. 131; Handelsman, Prawo karne, s. 210; Kutrzeba, Dawne polskie prawo, s. 12; J. Rafacz, Dawne polskie prawo karne, Warszawa 1932, s. 179. Punktem wyjścia, zdaniem ostatniego autora, było jednakowe zadośćuczynienie dla wszystkich wolnych. Ta faza źródłowo nie jest poświadczona. Wniosek ten wysunął Rafacz z jednolitych kar, idących przy zabójstwie na rzecz władcy, s. 180; por. tu jednak J. Matuszewski, Ręka pańska, Przegląd Zachodni 1955, s. 605. Trafne natomiast wydaje się twierdzenie Vetulaniego, Przemiany, s. 184, którego zdaniem zóżnicowanie okupu nastąpiło przed podziałem Polski na dzielnice; cofnęlibyśmy je do czasów rodowo-plemiennych.

${ }^{19}$ Pomijamy w swoich rozważaniach taksę mieszczańską, tym bardziej że rozwijała się ona pod wplywem prawa magdeburskiego, przy czym jeszcze ustawodawstwo szlacheckie postanawialo, że włościan i szlachtę należy sądzić w sprawach o rany i zabójstwo nawet w miastach tylko wedhug prawa polskiego - statut nieszawski z 1454 r., konstylucja z 1538 r., Volumina Legum, t. 1, s. 253,523 .

${ }^{20}$ Rafacz, Dawne polskie prawo, s. 179-80.

${ }^{21}$ Preussisches Urkundenbuch, t. 1, wyd. Philippi-Wölky, Königsberg i. Pr. 1882, nr 260. Literatura podana w Rocznikach Hist., 23, 1957, s. 147, przyp. 47.

${ }^{22}$ AKP, t. 2, Król., art. 91.

${ }^{23}$ Por. O. Balzer, Skartabelat $w$ ustroju szlachectwa polskiego, Kraków 1911, s. 5.

${ }^{24}$ Wyjąwszy szesnastowiecznych skartabelów; według L. Górnickiego, Rozmowa Polaka $z$ Wochem o wolnościach i prawach polskich, [w:] Pisma, opr. R. Pollak, t. 2, Warszawa 1961, s. 353, należała się im połowa główszczyzny szlacheckiej.

${ }^{25}$ Handelsman, Prawo karne, s. 202; Kutrzeba, Mężobójstwo, RAU, s. 131; Rafacz, Dawne polskie prawo, s. 180-1; Kutrzeba, Dawne polskie prawo, s. 40-1.

${ }^{26}$ Por. przyp. 21.

${ }^{27}$ Najstarszy Zwód prawa polskiego, wyd. J. Matuszewski, Warszawa 1959, art. 15.

${ }^{28}$ Por. niżej przyp. 29.

${ }^{29}$ W Lęczyckiem 7 grzywien, Kutrzeba, Dawne polskie prawo, s. 41. 
W ten sposób ustawodawca średniowieczny utrwalił - jak by się wydawało - zwyczajowe dystynkcje, wytworzone w dwu dzielnicach. W dalszym rozwoju wszakże, wbrew tej petryfikacji, statuty odegrały rolę unifikującą. Albowiem rycerska główszczyzna małopolska (60 grzywien), obowiązująca również na Rusi i w Sieradzkiem, przeciwstawiająca się typowi wielkopolskiemu, łącznie z Kujawami i Łęczyckiem (30 grzywien) zwycięża powoli: najpierw w Lęczyckiem (koniec XIV w.), potem w Wielkopolsce (XV w.) i na Kujawach ${ }^{30}$. Podobnie upowszechniła się malopolska glówszczyzna chlopska: taksa 10 grzywien obowiązuje w calej Koronie od statutu warckiego z $1423 \mathrm{r}^{31}$ Jeśli więc liczba wariantów w średniowieczu stawia reprezentatywność zachowanych taryf pod znakiem zapytania, to od XV w. taryfa małopolska uchodzić musi za miarodajną dla poważnego obszaru Rzeczypospolitej.

Późniejsze ustawodawstwo szlacheckie wprowadza już jednolite normy dla całej Korony. Taki zakres terytorialny przewidują konstytucje z lat 1493 i 1496, wprowadzające taksę szlachecką w wysokości 120 grzywien $^{32}$. W XVI w. glówszczyzny 10 grzywien (chłopska) i 120 (szlachecka) uchodzić muszą za ogólnopolskie. Obie zna Correctura iurium z $1532 \mathrm{r} \cdot{ }^{33}$ Odmienności mazowieckie utrzymały się niedlugo, bo tylko do 1540 r., kiedy to przyjęto i w tej dzielnicy takse 120 grzywien $^{34}$.

Taryfy 10 i 120 grzywien pozostają bez zmian do końca XVI w. Uderzająca przy tym jest trwałość główszczyzny chłopskiej: od statutu małopolskiego, rozszerzonego na całą Rzeczpospolitą, przez 200 lat pozostała ona niezmieniona. Była to prawdopodobnie skapitalizowana renta za okres 10 lat, przyjmując, że chłop placił z łanu 1 grzywnę czynszu rocznie ${ }^{35}$. Rzecz wymagałaby, oczywiście, uściślenia ${ }^{36}$.

Późniejsze zmiany ustawowe odnoszą się również do calej Rzeczypospolitej. Konstytucja z 1581 r. ustaliła główszczyznę chłopską na 30, konstytucja

${ }^{30}$ Kutrzeba, Mężobójsiwo, RAU, s. 131-2, 143.

${ }^{31}$ Kutrzeba, Mężobójstwo, Czasop. Pr. i Ek., s. 274, potwierdza ją Formula processus, ibidem, s. 275; tenże, Dawne polskie prawo, s. 41. Na Mazowszu dwa lata wcześniej.

${ }^{32}$ Rafacz, Dawne polskie prawo, s. 180-1.

${ }^{33}$ Kutrzeba, Męzobójsıwo, Czasop. Pr. i Ek., s. 263; tenże, Dawne polskie prawo, s. 52; I. Baranowski, Wieś i folwark, Warszawa 1914, s. 133, powołuje wypadek z 1545 r.: chłopi z Krowodrzy placa za zamordowanie szlachcica $200 \mathrm{zhp}$.

${ }^{34}$ Kutrzeba, Meżobójsıwo, Czasop. Pr. i Ek., s. 136; Rafacz, Dawne polskie prawo, s. 183.

${ }^{35}$ Por. K. Tymieniecki, Kmieć wielkopolski $w$ zapiskach sqdowych średniowiecznych, cz. I, Uposażenie i cieżary, Sprawozd. PTPN, t. 3 (1929), s. 48; A. Lauferski, Ludność wiejska pow. pyzdrskiego w świetle zapisek sqdowych XIV i $X V$ w., Rocz. Hist., 15, 1946, s. 225. Oczywiście łan jest tu rozumiany jako jednostka normalna dla określenia renty feudalnej, por. L. Żytkowicz, Studia nad gospodarstwem wiejskim w dobrach kościelnych XVI w., Warszawa 1962, s. 40.

${ }^{36}$ Stopa procentowa wynosiła wówczas 10 . Tymieniecki, op. cit.; Lauferski, op. cit., s. 227. Podobne obliczenie przy skupie solectw, S. Sochaniewicz, Wojtostwa i soltystwa, Lwów 1921, s. $125,372,382$. 
Z 1588 r, podniosła główszczyznę szlachecką do 240, konstytucja z $1631 \mathrm{r}$. wprowadziła główszczyznę plebejską w wysokości 100 grzywien $^{37}$. Daty 1588 - dla główszczyzny szlacheckiej, i 1631 - dla chlopskiej są ostatnimi, w których ukazały się postanowienia ustawowe $w$ tej materii. Do nich ograniczyła się działalność prawodawcza sejmu szlacheckiego, dalszej podwyżki tą drogą już nie dokonano. Nie oznacza to jednak, że glówszczyzna nie uległa ewolucji zwyczajowo. W osiemnastowiecznej praktyce Trybunału Królestwa przyznaje się za głowę szlachcica sumy znacznie wyższe: 1000,1200 , czy nawet 2000 grzywien $^{38}$. Poprzez indywidualne dekrety sądów uległa zatem główszczyzna szlachecka poważnej zwyżce.

A czy taksa chłopska nie została zmieniona do końca Rzeczypospolitej? Owszem, ulegla i ona ewolucji, i to w sposób dość swoisty. Przede wszystkim zwrócić należy uwagę na fakt, że kwota 30 grzywien, ustalona w $1581 \mathrm{r}$., nie jest główszczyzną generalną, płaconą przez wszystkich zabójców, bez względu na ich stanowisko społeczne; placi ją szlachcic w wypadku umyślnego zabójstwa chłopa (Który by zabil plebeium hominem rusticanum szlachcic). Tak, sądzimy, należy też rozumieć postanowienie konstytucji z 1631 r.: ustalona wówczas suma 100 grzywien jest znowu taksą, jaką uiszczal szlachcic. Tej sumy nie płacił wszakże chlop. Plebej zabijający plebeja będzie karany śmiercią - mówi ustawa z 1581 r.; oczywiście wówczas, gdy dokona zabójstwa z premedytacją. A gdy istniały jakieś okoliczności lagodzące, które wykluczaly ten wymiar kary, tak, że go na śmierć nie skazywano? Wtedy, jak należy sądzić, również chłop-zabójca placił główszczyznę ${ }^{39}$. Ustawa wszakże nie ustala jej wysokości. Szlachta nie interesowala się nią zupełnie, zostawiając swobodne pole działalności praktyce sądowej. Nie wiemy, czy doprowadziła ona do ustalenia zwyczajowej taksy. Literatura przedmiotu sprawia nam duży zawód. Dla ostatnich dwóch stuleci Rzeczypospolitej szlacheckiej brak prac analitycznych w rodzaju Mezzobójstwa St. Kutrzeby dla wieków poprzednich. Jak dotąd, stwierdzono, że w XVI i XVII w. nie występuje jakaś stała, określona główszczyzna.

${ }^{37}$ Rafacz, Dawne polskie prawo, s. 186; Kutrzeba, Dawne polskie prawo, s. 41; Volumina Legum, t. 3, s. 681 .

${ }_{38}$ Rafacz, Dawne polskie prawo, s. 184; J. Makarewicz, Polskie prawo karne. Czéść ogólna, Lwów-Warszawa 1919, s. 279. W 1631 r. Trybunał nakazał płacić za głowę szlachecką 2000, Liber generationis plebeanorum, wyd. Wł. Dworzaczek, i in. Wrocław-Warszawa-Kraków 1963, nr 1032.

${ }^{39}$ Przykładu dostarcza nam księga łącka. Dowiadujemy się z niej, że uderzenie, którego następstwem był zgon, nie z zlości ani zawziętości bylo, ale z omelki $i$ nie chcace, bo kogo innego uderzyć chcial, a podczas ciemnej nocy Gargula nieboszczyk naraziel sie; w następstwie winowajce skazano na grzywnę, a nie na karę śmierci. Ksiegi sqdowe wiejskie klucza lackiego, t. 1, Wroclaw-Warszawa-Kraków 1962, wyd. A. Vetulani, nr 684. 
Wykazano przy tym, że i w lonie stanu chłopskiego mamy do czynienia ze zróżnicowaniem kary, w zależności od sytuacji materialnej chłopa ${ }^{40}$.

Zwyczaj wywarł niemały wplyw na wysokość główszczyzny chłopskiej, płaconej przez szlachcica. Obok bowiem sumy 100 grzywien, przewidzianej przez konstytucję z 1631 r., wytworzyła się druga, nieco wyższa kara - 120 grzywien, będąca połową glówszczyzny szlacheckiej, zgodnie z dezyderatami szlachty, wyrażonymi w instrukcjach sejmikowych. Podwyżki chłopskiej glówszczyzny wynoszącej, od 1581 r. 30 grzywien, domagały się $\mathrm{m}$. in. sejmiki wielkopolskie. Instrukcja z $1625 \mathrm{r}$. brzmiała: $N a$ homicidia plebeiorum przez szlachcica, że male pretium jest naznaczone, żeby belo pretium auctum in duplo, tj. 60 grzywien pro capite plebei ${ }^{41}$. Wyższej główszczyzny - 100 grzywien domagała się instrukcja z $1630 \mathrm{r}^{42}$, i to właśnie żądanie znalazło rok później ustawową realizację. Podnieść należy motywację ostatniej instrukcji, mniejsza że historycznie błędną: İ $w$ starych statutach homicidia plebeiarum personarum ad dimidium poenae capit is nobilis szacowane byly, teraz zaś glowa ślachecka na 240 grzywien miasto sześcidziesiąt jest oszacowana... ${ }^{43}$.

Te uzasadnienia świadczą o oderwaniu się główszczyzny chłopskiej od dotychczasowej bazy gospodarczej, tzn. od związku wysokości glówszczyzny z czynszem płaconym z lanu. Podwyższenie taksy chłopskiej do połowy glówszczyzny szlacheckiej świadczy, że grały tu rolę inne bodźce. Obserwacje o charakterze tymczasowym, bo rzecz wymaga opracowania monograficznego, prowadzą do wniosku, że główszczyzna chłopska taryfowa miała charakter szczególny, była czymś pośrednim między wartością głowy denata a wartością glowy zabójcy-szlachcica. Nie sądzimy zresztą, by to teoretyczne rozróżnienie leżało u podstawy zmian z 1581 i $1631 \mathrm{r}$.

Konstytucja z 1768 r., wprowadzająca karę śmierci na szlachcica za umyślne zabójstwo chłopa, nie oznaczała bynajmniej likwidacji główszczyzny ${ }^{44}$.

${ }^{40}$ Dobrowolski, Wróżda, s. 24, 26. Ibidem, s. 25, zanotowano występowanie we wsiach beskidzkich w XVI w. glówszczyzny 20-30 grzywien, u schyłku XVIII w. - 100 grzywien. W 1634 r. za karczmarza, który zginął z nieszczęśliwego wypadku „z obu stron”, główszczyzna wynosiła 85 grzywien. Ksiegi sqdowe wiejskie klucza lqckiego, I, nr 504 . W 1730 r. sąd wiejski za nieumyślne spowodowanie śmierci chłopa nakłada karę 60 tynfów, płatną w czterech ratach, ibidem, nr 684. Przypomnijmy, że w macznej części Niemiec już w stuleciach 12 i 13. stała taryfa główszczyzny utrzymała się tylko dla osób stanu niższego, chłopów, a później w ogóle jedynie przy pewnych kategoriach zabójstwa (w afekcie, w obronie koniecznej), His., op. cit., s. $591-4$.

${ }_{41}$ Akta sejmikowe województw poznańskiego i kaliskiego, t. 1, cz. 2, Poznań 1962, wyd. W1. Dworzaczek, nr 283, p. 21.

${ }^{42}$ Ibidem, nr 340, p. 25.

${ }^{43}$ Dorzućmy jeszcze dezyderat odnośnie do nawiązki: Warowano także $i$ rany na polowice szacunku tego, jako teraz ślacheckie rany placq.

${ }^{44} \mathrm{O}$ zniesieniu główszczyzny pisze T. Korzon, Wewnętrzne dzieje Stanislawa Augusta, t. 1, s. $360-1,381$. 
Przede wszystkim nie dotyczyła ona zupełnie główszczyzny należnej za zabójstwo nieumyślne, popełnione przez szlachcica; nie odnosila się również do główszczyzny płaconej przez chłopa za zabójstwo chłopa. Nic więc dziwnego, że główszczyznę karną zna jeszcze kodeks Andrzeja Zamojskiego. $\mathrm{W}$ jego art. 31, § 21 obok kary śmierci wprowadza się grzywnę $1000 \mathrm{zlp}$, płacona przez sukcesorów zabójcy (poza tym cała rodzina najbliższa i poboczna denata zyskuje wolność) ${ }^{45}$. Podwyższenia główszczyzny do 2000 grzywien domagal sie jeszcze w swym projekcie z 1790 r. Hugo Kolłątaj ${ }^{46}$. Oczywista, projektowane wprowadzenie glówszczyzny obok kary śmierci dowodzi zupełnego niezrozumienia istotnego charakteru starodawnej instytucji prawa karnego.

Znając ewolucję glówszczyzny szlacheckiej i chłopskiej, przedstawiamy ją w tablicy zbiorczej. Unaoczni nam ona, jak zmienna była ,taryfa ludzkiego mięsa"47, oraz jaki byl stosunek taksy chłopskiej do szlacheckiej na przestrzeni pięciu stuleci ${ }^{48}$.

$\mathrm{Z}$ zestawienia widać, że w czasach nowożytnych obie glówszczyzny, rycerska i chłopska, wykazują ciągły wzrost w wielkościach bezwzględnych ${ }^{49}$. Nie ewoluują one jednak - jak to ilustruje ostatnia kolumna - równomiernie. Rozwój proporcji taks chłopskiej i szlacheckiej jest wręcz frapujący.

Wzrost główszczyzny w wielkościach bezwzględnych można by thumaczyć dewaluacją pieniądza. Ale to nie wyjaśnia nam nierównomierności tego wzrostu. Pewną rolę odgrywać musiały nadto inne bodźce. Zrozumiała wydaje się degradacja społeczna plebejów w średniowieczu. Szlachta, rwąc

${ }^{45}$ W. Hejnosz, Stanowisko prawne ludności wiejskiej w Zbiorze praw sqdowych $A$. Zamojskiego, Roczn. Dziejów Społ. i Gosp., 5, s. 78.

${ }^{46}$ Korzon, op. cit., s. 432.

${ }^{47}$ Wyrażenie Makarewicza, op. cit., s. 351.

${ }^{48}$ Sporządzono ją w oparciu o następująç̨ literaturę: Hube, Prawo polskie, s. 134-5, 202, 244-5; M. Winawer, Najdawniejsze prawo zwyczajowe polskie, s. 172, 185, 193-4, 204; Handelsman, Kara, s. 144, 174, 204; tenże, Prawo karne, s. 162, 163, 197, i 198; Kutrzeba, Mężobójstwo, RAU, s. 131, 132-3, 134-5, 138, 144, 145; tenże, Mężobójstwo, Czasop. Pr. i Ek., s. 274-5; Balzer, Skartabelat, s. 3; Makarewicz, Polskie prawo karne, s. 303; Kutrzeba, Dawne polskie prawo, s. 40-1; Rafacz, Dawne polskie prawo, s. 181, 183, 186 (tezy swoje powtórzył J. Rafacz, Dawne prawo sqdowe, s. 455-6); Bardach, op. cil., s. 231, 337, 400, 424, 534; Kaczmarczyk, op. cit., s. 190, 326.

${ }^{49}$ Dla średniowiecza trudno o uogólnienie ze względu na niereprezentatywność zachowanego materiału. 
się do władzy, myśli przede wszystkim o swoim wywyższeniu nad plebejską częścią spoleczeństwa. Jaskrawo uwydatniła się ta tendencja w statutach Kazimierza Wielkiego, a szczególnie w ustawodawstwie końca XV w.; degradacja chłopa osiągnęła wówczas swój szczyt. Ale jak tłumaczyć linję wstępującą w okresie rozrastania się folwarku pańszczyźnianego? Uzależnienie poddanego wówczas pogłębia się, chłop traci samodzielność - i gospodarczą, i osobistą.

\begin{tabular}{|c|c|c|c|c|}
\hline \multirow{2}{*}{ Data } & \multicolumn{4}{|c|}{ Główszczyzna } \\
\hline & \multicolumn{2}{|l|}{ rycerska } & chłopska & $\%$ \\
\hline $1252^{*}$ & rycerz-urzędnik & 30 & 6 & 20 \\
\hline & rycerz zwykły & 15 & & 40 \\
\hline $\mathrm{NZ}^{* *}$ & & 50 & 30 & 60 \\
\hline Statut wielkopolski & & 30 & 6 & 20 \\
\hline Statut małopolski*** & szlachcic & 60 & & 17 \\
\hline & włodyka & 30 & 10 & 33 \\
\hline & miles de sculteto vel cmethone & 15 & & 66 \\
\hline $1493-1496 * * * *$ & & 120 & & 8 \\
\hline 1581 & & & 30 & \\
\hline 1588 & & 240 & & 12,5 \\
\hline 1631 & & & 100 & 42 \\
\hline
\end{tabular}

* W XIII w. nie ma postanowień ogólnych, lecz tylko szczegółowe. St. Kutrzeba, Mężobójstwo, RAU, s. 130. Postanowienie z 1252 r. uchodzi za zaczątek taksy, która zostanie sformułowana w statutach. M. Handelsman, Kara, s. 214.

** Bardzo wysoka glówszczyzna chłopska tego zabytku znajduje potwierdzenie w dokumentach trzynastowiecznych, R. Hube, Prawo polskie w wieku trzynastym, Warszawa 1874, s. 161, 178. Podkreślamy też, że w Najstarszym Zwodzie główszczyźnie rycerskiej równa się główszczyzna kupca.

*** Przed statutami Kazimierzowskimi również w Małopolsce glówszczyzna szlachecka wynosiła 30 grzywien, J. Rafacz, Dawne polskie prawo, s. 183. Małopolska główszczyzna chłopska przedstatutowa - jak się na ogół przyjmuje - miała równać się 3 grzywnom; R. Hube, Ustawodawstwo Kazimierza, s. 135; M. Handelsman, Prawo karne, s. 162, 197; J. Rafacz, op. cit., s. 185; St. Kutrzeba, Dawne polskie prawo, s. 40 (odnosząc ją do XIII w.). Wszakże wątpliwości co do tej wysokości ma St. Kutrzeba, Mężobójstwo, RAU, s. 138; ob. też J. Bardach, [w:] Historia państwa i prawa..., t. I, s. 534, przyp. 93.

**** Podwyższenia główszczyzny szlacheckiej, bez wyraźnej zmiany taryfy chłopskiej, dokonał już statut kolski z 1472 r.; wszakże dotyczył on tylko Wielkopolski i obowiązywał przez lat trzy. Tych ograniczeń, terytorialnego i chronologicznego, nie zna już konstytucja piotrkowska z 1493 r., ani konstytucja z 1496 r. St. Kutrzeba, Mezzobójstwo, RAU, s. 134-5; tenże, Dawne polskie prawo, s. 40. 
$\mathrm{Z}$ pewnością nie odgrywała tu roli zmiana w sposobie podziału główszczyzny między zainteresowanych. Prawda, że od końca XVI w. dzielono ją po polowie między pana i dotknięta zabójstwem rodzinę ${ }^{50}$, ale podobnie bywało i dawniej, jak o tym świadczą trzynastowieczne przywileje immunitetowe $^{51}$, czy statut wielkopolski Kazimierza Wielkiego ${ }^{52}$. Co więcej, w pewnych dzielnicach (Lęczyckie, Sieradzkie) właśnie udział pana był w średniowieczu znacznie większy niż spadkobierców, sięgal bowiem $60-70 \%$, choć bywało też inaczej, np. w Małopolsce otrzymywal pan $40 \%{ }^{54}$, ale i tu różnica $w$ zestawieniu $z$ podziałem nowożytnym nie była zbyt jaskrawa ${ }^{55}$.

Nie w podziale glówszczyzny zatem doszukiwać się trzeba przyczyny, bo jakichś istotnych różnic nie było ${ }^{56}$. Leży ona gdzie indziej. Tracąc samodzielność gospodarczą, chłop staje się coraz bardziej częścią składową majątku pana, uważa się go za własność pańską ${ }^{57}$. Stąd chroni go coraz wyższa główszczyzna ${ }^{58}$. Wzrost taksy plebejskiej dokonuje się równocześnie $\mathrm{z}$ redukcją wartości inwentarza chłopskiego ${ }^{59}$. Zatem chłop biedniejszy staje

${ }^{50}$ Kutrzeba, Mężobójstwo, Czasop. Pr. i Ek., s. 275; Rafacz, Dawne polskie prawo, s. 185-6; Makarewicz, op. cit., s. 315; Dobrowolski, Wróżda, s. 33; Praktyka zna inne warianty podziału, na przykład w Łącku $z$ nałożonych 30 grzywien 10 poszło na rzecz kościoła miejscowego, 20 - dia syna denata; Ksiegi sqdowe wiejskie klucza lqckiego, $\mathrm{nr} 351, \mathrm{r} .1600$. W ustawie istnieje luka: nie wiadomo, kto brał pańska połowę, gdy sam pan był zabójcą. Czyżby on placił tylko połowę główszczyzn ustalonych w latach 1581 i 1631 r.? Opowiedzielibyśmy się raczej za innym rozwiązaniem: pan za swojego chłopa w ogóle żadnej główszczyzny nie uiszczał; por. B. Baranowski, O hultajach, wiedźmach $i$ wszetecznicach, Łódź 1963, s. 60, 63.

${ }^{51}$ Handelsman, Kara, s. 88; czasem bierze ją w całości pan-odbiorca immunitetowego przywileju, ibidem, s. 87; Hube, Prawo polskie w wieku trzynastym, s. 159-60.

${ }^{52}$ Hube, Ustawodawstwo Kazimierza, s. 184; Kutrzeba, Mężobójstwo, RAU, s. 143; Handelsman, Prawo karne, s. 163-191, 197-8.

53 Według Kutrzeby, Mężobójstwo, RAU s. 142-3, w Łęczyckiem główszczyzna wynosiła 7 grzywien, z czego panu należało się 5 , rodzinie denata 2 .

${ }^{54}$ Ibidem, s. 138-9; Rafacz, Dawne polskie prawo, s. 185-6.

${ }^{s 5}$ Kutrzeba, Dawne polskie prawo, s. 41, podaje następujące proporcje podziału między pana i rodzinę: 6:4, 5:2, 9:3; zaś Rafacz, op. cit. - 6:4, 4:6, 3:7.

${ }^{56}$ Pozostawiamy na uboczu kwestię kar na rzecz króla i urzędników sądowych, por. Bardach, op. cit., s. 458, 512, 518, 529.

${ }^{57}$ Makarewicz, op. cit., s. 311.

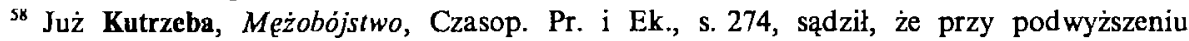
główszczyzny włościańskiej w XVI w. działał obok dewaluacji wzgląd gospodarczy: podniesienie się znaczenia pracy chłopa na folwarku, a więc jego wartość dla pana; por. tenże, Dawne polskie prawo, s. 41; podobnie Z. Kaczmarczyk, [w:] Historia państwa $i$ prawa, t. 2, s. 326, łączy zwiększenie główszczyzny ze wzrostem wartości poddanego chłopa przede wszystkim dla wielkiej własności magnackiej. Co prawda, identycznie tłumaczą mediewiści rolę immunitetu: przyznanie grzywny panu świadczy o silnie wyrobionym pojęciu poddaństwa. Hube, Prawo polskie w wieku trzynastym, s. 159-60; według Handelsmana, Kara, s. 85, kara prywatna należy się właścicielowi sił roboczych, pokrzywdzonemu przez zabójstwo włościanina.

${ }^{59} \mathrm{O}$ pauperyzacji ludności chłopskiej od końca XVI w. por. Żytkowicx, op. cit., s. 133, 137; Baranowski, O hultajach, s. 28. 
się bardziej pański, wskutek tego szlachta silniej go chroni ${ }^{60}$. W wieku XVIII odegrały swą rolę zapewne także bodźce ponownego wzrostu ekonomicznego.

W następstwie tych, tak różnych przyczyn, taryfa ustawowa główszczyzny uległa - licząc od statutu małopolskiego Kazimierza Wielkiego - nierównej podwyżce: czterokrotnej $(60$ grz. $\times 2 \times 2)$, gdy chodzi o szlachcica, dziesięcio- czy nawet dwunastokrotnej (10 grz. $\times 3 \times 3,3-$ bądź $\times 4)$ - dla poddanego.

Polskie prawo karne ziemskie nie znało różnic w główszczyźnie ze względu na pleć. Jak wykazały badania St. Kutrzeby, identyczna taksa obowiązywała przy zabójstwie mężczyzny i kobiety ${ }^{61}$. Ten stan rzeczy utrzymał się do początku XVII w. Wówczas to, jak się wydaje, wytworzyła się osobna taksa za głowę chłopki - w wysokości połowy taryfy męskiej. Stało się to prawdopodobnie dopiero po $1631 \mathrm{r}$. - dacie wprowadzającej główszczyznę 100 grzywien za zabójstwo chłopa. Nie wiemy, czy przypisać novum to wpływom stosunków miejskich, gdzie omawiane rozróżnienie znano już dawniej ${ }^{62}$, czy też $w$ uformowaniu się tej dystynkcji odegrały zasadniczą rolę tendencje, które doprowadziły do powstania glówszczyzny cywilnej, przeciwstawiającej wyraźnie taryfę męską (100 lub 120 grzywien) taryfie żeńskiej (50 lub 60 grzywien).

${ }^{60} \mathrm{O}$ pelnym poddaństwie w epoce nowożytnej K. Tymieniecki, Okresy w dziejach ludności wieśniaczej w Polsce średniowiecznej, [w:] Ksiega pamiqtkowa ku czci L. Pinińskiego, t. 2, Lwów 1936 , s. 317.

${ }^{61}$ Kutrzeba, Mężobójstwo, RAU, s. 140; tenże, Mężobójstwo, Czasop. Pr. i Ek., s. 263.

${ }^{62}$ Por. Z. Kaczmarczyk, [w:] Historia państwa $i$ prawa, t. 2, 190. Pół główszczyzny za kobietę zna też Prawda Ruska, Rafacz, Dawne prawo sqdowe, s. 458, przyp. 1. Istnieją wszakże systemy prawne, chroniące kobietę wergeldem podwójnym; tak bylo na Mazowszu, w prawie litewskim (Rafacz, op. cit., s. 458, 459, przyp. 1), jak i w prawie frankońskim (H. Brunner, Deutsche Rechtsgeschichte, t. 2, Berlin 1958, s. 797). 


\section{Chłopska glówszczyzna cywilna w Polsce*}

I. Problem. II. Ewolucja taksy cywilnej. III. Cechy charakterystyczne główszczyzny cywilnej. IV. Wartość ekonomiczna główszczyzny cywilnej. V. Glówszczyzna cywilna a karna. VI. Funkcja główszczyzny cywilnej. VII. Częstość transakcji i zasięg terytorialny główszczyzny cywilnej.

\section{Problem}

Glówszczyzna karna pochodzi z pradawnych czasów; na pewno odnieść ją można do okresu rodowo-plemiennego. Pobieral ją $w$ tym czasie zobowiązany do zemsty ród (rodzina) zabitego. W okresie feudalnym stara instytucja zemsty prywatnej i zastępującego ją okupu rozwija się bujnie. Wytworzenie się stosunku poddańczego nie pozostało bez wpływu na losy główszczyzny. Ponieważ poszkodowanym przez zabójstwo był wówczas nie tylko ród denata, ale $\mathrm{i}$ jego pan, dokonano podzialu wergeldu między te dwa czynniki, w proporcjach zresztą różnych ${ }^{1}$.

Jeśli dla rodziny (rodu) denata glówszczyzna stanowiła satysfakcję, która miała ułagodzić naturalne prawo zemsty krwawej, dla pana stanowiła ona odszkodowanie natury czysto cywilnej. Zabójstwo chlopa pomniejszało ludzki inwentarz dworu o jedną sztukę, za co należała mu się rekompensata pieniężna. Zaliczano ją do przychodów pańskich, jako casualia, podobnie jak inne nieperiodyczne świadczenia. Stąd, gdy przy zastawie nieruchomości zastrzegano, że pewne pożytki z dóbr nie pójdą do kieszeni wierzyciela, postanawiano wylączyć $m$. in. solucio homicidii ${ }^{2}$.

Skoro zabójstwo chłopa stanowilo dla pana szkodę czysto majątkową, nasuwała się możliwość podciągnięcia pod sankcję za zabójstwo straty identycznej dla seniora, choć nie połączonej z pozbawieniem życia poddanego: tej, która powstawala wskutek opuszczenia przez chłopa gruntu i przejścia do innego pana. Dla szlacheckiego państwa była to równa utrata sily roboczej, dlaczegożby więc nie żądać $i \mathrm{w}$ tej sytuacji satysfakcji pieniężnej?

* Przedruk z: Czasopismo Prawno-Historyczne 1964, t. 16, z. 1, s. 185-230.

1 J. Matuszewski, Glówszczyzna chlopska i szlachecka, K. H. 1964, z. 1, s. 17-26.

${ }^{2}$ SPPP, t. II, nr 1795; cytuje Z. Rymaszewski, Zastaw w świetle praktyki sqdów malopolskich $X V$ wieku, Zesz. Nauk. UŁ, Nauki Humanist.-Spol., S. I, z. 26, Łódź 1962, s. 118. 
A nie można sobie wyobrazić, by jakakolwiek strata pracowitego mogła być cięższa aniżeli powstała przez zabójstwo. O większym odszkodowaniu więc, aniżeli to, które świadczono w razie zupełnej likwidacji chłopa (pozbawienie go życia), nie było mowy. W tym kierunku poszła istotnie praktyka codzienna doby nowożytnej, acz nie bez pewnych wahań.

$\mathrm{Na}$ oba te odszkodowania - to znaczy płacone zarówno w razie zabójstwa poddanego, jak też w razie jego ucieczki - używają źródła jednego określenia: taxa capitis, a więc glówszczyzna. Zmuszeni - ze zrozumiałych względów - do przeprowadzenia między nimi rozróżnienia, pierwszą nazywać będziemy glówszczyznq karnq; dla drugiej nie znajdujemy trafniejszego określenia nad glówszczyznę cywilnq. Poslugując się nimi, oddajemy należny respekt terminologii źródeł, równocześnie zaś wprowadzamy wystarczające dla jasności wywodów distinguo.

Obie te instytucje niewątpliwie były związane w pewien sposób ze sobą, nie tylko terminologicznie; należą wszakże materialnie do różnych całkiem dziedzin życia prawnego. Wydaje się rzeczą niewątpliwą, że zakwalifikowanie penalne główszczyzny cywilnej nie znalazloby żadnego uzasadnienia; główszczyzna karna była przecież reakcją na zabójstwo, którego w drugim wypadku nie ma.

Brak dla tych dwu tak odmiennych taks rozróżnienia wyrazowego w źródlach jest wielce symptomatyczny dla prawnych poglądów naszych przodków. Świadczy o tym, że wspólcześni nie zdawali sobie sprawy z zaznaczonej dystynkcji, i to nie wyłączając nawet świata prawników ${ }^{3}$. A dzięki temu, że główszczyzna cywilna występuje w dokumentach, ujętych formalnie jako akty cesji poddanych, poczytali ją za cenę, a tym samym wspomniane transakcje za handel chłopami. Ujęcie takie $z$ pewnością nie grzeszy trafnością: nie bierze pod uwagę calego splotu zagadnień wiążących taksę cywilną $z$ karną. Nie chcemy tu wnikać w problem, w jakim stopniu ten przedrozbiorowy pogląd niejednego szlachcica zawdzięczal swe powstanie mniej lub więcej powierzchownej znajomości praw - polskiego i rzymskiego. Pamiętajmy, że niejeden $\mathrm{z}$ kontrahentów-szlachty podpisywał się piórem trzymanym (nr 525, r. 1791!). Czyż więc to dziwne, że do prawa polskiego, tworzącego się w głównej mierze - gdy chodzi o poddaństwo - drogą zwyczaju, przenoszono wzory pojęć prawnych, znajdywanych w antycznej kodyfikacji z okresu formacji niewolniczej, i wpychano weń zjawiska epoki feudalnej ${ }^{39}$, co prowadzić musiało do skrzywienia obrazu, jego zaciemnienia czy wręcz ukrycia instytucji, która tymczasem wystąpi z pełną wyrazistością.

${ }^{3}$ Por. J. Rutkowski, Poddanistwo wlościan w XVIII wieku w Polsce i niektórych innych krajach Europy, Poznań 1921, s. 63-64.

3a Por. naciągane wywody T. Dresnera o rzekomym podobieństwie prawa polskiego i rzymskiego w dziele Similium iuris Poloni cum iure Romano centuria una 1602; por. S. Kutrzeba, Historia źródel dawnego prawa polskiego, t. I, s. 278. 
Prawda, że i przedrozbiorowa publicystyka (zarówno Modrzewski, jak Leszczyński) - żeby się ograniczyć do nazwisk najgłośniejszych - nie wahała się pisać o sprzedaży chłopów i potępiać tej praktyki. Niebezpieczeństwo opierania się na prawnikach osiemnastowiecznych widzial J. Rutkowski; dla niego była też oczywista tendencyjność publicystyki ${ }^{4}$. Mimo to za sugestią interpretacyjną przedrozbiorową poszedł niejeden $\mathrm{z}$ współczesnych badaczy ${ }^{5}$. Najjaskrawsze sformułowanie znalazł ten pogląd w pracach J. Deresiewicza: dla ustalenia faktu sprzedaży, ,musi być obojętne [...], czy transakcji dokonano dla umoźliwienia zawarcia małzeństwa dwojga poddanych, dla zalegalizowania faktu zbiegostwa itp. Wystarczy, że pan feudalny oddaje drugiemu poddanego za określonym ekwiwalentem pieniężnym"6. Nie sądzimy, żeby ostatni warunek był wystarczający. Koncepcja handlu chłopami nie liczy się $\mathrm{z}$ brakiem tylu istotnych dla operacyj komercjalnych elementów. To uprawnia nas do zdecydowanego odrzucenia wspomnianej interpretacji.

J. Rutkowski - wiemy - z dużym niedowierzaniem odnosił się do prac prawniczych doby przedrozbiorowej, jak i do współczesnej publicystyki. Radził opierać się na materiałach archiwalnych jako jedynie miarodajnych? Odnosząc się z nieufnością do ich formuł prawnych, jak i całej terminologii, której brak należnej precyzji, idziemy o krok dalej; poszerzamy podstawę krytyczną wobec jednej kategorii źródeł więcej: literalna wykładnia dokumentów nowożytnych o prawnej treści wydaje się nie uzasadniona.

W naszym rozumieniu główszczyzna cywilna stanowiła kompromisowe rozwiązanie dwóch sprzecznych ze sobą, a silnych tendencyj: żywiołowego pędu migracyjnego chłopów $z$ jednej strony, chęci szlachty całkowitego przypisania chłopów do gruntu - $\mathrm{z}$ drugiej. Pierwsza, jako siła życiowa, nie dała się opanować; migracje chłopów ciągłe i masowe były faktem. Atoli pozycja szlachty $w$ Polsce przedrozbiorowej byla w stanie zadekretować całkowite skrępowanie poddanego. I to rzeczywiście zrobiła ${ }^{7 a}$. Wszakże nie

J. Rutkowski, Poddaństwo..., s. 8-9.

5 Ostatnio W. Dworzaczek pisze: „Były to najzwyklejsze w świecie sprzedaże” (Dobrowolne poddaństwo, Warszawa 1952, s. 6). Poprzednio już W. Kętrzyński, $O$ pierwotnym ustroju spolecznym $w$ Polsce, Ateneum, t. II, 1881, s. 476, przyp. 3 (incydentalnie); K. Zimmermann, Fryderyk Wielki $i$ jego kolonizacja rolna na ziemiach polskich, t. I, Poznań 1915, s. 145; J. Rutkowski, Poddaństwo wlościan..., s. 63; J. Bielecka, Kontrakty lwowskie w latach 1768-1775, Poznań 1948, s. 111-112; W. Rusiński, Straty i zniszczenia $w$ czasie wojny szwedzkiej oraz jej skutki na obszarze Wielkopolski, [w:] Polska w okresie drugiej wojny pólnocnej, 1655-1660, Warszawa 1957, s. 265, 301.

- J. Deresiewicz, Kilka uwag o poddaństwie chlopów w zwiqzku z transakcjami sprzedaży chlopów, K. H., t. LX, 1960, s. 90: za nim S. Grodziski, Ludzie luźni, Kraków 1961, s. 105, przyp. 23.

7 J. Rutkowski, o. c., s. 10.

7. Por. tu K. Tymieniecki, $W$ sprawie zaostrzonego poddaństwa w Polsce $i$ Europie środkowej, RH, t. 24, Poznań 1958, s. 290. 
była zdolna przeprowadzić swych własnych norm o przypisaniu chłopów. Rezultatem tych sprzecznych dążeń - naturalnego pędu kmieci do zmiany miejsca pracy i skrępowania ich prawnego - było wytworzenie się główszczyzny cywilnej. Niniejszy artykuł powstał z polemiki z poglądem o handlu chłopami.

Zasługę odkrywczą cywilnej strony główszczyzny przyznać należy J. Deresiewiczowi. Badacz ten najpierw w krótkim artykule, bogato ilustrowanym cytatami źródłowymi, zasygnalizował jej istnienie ${ }^{8}$. Następnie obszerną publikacją źródłową, zawierająca blisko 750 dokumentów, dowiódł jej egzystencji w sposób niezbity. Oto lakoniczna jego wypowiedź na ten temat, podana we wstępie do cennej edycji: „Remuneracja znana z donacyj odpłatnych i sprzedaży była również wyrażana $w \mathrm{mniej} \mathrm{wi} \mathrm{ęc} \mathrm{ej}$ stałej wysokości, przy czym powoływano się na istniejaca taksę. Najczęściej spotykana wys ok ość takiej taksy wynosi 60 grzywien za kobietę i 120 grzywien za mężczyznę"".

Przytoczony ustęp budzi pewne zastrzeżenia, którym wyraz daliśmy już gdzie indziej ${ }^{10}$. Wypowiedź o taksie jest $z$ calą pewnością trafna, gdy ją ograniczyć do stuleci XVII i XVIII ${ }^{10 a}$. Niewątpliwie obserwacje prof. Deresiewicza nie wyczerpują całego problemu główszczyzny cywilnej, jej ewolucji i roli, jaką odegrała w ustroju dominialnym, opartym na poddaństwie chłopów. Nie wyjaśniaja również jej genezy. Te zagadnienia pragniemy rozpatrzyć opierając się, w głównej mierze, na pomienionej źródłowej publikacji J. Deresiewicza.

\$ J. Deresiewicz, Kilka uwag..., s. 90 i n.; tenże, Handel chlopami w dawnej Rzeczypospolitej, Warszawa 1958. Ob. również tegoż artykuł o charakterze popularyzacyjnym: Sprzedaż chlopów, Wiedza i Życie, 24, 1957, s. 750-753, jak i wstęp do publikacji powołanej w przypisie następnym.

- Transakcje chlopami w Rzeczypospolitej szlacheckiej (w. XVI-XVIII), wyd. J. Deresiewicz, Warszawa 1959, s. VII. Pojawiły się recenzje tej publikacji: S. Grodziskiego, K. H., t. 66, 1959, s. 1270-1272, K. Orzechowskiego, Sobótka, t. 15, 1960, s. 80-82, i J. Matuszewskiego, RDSG, t. 22, 1960, s. 297-300. Zajęli się więc nią sami prawnicy, czego prof. J. Deresiewicz bardzo żałuje ( $W$ sprawie dwu wydawnictw $z$ dziejów wsi $i$ chlopów, KH, t. 67, 1960, s. 881). Tymczasem to zrozumiałe; jak bowiem podkreślono, publikacja jego przedstawia szczególnq wartość dla historyka prawa, mniejszą zaś dla historyka stosunków gospodarczych, spolecznych i kulturalnych (K. Orzechowski, O wladztwie pana feudalnego wobec uzależnionych od niego chlopów, CPH, t. XII, z. 2, 1960, s. 283). Mimo to ekskuzujemy się przed nim z niniejszej rozprawy.

10 Por. recenzje, powołana $\mathrm{w}$ przypisie poprzednim oraz komunikat: $C z y$ handlowano chlopami w Rzeczypospolitej szlacheckiej? Spraw. Wroc. TN, 1960, s. 71-74.

${ }^{100}$ Wydaje się, że podobnie rozumiał rzecz już wcześniej T. Korzon. Cytując (za Hoischem) niemiecka Auffahrt, opłatę przy przenoszeniu do innego pana (Wewnętrzne dzieje Polski za Stanislawa Augusta, wyd. 2, t. I, s. 357, przyp. 1), przytacza zaraz poiska takse 30 i 100 grzywien (s. 358). Jak zobaczymy $w$ dalszych wywodach, główszczyzna cywilna różni się zasadniczo od średniowiecznego wstanego. 


\section{Ewolucja taksy cywilnej}

Główszczyzna cywilna pozostaje w związku genetycznym, jak i rozwojowym $z$ główszczyzną karną. Dlatego przypominamy tu pewną charakterystyczną dla zadośćuczynienia karnego cechę. System polski brał w rachubę przy obliczaniu glówszczyzny karnej wartość glowy denata ${ }^{11}$. Ten fakt stanowi podstawę wspomnianej lączności taksy cywilnej z karną.

W rozwoju główszczyzny karnej, jak wiemy, wyróżnić można trzy etapy: do 1581 r.; 1581-1631; 1631-1795. Zbadajmy, jak w tych samych okresach kształtowała się główszczyzna cywilna.

1. Do 1581 r. U podstawy tego okresu leżą sankcje statutu małopolskiego. Thumaczony na język polski, upowszechnił zawarte $w$ nim postanowienia na caly kraj. Z początkiem XVI w. karna taksa chłopska wynosiła w całej Polsce 10 grzywien. W tej wysokości utrzymała się ona do $1581 \mathrm{r}$. Wyraźnego transponowania tej główszczyzny karnej na cywilną dokonała Formula processus z 1523 r. Mianowicie w formule pozwu o zbieglego kmiecia pomieściła ona postanowienie, że powód ceni zbiega na 10 grzywien, tj. tyle, ile wynosił okup za glowę zabitego ${ }^{12}$. Taką taryfę potwierdza też konstytucja z 1543 r., nakazująca zwrot zbieglych poddanych: ...et non poterit illum kmethonem redimere decem marcis pecuniae vel ulla alia summa ${ }^{13}$.

Postanowienie Formula processus, rozciągające wyraźnie główszczyznę karną na wynagrodzenie za zbieglych poddanych, nie było wszakże nowością. Faktycznie działo się tak już wcześniej, jak o tym świadczą dobitnie akty z 1513 r. W jednym z nich Goryński, domagając się zwrotu chłopa violenter recepti, oświadcza, że przeciwnik jego nie dokonal tego, prout hodie dare et restituere debuit, aut pro eodem Stanislao praefato 10 marcas pecuniarum dare et solvere ( $\mathrm{nr} 462$; niemal identycznie $\mathrm{nr} 461)^{14}$.

Zestawienie taks placonych faktycznie $w$ rozpatrywanym okresie przedstawia się następująco ${ }^{15}$ :

"Por. pozycję, wymienioną wyżej w przyp. 1; tam również szczegółowe uzasadnienie ram chronologicznych główszczyzny karnej.

12 Pro eo, quia tu non vis sibi extradere laboriosum $N$., kmethonem ipsius de villa $N$., ad villam tuam $N$. profugum, quem apud te in villa tua praefata $N$. arestavit per ministerialem terrestrem $N$. de $N$., quem sibi pensat ad decem marcas et totidem damni, Corpus iuris Polonici, ed. O. Balzer, t. IV, cz. 1, s. 66, punkt 97. Por. M. Bobrzyński, Karta z dziejów ludu wiejskiego, [w:] Szkice i studia historyczne, t. I, Kraków 1922, s. 209.

${ }^{13}$ VL, t. I, s. 575; M. Bobrzyński, o. c., s. 209.

${ }^{14}$ Numery w tekście odsyłają do Transakcji J. Deresiewicza.

is Zaznaczamy z góry, że nie uwzględniamy aktów dotyczących kmiecia-posesjonata. Nie jesteśmy bowiem w stanie wyliczyć, jaka kwota przypada na nieruchomość, jaka na glówszczyznę, np. $\mathrm{nr} 483$, r. 1592. 
6 grzywien (1502 r., $\mathrm{nr} 214$ )

10 grzywien (1505 r., nr 217)

(1513 r., $\mathrm{nr} 461$ )

(1513 r., nr 462)
10 grzywien (1544 r., nr 218)

30 grzywien (1567 r., $\mathrm{nr} 8$ )

10 grzywien (1575 r., $\mathrm{nr} 701$ )

17 grzywien (1577 r., nr 539)

$\mathrm{Z}$ powyższego widać, że kwota 10 grzywien występuje najczęściej, ale nie wyłącznie. Jeden wypadek taksy 6 grzywien, stwierdzony dla 1502 r., zgodny jest $\mathrm{z}$ główszczyzną karną wielkopolskiego statutu Kazimierza Wielkiego. Kwota 30 grzywien z 1567 r. wyprzedza o kilkanaście lat taryfe okresu następnego. Ponieważ liczba przekazów w ogóle, jaką dysponujemy, wydaje się zbyt mała, by na tej jedynie podstawie uznać taksę 10 grzywien za regułę - choć ona przeważa zdecydowanie (5 wypadków na 8 ) - rozejrzyjmy się za dodatkowymi argumentami, które nas do tego upoważniają.

a. Akt z 1544 r., wzmiankujący taksę $10 \mathrm{grzywi}$ en, powołuje się na decretum castrense Calissiense ( $\mathrm{nr} 218$ ). Dla sądu więc ta wysokość uchodzi za prawną.

b. W kilku wypadkach udzielono pożyczki w wysokości $10 \mathrm{grz}$ y wi en pod zastaw chłopa (nr 459, 1509 r.; nr 466, 1522 r.; nr 472, 1531 r.; nr 225, 1546 r.; nr 234, 1554 r.; nr 244, 1564 r.); musiał on widocznie uchodzić za wystarczające zabezpieczenie wierzytelności ${ }^{16}$.

c. W 1567 r. (nr 248) wynajmuje się kmiecia na trzy lata za cenę trzech grzywien, czyli za jedną grzywnę rocznie. Jest to wysokość rocznego czynszu chłopskiego z łanu (nr 234, 1554 r.). Kwota $10 \mathrm{grzy}$ wien stanowiłaby zatem skapitalizowaną rentę za okres 10 lat.

d. W akcie z 1562 r. ustalono $\mathrm{w}$ wysokości $10 \mathrm{grzy}$ wien vadium, platne $w$ razie niewydania kmiecia (nr 243$)^{17}$.

Zebrane informacje ustawowe, jak i zestawione konkretne przykłady płaconych kwot, muszą uchodzić za wystarczające dla umocowania tezy, że

${ }^{16}$ Ten argument dość względny, bo zastawiano faktycznie czynsz chłopski (...inscribunt et obligant laboriosum Petrum Szaczek [...] cmethonem suum, una cum censu marcae unius [...] absque tamen laboribus et oneribus, nr 234, r. 1554). Wolno jednak dopatrywać się jakiegoś związku między płaconym przez kmiecia czynszem a chłopską główszczyzną karną, ob. J. Matuszewski, Glówszczyzna...

${ }^{17}$ Powołajmy też informację małopolskich zapisek sądowych z końca XV w. Chłopa spornego oddaje się w opiekę osoby trzeciej, ustanawiając vadium w wysokości 10 grzywien (SPPP, t. II, nr 4325). Też zapiski podają najczęściej pretensje, powstałe z powodu wychodu kmieci, w wysokości 10 grzywien (SPPP, t. II: nr 4316, 4318 r. 1487; nr 4331 r. 1488; 4345 r. 1489). Prawda, występują i kwoty wyższe, 20 grzywien (SPPP, t. II, nr 4310, r. 1486), 30 grzywien (ibidem, $\mathrm{nr}$ 4376, 4378, r. 1491), czy nawet 40 grzywien (ibidem, nr 4315, r. 1487). Jednak nie wolno ich uznać za miarodajne. Kwota 20 grzywien dotyczy młynarza, który uciekł non expectans tempus sunm, czym spowodował tak wysoką szkodę. A już bardzo charakterystyczna jest wiadomość dotycząca 30 grzywien: przeciwnik zarzuca powodowi, że taxavit hominem ad triginta marcas contra laudum et statuta Regni; et trahebat se ad statuta - Et interrogabitur, si est iuridica taxa vel von ( $\mathrm{nr} 4378, \mathrm{r} .1491$ ). Czyż to nie powołanie się na taryfę statutów kazimierzowskich (w wersji małopolskiej)? 
w okresie do 1581 r. główszczyzna cywilna, ustawowa i zwyczajowa, pokrywała się z główszczyzną karną; wynosiła ona zatem, jak tamta, 10 grzywien. Prawda, istnieje od niej niejedno odstępstwo. Charakterystyczne jednak, że stawki różne od kwoty 10 grzywien nie są jednolite.

2. 158 1-1631. Jak wiemy, konstytucja z 1581 r. podniosła główszczyznę chłopską do wysokości 30 grzywien. $Z$ pięćdziesięcioletniego okresu jej obowiązywania posiadamy niewielką liczbę przykładów na główszczyznę cywilną:

$\begin{array}{ll}20 \text { grzywien } & (1601 \text { r., nr 282) } \\ 30 \text { grzywien } & (1604 \text { r., nr 492) } \\ & (1623 \text { r., nr 558) }\end{array}$

Wszakże $i$ ona upoważnia do stwierdzenia, że taryfa cywilna poszła w ślad za główszczyzną karną, skoro osiagnęła wysokość 30 grzywien.

3. $1631-1795$. Konstytucja z 1631 r. podniosła satysfakcję karną za zabójstwo chłopa do wysokości 100 grzywien. $Z$ tego okresu pochodza wyraźne wzmianki o tym, że zadośćuczynienie cywilne jest znowu takie samo, jak główszczyzna karna: accepta plenaria satisfactione ad mentem legis pro taxa capitis (1784 r., nr 356); za zupelnq ugodq $i$ satysfakcyjq taxae capitis (1766 r., nr 439, dok. 2). Takież znaczenie tkwi w wyrażeniach następujących: de persoluto pretio ad mentem legis i niżej ad mentem legis satisfactionem (1741 r., $\mathrm{nr} 682$ ); ob sufficientem [...] pro iisdem subditis vigore legis praestitam satiisfactionem (1743 r., $\mathrm{nr} 607)$; praevia subsequenda recompensa taxae ad mentem legis (1776 r., $\mathrm{nr} 350$ ); gdy ugoda zaszla $i$ podlug prawa taksujqca za czleka tegoż satysfakcyja pieniezżna nam jest zaspokojona (1778 r., nr 635); podlug prawa zaplacić bẹda powinni (1781 r., nr 353); a podiug prawa koronnego na takse [...] zezwolili; [...] co do tych ludzi dwóch podiug prawa otaksowanych (1784 r., nr 649). Sądzić wolno, że zwroty te powolują się bądź na taryfę 100 grzywien, ustaloną w 1631 r., za czym przemawia niedwuznacznie dokument z 1779 r.: podlug taksy prawa 100 grzywien (nr 637), albo na zwyczajową taksę 120 grzywien, o której niżej. $\mathrm{Z}$ kwotą 100 grzywien spotykamy się rzeczywiście w kilku wypadkach:

$$
\begin{aligned}
& 1633 \text { r., nr } 301 \text { - pow. kaliski } \\
& 1647 \text { r., nr } 504 \text { - pow. koniński } \\
& 1678 \text { r., nr } 728 \text { - pow. nakielski } \\
& 1700 \text { r., nr } 333 \text { - pow. kaliski } \\
& 1745 \text { r., nr } 686 \text { - pow. kcyński }
\end{aligned}
$$

${ }^{18}$ Polowa kmiecia wspólnego wynosi $100 \mathrm{fl}$, wszakże cum domo sive taberna [...] dum etiam cum horto et allodio (r. 1590, $\mathrm{nr} 266$ ). 
Nieraz wystąpi jej równowartość w złotych polskich, dokładna, tj. 160 złp:

1678 r., nr 728 - pow. nakielskj

1778 r., nr 636 - pow. gnieźnieński

lub przybliżona, zaokrąglona:

1723 r., nr 63 - pow. poznański (150 złp = 93,75 grz.)

1745 r., nr 685 - pow. kcyński (150 złp)

A zatem istnieje taksa cywilna wedhug prawa w tej samej wysokości co glówszczyzna karna, a wynosi ona 100 grzywien. Nie jest ona wszakże wyłączna.

Inne bowiem akty podają jako prawną taryfę kwotę 120 grzywien: domagający się zwrotu poddanego chce się ...i okupnem kontentować we dlug p raw a za chlopa 120 grzywien (1731 r., nr 341, pow. kaliski). Według aktu z 1781 r., wystawca jego odebrał 120 grz., oświadczając: z których kwituje $w$ taksie kwotę (nr 640, pow. gnieźnieński). Tę samą stawkę podają akty z $1750 \mathrm{r}$. ( $\mathrm{nr} 79$, pow. poznański; nr 618, pow. gnieźnieński ${ }^{18 a}$ ), $1755 \mathrm{r}$. (nr 693, pow. kcyński). Do nich dołączyć należy też informacje określające taksę we florenach czy zlotych polskich w okrąglej kwocie $200(=125$ grzywien): 1644 r., nr 39, pow. poznański; 1686 r. nr 51, pow. poznański; 1784 r., 649, pow. gnieźnieński - dwóch chłopów za 400 zlp. Zanotowaliśmy też dwa wypadki, w których nastąpiły donacje chłopa $\mathrm{z}$ rodziną za dług w wysokości 200 złp: 1636 r., nr 718, pow. nakielski; 1737 r., nr 602, pow. gnieźnieński. Wreszcie nie sposób nie przytoczyć tu przykładu z kwotą pośrednią, zbliżoną raczej do taksy wyższej: $180 \mathrm{złp}=112,5$ grz., r. 1635 , nr 317, pow. kaliski. Co więcej, źródła notują, że inne pretensje powstałe odnośnie do chłopów sąd szacuje również na 120 grzywien: pro angarisatione subditorum [...] et diversione in alia bona laborum eorum, 1758 r., $\mathrm{nr} 519$. Taką też kwotę (w zaokrągleniu do 200 florenów polskich) zawiera wzór na venditio subditi, podany przez Nixdorffa ${ }^{18 b}$.

Zestawione przykłady nie przesądzają tego, która kwota znajdowała szersze zastosowanie: ustawowa - wedhug konstytucji z 1631 r. - 100 grzywien, czy zwyczajowa, niewiele zresztą od niej odbiegająca, a równająca się połowie główszczyzny szlacheckiej - 120 grzywien. Rozstrzygnięcie tej trudności umożliwi nam dopiero zbadanie wysokości taksy kobiecej.

Omawiając glówszczyznę karną, stwierdziliśmy za S. Kutrzebą, że uiszczono ją w tej samej wysokości i za mężczyznę, i za kobietę ${ }^{19}$. Natomiast omówione wyżej taksy 120 i 100 grzywien dotyczyły tylko chłopów-mężczyzn. Za kobietę-chłopkę płacono kwotę inną.

\footnotetext{
${ }^{18 a}$ Wynik odejmowania: $180 \mathrm{grz} .-60=120$.

18b Przedruk u L. Pauliego, Jan Nixdorff, 1625-1697, Warszawa 1957, s. 81-82.

19 Por. artykuł Glówszczyzna chlopska i szlachecka, s. 142.
} 
Istnienie osobnej taksy żeńskiej $w$ trzecim okresie poświadczają źródła w sposób niewątpliwy: odebralem [...] satysfakcyja pienięzinq prawem za kobiete oznaczonq (1771 r., $\mathrm{nr} 440)$; podlug prawa za kobiete (1782 r., nr 354); oplata za żone secundum taxam prawa (1743 r., nr 608), podobnie w 1750 r. (nr 618); sąd zmusił tych, którzy przyjęli zbiegłą do oplaty [...] podlug prawa (1783 r., $\mathrm{nr} 645)$. Wynosi zaś ona wedlug prawa za chlopa 120 grzywien, za kobiete - 60 (1731 r., nr 341); ad mentem taxae capitis muliebris 60 grzywien $w$ zlocie (1741 r., nr 681); wiesz WWMP Dobrodziej, co za bialoglowskq pleć, za jedne należy ze grzywien 60 (1742 r., nr 342); secundum taxam prawa za te kobiete grzywien 60 (1743 r., nr 608); wedlug prawa grzywien 60 (1745 r., nr 684); spod taksy 60 grzywien wypuszczam (1784 r., $\mathrm{nr} 649)$; tak też $\mathrm{w}$ akcie z 1750 r. $(\mathrm{nr} 618)^{20}$.

$\mathrm{Na}$ taką wysokość taksy kobiecej powołuje się trybunal piotrkowski (1723 r., nr 61) i sąd kaliski: ob sufficientem et plenariam sibi pro taxa ejusdem subditae satisfactionem marcarumque 60 Polonicalium iuxta praeiudicata iudicii terrestris Calissiensis (r. 1725, $\mathrm{nr}$ 670). Wreszcie poświadczają ją mnogie akty praktyki, informujące o pobieraniu za kobietę 60 grzywien bez powołania się na taksę obowiązującą: nr 115 (1725 r.), 69 (1729 r.), 674 (1737 r.), 615 (1749 r.), 617 (1749 r.), 621 (1755 r.), czy też 90 złp, nr 651 (1789 r.).

Obok taksy kobiecej, wynoszącej 60 grzywien, współcześnie występuje druga, niższa o 10 grzywien: za takse p rawem op is an q, to jest grzywien 50 wyplaconych $(1779 \mathrm{r}$., $\mathrm{nr} 520)$. Na tę kwotę opiewa też jeden wyrok sądowy (1758 r., nr 519). Poświadczają ją dwa dalsze przykłady: nr 519 (1758 r.), nr 360 (1786 r.).

Jak przy mężczyznach istniały dwie taksy, 100 i 120 grzywien, tak i za kobiety znane są połowy kwot powyższych, 50 i 60 grzywien. Jeśli przy taksie męskiej nasuwały się wahania co do tego, która $\mathrm{z}$ nich przeważala, taksa kobieca liczbą reprezentowanych przykładów przechyla stanowczo szalę na rzecz główszczyzny wyższej, sześćdziecięciogrzywnowej. Tę zatem musimy uznać za podstawową. Taksa ustawowa najwidoczniej ustąpiła jej miejsca, utrzymując się jedynie sporadycznie.

Zestawione teksty poświadczają dla ostatniego okresu istnienie glówszczyzny cywilnej w wysokości 100 czy 120 grzywien za mężczyznę oraz 50 lub 60 grzywien za kobiete. Nie zawsze jednak trzymano sį tych taks, jak to unaoczni zestawienie innych satysfakcji, różnych od taksy. Oto plon dotyczący odstępstw od taksy męskiej:

${ }^{20}$ Znowu wynik operacji odejmowania: 180 grz. $-120=60$ grz. 
45 grz. (72 zlp), 1633 r., nr 497

65 grz. (104 ztp), 1634 r., nr 315

60 grz. (96 zhp), 1635 r., nr 316

$130 \mathrm{zlp}, 1649$ r., nr 725

$130 \mathrm{zhp}, 1687$ r., nr 52

$120 \mathrm{złp}, 1696$ r., nr 332 (młynarz)

30 czerw. węg. (540 ztp), 1733 r., nr 738

$320 \mathrm{zlp}, 1734 \mathrm{r}$., $\mathrm{nr} 673^{21}$

80 grz. (128 złp), 1741 r., $\mathrm{nr} 73$

$150 \mathrm{zlp}, 1745$ r., nr 685

200 grz. (320 złp), 1749 r., $\mathrm{nr} 614^{22}$

150 grz. (240 złp), 1765 r., nr $698^{23}$

$1000 \mathrm{fl}, 1776 \mathrm{r.}, \mathrm{nr} 350^{24}$

288 złp, 1789 r., nr 456

$Z$ danych tych widać, że odstępując od taksy legalnej, najczęściej godzono się na kwotę niższą, rzadziej wyznaczano wyższą. Dodajmy jeszcze, że wielokrotnie występują cesje gratisowe, donacje nieodpłatne - jak je nazywa J. Deresiewicz, a więc takie wypadki, w których satysfakcja spadła do zera.

Znacznie mniej odstępstw znaleźliśmy od taksy kobiecej. Akt z 1789 r.

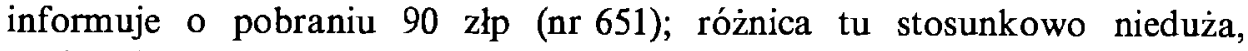
zaokrąglono satysfakcję w dól, kontentując się wspomnianą kwotą zamiast należnych 96 złp. Nie stanowi prawdopodobnie odstępstwa od reguły kwota $126 \mathrm{zlp}$, wymieniona w akcie z 1785 r. (nr 357). Domyślać się bowiem wolno w niej taryfy za poddaną w wysokości legalnej $96 \mathrm{zlp}$ oraz $30 \mathrm{zlp}$ za pretensyje do zbiega, którego strona zwraca prawowitemu właścicielowi.

Odstępstwa od taksy nie mogą nas zdumiewać. Są one oczywiste, skoro obracamy się $\mathrm{w}$ sferze prawa cywilnego. Istniała zawsze możliwość porozumienia się co do takiej, czy innej satysfakcji. W wypadkach redukcji, czy podwyższenia, w rachubę wchodziły najwidoczniej względy, których dziś nie znamy, ale które dla zainteresowanych stron posiadały istotną wartość. Odstępstwa od cywilnej główszczyzny są tym bardziej zrozumiałe, gdy zważymy, że zdarzały się one również w wypadkach główszczyzny karnej ${ }^{25}$. Prawna taksa wystąpi tam, gdzie strony toczą $\mathrm{z}$ sobą spór; ugodą mogły ustalić, co chciały, satysfakcję w wysokości taksy, albo jakąkolwiek inną, czy nawet $\mathrm{z}$ niej zrezygnować zupełnie. Mówi o tym dobitnie jeden $\mathrm{z}$ aktów: ...quia complanatione, non iure terrestri et officiose donatus praefatus laboriosus Mathias (r. 1740, nr 676). Tẹ swobodę umów poświadcza też cytowany niżej

\footnotetext{
${ }^{21}$ Do podanej kwoty doliczono wartość 300 mszy.

${ }^{22}$ Ponadto donatorka wzięła już przedtem 12 czerwonych złotych i zboże różnego gatunku.

${ }^{23}$ Chłop z żoną lącznie.

${ }^{24}$ Chłop łącznie z żoną: w kwocie podanej mieści się zwrot zapłaconej dawniej taksy kobiecej.

2s J. Rafacz, Dawne polskie prawo karne, Warszawa 1936, s. 459.
} 
akt z r. 1742 (nr 342); według niego, za jedną kobietę należy się 60 grzywien, ale w wyniku pertraktacji strony godzą się na sume $150 \mathrm{zlp}$, tj. 93,75 grzywien, za trzy kobiety - matkę z dwiema córkami ${ }^{26}$. W wolności kontraktów znajdzie też wystarczające uzasadnienie zamiana „dziewki” na „,chłopca ratajskiego" (nr 736, r. 1727), czy chlopa na kobietę (nr 89, r. 1782), albo pary małżeńskiej na dwie dziewczyny (nr 630, r. 1775). Wszędzie tu w rekompensate idzie glowa za głowę, choć żeńska nierówna męskiej. Tu również znajda wyjaśnienie fakty zamian kilku poddanych za jednego chłopa (nr 500, r. 1642; nr 350, r. 1776), zbiegłego młynarza z żoną na trzynastoletniego chlopaka ( $\mathrm{nr} 400, \mathrm{r}$. 1638).

Nie zawsze zresztą kwoty wymieniane $w$ dokumentach stanowią satysfakcje rzeczywistą za chłopa, wyższą czy niższą od ustawowej. Nie są nimi $\mathrm{z}$ pewnością roszczenia zgłaszane w sądach. I tak z racji niewzdania kowala Jerzego liczy sie taxae 500 marcarum Polonicalium. Objęte są jednak nią nie tylko żona i dzieci, nie tylko instrumenta ad artem ferrifabrilem pertinentia, lecz także kwota poenarum luitarum; co więcej, spór toczy się jeszcze o dwu innych poddanych (1644 r., nr 722). Suma 500 grzywien nie jest więc rzeczywistym zadośćuczynieniem, lecz roszczeniem w wysokości maksymalnej, dopuszczonej przez prawo ${ }^{27}$. W pięc lat później wystawiony akt zawiera również tę samą kwotę 500 grzywien. Wszakże znowu chodzi w nim nie tylko o zbiegłego piwowara, będącego przedmiotem sporu; okazało się, że pozwany przyjął zbiega, ale nie chciał go wydać, faciens praemissa in grave damnum eiusdem actoris et praeeiudicium non mediocre, quod is contra te pensat ad 500 marcas pecuniarum Polonicalium. Co więcej, okazuje się, że tenże piwowar zostal cedowany powodowi za 130 florenów! W akcie z $1621 \mathrm{r}$. podana została cena 200 grzywien za wychowanka Marcina (nr 556). Atoli akt podaje ze szczególami okoliczności, wśród jakich roszczenie powstało: ...tempore, quo ipse actor divinis officiis in templo, in oppido Kiszkowo, vacabat, superveniendo cum famulis in curiam Lubowice Minoris tenutae ipsius actoris, ibidemque laboriosum Martinum, alumnum [...] sua privata auctoritate nullo iure ad id habito, violenter inde accepit et ad bona sua villae Karczewo deduxit in grave damnum et praeiudicium actoris,

${ }^{26}$ Por. niżej s. 160 .

${ }^{27} \mathrm{Ob}$. art. 91 konstytucji z 1588 r. (VL, t. II, s. 1243). Na nią powołuje się późniejsza, z 1613 r. (VL, t. III, s. 182, art. 75). Por. M. Bobrzyński, Karta..., s. 210. Brzmienie wspomnianego art. 91 jest nastepujące: „Moderując nad shuszność wyniosły szacunek zbiegłych chłopów, postanawiamy, aby żaden nie kład w pozwie większej taxy o poddani zbiegłe, kładąc w to żonę, dzieci et omnem supellectilem, nad pięćset grzywien polskich sub nullitate totius actus". Temu to limitowi odpowiada akt nr 389 (r. 1615). Kwota istotnie wysoka w porównaniu z glówszczyzną cywilną. Taksę procesową za zbiega w wysokości 500 grzywien poświadcza jeszcze konstytucja z 1683 r. (VL, t. V, s. 671). Uległa one wszakże w niektórych województwach zdwojeniu: w bełskim i wołyńskim w r. 1661 (VL, t. IV, s. 704), w podolskim w 1699 r. (VL, t. VI, s. 63). 
aestimationis 200 marcarum. Sytuacja podobna zatem do tej, w której wystawiono akt poprzedni. Wczesny akt z 1568 r. poświadcza wysoka satysfakcję 400 zlp za chłopa, a więc 250 grzywien (nr 252). Już w regeście podaje wydawca, że przedmiotem transakcji jest chłop z całym mieniem ruchomym i nieruchomym. Nieruchomości jego obejmują 1,5 lana. Podana wysoka kwota mieści więc w sobie również wynagrodzenie za wartość gruntu. Zgodnie zatem $\mathrm{z}$ naszymi założeniami, usuwamy ten akt $\mathrm{z}$ rozważań. Chłop, co do którego pretensja wynosi 900 złp (562,5 grz.), zbiegł cum rebus variis curae illius commissis, modo furtivo, nocturno tempore; jest wśród skradzionych panu rzeczy i wóz (r. 1681, nr 46). Następujące dokumenty podaja, że wymienione w nich kwoty 100 grzywien (nr 371, 539), 50 grzywien (nr 372) lub 30 grzywien (nr 373) nie stanowią satysfakcji za chlopa, lecz taksę procesową. W akcie nr 539 taksę procesową w wysokości 100 grzywien przeciwstawiono wyraźnie zadośćuczynieniu 17 grzywien za chłopa.

Zauważmy, że w podanych przykładach powód szacuje sobie swoją pretensję aestimatio (nr 371), quem sibi pensat ad 30 marcas pecuniarum (nr 373). Nie znaczy to jeszcze, żeby kwotę żądaną sąd mu przyznawal. Zrozumiałe zaś, że strona szacowała sobie wysoko szkodę, powstałą occasione non restitutionis laboriosi (nr 373). Dorzućmy jeszcze, że w jednym $\mathrm{z}$ powolanych tekstów powód równocześnie zgłasza roszczenia o non administrata iusticia (nr 372).

Wreszcie zauważmy, że żądania wyższych kwot, znane nam $\mathrm{z}$ okresu pierwszego, pojawiają się pod sam jego koniec (1566-1567). Podobnie jest i z zastawami, dla których gwarancje stanowi kmieć: 20 grzywien - 1566 r., nr 480; 100 złp - 1579 r.

Wiemy, że główszczyznę w wysokości 100 grzywien wprowadziła konstytucja z $1631 \mathrm{r}$. Kiedy pojawila się taksa 120 grzywien? Zestawione wyżej teksty poświadczają istnienie jej już w 13 lat po ukazaniu się wspomnianej konstytucji (1644 r., nr 39). Omawiana w następnym zdaniu informacja o taksie kobiecej pozwoli nam cofnąć ją o dalsze dziewięć lat. Mianowicie dla taryfy kobiecej w kwocie 60 grzywien daje przykład jeszcze wcześniejszy akt z 1635 r. (nr 321). Skoro w tym czasie znano już połowę główszczyzny męskiej, wynosząca 60 grzywien, to istnienie pełnej taryfy 120 grzywien dla mężczyzn jest ewidentne. Z $1644 \mathrm{r}$. datuje się drugi dowód na pobieranie tej właśnie taryfy (nr 322); ponieważ główszczyznę wyrażono w złotych polskich, podano znowu cyfrę zaokrągloną: $100 \mathrm{złp}$ zamiast $96 \mathrm{złp}$, a więc faktycznie 62,5 grzywny. Zatem obie taryfy, ustawowa (100 grzywien) i zwyczajowa (120 grzywien), pojawiają się w źródłach niemal współcześnie.

W przedstawionym wyżej zestawieniu zwracaliśmy uwage na miejsce pochodzenia aktu. Wynika $\mathrm{z}$ niego, że istnienia dwu taryf nie można wyjaśnić względami regionalnymi, albowiem w jednym i tym samym powiecie sądowym spotyka się obie taksy. 
Główszczyzna cywilna uległa dyferencjacji w zależności od pkci: taksa kobieca jest o polowe niższa od taksy męskiej. Tego rozróżnienia nie znała główszczyzna karna ${ }^{28}$. Niełatwo jest uchwycić moment chronologiczny pojawienia się tego zróżnicowania. Powołaliśmy wyżej akt z r. 1635 jako pierwszy wypadek zmniejszonej do połowy taksy kobiecej. Czyżby nie znano jej w okresach poprzednich, kiedy taksa chłopska wynosiła 10 czy - później - 30 grzywien? Czy pojawiła się ona dopiero $\mathrm{z}$ chwilą podniesienia główszczyzny karnej konstytucją z 1631 r. z 30 na 100 grzywien? Jest rzeczą charakterystyczną, że $\mathrm{z}$ okresu przed tą datą nie znamy na nią żadnego przykładu. Co więcej, z początkiem XVI w. opłata za zbiegłą kobietę jest taka sama jak za mężczyznę, wynosi 10 grzywien (1513 r., nr 461). Może rozszerzenie kwerendy źródłowej na inne dzielnice dostarczy materiału, który pozwoli na konstatacje pewniejsze.

Przeprowadzona analiza upoważnia do ułożenia następującego schematu rozwojowego główszczyzny cywilnej: w pierwszym okresie - tj. do roku 1581 - taksa cywilna wynosi 10 grzywien, w drugim - lata 1581-1631 - 30 grzywien, w trzecim - lata 1631-1795, nastąpiło rozróżnienie, którego nie znały okresy poprzednie, a mianowicie obowiązywała inna taksa za mężczyznę, inna za kobietę. Pierwsza wynosi 100 lub 120 grzywien, druga - 50 lub 60 grzywien. Okazało się więc, że taryfa cywilna jest taka sama, jak karna. Identyczność ich, jak i zgodność pod względem chronologicznym unaoczni zestawienie.

\begin{tabular}{|c|c|c|}
\hline Podstawa prawna & Data & 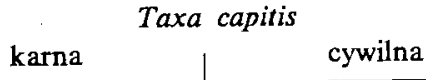 \\
\hline $\begin{array}{l}\text { Statut małopolski Kazimierza } \\
\text { Wielkiego } \\
\text { Konstytucja } \\
\text { Konstytucja } \\
\text { Zwyczaj }\end{array}$ & $\begin{array}{l}\text { XIV w. } \\
1581 \mathrm{r} . \\
1631 \mathrm{r} . \\
\text { najpóźniej } 1635 \mathrm{r} \text {. }\end{array}$ & 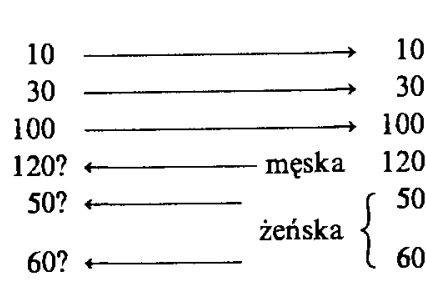 \\
\hline
\end{tabular}

Przy obecnym stanie badań monograficznych nie możemy stwierdzić, czy kwota 120 grzywien miała swój zwyczajowy odpowiednik karny, jak też czy ściągano za zabójstwo kobiety grzywnę o połowę niższą od męskiej. Parusetletnia zgodność rozwojowa obydwu taryf przemawia za odpowiedzią twierdząca.

Kierunek zależności główszczyzn jest niewątpliwy; główszczyzna karna była wzorem dla cywilnej. Tak było $\mathrm{z}$ cała pewnością jeszcze przez pierwszą połowę

${ }^{28}$ Taksę kobiecą o połowę niższą od męskiej znano w miastach, Z. Kaczmarczyk, Historia państwa o prawa, t. II, Warszawa 1957, s. 190. 
XVII stulecia. W dalszym ciągu, według wszelkiego prawdopodobieństwa, nastąpiło odwrócenie tej zależności. Glówszczyzna cywilna, nieskończenie częstsza, zepchneła w cień główszczyznę karną, uniemożliwiła dalszą jej ewolucję; co więcej, jak się domyślamy, wpłynęła na podwyższenie taryfy karnej do 120 grzywien, jak i na ukształtowanie się osobnej taxa muliebris w wysokości połowy męskiej.

\section{Cechy charakterystyczne glówszczyzny cywilnej}

W przedstawionej ewolucji główszczyzny cywilnej widoczna jest zgodność z rozwojem główszczyzny karnej. W badanym przez nas okresie trzech stuleci taksa cywilna trzyma się wyraźnie ustaleń glówszczyzny karnej. Wszakże podobieństwa obu taryf nie ograniczają się do tej tylko konkordancji.

Główszczyznę cywilną uiszcza się bez uwzględnienia kondycji fizycznej cedowanego chłopa. Według aktu z $1741 \mathrm{r}$. przedmiot transakcji stanowią trzej bracia: Walenty, Stanisław i Piotr Wojciechowscy. Pro capitibus supra expressorum laboriosorum zaplacona została ad mentem legis satisfactio. Jeden zaś $\mathrm{z}$ tych rodzeństwa jest surdus et mendicus ( $\mathrm{nr} 682$ ). W innym wypadku sprzedaje się postrzelonego Sebastiana Ciszaka: ...do tego ten czlowiek prędszq kuracyja ręki postrzelonej mieć może (nr 609, 1746 r.). Szacunek głowy pozostaje więc nie zmieniony, wady fizyczne chłopa są obojętne. Trudno więc zgodzić się ze zdaniem prof. Deresiewicza, jakoby „wartość pieniężna poddanych byla niewątpliwie uwzględniona w cenie określonej kontraktem kupna-sprzedaży"29. Tę samą cechę wykazuje główszczyzna karna. I ona była odszkodowaniem globalnym za życie ludzkie, nie brała $w$ rachubę właściwości fizycznych czy intelektualnych denata, obojętny był nawet, jak wiemy skądinąd, jego wiek ${ }^{30}$.

Obojętne też są walory fachowe poddanych. Chłopa zamienia się na cieślę (nr 311); stelmacha, bardzo dobrego rzemieślnika, na poddanych: o jakichkolwiek ich kwalifikacjach dokument nie wspomina (nr 524, r. 1791). Do podobnej zamiany doszło w r. 1742: za chłopa oddano parobka, rzemieślnika kunsztu plóciennickiego wraz z siostrą ( $\mathrm{nr} 683$ ). I to się nazywa pomiarkowanie ludzi $i^{31}$. Jeśli przy główszczyźnie karnej rzecz ta nie budzi

${ }^{29}$ J. Deresiewicz, Kilka uwag..., s. 87.

${ }^{30}$ Nawet nasciturus był poczytywany za głowę, choć go nieraz szacowano na połowę wartości człowieka, por. Iura Prutenorum, art. 91.

${ }^{31}$ Znowu zatem różnimy się $w$ poglądach z J. Deresiewiczem. Badacz ten, omawiając wypadek, w którym za rodzinę chłopską, składającą się z męża, żony, dzieci i ruchomości, oddano poddanego Tomasza, słodownika, stawia domysł, że „brano, być może, pod uwage fachowe umiejętności samotnego słodownika" (J. Deresiewicz, Uwagi..., s. 93-94). 
zdziwienia, przy główszczyźnie cywilnej tego rodzaju urządzenie musi uchodzić za wielce symptomatyczne.

Do tych punktów ogranicza się podobieństwo obu główszczyzn. Inna rola, jaką miała do spelnienia glówszczyzna cywilna, spowodowała wystąpienie szeregu jej cech odrębnych, wyróżniających ją od wzoru, z którego wyszla, zmuszających historyka do uznania jej za calkiem odrębną instytucję prawną.

Stwierdziliśmy wyżej, że inaczej niż przy główszczyźnie karnej, na wysokość cywilnej wywiera wpływ płeć: taksa kobiety równa się polowie taryfy męskiej. Nie mamy jednak pewności, czy podobna redukcja nie wytworzyla się zwyczajowo również w stosunku do wergeldu karnego. Następne cechy pozostaną nieznane główszczyźnie karnej w ogóle.

Ostatnia, ex vi definitionis, jest zadośćuczynieniem za głowę, za poszczególną głowę. Płacono zatem tyle główszczyzn, ile jednostek pozbawiono życia. Że tak nie pojmowano główszczyzny cywilnej, wykażą najewidentniej zestawione niżej teksty ${ }^{32}$. Transakcja chłopem obejmuje $\mathrm{z}$ reguły poddanego cum uxore (1564 r., nr 527 r.; 1626 r., nr 559; 1639 r., nr 323; 1642 r., nr 499,$501 ; 1644$ r., nr 39, 722, 723; 1682 r., nr 508), cum [...] consorte (1720 r., nr 593), lub poddanych cum uxoribus (1642 r., nr 500, dok. 1), uxoratos cum uxoribus (1642 r., nr 327). Rzadko przy tym podawano imię żony $^{33}$ : laboriosos Blasium Relak et Christinam, coniuges (r. 1700, $\mathrm{nr} 333$ ), pracowitych Tomasza z żoną Maryjanną (1789 r., nr 456). Tak też opiewa plenipotencja na odszukanie zbiegłych: Kazimierza Blaszczyka z żonq jego Reginq, pólrolników (1719 r., nr 335). W akcie donacyjnym Wawrzyńca Moczywąsa podkreśla się, że obejmuje on również córkę $\mathrm{z}$ pierwszego małżeństwa (1740 r., nr 605); jest bowiem oczywiste, że transakcja dotyczyła drugiej żony chlopa.

Glówszczyzną cywilną objęte są również dzieci chłopa: ipsum cum [...] pueris ex eo natis (1564 r., nr 527), cum [...] liberis (1554 r., nr 235; 1642 r., nr 327,499 , 500, dok. 1, 501; 1644 r., nr 39, 722; 1755 r., nr 693; 1695 r., $\mathrm{nr} 437), z$ dziećmi onychże (1789 r., $\mathrm{nr} 456)$. W razie ponownego ożenku chłopa zaznacza się z reguły, że transakcją objęto dzieci z obojga małżeństw: una cum [...] liberis eius, tam cum prioris voti consorte, quam et secundarii, procreatis (1720 r., $\mathrm{nr} 593)$, i z córkq jego z pierwszego malżeństwa, imieniem Maryjannq (1740 r., nr 605). W ostatnim przykładzie wymieniającym córkę $\mathrm{z}$ pierwszego małżeństwa zupełnie przemilczano los dzieci $\mathrm{z}$ drugiego malżeństwa: jest rzeczą oczywistą, że i one - jeśli istniały - zostały objęte cesją.

${ }^{32}$ W tym ustępie wykorzystano wszystkie akty, zwane przez J. Deresiewicza transakcjami, nie bacząc na to, czy w nich wyraźnie wymieniono taksę, czy też powołano się tylko na satysfakcję, czy nawet, gdy kwestį odpłatności pominięto milczeniem. Takie stanowisko podyktowało przekonanie o jednorodności wspomnianych aktów bez względu na ich formalne zróżnicowanie.

${ }^{33}$ Stwierdził to już J. Deresiewicz, Kilka uwag..., s. 88-89. 
Notowanie imion dzieci jest wyjątkowe: cum [...] liberis Gasparo, Ioanne, Alberto, Andrea, filiis, et Marianna (1695 r., nr 436). Czasem podaje się je tylko w części: także $i$ dziećmi ich, Jakubem, Zofiq, Ewq $i$ z drugimi dwojgiem, których imion nie pamięta się (1719 r., nr 335).

$Z$ reguly dokumenty nie tylko nie podaja imion dzieci, ale nawet ich liczby ${ }^{34}$ : za Tomasza gospodarza $i$ jego wszystkie dzieci (1784 r., nr 649). Takie globalne potraktowanie potomstwa świadczy o tym, że wiek ich był również dla stron obojętny.

W rachubę bierze się nawet dzieci ewentualne: cum liberis, quicunque ipsos ex predictis liberis habet (1695 r., nr 437). Co więcej, akty obejmują i potomstwo, które w przyszłości $\mathrm{w}$ małżeństwie się urodzi: cum liberis tam natis quam nascendis (1640 r., $\mathrm{nr} 660$ ) una cum [...] liberis protunc existentibus et in futurum, Deo dante, procreandis (1644 r., nr 723; 1682 r., $\mathrm{nr} 508$; 1700 r., nr 333; 1776 r., nr 350). O przyszlych dzieciach mówi się nawet wówczas, gdy chodzi o chlopa bezżennego: ...ac liberos, postquam nupserit (1633 r., nr 303), cum prole nascritura (1778 r., nr 636) czy po polsku: dziećmi dziś żyjącymi, a w przyszlości przybytemi (1779 r., nr 135). Jasne, że o taką rezygnację $\mathrm{z}$ nie istniejącego jeszcze potomstwa było nietrudno. Wzmianka o nim jest wysoce symptomatyczna; da się ona wykorzystać dla zagadnienia funkcji, jaką odgrywały transakcje chłopami.

Stwierdziliśmy wyżej, że ustaloną taryfę chłopską określają źródła terminem taxa capitis. Okazuje się tymczasem, że wyrażenie to jest całkiem nieadekwatne, wspomniana bowiem taksa obejmuje nie tylko chlopa, ale i całą jego rodzinę - zarówno żonę, jak i dzieci bez względu na ich wiek i płeć, potomstwo z pierwszego i drugiego małżeństwa, teraźniejsze i przyszłe ${ }^{35}$. Wbrew określeniu źródel nie jest to zatem glówszczyzna, lecz jakaś t a k s a rodzin na. Wydawnictwo prof. Deresiewicza dostarcza nam na to twierdzenie moc dowodów i to już od pierwszej połowy XVI w. Traktowanie całej rodziny chłopskiej jako jednostki poświadczają też wyraźnie inwentarze szlacheckie.

Od reguły, że taksa obejmuje całą rodzinę chłopską, znajdujemy dwa wyjątki. Pierwszy tylko pozorny. Dzieci los ojca dzielą tylko wtedy, gdy z nim wspólnie żyją. Usamodzielnieni, dorośli potomkowie, którzy stworzyli własną rodzinę i prowadzą własne gospodarstwo, nie mogli być „transakcją" objęci. Gdy chłop żenił się w obcej wsi i tam się osadzal, w starej wsi dzieci, które primo voto procreati $i$ do Wojnowa należce zostawil (nr 75, r. 1746$)^{36}$. Według aktu z r. 1750 rodzeństwo - brat z siostrą, przechodzą

${ }^{34}$ Również stwierdził to już J. Deresiewicz, ibidem.

${ }^{35}$ Niesłuszne jest zatem twierdzenie J. Deresiewicza, że liczebność rodziny, płeć, wiek dzieci miały niewątpliwie wplyw na wysokość sumy sprzedażnej (Handel..., s. 222).

${ }^{36}$ Podobnie działo się i z przyjęciem poddaństwa. Nie obowiązywało ono syna, prowadzącego gospodarstwo samodzielne: circa praenominatam subiectionem neque in bonis Niemczyno extitisse, immo servitia in bonis alienis per annos aliquot ante sui adventum ad bona Niemczyn continuasse, neque pro delicto parentis ad responsionem subditatus obligatum esse (nr 676, r. 1740). 
do dóbr arcybiskupa gnieźnieńskiego za kwotę 180 grzywien $(120+60)$, nr 618. Brat żeni się $w$ jednej wsi, siostra wychodzi za mąż za chlopa we wsi drugiej. Nie przechodzi więc rodzina $w$ całości $z$ jednego poddaństwa do drugiego. Zresztą są to znowu obie osoby dorosłe.

Drugi wyjątek stanowią przypadki tzw. ekscypowania dzieci w rodzaju: exceptis liberis, si quos ante donationem praesentem procreaverit (nr 559, r. 1626). Nie chcielibyśmy tu zatrzymywać się dhużej nad tym zagadnieniem - być może, uda nam się je przedstawić osobno - skonstatujmy wszakże, że są one zjawiskiem dość rzadkim, które wiązać trzeba z zaistnieniem względów szczególnych.

Zresztą podkreślić należy, że w obu grupach wypadków wyżej przedstawionych wyłączono pewne tylko kategorie potomstwa. Reszta została „transakcjami" objęta. Nie stoją więc one bynajmniej na przeszkodzie traktowaniu taksy jako rodzinnej.

Prawdziwy wyjątek od reguły, że taksa obejmuje chłopa $z$ rodziną, znaleźliśmy jeden jedyny, nasuwa on zresztą duże wątpliwości interpretacyjne. A mianowicie akt z 1544 r., (nr 218) stwierdza: ...pro ipso cmethone, uxore ac pueris ipsius cmethonis, pro quolibet seorsum per 10 marcas pecuniarum, a więc - jak to interpretuje wydawca - ,po dziesięć grzywien za kmiecia, żonę i dzieci". Takie wynagrodzenie stanowiłoby zatem właściwą główszczyznę: za każdą straconą glowę - obojętne czy chłopa, czy kobiety lub dziecka, płaci się 10 grzywien. Co przy tym ważne, restytucja kmiecia nastąpiła iuxta decretum castrense Calissiense. Choć interpretacja gramatyczna nie budzi wątpliwości, mimo to nie śmiemy wystąpić $\mathrm{z}$ tezą, jakoby główszczyzna cywilna, przynajmniej $\mathrm{w}$ rejonie grodu kaliskiego, nosiła charakter indywidualny. Drugiego podobnego tekstu nie znaleźliśmy w ciągu badanych trzech stuleci. Gdybyż to podano lącznie całą kwote, będącą przedmiotem roszczenia wedlug wspomnianego klucza, tzn. licząc po 10 grzywien za glowę!

$\mathrm{Na}$ przeszkodzie przyjęciu tezy o pobieraniu taksy 10 grzywien od każdej jednostki ludzkiej $\mathrm{z}$ osobna stoi fakt następujący. $Z$ kancelarii tegoż grodu kaliskiego pochodzi tekst nieco wcześniejszy, o brzmieniu: ...in summa 60 marcarum pecuniarum pro praefato cmethone et rebus receptis decretarum, in quibuslibet 10 marcis seorsum in unum mansum agri possessionatum, de quo marca census annui solveretur, aut in 2 desertas, si defuerint possessionati (r. 1505, nr 217). Wynika zaś z niego, że za każde 10 grzywien przewiduje się wwiązanie $w 1$ lan ziemi obsadzony, z którego czynsz roczny wynosi 1 grzywne, albo w 2 lany puste. Naturalnic oba powołane teksty i odmienne ich wykładnie wzajemnie się nie wylączają. Nic nie stoi na przeszkodzie przyjęciu jednej interpretacji dla tekstu pierwszego i drugiej - dla cytatu drugiego. W każdym razie pochodzenie ich $\mathrm{z}$ jednej kancelarii rzuca cień na wykładnię, którą poświadcza jeden jedyny przykład na trzy stulecia. Być 
może, jest on wyrazem tendencji - logicznej zresztą, gdy wziąć pod uwagę wzór, z którego wywodzi się główszczyzna cywilna, za którą jednak praktyka nie poszła.

Główszczyzna cywilna, mająca charakter rodzinny wówczas, gdy cała familia przechodzi $\mathrm{z}$ jednego państwa do drugiego, staje się siłą rzeczy indywidualną, gdy transfer obejmuje tylko jednostkę. Zdarza się to, gdy cesja dotyczy samotnego mężczyzny. Zbiorek prof. Deresiewicza dostarcza na taką ewentualność szeregu przykładów, np. z r. 1686, nr 51; z r. 1750, nr 79. Wszakże i w takich wypadkach ostrożność będzie jak najbardziej wskazana. Albowiem nawet gdy źródlo mówi o samym tylko mężczyźnie, jest to nieraz wypowiedź skrótowa, jak tego dowodzą dwa dokumenty z 1709 i 1710 r., W pierwszym z nich przedmiotem umowy jest sam chłop (nr 514, dok. 1), ale akt wystawiony $w$ roku następnym dotyczący tegoż samego poddanego, informuje, że chodzi o tegoż Pawła Surowika $\mathrm{z}$ żoną i dziećmi (nr 514, dok. 2). Zatem ze wzmianki o samym tylko chłopie nie wolno jeszcze wnioskować, że akt nie dotyczył również jego rodziny ${ }^{37}$. Ojciec występuje w tekstach jako głowa rodziny, jej reprezentant.

Indywidualny charakter ma główszczyzna cywilna $\mathrm{z}$ reguły, gdy dotyczy kobiet. Dziewczyna, wychodząca za mąż za chłopaka mieszkającego pod obcym panem, sama tylko opuszcza swojego pana; $z$ reguły bowiem jest bezdzietna. Każdy taki indywidualny wypadek uzasadnia główszczyznę. W tym świetle zrozumiały jest cytowany wyżej akt z 1742 r., wedlug którego za bialoglowskq pleć, za jedne, należy ze grzywien 60 ( $\mathrm{nr} 342$ ). Uderzające jednak, że i tu mamy do czynienia $z$ odstępstwem od głoszonej zasady: za matkę i dwie córki policzono nie 180 grzywien, jak by się należało w myśl powołanej zasady spodziewać, lecz tylko 150 zlp $(=93,75$ grz.). Być może ten właśnie indywidualny charakter, jaki ma $\mathrm{z}$ reguły taxa capitis muliebris, sprawil, że zwykłą glówszczyznę zniżono za kobiety w stosunkach cywilnych do połowy męskiej, choć w XVI w. główszczyzny karne i za mężczyznę, i za kobietę były równe, i choć żadna konstytucja nie przewidziała takiej redukcji główszczyzny żeńskiej.

W aktach „transakcyj” ojciec rodziny występuje w olbrzymiej ilości wypadków na jej czele, czasem nawet jako jej jedyny reprezentant. Dopiero w razie braku rodzica pojawiał się w tym charakterze ktoś inny; stąd to napotykamy wzmianki o bracie z siostra (1633 r., nr 304; 1640 r., nr 659; 1742 r., nr 683; 1779 r., nr 135), czy o bracie z dwiema (r. 1620, nr 656) czy z trzema siostrami (nr 277, r. 1595), o trzech braciach z siostrą - jeden $\mathrm{z}$ nich jest żonaty i ma własne dzieci, widocznie opiekuje się mlodszym rodzeństwem (nr 314, r. 1634), o dwóch braciach (nr 274, r. 1596), o stryju z synowcami (1642 r., nr 327), o wdowie z dziećmi (1639 r., nr 323). Raz nawet wymieniono kobietę na pierwszym miejscu przy żyjącym mężu:

${ }^{37}$ Takiż sąd wypowiedział już K. Orzechowski, $O$ wladztwie..., s. 294. 
Luciam cum marito et filiam eius (1639 r., nr 323). Bliższa znajomość konkretnych stosunków pozwoliłaby nam zapewne doszukać się uzasadnienia podobnego ujęcia. Domyślamy się, że to ona była possessionata ${ }^{38}$.

$\mathrm{Za}$ charakterem rodzinnym główszczyzny cywilnej przemawiają też niejednokrotnie wypadki zamiany poddanych. I tak w r. 1775 zamieniono parę małżeńską za dwie kobiety (nr 630). Komplanacja $z$ mocy dekretu trybunalskiego opiewała na zamianę stelmacha $\mathrm{z}$ żoną $\mathrm{i}$ trojgiem dorosłych dzieci na dwoje poddanych; akt zresztą zaznacza, jak transakcja ta korzystna jest dla jednej strony (nr 524). Według aktów z 1641 r., poddanego Bąka zamieniono na poddanego Tatarkę $\mathrm{z}$ żoną $\mathrm{i}$ dziećmi, $\mathrm{z}$ wylączeniem jednego syna (nr 661). Według aktów z 1690 r., zbiegły kmieć Lukasz Piłat został zamieniony wraz z czterema synami, Grzegorzem, Janem, Michałem i Pawłem, na zbiegłego karczmarza Jana z żoną Marianną i córką Reginą (nr 729-730). W 1742 r. doszlo do zamiany chłopa na parobka $\mathrm{z}$ siostrą (nr 683). Wreszcie przytoczmy przykłady powolane przez prof. J. Deresiewicza: za poddanego Wojciecha dano aź dwie osoby - Marcina parobka i jego siostrę Zofię ${ }^{39}$; za Jana Sobczaka dano in recompensationem poddanego Józefa Strynowskiego $\mathrm{z}$ żoną, dwojgiem dzieci, inwentarzem oraz sprzętem domowym $^{40}$. Nie może zaś ulegać wątpliwości, że wartość bezżennych poddanych była dla gospodarki pańskiej nierównie mniejsza niż ojców licznych rodzin ${ }^{41}$. Te rażące jak by się wydawalo dysproporcje między obiektami zamian świadczą o jednym: jednostką operacyjną jest rodzina chłopska, nie chłop indywidualny. Liczba zamienianych poddanych nie musiała więc być równa ${ }^{42}$, płeć dzieci nie odgrywala również roli. Jednostkową główszczyzną, taksą od glowy, staje się taxa capitis wówczas tylko, gdy przedmiotem transakcji jest mężczyzna samotny - co spotykamy rzadziej - czy samotna dziewczyna w wypadku, który jest regułą, pójścia za mąż za chlopa spod innego pana.

Według Orzechowskiego, chłop przechodził do nowego pana także $z$ ewentualną służbą ${ }^{43}$. Nie wynotowaliśmy $z$ zbiorku Deresiewicza ani jednego podobnego przykładu, a wspomniany badacz nie zacytowal tekstu zawierającego taka informację ${ }^{44}$. Nie jest to jednak niemożliwe, skoro czeladź u chłopa - jak to stwierdza Gostomski, jest zjawiskiem normalnym ${ }^{45}$.

${ }^{38}$ Por. I. Baranowski, Wieś i folwark. Studia z dziejów agrarnych Polski, Warszawa 1914, s. 188

39 J. Deresiewicz, Kilka uwag..., s. 94.

to Ibidem, s. 94, przyp. 65.

${ }^{41}$ W. Dworzaczek, Dobrowolne poddaństwo, s. 94.

42 J. Deresiewicz, stwierdzając, że przy zamianie nie zawsze dawano głowę za głowę, stawia domysl: „przy ocenie wartości brano z pewnością pod uwagę różne względy” (Uwagi.., s. 93).

${ }^{43}$ K. Orzechowski, $O$ wladztwie..., s. 295.

${ }^{44}$ Gdyby nawet to mialo miejsce, nie odważylibyśmy się pisać o władzy chłopa jako odpowiedniku rzymskiej władzy pater familias.

${ }^{45}$ I. Baranowski, Wieś i folwark, s. 73. 
Zestawione argumenty wykazują, jak dalece główszczyzna cywilna odbiegła od główszczyzny karnej, z której wyszła: przestała być taksą indywidualną, stała się opłatą od jednostki gospodarczej, jaką stanowiła dla pana rodzina poddańcza, tzn. chłop z żoną i dziećmi.

Konsekwentnym następstwem poglądu szlachty na rodzinę chłopską jako na jednostkę ekonomiczną musiał być fakt dalszy, który znowu znajdzie poświadczenie w bezliku aktów. Okazuje się z nich, że w transakcjach chłopem obok jego rodziny przechodzą wraz $z$ nim także inne, nie ludzkie wartości, jego inwentarz żywy i martwy. Nieraz akty mówią tylko o pierwszym: (pro eadem Barbara praefata), pro pecoribus et pecudibus (10 marcas pecuniarum dare), r. 1513, nr 461; pewna wdowa wyszła za mąż za obcego poddanego, mając już dwie córki z pierwszego malżeństwa: matka też niegolo poszla, bo zabrala kilka sztuk bydla u mnie przychowanego, a każdy rok uprzedawala (r. 1742, $\mathrm{nr} 342$ ); w innym tekście: et de pecoribus et pecudibus secum [...] abactis (r. 1545, nr 221); jedna donacja objęła Lucję cum vacca (r. 1637, nr 399); w akcie z 1745 r. stwierdza wystawca: wydaje $z$ Krzepiszyna kobiete imieniem Zofije z trojgiem bydla, ze świniami, kurami $i$ gesiami (nr 684).

Czasem dokumenty wymieniaja tylko inwentarz martwy: cum [...] supellectili domestica, si quae sit (r. 1624, $\mathrm{nr} 296$ ); cum omnibus et singulis rebus et supellectili domestica, cum quibus se illic contulit (r. 1544, $\mathrm{nr} 219$ ); innym razem dokonano wystarczającego zadośćuczynienia tam pro eodem laborioso Martino [z rodzina] quam et eius supellectili (r. 1755, $\mathrm{nr}$ 693).

Najczęściej wszakże w jednym zdaniu ujmuje się obie pozycje: ipsum cum [...] eius omnibus rebus mobilibus, pecoris [sic] ac pecudibus eiusdem (1564 r., nr 527); cum [...] pecoribus, pecudibus, equis, equireis ac tota supellectili domestica (r. 1604, nr 385); cum [...] pecoribus, pecudibus, totaque substantia eorum domestica, in quantum praemissis aliquis eorum subditorum gaudeat (r. 1642, nr 500, akt 1) ${ }^{46}$; cum [...] pecoribus, pecudibus, supellectili domestica ac rebus eorum omnibus (r. 1644, $\mathrm{nr}$ 39); una cum [...] pecoribus, pecudibus ac tota supellectili domestica (r. 1644, $\mathrm{nr} 723)^{47}$; una cum [...] totaque supellectili domestica, pecoribus, pecudibus, rebusque mobilibus eorum Relaków profugorum omnibus (r. 1700, nr 333); una cum rebus ipsius mobilibus, inventariis, pecoribus, pecudibus, totaque ipsius substantia et supellectili domectica (r. 1720, $\mathrm{nr} 593)$; cum [...] totaque re et supellectili eius domestica ac inventariis (r. 1755, $\mathrm{nr} 693$ ); nec non cum rebus omnium praefatorum subditorum propriis, eius ovibus, pecoribus, pecudibus, totaque supellectili eorum domestica (1695 r., nr 437). Takiż sens przypiszemy też zwięzłemu określeniu: cum tota eius substantia (r. 1628, nr 393). W tekstach polskich

${ }^{46}$ Passus powtórzony niemal dosłownie $w$ dwu innych aktach $z$ tegoż roku, $\mathrm{nr} 499,501$.

${ }^{47}$ Zwrot niemal doslownie powtórzony w akcie z 1682 r., nr 508. 
klauzula ta przedstawia się następująco: mojego wlasnego poddanego ze wszystkim, co ma $i$ mieć będzie inwentarza $i$ sprzętów swoich, ze wszystkim dobytkiem jego (r. 1749, nr 614); ze wszystkim, co tylko jej jest, juz to sprzętami $i$ inwentarzem wszystkim, jaki ma (r. 1783, nr 648); za Tomasza, gospodarza [...] wraz $z$ calkowitym onegoż inwentarzem, $z$ dóbr Marszewa zabranym $i$ przyrobionym (r. 1784, $\mathrm{nr} 649$ ); $z$ dobytkiem jego wlasnym wszelkim, sprzętami domowemi (r. 1724, nr 733); chlop posiada jemu [...] należacy inwentarz: sprzęty domowe, drobiazgi (r. 1743, $\mathrm{nr}$ 608); ze wszystkimi ich [...] inwentarzami i sprzetami domowymi (r. 1724, nr 734); $z$ inwentarzem rogatym $i$ nierogatym, tudzież $z$ calq ich ruchomościq (r. 1779, $\mathrm{nr} 135$ ); $\mathrm{z}$ inwentarzem, to jest $\mathrm{z}$ wolcem dwuletniakiem $\mathrm{i}$ świniami i $\mathrm{z}$ innemi ich własnemi sprzętami gospodarskiemi ( $r .1746, \mathrm{nr} 75) ; z$ majątkiem $i$ inwentarzem mianym (r. 1789, nr 456); z ogólnym jego majatkiem (r. 1782, nr 354).

Rzadziej pojawiają się wzmianki o zbożu: cum [...] omnique supellectili domestica ac singulis rebus ipsius per eum quodlibet habitis nec non frugibus hiemalibus (r. 1554, nr 235), czy narzędziach rzemieślniczych; donacja zbiega-kowala nastąpiła - oprócz inwentarza - cum [...] instrumentis ad artem ferrifabrilem pertinentibus (r. 1644, nr 722).

$Z$ rodziną chłopską przechodzą zatem res singulae, omnes res mobiles, supellectilis domestica = sprzęty domowe; tota substantia = majątek, dobytek; inventaria = inwentarz, inwentarze, drobiazgi; pecora, pecudes, oves, equi, equirea, vacca = bydło, świnie, kury, gęsi; fruges hiemales; cesja kowala obejmie i jego narzędzia rzemieślnicze; nieraz zaznacza się, że chodzi o rzeczy wlasne, propriae poddanego. Przedmioty te stanowią dla pana zupełną niewiadomą, do tego stopnia, że w aktach zaznacza się: si quae sit, in quantum praemissis [...] gaudeat. Tymi ruchomościami chłopskimi zatem pan wsi nie rozporządza ${ }^{48}$.

Powyższym obserwacjom nie są przeciwstawne wypadki, w których dokonywano (wyjątkowo - jak wiemy) podziału rodziny między panami, a w związku $z$ tym następowal i podzial inwentarza. Wdowiec wżeniający się u obcego pana musial dostarczyć dla dzieci z pierwszego malżeństwa, pozostawionych na dawnym majątku wieprzków 2 male. Pozostający in fundo dwaj synowie otrzymuja $z$ bydla krowe starq $i$ ciele $z$ tq krowa tegoroczne. $\mathrm{Z}$ donacji chlopa $\mathrm{z}$ rodziną ekscypowana została jedna córeczka, stąd też cesja dokonuje się $z$ bydlem prócz jednej krowy, która dziecięciu Helenie należeć ma (r. 1636, $\mathrm{nr} 718$ ).

Przy omawianiu charakteru rodzinnego główszczyzny cywilnej posłużyliśmy się argumentem zamiany nierównej ilości głów poddańczych. Ten sam argument można wykorzystać dla wykazania, że inwentarz nie wplywał zupełnie na wysokość główszczyzny. I tak według aktu z 1745 r. doszło do

${ }^{48}$ J. Rafacz, Ustrój wsi samorzqdnej malopolskiej w XVIII wieku, Lublin 1922, s. 98-100. 
zamiany dwóch kobiet, przy czym jedna tylko $\mathrm{z}$ nich posiadala inwentarz. Co więcej, akt przewiduje ewentualność, że nabywca tej zamożniejszej chłopki nie będzie $\mathrm{z}$ niej zadowolony; wówczas to jeśli się nie podoba, wróci ona do swego dawnego pana, który przeleje na rzecz drugiego kontrahenta tylko 60 grzywien ( $\mathrm{nr} 684$ ). A zatem kobieta $\mathrm{z}$ inwentarzem przedstawia dla pana taką wartość, jak kobieta bez inwentarza, równa się 60 grzywnom.

Obraz zatem otrzymujemy jednolity. Inwentarz, stanowiący własność chłopa, której - jak utrzymuje się w literaturze - nie było mu wolno sprzedać $c^{49}$, przechodził $z$ nim razem do nowego pana. Nie wywieral on żadnego wpływu na wysokość główszczyzny, nie liczyło się go osobno obok niej. Takie postępowanie poczytać wolno za regułę. Od niej znaleźliśmy dwa tylko wyjątki, oba $\mathrm{z}$ pierwszej połowy XVI w.: pro ipso (cmethone profugo) 10 marcas solvent et 50 marcas pecuniarum pro pecudibus, pecoribus, apibus et aliis supellectilibus domesticis (r. 1505, nr 217); nec non cum tota supellectili domestica et pecoribus, pecudibusque [...], valoris quoad pecora et pecudes 30 marcarum pecuniarum Polonicalium consuetarum (r. 1544, nr 218).

Zauważmy, że cytaty powyższe zaczerpnięto $\mathrm{z}$ tych samych dokumentów, które nastręczyły tyle trudności przy omawianiu sposobu obliczania główszczyzny cywilnej jako taksy rodzinnej. Oba pochodzą z powiatu kaliskiego. Czyżby to więc była praktyka tamtejszego sądu, która nie zdołała się upowszechnić? W każdym razie nie jest ona $w$ stanie wywołać $w$ nas wątpliwości co do ustalonej reguły, poświadczonej tylu przykładami na przestrzeni trzech stuleciso.

Skonstatowaliśmy wyżej, że niektóre dokumenty zaznaczają, iż chłop zabiera $z$ sobą rzeczy własne. Natomiast nie wolno mu było przenosić wartości, które stanowiły cząstkę majątku pańskiego, a więc chłopskich pasywów. Przede wszystkim $w$ rachubę wchodziła dana mu od dworu

${ }^{49}$ Zarówno sprzężaju, jak i nawet ważniejszych narzędzi rolniczych, J. Rutkowski, Badania nad podzialem dochodów $w$ Polsce $w$ czasach nowożytnych, t. I, Kraków 1938, s. 86.

${ }^{50}$ Tym bardziej że nasuwa się wyjaśnienie następujące: Być może, w tym czasie jeszcze nie doszło do występującej później stabilizacji zwyczaju. Swiadczą o tym wyraźnie wahania, przebijające się $\mathrm{z}$ małopolskich zapisek sądowych z końca XV w. Okazuje się z nich, że zgłaszane pretensje co do 10 grzywien czy większej kwoty obejmuja ita bonum kmethonem cum censibus, laboribus, proventibus, apibus, subsidiis... (SPPP, t. II: nr 4345, r. 1489; nr 4315, r. 1487: nr 4381, r. 1491). Gdy jednak powód zglosił roszczenie o 30 grzywien, a pozwany przeciwko tej wysokości żądania oponuje, powołując się na statuta Regni, udzielił pierwszy wyjaśnienia następującego: taxavit non simpliciter solum hominem ad triginta marcas, sed cum laboribus, censibus, proventibus, subsidiis (ibidem, nr 4378, r. 1491). I w nich zatem zaznacza się tendencja do innego szacowania samego kmiecia niż kmiecia z jego świadczeniami poddańczymi. W pierwszym wypadku należy się tylko główszczyzna (karna), w drugim odszkodowanie ma być trzykrotnie wyższe. Nie wiemy, jak sąd tę konkretną sprawę rozstrzygnął. W dalszym rozwoju odrębność zadośćuczynienia cywilnego nie utrzymała się, zrównało się ono - jak wiemy $-\mathrm{z}$ główszczyzną karną. 
załoga w bydle, stanowiąca własność pańską ${ }^{51}$, jak długo jej nie spłacil ${ }^{52}$. Excepto, co tylko do gruntu należy, wolów pary, $i$ co ze dwora dane jemu jest na role (r. 1724, $\mathrm{nr} 733$ ); excepto inventario fundi, si quod habet (r. 1725, nr 115). Przysądzając chłopa, wyrok sądu zastrzega, że należy go zmusić ad relinquendum frumenta aestivalia pro conseminandis agris ad eiusdam gazam spectantibus (r. 1740, $\mathrm{nr} 676)^{53}$. Za takie obiekty, jeśli miały przejść wraz $\mathrm{z}$ poddanym, należało się poddanym odszkodowanie osobno ${ }^{54}$.

Uregulowania wymagały również długi, zaciągnięte u dawnego pana, iuvamen $\mathrm{w}$ jakiejkolwiek postaci ${ }^{55}$. Ponieważ nam się zadosyć za jego pretensyje stalo, to jest mnie za zasiewek oziminy $i$ żyta, którego mu, targiem zgodzony, pożyczylem korcy 9, sume za niego wyliczyl jmp. Krzesiński zl 190 [...] Mnie także za poglówne i pożyczonych pieniędzy, i za lake, którq mu na borg dalem, oddal jmp. Krzesinski zlp 32 gr 19 (r. 1737, nr 603) ${ }^{56}$. U Biskupskiego wżenił się Wojciech Skoczek, chłop Wyganowskiego, i zamieszkal u nowego pana. Wszakże nastąpiła combinatio certa, w wyniku której Skoczek powrócił do swego właściwego pana wraz z żoną. Biskupski jednak różne do tegoż pracowitego ma swoje pretensyje, to jest za zasiewu jarzynnego 160 utracenie, tudzież za utracenie zasiewu ozimego, zabranie pare wolów gruntowych, woza ze wszystkiem oprawnego, pluga, radla, klód, gesi, świn, za dlugi $w$ gościńcu, za zatrzymane księdzu proboszczowi meszne, za zboże brane na gospodarstwo $i$ inne regestrem przez tegoz jmp. Biskupskiego podane pretensyje, za które suma wraz zlqczona $600 \mathrm{zl}$ jest wyrażona; jednakowoż wny jmp. Biskupski, idqc stopniami przyjaźni, za te wszystkie pretensyje, niemniej podlug prawa za kobiete, a pomienionego Wojciecha żone. sumq 268 zlp kontentuje sie (r. 1782, nr 354) ${ }^{57}$. Pan cedując chłopa, zastrzega się, że robi to bez dlugu jednak do niego mianego (r. 1791, nr 524). Za dwóch zbiegów królewskich komplanacja wyniosła 350 florenów: w tej sumie,

${ }^{51}$ Tak też K. Orzechowski, $O$ wladztwie..., s. 296.

52 Por. I. Baranowski, Wieś $i$ folwark, s. 293. Udzielenie załogi należało do obowiązków pańskich (J. Rafacz, Ustrój..., s. 86), zwłaszcza wobec chłopów nowo osadzonych (J. Rutkowski, Badania..., s. 76).

${ }^{53} \mathrm{Z}$ czego składała się załoga, podaje w swej Economice Haur; ob. A. Podraza, Jakub Kazimierz Haur. Pisarz rolniczy z XVII wieku, Wrocław-Warszawa-Kraków 1961, s. 56.

${ }^{54}$ Według aktu z 1767 r., nr 349, w cenę wchodzą dwaj chłopcy oraz także, cokolwiek proprii grani do tychże dóbr przywiózl $i$ spendowal jmp. Bratkowski, to jest pszenice wirt. 10, len, konopie, proso już oprzytarte w ziernie, jeczmienia ćw. 6 .

ss Por. I. Baranowski, Wieś $i$ folwark, s. 293; dla sprawy zadtużenia chłopów ob. też A. Mączak, Gospodarstwo chlopskie na Żulawach malborskich w poczqtkach XVII wieku, Rozpr. U. W., nr 2, Warszawa 1962, s. 282, 284.

56 W tym przypadku za chłopa nie uiszczono żadnego odszkodowania, ale wątpliwe było jego poddaństwo: chłop utrzymywał, że jest poddanym nabywcy!

${ }^{57}$ Oczywiście, skoro zbieg wżenił się $\mathrm{i}$ zadłużył u nowego pana, w wypadku zwrotu pierwotnemu wlaścicielowi, nowy pan zażąda zapłacenia „pretensyj” w wysokości 126 złp. Żona jego przechodzi wszakże już nieodpłatnie (r. 1785, nr 357). 
według brzmienia tekstu, mieściły się także koszta procesowe (r. 1740, nr 676$)^{58}$. Widać więc, jak znaczne były nieraz naklady szlachcica na gospodarstwo chlopskie ${ }^{59}$.

W klauzulach transakcyj niejednokrotnie dodaje się dalsze postanowienia. Przekazuje się poddanego cum omni iure suo, dominio, proprietate, cunctis commodis, usibus, fructibus ex eodem subdito modo quovis provenientibus (r. 1642, $\mathrm{nr} 499,501$ ), una cum [...] omnique iure, dominio, proprietate, propinquitate (1644 r., $\mathrm{nr}$ 723), cum [...] obsequiis et subditura (r. 1690, $\mathrm{nr} 731$ ), cum [...] omnibusque oboedientiis, dierum laboribus per ipsum praestari solitis (1720 r., $\mathrm{nr} 593$ ), cumque omni iure, dominio, proprietate, attinentiis, pertinentiis, cohaerentiis, usibus, fructibus, laboribus ac emolumentis generaliter universis (r. 1640, $\mathrm{nr} 402$ ); czy po polsku: ze wszystkimi ich robociznami, powinnościami (r. 1724, $\mathrm{nr}$ 734). Postanowienia te nie wnoszą jednak nic nowego do badanego przez nas zagadnienia. Dadzą się natomiast wykorzystać dla analizy treści poddaństwa ${ }^{60}$.

Uzupelnijmy powyższe zastawienia stwierdzeniem, że wszystkie wartości chłopa, ludzkie i nieludzkie, występują czasami w zbiorczej formule negatywnej: nihil sibi et suis successoribus ad eundem Gregorium, liberos, uxorem, pecora, pecudes ac supellectilem domesticam iuris, dominii, subditionis et proprietatis ac heroicae potestatis sibi et suis successoribus ad eundem subditum reservando seu excipiendo (r. 1635, $\mathrm{nr} 317$ ).

Taxa capitis cywilna obejmowała nie tylko poddanego $\mathrm{z}$ cała jego rodziną. W niej mieścił się również chlopski inwentarz, żywy i martwy, bydlo i sprzęty domowe. Gdy chodziło o rzemieślnika, przechodzily z nim także jego narzędzia. Pozycje te stanowiły zatem własność osobistą chłopa ${ }^{61}$. Zbiegając, poddany zabieral je $\mathrm{z}$ sobą, wracając do dawnego pana, znowu przynosił je (1724 r., nr 733). Własności nad tymi obiektami pan nie nabywał ${ }^{62}$. Niewątpliwie chłop $\mathrm{z}$ rodziną był więcej wart dla pana niż samotny. A jakąż ważną pozycję stanowil dla gospodarstwa folwarcznego kmiecy inwentarz, który odciążal pana od części nakładów inwestycyjnych. Dzięki pańszczyźnie dziedzic nie potrzebowal kupować ani narzędzi rolniczych, ani pociągowego bydla ${ }^{63}$. Tymczasem te wszystkie wartości nie wpływały

${ }^{58}$ Sytuacja, jak się wydaje, identyczna w akcie 436 .

59 Por. A. Podraza, o. c., s. 57.

${ }^{60}$ Wykorzystal je dla tego celu K. Orzechowski, $O$ wladztwie..., s. 297.

${ }^{61}$ Por. A. Lauferski, Ludność wiejska powiatu pyzdrskiego $w$ świetle zapisek sqdowych XIV $i X V$ w., RH, t. XV, 1946, s. 222; K. Orzechowski, $O$ wladztwie.., s. 295.

${ }^{62}$ K. Orzechowski, $O$ wladztwie..., s. 296.

${ }^{63}$ Por. I. Baranowski, Wieś $i$ folwark, s. 58, 64, 69, 70; A. Wyczański, Studia nad folwarkiem szlacheckim $w$ Polsce w latach 1500-1580, Warszawa 1960, s. 137; J. Borowiak, Gospodarstwo chlopskie, RDSG, t. XVIII, 1956, s. 267, 281. 
zupełnie na wysokość taksy. Inaczej niż przy libertacjach, gdzie cena wykupu zależała od zamożności chłopa ${ }^{63 \mathrm{a}}$. Czy wolno zatem wyłączyć rodzinę chłopską i jej inwentarz z rozważań o cywilnej taxa capitis? ${ }^{64}$ Gdy uwzględnimy te wszystkie składniki dodatkowe, mieszczące się w główszczyźnie cywilnej, ludzkie i nieludzkie, wartość ustalonej taryfy zredukuje się kolosalnie.

\section{Wartość ekonomiczna glówszczyzny cywilnej}

Jeśli główszczyzna karna posiadała w swoim czasie takie znaczenie, że mogła uchodzić za satysfakcję za głowę zabitego, główszczyzna cywilna stracila prędko odszkodowawczy charakter ekonomiczny. Zmniejszyło jej znaczenie przede wszystkim to, że $\mathrm{z}$ taryfy indywidualnej przedzierzgnęła się $w$ rodzinną. Bez względu na liczbę glów w rodzinie poddańczej, odszkodowanie ustabilizowało się w jednolitej wysokości. Zamiast kilku, czy nawet - w pewnych wypadkach - kilkunastu glówszczyzn, pan otrzymywał tylko jedną. Jedynie glówszczyzna kobieca zredukowana do połowy męskiej, płacona $\mathrm{z}$ chwilą pójścia za mąż pod obcego pana, utrzymała w zasadzie swój charakter indywidualny.

Zredukowana taxa capitis rodzinna uległa dalszemu jeszcze pomniejszeniu dzięki temu, że w niej mieścilo się równiez wyrównanie za chlopski inwentarz. Żeby zatem uprzytomnić sobie to, jaką wartość przedstawiała odszkodowawcza kwota 120 grzywien, płacona panu za utraconego poddanego, należy obliczyć wartość taryfową całej rodziny chłopskiej oraz posiadanego przez nią inwentarza.

Pierwsza jest prosta do wyrachowania, jeśli tylko źródła zawierają dostateczne informacje o liczbie i plci członków rodziny, co zdarza się nieczęsto. Będzie nią różnica dwóch wielkości - taksy cywilnej w wysokości 120 grzywien $^{65}$ oraz indywidualnych główszczyzn karnych: męskich i kobiecych. Jeśli przy główszczyźnie karnej dochód pański przedstawi się następująco:

632 W. Dworzaczek, Dobrowolne poddaństwo, s. 28.

o4 Uwidaczniała się tu różnica, tak podkreślana przez dawne prawo polskie, między dobrami ruchomymi i nieruchomymi. Gruntu zabrać z sobą zbieg nie mógl, natomiast skrępowanie poddanego w rozporządzaniu inwentarzem było równie nieskuteczne jak ograniczenie wychodu kmieci: nowy pan bronił i jednego i drugiego.

os Dla uproszczenia bierzemy $w$ rachubę tylko taryfę wyższą $z$ racji wyluszczonych w tekście. Zresztą nie będzie to istotna różnica, gdy do wzoru wstawimy liczby 100 i 50 . 
$\mathrm{S}$ (glów. $\mathrm{k}$ ) $=\frac{120 x+6 y}{2}$,

( $x$ oznacza liczbę męskich, $y$ - liczbę żeńskich członków rodziny ${ }^{66}$ ), stanowi zatem stale wartość dodatnią, to przy główszczyźnie cywilnej osiągniemy wzór całkiem inny:

$$
\mathrm{S} \text { (głów.c.) }=120 \text { grz. }-(120 x+60 y) \text {. }
$$

Jest rzeczą oczywistą, że poza jednym jedynym wypadkiem, gdy cesja dotyczy samotnego chłopa lub samotnej chłopki bez inwentarza, będzie to z reguly wielkość ujemna! ${ }^{17}$ Zmniejszy się ona jeszcze, gdy dodamy do niej wartość inwentarza. Jakiej byla ona skali?

Niektóre akty zawierają jakieś dane o wielkości majątku chłopa. Jest go tyle, że na jego przewiezienie otrzymuje poddany dwie fury (r. 1743, nr 608). W jednym akcie zaznacza się, że chlop przenoszący się na inne gospodarstwo znacznq kwote ma bydla. Ale niewiele znajdujemy w publikacji Deresiewicza dokumentów, które by podawały wartość inwentarza. Bywala ona nieraz znaczna ${ }^{68}$. Niewątpliwie należaloby kwerendę $w$ tej mierze poszerzyć. Tymczasem ograniczymy się do powolania dwóch aktów z pierwszej połowy XVI w. oraz jednegi, z samego końca Rzeczypospolitej.

W pierwszych dwóch policzono inwentarz obok główszczyzny. Według dokumentu z 1505 r. stosunek glówszczyzny, wynoszącej wówczas - jak wiemy - 10 grzywien, do inwentarza przedstawial się jak 1:5 (nr 217); wedhug aktu z 1544 r. - jak 1:3 (nr 218). W akcie z 1790 r. donator wydał pracowitego Mateusza wraz $z$ majqtkiem, $z$ znacznym majqtkiem. Obdarzony potym bardzi na jego majatek niż na jego glowe obróciwszy uwage, zmusil go do ucieczki, inwentarz jednak po nim i sprzety, $200 \mathrm{zl}$ przenoszqce na swój obrócil użytek (nr 362). Inwentarz chłopski mógł wiẹc przekraczać wartością główszczyznę cywilną, i to parokrotnie. Ograniczamy się do zasygnalizowania tych przypadków, obawiając się wysnuwania $\mathrm{z}$ nich wniosków o ewolucji w tej mierze. W każdym razie stwierdzić wolno, że nawet w wypadku taksy za chlopa samotnego mogła ona stanowić ze względu na sam inwentarz wartość negatywną. Oczywista, innym razem

${ }^{66}$ Przy założeniu, że kobieca główszczyzna karna równa się cywilnej, tzn. wynosi 60 grzywien. Jeśli była wyższa (120 grz.), należałoby wnieść do wzoru odpowiednią poprawkę.

${ }^{67}$ Weźmy dla przykładu średnią, pięcioosobową rodzinę chłopską, złożoną z ojca, matki, syna i dwóch córek. Wymordowanie jej pociągnie za sobą główszczyznę karną w wysokości 420 grzywien, z czego połowę, a więc 210 grzywien otrzyma pan. W razie ucieczki odszkodowanie pana wyniesie 120 grzywien.

${ }^{68}$ I. Baranowski, Wieś $i$ folwark, s. 70; B. Baranowski, Gospodarstwo chlopskie i folwarczne we wschodniej Wielkopolsce w XVIII w., Warszawa 1958, s. 28. 
inwentarz mógł być nieznaczny (np. nr 684), albo - jak to stwierdziliśmy wyżej - mogło go wcale nie być.

Jeśli więc uwzględnimy fakt, że główszczyzna cywilna stanowiła taksę rodzinną, że w niej mieścila się również wartość inwentarza żywego i martwego, dochodzimy do wniosku, że nie stanowiła ona poważniejszej remuneracji. Czyż to nie ryczałt za wszystkie należności i pretensyje miane do poddanego? Należałoby jeszcze zbadać, jaką siłę kupna posiadały 10,30 , 100 albo 120 grzywien, uiszczane w różnych okresach tytułem główszczyzny cywilnej. Wymaga to osobnego studium.

\section{Glówszczyzna karna a cywilna}

Glówszczyzna karna posiada charakter wtórny, zastępczy; znajduje zastosowanie wówczas tylko, gdy zabójca nie poniesie kary, płacąc winę własną głową. Glówszczyzna cywilna zawdzięcza swe powstanie istnieniu poddaństwa. Jest ona instytucją samodzielną, choć swoją genezę zawdzięcza ekonomicznemu podejściu do sankcji karnych ${ }^{69}$.

Gdy chodzi o wysokość główszczyzny cywilnej, wzoruje się ona dokładnie na karnej. Stąd dzieje ostatniej musiały leżeć u podstaw naszego studium. Zajęliśmy się nimi w zasygnalizowanym wyżej artykule. W ciągu badanego okresu główszczyzna karna ulegała podwyżce z 10 grzywien na 30 w r. 1581 i 100 lub 120 od $1631 \mathrm{r}^{70}$ Taryfa cywilna szla trop w trop za główszczyzną karną. Zgodnie obie też nie uwzględniały ani kondycji fizycznej, ani kwalifikacji fachowych chłopa. Atoli ponieważ pierwsza, cywilna, odpowiadała innej potrzebie niż jej wzór, taksa karna, uległa ona w ciągu wieków ewolucji, która nadała jej szereg cech specyficznych, swoistą fizjonomię.

1. Już geneza glówszczyzny cywilnej jest inna. Źródłem karnej była reakcja społeczna na przestępstwo; choć w dalszym rozwoju uległa silnemu zmaterializowaniu, swój charakter represji zachowala stale. Rola ekonomiczna (odszkodowania prywatnego) stanowiła wyłączną rację istnienia główszczyzny cywilnej.

2. Główszczyzna karna stanowiła instytucję prawa ziemskiego i chłopskiego. Regulowała ona stosunki między chłopem-mordercą a panem zabitego,

${ }^{69}$ Przy naszym ujęciu główszczyzny cywilnej jako cywilnego pendant do główszczyzny karnej nie jest do pomyślenia nawiązka cywilna. Jest to oczywiste. Można było bez obrazy prawa karnego (tzn. bez zabójstwa) pomniejszyć o glowę majątek drugiego szlachcica (w razie zbiegostwa czy zamążpójścia chłopki lub ożenku chłopa w innym państwie); zranienie tylko cywilne jest niemożliwe.

${ }^{70}$ Już J. Deresiewicz zaznaczył, że stwierdzona przezeń taksa 120 albo 60 grzywien „nie musiała obowiązywać w tej samej wysokości [...] we wszystkich odcinkach czasowych" (Transakcje..., s. VII). 
jak też wzajemne stosunki między chłopami, zabójcą i rodziną denata. Ten charakter utrzymała do końca Rzeczypospolitej szlacheckiej.

Główszczyzna cywilna była czystą instytucją prawa ziemskiego; określała stosunki między szlachtą, stosunki, w których chłop był tylko przedmiotem. W jego stanowisku prawno-społecznym nic nie ulegało zmianie, zostawał $\mathrm{z}$ reguły $\mathrm{w}$ dalszym ciągu poddanym (nowego pana).

3. Główszczyzna cywilna przestała być taksą indywidualną, stała się taryfą rodzinną. Była nie odszkodowaniem za chłopa, ale za jednostkę gospodarczą, jaką stanowil dla szlachcica chłop z żoną, dziećmi, inwentarzem żywym i martwym. Takiego ujęcia nie znała nigdy główszczyzna karna.

4. Główszczyzna cywilna wytworzyła osobną taryfę, o połowę niższą za kobietę. Uiszczano ją najczęściej $\mathrm{z}$ okazji pójścia za mąż dziewczyny za chłopa alterius potestatis. Jak dotąd, nie posiadamy żadnej poszlaki na to, by zredukowana do połowy cywilna taxa muliebris była odbiciem takiejże główszczyzny karnej. Konstytucje sejmowe jej nie znają. Z możliwością jej istnienia trzeba się wszakże liczyć. Gdyby udało się ją wykazać, należałoby się zastanowić, czy nie mamy tu do czynienia $\mathrm{z}$ odwrotną zależnością obydwu główszczyzn od siebie, a więc, czy cywilna nie była wzorem dla karnej.

5. Główszczyzna cywilna różni się od karnej swym przeznaczeniem. Skoro wergeld karny był odszkodowaniem za stratę, spowodowaną pozbawieniem życia, należał się tym, których ten uszczerbek dotknął. W rachubę wchodziła zatem zarówno rodzina denata, jak i jego pan zwierzchni. Stąd to pochodzi jej podział między te dwa czynniki - rodzinę i dwór, znany już od średniowiecza.

Glówszczyzna cywilna przechodzi wyłącznie na rzecz osoby, która tu jest poszkodowana, to jest na rzecz pana. Jeśli więc główszczyzna karna doby nowożytnej chroniła zarówno interesy chłopów, jak i panów (podział jej po polowie między te dwa czynniki), główszczyzna cywilna brała w ochronę tylko interesy panów.

6. Ale nie tylko osoby partycypujące w główszczyźnie cywilnej nie pokrywają się - siłą rzeczy $-\mathrm{z}$ beneficjariuszami główszczyzny karnej. Również kto inny uiszcza jedną i drugą. Wergeld płaci morderca, ewentualnie także krewni niedzielni i spadkobiercy ${ }^{71}$, a nawet liczyć się trzeba $\mathrm{z}$ możliwością płacenia go przez własnego pana zabójcy ${ }^{72}$.

Główszczyznę cywilną świadczy ten senior, do którego poddany (poddana) przechodzi, ten więc, który korzysta ze zmiany miejsca pobytu chłopa. Jest to zatem wyrównanie wartości między dwoma panami. Opłacanie jej przez własnego pana byloby sprzeczne z samą istotą główszczyzny cywilnej. Nie płaci też jej nigdy chłop-poddany. W dużym zbiorze aktów, publikowanych

${ }^{71}$ S. Kutrzeba, Dawne polskie prawo sqdowe w zarysie, wyd. 2, Lwów-Warszawa-Kraków 1927 , s. 21.

${ }^{72}$ Zdarza się też, że dochodzi do noxae datio (nr 368, r. 1558). 
przez J. Deresiewicza, znaleźliśmy od tej reguły dwa tylko wyjątki, zresztą tylko pozorne, w których za dziewczynę, braną za żonę, daje odszkodowanie chłop-nupturient. W pierwszym - odchodzący uczciwy Lukasz, który slużywszy $w$ dobrach moich lat 2 bez wszelkiej cenzury sprawowal sie, teraz przy podzięowaniu upodobal sobie z przeznaczenia boskiego poddanq, na imie Katarzyne Urbanówne do stanu malżeńskiego, którq sobie okupuje; i biorę od niego pieniqdze wedlug prawa mego $i$ wedlug prawa Rzeczypospolitej ( $\mathrm{nr} 620, \mathrm{r}$. 1753). Najwidoczniej był on czlowiekiem wolnym, siedzącym za kontraktem, skoro odszedl po dwu latach służby w charakterze owczarka. Ta sama sytuacja zachodzi, jak sądzimy, w wypadku poświadczonym przez akt z 1740 r., nr 676: owczarz, biorący sobie cudzą poddankę za żonę, placi jej panu verveces 10 , oves fructiferas 5 , agnellos itidem 5 . Ale $\mathrm{i}$ w jego położeniu trudno sobie wyobrazić, by płacil za niego pan, którego opuścił, lub by mu darowal dziewczynę nowy pan, skoro najwidoczniej się jemu nie powzdal. Przykłady te nie przeczą zatem podanej regule, ale ją rozszerzają na dalsze, niepomiernie rzadsze wypadki. Tak samo być musialo, gdy chłopkę-poddankę brał za żonę szlachcic. W XVI w. notuje się niejednokrotnie podobne wypadki ${ }^{73}$, w stuleciu następnym opinia potępia bardzo takie mezalianse ${ }^{74}$, ale zdarzały się one dalej (w r. 1752 nobilis Worgantz wziął sobie za żonę poddankę Sczanieckich, nr 82).

Tą cechą różni się główszczyzna cywilna od średniowiecznego wstawnego, świadczonego przez chłopa.

7. Stwierdziliśmy, że taryfa karna 100 (lub 120 grzywien) obowiązywała w stosunku do szlachty; placił ją zabójca-szlachcic, natomiast plebejusz, jeśli nie był karany śmiercią, uiszczal kwotę niższą.

Glówszczyzna cywilna uiszczana przez szlachcica równała się taryfie karnej. Co więcej, nawet gdy uiszczał ją - w nieczęstych wypadkach - plebej, to $w$ tej samej wysokości. Nie było bowiem żadnego tytułu do redukcji, skoro to nie była kara, lecz odszkodowanie cywilne za utraconego poddanego. Oczywista, że zainteresowany mógł się kontentować niższą oplatą lub nawet zrezygnować $\mathrm{z}$ niej zupełnie. Pod tym zresztą względem nie było różnicy $\mathrm{z}$ główszczyzną karną.

8. Główszczyzna cywilna była tak naturalną rzeczą w ustroju feudalnym, że respektowały ja po rozbiorach wladze pruskie: za poddanego placono w razie małżeństwa 6 talarów, za poddaną -3 talary ${ }^{75}$. Utrzymal się więc dalej nawet stosunek identyczny opłat $w$ zależności od płci ${ }^{76}$.

${ }^{73}$ Szczególnie liczne były takie wypadki w Lęczyckiem w pierwszej połowie XVI w., B. Baranowski, Gospodarstwo..., s. 28; tenże, $O$ hultajach, wiedźmach $i$ wszetecznicach. Szkice $z$ obyczajów XVII i XVIII wieku, Lódż 1962, s. 17.

${ }^{4}$ B. Baranowski, $O$ hultajach..., s. 247.

75 Amelang, Neues Archiv für Gesetzgebung, t. I, Poznań 1800, s. 27, przyp. 107; cytujemy za J. Wąsickim, Prusy Poludniowe (1793-1806), Wrocław 1957, s. 257.

${ }^{76}$ Według J. Wąsickiego (o. c.), prawa i zwyczaje polskie o nich nie mówily. 
9. Niewątpliwie źródłem obydwu główszczyzn był zwyczaj. Wszakże główszczyzna karna, od statutów Kazimierza Wielkiego począwszy, stała się przedmiotem zainteresowań ustawodawcy. Jej dalsze zmiany następowały drogą konstytucji sejmowych. Glówszczyzna cywilna tymczasem pozostala tworem prawa zwyczajowego do końca. Tak przynajmniej wydaje się to historykowi. Istotnie, żadna konstytucja tej instytucji nie zna. Zastanowić się wszakże wolno, czy taki pogląd nie zawiera pewnego ahistoryzmu: szlachta, jak się zdaje, po prostu nie odróżniała jednej od drugiej i dlatego postanowienia karne konstytucji uznawala za miarodajne dla taksy cywilnej. Zdumiewająca zgodność obydwu taryf przemawia za takim ujęciem rzeczy. Atoli nie można nie uznać, że ta rozszerzająca interpretacja była tworem zwyczaju.

\section{Funkcja glówszczyzny cywilnej}

Wytworzenie się główszczyzny cywilnej drogą zwyczajową świadczy o jej pilnej potrzebie, bo taka tylko mogła dać życie instytucji prawnej równie sprecyzowanej. Istotnie, rzadko twór zwyczaju posiada tak wyraziste kontury, pozwala na tak wyczerpujące omówienie, jak to ma miejsce $w$ naszym wypadku. Naturalnie, w dużym stopniu zawdzięcza główszczyzna cywilna tę wyrazistość swej starszej siostrzycy - główszczyźnie karnej. Ale to nie thumaczy jeszcze wszystkiego. Przyczyną, która naprawdę ją stworzyła, byla żywiołowość migracyjna chłopa, przejawiająca się $w$ tzw. zbiegostwie ${ }^{77}$.

Nie chcielibyśmy tu wnikać $w$ ten problem, który wymagałby osobnego studium. Nie będziemy więc formulować definicji zbiegostwa ważnej dla wszystkich epok. Niewątpliwie w ciągu stuleci pojęcie zbiegostwa ulegało dużej ewolucji. W odniesieniu do średniowiecza możemy mówić o legalnym wychodzie kmieci ${ }^{78}$; zbiegiem był ten tylko, kto nie wypełnil swych zobowiązań wobec pana - pisze K. Tymieniecki ${ }^{79}$. Możność przenoszenia się polączona była tylko $\mathrm{z}$ pewnymi opłatami, uważanymi za czysto gospodarcze od-

${ }^{77} \mathrm{~W}$ białoruskim hrabstwie bychowskim w ciagu 7 lat (1762-1770) wyszło lub uciekło 130 chłopów (I. Baranowski, Wieś i folwark, s. 270). O żywiołowości tego zjawiska nadmienialiśmy w artykule: $C z y$ handlowano chlopami w Rzeczypospolitej?, Spraw. Wrock. TN 1960, s. 74. Przypomnijmy, że uzasadnieniem dla konstytucji z 1659 r. jest fakt, że poddani uchodzą turmatim (VL, t. IV, s. 681). O zagadnieniu zbiegostwa najobszerniej pisał S. Śreniowski, Zbiegostwo chlopów w dawnej Polsce jako zagadnienie ustroju spolecznego, Warszawa 1948. Poruszamy tę problematyke $w$ tej tylko mierze, jaka wydaje się niezbędna dla rozumienia omawianej przez nas instytucji.

${ }^{78}$ Por. F. Sobalski, Constitutiones Lancicienses $i$ uchwaly lekkoszyńskie o zbiegostwie $i$ prawie wychodu chlopów, CPH, t. IX, z. 2 (1957), s. 66.

${ }^{79}$ K. Tymieniecki, Konstytucja $z$ r. 1501 o przytwierdzeniu kmieci, [w:] Studia ku czci S. Kutrzeby, t. I, Kraków 1938, s. 470. Za nim A. Lauferski, Ludność wiejska powiatu pyzdrskiego, RH, t. XV, 1939-1946, s. 249. 
szkodowanie dla pana $\mathrm{z}$ powodu narażenia jego interesów przez zmianę posiadacza $^{80}$. O generalnym przytwierdzeniu w ustawach z 1496 r. i 1501 r., mimo ich nieprzychylności dla chłopów ${ }^{81}$, nie było mowy ${ }^{82}$. Niecałe sto lat później (w latach 1562-1577) dokonała się likwidacja prawa wychodu chłopa $^{83}$. Odtąd - i tak już chyba aż do rozbiorów - $\mathrm{k}$ ażd e samowolne opuszczenie przez poddanego państwa, którego byl rodzicem, uchodziło za zbiegostwo. Legalnego wychodu bez pozwolenia pana nie było ${ }^{84}$. Ta sztywna norma okazala się nie do przeprowadzenia. Dlatego to źródła bez przerwy informują o zbiegach.

Takie ujęcie poddaństwa, że chłopu nie wolno opuszczać gruntu bez zezwolenia pana $w$ żadnym wypadku, było następstwem koncepcji ściśle terytorialnej władzy pańskiej nad poddanym. Chłop, który znalazł się poza granicami swego państwa, który zatem nie znajdował się bezpośrednio pod „ręką pańską", nie podlegał faktycznie jego władzy. Dla jej efektywności konieczne było ściągnięcie poddanego $\mathrm{z}$ powrotem do dawnego państwa. W stosunkach polskich nie wskazano dotąd ani jednego przykładu na to, by chłop osiadły w obcym państwie $\mathrm{z}$ tytułu swego osobistego poddaństwa składał jakiekolwiek świadczenia dawnemu, prawnemu panu. Nowy jego zwierzchnik nigdy by na to nie zezwolit! ${ }^{85}$ Jeśli więc mówimy o zależności osobistej chłopa $w$ okresie zaostrzonego poddaństwa, to jest ona $w$ znacznym stopniu ograniczona: utrzymuje się tak dhugo tylko, jak dhugo poddany mieszka w dominium swego pana.

Powody opuszczenia pana były mnogie, natury ekonomicznej, społecznej, demograficznej $\mathrm{i}-\mathrm{w}$ pewnym stopniu - osobistej. Na pierwszym miejscu stawilibyśmy pogoń za chlebem. Jeśli klęski elementarne zniszczyły pewną okolicę, chłop przed śmiercią głodową uciekal gdzie indziej ${ }^{86}$. Podobnie

${ }^{80} \mathrm{~W}$ zapiskach sądowych $\mathrm{z}$ końca XV w. odróżnia się takiego kmiecia, który faciens fecit iuste, hospitale ponendo (SPPP, t. II, $\mathrm{nr} 3480$ ) od innego, klóry profugit, non (domino) iuste, non ponens gosczinnego (ibidem, nr 2666). Por. też charakterystyczną sytuację, o jakiej informuje zapiska z 1487 r.: Demum tempore posicionis hospitalitatis, alias gosczynnego, adveniente, idem Mathias Borutha, satisfacere volens sibi, et ritui, et consuetudini iuris, cum iisdem duobus hominibus et ministeriali, gosczynne dicto, procuratori ville ponebat, volens de agro, quem tenebat, discedere (ibidem, nr 4325). Ob. K. Tymieniecki, Pisma wybrane, Warszawa 1956 , s. 201.

${ }^{81}$ F. Papée, Jan Olbracht, s. 201-202.

${ }^{82}$ K. Tymieniecki, Pisma..., s. 309; tenże, W sprawie..., s. 304.

${ }^{83}$ A. Wawrzyńczykowa, Gospodarsiwo chlopskie w dobrach kościelnych na Mazowszu w XVI i na poczqtku XVII w., Warszawa 1962, s. 199.

${ }^{84} \mathrm{O}$ trudnościach legalnego odejścia nawet ze strony zamożnych chlopów A. Wawrzyńczykowa, Gospodarstwo..., s. 200.

${ }^{85}$ Por. J. Rutkowski, Poddaństwo..., s. 14-15.

${ }^{86} \mathrm{O}$ doniosłym znaczeniu klęsk elementarnych dla rozwoju poddaństwa, S. Hoszowski, Kleski elementarne $w$ Polsce $w$ latach 1587-1648, [w:] Prace $z$ dziejów Polski feudalnej ofiarowane R. Grodeckiemu, Warszawa 1960, s. 454 455, 464 465. Por. też W. Rusiński, Straty $i$ zniszczenia w czasie wojny szwedzkiej, t. II, Warszawa 1957, s. 298. 
wojny rujnowały nieraz zupełnie wieś, zmuszając chłopstwo do ucieczki ${ }^{87}$. $\mathrm{Na}$ nic wówczas zakazy wszelkie. Poddany wtedy tylko się zatrzyma, gdy mu pan pomoże przetrzymać kryzys. Niechcacy ich zapomagać, gdy jeść nie mieli, po żebranym chlebie posz $i^{88}$. Z drugiej strony, gdy chłop zadłużył się u swego pana, skłonny byl do ucieczki, by uchronić się od spłaty należności (nr 348, r. 1761; nr 524, r. 1791). Również wzrost pańszczyzny powodował zbiegostwo $^{89}$. Do zmiany państwa zmuszała niejednokrotnie chęć ożenku czy zamążpójścia za obcego poddanego. Wreszcie bodźce natury osobistej: śmierć żywiciela rodziny, nieporozumienia $\mathrm{z}$ ekonomem, ucieczka przed karą za przestępstwo, szykany ze strony pana. Oto, o czym informuje nas akt z 1790 r.: ...nie mogqc znieść delikatnego siebie wychowania, zostal [chłopiec Młynarczyk] przymuszonym oddalić sie na preczke od niego (nr 362); u tegoż szlachcica drugi wypadek: tego prac. Mateusza przykrym swym jemu panowaniem do podobnej, jak pierwszego Jana Mlynarczyka, przynaglal preczki (nr 362) ${ }^{90}$.

Oto, jakie racje skłaniały pracowitego do ucieczki. $Z$ jakiej by zaś przyczyny opuszczał on pana, stawał się zbiegiem. Bodźce natury gospodarczej odgrywały tu rolę prymującą i bezwzględną. Można było drogą ustawodawczą hamować tyranię pańską, stwarzając odpowiednie do celu sankcje karne. Norma nie była $w$ stanie zahamować procesów ekonomicznych. Nic więc dziwnego, że ciekawy zbiór prof. J. Deresiewicza zawiera aż $20 \%$ aktów dotyczących wyraźnie zbiegów. A ileż $\mathrm{z}$ nich samego terminu nie używa, choć również dotyczy fugitivi? Do nich policzyć należy także wszystkie dokumenty wystawione $\mathrm{w}$ związku z forismaritagium.

Wśród przepisów zwalczających zbiegostwo wyróżnić można dwa rodzaje: pierwsze - skierowane przeciwko chłopom, drugic - przeciwko szlachcie. Pan stosowal surowe sankcje na zbiegu, którego zdołal rewindykować

${ }^{87}$ Por. brzmienie konstytucji z r. 1520: ...qui a domino suo ob praesentis belli inflictam sibi calamitatem fugerit... (VL, t. I, s. 393). Ob. też L. Wiatrowski, $Z$ dziejów latyfundium klasztoru klarysek ze Starego Sqcza (XIII-XVIII wiek), Wroclaw 1959, s. 131, 133, 135.

${ }^{88}$ J. Bielecka, Kontrakty..., s. 111. I. Baranowski cytuje przykład poddanego, który kupił w obcej wsi chałupę, bo u plebana dostatecznego wyżywienia nie miał (Wieś $i$ folwark, s. 184). Że nieudzielenie pomocy chłopu pociągało za sobą zbiegostwo, pisał już Haur; ob. A. Podraza, o. c., s. 69 . Nie znamy dla Korony wyraźnego przepisu, który by tę sprawę regulował formalnie, sądzimy, że faktycznie rzeczy ułożyly się tak samo, jak to postanawia statut litewski I w art. 11: Kiedy kto w czasie glodu chlopów lub czeladź nie karmi, ci ludzie zupelnie sq wolnymi (T. Czacki, O litewskich $i$ polskich prawach, t. II, Kraków 1861, s. 234).

89 B. Baranowski, Gospodarstwo..., s. 45.

${ }^{90}$ Już hetman Tarnowski przykazywal, aby włodarz poddanym folgowal; I. Baranowski, Wieś $i$ folwark, s. 25, to samo zalecał Haur, ob. A. Podraza, o. c., s. 50. Por. też tak symptomatyczny przypadek, w którym poddany po śmierci pańskiej z preczki powrócił, Materialy do dziejów chlopa wielkopolskiego $w$ drugiej polowie XVIII wieku, wyd. J. Deresiewicz, t. III, Wroclaw 1957, s. 109. Ob. też W. Rusiński, Straty $i$ zniszczenia..., s. 300, i A. Wyczański, Studia nad folwarkiem..., 117. 
(przybijanie do pręgierza, śmierć) ${ }^{91}$. One miały odstraszyć innych. Ale te represje zbyt ostre mogły skłonić do ponownej ucieczki. Przy tym założeniem ich było uprzednie schwytanie zbiega, a to nie było sprawą prostą. Chłop bowiem $\mathrm{z}$ reguly osadzal się u nowego pana, który otaczał go swoją opieką. Należało więc wydać zakazy przyjmowania zbiegów i zaopatrzyć je sankcjami skierowanymi przeciwko szlachcie, jak i nakazy wydawania już przyjętych. Zestawil je ongiś M. Bobrzyński ${ }^{92}$. Sankcje, wyłącznie pieniężne, miały swą wysokością odstraszyć od przyjmowania zbiegów. Sądy też nakładały poenae magnae iudiciales ( $\mathrm{nr} 461, \mathrm{r} .1513$ ). Wszakże ta cała walka przepisami prawnymi ze zbiegostwem zawierała $w$ sobie $z$ góry poważny zadatek nieskuteczności. Dekretując na sejmikach i sejmach uchwały contra profugos, każdy poseł szlachecki miał na myśli taką sytuację, w której jego własny poddany ucieka. To było $w$ jego oczach przestępstwem. Natomiast gdy do niego zbiegł cudzy chłop, wtedy nie zamierzał stosować się do obowiązujących przepisów, lecz przyjmowal zbiega u siebie i osadzal bez wahania, jeśli mu był potrzebny. Interes jednego szlachcica walczył $z$ interesem drugiego ${ }^{93}$. Przy takiej postawie - a była ona dominująca - o wykonywaniu ustaw nie było mowy ${ }^{94}$. O bezskuteczności praw świadczy najlepiej ich ponawianie: przez trzy ostatnie stulecia wydano około 50 konstytucyj de fugitivis! ${ }^{95}$

Szlachta nie tylko patrzyła chẹtnym okiem na zbiegostwo cudzych poddanych, ale i popierała je czynnie: namawiała do ucieczki (nr 524, r. 1791), ułatwiała ją czy wręcz wykradała poddanych (nr 462, r. 1513; nr 371, r. 1566; nr 556, r. 1621; nr 339, r. 1728; nr 652, r. 1791 ${ }^{96}$. Największą plaga gospodarki szlacheckiej były pustki ${ }^{97}$. Ilość ich tymczasem była olbrzymia, stąd ta chłonność rynku pracy, zbieg zawsze znalazł sobie zajęcie. Nie bez racji zalecał Haur w swym podręczniku gospodarstwa „osadzanie" kmieci" ${ }^{98}$. Stosując się do jego rad, pan kaptowal sobie cudzych poddanych zapewnieniem im lepszych warunków. Dlatego zrozumiałe zo-

${ }^{91}$ K. Górski, Monarchia, s. 291.

${ }^{92}$ M. Bobrzyński, Karla..., s. 219-221 (dla stuleci XVI i XVII); F. Sobalski, o. c., s. 74 (odnośne postanowienia Constitutiones Lancicienses). Ob. też VL, t. II, s. 731. O akcji przeciwko szlachcie przyjmującej zbiegłych J. Michalski, Studia nad reformq sqdownictwa i prawa sqdowego w XVIII wieku, cz. I, Wrocław-Warszawa 1958, s. 252-253.

${ }^{93}$ M. Bobrzyński, Karta..., s. 217. K. Tymieniecki twierdzi, jakoby ta rywalizacja traciła na znaczeniu, gdy zjawił się wspólny konkurent, jakim były miasta (Powstanie zaostrzonego poddaństwa chlopów w Polsce, Spraw. PTPN 1955, s. 31). Opowiedzielibyśmy się w tym wypadku raczej za zdaniem M. Bobrzyńskiego, że o solidarności szlachty nie było mowy (Karta..., s. 218).

${ }^{44}$ M. Bobrzyński, Karta..., s. 223; W. Dworzaczek, Dobrowolne poddaństwo, s. 77.

95 E. Stawiski, Poszukiwania do historii rolnictwa krajowego, s. 185 (cyt. za I. Baranowskim, Wieś $i$ folwark, s. 99).

96 Tak dla 15 w. F. Sobalski, o. c., s. 65; dla XVIII w. J. Rafacz, Uströj..., s. 122 i n.

${ }^{97}$ K. Tymieniecki, Powstanie zaostrzonego poddaństwa..., s. 31.

${ }^{98}$ A. Podraza, $O, c$., s. 55. 
bowiązanie, zaciągnięte przez pana, wynajmującego na pewien czas cudzego potażnika: ani żadnej protekcyjej dawać (nr 71, r. 1737). Oto, co otrzymał zbieg osiadły we wsi proboszcza szubińskiego, o czym informuje nas akt komplanacji, zmuszający do zwrotu poddanego: excepto, co tylko do gruntu należy, wolów pary $i$ co ze dwora dane jemu jest na rolq, co zostaje wyszczególnione niżej: chlop zaś ten, nie ogalacajac placu $z$ inseminacji aestiwalnej, na gruncie zostawić powinien miary tamecznej kcyńskiej: jęczmienia wiert. 6 , owsa wiert. 6 , grochu wiert. 2 , et in quantum by krescencyja tegoż chlopa tegoroczna jarzynna diminucyjq kwoty wyżej specyfikowanej mieć miala, tedy medietate cuiuslibet grani dzielić się powinien et in fundo zostawić (nr 733, r. 1724). Nie tylko załoge przybyszowi dawal, zwabiał go pokryciem starych długów i oddaniem dziewczyny za żonę (nr 354, r. 1782) ${ }^{99}$. Gdy już taki zbieg się osiedlil, trudności jego odzyskania były duże - stwierdził współcześnie Haur ${ }^{100}$. Te warunki stwarzały dogodne pole dla przedsiębiorczości chłopa ${ }^{101}$. Edycja J. Deresiewicza zawiera moc informacji o tym, jak przebiegały faktyczne próby rewindykacyj.

Najpierw droga pokojową. Dawny pan zwracał się do nowego listownie, żądając wydania zbiega; ten jednak w konkretnym wypadku ani dziewczyny nie oddał, ani nawet na list nie odpisal (nr 647, r. 1783). Inny domagał się zwrotu przez umyślnie posylanego wprzody podstarościego ( $\mathrm{nr} 646, \mathrm{r} .1783$ ).

Nieraz na żądanie uprawnionego brat szlachcic zwracal dobrowolnie zbiega. Ale jego prawa znajdowały w pewnym stopniu uwzględnienie, zwrot następowal nie zaraz, lecz pro festo sancti Thomae proximo ( $\mathrm{nr} 529, \mathrm{r} .1565$ ). Zgadzając się we wrześniu $1706 \mathrm{r}$. ex libero consensu transfundować poddanych, zastrzegał się Latalski, aby się jmp. Jerzy do tychże chlopów odbierania nie interesowal aż po Godzich, da Bóg, in anno 1707 (nr 588). Zbieg osiedlony na gruncie zwrócony zostanie praecise na dzień przyszly, da Pan Bóg, wielkiego czwartku blisko nastepujqcy (nr 733, r. 1724). Respektuje się zatem umowę zawartą między zbiegiem a nowym panem; zerwanie jej następuje podobnie jak z ludnością najemną, umawiającą się na rok $^{102}$.

Dobrowolny zwrot poddanego nie odbywal się bez wzajemności. Małachowski oddal chłopów Głębockiemu, za to otrzymał poddankę, o której sie jegomość dowiedzial (nr 585, r. 1670). Nastąpiło tu więc uregulowanie wzajemnych pretensji dwojga szlachty.

Nieraz przytrzymujący zbiega obiecywał go zwrócić, ale obietnicy nie dotrzymał [zbiega] po kilkakrotnie swych ludzi slaniach obiecaniem dotychczas niepowróconego $(\mathrm{nr} 355 \text {, r. } 1784)^{103}$. Akt z 1730 r., przedstawia nam dość

\footnotetext{
${ }^{99}$ Por. M. Bobrzyński, Karta..., s. 220-225; W. Dworzaczek, Dobrowolne poddaństwo, s. 101.

${ }^{100}$ A. Podraza, o. c., s. 70.

${ }^{101}$ M. Bobrzyński, Karta..., s. 227

102 Por. A. Wyczański, Studia nad folwarkiem..., s. 125.

${ }^{103}$ Por. M. Bobrzyński, Karta..., s. 218.
} 
skomplikowaną sytuację. Stanisławowi Kierskiemu zbiegł poddany imieniem Jakób. O miejscu jego pobytu wiedział dobrze szlachetny Lakiński, który assecuraverat se sibi, manifestanti [tj. Kierskiemu] eundem laboriosum Iacobum proprio sumptu vindicare, vindicatumque adducere, adductumque sibi, manifestanti, extradere et reddere, za co Kierski darowal mu czterech poddanych (nr 737). Z obietnicy wszakże Lakiński się nie wywiązal, wobec czego Kierski unieważnił dokonaną przez siebie darowiznę.

Kompromisowo nastrojony pan, zanim skieruje pozew do sądu, żąda oddania poddanego, ale też chce sie jegomość pomieniony i okupnem kontentować (nr 341, r. 1731); albo dziewka Anna, albo 60 grzywien, mówi akt z 1745 r., nr 684; albo taksa, albo inny poddany, wyraża się dokument z 1779 r., nr 637; donator dostarczy albo chłopa, albo uiści 10 grzywien (nr 701, r. 1575). $\mathrm{Z}$ góry zatem zainteresowany godzi się $\mathrm{z}$ tym, że poddanego nie odzyska!

Jeśli szlachcic zbiega nie zwracal, poszkodowany uciekał się do interwencji przyjaciól, których causa requisitionis eiusdem mulieris cum filia cum expostulatoriis ordinavit; et prout nihil quidquam iidem generosi amici lucrati, protestował i groził wytoczeniem powództwa (nr 678, r. 1740). Już groźba procesu mogla być czasami skuteczna. Według aktu z 1647 r., gdy sprawa o zbiega znalazła się $w$ sądzie, pozwany dał $w$ zamian innego chłopa (nr 421). Jeśli ani propozycje ugodowe, ani zagrożenie procesem nie były skuteczne, musiało dojšć do rewindykacji sądowej. Czy jednak uprawniony szlachcic zawsze się na tę drogę decydowal? Gdy przeciwnikiem był magnat, proces $\mathrm{z}$ góry nie dawal żadnych widoków. Jedynie $\mathrm{z}$ równym sobie był sens się procesować, albo ze słabszym. A i tak osiągnięcie wymiaru sprawiedliwego nie było proste. Procedura była rozwlekła; starano się jej dłużyznom zapobiec drogą ustawodawczą: proces o zbiegle poddane miał należeć do uprzywilejowanej kategorii skróconej ${ }^{104}$; ale i te usilowania były daremne ${ }^{105}$. Sprawy przechodziły aż do Trybunału ${ }^{106}$. Według aktu z 1750 r., postępowanie toczyło się już od 5 lat (nr 618)! ${ }^{107}$

Proces jest rzeczą kosztowną. Strony zatem niepotrzebnych unikajac unkosztów, dokonują komplanacji (nr 608, r. 1743); takież uzasadnienie podaje akt z $1741 \mathrm{r}$.: uchodzqc tedy wszelkich prawnych intrygów i unkosztów zobopólnych (nr 73). Podobnie postą̧piła Elżbieta Zabłocka, gdy jej paru chłopów zbiegło: o których sie dowiedzieć $i$ ich znaleźć nie moge, a zatem

104 Skrócony proces o zbiegłych wprowadzają Zwyczaje mazowieckie, VL, t. II, f. 950 (1576 r.); por. J. Michalski, Studia..., s. 216-218.

105 M. Bobrzyński, Karta..., s. 210-211.

106 Np. nr 422, 579, 573, 574.

107 W. Hejnosz powohje proces o zbiegłych, który trwal blisko 10 lat, a jeszcze do wydania nie doprowadzil (Znamienny dekret sqdu referendarskiego, RDSG, t. II, 1933, s. 102, przyp. 33). 
że na szukanie tych ludzi $i$ na windykacyjq ich, jeżeli się gdzie wynurzq, lożyć trzeba, a ja nie mam ską $i$ dla niepewnych rzeczy tracić pewne ( $\mathrm{nr} 83$, r. 1765). Koszta procesu przerastać moga nieproporcjonalnie wartość samego poddanego: uważając wielkość procesu $w$ grodzie poznańskim $i$ trybunale koronnym piotrkowskim.

Zamiast więc toczyć długi spór i kosztowny, lepiej dokonać complanatio amicabilis. Ileż przykładów na takie ugodowe załatwienie sporów, które już się toczą przed sądami ( $\mathrm{nr} 285,294,241,316,329,320,370,400,405,415$, $425,492,503,568,135,425,568,723,369,543,337,333,389,730$ ), i to bynajmniej nie $\mathrm{z}$ korzyścią dla powoda. Zilustrujmy to twierdzenie jednym przykładem: Skrzetuskiemu zbiegło trzech chłopów: Krzysztof, Wojciech Mały i Mikołaj. Wszczął o nich proces przed sądem grodzkim w Kaliszu przeciwko Wojciechowi Stawiskiemu, do którego widocznie zbiegli się udali. Sprawa kończy się polubownie, Skrzetuski rezygnuje $\mathrm{z}$ nich, w zamian za Krzysztofa otrzymal od Stawiskiego zbiega - Błażeja Relaka - musiał go jednak dopiero rewindykować! $\mathrm{Za}$ Wojciecha Małego otrzymał 100 grzywien; o rekompensacie za Mikołaja nie dowiadujemy się nic: widocznie przeszedł na własność nowego pana bez żadnego odszkodowania (nr 333, r. 1700).

Co więcej, nawet wygranie sprawy przed sądem nie zapewni powodowi zwrotu pracowitego. Wyrok bowiem opiewał nieraz na dwa świadczenia alternatywne, spośród których wyboru ma dokonać pozwany: albo zbiega, albo taksę (nr 217, r. 1505, nr 218, r. 1513, nr 462, r. 1513); przykłady te pochodzą z XVI w. Ze stuleci XVII i XVIII sąd w wyroku już nawet nie mówi o zwrocie poddanego, lecz wylącznie o należnej za niego taksie 60 (nr 316, r. 1635) czy 50 grzywien (nr 519, r. 1758), lub orzeka uiszczenie opłaty podlug prawa (nr 645, r. 1783). Czyż więc warto było w ogóle spór toczyć? Czy nie lepiej od razu kontentować się należną taksą legalną?

Nieraz wszakże dekret sądowy brzmiał ad extradendum. Tymczasem pozwany bynajmniej się do wyroku nie stosuje. Biskupski otrzymał w sądzie ziemskim pyzdrskim dekret, przysądzający mu Małgorzatę Bieńkową z dwiema córkami - Agnieszką i Dorotą. Otrzymuje wszakże od pozwanego Rogaskiego tylko dwie córki, za co darowal mu matkę, rezygnując $\mathrm{z}$ wszelkich kroków sądowych (nr 410, r. 1643). W 1743 r. proces skończył się kondemnatą na wydanie zbiega; strony jednak, chcąc uniknąć dalszych kosztów, dokonały komplanacji (nr 608). Klaryski gnieźnieńskie wygrały proces o zbiega, ale potem darowały go pozwanemu, u którego ów poddany przebywa $a b$ annis aliquot ( $\mathrm{nr} 598$, r. 1724; podobny wypadek z r. 1644, $\mathrm{nr} 722$ ). Czasami i wyrok robi wrażenie polubownej transakcji, dokonywanej $w$ Piotrkowie sub securitate iudiciorum tribunalium (nr 733, r. 1724). I to takiej, przy której interesy uprawnionego powoda zostały tylko w części uszanowane. Postanawia się, co prawda, że tego zaś chlopa in fundo bonorum Wieszek 
za przysianiem po niegoż jm. ks. Chrzanowski wydać deklaruje się absque omni tergiversatione et omnibus iuris diffugiis, ale właściciel tego poddanego zrezygnowal $\mathrm{z}$ dwojga starszych dzieci zwracanego sobie zbiega oraz darowal swemu adwersarzowi dwie kobyly. Mimo że był pełnoprawnym panem zbiega! Jakoś te „właścicielskie” prawa w niskiej stały cenie. Inny znowu szlachcic, zobowiązal się $w$ Trybunale wydać zbieglych w ciągu 4 tygodni, ale ugody nie dotrzyma1 ${ }^{108}$.

Widać więc, że zachowanie się stron po wyroku było takie samo, jak przed procesem czy $w$ toku procesu. Najwidoczniej nie mogły one liczyć na egzekucję wyroku, o czym świadczą wysokie kary nakładane na starostów przechowujących zbiegów, czy wojewodów nie wykonujących wyroków o zbiegle poddane ${ }^{109}$. Zresztą należy wziąć w rachubę następującą niedogodność polskiego procesu: wyrok nie był nigdy ostateczny. Ilustracje tego faktu stanowi cytowany akt z $1724 \mathrm{r}$. ( $\mathrm{nr} 733$ ): powód, majac intentatam actionem do ziemstwa woj. kaliskiego ratione chlopa Jedrzeja Bartniaka, poddanego swego, $i$ tegoż dekretem ziemskim ante diem hodiernam $w$ Kcyni z żonq $i$ dziećmi przysqdzonego ad extradendum, eaque ex causa tęz sprawe ex parte adversa per gravamen detentam, tedy strony ab invicem sistendo ulteriores iuris gradus ac abbreviando quaevis litigia przez śrzodek przyjacielski i przyjaźn takiem sposobem komplanuja sie.

Te przykłady - a można by liczbę ich wielokrotnie powiększyć - wystarczająco wykazują daremność procesów o zbiegłych ${ }^{110}$. Nic dziwnego, że pan zbiega zwraca się aż do króla z prośbą o interwencję, której wynikiem jest wydany przez władcę mandat (nr 725, r. 1649). Ta trudność czy wręcz niemożność rewindykacji sprawia, że eks-właściciel kontentuje się taksą czy błahym przedmiotem - jak pisze J. Deresiewicz; nie dlatego jednak, żeby sobie nisko cenil poddanego ${ }^{111}$.

To jest też racja, dla której transakcje w znacznej części potwierdzają stan faktyczny, stworzony przez zbiegostwo (np. nr 125, 127, 129, 78, $359)^{12}$. Symptomatyczne przy tym jest wielce, że dzieje się tak nawet wówczas, gdy zbieg osiadl we wsi, stanowiącej własność miasta Kalisza

108 Ibidem, s. 102.

109 M. Bobrzyński, Karta..., s. 219, 221; por. też J. Michalski, Studia..., s. 102.

110 Pisał już o niej Haur; por. A. Podraza, o. c., s. 68-69. W literaturze naukowej ostatnio W. Dworzaczek, Dobrowolne poddaństwo, s. 28; W. Rusiński, Straty i zniszczenia..., s. 298.

111 J. Deresiewicz, Handel chlopami..., s. 238. Nie zajmujemy stanowiska wobec komentarza, jakim uczony ten zaopatrzył swój tekst; według niego, ,złamanie postu groziło ogniem piekielnym, z całą pewnością" (ibidem, s. 240). Przyznajemy się do stuprocentowej niekompetencji w zagadnieniach teologicznych.

112 Stwierdził to już W. Dworzaczek, Dobrowolne poddaństwo, s. 25; A. Wawrzyńczykowa, Gospodarstwo..., s. 200 . Według aktu nr 78, ,sprzedanych" zostało 37 zbiegów; z nich wszyscy byli już u nabywcy! 
(nr 329, r. 1646), czy zamieszkał w samym mieście (nr 396, r. 1633) ${ }^{113}$. W ostatnim wypadku poddany zostawał rzeźnikiem, chirurgiem, mielcarzem (nr 58, 65, 118). Szlachcic musial czekać, by się z miasta wychylił, wtedy dopiero mógł go ująć (nr 112). Wydaje się więc, że i ordynacje dla miast, zakazujące przyjmowania luźnych ${ }^{114}$, byly bezskuteczne.

Zbiegostwo bylo zjawiskiem chronicznym ${ }^{115}$. Bylo ono powszechne i masowe; nieraz cale wsie zbiegaly ${ }^{116}$. Walka $\mathrm{z}$ nim byla beznadziejna. Nawet król byl tu bezsilny ${ }^{117}$. Stąd to $w$ aktach strony biora je w rachubę jako rzecz normalną ${ }^{118}$. Ale też nie należy sugerować się terminem zbiegostwo. Nie zawsze mamy $z$ nim faktycznie do czynienia, tzw. zbiegowie osadzaja się w obrębie nie tylko jednego województwa, ale i powiatu ${ }^{119}$. Przy szlachcie cząstkowej kmieć „zbiega” w granicach tej samej wsi z jednego źrebu na drugi (nr 370, r. 1560). W istocie swej tzw. zbiegostwo nie jest niczym innym, jak samowolną zamiana jednego pana na drugiego, zerwaniem dotychczasowego stosunku poddańczego i wejściem w nowy ${ }^{120}$. Dokonywało się ono w okresie największego nasilenia ucisku feudalnego ${ }^{121}$. Nie bez racji pisal kiedyś M. Bobrzyński: przyznaje szlachta sama, że włościanin odzyskał w rzeczywistości wolność osobistą ${ }^{122}$, w sensie możności poruszania się $\mathrm{z}$ miejsca na miejsce; ten fakt podkreśla również J. Rutkowski ${ }^{123}$. Ciągła

${ }^{113} \mathrm{O}$ sile atrakcyjnej miast i zasadzie Stadtluft macht frei, zwłaszcza w miastach średnich i wielkich, J. Bieniarzówna, Gospodarka miejska..., s. 473. Ucieczki chłopów do miast świadczą o nieskuteczności konstytucji z 1496 r., zakazującej mieszczanom trzymać poddanych, którzy odeszli ze wsi bez świadectwa odejścia (M. Bobrzyński, Karıa.., s. 207). O niemożności wydobycia zbiegłych do małych miast (Laska, Korabia) w XVI w. A. Wyczański, Studia..., s. 117. Niejednokrotnie kończyły się one libertacją za wykupem, S. Szczotka, Zwalnianie chlopów z poddaństwa w województwie krakowskim, CPH, t. III, 1951, s. 278-286. O bezsilności pana wobec kmiecia, który zbiegł do miasta, K. Tymieniecki, W sprawie..., s. 298.

114 Por. J. Bieniarzówna, Gospodarka miejska biskupa krakowskiego Jakuba Zadzika (1635-1642), [w:] Prace [...] ofiarowania R. Grodeckiemu..., s. 474.

is M. Bobrzyński, Karta..., s. 225.

116 S. Szczotka, Zwalnianie..., s. 300; W. Dworzaczek, Dobrowolne poddaństwo, s. 25-26; W. Rusiński, Straty i zniszczenia..., s. 298; J. Deresiewicz, Handel..., s. 180; B. Baranowski, Gospodarstwo..., s. 34.

117 Zbiegli honorati subditi królewscy, nullius potestati subesse volentes. Wobec tego król przelewa swe prawa do nich na Michała Raczyńskiego (nr. 56, r. 1702).

${ }_{118} \mathrm{Nr} 88,644,728$.

119 W. Dworzaczek, Dobrowolne poddaństwo, s. 27. Badacz ten stwierdzil, że ze zbiegów przyjmujących poddaństwo, $60 \%$ stanowią przybysze $\mathrm{z}$ najbliższych okolic, $\mathrm{z}$ tego samego powiatu, s. 77.

${ }^{120}$ Ibidem, s. 27.

121 L. Wiatrowski, o. c., s. 135-137, 151, 161.

122 M. Bobrzyński, Karta..., s. 226.

123 J. Rutkowski, Poddaństwo..., s. 60-61. Ostatnio K. Tymieniecki wyraża wątpliwości co do faktu, czy pełne przytwierdzenie kmieci do ziemi zostało kiedykolwiek przeprowadzone generalnie w całym państwie ( $W$ sprawie..., s. 304-305). 
rywalizacja między szlachtą o siłę roboczą, następstwo słabego zaludnienia ${ }^{124}$, byla najlepszą obrona przed despotyzmem pana ${ }^{125}$. Konflikt między panami był mocną gwarancją bezsilności przepisów prawnych, skierowanych przeciwko zbiegostwu. Chłop zbiegły - to klasyczny kandydat na dobrowolnego poddanego. $Z$ nich czy ich potomstwa rekrutują się fugitivi w $82 \%$ - według obliczeń W. Dworzaczka ${ }^{126}$.

Prawda, mógl pan domagać się zwrotu zbiega. Ale mial minimalne widoki na prędkie ukończenie procesu, a potem - w razie wygranej - nie większe na przeprowadzenie egzekucji. Słabość państwa, zorganizowanego czy raczej zdezorganizowanego przez szlachtę, dawała się odczuć jej samejej. W takiej sytuacji wyjście kompromisowe stanowila taksa. Mógł szlachcic-pieniacz żądać zwrotu poddanego, kładąc w pozwie wysoki szacunek, ograniczany zresztą przez konstytucję. Wszakże rozsądek skłaniał ku kontentowaniu się opłatą. Oczywiście, nie każdy szedł za jego podszeptami ${ }^{128}$. Stąd geneza licznych procesów o zbiegłych. Kompromisowa postawa przysparzała przynajmniej zainteresowanemu parę złotych, chroniła od narażenia się na proces dhugi, kosztowny i o wyniku dość wạtpliwym. Stąd praktyka tej opłaty była częsta, do tego stopnia, że wytworzyła się zwyczajowa taksa, nawiązująca do główszczyzny karnej. Była ona stosunkowo niedużej wysokości, a redukowała się jeszcze stale $w$ miarę dewaluacji pieniądza, a zwłaszcza wskutek katastrofalnego wyludnienia, będącego następstwem długotrwałych wojen od polowy XVII w., kiedy to stan zaludnienia spadl do połowy dawnego ${ }^{129}$. Główszczyzna cywilna stanowiła prawną pokrywkę dla zmian poddaństwa, zachodzących wskutek ustawicznej migracji chłopskiej, której nic nie było w stanie powstrzymać ${ }^{30}$. Jej powszechność i częstość przyczynily się do wytworzenia precyzyjnych reguł postępowania, nakreśliły wyraziście kontury tej niezbędnej $w$ opisanych warunkach instytucji, jaką stanowiła główszczyzna cywilna. Zewnętrzny swój aktowy wyraz znalazła ona w tzw. transakcjach dokonywanych masowo ${ }^{131}$. Ponieważ poddany należał do inwentarza dóbr (wyrażenie aktu nr 624, r. 1762), opuszczenie przezeń

124 J. Rutkowski, Poddaństwo..., s. 9.

125 W. Dworzaczek, Dobrowolne poddaństwo, s. 10.

126 Ibidem, s. 66.

127 J. Rutkowski, Poddaństwo..., s. 10, 108.

${ }^{128}$ Zacytujemy jeden charakterystyczny przykład: Maciej Rokossowski oferuje taksę za Mariannę Wojciechowską, która wyszła za mąż za jego poddanego, jej panu Stefanowi Trzcińskiemu; ten wszakże taxam capitis pro eadem laboriosa Wojciechowska a manifestante recipere noluit, omnino vero redditionem eiusdem una cum marito urgebat (nr 681, r. 1741). Jest to typowy wypadek komplikacyj powstałych przez forismaritagium.

${ }_{12}$ W. Rusiński, Straty $i$ zniszczenia..., s. 275, oraz tabela na s. 276.

${ }^{130}$ Nie pisalibyśmy się zatem na pogląd W. Rusińskiego, jakoby wzrost liczby transakcji był wyrazem pogarszającej się sytuacji chłopa (Straty $i$ zniszczenia..., s. 301).

131 J. Deresiewicz, Handel..., s. 180. 
państwa, legalne i nielegalne, oraz osadzenie się w nowym państwie znaleźć musiało $w$ tych transakcjach swój wyraz prawny: stanowily one perpetua resignatio ratione subditi $(\mathrm{nr} 728)$, formalne przelanie praw zwierzchnich ${ }^{132}$. Właściciel zbiega mógł się nie domagać zwrotu zbiega ani należnej zań taksy ze względu na przyjaźń; gdy jednak swój majątek sprzedał, nowy nabywca dokonywal donacji na rzecz pana, u którego poddany osiadł (nr 687, r. 1746). Zbiegostwo chłopów było problemem wiecznie nie uregulowanym ${ }^{133}$. Tej luce w dużej mierze czyniła zadość główszczyzna cywilna. Uiszczenie jej było widocznym przejawem przeniesienia praw pańskich. Chłop nabywał $\mathrm{w}$ ten sposób nowe poddaństwo, a jego dzieci uchodzić będą za rodziców tej wsi, w której zbiegły zamieszkal.

Stwierdziliśmy wyżej, że taksę cywilną oplacał nie chłop, lecz przyjmujący go szlachcic. Oto jakie nieoczekiwane nastepstwo przypisania chlopa do gruntu. W średniowieczu chlop mógł swobodnie opuścić swoją siedzibę, jeśli tylko wywiązal się $\mathrm{z}$ swych zobowiązań, zaciągniętych wobec pana; za nie był pociągany do odpowiedzialności majątkowej. Ta odpowiedzialność wygasła w czasach nowożytnych zupełnie. Poddanemu gruntu w żadnym wypadku opuszczać nie wolno, może to zrobić tylko nielegalnie, a zatem bez jakichkolwiek opłat! Stąd ta zdumiewająca ruchliwość poddanych, która doprowadziła do nie znanej przedtem liczby luźnych. Koszty migracji chlopskich spadły na warstwę szlachecką w całości.

\section{Częstość ,transakcyj” \\ i zasięg terytorialny glówszczyzny cywilnej}

W literaturze dotychczasowej, zajmującej się „sprzedażą" chłopów, wyróżnić można dwa stanowiska. Dawniejsza poczytywała transakcje za rzecz sporadyczną, wręcz wyjątkową; taka też była opinio communis nauki jeszcze w czasach powojennych ${ }^{134}$. Najnowsza, z W. Dworzaczkiem i J. Deresiewiczem, uważa je za zjawisko masowe. Proponując inną jego interpretację, tylko drugie stanowisko uznamy za słuszne. Jak się wydaje, od chwili pojawienia się obszernej publikacji J. Deresiewicza nie może być co do tego żadnych wątpliwości. Uczony ten odszukal blisko 3000 aktów (dokładnie 2788) z dwu tylko województw - poznańskiego i kaliskiego, na przestrzeni trzech stuleci; $\mathrm{z}$ nich opublikował 747 pozycyj.

${ }^{132}$ Trafne wyrażenie W. Dworzaczka, Dobrowolne poddaństwo, s. 28. Takąż myśl wypowiada i J. Deresiewicz, Sprzedaż chlopów..., s. 752. Ob. też gruntowne studium K. Orzechowskiego, O wladztwie..., s. 292, 297-298.

${ }^{133}$ H. Olszewski, Doktryny prawno-ustrojowe czasów saskich (1697-1740), Warszawa 1961, s. 117.

${ }^{134}$ K. Zimmermann, Fryderyk Wielki..., t. I, Poznań 1915, s. 125; J. Rutkowski, Poddaństwo..., s. 64; za nim J. Bielecka, Kontrakty..., s. 111-112. 
Zważyć przy tym należy, że księgi sądowe nie odzwierciedlają w pełni omawianego zjawiska transakcji ${ }^{134 a}$. Dokonywano ich bowiem nieurzędowo, przez osobiste porozumienie zainteresowanych, nieraz tylko ustnie ( $w$ ustapieniu slownym poddaństwa, $\mathrm{nr}$ 646), częściej zapewne za pomocą pisemnego rewersu (litterae, $\mathrm{nr} 374$; donatio manualis, $\mathrm{nr} 440$; scriptum manuale, cessio manualis, nr 628; lub po polsku: skrypt, nr 443; karta, nr 624; rewers, nr 728; rekognicja, nr 585; donacja, nr 641), który wyjątkowo tylko mial szanse ujścia zębowi czasu. $Z$ reguły ginął wskutek niedbalstwa wlaściciela, gdy się zdezaktualizował. Wiadomości o takich transakcjach czerpiemy $\mathrm{z}$ ksiąg sądowych, acta publica Regni (nr 678), w które je wciągano, by nadać im charakter publiczny. A w iluż wypadkach do takiej roboracji nie doszło? ${ }^{134 b}$ Masowość omawianego zjawiska musi uchodzić $w$ tych warunkach za dowiedzioną.

Materiał, na którym opierają się nasze wywody, pochodzi wyłącznie z Wielkopolski ${ }^{135}$. Tym samym więc - jeśli mogą uchodzić za przekonywające - dowiedliśmy istnienia główszczyzny cywilnej w tej tylko dzielnicy. Wszakże zestawione niżej racje pozwolą nam rozciągnąć zasadnie otrzymane wyniki na całą Polskę przedrozbiorową.

Jak wiemy, główszczyzna karna o jednolitej taryfie obowiązywała w całej Polsce co najpóźniej od początku XVI w. Ona tymczasem stanowiła wzór dla główszczyzny cywilnej. Powołane wyżej akty ustawodawcze, które - acz ubocznie - zajęły się główszczyzną cywilną, nie ograniczały się terytorialnie do Wielkopolski. Pierwszy, Formula processus, odnosil się zrazu do Małopolski, ale wcześnie rozszerzono jego moc obowiązującą na województwa inowrocławskie, brzesko-kujawskie, na Wielkopolskę i Mazowsze ${ }^{136}$. Drugi, konstytucja z 1543 r., dotyczył całej Polski. Znajomość taksy kobiecej poświadcza wyrok Trybunału Piotrkowskiego z r. 1723 (nr 61); sąd zaś ten swoim zasięgiem obejmował znacznie większe obszary aniżeli Wielkopolska historyczna. Wreszcie akt z 1784 r., powolany wyżej, stwierdza w sposób dobitny: a podlug $p r a w a$ $k$ oronnego na takse [...] zezwolili (nr 649). Już te argumenty nie pozwalaja zacieśniać główszczyzny cywilnej do regionu Wielkopolski.

Dalsze jeszcze względy przemawiają nie mniej stanowczo za występowaniem cywilnej taxa capitis w całym kraju. Unifikacja urządzeń feudalnych w sprawach chłopskich, zaawansowana w dobie nowożytnej, prowadzić musiała

${ }^{134 a}$ Terminu tego używamy za J. Deresiewiczem w rozumieniu szerszym, zgodnie też ze źródłami, według których w transactiones mieszczą się zarówno donatio chłopa, jak i subditio, to jest dobrowolne przyjęcie poddaństwa ( $\mathrm{nr}$ 676).

${ }^{134 b}$ J. Bielecka w przekonaniu, że omawiane transakcje w przeważającej mierze wpisywano do ksiąg, ujęła donacje chłopów w osobnej tabeli (Kontrakty..., tab. XLVIII).

135 Zwracano w literaturze uwage na to, ze J. Deresiewicz dał swej publikacji tytuł zbyt szeroki; zarzut ten uznał wydawca za shuszny (KH, R. 67, 1960, s. 881.).

${ }_{136}$ S. Kutrzeba, Historia źródel dawnego prawa polskiego, t. I, Lwów-Warszawa-Kraków 1926 , s. $218-219$. 
do identycznych rozwiązań tego palącego problemu. Migracja żywiołowa poddanych występowała w całym kraju, wymagała więc wszędzie odpowiednich rozwiązań. Nie mogąc przeprowadzić szczególowej kwerendy, zaryzykujemy twierdzenie, że główszczyznę cywilną znano wszędzie tam, gdzie dochodziło do transakcji chłopami. Te zaś występowały w Małopolsce ${ }^{137}$, w dzielnicach centralnych - w Sieradzkiem ${ }^{138}$ i Lęczyckiem ${ }^{139}$, i na Mazowszu ${ }^{140}$, i w Prusach Królewskich $^{141}$, na Rusi i Litwie ${ }^{142}$.

Najdobitniejszy wyraz ogólnopolskiego charakteru transakcyj chłopami i uiszczanej w tym związku glówszczyzny cywilnej stanowi fakt, że formularz na venditio subditi pomieścil $\mathrm{w}$ swoich wzorach pism procesowych ein Danziger Rechtsgelehrter, Jan Nixdorff ${ }^{143}$. Pochodząc sam z Prus Królewskich, $\mathrm{z}$ praktyki tej dzielnicy zaczerpnąl on swoje formuły ${ }^{144}$. Szablon przezeń podany nie różni się od tego, jakim się posługiwała szlachta wielkopolska.

Tezę o powszechności transakcji chłopami stawił J. Deresiewicz ${ }^{145}$. Akces nasz do niej jest pelny. Przy takim rozumieniu stosunków poddańczych w dobie nowożytnej, jakie przedstawiliśmy w tym studium, transakcje były zjawiskiem nieodzownym tam, gdzie wytworzyły się państwa-seniorie ${ }^{146}$. Musiały one zatem występować i w krajach ościennych ${ }^{147}$. W konsekwencji trudno też domniemywać, by tylko w Polsce uformowala się główszczyzna cywilna.

${ }^{137}$ T. Lubomirski, Rolnicza ludność w Polsce od XVI do XVIII wieku, Biblioteka Warszawska, 1862, t. II, s. 9, i ibidem, przyp. 1; A. Bocheński, Beitrag zur Geschichte der gutsherrlich-bäuerlichen Verhältnisse in Polen auf Grund archivalischen Quellen der Herrschaft Kock, t. I, Kraków 1895, s. 145; J. Rafacz, Ustrój..., s. 98; J. Bergerówna, Księżna pani na Kocku i Siemialyczach (dzialalność gospodarcza i spoleczna Anny z Sapiehów Jablonowskiej), Archiwum Tow. Nauk. Lwowskiego, dz. 2, t. XVIII, z. 1, Lwów 1936, s. 261, przyp. 2; S. Szczotka, Zwalnianie..., s. 299; B. Baranowski, Z. Libiszowska, R. Rosin, Polożenie chlopów u schylku Rzeczypospolitej szlacheckiej, Warszawa 1953, s. 50-51; J. Mazurkiewicz, Podleglość sqdowa szlachty w stosunku do starosty niegrodowego kazimierskiego w XVII w., CPH, t. XII, z. 1, 1960, s. 220. Por. też powołane wyżej informacje małopolskich zapisek sądowych.

138 J. Rafacz, Przyjecie poddaństwa, Themis Polska, t. IX, 1935.

${ }^{139}$ B. Baranowski na podstawie kwerendy wiejskiej $w$ ksieggach grodzkich i ziemskich stwierdza 270 przypadków „sprzedaży” chłopów, z czego 4/5 z XVIII w. (Gospodarstwo..., s. 63).

${ }^{140}$ A. Wawrzyńczyk, Gospodarstwo..., s. 200.

141 W. Kętrzyński, O pierwotnym ustroju spolecznym w Polsce, t. II, Ateneum 1881, s. 476 przyp. 3; M. Bär, Westpreussen unter Friedrich dem Grossen, t. I, Leipzig 1909, s. 308, przyp. 1 (z podaniem dawniejszych poglądów na kwestię), R. [omyłkowo miast B.] Baranowski, Z. Libiszowska, R. Rosin, Polożenie chlopów..., s. 48-50; W. Odyniec, $Z$ badań nad rozwarstwieniem wsi na Pomorzu w XVIII w., KH, t. 62, 1955, s. 202.

142 J. Deresiewicz, Transakcje..., s. XXI.

${ }^{143}$ L. Pauli, o. c., s. 81-82 oraz s. 23.

144 S. Kutrzeba, Historia źródel, t. I, s. 281.

${ }_{145}$ Por. zestawienie jego wypowiedzi, dokonane przez K. Orzechowskiego, $O$ wladztwie..., s. 281.

${ }^{146}$ K. Orzechowski, $O$ wladzlwie..., s. 293-294.

${ }^{147}$ J. Deresiewicz, Transakcje..., s. XXI. 


\section{Rodzic i rodziczka*}

Jak wykazal ostatnio J. Reczek, w staropolszczyźnie na oznaczenie parentes używano ośmiu rzeczowników; wśród nich znajdował się również termin rodzicy - rodzice. Ten $w$ dzisiejszym języku jedyny określnik nie był w omawianym sensie szeroko rozpowszechniony do końca XV w. ${ }^{1} \mathrm{~W}$ źródłach nowożytnych określenie to, bądź w liczbie pojedynczej (rodzic), bądź mnogiej (rodzice), pojawia się bardzo często. Już sam fakt występowania tego substantivum $w$ singularis ostrzega przed przypisywaniem mu znaczenia dzisiejszego.

Historycy zetknąwszy się z nim, nie rozwiązywali go w sposób identyczny. I tak I. Baranowski, znalazłszy go u Gostomskiego w zdaniu: Rodziców nie ma żaden urzednik bez pańskiej wolej ze wsi wypuszczać ${ }^{2}$, poczytał rodziców za poddanych, którzy zrzekli się gospodarstwa na rzecz dzieci ${ }^{3}$. Miał on niewątpliwie na myśli sytuację, poświadczoną wielokrotnie przez wiejskie księgi sądowe, w której rodzice (parentes) na stare lata zapisują gospodarstwo dzieciom, zastrzegając sobie dożywocie ${ }^{4}$. Tenże badacz wyjaśnia w dalszym ciągu tekstu, że zakaz samowolnego opuszczania nawet przez r od z in ę kmiecia dlatego wprowadzono „niewątpliwie”, gdyż chodzilo o zapewnienie możności rekrutowania czeladzi dla dworu oraz czeladzi dla chłopów ${ }^{5}$. Wyjaśnienie to - zauważmy - nie bardzo zgodne jest $\mathrm{z}$ interpretacja sugerowaną wyżej.

Inaczej ujął rzecz S. Inglot. W objaśnieniach do wydania wspomnianego pisarza staropolskiego, A. Gostomskiego, podał on: „w miejscu urodzony ${ }^{6}$.

$\mathrm{Z}$ nową całkiem koncepcją wystąpił ostatnio A. Wyczański: „Szukając w źródłach ludności wiejskiej, mogącej stanowić pewną rezerwę siły roboczej, należy zwrócić uwagę na osobną kategorię ludzi, nazywanych najczęściej

* Przedruk z: Czasopismo Prawno-Historyczne 1964, t. 16, z. 1, s. 321-328. Por. S. Urbańczyk w: Język Polski 1964, t. 44, s. 178

1 J. Reczek, Oddawanie pojęcia parentes 'rodzice'w staropolszczyźnie, Język Polski, t. 43, 1963 , s. $49-57$.

2 A. Gostomski, Gospodarstwo, wyd. S. Inglot, Bibl. Nar., ser. 1, nr 139, Wroclaw 1951, s. 24.

${ }^{3}$ I. Baranowski, Wieś i folwark. Studia z dziejów agrarnych Polski, Warszawa 1914, s. 67.

4 Np. Ksiegi sqdowe wiejskie klucza lqckiego, wyd. A. Vetulani, cz. 1: (1526-1739), Wrocław-Warszawa-Kraków 1962, nr 96 (1544 r.); nr 165, 261, 372, 539 (1655 r.).

${ }^{5}$ I. Baranowski, o. $c$.

${ }^{\circ} \mathrm{S}$. Inglot, o. c., s. 24 , przyp. 7. 
«rodzice» i, jak wynika $z$ nomenklatury inwentarzy, zbliżonych do grupy zwanej przez rejestry poborowe ludźmi «luźnymi», «hultajami», czy z lacińska «vagi»"7. Tę myśl powtarza A. Wyczański na dalszych stronicach swego pracowitego dziela, wymieniając rodziców wśród różnego rodzaju luźnych (rodzice, dziedzice, hultaje, luźni) ${ }^{8}$.

Inną znowu interpretację terminu podał L. Żytkowicz. Jego zdaniem, są nim określani „dorośli synowie kmieci lub mieszkający razem bracia, którymi niekiedy interesowali się wizytatorzy jako kandydatami na wakujące gospodarstwa. Z tego zapewne powodu wizytacje niektórych wsi wyszczególniają młodzież męską w wieku ponad 18 lat"'. W dalszym ciągu tenże badacz stwierdza, że są to członkowie rodzin kmiecych, którzy byli na miejscu (nativi) ${ }^{10}$.

Stwierdzamy więc dużą rozbieżność $\mathrm{w}$ rozumieniu rodziców: uważa się ich bądź za rodziców w sensie dzisiejszym (Baranowski), bądź za starsze dzieci (Żytkowicz), to znów za tubylców (Inglot) lub za ludzi luźnych (Wyczański). Czyżby rzeczywiście omawiany termin posiadal aż tyle różnorodnych, a sprzecznych po części $z$ sobą znaczeń?

Znamy dobrze tekst interpretowany przez I. Baranowskiego i S. Inglota, jak i podstawę źródłową L. Żytkowicza. Natomiast A. Wyczański nie podał cytatu, który go skłonil do podanej przez siebie wykładni. Inwentarze, na których nomenklaturę się powoluje, są zazwyczaj - jak wiemy - zbyt lakoniczne, by na ich podstawie ustalać zakres znaczeniowy używanych przez nie terminów. $Z$ pewnością nie wynika taka interpretacja $z$ wiadomości zestawionych przez samego autora" ${ }^{11}$.

$\mathrm{Z}$ proponowanych wykładni odrzucimy a limine pierwszą. Niewątpliwie - stwierdziliśmy to wyżej - i dawna polszczyzna używa terminu rodzice w znaczeniu parentes ${ }^{12}$, ale w kontekście, występującym u Gostomskiego, prowadzi ta interpretacja do tak niefortunnych konsekwencji - jak to zauważyliśmy u Baranowskiego - że rozejrzeć się trzeba za inną. Którą przyjąć z trzech dalszych: Inglota czy Wyczańskiego, zważywszy na to, że obie sa sobie przeciwstawne, czy wreszcie Żytkowicza?

Podkreślmy, że na temat ludzi luźnych ukazało się niedawno interesujące studium S. Grodziskiego. Autor zestawił w nim wszystkie terminy oznaczające

${ }^{7}$ A. Wyczański, Studia nad folwarkiem szlacheckim w Polsce w latach 1500-1580, Warszawa 1960, s. 127.

${ }^{8}$ Ibidem, s. 130.

${ }^{9}$ L. Żytkowicz, Studia nad gospodarstwem wiejskim $w$ dobrach kościelnych XVI w., Warszawa 1962, s. 79.

10 Ibidem, s. 81.

1 A. Wyczański, o. c., s. 128.

12 Por. Materialy do dziejów chlopa wielkopolskiego, wyd. J. Deresiewicz, t. I-III, Wrocław 1956-1957, pod hasłem rodzica, rodzice; ob. też powołaną wyżej Księgę łącką, nr 572. 
tę kategorię plebejów. Wśród nich wszakże rodziców nie znajdujemy ${ }^{13}$. Przeciwko thumaczeniu Wyczańskiego przemawiają stanowczo zestawione niżej teksty, zaczerpnięte $\mathrm{z}$ cennej publikacji J. Deresiewicza ${ }^{14}$.

[1] 1639: ...żeśmy [...] dali $i$ darowali czasy wiecznemi chlopca, poddanego, swego wlasnego rodzica (nr 498).

[2] 1699: ...chlopa, poddanego mego, na imie Ludwika Jana Kodyńczaka, $z$ dóbr moich dziedzicznych, Woli Czujewskiej, rodzica, [...] na wieczne czasy daje, daruje i zapisuje (nr 587).

[3] 1777: Maryjanne, Michala $i$ Krystyny Pijanowskich z dóbr Werkowa moich dziedzicznych poddanych rodz icó w córe [...] ustepuje, daje, daruje (nr 633).

Interesujący nas termin nie jest też obcy instrukcjom sejmikowym, zna go mianowicie instrukcja sejmiku średzkiego z 1628 r.: Wielkie bezprawie dzieje sie poddanym naszym, że ludzie plebei, jako zbiegowie tak rodzicy $z e$ wsi naszych, rocznie sie nie rzqdzqc, dietim sie najmujac do roboty, poddane nasze do wielkich szkód przywodzq ${ }^{15}$.

Wedhu tych tekstów zatem rodzic nie jest chłopem luźnym, lecz przeciwnie - poddanym, własnym poddanym, pochodzącym $z$ dóbr dziedzicznych. Ale liczba podanych cytatów może się wydawać zbyt mała, a stąd nieprzekonywająca.

Aktowy termin polski musiał mieć swój aktowy odpowiednik laciński. L. Żytkowicz za taki uznal nativus ${ }^{16}$. Z wspólczesnych dokumentów powołać możemy tekst następujący:

[4] 1740: ...verum quoniam ex eisdem transactionibus luculenter patet eundem laboriosum Albertum Nowaczyk de dicta villa Odroważ praestimoniali na tivum esse i niżej: eundem laboriosum Albertum, de villa Odrową̇ nativum (nr 676).

Charakterystyczne są również poniższe cytaty zaczerpnięte $z$ aktów dotyczących tej samej problematyki, co podane wyżej teksty polskie, aktów, dotyczących „transakcji” chłopami.

${ }^{13}$ S. Grodziski, Ludzie luźni, Kraków 1962, s. 14-19. Nie znał go też Ostrowski, por. Z. Zdrójkowski, Teodor Ostrowski, Warszawa 1956, s. 251-252. Ob. też J. Gierowski, Ludzie luźni, PH, t. 40, z. 2, 1949, oraz B. Baranowski, Ludzie luźni, Przegląd Nauk Historycznych i Społecznych, t. III, 1953.

${ }^{14}$ Transakcje chlopami w Polsce szlacheckiej XVII-XVIII w., wyd. J. Deresiewicz, Warszawa 1959.

is Akta sejmikowe wojewódzıwa poznańskiego i kaliskiego, t. I, cz. 2, wyd. W. Dworzaczek, Poznań 1962, s. 288, pkt 29.

${ }_{16}$ L. Źytkowicz, o. c., s. 79. J. Deresiewicz zestawiał nativi z rodowitymi (Sprzedaż chlopów, Wiedza i Życie, R. 24, 1957, s. 752). 
[5] 1562: ...quia Laboriosum Blasium Szalkowicz, filium laboriosi Martini Szalek, smethonis et subditi sui de villa Gawrzalowo [...] nat ivum su um de eadem villa Gawrzalowo [...] dedit (nr 242).

[6] 1620: ...quia ipse laboriosos Michaelem, Lucam et Catharinam, [...] laboriosi Sigismundi, cmethonis et subditi de villa Malice, liberos, ibidemque in eadem villa oriundos, $n$ a tivos vero suos proprios [...] dedit ( $\mathrm{nr} 656$ ). [7] 1640: ...quia ipse laboriosum Gregorium Waskowicz, subditum suum proprium, nativum et hereditarium de oppido praefato Osjaków [...] dedit (nr 324).

[8] 1720: ...quia ipse [...] considerando e cunabulis educationem infrascripti laboriosi Francisci, pueri laboriosi Mathie, ovilionis, eundem puerum, nomine Franciscion, de praefata villa Wilkowyja subditi filium, subditum suum proprium, de memorata villa Wilkowyja nativum [...] dat, donat et inscribit (nr 591).

Ograniczamy się do tych paru cytatów pochodzących z trzech stuleci; zaznaczamy wszakże, że liczbę ich można snadnie powiększyć. Jest to terminologia obiegowa wspomnianych aktów transakcyj ${ }^{17}$. Powołane cytaty lacińskie zestawione $\mathrm{z}$ polskimi, podanymi wyżej, upoważniają nas do postawienia znaku równości między nativus i rodzic, nativus suus proprius i swój wlasny rodzic. Tym samym wyjaśnia się niezbicie, kim byl rodzic. Był to poddany $z$ urodzenia, $z$ ojca poddanego, urodzony we wsi, stanowiącej własność pana, który tym poddanym rozporządzal.

Takiż desygnat dla nativus podaje Ducange: ...nativus - oriundus de qua vel civitate esset nativus; nativi - servi glebae, origine et nativitate, eoque ipsi dominis suis obnoxii; placitum de nativis, id est de servis fugitivis; nativitas - servitus. Cytaty powyższe zakończmy zdaniem Bractona: Servi aut nascuntur, aut fiunt. Nascuntur autem ex nativo et nativa alicuius.

Tej interpretacji nie sprzeciwiają się cytaty źródlowe powolane przez L. Żytkowicza: ...in eadem villa sunt nativi, qui locari possint in desertis; apud cmetones sunt multi adolescentes nativi, quibus agri deserti locari possint ${ }^{18}$.

Akty transakcyj wymieniają niejednokrotnie obok poddanego - poddankę, nativa et subdita (np. $\mathrm{nr} 655,1589$ r.). Znamy odpowiednik polski i tego terminu:

[9] 1641: zeznawam tym pisaniem moim, żem ja robotnq Zofija, dziewczyne moja i rodziczke z Komorza, majetności mojej [...] dawam $i$ daruje (nr 406).

${ }^{17}$ Wyrażenie subditus (suus) et nativus proprius zawierają też akty nr 492 (1604 r.) i nr 503, dok. 2 (1645 r.).

${ }^{18}$ L. Źytkowicz, o. c., s. 79, przyp. 1. 
Rodzic nie jest jedynym odpowiednikiem nativus. Oto, co podają następujące teksty:

[10] 1588: ...iżem przedal Patulinego syna z Sẹdziwojewa, na imie Boczianka Wojciecha, który na ten czas we Wrześni mieszkal, szlachetnemu panu Stanislawowi Bronikowskiemu, którego to Wojciecha Boczianka, kiedy pan Bronikowski dostanie, albo kiedy mu go wydadza, wtedy ten pan Stanislaw Bronikowski już go za swego wlasnego rodo wi c z a wiecznymi czasy ma otrzymać (nr 374).

[11] 1588: Jędrzeja Mielczarza, rodowic z a swego ze wsi Blekwita, dawam $i$ daruje ( $\mathrm{nr} 704$ ).

[12] 1595: ...zeznawam tq niniejszq rekognicyja swojq, iżem rodowicza sivego wlasnego [...] dal $i$ darowal (nr 708).

[13] 1678: ...za zupelnq nam satysfakcyja o odliczeniem pieniędzy od jm. księdza Waldowskiego 100 grzywien za Marcina z Niewieścina, poddanego naszego, który lubo z mlodości lat wychowawszy sie $w$ majętności jm. księdza Waldowskiego et ex certis rationibus wpadszy $w$ poddaństwo jego, tedy, aby tym gruntowniejsze posesyi prawo do niego sobie ugruntowal na ukontentowanie nas wyżej mianowanq sume nam jako za rodowica $z$ naszej majętności wyliczyl ( $\mathrm{nr} 728$ ).

Wedhug aktu z 1741 r., zwraca się Andrzej Wysogota Zakrzewski do oporowskiego prepozyta, ks. Macieja z Kiszewy Lisieckiego, by mu

[14] chlopa imieniem Szymona, przezwiskiem Poboka, rodak a i poddanego Kaminieckiego, ustapil i darowal (nr 122).

Wreszcie w jednym wypadku pojawi się dalszy wariant:

[15] 1723: ...że ja, majqc prawo moje [...] do urodzonego Marcina Skrzętnego, poddanego z Gorzeń, prawu memu podleglego [...] Który to u rodz ony Marcin Skrzetny, poddany z Gorzeń... (nr 732).

Powyższe zestawienie upoważnia nas do traktowania jako synonimów, terminów następujących: nativus $=$ rodzic (nativa $=$ rodziczka), rodowic, rodak, urodzony.

Przytoczone teksty pochodzą bez wyjątku z Wielkopolski, nie wylączając i cytatów L. Żytkowicza; trzeba zatem liczyć się z możliwością, że ustalenie powyższe odnosi się do tej tylko dzielnicy, innymi słowy, że nativus = rodzic stanowi ceche Wielkopolan. Gdyby nawet tak było, wynik nasz nie pozostanie bez znaczenia dla wywodów A. Wyczańskiego, skoro uczony ten powołuje się na cytowanych stronicach właśnie na stosunki panujące 
w Wielkopolsce ${ }^{19}$. Wszakże przeciw takiemu geograficznemu zacieśnieniu omawianego wyrazu przemawia już powołany wyżej Mazur - Gostomski. Z Mazowsza też możemy przytoczyć kilka konstytucyj, w których rodzic występuje. I tak art. 46 eksceptów mazowieckich z 1576, zakazuje, by żaden nie śmial przyjąc $i$ zachować tak zbieglego kmiecia, jako $i$ rodzica, $i$ slugi utriusque sexus, który by listu nie mial, iż od pana swego jest wolny ${ }^{20}$.

Postanowienie art. 37 konstytucji z 1578 r. brzmi następująco: ...a kto by sie ważyl przyjać plebeium sluge albo rodzica czyjego, bez listu wyświadczonego [...] taki [...] wydać powinien onego zbiega, sluge albo rodzica [...] Jednak nikogo nie chcqc zniewolić, będzie wolno sludze od pana swego odstać, gdy czasu dosluży swego, sine quovis impedimento pana, któremu slużyl; a jeśliby go pan odprawić albo listu dać nie chcial, takiemu sludze będzie wolno wziqć list wyświadczony od sqdu ziemskiego albo grodzkiego onegoż powiatu; secus o rodzica, który nigdzie indzie listu nabywać nie $m a$, tylko u pana swego ${ }^{21}$. Wyraźne jest tu przeciwstawienie sługi wolnego rodzicowi. Ścisły związek ostatniego $\mathrm{z}$ panem, podległość wobec niego rzucają się w oczy.

Wreszcie zwyczaje województwa mazowieckiego z 1576 r. zawieraja normę następującą: $A$ zbieglych kmieci i rodziców ich prawem koronnym dochodzic im bedzie wolno tym sposobem: aby każdy o kmiecia, o poddanego $i$ wszelakiego zbieglego rodzica $i$ sluge plebeum utriusque sexus [...] Azeby się ultaje nie mnożyli, aby żaden nie śmial przyjać $i$ zachować tak zbieglego kmiecia jako $i$ rodzica $i$ slugi utriusque sexus [...]; a tym sposobem gwaltem wzietych kmieci, poddanych, rodziców i slug dochodzić każdemu ma być wolno...22. Tak więc nie może ulegać wątpliwości występowanie wyrazu rodzic na Mazowszu. Co więcej, znają go i teksty małopolskie w znaczeniu tubylczego poddanego ${ }^{23}$.

Wydaje się, że przeprowadzoną dokumentację można uznać za wystarczającą w pełni: w tekstach prawnych, które wyżej zestawiono, rodzic (i jego synonimy) oznacza poddanego urodzonego na miejscu; jego odpowiednikiem łacińskim jest nativus. Podane niżej dane wykażą, że w tym samym znaczeniu termin ten był używany w języku potocznym.

Biblia Zofii: ...wszitko jeden zakon będzie tu rodzycowi $(56, \mathrm{~b} / 14)$ eadem lex erit indigenae, in dem selben Lande geboren ( u tec z nemu w Biblii Leopolity ${ }^{24}$.

\footnotetext{
${ }^{19}$ A. Wyezański, o. c., s. 129.

${ }^{20}$ Cytuje M. Bobrzyński, Karta z dziejów ludu wiejskiego w Polsce, [w:] Szkice i studia historyczne, t. II, s. 219.

${ }^{21}$ VL, t. II, s. 972. Cytuje S. Grodziski, o. c., s. 91, przyp. 47.

22 VL, t. II, f. 949-950.

${ }^{23}$ Księga łącka, nr 586.

24 A. Babiaczyk, Lexikon zur altpolnischen Bibel 1455, Breslau 1906, s. 245.
} 
Mączyński: ...verna, servus et ancilla domi natus, rodzic y rodziczka $w$ domu naszym urodzona, niewolnik, wychowaniec (485, b/2); Pamphila mea inventa est civis, nalazla sie być rodzic $z$ kq miasta (482, d/6); iam susurare audio civem Atticam ess hanc, Teren. A nusz miedzy sobq szepcq jako by wrzkomo rodziczka ta miala być Atenieńkq (435, d/41).

Cnapius: Rodzic, ztqd, tuteczny, indigena, populi Latii indigenae, Sidonida nomine dicunt, oriundus hinc.

W tym też znaczeniu używa go III Statut litewski z roku 1588; król obiecal nie nadawać urzędów cudzoziemcom, ale to wszystko My [...] dawać będziem powinni tylko Litwie, Rusi, Żmujdzi i rodzicom starożytnym $i$ urodzeńcom Wielkiego Xiestwa Litewskiego ${ }^{25}$. Podobnie zreszta i W. N. Trepka, który podaje o Jakubie Suchorowskim, że zabiel bel we drzwiach kuncerzem studenta, $z$ Bochnie rodzica, a o Choińskim Janie wyraża się tak: ...co wiedzieć, skqd jest? Rodzic jest od Brodnice, chlopski $s y n^{25 a}$.

W okresie oświecenia rodowic, rodzic - rodak, tegoż rodu, uchodzi za wyraz dawny zaniedbany ${ }^{26}$, rodzicy - forma podejrzana albo rzadko używana ${ }^{27}$.

Linde: rodzic skad, rodowic, rodak indigena; Slownik Warszawski zna rodzic - rodem stad - w opozycji do gość.

Tubylczość wybija się zatem jako cecha charakterystyczna rodzica, zresztą zgodnie $\mathrm{z}$ etymologią słowa. Jest to, najszerzej biorąc, człowiek miejscowy, w przeciwstawieniu do obcego, cudzoziemca. Szczególnie często dotyczy poddanego chłopa. Inne znaczenie, sprzeczne z poprzednim, przyjęte przez I. Baranowskiego, jest anachronizmem; interpretacja A. Wyczańskiego jest jaskrawym błędem, sens przyjęty przez L. Żytkowicza jest za ciasny. Jedynie trafna okazuje się wykładnia $S$. Inglota. $Z$ pewnością rodzic to nie czlowiek luźny, ale poddany na danym gruncie urodzony. Otrzymany wynik potwierdza informacje Lindego i SW, z tym uzupelnieniem, że poszerza określniki rodak, urodzony o znaczenie dodatkowe nativus, obce obu tym słownikom ${ }^{28}$.

${ }^{25}$ Cytat podaje S. Grodziski, Obywatelstwo w szlacheckiej Rzeczypospolitej, Kraków 1963, s. 109; ob. też ibidem, s. 110. Na Litwie używano na oznaczenie pewnej kategorii ludności niewolnej, mającej swe własne gospodarstwa, określenia ojczyce, S. Kutrzeba, Historia ustroju Polski $w$ zarysie, t. II: Litwa, wyd. 2, Lwów-Warszawa 1921, s. 54, oraz t. I, wyd. 8, Warszawa 1949, s. 250.

2sa W. N. Trepka, Liber generationis plebeanorum („Liber chamorum"), wyd. W. Dworzaczek, J. Bartyś, Z. Kuchowicz, Wroclaw-Warszawa-Kraków 1963, nr 1998, nr 626. Zauważ, że wydawcy nie wylypowali w swym szczególowym indeksie rzeczowym hasła rodzic.

26 I. Whodek, Slownik wyrazów dawnych zaniedbanych, Rzym 1780; cytuję za: Ludzie Oświecenia o jezzku i stylu, t. III, 1957, opr. Z. Florczak, L. Pszczolowska, red. M. Mayenowa.

27 Trotz, Nowy Dykcjonarz, 1764 (cytuje za: Ludzie Oświecenia).

${ }_{28} \mathrm{~W}$ przejrzanych dokumentach nie znaleźliśmy natomiast znanego Lindemu w tym samym znaczeniu terminu urodzeniec. 
Już w literaturze stwierdzono, że inwentarze przeciwstawiają niepoddanym - chłopów z dawna osiadlych" ${ }^{29}$, luźnemu - poddanego, który tu z dziadów urodzony $^{30}$. Nie potrzebujemy podkreślać waloru ustalenia semantycznego wyrazu do badań historycznych. Zaliczenie rodziców do luźnych powiększyło znacznie, a niezasadnie liczbę chłopów ostatniej kategorii kosztem subditi ${ }^{31}$. Interpretacja L. Żytkowicza dała podstawę obliczenia cyfry „,dorosłych synów lub braci zdolnych do pracy" na wsi ${ }^{32}$. W naszym rozumieniu obu tym obliczeniom brak nie tylko źródłowego uzasadnienia; są one wyraźnie ze źródłami sprzeczne ${ }^{33}$.

${ }^{29}$ J. Rutkowski, Zagadnienie reformy rolnej w Polsce XVIII wieku na tle reform przeprowadzonych we wsiach miasta Poznania, Poznań 1925, s. 30.

${ }^{30}$ Ibidem, s. 122, przyp. 206.

${ }^{31}$ A. Wyczański doliczył się w niektórych wsiach wielkopolskich powyżej 30 rodziców, a więc, jego zdaniem, luźnych, o. c., s. 125.

${ }_{32}$ Mialo ich być, rzekomo, 1-6 na gospodarstwo, ibidem, s. 79.

33 Przy naszym rozumieniu terminu nativus należy uznać tabelę 4, zestawioną przez L. Zytkowicza, o. c., tablice, s. 14, za bezprzedmiotową. 


\title{
Sprzedawalność urzędów w Polsce*
}

\author{
Urbem venalem et mature perituram, si emptorem \\ invenerit
}

Sallustius Crispus, De bello Iugurthino, cap. 35.

I. Sposoby obsady urzędów. II. Literatura o sprzedawalności urzędów w Polsce. III. Tzw. Rady Kallimachowe o sprzedawaniu urzẹdów. IV. Data powstania sprzedawalności urzędów. V. Sprzedawalność tworem prawa zwyczajowego. VI. Pojęcie urz̨̨du. VII. Uposażenie urzędów. VIII. Zastępstwo. IX. Kumulacja urzędów. X. Urząd uposażeniem. XI. Rodzaje sprzedawanych urzędów. XII. Przyczyny sprzedawalności urzędów. XIII. Status prawny urzędu w świetle prawa prywatnego. XIV. Status prawny urzędu w świetle prawa publicznego. XV. Sprzedawalność ex parte regis. XVI. Forma zapłaty. XVII. Walka za sprzedawalnością urzędów. XVIII. Cena urzędów. XIX. Rentowność urzędów. XX. Ocena instytucji. XXI. Zestawienie wyników. XXII. Porównanie sprzedawalności urzędów polskiej z francuską.

\section{Sposoby obsady urzędów}

Historia administracji zna kilka sposobów powoływania na stanowiska urzędnika: losowanie, oddawanie w lenno, dziedziczenie, wybór, nominację, sprzedaż i uzurpację. Uzurpację, być może, należałoby ograniczyć tylko do najważniejszego magistratus, głowy państwa - tyrana, cesarza, bazileusa, dyktatora, króla, pierwszego konsula, führera. Byłby to zatem problem z zakresu stosunków prawno-państwowych, a nie administracyjnych. Uzurpacja urzędu, funkcji w istocie podległej, mieści się faktycznie w przejściu urzędu w dziedziczny. Ono chyba stanowi wypadek największego uniezależnienia się od przełożonego - wladcy, który - przynajmniej teoretycznie - swą nadrzędność utrzymuje zawszel.

* Przedruk z: Czasopismo Prawno-Historyczne 1964, t. 16, z. 2, s. 101-174.

${ }^{1}$ Nie traktowalibyśmy zasiedzenia jako osobnego sposobu nabywania urzędu. Jeśli konstytucje polskie, o których bẹdziemy mówić niżej, wprowadzają jako warunek sprzedawalności stopnia oficerskiego co najmniej piętnastoletnią służbe, to przez to zasiedzenie oficer nabywał tylko prawo sprzedaży swego stopnia. Otrzymał go zaś najwidoczniej drogą nominacji czy też kupna. 
Obok czystych typów obsady urzędów zna historia sposoby mieszane, np. elekcję z nominacja, sprzedawalność $\mathrm{z}$ dziedzicznością itp.

W Polsce nie spotykamy się z losowaniem. Nie praktykowana jest też elekcja na urzędy administracyjne ${ }^{2}$. Stanie się ona natomiast charakterystyczna przy urzędach sędziowskich od chwili stworzenia Trybunału ${ }^{3}$. Podobnie zresztą było i z Trybunałem radomskim ${ }^{4}$. $O$ mieszanej formie, polegającej na polączeniu elekcji z nominacją, napomkniemy niżej. Nie znano też w Polsce nadań urzędów w lenno. Jedynie na Śląsku od końca XIII w. notuje się kilka wypadków oddania w lenno niektórych grodów kasztelańskich (feudum castrense, burklen); wówczas jednak kasztelan nie jest już sędzią̧ Nie było też dziedziczności urzędów nigdy. Tym różni się Polska zdecydowanie od sfeudalizowanych krajów zachodnich. Uniemożliwił ją - jak się mniema - podział kraju na dzielnice ${ }^{6}$. Aczkolwiek tendencje $w$ tym kierunku istniały ${ }^{7}$ i faktycznie doszło nieraz do dziedziczności urzędów ${ }^{8}$.

Znanym w Polsce sposobem była nominacja. Już w czasach przedrozbiorowych rozumiano znaczenie tego uprawnienia w ręku króla. Piasecki nazywal je auctoritatis regiae nervus ${ }^{9}$. Wydawałoby się, że pod tym względem pozycja monarchy polskiego była bardzo mocna, skoro do r. 1775 miał wyłączne prawo mianowania wszystkich urzędników ${ }^{10}$, a od r. 1776 dokonuje nominacyj na wszystkie stanowiska wojskowe ${ }^{11}$. M. Christophorus Hartknoch, charakteryzując ją, podal konkluzję następującą: ...ex his satis, superque constat, magnam esse regis Poloniae potestatem in conferendis magistratibus, tam secularibus quam ecclesiasticis ${ }^{12}$. Wszakże władza króla polskiego $\mathrm{z}$ pew-

${ }^{2}$ Pomijamy tu, oczywiście, stosunki panujące w miastach.

${ }^{3}$ O. Balzer, Geneza Trybunalu Koronnego. Studium z dziejöw sqdownictwa polskiego XVI wieku, Warszawa 1886 , s. 322.

${ }^{4} \mathrm{M}$. Nycz, Geneza reform skarbowych sejmu niemego (Studium z dziejów skarbowo-wojskowych $z$ lat 1697-1717), Poznań 1938, s. 128.

${ }^{5}$ S. Kutrzeba, Historia ustroju Polski, wyd. 8, Warszawa 1949, s. 133; Z. Wojciechowski, Państwo polskie $w$ wiekach średnich, wyd. 2, Poznań 1948, s. 70, 108, 341.

6 Z. Wojciechowski, Ustrój polityczny Ślaska, [w:] Historia Ślqska od najdawniejszych czasów do r. 1400, t. 1, Kraków 1933, s. 576; tenże, Państwo polskie..., s. 348; J. Bardach, Historia państwa i prawa Polski do polowy XV wieku, Warszawa 1957, s. 221.

7 J. Bardach, $l$. $c$.

B Ibidem, s. 258, oraz W. Palucki, Studia nad uposażeniem urzędników ziemskich w Koronie, Warszawa 1962, s. 190, 268; tamże o głosie Ostroroga piętnującego dziedziczność urzędów (s. 287). O dziedziczeniu starostw sądowych w czasach nowożytnych, co prawda $\mathrm{z}$ ograniczeniem do potomstwa męskiego, mającego odpowiedni wiek i rozeznanie, G. Lengnich, Ius publicum Regni Poloniae, t. 2, s. 324.

${ }^{9}$ Cytuje tę wypowiedź G. Lengnich, o. c., t. 1, s. 273.

${ }^{10}$ Z. Kaczmarczyk, B. Leśnodorski, Historia państwa i prawa Polski od polowy $X V$ w. do r. 1795, Warszawa 1957, s. 126.

11 W. Skrzetuski, Prawo polityczne narodu polskiego, t. 1, Warszawa 1782, s. 107.

12 M. Ch. Hartknoch, Respublica Polonica duobus libris illustrata, Francofurti et Lipsiae 1678 , s. 279. Również G. Lengnich wyraża się w sposób następujący: dignitarios rex creat (G. Lengnich, $o . c$. , t. 2, s. 278). 
nością nie była tak bezwzględna, jakby $z$ powyższego sformulowania wynikało. Jeśli władca ma zachować pozycję nadrzędną wobec urzędnika, musi również posiadać prawo do jego deponowania, urzędnik jest wtedy amovibilis ad nutum. Tymczasem w Polsce wytworzyła się zwyczajowo zasada dożywotności. Wypadki jej występują na Śląsku sporadycznie przy nadaniach lennych już $w$ końcu XIII $w^{13}$ W XIV w. ogarnęła ona urzędy ziemskie $^{14}$. Przyjęła się też $w$ praktyce wobec stanowisk koronnych i nadwornych. Początkowo nie byl dożywotni urząd starościński. Będąc namiestnikiem króla, mógł być odwołany ze swej funkcji każdej chwili ${ }^{15}$. Od XVI w. także i starostwa zaczęły przeradzać się $w$ godność dożywotnią ${ }^{16}$. Od roku 1581 dożywotność ogarnęla także urząd hetmański ${ }^{17}$, choć nie jest ona dostatecznie ugruntowana jeszcze $\mathrm{w}$ XVII $\mathrm{w}^{18}$

Przejawiały się dążenia ku ograniczeniu do dwóch lat ministeria senatoria (konfederacja goląbska), mansit tamen antiqua consuetudo, quae ministeria nullo temporis spatio terminat ${ }^{19}$. Zasadę nieusuwalności podkreślają egzorbitancje $\mathrm{z} 1669$ r.: ...i tak, jakośmy którego in possessione zastali, pacifice konserwowa $\hat{c}^{20}$. Prawdopodobnie chodzi $\mathrm{w}$ tym przepisie $o$ to, by nowy

${ }^{13}$ Z. Wojciechowski, Ustrój polityczny Ślaska, s. 615. Według tegoż autora za swoistą dla stosunków polskich feudalizację można poczytać przekształcenie urzędów w urzędy ziemskie (ibidem, s. 616). Podobieństwo ogranicza się do zaznaczenia w obu typach ustrojowych tendencyj centryfugalnych.

${ }^{14}$ S. Kutrzeba, o. c., s. 207; J. Bardach, o. c., s. 259, 444; Z. Kaczmarczyk, B. Leśnodorski, o. c., s. 134, 298.

is Z. Wojciechowski, Ustrój polityczny Ślqska, s. 764.

${ }^{16} \mathrm{~S}$. Kutrzeba, o. c., s. 207. Jest prawdopodobne, że ten charakter dożywotni starostwa, jak i zamiana jego w urząd ziemski nastąpiły w wyniku poruczenia staroście administracji dóbr królewskich pod taką czy inną postacią. Nie mieli jej starostowie czescy, będąc tylko urzednikami publicznymi. Powierzył ja starostom dopiero Władysław Łokietek, S. Kutrzeba, Starostowie, ich poczq̨tki i rozwój $w$ XIV w., RA, t. 45, Kraków 1903, s. 302.

${ }^{17}$ Ibidem, s. 330. Prawda, że usiłowano ograniczyć ich władzę do lat dwóch (konfederacja gołąbska) czy trzech (żądania na sejmie w r. 1676), pozostało jednak przy starym (por. G. Lengnich, o. c., t. 2, s. 252). O planach nadania hetmanom charakteru czasowego po kompromitacji z r. 1648 ostatnio B. Baranowski, Organizacja wojska polskiego w latach trzydziestych $i$ czterdziestych XVII wieku, Warszawa 1957, s. 175. Nie poruszamy tu kwestii początków hetmańskiej władzy; zakończenie dyskusji na ten temat daje silnie udokumentowany artykuł S. M. Kuczyńskiego, W sprawie niektórych tez artykulu dr Z. Spieralskiego pt. Geneza i poczqtki hetmaństwa w Polsce, [w:] Studia $i$ materialy do historii wojskowości, t. 9, z. 1, Warszawa 1963, s. 277-293.

${ }_{18}$ B. Baranowski, o. c., s. 173.

19 G. Lengnich, o. c., t. 2, s. 153.

${ }^{20} \mathrm{VL}$, t. 3, s. 766 . Za nadużycie uchodzi też odebranie starostwa: starostwa stantibus privilegiis od possessorow odebrane bezprawnie $i$ bez sqdowych dekretow, aby do swych possessorów wracaly sie, ma wejrzé król Imć na sejmie coronationis, VL, t. 5, s. 16. Postanowienie to jest reakcją na postępowanie Jana Kazimierza, który odebrał był nieklóre starostwa minus legitime, jak się wyraża G. Lengnich (o. c., t. 1, s. 326). Przepis dotyczy przede wszystkim capitaneatus sine iurisdictione, choć i starostwa sadowe nie są tu wykluczone. 
elekcyjny władca nie pozbawiał urzędów za popieranie innego kandydata do tronu ${ }^{21}$. Dożywotność urzędów i nadań królewskich zagwarantowały też prawa kardynalne $(1768,1775)^{22}$.

Niewątpliwie, urzędnik choć dożywotni, ale mianowany przez króla, nie jest tak niezależny od panującego, jak urzędnik dziedziczny, ale doń się stanowiskiem swym bardzo zbliża. W tej dożywotności urzędów wolno dopatrywać się $\mathrm{m}$. in. słabości władzy wykonawczej $w$ Polsce. Nie bez powodu marszałek sejmu 1565 r. piętnuje niewykonywanie obowiązków przez wojewodów i starostów: stąd szwankował wymiar sprawiedliwości, jak i brakło w kraju bezpieczeństwa ${ }^{23}$.

Rozumial to dobrze Modrzewski, który domagal się urzędów nie dożywotnich, lecz odwołalnych ${ }^{24}$. Rozumiała też szlachta występująca z propozycjami, aby urząd hetmana byl tylko od sejmu do sejmu ${ }^{25}$.

Naturalnie, szkodliwość systemu dożywotności, sprzeczność jego z wymogami sprężystości aparatu państwowego, wystąpi na jaw - może wyłącznie - odnośnie do urzędów najwyższych, naczelnych, o charakterze w pełni politycznym. Praktycznie bowiem tacy dygnitarze są nieodpowiedzialni karnie $^{26}$. Uchylenie $w$ stosunku do nich odpowiedzialności politycznej prowadzić musi do nadużyć w skali najwyższej. W stosunkach polskich zatem $\mathrm{w}$ rachube wchodzą tzw. maiora ministeria (mareschalcatus, cancellariatus, thesaurariatus) i hetmańska godność oraz - być może - dignitates senatoriae, a już nie dignitates minores, a tym mniej dignitates aulicae czy plejada urzędów ziemskich, $\mathrm{z}$ wyjątkiem oczywistym urzędu starościńskiego ${ }^{27}$.

Dożywotność urzędów ograniczała w dużym stopniu uprawnienia nominacyjne monarchy. Nie bylo to jednak skrępowanie jedyne. Pomijamy już postanowienia warujące, by król konferowal urzędy tylko osobom aetate et discretione vigentibus ${ }^{28}$. Rozumieją się one same przez się. - Wszelkie godności i beneficja obejmować może wyłącznie szlachta, przy tym jeszcze

\footnotetext{
${ }^{21}$ G. Lengnich, o. c., t. 1, s. 325-326.

${ }^{22}$ Z. Kaczmarczyk, o. c., s. 404. Nie dożywotni, lecz do czasu tylko naznaczeni mieli być generałowie-inspektorowie, VL, t. 7, s. 458.

${ }^{23}$ I. Kaniewska, Walka o wprowadzenie instygatorów na sejmie piotrkowskim $1565 \mathrm{r}$., [w:] Odrodzenie $i$ Reformacja w Polsce, t. 7, Warszawa 1962, s. 75.

${ }^{24}$ Z. Kaczmarczyk, o. c., s. 104.

${ }^{25}$ Akta sejmikowe województwa krakowskiego, t. 1, wyd. S. Kulrzeba, Kraków 1932, s. 376, punkt 5 .

${ }^{26}$ Zwłaszcza gdy upadł na zawsze projekt z 1565 r., przewidujący wprowadzenie instygatorów, którzy mieli ścigać przestępstwa urzędników, przede wszystkim magnatów. I. Kaniewska, $o . c$, s. $74,97$.

${ }^{27}$ Charakteryzowal go trafnie G. Lengnich: ministri recte sunt capitanei cum iurisdictione (o. c., t. 2, s. 152).

${ }^{28}$ Pakta Wladysława IV, VL, t. 3, s. 766, p. 54.
} 
z zastrzeżeniem, by to byli possessionat ${ }^{29}$. W miarę umacniania się pozycji szlachty i wzrostu anarchii w Rzeczypospolitej wymóg ten rozszerzano coraz bardziej. W XVIII w. plebej nie może być nawet pisarkiem w sądzie ani funkcjonariuszem celnym. W paktach Stanisława Augusta już nie tylko wójtostwa, ale i leśnictwa większe zastrzega się wylącznie dla szlachty, a tylko mniejsze mógł król nadawać bene meritis ${ }^{30}$.

Ten monopol stanowy utrudni bardzo królowi przeprowadzenie walki z grupą uprzywilejowaną, uniemożliwiając mu oparcie się na promowanych przez siebie jednostkach pochodzenia plebejskiego. Niedostępna jest dla władcy polskiego stara, a tak skuteczna taktyka Sieciecha, który - jak się wyraża Gall - ignobiles vero nobilibus preponebat ${ }^{31}$, i tą drogą reknutowal kadry oddanych sobie urzędników ${ }^{32}$. Nie tylko magnaci obejmujący najwyższe godności byli zupelnie niezależni od monarchy. Monopol szlachty na urzędy, wykluczający od nich plebejów i Źydów, dawał najgorsze następstwa nawet na niskich stanowiskach funkcjonariuszy celnych. Szlachcic taki czuł się niezawisły od podskarbiego, mimo że ten miał prawo usuwania nieuczciwych urzędników ${ }^{33}$. Prawdopodobnie obawą przed kreowaniem noblesse de robe thumaczyć należy powstanie specjalnej kategorii szlachty - szlachty drugiego rzędu, skartabelów, którymi zostawali świeżo nobilitowani ${ }^{34}$. Takim szlachcicom, jak zresztą i cudzoziemcom, którzy otrzymali indygenat, nie wolno officia et beneficia ad tertiam progeniem dawac $\dot{c}^{35}$.

Urzędnik musiał być obywatelem danej ziemi, w której miał funkcję pełnić, mieć jej indygenat ${ }^{36}$. Tak już było od r. $1374^{37}$. Dzięki temu był on związany $z$ terenem koligacjami $i$ interesami, $z$ pewnością więc

${ }^{29}$ G. Lengnich, o. c., t. 1, s. 277-278, 284. Wedkug tegoż autora possessionum necessitas dotyczyła tylko godności świeckich, a nie duchownych (ibidem, s. 285).

${ }^{30}$ VL, t. 7, s. 206.

31 Anonima tzw. Galla Kronika, czyli dzieje ksiqżat $i$ wladców polskich, wyd. K. Maleczyński, MPH, ser. 2, t. 2, Kraków 1952, s. 68.

${ }^{32} \mathrm{~W}$ Prusach Królewskich ten monopol szlachty nie był nigdy bezwzględny. Jak stwierdza G. Lengnich, nadawano tam godności, starostwa i tenuty także mieszczanom (Mémoires..., s. 103 , przyp. 12, Ius publicum, t. 1, s. 280).

${ }^{33}$ M. Nycz, o. c., s. 99.

${ }^{34}$ O. Balzer, rozpatrując genezę skartabelatu, przyjmuje pobudki społeczne i ekonomiczne, wylącza natomiast wzgleddy natury politycznej (Skartabelat w ustroju szlachectwa polskiego, Kraków 1911, s. 353-354); mogły one jednak występować łạcznie.

${ }^{35}$ VL, t. 5, s. 22 (r. 1669), s. 267; t. 6, s. 22 (r. 1699). Por. O. Balzer, Skartabelat, s. 77 i n.

36 Indigenis Regni, bona immobilia habentibus, pisał T. Dresner, Institutionum iuris Regni Poloniae libri IIII, Zamość 1613, s. 28; ob. też M. Ch. Hartknoch, o. c., s. 274, oraz S. Grodziski, Obywatelstwo w szlacheckiej Rzeczypospolitej, Kraków 1963, s. 65 i n.

${ }^{37}$ G. Lengnich, Mémoires..., s. 96, przyp. 5; J. Bardach, o. c., s. 444 . Zastrzeżenie indygenatu $w$ przywileju koszyckim dotyczyło tylko ziemskich urzędów, a nie starostw, S. Kutrzeba, Starostowie..., s. 309. 
nie reprezentowal zawsze interesów królewskich ${ }^{38}$. Mimo nominacji ze strony monarchy, nie stanowil on jego bracchium bezwzględnie.

W ostatnim stuleciu Rzeczypospolitej, gdy arystokracja zlączona z sobą licznymi związkami stworzyła jednolitą warstwę w całym kraju, już tego wymogu nie traktowano rygorystycznie. Indygenat ściślejszy, singularum terrarum, indigenatus peculiare, ustapil miejsca szerszemu indigenatus iam latius patens: Poloniae, Lituaniae et iunctarum provinciarum indigenae aequo iure habeantur, et illis promiscue in quavis terra ad dignitates et regia bona accessus detur ${ }^{39}$. Wyjątek miały stanowić Prusy. Zgodnie $\mathrm{z}$ przywilejem inkorporacyjnym, za obcych uchodzą tu wszyscy qui non Prussi. Stwierdza to $\mathrm{z}$ satysfakcją patriota pruski - G. Lengnich ${ }^{40}$. Tenże jednak konstatuje, że i w tej prowincji, często wbrew przywilejom, bardzo często nadawano godności nie indygenom pruskim, a mimo energicznych protestów rzadko się takie nieprawnie nadane godności odbiera ${ }^{4 !}$.

Przy obsadzie urzędów centralnych indygenat lokalny, ziemski czy dzielnicowy, nie mógl być brany $w$ rachubę. Miarodajny byl $w$ takim wypadku indygenat państwowy, tak charakterystyczny dla monarchów elekcyjnych, rekrutujących się w tylu wypadkach $\mathrm{z}$ władców-cudzoziemców. Królom zakazuje się obsadzać stanowiska cudzoziemcami. Zakaz ten pojawi się już w umowach z Henrykiem III: Nullas etiam possessiones aut dignitates vel officia illis concedit, sed tantum indigenis Polonis iuxta statutum Regnit2. Powtórzony zostanie dosłownie w akcie Zygmunta III z uzupelnieniem co do consiliarii et officiales regni Sveciae, ze względu na zrozumiałe niebezpieczeństwo, jakie groziło $\mathrm{z}$ tej strony; zważywszy na bliskość geograficzną i polityczna kraju: nullis Regni Poloniae et Magni D. L. consiliis, negotiis, intercessionibus, promotionibus adhibebit, aut iis se immisceri patietur ${ }^{43}$. Sprawą tą zajęła się ponownie konstytucja z $1607 \mathrm{r}^{44}$ Pojawi się ona w aktach Władyslawa IV: Cudzoziemców wszelakiej kondycji ad consilia nostra, ani do żadnych rzqdów przypuszczać, ani im dignitates, starostw, dzierżaw $i$ urzędów dawać nie będziemy iuxta praescriptum constitutionis 1607, wedle której we wszystkim zachować sie będziem powinnit ${ }^{45}$. Tekst ten powtórzą dosłownie pakta Jana Kazimierza ${ }^{46}$, w innych nieco slowach ujmą

${ }^{38}$ Nie wchodzimy tu w problem, jaką on reprezentował grupę, por. S. Russocki, „Grupy interesu" w spoleczeństwie feudalnym, KH, R. 70, 1963, s. 906.

${ }^{39}$ G. Lengnich, Ius publicum, t. 1, s. 281-283.

${ }^{40}$ Ibidem.

${ }^{41}$ G. Lengnich, Mémoires..., s. 185, przyp. 13; autor powołuje się na przykłady ogloszone przez siebie w Historii Prus.

42 VL, t. 2, s. 862.

${ }^{43}$ VL, t. 2, s. 1099.

${ }^{44}$ VL, t. 2, s. 1598-1599, tytuł: $O$ cudzoziemcach.

${ }^{45}$ VL, t. 3, s. 765.

${ }^{46}$ VL, t. 4, s. 195. 
je pakta Augusta $\mathrm{II}^{47}$, Augusta $\mathrm{III}^{48}$ i Stanisława Augusta ${ }^{49}$. Pakta Michała rozciągnęły ten zakaz na stanowiska duchowne: 56 . Coadiutoria na opactwa et pingviora beneficia ecclesiastica ${ }^{50}$. Zakaz ten zaopatrzono silną sankcją: $w$ razie ingerencji cudzoziemca in materias status przyshuguje skarga do Trybunału ad instantiam cuiusvis $^{51}$. Niewątpliwie i ten przepis, jak tyle innych w Polsce, stanowil lex minus quam imperfecta. Prohibicyjne postanowienia odnośnie do cudzoziemców szły tak daleko, że monarsze w zasadzie nie wolno mieć nawet zagranicznej slużby domowej: ...nullos peregrinos homines adducturum - zawarowano w umowie z Henrykiem III - praeter paucos, quorum opera in ministerio domestica utetur, quos tamen postea brevi remittet, persolutis illis stipendiis de suo ${ }^{52}$. Postanowienie to zatwierdzi Zygmunt III $^{53}$. Później wprowadzono ograniczenie liczbowe; mianowicie od paktów z Michałem przy boku pańskim może być najwyżej 6 cudzoziemców ${ }^{54}$. Nawet $w$ górnym francymerze królowej dopuszczone być moga tylko 4 cudzoziemki ${ }^{\text {ss }}$. I tych zakazów nie respektowano zbytnio.

Dalszą restrykcją było zamknięcie królewskiego prawa nominacji do listy czterech kandydatów, których proponowala ziemia. Z wybranego kwaterna król obdarzał jednego godnością ${ }^{56}$. W ostatnim wypadku nominacja i wybór schodzą się razem, bynajmniej nie są sobie przeciwstawne.

W ostatnim stuleciu niepodleglości wprowadzono wymóg wyznawania religii katolickiej, wykluczając w r. 1733 dysydentów od urzędów ziemskich i grodzkich ${ }^{57}$.

Ale to jeszcze nie wszystkie ograniczenia władzy królewskiej w Polsce quod ad ius conferendorum magistratuum attinet. W czasach nowożytnych, w obawie przed absolutum dominium, ciągle dręczącej bardziej magnaterię niż szlachtę, wprowadza się zastrzeżenie, że urzędy nadawane będa jedynie indigenis paritate iuris gaudentibus ${ }^{58}$; promowani zatem moga być tylko conditione aliis aequales ${ }^{59}$, a tym samym wykluczeni od stanowisk pochodzący

${ }^{47}$ VL, t. 6, s. 23.

${ }^{48}$ VL, s. 625 . Por. też G. Lengnich, Pacta conventa, s. 56.

${ }^{49}$ VL, t. 7, s. 203.

so VL, t. 5, s. 17.

s1 VL, t. 5, s. 14.

s2 VL, t. 2, s. 862.

53 VL, t. 2, s. 1099.

${ }^{54}$ VL, t. 5, s. 14.

s5 VL, t. 6, s. 23 .
${ }^{56}$ G. Lengnich, Ius publicum, t. 2, s. 278; S. Kutrzeba, Historia ustroju..., s. 155. Podobne urządzenie na Litwie w stosunku do marszalków powiatowych, VL, t. 5 , s. 17. W Wielkim Księstwie dokonuje się wyborów i na godności senatorskie; potwierdza je również monarcha,

G. Lengnich, Ius publicum, t. 1, s. 306-307.

${ }^{37}$ G. Lengnich, Ius Publicum, t. 1, s. 290; t. 2, s. 289.

58 VL, t. 3, s. 766 (pakta Władysława IV).

${ }^{59}$ G. Lengnich, Ius publicum, t. 1, s. 277-278. 
ex stirpe regia ${ }^{60}$ quos splendor natalium supra ceterorum conditionem extollit ${ }^{61}$. Jeszcze w paktach Stanisława Augusta pomieszczono postanowienie: Dom nasz aequalitati subiaceat ${ }^{62}$.

Wymagane kwalifikacje, pozytywne i negatywne, krępujące bardzo swobodę poczynań króla w dziedzinie urzędniczej polityki kadrowej, wieńczyła norma stwarzająca przymus nadawania urzędów, przymus prawa publicznego. Znaczenie jego było dość względne dopóty, dopóki nie oznaczono dokładnie terminu, w ciągu którego król był zobowiązany wakujące dignitates nadać. Określono go w r. 1588, wprowadzając czasokres 6 miesięcy od chwili osiągnięcia wiadomości przez króla o wakansie. Od paktów Wladysława IV skrócono go do 6 tygodni $^{63}$, co utrzymało się już później ${ }^{64}$. Dalszym ograniczeniem swobody monarszej był nakaz rozdawania godności na sejmie ${ }^{65}$. Norma ta, w dużej mierze sprzeczna $\mathrm{z}$ poprzednią, ustępowała jej, skoro sejm nie pracował w permanencji. Świadczy to o wadze, jaka przywiązywały sfery decydujące do niezwłocznego obsadzenia wakujących stanowisk.

Do tych wszystkich ograniczeń, które sprawiaja, że monarcha polski nie włada zupełnie administracją - stała się ona odeń niezależna - dodano jako nieodzowny człon postanowienie następujące: In dignitatibus nihil mutandum, sed status illarum, cuiuscunque generis fuerint, integer servandus, ut neque potestati, neque proventibus illarum aliquid subtrahatur, aut in veterum iniuriam novae instituantur ${ }^{66}$. Doktryna zatem całkowitego skrępowania

${ }^{60}$ M. Ch. Hartknoch, o. c., s. 277.

${ }^{61}$ G. Lengnich, Ius publicum, t. 1, s. 286. W paktach Michała z 1669 r. postanawia się, że dom królewski nie ma ullam successionem et praetextum proximitatis ad Regnum, VL, t. 5 , s. 18. Wspomniana reguła objęła więc i najwyższy urząd w państwie, tron królewski. Tłumaczy ją wspomniany prawnik gdański trafnie parostwem polskiego typu: in Polonia omnes nobiles aequo, iure censentur.

${ }^{62}$ VL, t. 7 , s. 200.

${ }^{63}$ VL, t. 3, s. 766 p. 54.

${ }^{64}$ Pakta Michała, VL, t. 5, s. 25-26; Jana III, VL, t. 5, s. 272; Augusta II, VL, t. 6, s. 21; Augusta III, VL, s. 623 i Stanisława Augusta, t. 7, s. 202-203. Czasokres wspomniany zna już M. Ch. Hartknoch, o. c., s. 276. W komentarzu do paktów Augusta III podaje G. Lengnich, że dotyczył on stanowisk kanclerzy i generalów armii (Mémoires..., s. 92, przyp. 1). O czasokresach dla konferowania urzędów por. też ibidem, s. 93, przyp. 2, oraz tegoż Ius publicum, t. 1, s. 274-275. W średniowieczu rzecz ta nie była znana. W 1319 r. po śmierci wojewody poznańskiego, Dobrogosta, trzyma przez parę lat Łokietek tę godność w swym ręku, K. Potkański, Zdrada Wincentego z Szamotul, odb. z t. 38 RAU WHF, Kraków 1899, s. 3.

${ }^{65}$ G. Lengnich, lus publicum, t. 1, s. 275 . Konstytucja z 1716 r. wprowadziła przymus nadawania na sejmie także szarż wojskowych, najwyższych i mniejszych. Wyłom ważki $w$ tej zasadzie wprowadziły acta interregni z $1736 \mathrm{r}$. : ministeriorum zaś belli rozdawanie, non obstante constitutione 1717, ad ius maiestaticum odtqd należec bedzie, aby się temi wakansami sejmy nie trudnily (VL, t. 6, s. 577, 590). Ob. też G. Lengnich, Ius publicum, t. 1, s. 278.

${ }^{66}$ G. Lengnich, Ius publicum, t. 1, s. 274. Autor ten streścił w cytowanym zdaniu postanowienia paktów Władysława IV (p. 50, VL, t. 3, s. 766), ponawiane w późniejszych paktach: Jana Kazimierza (VL, t. 4, s. 196), Michala (VL, t. 5, s. 14, 87), Jana III (ibidem, s. 271). 
króla znalazła tu swój najpelniejszy wyraz. Kadra istniejąca, na pewno przestarzałą, król nie dysponuje; nowej stworzyć mu nie wolno. Si quid ergo novandum, Ordinum consensus exigitur ${ }^{67}$. Trudno o lepszy obraz bezsily monarchy. Tym samym ścieśnienie nominacyjnych uprawnień jego w r. $1775^{67 a}$ wydaje sie tylko pozorne. W przedstawionej sytuacji nie ratuje stanowiska króla przepis, zakazujący nadawania godności w czasie bezkrólewia ${ }^{68}$.

Do tych uwag należy dorzucić jeszcze fakt, że uprawnienia nominacyjne króla rozciągają się również na godności duchowne, arcybiskupstwa, biskupstwa i opactwa. Król dignitates sacras [...] ut saeculares confert - stwierdzali kompetentnie przedrozbiorowi prawnicy ${ }^{69}$.

Tak czy inaczej kreowani urzędnicy wykonywali nałożone na nich zadania $w$ imieniu państwa, jako jego organy. Pełnili swe funkcje nieraz w interesie publicznym, obok którego, niejednokrotnie, pojawiał się również interes prywatny funkcjonariusza. Stopień jednego czy drugiego momentu zależał od wielu okoliczności, w które nie chcielibyśmy wnikać. W założeniu wszakże - powtarzamy - były to funkcje pełnione bezpośrednio dla państwa. Wszakże historia zna jeszcze inny sposób wykonywania zadań państwowych.

Zamiast pełnić je przez urzędników państwowych, mniej lub więcej podporządkowanych władcy, w wielu krajach odstępowano funkcje publiczne osobom prywatnym lub ich zrzeszeniom za ryczaltowaną oplata. Przede wszystkim dzieje się to w domenie skarbowej. Państwo nie ściągało podatków przez własnych funkcjonariuszy, lecz odstępuje to zadanie prywatnej osobie za ryczałtową oplatą. Dzierżawca, uposażony w egzekucję państwową, sam ściąga następnie podatki do własnej kieszeni. $Z$ takiego systemu administracji państwowej znany był Rzym (osławieni publicani). Ale nieobcy był również stosunkom polskim: u nas, od najdawniejszych czasów oddawano w dzierżawę dochody celne. Taki system utrzymuje się jeszcze w XVIII w. Podobnie postępowano jeszcze $\mathrm{w}$ tym czasie $\mathrm{z}$ monopolami, wydzierżawiając je zwykle plus offerenti ${ }^{70}$. Od średniowiecza oddawano w dzierżawę albo w zastaw majątki królewskie.

Stąd już jeden krok tylko do takiej transakcji urzędem, która jest niczym innym jak jego sprzedażą.

${ }^{67}$ G. Lengnich, Ius publicum, t. 1, s. 274. Ten stan prawny poświadcza jeszcze W. Skrzetuski, o. c., s. 81 .

o7 W. Skrzetuski, o. c., s. 105; Z. Kaczmarczyk, Historia państwa i prawa, t. 2, s. 126.

68. Lengnich, lus publicum, s. 311-312.

69 M. Ch. Hartknoch, o. c., s. 269, oraz G. Lengnich, Ius publicum, t. 1, s. 294, 298, 301.

70 M. Nycz, o. c., s. 20, 85, 100. 


\section{Literatura o sprzedawalności urzędów w Polsce}

Sprzedawalności urzędów poświęcili niemalo uwagi historycy francuscy, zajmując się oczywiście tą instytucją we Francji. A czy nie znano jej w Polsce? Podręczniki ustroju o niej milczą ${ }^{71}$. Co więcej, niektórzy badacze wyraźnie jej przeczą. Tak S. Kot stwierdza (shusznie), że nie sprzedawano w Polsce urzędu sędziego ${ }^{72}$, a zashużony historyk prawa - J. Rafacz, konstatuje, że w Polsce urzędy nie stały się fikcyjnymi nieruchomościami, jak to mialo miejsce we Francji ${ }^{73}$.

Ostatnio przeczy również J. Bardach, by istniala sprzedawalność urzędów (na Litwie i) w Koronie. Zestawiwszy teksty, z których wynika odpłatność urzędów na Litwie, przejawiająca się w instytucji czołobicia, kwalifikuje ją wspomniany badacz jako darowiznę odpłatnq ${ }^{74}$. Równocześnie jednak notuje dla XVI w. sporadyczne wypadki przekraczania granic tej archaicznej darowizny odpłatnej ${ }^{75}$. Wszakże dla sprzedawalności brak, jego zdaniem, jednego momentu: nie znano na Litwie odsprzedaży urzędów przez tytulariuszy ${ }^{76}$.

Wśród historyków istnieje atoli i druga grupa, która nie ma wątpliwości co do faktu, że sprzedaż urzędów znano i w Polsce. Z takim zdaniem wystąpili kiedyś historycy wojskowości: K. Górski i T. Korzon, za nimi poszedł M. Kukiel. Zlem była, szczególnie w wojsku cudzoziemskiego autoramentu, sprzedaż rang i porcyj - stwierdza pierwszy ${ }^{77}$. Sprzedaż ta, choć w mniejszym stopniu, istniała $\mathrm{i} w$ jeździe autoramentu polskiego, tak co do rang oficerskich, jak i regestów towarzyskich - stwierdza tenże autor ${ }^{78}$.

Nowsi badacze wykazują, że i cywilne urzędy bywały przedmiotem transakcyj. O tym pisze ubocznie $w$ swym podręczniku W. Konopczyński, wzmiankuje też $\boldsymbol{Z}$. Wojciechowski ${ }^{79}$. Wnikliwą rozprawkę poświęcił temu zagadnieniu ostatnio W. Czapliński, ograniczając się do połowy wieku $\mathrm{XVII}^{80}$. Cenne uwagi dla w. XVI zawiera nowa pozycja W. Paluckiego ${ }^{81}$.

${ }^{71}$ Por. W. Czapliński, Sprzedawanie urzędów w Polsce w polowie XVII wieku, PH, t. 50, 1959, s. 51.

72 S. Kot, Rzeczypospolita Polska w literaturze politycznej Zachodu, Kraków 1919, s. 137

${ }^{73}$ J. Rafacz, Dawne prawo sqdowe, s. 291, przyp. 1.

${ }^{74}$ J. Bardach, Czolobicia $i$ poklony. Kartka $z$ dziejów administracji Wielkiego Ksiestwa Litewskiego w XV-XVI wieku, [w:] Wieki średnie - Medium Aevum. Prace oflarowane Tadeuszowi Manteufflowi w 60. rocznice urodzin, Warszawa 1962, s. 314.

75 Ibidem, s. 315.

${ }^{76}$ Ibidem, s. 314.

${ }^{77}$ K. Górski, Historia piechoty polskiej, Kraków 1893, s. 124; M. Kukiel, Zarys historii wojskowości w Polsce, wyd. 5, Londyn 1949, s. 113. Dzieła T. Korzona cytujemy niżej.

${ }^{78}$ K. Górski, Historia jazdy, s. 145.

${ }^{79}$ W. Konopczyński, Dzieje Polski, t. 2, s. 15; Z. Wojciechowski, Zygmunt Stary, s. 303.

${ }^{80}$ W. Czapliński, o. c., s. 51-61.

${ }^{81}$ W. Palucki, o. c., s. 19 i n. 
Historycy nasi zestawiający stosunki polskie z francuskimi (Kot, Rafacz), gdzie - jak wiadomo - vénalité des offices kwitnęła, w stwierdzonym przez siebie braku instytucji sprzedawalności w Polsce dopatrywali się wyższości naszych urządzeń nad urządzeniami Francji. Wychodzili, oczywiście, z założenia, że handel urzędami stanowi rzecz brzydka, że to negotium turpe. Ten pogląd przebija się też u innych autorów; świadczy o tym wypowiedź Z. Wojciechowskiego, który konstatuje, że Bona nie gardziła takimi środkami, jak sprzedaże urzędów, jak i W. Czaplińskiego, który nazywa omawianą praktykę niezbyt chwalebnym zwyczajem ${ }^{82}$. Podobne wypowiedzi spotykamy zresztą również $w$ literaturze obcej, np. E. Hassinger mówi o Übel der Ämterkäuflichkeit- und - erblichkeit, z którym walczył Richelieu ${ }^{83}$.

Przystępując do rozpatrzenia sprzedawalności urzędów w Polsce, chcielibyśmy odciąc się zdecydowanie od kwalifikacyj czy dyskwalifikacyj moralnych tej instytucji. $Z$ obiektywizmem, na jaki nas stać, pragniemy zbadać samo urządzenie, stwierdzić czas jego powstania i zaniku, przedstawić ewolucję i wyjaśnić rolę, jaką ono pełniło, oraz wskazać na złe i dobre strony instytucji.

\section{Tak zwane Rady Kallimachowe o sprzedawaniu urzędów}

Zagadnieniu sprzedawalności urzędów w Polsce nadały najwięcej rozgłosu tzw. Rady Kallimachowe. Zajęly się one interesującą nas instytucją w dwu artykułach $^{84}$ :

art. 12

Officia gratis nemini dato. Fideles Officia darmo nikomu nie dawaj. Miej ministros, qui ea licitentur, habeto. wierne, co by o tem traktowali. Który Qui maiorem pecuniae summam nu- więcej da, niech będzie u ciebie godmeravit, dignior esto. niejszy.

art. 21

in quibus singulis (abbatiis) annuam $A$ na to w każdem opactwie secundum pensionem tibi secundum proportionem proportionem zostaw sobie jurgielt. proventorum relinquito.

${ }^{82}$ Z. Wojciechowski, Zygmunt Stary (1506-1548), Warszawa 1946, s. 303; W. Czapliński, Ideologia polityczna ,Satyr" Krzysztofa Opalinskiego, PH, t. 47, 1956, s. 119.

${ }^{83}$ E. Hassinger, Das politische Testament Richelieu, Hist. Zeitschrift, t. 173, s. 503.

${ }^{84}$ Tzw. Rady Kallimachowe, wyd. I. Chrzanowski, S. Kot, Humanizm i Reformacja w Polsce, Lwów-Warszawa-Kraków 1927, s. 133 (przedruk z Pamiętnika sluchaczy Uniwersytetu Jagiellońskiego, Kraków 1887). Por. S. Estreicher, Rady Kallimacha, [w:] Studia z dziejów kultury polskiej, Warszawa 1947, s. 173, oraz W. Palucki, o. c., s. 22, przyp. 66. 
Ale czy odzwierciedlały one stosunki faktyczne? Albo czy za ich wpływem doszło do wytworzenia tej instytucji? A może głosiły one hasła, które nigdy nie zostały zrealizowane $w$ Polsce? Może nakłaniały do poczynań, które były bezprawne i takimi zostały do końca Rzeczypospolitej.

\section{Data powstania sprzedawalności urzędów}

W. Czapliński, zajmując się sprzedażą urzędów w w. XVII, stwierdza, że jest to dawny zwyczaj, dość powszechnie stosowany za Władysława IV i Jana Kazimierza ${ }^{85}$. Sięga on jednak dawnych czasów ${ }^{86}$. W. Palucki uważa kupowanie urzędów za rozpowszechnione już w Polsce szesnastowiecznej, skoro znalazło ono swój wyraz w literaturze spoleczno-politycznej ${ }^{87}$. Podaje też konkretne przykłady sprzedaży $\mathrm{z}$ epoki jagiellońskiej ${ }^{88}$. Co więcej, w świetle jego wywodów można by ją odnieść jeszcze do stulecia poprzedniego, tj. piętnastego ${ }^{89}$. Potwierdzają ten wniosek zestawione przez nas teksty, zaczerpnięte $\mathrm{z}$ zapisek sądowych, a informujące o transakcjach urzędami u samego progu $X V$ w. (r. 1405$)^{90}$. W tych warunkach wolno snadnie cofnąc je do poprzedniego jeszcze stulecia, zwlaszcza gdy wziąć pod uwage to wszystko, co zestawiamy niżej odnośnie do administracji starostw (ustęp VII). Tak dawną, bo średniowieczną metrykę, posiada w Polsce sprzedawalność urzędów cywilnych.

Sprzedaż stopni wojskowych odniósł K. Górski do czasów Stanisława Augusta; wcześniejszej o niej wzmianki nie znalazł ${ }^{91}$. Ale cytowana niżej deklaracja Stanislawa Augusta, znosząca sprzedaże stopni oficerskich, stwierdza, że to $z$ dawna prowadzona wolność sprzedawania szarży wojskowych ${ }^{92}$.

Zdaniem T. Korzona, zrodzila to zło, nieznane dawniej, punktualna placa, ustanowiona na sejmie z $1717 \mathrm{r}^{93}$ Zwyczaj obcy sprzedawalności stopni wojskowych zakorzenił się u nas od czasów saskich - pisze też M. Kukiel ${ }^{94}$.

Wszakże te informacje, które zebrał K. Górski odnośnie do piechoty cudzoziemskiej, każą się zastanowić, czy nie należałoby przesunąć tej

\footnotetext{
${ }^{85}$ W. Czapliński, Sprzedawanie urzędów..., s. 58.

${ }^{86}$ W. Czapliński, Ideologia..., s. 119.

${ }^{87}$ W. Palucki, o. c., s. 23.

${ }^{88}$ Ibidem, s. 58.

${ }^{89}$ Ibidem, s. 25.

${ }^{90}$ SPPP, t. 2, nr 1089; ob. też ibidem, nr 1100.

${ }^{91}$ K. Górski, Historia piechoty, s. 124.

${ }^{92}$ L. C.

${ }^{93}$ T. Korzon, Dzieje wojen $i$ wojskowości w Polsce, t. 3, s. 113.

${ }^{94}$ M. Kukiel, o. $c$., s. 125 .
} 
praktyki do czasów wcześniejszych. Okazuje się bowiem, że już w XVII w. traktowano regiment piechoty cudzoziemskiej tylko jako źródło dochodów. Dlatego do komend nimi dobrali się magnaci, a prędko i mniejsza szlachta. Śladem tych stosunków jest postanowienie paktów z 1699 r.: Przywodzac ad executionem disciplinam militarem, regimentów żadnych, freikampanii skwadronów i listów przypowiednich, konferować nie bẹdziemy tak senatorom, jako $i$ starostom sqdowym ${ }^{\text {s5 }}$.

Komendanci polscy byli tytularni. Panowie wyrabiali sobie listy przypowiednie na regimenty, ale sami nie zajmowali się nimi, zadowalając się ciągnieniem pożytków\%. Dawali oni swoich zastępców, zawierając z Niemcami kapitulacje, w których wymawiali sobie poglówne. Mieć regiment pieszy znaczyło tyle, co posiadać dobrą wieś ${ }^{97}$. Czyż więc to nie były idealne przesłanki do transakcyj jednostkami wojskowymi? Odpowiedź twierdzącą na to pytanie daje G. Lengnich. Według niego, zwyczaj pozwala kapitanom i pułkownikom na sprzedawanie ich kompanii i pułków ${ }^{8 B}$. Sprzedaje się również odrębne porcje, jak na to wyraźnie wskazuje osiemnastowieczny ordynans Komisji Wojskowej, postanawiający, aby żadnych odtqd podzialów $i$ sprzedaży porcyj nie bylo ${ }^{99}$.

Zatem wpierw zrodziła się sprzedawalność urzędów cywilnych, znacznie póżniej - wojskowych. Jeśli historycy wypowiadają odmienne opinie o czasie wytworzenia się sprzedawalności jednych i drugich, fakt ten wiązać trzeba $\mathrm{z}$ brakiem ustawy, która by powoływała formalnie instytucję do życia. Takiej rzeczywiście nie było, sprzedawalność urzędów bowiem stworzył zwyczaj.

\section{Sprzedawalność tworem prawa zwyczajowego}

Instytucji sprzedawalności urzędów w Polsce nie powołała do życia ustawa. Byla ona tworem prawa zwyczajowego. Nie bez racji wyraża się konstytucja z 1784 r., że to wzwyczajona przedaż ${ }^{100}$. Prawda, zajmowały się nią niektóre wcześniejsze konstytucje, zwlaszcza pakta konwenta poświęcały jej sporo uwagi. Wszakże dopiero u zmierzchu Rzeczypospolitej pojawią się szczegółowe przepisy, które zmierzać będą do jej likwidacji (od r. 1783

${ }^{95}$ VL, t. 6, s. 25. Jest rzeczą jasną, na czym polegało naruszenie wojskowej dyscypliny.

96 B. Baranowski, o. c., s. 133, 139.

${ }^{97}$ K. Górski, Historia piechoty, s. 55-56, 103, 109-110. B. Baranowski jeszcze wyżej szacuje te dochody, skoro pisze, że regiment piechoty przynosił więcej niż najlepsza wieś (o. c., s. 133).

98 G. Lengnich, Mémoires..., s. 234, przyp. 5.

99 K. Górski, Historia piechoty, s. 103.

100 VL, t. 9, s. 12. 
począwszy). $\mathrm{Z}$ takim stanem niejednokrotnie mamy do czynienia w przedrozbiorowej praktyce prawniczej. Instytucja jakaś rozwija się przede wszystkim drogą zwyczajową, a jej likwidację dopiero przeprowadza się drogą ustawy. U kresu pojawiają się pisane normy, które dają kasowanej instytucji wyraziste rysy. Stąd to badania napotykają na te olbrzymie trudności, które nastręczają wszystkie twory prawa zwyczajowego.

Instytucję, uregulowaną przez normę stanowioną, latwo stosunkowo zbadać. Historyk zapoznaje się z wydaną ustawą i ją interpretuje. Dobry historyk prawa zastanowi się również nad tym, jaki cel przyświecał ustawodawcy przy wydawaniu ustawy; zajmie się również tym, w jakim stopniu wydaną normę wprowadzono w życie. Dla tego celu zgromadzi wystarczającą ilość faktów, które wyświetlą interesujące go zagadnienie. Wszakże podstawę wywodów stanowić będzie zawsze norma pisana. Instytucja prawa zwyczajowego powstaje - żeby użyć definicji Ulpianowskiej - rebus ipsis et factis. Historyk więc zmuszony jest zebrać jak największą liczbę faktów, by z nich wysnuć regułę, która przyświecała ówczesnym ludziom mniej lub więcej świadomie.

Nie jest rzeczą latwą zgromadzić wszystkie wiadomości o sprzedaży urzędów na przestrzeni kilku stuleci. Należałoby pod tym kątem przewertować wszystkie źródła, a to przerasta siły jednego człowieka. Zresztą byłaby to praca nieopłacalna. W swoich wywodach ograniczymy się przeto do materiału już zestawionego $w$ literaturze. Jest on tak obfity, że pozwoli na wysnuwanie dość pewnych wniosków. Prace W. Czaplińskiego i W. Paluckiego stanowić będą dla nas kopalnię wiadomości, z której czerpać będziemy przy omawianiu sprzedawalności urzędów cywilnych. Dzieła K. Górskiego i T. Korzona, jak i późniejsze M. Kukiela, pomogą nam w naszkicowaniu sprzedawalności stopni wojskowych. Uzupełnimy je wiadomościami, które sami zgromadziliśmy, przypadkowo przyznajemy, w toku lektury ${ }^{101}$. Skompletujemy analizy norm wydanych w ostatnich latach Polski przedrozbiorowej.

Studium nasze wykazuje więc dużą niedomogę, wynikającą $\mathrm{z}$ niepełnej heurezy. Nie jest ona jedyna. Istnieją poważne luki w istniejących źródłach. Nie wszystkie dochowały się do naszych czasów. Historia, wiadomo, opiera się zawsze na materiałach fragmentarycznych. Co więcej, nie wszystkie wypadki sprzedaży urzędów zostały zanotowane. Ze względu na szczególny charakter omawianej instytucji, graniczącej zawsze z lapownictwem - przejdziemy do tego zagadnienia niżej - niejednokrotnie nie tylko nie notowano podobnych faktów, lecz je wręcz zatajano. Dopiero cudza niedyskrecja uchyliła rąbka tajemnicy. Na ten szczególny charakter informacyj o sprzedaży urzędów pragnęlibyśmy zwrócić uwagę. Nieurzędowe wiadomości są podstawą naszych badań, lecz czerpiemy je często z plotek.

101 Na dwie informacje (Hartknocha i Kochanowskiego) zwrócił moją uwage H. Grajewski, na jedną (Plebańskiego) - moja żona, M. Matuszewska. 
Załóżmy, że zgromadziliśmy już, jeśli nie wszystkie, to dostateczną liczbę przykładów, które pozwolą nam na sformułowanie jakichś wypowiedzi o badanej instytucji. Osobny szkopuł nasunie się $\mathrm{z}$ następującego powodu. Sam fakt sprzedaży urzędów niekoniecznie dowodzi sprzedawalności urzędów jako instytucji prawnej. Sprzedaż taka może być sprzeczna $z$ prawem obowiązującym, a zatem stanowić nadużycie - to, co w prawie kanonicznym nazywa się symonią. Ona to, jak się wydaje, leży u kolebki naszej instytucji. Takim nadużyciem - przynajmniej w oczach szlachty - musiała być sprzedawalność urzędów, jaką zalecały królowi tzw. Rady Kallimachowe.

Za nadużycie uchodziła też cała działalność Bony. Współczesna złośliwa satyra Krzyckiego pt. Ad novos aulicos glosi, że symonia nie jest grzechem $^{102}$. Podobne nastawienie przejawia się jeszcze w satyrach siedemnastowiecznych ${ }^{103}$. $\mathrm{Za}$ nadużycie traktowano również sprzedaże dokonywane przez królowe pochodzenia francuskiego ${ }^{104}$, jak i branie pieniędzy przez faworytów królewskich, dworzan i urzędników. A czy królowi było kiedykolwiek wolno urzędy sprzedawać? Czy fakty takie nie spotykały się stale $\mathrm{z}$ dezaprobatą? Jeśli nawet sprzedaż urzędów przez króla uznać za consuetudo, to z pewnością uważano ją za mala consuetudo. Stąd ta pewna dyskrecja, jaka stale otacza ten „handel”. Stąd historyk niejednokrotnie operuje zwrotem, że ktoś „podobno" zapłacil ${ }^{105}$. Szlachta i magnateria narzekała na to, że godności są sprzedawane ${ }^{106}$. Zwracano się nawet do marszalka, by wytknął zgrabnie królowi, że urzędy są sprzedawane ${ }^{107}$. Zwyczaj bowiem drażnil i magnata, który nie dość wcześnie docisnął się $\mathrm{z}$ ofertą, a jeszcze bardziej gniewał szlachtę, która widziała w nim przekreślenie zasady równości w dostępie do wszystkich godności - stwierdza W. Czapliński ${ }^{108}$. Na sejmie 1652 r. konstatuje się, że $u$ dworu omnia venalia $w$ Rzeczypospolitej, czyniq to sami suo exemplo, speciosa gratitudine kupujac officia et beneficia ${ }^{109}$. Dlatego to na sejmiku krakowskim szlachta podkreśla zasługi biskupa Szyszkowskiego, który u króla urzędy różne wedlug zaslug, nie przedajac, ani nimi kupczqc, upraszal ${ }^{10}$. A choć szlachta niechętnym patrzyla na sprzedawalność urzędów okiem, zdecydowanych wystąpień nie było ${ }^{111}$. Czyż więc to była rzeczywiście

${ }^{102}$ W. Pociecha, Królowa Bona (1494-1557). Czasy i ludzie Odrodzenia, t. 2, Poznań 1949 , s. 73.

${ }^{103}$ W. Voisé, O ideologii spoleczno-ustrojowej Andrzeja Frycza Modrzewskiego, CPH, t. 4, Poznań 1952, s. 19: W. Czapliński, Ideologia..., s. 111.

${ }_{104}$ W. Czapliński, Ideologia..., s. 119-120.

${ }_{105}$ K. Piwarski, Hieronim Lubomirski, hetman wielki koronny, Kraków 1929, s. 50.

${ }_{106}$ W. Czapliński, Dwa sejmy w roku 1652, Wrocław 1955, s. 34.

${ }^{107}$ Ibidem, s. 81.

${ }^{108}$ W. Czapliński, Ideologia..., s. 119-120.

109 Tenże, Sprzedawanie urzędów..., s. 60.

${ }_{110}$ Tenże, Dawne czasy. Opowiadania i szkice historyczne z XVII w., Wroclaw 1957, s. 160.

11 Tenże, Sprzedawanie urzędów..., s. 58, 59. 
stale ,symonia", czy też norma zwyczajowa legalna? Przecież poglądy współczesnych, potępiające ten zwyczaj, nie wiążą historyka w sposób absolutny. Potępiać można i najbardziej legalną instytucję. Starający się o urząd, jeśli jego starania nie zostały uwieńczone sukcesem, oburzał się na kupczenie urzędami, choć sam tą samą drogą na godność wejść pragnąl. Przez jego usta zatem tylko zawód przemawia; nie możemy więc takiej wypowiedzi poczytać za miarodajną dla oceny legalności instytucji. Sprzedaż urzędów uchodziła zawsze za negotium turpe. Taki pogląd wypowiadają też historycy współcześni ${ }^{112}$. Ale to nie powód, by nie uznać powszechnej, wiele set lat trwającej praktyki za consuetudo.

$\mathrm{Z}$ taką zwyczajową instytucją historyk ma niemały kłopot. Jej zmienność w czasie czy mnogość wariantów regionalnych utrudnią mu bardzo opis. Nie da się wykluczyć nigdy dużej dozy subiektywizmu w ocenie faktów: które poczytać za konstytuujące prawo, które zaś za wyjątek od wypracowującej się dopiero reguły. Te rzeczy znane są fachowej literaturze. Ograniczamy się przeto jedynie do ich zasygnalizowania, nie zatrzymując się nad nimi. Ale nie sposób nie zwrócić uwagi na jedną cechę norm prawnych. Jeśli wśród reguł stanowionych znamy taką kategorię, którą się określa terminem leges imperfectae, to czy takiej właściwości może nie posiadać i consuetudo? Czy w ogóle istnieje consuetudo perfecta?

\section{Pojęcie urzędu}

Załóżmy, żeśmy zwycięsko przebyli te wszystkie trudności, które się wiążą $\mathrm{z}$ analizą zwyczajowej normy prawnej. Zebraliśmy wystarczającą liczbę faktów, z których szczęśliwie wyłoniła się consuetudo, dająca się wyraźnie oddzielić od „symonii”, stojącej według wszelkiego prawdopodobieństwa u jej genezy. Wystąpi wszakże dalsza trudność $z$ chwilą, gdy przystąpimy do definicji urzędu. Czy będzie dla nas użyteczna taka, jaką daje współczesny podręcznik prawa administracyjnego? „Jest to grupa zadań, funkcji publicznych, wyodrębnionych i ściśle określonych, spełnianych stale i obowiązkowo $\mathrm{z}$ ramienia danego zwiazku publicznoprawnego na pewnym oznaczonym terytorium przez wyznaczonych do tego ludzi - funkcjonariuszy publicznych - przy pomocy trwałego zespołu środków materialnych, na podstawie stałych prawidel postępowania"113. Co nam da ta definicja, gdy ją zastosujemy dla okresu, w którym nie bardzo odróżniano sferę prawnopubliczną od domeny prawnoprywatnej, gdy wyodrębniania funkcyj nie przeprowadzano dokładnie, gdy nie było jakichś stałych prawideł postępowania?

112 Por. tenże, Ideologia..., s. 119-120.

${ }^{113}$ S. Kasznica, Polskie prawo administracyjne, wyd. 4, Poznań 1947, s. 44. 
Niewyróżnianie stosunków publicznoprawnych od prywatnoprawnych, charakterystyczne dla okresu feudalnego, doprowadziło - jak wiadomo - do tego, że funkcje, które dziś uchodzą za typowe dla zadań państwa, jak wymiar sprawiedliwości, porządek i bezpieczeństwo, pobór świadczeń, zostały związane $\mathrm{z}$ gruntem. Pelnil je rycerz średniowieczny, który otrzymał ius militare ${ }^{114}$, jak i klasztor czy biskup, obdarzeni immunitetem ${ }^{115}$. Już to połączenie Gerichtsherrschaft z Grundherrschaft czyni wspólczesną definicję urzędu dla historyka całkiem nieprzydatną. Wieś wolno było wlaścicielowi sprzedać, darować, przekazać w spadku, zastawić, w ogóle dokonać wszelkich operacyj, których się dokonuje mieniem prywatnym. Ale tym samym sprzedawca cedowal i funkcje, które były z gruntem związane, a które dziś uznajemy za typowo publiczne.

Nie tylko właściciel gruntu - świecki czy duchowny - był sędzią, policjantem, poborcą podatku; mógł on zadania tego rodzaju zlecać innej osobie $\mathrm{i}$ robił to $\mathrm{z}$ reguły, przybierając sobie prywatnego urzędnika, sołtysa czy wójta. Ten urząd sołtysi, z którym związane bylo pewne uposażenie w gruntach, jak i w części opłat pobieranych dla pana (kar, opłat sądowych $i$ in.) traktowano również jako nieruchomość, którą można było sprzedać, zastawić, itd. ${ }^{116}$ Wydawało się to rzeczą naturalną. Do tego stopnia, ze

${ }^{114}$ Por. Z. Wojciechowski, Das Ritterrecht in Polen vor den Statuten Kasimirs des Grossen, Breslau 1930, s. 68 i n. U tegoż autora czytamy o formalnym związaniu beneficium rycerskiego $z$ officium od polowy XII w., ibidem, s. 170, przyp. 4; wszakże ma on tu na myśli służbę wojskowa.

115 Por. Z. Kaczmarczyk, Immunitet sqdowy $i$ jurysdykcja poimmunitetowa $w$ dobrach Kościola w Polsce do końca XIV wieku, Poznań 1936, szczególnie s. 76 i n.; J. Matuszewski, Immunitet ekonomiczny w dobrach Kościola w Polsce do roku 1381, Poznań 1936, szczególnie s. $80-82$.

116 Przykładów na transakcje dobrami szlacheckimi nie dajemy, jest ich bez liku. Dla operacyj sołectwami wybraliśmy trzy charakterystyczne teksty - 1363 r.: veniens providus vir Adam, scultetus de Glogova, cum uxore sua, Dobka, quam videlicet scultetiam in Glogovia habet post uxorem suam, Dobka, quam sculteciam habet uxor sua a patre et a matre sua, KDWP, t. 3, nr 1506; 1358 r.: Hektor z Lęcka, lokując wieś Wyskidno na prawie chelmińskim, postanawia: Volumus eciam, quod predictus scultetus et sui posteri predictam sculteciam in 1010 vel in parte, cui vult, vendat, obliget, resignet, commutet, prout sibi placuerit, quia eandem sculteciam a nobis propria pecunia comparavit et emil: stwierdza się przy tym w dokumencie, ze soltys posiada omnes causas, parvas et magnas, civiles et criminales, KDWP, t. 3, nr 1393; 1360 r.: niejaki Wygandus, sołtys wsi Clymanczicze, sculteciam ibidem Petro, kmetoni de Crampkovo, vendidit, tradidit et resignavit pro certa pecunie quantitate, co zatwierdził biskup poznański, Jan, KDWP, t. 3, nr 1441. Ob. też S. Sochaniewicz, Wójtostwa i soltystwa pod względem prawnym i ekonomicznym w ziemi lwowskiej, Lwów 1921, s. 104 i n., 360 i n. Dla czasów nowożylnych powolamy jeden tekst charakterystyczny z 1532 r. Zygmunt I, uważając, że wsie królewskie nie moga być bez wójtów, Wojsławskiemu daje upoważnienie do sprzedaży wojjtostw, atque eos, quos ad ferenda onera advocatialia dignos et idoneos putaverit, collocet pro pecunia, quam iustam censuerit, quod nos approbaturos per praesentes promittimus, Acta Tomiciana, t. 14, nr 529. 
wielki reformator, wójt wolborski, zdumialby się z pewnością, gdyby mu zabronić dysponowania posiadanym przezeń stanowiskiem.

Skoro uprawnienia natury publicznej związane zostały $z$ gruntem, a tym samym podpadły pod normy dyspozycyjne prawa prywatnego, każdorazowa sprzedaż gruntu pociągała za sobą również alienację złączonych $\mathrm{z}$ nim uprawnień. W tej sytuacji musielibyśmy stwierdzić, że handel urzędami był zjawiskiem powszechnym. Takie ujęcie poczytamy wszakże za wadliwe. Współcześni nie traktowali feudalnej własności za urząd, nie wolno tego robić i historykowi.

Dalszy zatem człon cytowanej wyżej definicji urzędu - funkcje publiczne - nie może stanowić wystarczającego oparcia w badaniach historycznych. Wyłączymy, ze względów praktycznych, takie zadania, które stanowią własność pana-seniora, jak $i$ te wszystkie funkcje o aspekcie niewątpliwie publicznym, które znalazły się w okresie feudalnym ,pod panem” (stanowiska wójtów i sołtysów przede wszystkim). Zajęcie innego stanowiska byłoby niewątpliwie anachronizmem. Nie potrafimy w tej chwili uzasadnić teoretycznie tego kroku. Może za wzorem historyków gospodarczych należałoby stworzyć model prawny państwa feudalnego ${ }^{117}$. W nim znalazłaby miejsce definicja feudalnego urzędu.

W łacinie średniowiecznej na oznaczenie urzędnika, zwłaszcza wyższego, używa się terminu officiarius ${ }^{118}$. W tym samym znaczeniu przeszło to substantivum do języka francuskiego (officier). Ale, wiadomo, rzeczownik ten służył równocześnie jako określnik wyższych stopni wojskowych. Zatem stanowiska cywilne utożsamiano ze stopniami wojskowymi. Z tym samym zjawiskiem, mimo różnej terminologii, mamy do czynienia $\mathrm{i}$ w stosunkach polskich. Konstytucja z 1784 r. wyraźnie stwierdza: Jako te szarże (wojskowe) sq urzędami koronnemi i litewskiemi, $i$ do nich obowiqzuje wymóg szlachectwa lub indygenatu ${ }^{119}$. Okazuje się więc, że wbrew przyzwyczajeniom dzisiejszym nie wolno dla czasów przedrozbiorowych przeciwstawiać obydwu kategoryj funkcyj - cywilnych i wojskowych. Tym bardziej że i jedne, i drugie stanowiły dla nabywców synekury.

Jeśli więc wyżej wyłączyliśmy pewne stanowiska $\mathrm{z}$ pojęcia urzędu feudalnego, tutaj włączamy do niego zajęcia, których nie obejmuje już współczesna nam definicja urzędu, mianowicie stopnie wojskowe. Analiza nasza ograniczy się przeto do godności koronnych i nadwornych, urzędów ziemskich oraz stopni oficerskich.

117 J. Rutkowski, Czy jest potrzebna teoria ekonomiczna ustroju feudalnego? Sprawozdanie PTPN 1934, s. 44-45; W. Kula, Teoria ekonomiczna ustroju feudalnego. Próba modelu, Warszawa 1962.

${ }^{118}$ E. Habel - F. Gröbel, Mittellateinisches Glossar, wyd. 2, Paderborn 1959; ob. też Ducange Verbis: officiarius, officialis.

119 VL, t. 9, s. 11-12. 


\section{Uposażenie urzędów}

Problem wynagrodzeń urzędniczych w Polsce średniowiecznej i nowożytnej . nie doczekał się długo opracowania monograficznego. Stosunkowo najwięcej uwag temu problemowi poświęcił w swoim pięknym studium o starostach S. Kutrzeba. Zajmując się ich uposażeniem, nadmienil ten badacz, że urzędnicy i dostojnicy polscy z reguly mieli uposażenie swoje w ziemi ${ }^{120}$. Tenże zauważył równocześnie, że pierwszy dostojnik i może najbogaciej uposażony, kasztelan krakowski, ma jednak tylko kilka wsi $\mathrm{i}$ trochę dochodów płynnych ${ }^{121}$, choć na innym miejscu utrzymuje, że uposażenie kasztelana krakowskiego było bardzo hojne ${ }^{122}$. Równocześnie, zajmując się dochodami kasztelanów $w$ okresie dzielnicowym, przed osłabieniem ich władzy przez akcję immunitetów, stwierdza, że kasztelan osobnego uposażenia w ziemi nie miał, bo on rządził majątkami księcia $w$ kasztelanii, tu więc też posiadał swoje źródło dochodów. Monarcha ze swego majątku wydzielal część na uposażenie kasztelana, tworząc dla niego beneficjum, jak je posiadali wojewoda, cześnik $\mathrm{i}$ inni ${ }^{123}$. Ten pogląd o uposażeniu urzędników w ziemię znalazl się w opracowaniach syntetycznych ${ }^{124}$. Ona stanowic miała niejako beneficjum związane $z$ officjum. Podzielał go też T. Tyc, choć tenże przyjmował również uposażenie częściowe $w$ pewnych udziałach $w$ świadczeniach skarbowych i sąowych ${ }^{125}$. Podzielał go również w swym młodzieńczym studium Z. Wojciechowski ${ }^{126}$, ale już w pracy poświęconej ustrojowi Śląska zauważył, że fakt ten w źródłach owej dzielnicy nie znajduje potwierdzenia ${ }^{127}$. Ostatnio omawianemu zagadnieniu poświęcił kilka marginesowych uwag W. Palucki w swym dziele o naroku ${ }^{128}$. Wreszcie tenże historyk zająl się nim ponownie w osobnej monografii, w której uznal uposażenie ziemskie za stary, beneficjalny system wynagrodzeń urzędników państwowych ${ }^{129}$; stanowić ono miało jedno z podstawowych źródeł tego

${ }^{120}$ S. Kutrzeba, Starostowie..., s. 285, 289, 315.

121 Ibidem, 285-286.

122 Ibidem, s. 316.

${ }^{123}$ Ibidem, s. 315.

${ }^{124}$ S. Kutrzeba, Historia ustroju, s. 98, 129, 328, 362; Z. Wojciechowski, Państwo polskie w wiekach średnich, wyd. 2, Poznań 1948, s. 70 (zaopatrzenie urzedników ,głównie, zdaje się, polegało na uposażeniu w ziemię); J. Bardach, Historia państwa i prawa, t. 1, s. 272.

${ }_{125}$ T. Tyc, Poczq̨tki kolonizacji wiejskiej na prawie niemieckim w Wielkopolsce (1200-1333), Poznań 1924, s. 64 (powoluje on obok S. Kutrzeby także Lagunę, Grodeckiego i Handelsmana).

${ }^{126} Z$. Wojciechowski, $Z$ studiów nad organizacja państwa polskiego za Piastów, Lwów 1924, s. $68-69$.

${ }^{127}$ Tenże, Ustrój polityczny Sllqska, s. 614.

${ }^{128}$ W. Palucki, Narok. Studium z dziejów slużby informacyjno-lacznikowej w Polsce wczesnośredniowiecznej, Wroclaw 1958, s. 48, 54, 71, 133, 136-137.

129 Tenże, Studia nad uposażeniem..., s. 37, 141, 142-144. 
uposażenia ${ }^{130}$. Przeciwko tej tezie wystąpił zdecydowanie K. Buczek. Uważa on ją, jeśli nie za całkiem fałszywą, to w każdym razie mocno przesadzoną ${ }^{131}$. Ziemia nie była podstawą dochodów urzędniczych ${ }^{132}$. Ewentualne uposażenie w niej ograniczało się do jednego czy kilku źrebów ${ }^{133}$. Zresztą uposażenie w ziemi było dla nich niepotrzebne, bo ci potentaci mieli swoje własne dwory ${ }^{134}$. Zasadniczy trzon stanowiły dla nich dochody $w$ gotówce $i$ naturaliach oraz posługi ludności ${ }^{135}$. Tym samym sąd dawniejszy o podstawowym uposażeniu urzędników w ziemię ulegl poważnemu zachwianiu ${ }^{136}$. Natomiast teza o wynagrodzeniu ich pewnymi dochodami płynnymi jest powszechnie przyjęta. Co więcej, główny akcent - jak się wydaje - należałoby położyć właśnie na ostatnie.

Jakkolwiek by się rzecz miała, w tych wypadkach (prawdopodobnie nieczęstych), w których urzędnik otrzymywal uposażenie w ziemi, nie placił $\mathrm{z}$ niego nic panującemu, albowiem stanowiło ono wynagrodzenie za spełniane funkcje ${ }^{137}$. Sprawa jednak komplikowała się nieraz poważnie. Urzędnik oprócz władzy, oprócz wspomnianego uposażenia dla siebie, otrzymywał w administrację majątki królewskie. Jako przykład posłużyć nam może urząd starościński. Starosta (dobrzyński i kujawski) jest administratorem wszystkich dóbr królewskich danej dzielnicy ${ }^{138}$. Monarcha oddaje starostwa bądź do wiernych rąk, bądź w dzierżawę czy zastaw ${ }^{139}$. We wszystkich wypadkach, a więc nawet wtedy, kiedy mamy do czynienia ze starostązastawcą czy starostą-dzierżawcą, jest on równocześnie urzędnikiem ${ }^{140}$.

${ }^{130}$ Ibidem, s. 14.

${ }^{131}$ K. Buczek, Uposażenie urzędników w Polsce wczesnofeudalnej, Małopolskie Studia Historyczne, t. 5, 1962, z. 3/4, Kraków 1963, s. 59.

132 Ibidem, s. 64, 86.

${ }^{133}$ Ibidem, s. 64.

134 Ibidem, s. 60-61.

${ }^{135}$ Ibidem, s. 57, 61, 78, 79, 80-81, 83-87. Dodatkową korzyścią bywało zwolnienie urzẹdnika od podatków z jego dóbr dziedzicznych, W. Palucki, Studia nad uposażeniem..., s. 102-103. K. Buczek, wypowiada się też przeciwko powszechnie przyjętej tezie (ostatnio referuje ją E. Trzyna, Polożenie ludności wiejskiej w królewszczyznach województwa krakowskiego w XVII wieku, Wrocław 1963, s. 35), jakoby kaszlelanowie zarządzali w swoich okręgach dobrami książz̨cymi, o. c., s. 73-74.

${ }^{136}$ Mocny zwłaszcza wydaje się argument K. Buczka o braku zupełnym dowodów na likwidację ziemskich uposażeń urzędniczych (Uposażenie..., s. 58-59). Uposażenie kasztelana krakowskiego (w XVII w. 12 wsi $z$ miastem Myślenice) oraz wojewody krakowskiego ( 7 wsi, E. Trzyna, o.c., s. 13, 34, 36, 40) miały charakter wyjątkowy. Zauważmy też, że np. włość myślenicka, wedhug domysłu Buczka weszła w skład uposażenia kasztelana krakowskiego dopiero po śmierci Kazimierza W. (o. c., s. 69).

137 S. Kutrzeba, Starostowie..., s. 286-289.

${ }^{138}$ Inaczej było $w$ Małopolsce, gdzie starostowie nie mieli zarządu majątku królewskiego, lecz otrzymywali jedynie dla siebie uposażenie w ziemi (S. Kutrzeba, Starostowie..., s. 337).

${ }^{139}$ S. Kutrzeba, Starostowie..., s. 292-293, 295 i n.; Z. Wojciechowski, Ustrój polityczny Ślqska..., s. 764.

${ }^{140}$ S. Kutrzeba, Starostowie..., s. 283-299; Z. Wojciechowski, Ustrój polityczny Ślqska..., s. 601. 
W razie oddania zarządu do wiernych rąk, starosta rozliczał się $z$ osiagniętych dochodów $^{141}$ i przelewal je na rzecz króla. Atoli jeśli władca znalazł się w pilnej potrzebie pieniężnej - a który monarcha takich sytuacyj nie zna? - a pojawił się usłużny kandydat na starostę, który z góry ofiarowal większą kwotę na poczet przyszłych dochodów z królewszczyzn, czy nie było to kupnem urzędu? A przy dzierżawie i zastawie, jak wyróżnić zakres prywatnego kontraktu od nadania publicznego urzędu? Naszym zdaniem, wszelkie próby robione $w$ tym kierunku skazane są z góry na niepowodzenie. Zwłaszcza gdy uznamy za słuszne zdanie S. Kutrzeby - a wydaje się ono takie - że nadanie praw publicznych bylo jakby dodatkiem do umowy o charakterze prawnoprywatnym ${ }^{142}$.

$\mathrm{Z}$ jednego starostwa nie zawsze świadczono królowi tytulem dzierżawy równe kwoty. Bartosz placil za starostwo kujawskie 800 grzywien $^{143}$. W r. 1377 Elżbieta przeprowadzila zmianę starosty: nowy nabywca, Pietrasz Małocha z Małochowa, zobowiązał się do placenia 2000 grzywien $^{144}$. Czyżby ta zmiana podyktowana byla lepszą ofertą złożoną królowi? Możliwości takiej nie należy wykluczać. S. Kutrzeba podaje przyklad Jana z Plonkowa, który starając się o starostwo whocławskie, obiecywal królowi dać rocznego czynszu 1000 grzywien, sed ipse (rex) nolebat facere ${ }^{145}$. Odbywały się widocznie pertraktacje z królem na temat objęcia starostwa; ponieważ kandydat oferował za mało, wobec tego upad1 ${ }^{146}$. Najwidoczniej więc kandydaci wzajemnie się licytowali!

We wszystkich wspomnianych wypadkach - zarówno gdy oddawano starostwo (sądowe) w zastaw lub w dzierżawę, jak też niekiedy nawet w razie powierzania go ad fideles manus - trudno nie poczytać takich transakcyj za sprzedaż urzędu starościńskiego. W tym przekonaniu umocni nas jeszcze szeroko udzielane ius communicativum, o którym niżej.

Stwierdziliśmy wyżej, że uposażenie urzędników w dochody gotówkowe przyjmują zgodnie wszyscy historycy. Co więcej, one właśnie wysuwać się mają na plan pierwszy. Już S. Kutrzeba pisał, że urzędnicy mieli swoje uposażenie ,niekiedy także w dochodach płynnych z cel lub żup" ${ }^{\prime 14}$. Na Śląsku w średniowieczu starosta pobierał opłatę pewną z okazji zatwierdzania alienacyj. Zabronil tej praktyki Jan Luksemburski ${ }^{148}$. Sędzia pobieral 1/3 kar sądowych ${ }^{149}$, mincerze $4 \%$ dochodu ${ }^{150}$, wojewodowie, kasztelanowie

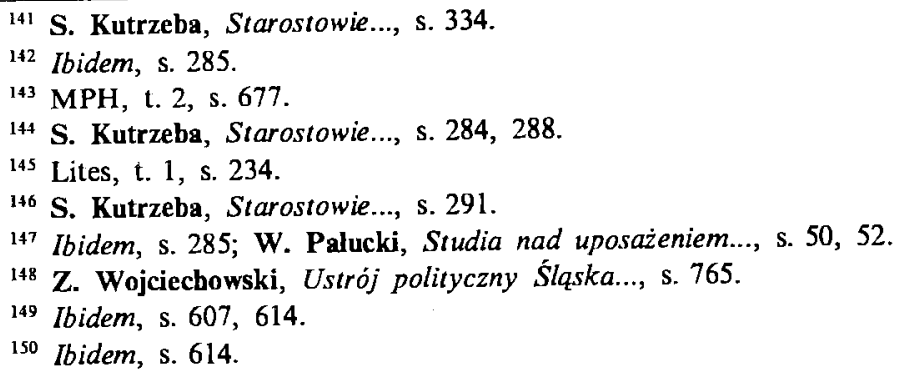


i inni officiales uposażeni byli w części danin ${ }^{151}$. Kromer dla czasów sobie współczesnych stwierdzał: Sunt autem certae mercedes et quasi sportulae, quae iudicibus, iudiciorumque administris penduntur a litigantibus ${ }^{152}$. Podkomorzy i komornicy pobierali trzy grzywny za każde rozgraniczenie gruntów według statutu Jana Olbrachta. Quod operae pretium hodie aliter se habet - stwierdza G. Lengnich ${ }^{153}$, nie podaje wszakże, jak współcześnie jemu przedstawiało się ich wynagrodzenie. W jaki sposób rozliczali się oni $z$ władcą? Czy nie zachodziły pomyłki na niekorzyść skarbu? A czy w takiej sytuacji urzędnik nie „odpalil” od czasu do czasu równej sumki do kiesy królewskiej, by nie zostać usuniętym $\mathrm{z}$ dochodowego stanowiska? Albo czy znowu $\mathrm{z}$ góry à conto pewnej kwoty nie wpłacil? Byłoby to dziwne i na stosunki ludzkie wysoce nieprawdopodobne. Jeśli nawet to nie jest jeszcze sprzedażą, niewątpliwie takie operacje trącą kupczeniem.

Zdumiewające jednak, że mimo to wszystko, co stwierdziliśmy o uposażeniu urzędników w ziemię czy dochody gotówkowe, nie wahal się pisać Marcin Kromer: Reditus magistratuum Regni exigui, terrestrium vere et aulicorum nulli fere sunt ${ }^{\mathrm{t54}}$. Co do ministrów stanu senatorskiego stwierdza jeszcze G. Lengnich, że nie ma dla nich publicum salarium constitutum ${ }^{155}$. Podobnie zresztą przedstawia się sprawa z godnościami niesenatorskimi, ministri togati ${ }^{156}$. Wojscy są beneficiati et non beneficiati - konstatowal G. Lengnich ${ }^{157}$. Czyżby rzeczywiście urzędy były tak całkiem niedochodowym zajęciem dla tytulariusza? Odpowiedź, zdaje się, leży gdzie indziej. Już w średniowieczu było zwyczajem księcia nadawanie wsi w pelną niemal własność - przede wszystkim na rzecz urzędników, dygnitarzy ${ }^{158}$. One stanowiły wynagrodzenie za pelnione funkcje ${ }^{159}$. Ta praktyka $w$ zmienionej postaci przeszła w czasy nowożytne. Nie zniosła jej reforma z $1590 \mathrm{r}$. Wydzielono wówczas tzw. ekonomie, z których dochody były przeznaczone wylącznie na rzecz króla, oraz królewszczyzny, starostwa i tenuty, przewidziane na uposażenie dla urzędników, a w części rozdawane w dożywocia jako panis bene merentium $^{160}$. W rzeczywistości jedna i ta sama grupa ludzi

151 Ibidem.

152 M. Kromer, Polonia, s. 106; tę samą sytuację stwierdza jeszcze G. Lengnich: Quod autem ad honorarium dignitariorum iudicialium, confertur illud a litigantibus et aliis, qui actis terrestribus utuntur, ac operae pretium leges passim statuunt (Ius publicum, t. 2, s. 283).

153 Ibidem, s. 280.

154 M. Kromer, Polonia, s. 106.

iss G. Lengnich, Ius publicum, t. 2, s. 208.

1 s6 Ibidem, s. 246.

157 Ibidem, s. 284.

${ }^{158}$ M. Sczaniecki, Nadania ziemi na rzecz rycerzy w Polsce do końca XIII wieku, Poznań 1938 , s. 80.

is9 Ibidem. Autor wszakże podkreśla, że była to jedynie remuneracja dodatkowa.

160 S. Kutrz.eba, Historia ustroju..., s. 361-362; W. Palucki, Studia nad uposażeniem..., s. 85, $204,285,290$. 
otrzymywała urzędy i tenuty. Co więcej, także ekonomie, mimo wyraźnych zakazów, dostawały się $w$ ręce wielmożów tytułem zastawu ${ }^{161}$. Prawda, że na dobrach tych ciążyła kwarta. Ale w jakim procencie była ona oddawana do skarbu? Niedobory sięgały $60 \%$ - pisze $M$. Nycz ${ }^{162}$. W polowie XVIII w. kwarta stanowila $1 / 20$ część rzeczywistych przychodów ze starostw ${ }^{163}$, a więc wynosiła $5 \%$. Interesy tenutariuszy były zatem aż nadto dobrze zagwarantowane.

Jeśli nawet uposażenie urzędów w ziemi było raczej wyjątkowe i z reguły - poza jakimiś wyjątkami - skromne, jeśli dochody płynne, choć poważniejszego znaczenia, czyniły beneficjariusza zależnym od władcy, to nadania i dożywocia dawały mu dużą niezawisłość i czyniły urzędy atrakcyjnymi. Czyżby więc $w$ takiej sytuacji otrzymujący dzierżawe nie odwzajemnił się w taki czy inny sposób królowi, pośrednio lub bezpośrednio? A w takim razie, czy taka transakcja nie stanowiła kupna, choć formalnie nabywca nie świadczyl nic za urząd?

$\mathrm{Z}$ omówionym rodzajem uposażenia, typowo średniowiecznym, mamy do czynienia aż po skłon szlacheckiej Rzeczypospolitej. Dopiero w r. 1775 przeprowadzono reformę emfiteutyczna starost ${ }^{164}$. Dokonana zbyt późno ${ }^{165}$, oznaczała ona przejście ostateczne do nowoczesnej formy uposażenia, to jest stałych pensyj. Najpierw weszly one w zastosowanie do urzędników niższych $^{166}$, potem coraz częściej dla wyższych ${ }^{167}$. Ale z jakimi oporami! Według G. Lengnicha, podskarbiemu wyznaczono pensję w r. 1736: fuit annua illa pecunia primum in gratiam Moszynii constituta, nullo ante ipsum thesaurariis per legem decreto salario. Wszakże nie wiadomo - pisze dalej tenże autor - czy ta forma uposażenia utrzyma się za jego następców, skoro sejm z r. 1736 został zerwany ${ }^{168}$. Jakżeż wiele mówiące to zastrzeżenie

${ }^{161}$ M. Nycz, o. c., s. 14; E. Trzyna, o. c., s. 37.

162 M. Nycz, o. c., s. 23.

${ }^{163}$ Ibidem, s. 33.

${ }^{164}$ S. Kutrzeba, Historia ustroju..., s. 328, 367.

165 Tenże, Starostowie..., s. 348. Odżywa ten problem w okresie Królestwa. Zdecydowanym przeciwnikiem dóbr narodowych, w zmienionych zresztą warunkach politycznych, jest Lubecki, który przygotował szeroki plan ich sprzedaży, S. Smolka, Polityka Lubeckiego przed powstaniem listopadowym, t. 1, Kraków 1907, s. 170-172.

166 Znacznie wcześniej, bo już w czasach Kazimierza W., ustalono salarium dla 10 burgrabiów krakowskich; podwyższył je później Władysław Jagielło, G. Lengnich, Ius publicum, t. 2 , s. $287-288$.

${ }^{167}$ S. Kutrzeba, Historia ustroju..., s. 369; Z. Kaczmarczyk, Historia państwa i prawa..., 1. 2, s. 415; J. Rutkowski, Historia gospodarcza Polski, t. I, Poznań 1947, s. 354. W oparciu o informacje zestawione przez G. Lengnicha można by mniemać, że w przejściu na stałe pensje Litwa wyprzedziła Koronę (Ius publicum, t. 2), s. 246 (instigator), s. 261 (excubiarum praefecti, metator), s. 266 (praefecti rei tormentariae). Pensje, które dawniej próbowano zaprowadzić zanikły, W. Palucki, Studia nad uposażeniem..., s. 108.

${ }^{168}$ G. Lengnich, Ius publicum, t. 2, s. 203. 
doskonałego znawcy rzeczy polskich! Stałe stipendia przyznano w pierwszej linii wojskowym $(1717 \mathrm{r} .)^{169}$. I tu jednak dawna forma uposażenia nie zaniknęła od razu, jak o tym świadczy przykład następujący: konstytucja z r. 1659 zapewnila generałowi artylerii tytułem uposażenia dwa starostwa, które przyniosą renty $30000 \mathrm{złp}$. Postanowienie identyczne znajdzie się nie tylko w paktach Jana $\mathrm{III}^{170}$ i Augusta $\mathrm{II}^{171}$, ale przejdzie jeszcze do paktów Augusta III ${ }^{172}$.

Rozumiemy, że przy pustym skarbie, mimo ustanowienia pensji, nie zawsze ją wyplacano uprawnionemu ${ }^{173}$.

$\mathrm{Z}$ wywodów naszych wynika, że pełnienie funkcyj urzędowych było zajęciem intratnym. Pod postacią rent, zapisanych na dochodach królewskich lub w formie starostw, wyjątkowo pod postacią stalych uposażeń, dygnitarz ciągnąl poważne korzyści. Nie wyczerpują one wszakże wszystkich walorów związanych $\mathrm{z}$ urzędem. Oto, co kompetentny Lengnich stwierdza odnośnie do ministrów ordinis senatorii: Esse tamen illis emolumenta, quae tum a privatis, tum aliunde obveniunt, ac ministerium ipsorum infructuosum esse non patiuntur ${ }^{174}$. Nie inaczej według tegoż autora przedstawiała się sprawa $\mathrm{z}$ godnościami niesenatorskimi: sed quod quibusdam ex suo munere obvenit, a privatis confertur ${ }^{175}$. Istnieją zatem jakieś dodatkowe obwencje, z których współcześnie zdawano sobie dobrze sprawę. Do takich zaliczylibyśmy np. dochody podskarbiego $\mathrm{z}$ ceł. Było też zwyczajem od dawna praktykowanym, że dla siebie ciągnął on korzyści $\mathrm{z}$ administracji wakujących starostw ${ }^{176}$. Poza podatkami, którymi zarządzal, powierzano mu jeszcze inne: za administrację $6 \mathrm{kwartalów} \mathrm{żoldu} \mathrm{dla} \mathrm{wojska} \mathrm{w} \mathrm{latach} \mathrm{1710-1712} \mathrm{osiągnął} \mathrm{on}$ minimum $617000 \mathrm{zlp}^{177}$. O hetmanach podaje G. Lengnich: Habebant etiam antea (tzn. przed r. 1717) suos reditus duces ex thesauro, hibernis, quarta, militum donativis et aliis $^{178}$.

Jest rzeczą charakterystyczną, że wprowadzenie pensji nie oznaczało jeszcze zerwania $\mathrm{z}$ dawną formą uposażenia. Przyznana podskarbiemu koronnemu w r. 1736 pensja w wysokości 120000 złp nie była wyłącznym

${ }^{169}$ Pensja hetmana wielkiego wynosiła 120000 złp. Obok tego jednak otrzymywał jeszcze $100000 \mathrm{ztp}$ in certos sumtus eroganda ac in rationes referenda, G. Lengnich, Ius publicum, t. 2, s. 257. Uposażenia innych dygnitarzy wojskowych: ibidem, s. 260, 261, 266.

${ }^{170}$ VL, t. 5 , s. 265.

${ }^{171}$ VL, t. 6 , s. 24.

172 G. Lengnich, Mémoires..., $\S 52$.

173 Odnośnie do skarbnika pruskiego konstatuje G. Lengnich, Ius publicum, t. 2, s. 272.

${ }^{174}$ G. Lengnich, Ius publicum, t. 2, s. 208.

175 Ibidem, s. 246.

${ }^{176}$ M. Nycz, o. c., s. 104. Według W. Paluckiego, nie było tak w stuleciach poprzednich, Studia nad uposażeniem..., s. 24-25.

${ }^{177}$ Ibidem, s. 105.

${ }^{178}$ G. Lengnich, Ius publicum, t. 2, s. 258. 
wynagrodzeniem; mial on ją pobierać praeter solitas ministrorum thesauri pensiones $^{179}$. Nie inaczej było i z niższymi urzędnikami skarbowymi - jak to stwierdza $\mathrm{G}$. Lengnich w stosunku do skarbnika pruskiego: ex ipsis etiam tributis aliquid thesaurario obveniebat ${ }^{180}$.

Wszakże i te obwencje nie wyczerpują wszystkich dochodów urzędniczych. Ks. Kitowicz wyróżnia wśród nich następujące pozycje: lafa, czyli pensja, $\mathrm{i}$ obwencje, czyli dochody $\mathrm{z}$ boku. Ostatnie dzieli on na dwie grupy - uczciwe $\mathrm{i}$ lotrowskie ${ }^{181}$. Instygatorowie trybunalscy - bo to $\mathrm{z}$ okazji omawiania ich działalności ks. Kitowicz przeprowadził wspomniane rozróżnienie - żywili się „u stołu prezydenta lub marszałka $\mathrm{z}$ ich shuzą̧cymi, kiedy ci panowie byli i hojni, i dostatni"182. Tu już kryje się pewien dochód, nie zawarty w pensji. Wszakże dowiadujemy się od pamiętnikarza czegoś więcej: ,instygatoria bezpieczeństwa prócz lafy szczupłej nie miała innych uczciwych "obwencyj, tylko lotrowskie wyżej wyrażone"183. Oto na czym one polegały: „Obrywczą (= gratką) niemałą bywalo instygatorów securitas zdybanego na zabawie nieprzystojnej $\mathrm{z}$ osobą podejrzaną jakiego mlodzika, służalca przejeżdżającego albo rzemieślniczka, lub kupczyka - obrać z pieniędzy, z pasa, z czapki, z zegarka i szabelki, i tak wystrychnionego puścić, niby z laską niepojmania do aresztu, wiedząc, że - dla wstydu - nikt się o poniesioną takową grabież nie będzie skarżył, chociaż ta czasem mniej sprawiedliwą była, owszem każdy w taki trafunek wpadający szkodę poniesioną na inne nieszczęście zwali. Tym sposobem obchodzili się instygatorowie i z niewiastami publicznymi, gdy miarkowali, że się już w ogarnięcie i grosze zapomogły, chyba że z nimi mialy zmowę, aby im znać dawały, kiedy u siebie jakiego gaszka strojnego mieć będą, albo kiedy się instygatorom powolnością dla nich samych lub miesięczną kwotą umówioną oplacały"184. To były łotrowskie dochody na poziomie woźnego. A jak się przedstawiało to samo źródlo u wielkich dygnitarzy?

W średniowieczu - jak pisze M. Sczaniecki - zagarniali urzędnicy dobra książęce. Ta praktyka $w$ czasach nowożytnych, być może, nie przybierała już większych rozmiarów ${ }^{185}$. Natomiast krociowe nadużycia umożliwiał podskarbiemu brak osobnej kasy państwowej, do której by odprowadzał dochody publiczne. $Z$ takim stanem rzeczy spotykamy się jeszcze w XVIII w. ${ }^{186}$

${ }^{179}$ Ibidem, s. 203.

${ }^{180}$ Ibidem, s. 272.

18 J. Kitowicx, Opis obyczajów za panowania Augusta III, opr. R. Pollak, Bibl. Narod., wyd. 2, Wroclaw 1951, s. 188.

182 Ibidem, s. 189.

183 Ibidem.

184 Ibidem, s. 188.

iks M. Sczaniecki, Nadania ziemi..., s. 150-152; W. Palucki, Studia nad uposażeniem..., s. 119, 176, 203-204.

${ }^{186}$ R. Rybarski, Skarbowość Polski w dobie rozbiorów, Kraków 1937, s. 13. 
$Z$ r. 1736 cytuje $G$. Lengnich pokwitowanie, wydane sukcesorom zmarkego podskarbiego, $\mathrm{z}$ rachunków, których od nich żądano ${ }^{187}$. Najwidoczniej więc oni weszli w posiadanie sum publicznych, z których musieli się rozliczyć. Podobnie w r. 1766 przysądzono z majątku zmarkego podskarbiego Siedlnickiego sume jakąś dla Rzeczypospolitej; Sejm zamiast niej zgodził się na kwotę 300000 złp, które obiecal zapłacić podstoli koronny, Aleksander Borzęcki ${ }^{188}$. Nie zdumiewa przeto nas tekst przysięgi składanej przez podskarbiego po wprowadzeniu pensji: se reditus in usus publicos iuste et integre expensurum, nec quidquam praeter constitutum salarium in proprios usus versum esse ${ }^{189}$. Tak wydawaly się zwykłe sprzeniewierzenia grosza publicznego w owych czasach!

Trudno też jako uczciwą potraktować operację z 1710 r. Do tego czasu wydzierżawiano składne winne najwięcej dającemu. Od czerwca $1710 \mathrm{r}$. podskarbi objął ten podatek $w$ bezpośredni zarząd. Od razu dochody skarbu spadły ${ }^{190}$. Wyraźnie łotrowski charakter mają już dalsze obwencje. Podskarbi zawieral prywatne umowy z miastami (Toruń) oraz z kupcami węgierskimi i tureckimi, w których udzielał ulg celnych za opłatą dla siebie $^{191}$. $\mathrm{Z}$ okazji oddawania $\mathrm{w}$ dzierżawę prowincyj celnych brał Przebendowski rękawiczne ${ }^{192}$. A dodajmy do tego jeszcze fakt, że od Przebendowskiego począwszy żaden $\mathrm{z}$ podskarbich - $\mathrm{z}$ wyjątkiem Grabowskiego - nie wyrachował się $\mathrm{z}$ administracji skarbu. Ściągano więc zaległości dopiero od ich spadkobierców, $\mathrm{i}$ to $\mathrm{w}$ kwotach poważnych (od sukcesorów Ossolińskiego i Czapskiego - 332 000; po Moszyńskim - 226000 ; po Siedlnickim - 2800000 , a jeszcze nie rozstrzygnięta była kwestia 1300000 zlp $^{193}$. Stanowczo nie lepiej przedstawiała się i galeria podskarbich litewskich. Jeden $\mathrm{z}$ nich, Kociell, trudnil się ponadto rozbojem na drogach (a mimo to został na urzędzie do śmierci) ${ }^{194}$. Nic więc dziwnego, że Przebendowski wydatkować musiał kilkaset tysięcy złotych na jednanie sobie zwolenników ${ }^{195}$. Zrozumiałe też, że odrzucił on $\mathrm{z}$ oburzeniem proponowaną mu pensję w wysokości $60000 \mathrm{zlp}$, a jego następca wahał się z przyjęciem wyznaczonej mu dwukrotnej tej kwoty ${ }^{196}$. Czy w tych warunkach pólmilionowy dochód

${ }^{187}$ G. Lengnich, Ius publicum, t. 2, s. 201.

${ }_{188}$ VL, t. 7, s. $446-447$.

189 G. Lengnich, Ius publicum, t. 2, s. 203. W. Palucki, podaje przykład pobierania dochodów z urzędu przez rodzinę po śmierci tytulariusza, Studia nad uposażeniem..., s. 217.

${ }^{190}$ M. Nycz, o. c., s. 97. Nie wiemy, co sq̨dzić o relacji Przebendowskiego, według której kołowe, uchwalone w r. 1700, z którego spodziewano się około 200000 złp, przyniosło wszystkiego 70 talarów, ibidem, s. 86.

191 Ibidem, s. 100.

192 Ibidem, s. 100.

193 Ibidem, s. 258.

194 Ibidem, s. 69, 108.

195 Ibidem, s. 108.

196 Ibidem, s. 106. 
podskarbiego w r. $1727-1728^{197}$ może uchodzić za szacunek zbyt wysoki? Czy obliczenia współczesnych statystów, przypisujących podskarbiemu litewskiemu z samych tylko cel dochód w wysokości 820000 zlp rocznie, są rzeczywiście przesadne? ${ }^{198}$ Jakich olbrzymich sprzeniewierzeń dopuszczal się podskarbi, uprzytomnimy sobie, stwierdziwszy, że urząd jego oddany per plus offerentiam przynosić miał $\mathrm{w}$ pierwszym roku podwójną sumę, a w drugim czterokrotną (!) wpływów dawnych. A z pewnością i nowy podskarbi, który drogą licytacji wszedł w posiadanie urzędu, również nieźle się na nim obłowił. Jak wiemy, w cyfrach absolutnych wyraża się wspomniana różnica kwotami 500000,1000000 względnie $2000000 \mathrm{zlp}^{199}$. A zatem w ciągu dwóch lat Rzeczypospolita zamiast miliona złp wpływów osiągnęła ich trzy miliony! Na dwudziestoletni bez mała okres rządów Przebendowskiego uczyniło to około 20 milionów złotych sprzeniewierzonych! Peculatus więc wręcz olbrzymich wymiarów. Być może, nie zawsze podskarbi podobne krocia dla siebie ściągał ze szkodą Rzeczypospolitej. W okresie wojen niewątpliwie i jego dochody malały $^{200}$. Z reguły też podwładna mu administracja skarbowa zagarniała niemale kwoty dla siebie clandestine $e^{201}$. Wszakże informacje, zebrane na innej drodze, potwierdzają fakt zaboru przez nich olbrzymich dochodów skarbowych in proprios usus.

Nie inaczej przedstawia się też sprawa dochodów hetmańskich. Mówiliśmy wyżej o sumach, które czerpal on przed r. 1717 ze skarbca, hiberny, kwarty itd. Informujący o tym $G$. Lenginch nie omieszkal dodać następującego zdania: sed summa erat incerta ac querelae auditae, quasi duces plus, quam fas esset, exigerent ${ }^{202}$. Dość zawoalowana wypowiedź gdańskiego prawnika znajduje w pelni poparcie źródłowe. Sieniawski w r. 1706 nie wyrachowal się zupelnie $\mathrm{z}$ dochodów kwarcianych; co do innych rachunków $\mathrm{z}$ tego czasu miano duże zastrzeżenia ${ }^{203}$. Hetmanowie zwalniali od hiberny dzierżone przez siebie starostwa, a mieli ich więcej ${ }^{204}$. Trzymano $10 \%$ planowanego wojska, a najwyższy dowódca brał całą sumę dla siebie. Co więcej, podawał on do tysiąca $\mathrm{i}$ więcej koni ultra computum ${ }^{205}$. W okresie wojny północnej hetman opanowal stanowisko marszałka trybunału skarbowego ${ }^{206}$. W ten sposób nie podlegal już żadnej kontroli. Nic dziwnego więc, że pomawiano

\footnotetext{
${ }^{197}$ Ibidem, s. 106, przyp. 2.

198 Ibidem.

199 Por. wyżej, s. 213.

${ }^{200}$ M. Nycz, o. c., s. 102

201 Ibidem, s. 99.

202 G. Lengnich, Ius publicum, s. 258.

${ }^{203}$ M. Nycz, o. c., s. 94.

204 Ibidem, s. 110.

${ }^{205}$ Ibidem, s. 115.

206 Ibidem, s. 128.
} 
go o milionowe dochody ${ }^{207}$. Nie bez racyj nie posiadający znaczniejszej fortuny Koniecpolski dorobil się na hetmaństwie olbrzymiego majątku ${ }^{208}$. Wobec takich dochodów naczelnego dowódcy wyznaczona dlań pensja nie stanowiła poważniejszej pozycji ${ }^{209}$.

Jak nieprzyzwoicie kosztowna była polska administracja, świadczy o tym fakt, że pochłonęła ona 3/4 sum uchwalonych w r. 1690 na zapłatę wojska ${ }^{210}$.

Wzmiankujmy jeszcze o pensjach wypłacanych dygnitarzom przez ościenne mocarstwa ${ }^{211}$.

Jeśli Dhondt, charakteryzując feudalizm zachodnioeuropejski, definiuje go tak: c'est une époque ou tout le monde vole, plus ou moins noblement, to ta wypowiedź znajduje pelne pokrycie dla stosunków polskich XVIII w.

Te olbrzymie „łotrowskie” dochody znajda pewne uzasadnienie w wydatkach związanych $\mathrm{z}$ pelnieniem funkcyj urzędowych. Podskarbi, hetmani, kanclerze ponosili sami wydatki na cele publiczne, gdy w skarbie były pustki, a potrzeba pilna - pisze J. Rutkowski ${ }^{212}$. Podskarbi udzielal prenumeraty, czyli pożyczki na erekcję regimentów ${ }^{213}$. Koszta związane $z$ hetmaństwem przekraczały znacznie ich uposażenie ${ }^{214}$. Musial więc on własne wykładać fundusze na wojsko $^{215}$. Ale te sumy $\mathrm{z}$ reguly zwracano im. Lektura aktów sejmikowych poświadcza, jak olbrzymie kwoty szły na dygnitarzy tytułem zwrotu poniesionych przez nich kosztów. Czyż i tu nie kryła się forma przywłaszczania grosza publicznego na spółkę ze szlachtą, żyjącą $\mathrm{z}$ pańskiego stołu? Choć już w 1710 r. postanowiona została regularna i punktualna kwartalowa placa wojsku koronnemu ze skarbca koronnego ${ }^{216}$, jeszcze konstytucja z 1793 r. przewiduje, że „towarzystwo" i „namiestnicy” mają otrzymać zwrot tego, co stanowi, jak się wyraża ustawa, naklad przy zaciqgu zrobiony ${ }^{217}$.

Przy takich dochodach legalnych, a zwlaszcza nielegalnych, urzędy były atrakcyjne. Stąd współzawodnictwo o nie silne, stąd też zrozumiała licytacja, którą monarcha nieraz wykorzystywał dla swoich celów, biorąc, ile się da.

\footnotetext{
207 Ibidem, s. 115.

${ }^{208}$ B. Baranowski, Organizacja..., s. 174, 177.

${ }^{209}$ M. Nycz, o. c., s. 116.

210 Ibidem, s. 134.

${ }^{211}$ Znano je już za Kazimierza Wielkiego, por. R. Grodecki, Kongres krakowski, s. 57. Por. też niedyskrecje zawarte w responsie kasztelana krakowskiego, Warszyckiego, skierowanym do kanclerza koronnego, Prażmowskiego, a włączonym do dzieła J. Ch. Paska, Pamiętniki, Warszawa 1955, s. 257.

212 J. Rutkowski, Zagadnienie podzialu spolecznego do XVIII wieku, [w:] Pamiętnik VII Powszechnego Zjazdu Historyków Polskich we Wroclawiu, t. 1, Wroclaw 1948, s. 377.

${ }^{213}$ M. Nycz, o. c., s. 107.

${ }^{214}$ B. Baranowski, o. c., s. 177.

215 Ibidem, s. 172-173.

${ }^{216} \mathrm{VL}$, t. 6, s. 170 .

${ }^{217}$ VL, t. 10, s. 190.
} 


\section{Zastępstwo}

Według naszych pojęć urzędnik wykonywać musi swe funkcje osobiście. Tego wymogu nie znano dawniej. Wykonywanie zadań zlecal urzędnik swemu prywatnemu zastępcy. Starosta wielkopolski miał stale swego surrogatora, podstarościego czy sędziego grodzkiego ${ }^{218}$. Pisarz na komorze celnej odstępował swe stanowisko za pewną sumę kolegom ${ }^{219}$. Z takim rozwiązaniem liczyć się należało zawsze $w$ wypadku nadawania godności nieletnim ex meritis ojca czy antecessorów, czego zakazały pakta z 1699 r. ${ }^{220}$ Co prawda, ci zastępcy mają być wybierani publica autoritate in comititis ${ }^{221}$, ale czy tak rzeczywiście postępowano?

Zastępstwo znano również w wojsku. Jeszcze w XVIII w. (!) hetman jako generalissimus nie pełnił swych funkcji sam, lecz zlecal je innej osobie, czego zakazała konstytucja z $1736 r$ r. $^{222}$ A już szczególny charakter miała instytucja zastępstwa wśród niższych kadr oficerskich: towarzysz mógł dać za siebie dwóch gemejnów - tworzyło to poczet sowity w odróżnieniu od przytomnego $^{223}$ - a sam równoczé́nie pełnil obowiązki ekonoma czy pisarza prowentowego ${ }^{224}$, zjawiając się w wojsku raz na dwa lata po odbiór żołdu ${ }^{225}$.

$Z$ tej wady zdawal sobie dobrze sprawę Modrzewski, który domagał się - daremnie - by urzędnicy pełnili swe funkcje osobiście ${ }^{226}$.

\section{Kumulacja urzędów}

Ponieważ urząd dawał niemałą intratę, $\mathrm{z}$ pewnością nie zawsze czystą - pomijam tu sprawę godności honorowych, acz i one przy pewnych poglądach nie są pozbawione jakichś walorów - znajdywali się kandydaci,

${ }^{218}$ M. Ch. Hartknoch, o. c., s. 571-572; G. Lengnich, Ius publicum, t. 2, s. 289. Nieshusznie zatem dopatrywano się zakazu łączenia dwu starostw sądowych $w$ niemożności wykonywania wymiaru sprawiedliwości w dwu miejscach, por. G. Lengnich, lus publicum, t. 1, s. 321.

${ }^{219}$ M. Nycz, o. c., s. 98.

${ }^{220}$ Mają one na względzie opactwa, dygnitarstwa, starostwa, dzierżawy, VL, t. 6, s. 20.

${ }^{221}$ G. Lengnich, Ius publicum, t. 2, s. 288.

${ }^{222}$ Zakaz, by hetmani nikomu generalnej kommendy nad wojskiem koronnym i litewskim cudzoziemskiego zaciagu nie ustępowali, pro perpetua lege stanowiemy. Tamże uzasadnienie tego przepisu: doznala Rzplita multas tribulationes [...] przez ustapienie kommendy nad wojskiem cudzoziemskiego authoramentu, VL, t. 6, s. 590.

${ }^{223}$ K. Górski, Historia jazdy..., s. 129-130.

224 Ibidem, s. 141. Przebywający w domu oficer trudnil się hodowlą koni i handlem (ibidem, s. 208); T. Korzon, Wewnętrzne dzieje Polski za Stanislawa Augusta (1764-1794), KrakówWarszawa 1897 , t. 4, s. 302.

${ }^{225}$ T. Korzon, o. c., s. 302.

${ }^{226}$ Z. Kaczmarczyk, Historia państwa i prawa, t. 2, s. 104. Nieraz akty królewskie wyraźnie zastrzegajz obowiązek rezydencji, W. Palucki, Studia nad uposażeniem..., s. 195. 
którzy go chętnie przyjmowali. I to nawet nie jeden. Dotykamy tu problemu staropolskiej wieloetatowości, zwanej wówczas kumulacją. Istniały zakazy łączenia w jednym ręku pewnych przynajmniej godności ${ }^{227}$, jak też - choć w formie złagodzonej - więcej beneficjów ${ }^{228}$. Mimo to kumulacja była rozpowszechniona. Nawet na komisjach nie wahano się lączyć kilku funkcyj ${ }^{229}$. Kumulacja urzędów, znana od dawna ${ }^{230}$, wytępić nie dała się nigdy. Oczywiście urzędnik, posiadający kilka godności, tym bardziej nie wykonywał sam odnośnych funkcyj, lecz ograniczal się do pobierania dochodów związanych z dzierżonymi godnościami.

\section{Urząd uposażeniem}

. Jeśli więc urząd jest dziś funkcją publiczną, pełnioną w interesie ogólnym i wykonywaną osobiście przez danego urzędnika, który pobiera uposażenie przyznane mu przez państwo, przy czym wszelkie inne dochody, jakie by ciągnąl w związku $z$ tym urzędowaniem, traktuje się jako nadużycie (lapówkę), to takie ujęcie nie odpowiada zupełnie stosunkom przedrozbiorowym.

Istniały zajęcia dobrze płatne, $\mathrm{z}$ którymi nie lączyły się żadne funkcje ze względów faktycznych: komisje hibernowe, coraz liczniejsze, nie robily nic, bo nie było pieniędzy, którymi miały zawiadywać ${ }^{231}$. Silą rzeczy były to synekury. Ale przy podanych wyżej cechach urzędy staropolskie w ogóle uchodziły za uposażenie, a funkcja służbowa stanowiła dodatek do niego.

${ }^{227}$ Por. pakta Wladysława IV (VL, t. 3, s. 766), Jana Kazimierza, (VL, t. 4, s. 196), egzorbitancje z 1669 r., punkt 41 (VL, t. 5, s. 13), potwierdzone w paktach (ibidem, punkt 80), ponawiane przez Jana III (VL, t. 5, s. 267), Augusta II (VL, t. 6, s. 21), Augusta III (VL, t. 6, s. 624), Stanisława Augusta (VL, t. 7, s. 202). Ob. też M. Ch. Hartknoch, o. c., s. 277; G. Lengnich, Ius publicum, t. 1, s. 292, t. 2, s. 151. O niełączeniu w jednym ręku dwu starostw cum iurisdictione, G. Lengnich, Ius publicum, t. 1, s. 320-321. Wszakże tej lex de incompatibilibus quoad personam nie zawsze przestrzegano; zalecały jej przekroczenie instrukcje sejmikowe, jak np. instrukcja rawska z r. 1667, cytowana przez J. Paska, Pamiętniki, s. 282. Od wspomnianej incompatibilitas, zakazującej kumulacji dwu urzędów w jednym ręku, odróżnić należy incompatibilitas $w$ jeden dom; dwa ministeria status nie mogły się znaleźć równocześnie w ręku dwu osób należących do jednej rodziny, VL, t. 6, s. 20 (r. 1699); VL, t. 7, s. 202 (1764), oraz G. Lengnich, Ius publicum, t. 1, s. 293; t. 2, s. 152.

${ }^{228}$ Nie wolno było mieć powyżej dwóch królewszczyzn, VL, t. 6, s. 20: jednej osobie nad dwie starostw proventowych albo dzierżaw znacznych (w co jurydyczne starostwa includi nie majq); podobnie VL, t. 7, s. 202 (1764). Por. tu G. Lengnich, Ius publicum, t. 1, s. 320, 322, 324. Podobne ograniczenia pojawiły się odnośnie do dożywoci dla wdów, VL, t. 4, s. 839 (r. 1662). Rozciągał się też zakaz i na ius communicativum, VL, t. 7, s. 202.

${ }^{229}$ M. Nycz, o. c., s. 121.

${ }^{230}$ W. Palucki, Studia nad uposażeniem..., s. 19, 113, 266; o łączeniu województw ze starostwami, ibidem, s. 109, 135, 271.

${ }^{231}$ M. Nycz, o. c., s. 110-115, 131. 
Stąd to zrodzil się pomysł rezerwowania ich dla bene meriti. Urzędy mają stanowić wynagrodzenie za zasługi! Nadaje je król i Rzeczpospolita tym, którzy oddali znaczne usługi Państwu. Widać to wyraźnie z konstytucji o miesiącach żołnierskich ${ }^{232}$. Takie przekonanie znalazło odbicie $w$ aktach na wskroś publicznego i podstawowego dla ustroju charakteru, jakimi były pakta konwenta. Oto brzmienie tychże paktów Augusta III: gratiis, beneficiis et muniis Regni nie inaczej szafować bedzie, tylko konformujac sie do opisania prawa $i$ wedlug zaslug, nie $z$ inszej, tylko $z$ samych cnot zalety $i$ dystynkcji $i^{233}$. Przypominanie o obowiązku nadawania urzędów solis bene meritis w Rzeczypospolitej jest wiecznie powtarzającym się refrenem, który wystąpi jeszcze w paktach Stanisława Augusta ${ }^{234}$.

Jeśli takie było oficjalne stanowisko sfer najwyższych wobec naczelnych godności i magistratur, nic dziwnego, że ta nuta - urzędu jako źródła dochodu - wystąpi także niżej, np. w stosunku do stanowisk woźnych (instygatorów Trybunału). Nadawali je prezydent czy marszałek Trybunału komuś ze swoich przyjaciół lub służących po to tylko, by ci odsprzedali je dalej $^{235}$. Z góry wiedzieli oni, że obdarzony urzędem nim bawić się nie będzie. Prywatny interes nadawcy (opłacanie prywatnej klienteli) szedł $w$ parze $z$ najbardziej prywatnym interesem odbiorcy funkcji (dochód kilkudziesięciu czerwonych złotych).

Pojmowanie urzędu jako synekury, czy premii dla dobrze zasłużonych, znalazło swój wyraz jeszcze w następującym fakcie. Jest rzeczą charakterystyczną dla dawnych ustaw, jak i przedrozbiorowych pisarzy, że w jednym ustępie czy wręcz w jednym zdaniu omawiają sprawę nadań dignitates et bona regia ${ }^{236}$. Znane postanowienie, ograniczające uprawnienia skartabellów, rozciąga się równocześnie na officia et beneficia ${ }^{237}$. Świetny znawca polskiego prawa publicznego, G. Lengnich, nie wahał się pisać, że dignitates różnią się od bona regia tym jedynie, że nie może w nie sukcedować żona ${ }^{238}$. Obie kategorie zatem pokrywają się, wyjąwszy zacieśnienie kręgu spadkobierców!

${ }^{232}$ Ob. VL, t. 4, s. 840 (r. 1662); t. 6, s. 19; M. Ch. Hartknoch, o. c., s. 277-278; G. Lengnich, Ius publicum, t. 2, s. 507. Dlatego to, jak zauważono, nadanie urzędu mogło pełnić rolę odprawy emerytalnej, W. Pahucki, Studia nad uposażeniem..., s. 99, przyp. 106, 181, 239.

${ }^{233}$ VL, t. 6, s. 634, oraz G. Lengnich, Mémoires..., s. 101, przyp. 9.

234 VL, t. 7, s. 202. Nadanie wojstwa jako uposażenia W. Palucki, Studia nad uposażeniem..., s. 182 .

${ }^{235}$ J. Kitowicz, o. c., s. 185.

236 Np. pakta Stanislawa Augusta z 1764 r., VL, t. 7, s. 203. Z dawnych prawników postępuje w ten sposób choćby G. Lengnich, Ius publicum, t. 1, s. 280, 288-289. Tenże autor, zajmując się w dalszym ustępie dobrami królewskimi, kontentuje się odesłaniem do wywodów wcześniejszych: quibus bona regia obvenire debeant, ex superioribus constare potest, ubi simul de illorum et dignitatum candidatis actum, ibidem, s. 317.

237 VL, t. 5, s. 22.

${ }^{238}$ G. Lengnich, Ius publicum, t. 1, s. 322. 
To ścisłe powiązanie urzędów i uposażeń przebija też $\mathrm{z}$ egzorbitancyj z 1669 r.: 44. Dygnitarstwa $i$ urzedy koronne $i W$. X. Litewskiego $w$ cale przy wlasnych wladzach zachowamy $i$ prowentow ich żadnym wymyślnym sposobem ujmować nie pozwolemy ${ }^{239}$. Stąd ta niejasność źródła, które informuje o zaborze przez króla starostw, dokonanym minus legitime ${ }^{240}$. Nawet ustawodawca nie precyzuje w nim bliżej, o które starostwa mu chodzi: sądowe czy sine iurisdictione (prawdopodobnie o jedne $\mathrm{i}$ drugie). Tak ten fakt „władzy” był dla współczesnych obojętny. W ich oczach było to uposażenie w obydwu wypadkach i nim się zajmuje ustawa ${ }^{241}$.

\section{Rodzaje sprzedawanych urzędów}

Przedmiotem obrotu były urzędy cywilne, jak i wojskowe, togatae i militares - jak się wyraża G. Lengnich ${ }^{242}$.

$Z$ pierwszych sprzedawano wszystkie, od najwyższych do najniższych, zarówno - znowu wyrażenie Lengnicha - senatorii, jak i equestris ordinis. Najstarszych przykładów na transakcje nimi dostarczają nam krakowskie zapiski sądowe. Dotyczą one urzędu żupnika, magistratus moncium, officium magistratus moncium, barkmistrzostwa, warkmistrzostwa (r. 1405) ${ }^{243}$ i burgrabstwa krakowskiego (r. 1467) ${ }^{244}$. Z późniejszych źródeł dowiadujemy się, że obiektem operacyj urzędami były: podskarbiostwo koronne ${ }^{245}$, podkanclerstwo ${ }^{246}$, podkomorstwo koronne ${ }^{247}$, marszałkostwo nadworne ${ }^{248}$, sekretarstwo $^{249}$, wojstwo (sochaczewskie ${ }^{250}$, sanockie ${ }^{251}$ ), sędztwo, pisarstwo ${ }^{252}$, kasz-

239 VL, t. 5, s. 14.

${ }^{240}$ VL, t. 5 , s. 16 p. 54.

${ }^{241}$ Uwagi godny jest stosunek między starostwami grodowymi i niegrodowymi. W XVIII w. w województwie krakowskim na 4 starostwa grodowe było 34 starostw niegrodowych, E. Trzyna, o. c., s. 37 .

${ }_{242}$ G. Lengnich, Ius publicum, t. 1, s. 273.

${ }^{243}$ Por. wyżej przyp. oraz sprzedaż z 1473 r.: ...totum magistratum moncium dictum warkmystrzostwo, quod habet in Bochnya, ipsius cum familiaribus alias parobky suis [...] vendidit, SPPP, t. 2, nr 4099.

${ }^{244}$ R. 1467: ...burgrabius castri Cracoviensis burgrabiatum seu officium burgrabiatus suum castri Cracoviensis [...] vendidit et imperpetuum resignavit, SPPP, t. 2, $\mathrm{nr} 3890$.

${ }^{245}$ M. Ch. Hartknoch, o. c., s. 278-279 (dla r. 1668); K. Piwarski, Hieronim Lubomirski..., s. 50 (dla r. 1692).

${ }^{246}$ W. Czapliński, Sprzedawanie urzędów..., s. 56; tenże, Dwa sejmy..., s. 85.

${ }^{247}$ Tenże, Sprzedawanie urzędów..., s. 56.

${ }^{248}$ Ibidem.

${ }^{249}$ Brat jego (Jana Marcinkiewicza) sekretarstwa dokupiel sie też bel u kröla J. M. Wladyslawa IV, W. N. Trepka, Liber generationis plebeanorum (liber chamorum), Wroclaw-Warszawa-Kraków 1963, nr 1226.

${ }^{250}$ W. Pałucki, Studia nad uposażeniem..., s. 22, przyp. 65.

251 Ibidem, s. 54, przyp 1.

${ }^{252}$ W. Czapliński, Sprzedawanie urzędów..., s. 57. 
telania (sandomierska ${ }^{253}$, lubelska ${ }^{254}$ ), województwo (smoleńskie ${ }^{255}$ ), podwojewództwo (poznańskie ${ }^{256}$ ), burgrabstwo krakowskie $e^{257}$, starostwo ${ }^{258}$. Nie były wyłączone spod transakcyj także viliora ministeria: instygatorowie skrzynkowi trybunalscy do odbierania grzywien ${ }^{259}$, instygatorowie securitatis w Trybunale Koronnym ${ }^{260}$. Przedmiotem sprzedaży były zatem urzędy koronne i ziemskie, senatorskie i stanowiska woźny $\operatorname{ch}^{261}$. Na transakcje urzędami ziemskimi dysponujemy niewielką liczbą przykładów ${ }^{262}$.

$Z$ wojskowych wchodzą $w$ rachubę: generalmajorostwo dywizji ${ }^{263}$, generał adjutant Komisji Wojskowej ${ }^{264}$, podpulkownikostwo ${ }^{265}$, majorostwo ${ }^{266}$, sztabskapitan, kapitan $\mathrm{z}$ kompanią ${ }^{267}$, porucznik ${ }^{268}$, regencja, pisaria wojskowa ${ }^{269}$, egzercyjer-majster ${ }^{270}$. Dalecyśmy od wyczerpania materiału. Podane fakty mają służyć jako przykłady praktyki powszechnej. Magistratus saeculares nie wyczerpują wszystkich urzędów, będących przedmiotem transakcji. $\mathrm{Z}$ całą pewnością sprzedawalność objęła i dignitates sacrae, stanowiska duchowne ${ }^{271}$. Jest to zrozumiale, skoro - jak wiemy - były one w dyspozycji władzy świeckiej ${ }^{272}$. O Bonie wyrażał się Krzycki: sacra ac profana omnia vendeba $t^{273}$. Rozumiemy, że dyskrecja $w$ tych wypadkach panowała jeszcze

${ }^{253}$ Ibidem, s. 56.

${ }^{254}$ K. Zienkowska, Jacek Jezierski, kasztelan krakowski 1772-1805, Warszawa 1963, s. 29.

${ }^{2 s s}$ W. Sobociński, CPH, t. 6, z. 2, s. 386; W. Czapliński, Sprzedawanie urzędów..., s. 56.

${ }^{256}$ Sprzedaży stanowiska podwojewodzego dokonał w 1776 r. Józef Wybicki, przenosząc się z Wielkopolski do Warszawy, Literackie przystanki nad Warlq, red. Z. Szweykowski, Poznań 1962, s. 18-19, 389.

${ }^{257}$ W. Palucki, Studia nad uposażeniem..., s. 22, przyp. 65 i przyp. 72.

${ }^{258}$ PSB, t. 9, s. 169 (starostwo kościańskie, r. 1694), toż starostwo przedmiotem obrotu w latach 1705,1720 , PSB, t. 9, s. 170. Zauważmy, że M. Kromer wymienia już starostę wśród officiales terrestres (Polonia, s. 8). Nieraz może chodzić o starostwo niegrodowe, np. W. Sobociński, CPH, t. 6, z. 2, s. 386; W. Czapliński, Sprzedawanie urzedów..., s. 55.

259 J. Kitowicz, o. c., s. 185.

${ }^{260}$ Ibidem, s. 186.

${ }^{261}$ Por. W. Czapliński, Sprzedawanie urzédów..., s. 57.

262 Ibidem, s. 57.

${ }^{263}$ PSB, t. 8, s. 544.

${ }^{264} \mathrm{VL}, \mathrm{t} .10$, s. 70.

${ }^{265}$ PSB, t. 8, s. 551,$594 ;$ t. 9, s. $310,607$.

${ }^{266}$ PSB, t. 8, s. 551.

${ }^{267}$ PSB, t. 9, s. 310.

268 Ibidem.

${ }^{269}$ VL, t. 10 , s. 79.

${ }^{270}$ PSB, t. 8, s. 577.

${ }^{271}$ W. Cxapliński, Sprzedawanie urzędów..., s. 57.

${ }^{272}$ Por. wyżej s. 201 i n.

${ }^{273}$ W. Pociecha, Bona..., s. 482 , przyp. 160; o sprzedaży biskupstw, ibidem, s. 73. Tak samo było na Litwie, w szczególności w kościele wschodnim (za Zygmunta Starego), J. Bardach, Czolobicie..., s. 309-310. 
większa ze względu na sankcje surowe, jakie przewidywało prawo kanoniczne za symonię.

Dysponować można było i królewszczyznami za wynagrodzeniem pieniężnym. Konstytucja z 1662 r., nakazująca odebranie plebejom wójtostw koronnych, które mają być nadane zasłużonym wojskowym, postanawiała: nie zagradzajqc jednak tak modernis possessoribus, jako i na potym żolnierzom wolnego tychże wójtostw za konsensem naszym personis nobilibus przedawania ${ }^{274}$.

Bardzo pouczająca jest tu informacja G. Lengnicha: bona regia pariter regis consensu in alios transferuntur, soletque cedens sibi $a b$ eo, cui cedit, certam pecuniae summam pacisci; quod usus multis exemplis docet ${ }^{275}$.

Sprzedawalność urzędów nie była tylko wlaściwością stosunków ziemskich. Nie były od niej wolne i stanowiska kompanów oraz mistrzów w cechach miejskich ${ }^{276}$, a być może, także inne stanowiska w hierarchii miejskiej.

Presumować wolno, że przedmiotem transakcyj były nie urzędy honorowe, ale takie, z którymi związane były dochody. Mogły to być nawet stanowiska bez funkcyj, byleby płynęły $z$ nich korzyści ${ }^{277}$. To smutne zjawisko stwierdza się $w$ wojsku, gdzie niewatpliwie mamy do czynienia $z$ hypertrofią szarz ${ }^{278}$. Nie można wykluczyć, że nabywano i godności czysto tytularne, traktując je jako gradus ad Parnassum ${ }^{279}$. Snobizm, wlaściwy szlachcie, silnie przemawia za taka ewentualnością. Wiadomo bowiem, że szlachcic bez urzędu... Ale, oczywiście, za takie honores nie płacono prawdopodobnie zbyt wysokich $\mathrm{kwot}^{280}$. Dla uwypuklenia handlowej struktury polskiego feudalizmu dorzućmy, że urzędy czy stopnie wojskowe nie stanowily jedynego przedmiotu sprzedaży res incorporales. Nie wahano się i samym szlachectwem kupczyć. Prawda, krwią się miano na nie zashugiwać, ale wystarczały już virtutes et merita in Republicam $^{281}$. A pieniądz łatwo umożliwiał zasługi ${ }^{282}$.

${ }^{274}$ VL, t. 4, s. 345 . Por. M. Ch. Hartknoch, o. c., s. 279. O tym pruskim historyku polskiego prawa por. artykuł K. Piwarskiego, PSB, t. 9, s. 296-297, oraz króciutką wzmiankę u S. Salmonowicza, Krystian Bogumil Steiner (1764-1814), toruński prawnik $i$ historyk, Toruń 1962, s. 63.

${ }^{275}$ G. Lengnich, Ius publicum, t. 1, s. 327.

${ }^{276}$ C. Biernat, Stanowisko rady gdańskiej wobec nadużyć mierników zbożowych $w$ XVII i XVIII w., RDSG, t. 15 (1953), Poznań 1955, s. 201.

${ }^{277}$ Por. tu W. Palucki, Studia nad uposażeniem..., s. 47.

${ }^{278}$ M. Nycz, o. c., s. 223-224.

279 W. Palucki, Studia nad uposażeniem..., s. 31.

${ }^{280}$ Por. rozumowanie S. Kutrzeby odnośnie do stanowiska starosty, Starostowie..., s. 284.

${ }^{281}$ VL, t. 6, s. 22.

${ }^{282}$ Przy nobilitacjach brano niejednokrotnie pod uwage pieniądze. W r. 1658 nadawano szlachectwo za pieniądze $\mathrm{i}$ konstytucje $\mathrm{z}$ tego roku chwala niektórych obdarzonych indygenatem czy szlachectwem, że przelali znaczne sumy na potrzeby publiczne. Co więcej, w r. 1661 Prusacy wystapili $z$ formalnym wnioskiem, by od kandydatów na szlachtę żądać co najmniej 300000 florenów, G. Lengnich, Mémoires..., s. 142, przyp. 7. Nie inny sens ma też postanowienie, które znalazło się w paktach Michała z 1669 r., punkt 78. Według niego, zmaza skartabelatu, 


\section{Przyczyny sprzedawalności urzędów}

Jak wiemy, wypowiadano w literaturze zdanie, że w Polsce sprzedawalności urzẹdów nie było. Oto jak się thumaczy to rzekome zjawisko. Władza monarsza była zbyt słaba i znalazła się w sytuacji, która wymagała zjednywania sobie magnatów i szlachty nadaniami o charakterze nieodpłatnym ${ }^{283}$. Ten argument oczywiście nie wytrzymuje krytyki. Jak wiemy, przeczy mu przeciwna praktyka. Ale też sam w sobie nie jest mocny. Cena urzędu mogla być przecież tak niska, że istniejąca marża wytrzymywała kupiecką kalkulację. Stąd ta konkurencja kandydatów na urzędy ${ }^{2839}$. A przy tym, nie zapominajmy, wraźliwość na zaszczyty i dostojeństwa, chęc posiadania tej cząstki wladzy, jaka jest związana $\mathrm{z}$ urzędem, traktowanie nawet niedochodowego urzędu jako stopnia do godności wyższych, pchać musiały do ubiegania się o ministeria i dignitates, nawet gdyby bezpośrednio nie dawały majątkowych korzyści, co więcej, nawet gdyby pociągały za sobą duże ekspensy. Tym się tłumaczy po części vénalité des offices we Francji, choć jak wiemy, w tym kraju tego rodzaju inwestycja była dość nisko oprocentowana wkładem kapitałowym.

Argumentu przedstawionego nie sposób nie uznać za wadliwy $\mathrm{z}$ tej jeszcze racji, że można odwrócić jego ostrze przeciwko tezie o niewystępowaniu sprzedawalności urzędów $w$ Polsce. Przecież z niedogodności systemu obsadzania stanowisk drogą kupna zdawano sobie sprawę wszędzie. Jeśli zaś nie dało się go usunąć monarchii absolutnej, to czyż energiczniejsi mieli się okazać władcy wybieralni, skrępowani do ostatecznych granic malowani królowie polscy?

Jeśli więc spotykamy się ze sprzedawalnością urzędów współcześnie - zarówno w monarchii absolutnej, jak też w polskiej demokracji szlacheckiej - to gdzie indziej musiała leżeć tego systemu przyczyna. Nie tlumaczy go ani silna władza monarchy absolutnego, ani też bezsiła króla polskiego.

odbierająca zdolność piastowania urzędów ad tertiam progeniem, nie dotyczy tych, którzy... substancyja swojq zaszczycali i zaszczycać będq calość tej ojczyzny, VL, t. 5, s. 22; przepis powtórzony w paktach z 1699 r., VL, t. 6, s. 22. Dla tej kwestii pozwolimy sobie zacytować w całej rozciągłości dalsze obserwacje gdańskiego konstytucjonalisty: „,au reste, nous ne releverons pas le jugement qu'a porté, autrefois, le prince et l'évéque de Warmie, par lequel il semble insinuer que la noblesse n'est plus qu'un don avili et commun, pour lequel il n'est plus besoin de répandre son sang et de rendre de grands services a la République, mais que le crédit des grands ou l'argent peuvent la procurer aux moindres esclaves", G. Lengnich, Mémoires..., s. 142, przyp. 7. Trudno o bardziej druzgocącą, a równocześnie nader zawoalowaną krytyke szlachectwa $w$ pierwszej połowie XVIII w. Tę samą sytuację poświadcza sto lat wcześniej Walerian Nekanda Trepka, Liber generationis plebeanorum (Liber Chamorum), wyd. W. Dworzaczek, J. Bartyś, Z. Kuchowicz, Wroclaw-Warszawa-Kraków 1963. Oto cena za fałszywe świadectwo płacona urodzonym przez plebeja, pragnącego wszrobować się do stanu szlacheckiego: piwa beczke za to im kupiel, a na bóty im dal, nr 234.

${ }^{283}$ J. Bardach, Czolobicie..., s. 315.

283a Por. W. Palucki, Studia nad uposażeniem..., s. 219. 
Przyczyną sprzedawalności urzędów był pusty skarb królewski, twierdzi W. Czapliński ${ }^{284}$. Trudno mu zaprzeczyć shuszności, ale nielatwo też uznać podane wyjaśnienie za uzasadnienie wystarczające. $Z$ saturacją skarbu państwa nie mamy do czynienia nigdy. Co więcej, wiemy, że dochody ze sprzedaży urzędów nieczęsto trafiały do szkatuły królewskiej. A już sprzedawalności alter alteri nigdy interesami skarbu nie da się wyjaśnić.

Przyczyną sprzedawalności były wpływy królowej pochodzenia francuskiego, Marii Ludwiki - utrzymuje również W. Czapliński ${ }^{285}$. Prawda, we Francji vénalité des offices rozwinęla się $\mathrm{w}$ przedsiębiorstwo państwowe $\mathrm{z}$ osobnym biurem ${ }^{286}$. Ale znowu nie sposób tym wpływom przypisywać znaczenia decydującego: sprzedawalność urzędów w Polsce jest znacznie starszej daty (ustęp IV). Można by, co najwyżej, z obcymi wplywami wiązać w zm o że n i e się praktyki sprzedaży godności urzędowych. Jesteśmy skłonni przyjąć, że dwór umyślnie pomieścił w „Merkuriuszu” wiadomość o sprzedawaniu urzędów przez Mazariniego ${ }^{287}$, by $\mathrm{z}$ samą myślą oswoić spoleczeństwo szlacheckie. Byłoby to zgodne $\mathrm{z}$ ogólną tendencją tego pierwszego polskiego dziennika ${ }^{288}$. Zresztą podaną przyczynę trudno uznać za źródło sprzedawalności urzędów alter alteri, nawet gdyby ją uznać dla sprzedaży ex parte regis.

Mówiliśmy wyżej o wpływach. Niewątpliwie, i bez nich się nie obywało. Może raczej należaloby mówić o wzorach. Dopatrywalibyśmy się ich gdzie indziej. Dostarczala ich organizacja kościelna. Prawda, i tam formalnie sprzedaż urzędów była niedopuszczalna, uchodziła nawet za ciężkie przestẹpstwo i grzech, określany terminem biblijnym symonii. Wszakże ludzie są istotami słabymi, nęcą ich zarówno godności duchowne, jak i beneficja $\mathrm{z}$ nimi związane. $Z$ drugiej strony władza zwierzchnia (papiestwo) także potrzebuje pieniędzy. Te sprzeczności potrafiono w pewien sposób pogodzić, wynajdując annaty. Każdy nowy dygnitarz uiszczal je papiestwu. I to nikogo nie raziło. Zresztą, $\mathrm{z}$ punktu widzenia prawnego był to ciężar rzeczowy, świadczony przez beneficjum. Takie zawoalowanie nie może jednak zakryć gospodarczej funkcji. Annaty, znane od drugiej polowy XIII w., utrzymały się bez przerwy do XVIII w. ${ }^{289}$ Inna rzecz, że zdewaluowały się poważnie, bo wynosiły tylko $1 / 3$ dochodów rocznych ${ }^{290}$, zwłaszcza od

${ }^{284}$ W. Czapliński, Ideologia..., s. 119-120.

${ }^{285}$ Ibidem.

${ }^{286}$ E. Chénon, Histoire générale du droit français public et privé des origines à 1815, Paris 1929 , t. 2, s. 567; F. Olivier-Martin, Histoire du droit français des origines à la Révolution, Paris 1948, s. 461 i n., 507.

${ }^{287}$ Merkuriusz Polski, opr. A. Przyboś, Kraków 1960, s. 363.

${ }^{288}$ Ibidem, s. 14.

${ }^{289}$ Por. J. Dudziak, Platnicy i platności annat w Polsce, Rocz. Teolog.-Kanon., t. 9, Lublin 1962, s. 41-42.

${ }^{290}$ Ibidem, s. 59. 
XVI w., kiedy zwiększono uposażenia oficjów kościelnych, a taksy uległy stabilizacji ${ }^{291}$.

Analogiczne opłaty znało zresztą również prawo lenne: w razie przeniesienia feudum na spadkobierców senior pobierał dochód jednoroczny odnośnego beneficjum. W istocie nie co innego wprowadzaja konstytucje z 1641 i 1658 r., które G. Lengnich streścil lakonicznie w sposób następujący: Bonorum regiorum reditus omnes, quam diu vacua, et primi anni, quo a novo possessore tenetur, quarta quadruplex, in thesaurum quartarum Ravam inferri, lege recentiori iubentur ${ }^{292}$.

Racją zasadniczą, przyczyną sine qua non, była prywatyzacja stosunków prawnopublicznych. Nie odróżniano aktu publicznego (nadania urzędu) od aktu prywatnego (kupno, darowizna) - zauważa trafnie J. Bardach ${ }^{293}$. Urzędów nie traktowano jako odpowiedzialnej funkcji publicznej, powierzanej osobom, które dają gwarancję, że się z niej należycie wywiążą. Uważa się je za źródło dochodów prywatnych. Zachłanność ludzka znalazła tu więc pełne pole popisu. Elementy natury majątkowej wzięły wyraźnie górę nad zadaniami publicznymi, jakie ma wykonywać urzędnik. A więc jest to zjawisko tej samej natury, jaką wykazywały kiedyś lenna ${ }^{294}$.

Tego prywatnego nastawienia do funkcji publicznych nie można się nie dopatrywać także i u monarchy. I dla niego królestwo - to źródlo dochodów. Władca bez skrupułów brał pieniądze za wszystko: za nadawane przywileje szlachcie czy miastom, za wyrażenie zgody na alienacje nieruchomości, za wydanie jakiejkolwiek decyzji ${ }^{295}$. Dlaczegoż by więc nie brał pieniędzy za konferowanie godności? Dlaczegoż od niego oczekiwać zaparcia się, obcego całkowicie współczesnym?

Sprzedawalność urzędów tkwi swymi korzeniami w średniowieczu, w poglądach prawnoprywatnych na państwo oraz na związane $z$ nim zadania publiczne i... dochody. To wszystko, cośmy powiedzieli wyżej o powiązaniu funkcyj publicznych $\mathrm{z}$ wlasnością, o zastępstwie prywatnym na urzędach, o ich kumulacji, wreszcie o traktowaniu magistratus wyłącznie jako źródła dochodu, a $\mathrm{w}$ następstwie tego o pomieszaniu dignitates $\mathrm{i}$ bona regia, złożyło się na powstanie takiego układu rzeczy, w którym transakcje urzędami wydawały się rzeczą normalną. Tym samym stały się stanowiska publiczne przedmiotem $\mathrm{w}$ rozumieniu prawa prywatnego.

291 Ibidem, s. 61. Tytułem przykładu podajmy, że arcybiskupstwo gnieźnieńskie płaciło $\mathrm{z}$ tego tytuhu 5000 florenów, ibidem, s. 57-58.

${ }^{292}$ G. Lengnich, Ius publicum, t. 2, s. 507; por. też M. Nycz, o. c., s. 28.

${ }^{293}$ J. Bardach, Czolobicie..., s. 315; tenże, $Z$ praktyki kancelarii litewskiej, s. 345.

${ }^{294}$ Z. Wojciechowski, Ustrój polityczny Ślqska..., s. 615, przyp. 4.

295 J. Bardach, Czolobicie..., s. 311-312. O pojmowaniu prawno-prywatnym stosunku monarchy do państwa pisał też R. Grodecki, Kongres krakowski, Kraków 1939, s. 52. 


\section{Status prawny urzędu w świetle prawa prywatnego}

Tak też było niewątpliwie. Jak przy każdej zatem umowie, mamy do czynienia z dwoma kontrahentami, z których jeden sprzedaje urząd, a drugi go nabywa, płacąc pewną cenę. Wymiar sprawiedliwości z 1793 r. wyraźnie postanawia: Która to suma podlug sancitum przez abcug od posuniętego na tenże plac powrócona być ma, ostrzegamy ${ }^{226}$. Nabywca urzędu staje się jego właścicielem $\mathrm{w}$ rozumieniu prawa prywatnego.

Jak wiemy, polski system prawny przywiązywal zasadniczą wage do podziału rzeczy na ruchome $\mathrm{i}$ nieruchome ${ }^{297}$. Do tego podziału wlączone zostały i rzeczy niezmysłowe, czyli prawa ${ }^{298}$. Skoro urząd dawal trwałe, czasowo nieograniczone dochody, musiał być zaliczony w konsekwencji do nieruchomości sztucznych. Wyraźnie o tym świadczy zapiska z 1446 r.: non est consuetudo Regni, ut aliqua bona hereditaria et presertim burgrabiatum Cracoviensem aliquis posset obligare... ${ }^{299}$

Zajęcie takiego stanowiska prowadzilo do dokonywania wszelkiego rodzaju operacyj urzędami, tak jak to robiono $\mathrm{z}$ nieruchomościami. Zachodzily więc alienacje czasowe $\mathrm{i}$ trwałe, darmowe $\mathrm{i}$ odpłatne, inter vivos $\mathrm{i}$ mortis causa. Zestawimy tu kilka przykładów, które zdołaliśmy zgromadzić. Na pierwsze miejsce wysunie się kupno-sprzedaż.

S p rzeda $\dot{z}-$ konstytucja z 1662 r., cytowana przez M. Ch. Hartknocha, przewidywała obrót solectwami: militibus etiam permissum est advocatias, a rege sibi collatas, aliis nobilibus vendere ${ }^{300}$. Chodziło w niej, oczywiście, o wójtostwa wchodzące w skład bona regia. Ale nie tylko one podlegały sprzedaży. Ten sam Hartknoch wypowiada zdanie następujące: ad extremum hoc etiam de magistratibus notandum est, quod alter alteri dignitatem vel officium suum vendere possit ${ }^{301}$. Sprzedawalność urzędów nie uszła też uwadze Lengnicha. Wynika to wyraźnie z komentarza do paktów Augusta III. W jednym paragrafie król zobowiązuje się nie udzielać zgody na cesje godności w Prusach. W razie wystawienia przywileju wbrew temu zobowiązaniu, ma on być $\mathrm{z}$ góry nieważny. Przewiduje się przy tym środki egzekwujące

296 VL, t. 10 , s. 70.

297 P. Dąbkowski, Prawo prywatne polskie, t. 1, s. 243-244.

298 Ibidem, t. 2, s. 248, 285, 675; P. Dąbkowski, Zarys prawa polskiego prywatnego, wyd. 3, Lwów 1922, s. 68, 81-82.

299 SPPP, t. 2, nr 3271.

300 M. Ch. Hartknoch, Respublica Polonica..., s. 279. Cytuje ją też G. Lengnich, Ius publicum, t. 1 , s. 320 .

301 M. Ch. Hartknoch, o. c., s. 278-279. Powtórzoną niemal dosłownie w wydaniu drugim z 1687 r. oraz w tegoż, De Republica Polonica libri duo, Francofurti et Lipsiae 1697. 
powyższy zakaz ${ }^{302}$. Lengnich komentuje cytowany paragraf $w$ sposób następujący: wolno cedować innym pewne godności czy dobra królewskie, ale do takich aktów trzeba zgody króla. Jeśli więc Prusak dokonuje podobnej cesji na rzecz cudzoziemca, tzn. nie mającego indygenatu pruskiego, król odmówi swej zgody na podobną transakcję $e^{303}$. Sama cesja (urzędów czy dóbr królewskich) jest $w$ rozumieniu Lengnicha legalna.

O alienacji urzędu świadczy też pośrednio postanowienie konfederacji generalnej z 1736 r.: PP starostowie sqdowi, którzy od śp. króla imci przywileje na starostwa, albo cessye za konsensami tegoż pana maja, a jeszcze nie przysiegli... ${ }^{304} \mathrm{Te}$ informacje źródłowe, lącznie z zestawionymi już $w$ literatu$\mathrm{rze}^{305}$, świadczą o rozwiniętej szeroko praktyce sprzedaży urzędów cywilnych.

Sprzedawalność alter alteri wystạpi szczególnie jaskrawo co do szarż wojskowych czy cywilno-wojskowych. Kupno szarż wojskowych w okresie przedrozbiorowym było zwyczajem powszechnym. Konstytucja z 1793 r. zawiera postanowienia, które wyraźnie o tym świadczą. I tak zalecenie deputacji do egzaminowania stanu wojska Rzeczypospolitej wyznaczonej przewiduje następujący kwestionariusz: ...kto z boku, nie slużac w tymże wojsku, wszedl do niego, za jakie zaslugi, i czyli oplacil lub darmo wziql stopień, czy nie wziql dawniej jakiego stopnia $w$ wojsku bez oplaty, nie przedal go, a powtórnie bez oplaty czy nie wszedl na jaki stopnień, kto z zagranicznej slużby wszedl [...] i czy oplacil range lub one darmo wziql [... ${ }^{306}$. A deputacja do egzaminu Komisyj Wojskowych wyznaczona respektuje kupno regencji niejakiego Trębickiego, który przekonal ja o niezaprzeczonym swym prawie lub zwrotu do regencji a zatem $i$ do awansu na pisarie wojskowa litewskq, lub do splacenia go tego placu ${ }^{307}$.

Legalności instytucji dowodzi fakt, że $w$ razie sporów, powstałych w związku z transakcjami stopniami wojskowymi, zainteresowani zwracali się do Departamentu Wojskowego ze skargami. K. Górski podaje dwa tego rodzaju przykłady. W $1785 \mathrm{r}$. złożyła skarge osoba trzecia, która miała skrypt porucznika kawalerii narodowej, Turkuła, obowiązującego się zapłacić porucznikowi Zalatyńskiemu za kupioną szarżę porucznika 80 zlp. Drugą skierował towarzysz chorągwi kawalerii narodowej; nabył on w $1779 \mathrm{r}$. regestr towarzyski w choragwi kawalerii narodowej Mniszcha od niejakiego Rościszewskiego, a nie pobierał płacy ${ }^{308}$.

${ }^{302}$ VL, t. 6, s. 626

${ }^{303}$ G. Lengnich, Mémoires..., s. 184, przyp. 12.

${ }^{304}$ VL, t. 6, s. 588.

${ }^{305}$ W. Czapliński cytuje jeden wypadek, Sprzedawanie urzédów..., s. 59, kilka wypadków W. Palucki, Studia nad uposażeniem..., s. 110, 145, 146, 185, 191, 216. O sprzedaży starostw informuje też PSB, t. 9, s. 169.

${ }^{306}$ VL, t. 10, s. 77.

${ }^{307}$ Ibidem, s. 79.

${ }^{308}$ K. Górski, Historia jazdy..., s. 163. 
W tych warunkach nie może dziwić, że autorzy oczytani w źródłach tego okresu uważają sprzedaż stopni oficerskich za rzecz naturalną, charakterystyczną dla ówczesnego zwyczaju ${ }^{309}$.

Sprzedaż była najdalej posuniętą transakcją urzędem. Ale, podobnie jak z nieruchomościami, można było nimi dokonywać także innych operacyj. W rachube wchodzily.

$\mathrm{Z}$ a s t a w - 1405 r.: et cum toto magistratu moncium obligando ${ }^{310}$.

$\mathrm{Dzi}$ rżawa - 1458 r.: totum officium magistratus moncium, alias barkmystrzostwo in zuppis zuppe Welicensis [...] in totum arendavit ${ }^{311}$; o dzierżawie pisarstw ziemskich, lomżyńskiego i wizkiego (lącznie $\mathrm{z}$ dwoma starostwami niegrodowymi) duchownemu na lat $10 \mathrm{za}$ rocznym czynszem 4100 zl informują Acta Tomiciana ${ }^{312}$.

D ożyw ocie - 1440 r.: Nos $J$. de Cz., castellanus et capitaneus Cracoviensis publice recognoscimus [...], quomodo ex commisso domini regis [...] nobili Gyencze intromissionem omnimodam in officium portulanie, alias wrotnitstwo, in Bochenensibus gazis dedimus [...] per ipsum tenendum ad tempora vite sue ${ }^{313}$.

Najogólniejszą formą, pod którą kryją się rozmaite postaci dyspozycji urzędami, była resignatio in favorem. Jak stwierdza G. Lengnich, z munus wolno rezygnować (abdicare) ${ }^{314}$. Rezygnacja jest przy tym $z$ reguly polączona ze wskazaniem osoby, na rzecz której się jej dokonuje. Lengnich daje przykład takiej rezygnacji ze strony prokanclerza litewskiego, Kazimierza Czartoryskiego, na rzecz jego syna ${ }^{315}$. W. Palucki przytacza kilka takich wypadków ${ }^{315 a}$. W tej właśnie instytucji, tak dobrze znanej prawu kanonicznemu, dopatrywalibyśmy się najpospolitszej formy transakcyj urzędami. Poprzez takie rezygnacje realizowaly się zarówno cesje darme, jak i odpłatne.

$\mathrm{Z}$ pewnością podane przykłady nie wyczerpują ogólu możliwych transakcyj urzędami. Ilustrują one jednak wystarczająco ich szeroką skalę.

$\mathrm{W}$ toku swoich wywodów mówimy $\mathrm{z}$ reguły tylko o sprzedawalności urzędów. Robimy to dla uproszczenia rzeczy, nie chcąc nawiązywać ciągle do wszystkich możliwych typów transakcyj nimi. Sprzedaż jako alienację najdalej posuniętą, wzięto po prostu za operację typową.

\footnotetext{
309 J. Pachoński, PSB, t. 8, s. 543; ob. też K. Zienkowska, o. c., s. 20.

310 SPPP, t. 2, nr 1089, podobnie nr 1100.

${ }^{311}$ Ibidem, nr 3596, por, też nr 3495.

312 Acta Tomiciana, t. 14, ed. W. Pociecha, Poznań 1952, nr 529. Cytuje W. Sobociński, $\mathrm{CPH}$, t. 6 , z. 2 , s. 386 .

313 SPPP, t. 2, nr 2845.

314 G. Lengnich, Ius publicum, t. 1, s. 327.

$315 \mathrm{Z}$ tym zagadnieniem resignatio in favorem łączy się problem ius communicativum, o którym niżej.

315a W. Palucki, Studia nad uposażeniem..., s. 100, 108, 191, 230, 238, 268, 280.
} 
Omówiliśmy dotąd transakcje urzędami między żyjącymi. Dla pełności obrazu rozpatrzeć należy zagadnienie, czy nie było nimi wolno rozporządzać aktem mortis causa. Odpowiedź pozytywna świadczyć będzie o tym, że urzędy w pelni uległy prywatyzacji, że są calkowicie in commercio.

Niestety, kwerenda nasza, dość szczupła, nie pozwala nam na rozstrzygnięcie problemu w sposób decydujący. Zaznaczmy jednak, że pewne akty, dotyczące alienacji czasowej urzędów (zastaw), zawierały klauzulę, w której król zaciągal zobowiązanie, że zastawione przez niego starostwo przejdzie na żonę i dzieci zastawnika, jak długo kwota dłużna nie zostanie zwróco$n^{316}$. Formą dyspozycji na wypadek śmierci jest również ius communicativum: dzierżyciel beneficjum, który je otrzymał, mógł przekazać tenutę dzieciom czy żonie, żona mogła przekazać drugiemu mężowi itd. Ta praktyka była tak częsta, że Karwicki wyśmiewal jako bezprzedmiotową nazwę określenie panis bene merentium ${ }^{317}$. Prawda, były kobiety wykluczone od capitaneatus cum iurisdictione ${ }^{318}$. Ale czy tego zakazu się trzymano? $\mathrm{Z}$ pewnością, przysługiwało im ius communicativum co do capitaneatus et tenuta $^{318 a}$. Ale nawet ograniczenie do kobiet nie wylączało dzieci płci męskiej od uzyskania prawa następstwa do starostw sądowych. Wolno wreszcie zwrócić uwage na fakt, że dziedziczenie urzędów kryło się niejednokrotnie pod postacią resignatio in favorem. Przykład ciekawej ugody z 1576 r., zawierającej postanowienia co do losów wojstwa drohickiego za życia stron i po ich śmierci, wydrukowal $w$ swym pracowitym studium W. Pahucki ${ }^{319}$.

Ponieważ urzędy traktowano jako nieruchomości, przy transakcjach nimi stosowano nie tylko przepisy prawa materialnego, odnoszące się do nieruchomości, ale i odpowiednie normy formalne. Cytowana wyżej zapiska z 1446 r. stwierdza, że obie kategorie (bona hereditaria i burgrabiatus krakowski) moga być zastawione nie per litteras sub proprio sigillo, nisi sub sigillo dominis regis vel iudicis terrestris ${ }^{320}$. Wwiązanie w urząd dokonuje się analogicznie jak w dobra nieruchome: Nos $J$. de Cz., castellanus et capitaneus Cracoviensis publice recognovimus [...], quomodo ex commisso domini regis [...] nobili Gyencze [...] intromissionem omnimodam in officium portulanie, alias wrotnitstwo in Bochnensibus gazis dedimus [...] per ipsum tenendum [...]

${ }^{316}$ S. Kutrzeba, Starostowie..., s. 348.

317 Powohuje M. Nycz, o. c., s. 163.

${ }^{318}$ Zakaz obejmował także starostwa graniczne. Sądzimy, że tym samym nie były możliwe i transakcje takich starostw przez kobiety. G. Lengnich wyraża się krótko: foeminae per leges arcentur, Ius publicum, t. 1, s. 323; por. też G. Lengnicha, Pacta conventa Augusti III, s. 27.

318a Ibidem, s. 26-27. Prawda, że ograniczono je do dwóch starostw, ale to zastrzeżenie odnosiło się w ogóle do nadań capitaneatus et tenutae, § 12 paktów Augusta III, G. Lengnich, o. c., s. 25 .

${ }_{319}$ W. Palucki, Studia nad uposażeniem..., s. 291-293; omówienie jej ibidem, s. 280-281. ${ }^{320}$ SPPP, t. 2, nr 3271. 
ad tempora vite sue ${ }^{321}$. Oczywiście, $\mathrm{z}$ racyj, o których niżej, nie przestrzegano tych form zawsze, a przede wszystkim wówczas, gdy usilowano transakcje ukryć.

\section{Status prawny urzędu w świetle prawa publicznego}

Wszystko, cośmy powiedzieli o traktowaniu urzẹdów jako mienia prywatnego, podlegającego przepisom o nieruchomościach, nie wyklucza tego, by też same urzędy podlegały równocześnie normom, które zaliczylibyśmy dziś do publicznych. Albowiem podejście do funkcji jako do źródła dochodu nie pozbawiło jej $w$ całości cechy stanowiska o charakterze publicznym, choć ją usunęło niewątpliwie na plan dalszy. Nad urzędami stoi zawsze ex definitione jakaś władza, choćby najskromniejsza. Nawet państwo typu feudalnego, a więc takie, w którym siły centryfugalne doprowadziły do rozkładu daleko posuniętego struktury organizacyjnej status, zachowywało choćby tylko pozory zwierzchności nad urzędami, które nie zatraciły nigdy pewnego rysu politycznego. Za rozdawcę urzędów uchodził stale król. On mógł nie zgodzić się na cesję urzędu w ręce osoby, której sobie na danym stanowisku nie życzyl. Stąd to alienacje urzędów podlegały pewnym ograniczeniom. Najpierw natury politycznej. Wynikały one już z faktu zrównania urzędów z nieruchomościami ziemskimi. Wymogiem była zatem zgoda króla na transakcję. Pod tym względem jest bardzo wyrazisty tekst $\mathrm{z}$ połowy $X V$ w. Stwierdza się w nim, że zastawu burgrabstwa krakowskiego nie wolno dokonywać per litteras sub proprio sigillo, nisi sub sigillo domini regis vel iudicis terrestri ${ }^{322}$. Tak było też $\mathrm{w}$ XVI $\mathrm{w}^{323}$

Ustawa o wójtostwach koronnych z $1662 \mathrm{r}$. dozwala na ich sprzedaż $z a$ konsensem naszym ${ }^{324}$. Ten warunek zna i Hartknoch: si rex consentiat ${ }^{325}$. O zgodzie na cesję urzędów wspominają też pakta Augusta III $^{326}$ i komentujący je Lengnich ${ }^{327}$. O zgodzie zmarlego króla na alienacje starostw sądowych wzmiankuje też konfederacja generalna z 1736 r.: albo cessye za konsensami tegoż Pana maja ${ }^{328}$. Taż zgoda była potrzebna w wypadku

321 Ibidem, nr 2845 (r. 1440).

${ }^{322}$ SPPP, t. 2, nr 3271 (r. 1446).

${ }^{323}$ W. Palucki, Studia nad uposażenem..., s. 22, przyp. 65.

324 VL, t. 4 , s. 845.

${ }^{325}$ M. Ch. Hartknoch, o. c., r. 1678, s. 278-279. W wydaniu drugim stylistyczna odmianka: si regis consensus accedat, utrzymana również w dziele z $1697 \mathrm{r}$.

${ }^{326}$ VL, t. 6, s. 626.

${ }^{327}$ G. Lengnich, Mémoires..., s. 184, przyp. 12.

${ }^{328}$ VL, t. 6, s. 588. 
resignatio in favorem ${ }^{329}$. O niej też mówi się $w$ literaturze ${ }^{330}$. Niezbędny też regis consensus przy cesjach bona regia ${ }^{331}$, jak i przy udzielaniu na królewszczyzny ius communicativum ${ }^{332}$ we wszystkich jego wariantach.

Tej zgody królewskiej potrzeba też na sprzedawanie kompanii i pułków przez kapitanów i pułkowników ${ }^{333}$. Szczególnie jaskrawo wystąpi ta rzecz odnośnie do stopni oficerskich, jak o tym świadczy konstytucja z 1784 r.: warujemy, iż nie wolno odtąd bẹdzie nikomu [...] wyjednywać u nas, króla, pozwolenia na sprzedanie szarży swojej; w wyjatkowych wypadkach monarcha może go udzielić; a na ten czas dozwolemy - postanawia ta sama konstytu$\mathrm{cja}^{334}$. Jak się wydaje, także interwencja bezpośredniego przełożonego nie pozostawała bez znaczenia: oficer zwracal się do swego generała z prośba o ulatwienie sprzedaży szarży ${ }^{335}$.

Inny charakter, nie polityczny, mają ograniczenia dalsze. Późny, jak się wydaje, jest wymóg kwalifikacyj zawodowych. W wojsku mają pierwszeństwo do opróżnionej przez cesję godności najbliżsi awansu ze względu na swoje starszeństwo. Takie stanowisko zajmuje wyraźnie konstytucja z 1784 r.: a na ten czas dozwolemy, aby starszeństwo do awansu $w$ sztabie generalnym, $w$ brygadzie, korpusie, pulku lub regimencie majq̨cy odchodzqcemu czteroletniq gaże zaplacil. A na wyż wspomniane urzędy cywilno-wojskowe w tabelli placy wojsk obojga narodów wyrażone, sami tylko wyslużeni generalowie amplojowani patentowanemi od nas bedq $q^{336}$. Ale czy takie stanowisko nie jest wynikiem chęci uzdrowienia stosunków panujących w wojsku, odbiegających od tego ideału, do którego ustawa dąży? Powoływaliśmy wyżej wypadek nabycia stopnia generała artylerii przez Szczęsnego Potockiego, który poprzednio nie mial nic wspólnego z wojskową karierą. Zamożność i wpływy wystarczyły za wszystko.

W okresie prób likwidacji sprzedawalności szarż wojskowych wymaga się od nabywców stopni oficerskich, by cechowała ich dobra wiara publiczna ${ }^{337}$. Ten wymóg stawia też wymiar sprawiedliwości dla wojska, według którego takie nabytki będą respektowane: kupno rang na dobrej ugruntowane wierze swoje sprawiedliwe znalazly względy; niżej mowa również o tych, którzy rangi takowe $w$ dobrej pokupowali wierze $e^{338}$. Nie jesteśmy w stanie sprecyzować, co do jakich okoliczności wymaga się od nabywcy wiary publicznej; mniemać można, że chodzi o przekonanie, iż dana szarża jest rzeczywiście in commercio.

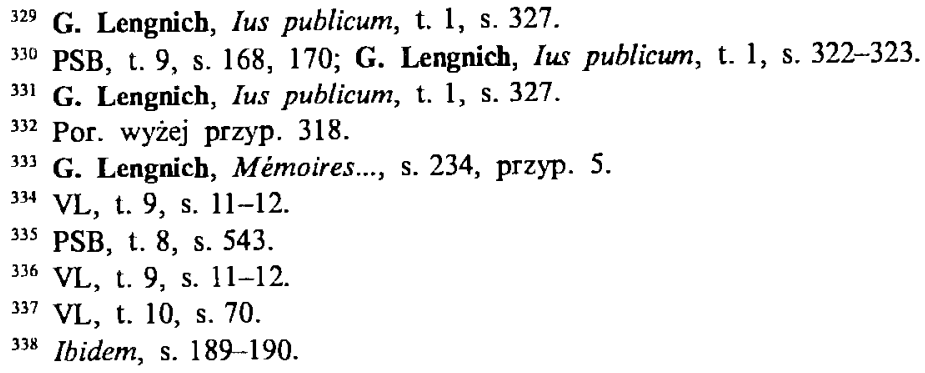


Charakter publiczny urzędów przejawiał się w dalszych szczegółach. Mówiliśmy wyżej o ich dożywotności. Z chwilą śmierci tytulariusza godność opróżniała się i wracała do króla, który znowu obsadzał ją dowolnie albo - w pewnych wypadkach - mógł ją nawet skasować. Takie samo następstwo pociągala $\mathrm{i}$ wolna rezygnacja, tzn. dokonana bez wskazania następcy. Przykładu na nią dostarcza nam postanowienie z 1710 r., dotyczące zresztą stosunków panujących w Wielkim Księstwie Litewskim: 9. Pulkownictwo $W . X$. L. przeszle, ponieważ jest libere rezygnowane, tedy etiam in virtute zjazdu teraźniejszego protunc abrogujemy ${ }^{339}$.

$\mathrm{Z}$ reguly rezygnacja na czyjąs rzecz wiązała $\mathrm{w}$ pewien sposób króla, mianowicie pieniężnie. Posiadacz urzędu był wierzycielem skarbu państwa, mógł się więc domagać od niego zaspokojenia długu. Jeśli król nie zgodził się na cesję, musial temu wierzycielowi spłacić należną mu kwotę. Gdy egzercyjermajster, K. Griesheim, pobierający gaży $4000 \mathrm{złp}$, domagał się w r. 1783 zezwolenia na sprzedaż rangi, Departament Wojskowy sam ją wykupil, przez co faktycznie wspomniane stanowisko zostalo zniesione $\mathrm{e}^{340}$. Królewska „własność" nadrzędna przejawia się tu w sposób wyraźny.

Co więcej, monarcha mógł odebrać urząd, przynajmniej w pewnych sytuacjach. Ale i wtedy należało spłacić tytulariusza danej godności. To była, jak zobaczymy niżej, największa trudność, na jaką napotykał król w walce ze sprzedawalnością urzędów. I tak Zygmunt I postanawia w akcie z 1532 r.: Si vero praefatus Ioannes Woyslawski ex causa legitima, inferius descripta, ab huiusmodi arenda et tenuta per nos alienaretur, extunc nos aut nostri successores tenebuntur et debebunt eidem Ioanni Woyslawski summam, quam pro redemptione oppidi Colno et villarum ad illud pertinentium ac advocatiarum praedictarum exposuerit, reddere et exsolver ${ }^{341}$. Tenże monarcha zobowiązal się wobec Fedora Januszewicza do zwrotu pobranej przez Aleksandra I kwoty, wynoszącej 1400 czerwonych złotych węg., zapłaconej tytulem czołobicia za nadane dożywotnio starostwo luckie i marszałkostwo ziemi wolyńskiej, gdyby zechciał mu te urzędy odebraćc ${ }^{341 a}$.

Jak się wydaje, stanowisko urzędu było takie samo, jak sołectwa czy wójtostwa. Można więc tu powołać się na postanowienia odnoszące się do skupu sołectw: est autem ius, fasque domino amovere scultetum et advocatum haereditarium, contumacem aut inutilem, persoluto ipsi pretio, quod habet

339 VL, t. 6, s. 213.

340 E. Rostworowski, PSB, t. 8, s. 577.

341 Acta Tomiciana, t. 14, wyd. W. Pociecha, nr 529.

$34{ }^{2}$ J. Bardach, Czolobicie..., s. 309. Tenże badacz podaje ciekawy inny przypadek: Żydom odebrano majątki. Aleksander przyznał ich zwrot z zastrzeżeniem, że aktualnym posiadaczom zwrócą koszty czołobicia, ibidem, s. 311. Nie panujący zatem, który sumy pobrał, zwróci je uprawnionym; stając się dobrodziejem Źydów, na Źydów przerzucił Aleksander koszty tego dobrodziejstwa, wchodząc sam bezprawnie w posiadanie pewnej kwoty pieniężnej. 
inscriptum in diplomate ${ }^{342}$. Taka mocna sytuacja prawna, wytworzona już w średniowieczu, utrzymała się w czasach nowożytnych, choć w zmienionych warunkach. Mianowicie siedemnastowieczna konstytucja, deklarująca wójtostwa znajdujące się w rękach plebejskich pro vacantibus, zastrzegała równocześnie, że nie moga być one odebrane violenter, lecz legitima iuris via, a więc, wedhug wyrażenia tejże konstytucji, praevia exolutione summarum et sumptuum, które legitime na wojtostwach extenduntur ${ }^{343}$.

Istnienie dwóch niejako „,wlaścicieli” urzędu, piastującego go urzędnika i króla, prowadziło w pewnych przypadkach do dwóch transakcyj równocześnie: urząd splaca częścią skarb państwa, częścią nabywca. Jeden przyklad tego rodzaju postępowania zawierają Volumina Legum. Trębicki, który nabyl kiedyś regencję, pozyskał prawo do awansu na pisarię litewską. Wierzytelność jego wynosila 34000 złp. Skarb litewski zwrócil mu 12000 , resztę, tj. 22000 , mają spłacić awansujący z porządku na wakujące stopnie regencji $\mathrm{i}$ pisarii wojskowej $\mathrm{w}$ połowie ${ }^{344}$. Nie śledziliśmy racji takiego rozwiazania sprawy.

Jeśli więc przepisy prawa publicznego, dotyczące urzędów, brały w pewnym stopniu górę nad regulami prawa prywatnego, którymi się te urzędy rządziły, to jednakowoż respektowaly prawa nabyte urzędnika.

Objęcie urzędów normami prawa publicznego przejawi się jeszcze w sprzedawalności ze strony właściwego ich szafarza, w sprzedaży ex parte regis.

\section{Sprzedawalność ex parte regis}

Omówiliśmy wyżej sprzedawalność urzędu przez dotychczasowego jego „właściciela”, sprzedaż alter alteri. Wszakże rozdawca godności i beneficjów był $\mathrm{z}$ natury rzeczy król, prawdziwy dominus eminens. Czy władca nie pobierał opłat za konferowane godności? Czy zatem nie było sprzedawalności ex parte regis? Odpowiedzi pozytywnej na to pytanie udzielił już niejeden $\mathrm{z}$ historyków. Praktykowano ją za Jagiellonów ${ }^{345}$. Nią się zajmują tzw. Rady Kallimachowe ${ }^{346}$. Zna ją też stulecie siedemnaste ${ }^{347}$, jak i osiemnaste ${ }^{348}$.

${ }^{342}$ M. Kromer, Polonia..., s. 99, 105. Utrzymuje się więc jeszcze w mocy przepis art. 24 statutu krakowsko-warckiego z 1423 r., por. Polskie statuty ziemskie w redakcji najstarszych druków (Syntagmata) opr. L. Lysiak i S. Roman, Wrocław-Kraków 1958, s. 124

${ }^{343}$ VL, t. 4 , s. 845.

${ }^{344}$ VL, t. 10, s. 70.

${ }^{345}$ W. Palucki, Studia nad uposażeniem..., s. 58.

${ }^{346}$ Por. wyżej ustęp III.

${ }^{347}$ W. Czapliński, Sprzedawanie urzędów..., s. 59.

${ }^{348}$ Por. tekst z Kitowicza przytoczony niżej. 
Niejednokrotnie wykorzystywal to uprawnienie monarsze ktoś z bliskich władcy, jego żona, dworzanie, faworyci. Prawdopodobnie pierwszą królową, która parała się sprzedażą urzędów, była Bona: episcopatus, palatinatus, castellanatus et caetera regia officia vendere cepit - pisze Stanisław Orzechowski ${ }^{349}$.

Fakt ten znany był współcześnie ${ }^{350}$; jest on przedmiotem satyr w wieku następnym ${ }^{351}$. W stuleciu siedemnastym sprzedawały urzędy królowe-Francuzki ${ }^{352}$. Maria Ludwika, jak się wydaje, wybiła się w tej mierze w sposób szczególny ${ }^{353}$.

Sprzedawały też urzędy, jak świadczą o tym cytowane wyżej teksty, bialeglowy dworskie cudzoziemskie; niejedna $\mathrm{z}$ nich wyszła za mąż za polskiego magnata ${ }^{354}$. Kupczyli urzędami faworyci, dworzanie ${ }^{355}$, urzędnicy dworscy ${ }^{356}$. Nie byli bezinteresowni kanclerz i podkanclerzy ${ }^{357}$. Ciekawej informacji dostarcza nam ks. Kitowicz: „(Pieczętarze oczekiwali posmarowania złotem), którym się przy końcu panowania i sam dwór nie brzydził, biorąc znaczne sumy za konferowane panom polskim wakanse i starostwa; acz, po prawdzie, te opłaty nie dostawały się do kasy królewskiej, na imię której były wyciągane, ale szły do szkatuł grafa Brülla, ministra królewskiego, i Mniszcha, marszałka nadwornego, zięcia jego ${ }^{358}$. Chęć zarobku prowadziła nieraz do współzawodnictwa między magnatami. Nią właśnie - częściowo może i nieporządkiem panującym w administracji - tłumaczyć należy wydawanie przywilejów na jeden urząd dwom osobom. Przeciw temu występowano w paktach Augusta II i Augusta III ${ }^{359}$.

$\mathrm{Z}$ podanego zestawienia wysnuć można wniosek, że uprawnionym do sprzedaży urzędów był król. Wszakże nie doszło w Polsce do formalnego uznania tego prawa, a w związku $z$ tym do stworzenia czegoś $w$ rodzaju bureau des offices casuels. Sprzedaż ze strony króla utrzymala się w fazie sprzedawalności ukrytej. Tę sytuację wykorzystywało otoczenie królewskie.

${ }^{349}$ Annales Stanislai Orichovi, wyd. T. Działyński, s. 206; cytuję za W. Paluckim, Studia nad uposażeniem..., s. 23, przyp. 68.

${ }^{350}$ W. Pociecha, Bona..., t. 2, s. 482, przyp. 160; W. Palucki, Studia nad uposażeniem..., s. 23.

${ }^{351}$ W. Czapliński, Ideologia..., s. 111.

${ }^{352}$ Tenże, Dawne czasy..., s. 150, oraz Sprzedawanie urzędów..., s. 57.

353 J. K. Plebański, Maria Ludwika Gonzaga. Dwa obrazy historyczne, Warszawa 1862,

s. 78-79; ibidem, w przyp. 79 powołanie cytatów ze źródeł i zestawienie literatury.

${ }^{354}$ Ibidem, s. 81, przyp. 82.

355 W. Czapliński, Sprzedawanie urzędów..., s. 57-58.

${ }^{356}$ Ibidem, s. 59.

${ }^{357}$ W. Palucki, Studia nad uposażeniem..., s. 23.

${ }^{398}$ J. Kitowicz, o. c., s. 254.

${ }^{359}$ VL, t. 6, s. 20 oraz s. 623. Por. też G. Lengnich, Pacta..., s. 30; tenże, Ius publicum, t. 1, s. 291-292. Wypadek dwóch aktów nominacyjnych na jeden urząd notuje w. Palucki, Studia nad uposażeniem..., s. 98, przyp. 103. 
Ono też czasami pośredniczyło $w$ takich transakcjach $w$ porozumieniu z królem. Krzycki, krytykujący postępowanie Bony, pisał o niej, że działała connivente rege ${ }^{360}$. Co najmniej milczącą zgodę monarchy przyjąć też należy w czasach późniejszych. Naturalnie niejednokrotnie dworzanie kupczyli urzędami poza plecami monarchy, biorąc pieniądze na jego imię. W drugim wypadku - sprzedaży bez wiedzy króla - można by mówić zarówno o łapownictwie, jak i platnej protekcji. Oczywiście nie łatwo tu wyróżnić, kiedy tego rodzaju świadczenie uchodziło za legalne, kiedy zaś szło na przekór prawu. Bo urzędnicy dawni, nie biorący pensji, mieli - jak wiemy - prawo do pewnych opłat od stron, a tylko w pewnych wypadkach nabierały one charakteru exemia (lapówek) ${ }^{361}$. Nie traktowano też chyba płatnej protekcji za akt przestępczy ${ }^{362}$.

Sprzedawalność urzędów była tworem prawa zwyczajowego. Utrzymywała się w postaci ukrytej. Współcześni zbierali wiadomości o konkretnych faktach sprzedaży. Historyk opiera się na tych informacjach i na ich podstawie formukuje regulę prawną. W literaturze przedmiotu zwracano uwage na to, że ustawodawstwo przedrozbiorowe nie zajmowało się w ogóle tym problemem ${ }^{362 a}$. Ale zajrzyjmy do paktów Augusta III z 1736 r.: Dochody skarbu Rzplitej, tak $w$ Koronie jako $i w W$. X. Litewskim, aby per plus offerentiam chodzily, na przyszlym sejmie starać sie będziemy: que res in Comitiis decidetur ${ }^{363}$. Na pierwszy rzut oka wydawać by się mogło, że powolany tekst nie zajmuje się kwestią sprzedaży urzędu (podskarbiowskiego), lecz licytacją dochodów skarbu. Kim jednak stanie się ich nabywca? Oczywiście: podskarbim koronnym czy litewskim. Ten urząd da mu prawo do poboru dochodów, o których w tym postanowieniu mowa ${ }^{364}$. Co ważne,

360 W. Pociecha, Bona..., t. 2, s. 482, przyp. 160.

361 J. Bardach, Czolobicie..., s. 314.

362 Najstarszego przykładu płatnej protekcji, jaki znamy, dostarcza Księga Henrykowska. Gdy Henryk IIl Biały odwołał nadania swego rozrzutnego brata, Bolesława Rogatki, odebrał klasztorowi henrykowskiemu wieś Jaworowice. By wejść w posiadanie ponownie, zapłacił opat henrykowski księciu 80 grzywien i darował konia za 10 grzywien; ponadto wynagrodzenj zostali dwaj officiales książęcy pro eodem negotio komes Jan z Wierzbna i notariusz mistrz Walter: każdy $z$ nich otrzymał konia wartości 10 grzywien. W przywileju poświadczającym to kupno z 27 czerwca 1255 r., a redagowanym przez wspomnianego notariusza, o tych dodatkowych świadczeniach dla officiales nie ma wzmianki, Liber fundationis claustri S. Mariae Virginis in Heinrichow, wyd. J. Matuszewski i S. Rospond, Poznań 1949, s. 272.

362a Por. niżej przyp. 388.

363 VL, t. 6 , s. 624.

364 Skłonni bylibyśmy wiązać podany wyżej tekst $z$ następującym postanowieniem paktów Augusta II: Urzqd podskarbiego Koronnego Nadwornego podlug dawnego statutu króla Aleksandra konstytucji a. 1607 i w pośledniejszych prawach urzędowi temu należqcych utwierdzamy, do prowentów $i$ intrat stolowych ekonomii królewskich, także $i$ dochodów zwyczajnych sine ulla praepeditione osób duchownych inviolabiliter zachowamy, VL, t. 6, s. 29. 
tak rozumiano je współcześnie. Oto jak interpretuje je Lengnich ${ }^{365}$. W $\S 20$, noszącym tytuł Thesaurariatus magni, cui conferendi, pomieścil następujące tłumaczenie: Thesaurariatus magni, Regni et $M$. D. Lituaniae, ut in futuris comitiis per plus offerentiam conferantur, curabimus: quae res in comitiis decidetur. Tenże G. Lengnich, który zaopatrzył wspomniane pakta w historyczny komentarz, dał następujące wyjaśnienie: Scilicet, ut magnus thesaurariatus, cum Regni tum Lituaniae, illi conferatur, qui plus caeteris in aerarium, ex constitutis reditibus, illaturum, se promiserit $t^{366}$. Co więcej, tenże autor stwierdza, że podobnie postąpiono, o ile sobie przypomina, już przedtem, bo w r. 1729 po śmierci podskarbiego koronnego, Przebendowskiego ${ }^{367}$, który był nim długie lata $^{358}$. $\mathrm{Na}$ innym miejscu już dokładnie informuje o faktach, które doprowadzily do wydania omawianej normy. Mianowicie we wspomnianym roku dochody skarbu koronnego wynosiły $500000 \mathrm{złp.} \mathrm{Z} \mathrm{chwilą} \mathrm{wakansu} \mathrm{podskar-}$ biostwa zgłosił się starosta spiski, Teodor Lubomirski, z propozycją następującą: si sibi regni thesaurus in biennium mandaretur, se industria sua primo anno redditus a quingentis milibus ad millionem, altero autem anno - ad duos milliones aucturum. Ex hac causa in pactis conventis Augusti III constitutum, curatum iri in proximis comitiis, ut reditus utriusque thesauri ad iudicium eorum, qui plurimum oblaturi, aestimentur ${ }^{369}$.

Tego rodzaju postępowanie - licytacja urzędu - było jak najbardziej zgodne z Radami Kallimachowymi, nie razilo też współczesnych. Postępowano tak już wcześniej - jak stwierdza znakomity gdański prawnik z powołaniem się na Załuskiego: ante Augusti II regnum audiebatur querela, maiorem pretii quam virtutis haberi rationem, et plus offerentibus obvenire, quae bene meritis deberentur ${ }^{370}$.

Co więcej, historyk tego okresu, nie znający przedstawionych tu wiadomości, wyraził zdziwienie, że Rzeczpospolita nie zniosła całkiem instytucji podskarbiostwa i nie zastąpiła go tańszą plus offerencją czy czymś podobnym $^{371}$. Zarząd podskarbiostwa był bowiem sui generis dzierżawą bez umowy $^{372}$. Wynika to $\mathrm{z}$ faktu, że podskarbi pensji nie pobieral nigdy. Jego

${ }^{365}$ Znakomity prawnik gdański zasługuje, jak się wydaje, na szersze uwzględnienie przez badaczy dawnego prawa polskiego. Sylwetkę jego skreślił ostatnio w króciutkim artykule Z. Żukowski, Profesor „Aten gdańskich”, Prawo i Życie, t. 7, 1962, nr 15, s. 7. Ob. też S. Salmonowicz, praca cytowana wyżej w przyp. 274, s. 136.

${ }^{366}$ G. Lengnich, Pacta, komentarz do $\$ 20$.

${ }^{367}$ G. Lengnich, Mémoires..., s. 110, przyp. 2. Także dyplomatyczna uwaga: et nous verrons à la Diète prochaine, comment la prudence royale en disposera.

${ }^{368}$ Przebendowskiego wymienia jako podskarbiego wielkiego koronnego konstytucja

z 1710 r., VL, t. 6, s. 172 .

${ }^{369}$ G. Lengnich, Ius publicum, t. 2, s. 203.

${ }^{370}$ G. Lengnich, Ius publicum, t. 1, s. 288.

${ }^{37 t}$ M. Nycz, Geneza reform skarbowych..., s. 106.

${ }^{372}$ Ibidem, s. 106. 
dochód osobisty stanowiła nadwyżka ponad pewną tradycją ustaloną kwotę z cel $\left(\begin{array}{llll}180 & 000 & \text { zlp }\end{array}\right)^{373}$.

Podkreślamy jeszcze: $\mathrm{z}$ przytoczonej informacji Lengnicha wynika, że sprzedaż drogą licytacji stosowano do urzędów w ogóle, a nie tylko do podskarbiostwa.

Przy nastawieniu pekuniarnym do funkcji urzędowych doszło wcześnie do wytworzenia się ekspektatyw ${ }^{374}$, zresztą zakazanych przez konstytucje ${ }^{375}$.

Jeśli mówiliśmy o uprawnieniu króla do rozdawnictwa urzędów, to mieliśmy, oczywiście, na myśli stanowiska godniejsze. Monarcha nie mianował funkcjonariuszy na stopniu woźnych, np. instygatorów koronnych. Te etaty obsadzali prezydent Trybunału albo marszalek Trybunalu. Ale chyba ich nie sprzedawali, bo to urząd za niski, a zatem i wartość jego nieznaczna. Nadawali je więc komuś ze swoich przyjaciół albo służących ${ }^{376}$, gromadząc $\mathrm{w}$ ten sposób koło siebie prywatną klientelę. Ale w innych, podobnych wypadkach sprzedawalności wykluczyć nie można.

\section{Forma zaplaty}

Zaplata za urząd następowala najczęściej w pieniądzu, nieraz prezentami $\mathrm{i}^{377}$. Umówioną kwotę uiszczano gotówką, niejednokrotnie rozkładano ją na raty, które należało spłacać w krótszym lub dłuższym odcinku czasu $^{378}$. Nabywcy szarź oficerskich, zobowiązani do zapłaty 22000 złp uiszczą połowę, tj. 11000 złp, przed otrzymaniem przywileju królewskiego (na dowód zapłaty tej sumy przedstawią kwit), drugą polowę przez abcug polowy ich gaży aż do zupelnego zaspokojenia ${ }^{379}$. W następstwie sprzedaży na kredyt powstawaly spory na tle nieuregulowania należności ${ }^{380}$.

${ }^{373}$ Ibidem, S. 98.

${ }^{374}$ W. Palucki, Studia nad uposażeniem..., s. 20.

${ }^{375}$ Taki jest sens postanowienia paktów z 1699 r.: ani ante actualem ascensum jednego, po nim drugiemu konferować nie bedziemy, VL, t. 6, s. 20. Por. również z tego roku konstytucję, zakazującą ekspektatyw z powołaniem na konstytucje z 1550 i 1613 r., VL, t. 6, s. 61. O tych zagadnieniach pisze G. Lengnich, Ius publicum, t. 1, s. 291.

${ }^{376}$ J. Kitowicz, o. c., s. 185.

377 W. Czapliński, Sprzedawanie urzédów..., s. 56. Te same formy zapłaty na Litwie: $\mathrm{z}$ reguły $\mathrm{w}$ pieniądzu, ale także $w$ postaci bachmata, J. Bardach, Czolobicie..., s. 312. W prezencie mogła iść nawet wieś czy miasteczko; o odstąpieniu Bonie Brodów za kasztelanię krakowską W. Palucki, Studia nad uposażeniem..., s. 125, choć powołana tam informacja trąci anegdotą.

${ }^{378}$ W. Czapliński, Sprzedawanie urzędów..., s. 58.

379 Ibidem, s. 79.

380 Ibidem, s. 58 oraz niżej. 
Obok sprzedaży za określoną ściśle sumę, płaconą gotówką lub rozłożoną na raty, znano i taką transakcję, w której kupujący zobowiązywal się do uiszczenia trwakej renty na rzecz monarchy w proporcji do uzyskiwanych dochodów. Taką umowę przewidują Rady Kallimachowe w art. 21 (wyżej ustęp III). Konkretne przykłady takiego uregulowania odpłatności posiadamy dla Luckiego i dla Litwy ${ }^{381}$.

Nie zawsze rekompensata za urząd, przez króla wymagana, opiewała na gotówkę. Król żądał nieraz innych świadczeń. Za Jana Kazimierza nova, antea incognita, ad dignitates et bona regia patebat via: prywatna przysięga popierania króla $\mathrm{w}$ jego staraniach o zapewnienie sukcesji vivente rege.

Król też obiecywał urzędy z góry, chcąc zapewnić sobie elekcję. Tego rodzaju postępowanie spotyka się $\mathrm{z}$ reprobatą; wszelkie tego rodzaju zobowiązania są nieważne - jak to postanawiają pakta konwenta Michała Wiśniowieckiego ${ }^{382}$. Jan Kazimierz domagal się od kandydatów na urząd, aby scripto profiterentur, quod in hoc se regis arbitrio submitterent. Zarówno privatum iusiurandum, jak i submissiones zostały zakazane w egzorbitancjach z $1699 \mathbf{r}^{383}$

\section{Walka ze sprzedawalnością urzędów}

Współcześni zdawali sobie dobrze sprawę $\mathrm{z}$ tego, jaką niebezpieczną włada król bronią, dysponując urzędami. Dlatego to zostal tak skrępowany $\mathrm{w}$ rozdawnictwie dignitates. Walka $\mathrm{z}$ absolutum dominium rozciagnęła się i na sprzedawalność urzędów, choć wątpić można w jej szczerość. Stąd to następujące postanowienie znalazło się $w$ akcie z 1699 r.: Za honory też $i$ dygnitarstwa, za urzędy wszelkie $i$ wakanse, tak duchowne jako i świeckie, $w$ Koronie i $w W$.X. Litewskim et annexis eo provinciis, praemia żadnych akceptować sub nexu iuramenti nie będziemy: a kto by się ex civibus ważyl za jaki urzqd $i$ dygnitarstwo nam co ofiarować $i$ dawać, tedy nie tylko ma dignitate vel officio carere, ale eo ipso pro incapaci ma być rozumiany. W dalszym ciagu tekstu czytamy: Wakanse generaliter wszystkie nie pod szacunkiem pieniędzy, ale pretio virtutis et meritorum będq rozdawane, ani by się haec labes in delicato pectore Najjaśniejszego Elektora zmieścić mogla, którego generositas takie detestatur wziatki $i$ obwencyje: nec sua privatis

${ }^{38 I}$ W. Palucki, Studia nad uposażeniem..., s. 278; dla Litwy - J. Bardach: Zygmunt I, uchylając w roku 1522 licytację godnoścj archimandryty Lawry Peczerskiej, wprowadził w jej miejsce stałą oplatę od klasztoru; potwierdził ją w latach 1550 i 1570 Zygmunt August, Czolobicie..., s. 310.

${ }^{382}$ VL, t. 5, s. 20 , p. 69; G. Lengnich, Ius publicum, t. 1, s. 289.

${ }^{383}$ G. Lengnich, Ius publicum, t. 1, s. 288-289. 
crescunt aeraria damnis. Precz od tego Pana oddalone indecora lucra, gdzie hojna munificentia każdemu wiernie slużqcemu nie skapo udziela lask... ${ }^{384}$

Podobne postanowienie znalazło się i w paktach Augusta III ${ }^{385}$. Streścił je w swoich wywodach G. Lengnich ${ }^{386}$. Pojawiają się one i w paktach Stanisława Augusta z 1764 r. w nieco odmiennej redakcji: Za honory $i$ dygnitarstwa, za urzędy wszelkie $i$ wakanse, tak duchowne, jako $i$ świeckie, $w$ Koronie $i w W . X$. Lit., offerencyj pieniężnych ullo titulo pretendować nie będziemy pod identycznymi dla przestępujących ten zakaz sankcjami ${ }^{387}$. Wystąpią i w paktach z $1793 \mathrm{r}$.: (król) nie dopuści, aby jakie oplaty pieniężne od urzędów wymagane byly i tych sam żadać $i$ brać nie będzie 388 . Taż sama konstytucja z 1793 r. zawiera co do jednego $z$ urzędów cywilnych następujący przepis: Pierwszy oficjalista skarbowy w Koronie przy boku komisji będzie pisarz; powinien być osiadly, urzqd jego dożywotni nikomu przedanym ani ustapionym być nie może, acz dzierżący go może zeń dobrowolnie zrezygnować ${ }^{389}$. W monarchii elekcyjnej mogłoby formę kupczenia urzędami stanowić obiecywanie ich za popieranie kandydatury do tronu. Takich obietnic dokonywać nie wolno, $i$ jeżeliby komu za promocja na Krolestwo co obiecal $i$ assekurowal, tak $w$ Koronie jako $i w$ W. X. Litewskim, to ma być nullitatis, nec ullatenus promissum exolvat ${ }^{390}$.

Wreszcie, by już innych, niemajątkowych świadczeń król się za nadane urzędy nie domagał, egzorbitancje przedłożone Michałowi zakazały wymagać od nominata prywatnych przysiąg i pisemnych zapewnień podleglości ${ }^{391}$.

${ }^{384}$ VL, t. 6, s. 30 .

${ }^{385}$ Ibidem, s. 634 .

${ }^{386}$ Dlatego to w czasie starań o tron Augusta Il i Augusta III obiecano ich imieniem: non nisi ex meritis et virtutis praemium dispensaturos, quae vacua futura, quod magnus illorum animus ab indigno lucro abesset quam longissime. G. Lengnich, Ius publicum, t. 1, s. 288. Autor powolał się na pakta konwenta Augusta II (Wakanse generaliter) i Augusta III ( $A$ gdy ta jest). Następnie w paktach przez siebie zaprzysiężonych obiecał August Il pro collatis, quae vacua, nulla se accepturum dona pod sankcja nieważności nadania godności i odpowiedzialności sądowej: Et qui ex civibus aliquid obtuerit aut dederit, illum non solum dignitate praesenti carere, sed etiam inposterum veluti minus idoneum nulli publico muneri admoveri, et ad declarationem cuiusvis nobilis tribunali causam dicere, ibidem, s. 288 (z powołaniem na pakta konwenta Augusta III ( $Z a$ honory).

${ }^{387}$ VL, t. 7, s. 201-202.

${ }^{388}$ VL, t. 10, s. 115. Sprostować zatem należy wypowiedż W. Czaplińskiego, jakoby nie wspominały o sprzedaży urzędów konstytucje i zwody prawne (Sprzedawanie urzędów..., s. 51).

${ }^{389}$ VL, t. 10, s. 212.

${ }^{390}$ VL, t. 5, s. 14 . Por. M. Ch. Hartknoch, o. c., s. 278; G. Lengnich, dzieła cytowane w przyp. 227

391 42. Zeby iustitia distributiva occasionem ambitui civium nie podawala, tedy Król Imć przy konferowaniu honorów jako $i$ beneficiorum od nikogo iuramentów żadnych prywatnych odbierać nie będzie, także submissiones subscriptas wymagać...", VL, t. 5, s. 14. Przepis znalazł się w paktach tegoż Michała pod punktem 69, VL, t. 5, s. 20, oraz w paktach Jana III, VL, t. 5, s. 265; Augusta II, VL, t. 6, s. 19; Augusta III, ibidem, s. 622-623, i Stanisława Augusta, VL, t. 7, s. 201. Por. tu M. Ch. Hartknoch, s. 277-278; G. Lengnich stwierdza, że postępowano $\mathrm{w}$ ten sposób za Jana Kazimierza reginae in primis auspiciis (Pacta conventa, s. 21). 
Identyczne zakazy wydawano przeciwko kupczeniu urzędami przez królowe oraz przez bialeglowy dworskie cudzoziemskie. Oto jak je sformułowano w egzorbitancjach, przedłożonych Michałowi w r. 1669, pod tytułem: Królowa Ieymć żeby sie in materias Status nie mieszala, ani bialoglowy in promotiones. 46. Królowa leymć aby sie in negotia Status nie mieszala; promocyje także aby nigdy przez bialeglowy dworskie cudzoziemskie nie chodzily. Sankcja za przekroczenie tego zakazu jest relegowanie $\mathrm{z}$ dworu ${ }^{392}$. Przejął je król do paktów (punkt 70). Ponowił Jan III' ${ }^{393}$. W paktach z 1699 r. zredagowano odnośny zakaz następująco: Królowa nie ma się mieszać in negotia Status Reipublicae per se et subordinatas quasvis personas $i w$ promocje żadne wdawać się nie będzie. Promocyj takíe przez bialeglowy dworskie $i$ osoby cudzoziemskie, ani per intimos cubicularios nostros cuiuscunque nationis extraneos nigdy czynić ani przyjmować nie będzie ${ }^{34}$. Przepisy te pojawiają się również w paktach konwentach Augusta III ${ }^{395}$. A jeszcze w paktach Stanisława Augusta spotykamy klauzulę: a ta malżonka nasza w rzqdy Rzeczypospolitej, ani in materias Status wdawać się nie bedzie $e^{396}$.

Ale postanowienia te zwracały się nie tylko przeciwko sprzedaży urzędów przez króla i jego bliskich. Zakazują one również transakcyj alter alteri, choć tego rodzaju przepisy pojawiają się znacznie rzadziej. Oto tekst odnośny egzorbitancyj, przedłożonych Michałowi w r. 1669: ...także urzędy obojga narodów, koronne i ziemskie, per cessiones chodzić nie maja sub eadem nullitate privilegiorum. A które takowe mialyby być, pro vacantibus oddawane bedq, salvis jednak modernis possessoribus ${ }^{397}$. Powolując je w swym dziele, stwierdza G. Lengnich, że nie jest dozwolone, by publica autem munia in alios cessione transferri ${ }^{398}$.

Te wszystkie zakazy były to leges imperfectae. Już wielokrotne powtarzanie ich w tak podstawowym akcie konstytucyjnym, jaki stanowiły pakta konwenta, świadczy o ich daremności. Królowie, widocznie, sprzedawali urzędy stale. Bezsensowność zakazu uwydatni wprowadzona równocześnie $\mathrm{z}$ nim $\mathrm{w}$ jednym akcie, w paktach Augusta III, licytacja urzędu podskarbiego. Nie usunięto też cesyj prywatnych.

Cytowane postanowienia nie zdołały zniweczyć zakorzenionego zwyczaju. W tej walce zwyczaju i norm stanowionych nieskuteczność ostatnich pokazała się w całej pełni. Okaże się ona jeszcze w działalności normodawczej

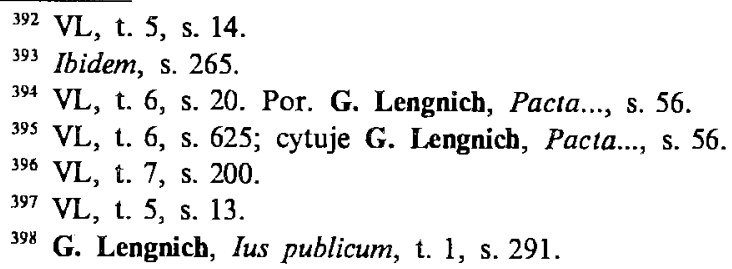


Stanisława Augusta. Król ten wydal 11 maja 1763 r. deklarację dotyczącą stopni wojskowych:

[1] ...iż sprzedaż szarż wszystkich $w$ wojsku Obojga Narodów, $w$ brygadach, regimentach $i$ pulkach, od najwyższej do najniższej bez ekscepcji od dnia 1 stycznia $1784 \mathrm{r}$. miejsca mieć nie będzie.

[2] Ktokolwiek zechce od niniejszej daty, aż do końca niniejszego roku, dla swego zysku, sprzedać szarże, nie wolno będzie jak $w$ wlasnym korpusie podlug starszeństwa lub za zgodnq umowq ze starszymi, za czteroletniq gaże; a ci wszyscy, którzy teraz splacq odchodzacych, żadnej potem do splacenia siebie pretensji mieć nie mogq $q^{399}$.

Intencją zatem jej było skasowanie całkowite sprzedaży szarż wojskowych. Przepisy przejściowe umożliwiają transakcje nimi jeszcze do końca $1783 \mathrm{r}$., acz z pewnymi ograniczeniami. Zastrzegaja wszakże, że nowi nabywcy nie będą mogli w przyszłości rościć żadnych pretensyj do spłaty.

I tej deklaracji nie udalo się wprowadzić $w$ życie, jak to wynika z konstytucji z 1784 r., która sprzedaż stopni wojskowych $z$ urzędników koronnych $i$ litewskich cywilno-wojskowych, jako tez z generalów $i$ officyerów, $w$ brygadach, korpusach, pulkach, regimentach $i$ choragwiach oddzielnych, uzależniała od pełnienia funkcyj przez określony przeciąg czasu: dopóki by od czasu wniścia $w$ slużbe wojskowq lat piętnaście slużby swojej nie dowiódl ${ }^{400}$. Równocześnie wprowadzono ograniczenia co do nabywców tych stopni. Nabywać rangi mogli ci tylko, którzy posiadali do nich starszeństwo ${ }^{401}$.

Okazuje się zatem, że zdecydowane stanowisko króla, likwidujące zupełnie sprzedaż stopni oficerskich, nie dało się przeprowadzić. Choć król widział nadużycia, ,tyle pieniędzy nie mial, aby tyle rang zapłacił dla pomieszczenia znających slużbę wojskową" - pisze wspólczesny pamiętnikarz ${ }^{401 a}$.

Konstytucja z 1784 r. jest wyrazem pewnego kompromisu między praktyka dotychczasową a nowymi tendencjami, charakterystycznymi dla Stanislawowskich reform ${ }^{402}$. On też znalazł potwierdzenie $w$ ordynansie Komisji Wojskowej z 27 lutego 1790 r., wedhug którego żaden z awansujących na rangi nowo utworzone sprzedawać miejsca swego nie mógł przed wysłużeniem lat piętnastu ${ }^{403}$. Na nią powoła się też konstytucja z $1793 \mathrm{r}$.: Prawo na sejmie 1784 r. wzgledem przedaży tych szarż wojskowych zapadle

${ }^{399}$ Deklaracja opublikowana w Gazecie Warszawskiej, $\mathrm{nr}$ 39, suplement. Cytujemy za K. Górskim, Historia piechoty, s. 125; por. też tenże, Historia jazdy, s. 145, oraz T. Korzon, Wewnętrzne dzieje Polski.., t. 4, s. 300.

${ }^{400}$ VL, t. 9, s. $11-12$.

${ }^{401}$ Por. tu K. Górski, Historia piechoty, s. 125, oraz M. Kukiel, Zarys..., s. 125.

${ }^{4012}$ S. Kosmowski, Pamiętniki z końca XVIII w.; cytat za: B. Baranowski, W. Bortnowski,

W. Lewandowski, Dzieje wojskowości polskiej do roku 1831 (Wypisy źródlowe), 1949, s. 200-201.

${ }^{402}$ K. Górski, Historia piechoty, s. 125; T. Korzon, Dzieje wojen, t. 3, s. 176.

${ }^{403}$ K. Górski, Historia piechoty, s. 161. 
do najściślejszej egzekucji przyprowadzone mieć chcemy ${ }^{404}$, choć skróciła czasokres „zasiedzenia: $\ddot{z}$ nikt urzędu swego przedać nie będzie mógl odtq̨d, wyjq̨wszy tych, którzy lat dziesięc ciagle wysluzyli lub funkcje przed niniejszym prawem $z$ majątku wlasnego kupili ${ }^{405}$. Odtąd awanse iść mają według starszeństwa, zdatności i zasług. Zatem sprzedaż szarż - acz z ograniczeniem - utrzymuje się dalej. Jeszcze w r. 1795, po swej detronizacji, Stanisław August zwrócił się z prośbą do carycy, by zwróciła oficerom sumy popłacone za szarże, co wynosić miało 400000 dukatów ${ }^{406}$.

Poważnym ciosem dla omawianej instytucji było zniesienie nadań starostw przez reformę emfiteutyczną z r. 1775 . To jest dopiero właściwa data egzekucji dóbr. Prawda, nie chodziło w niej o officia, lecz jedynie o beneficia sine officio. Ale te rzeczy, jak stwierdziliśmy wyżej, były ściśle $\mathrm{z}$ sobą związane. Wprowadzenie pensyj, a więc wynagrodzeń $w$ gotówce, w odróżnieniu od dawnych zaopatrzeń, umożliwiło zniesienie nadań dożywoci. Majętności, które odtąd miały stanowić źródło dochodów państwowych, skarb puszczał $w$ długoterminową, 50 lat wynoszącą dzierżawę iure emphiteutico, droga licytacji ${ }^{407}$ (sposób zatem, który zalecały tzw. Rady Kallimachowe! ${ }^{408}$ ). Ostateczną wreszcie likwidację tej formy eksploatacji państwa przez możnych przeprowadził Sejm Czteroletni, dekretując ustawę o sprzedaży wszystkich królewszczyzn drogą publicznej licytacji ${ }^{409}$. Omówione normy z r. 1783 i 1784 dotyczyły szarż wojskowych. Wszakże konstytucja z 1793 r., odsyłająca do ustawy z 1784 r., postanowiła: do którego prawa (z 1784 r.) $i$ urzędy cywilne stosujemy ${ }^{410}$. Tym samym więc, jak się wydaje, należy odnieść także do nich przepisy o pewnym minimalnym staźu sprzedawcy urzędu, jak też - być może - i reguły co do pewnych kwalifikacji nabywców. Wkrótce potem przeprowadzony trzeci rozbiór pozbawił znaczenia wszystkie te normy, wydane in extremis.

A zatem do końca Rzeczypospolitej szlacheckiej utrzymała się sprzedawalność urzędów cywilnych i stopni wojskowych. Nie było w Polsce czynnika, który by wydał zdecydowaną walkę temu zadawnionemu zwyczajowi. Nie był $w$ stanie jej przeprowadzić marionetkowy sejm szlachecki. Sanacji nie należało oczekiwać ze strony senatu, którego członkowie korzystali w pierwszej linii $\mathrm{z}$ dobrodziejstw sprzedawalności urzędów. Skrępowany ponad wyraz monarcha nie mógł przeciwstawić się instytucji, która zapewniala tyle prywatnych korzyści wszystkim. Przeciwakcja ograniczała się do wystąpień

\footnotetext{
404 VL, t. 10 , s. 232.

405 Ibidem.

406 T. Korzon, Dzieje wojen..., t. 3, s. 176.

407 VL, t. 8, s. 138-144; B. Leśnodorski, Historia państwa i prawa, t. 2, s. 414.

${ }^{408}$ W. Pociecha, Bona..., t. 2, s. 482, przyp. 160.

409 B. Leśnodorski, Historia państwa $i$ prawa, t. 2, s. 471.

410 VL, t. 10, s. 232.
} 
niewątpliwie szczerych publicystyki, $i$ to $w$ najlepszym słowa znaczeniu (Modrzewski), do demagogicznych wystąpień posłów na sejmie i braci-szlachty na sejmikach oraz do uchwał sejmowych, z którymi nie liczył się nikt - ani król, ani magnaci, ani szlachta.

\section{Cena urzędów}

Zestawiamy poniżej kwoty, które placono za nabywane urzędy:

- wielki podskarbi koronny (1692 r.)

- mała pieczęć

- mała pieczęć

- podkomorstwo koronne

- województwo smoleńskie

- kasztelania sandomierska

- starostwo brzeskie i lidzkie

- starostwo drohickie

- starostwo kowieńskie

- starostwo Geranojny

- starostwo wareckie

18000 dukatów ${ }^{411}$

$100000 \mathrm{ztp}^{412}$

40000 czerw. $\mathrm{zlp}^{413}$

$30000 \mathrm{zlp}^{414}$

$60000 \mathrm{złp}^{415}$

$50000 \mathrm{zlp}^{416}$

500 kóp groszy i 2000 czerw. zł

1000 kóp groszy ${ }^{417}$

24000 kóp groszy

1000 kóp groszy

130000 kóp groszy ${ }^{418}$

Sumy płacone za szarże wojskowe przedstawiają sį̨ następująco:

- general-major dywizji małop. (1780 r.)

$48 \quad 000 \mathrm{zlp}^{419}$

- leibkompania

$18000 \mathrm{zlp}$

- majorostwo

$12000 \mathrm{złp}$

- podpułkownikostwo

- kompania 1. regimentu (1790 r.)

$4000 \operatorname{zlp}^{420}$

- podpułkownikostwo (1791 r.)

$4000 \mathrm{zlp}$

- general adjutant Komisji Wojsk. Lit. przy magistraturze wojskowej

- regencja lit.

411 K. Piwarski, Hieronim Lubomirski, s. 50.

${ }^{412}$ W. Czapliński, Dwa sejmy, s. 85; tenże, Sprzedawanie urzedów..., s. 56.

413 Tenże, Sprzedawanie urzędów..., s. 55-56.

414 Ibidem, s. 56.

415 Ibidem. Nabywca zapłacił ponadto kilkadziesiąt tysięcy na dworze.

416 Ibidem.

417 J. Bardach, Czolobicie, s. 309.

418 W. Czapliński, Sprzedawanie urzedów..., s. 55.

419 PSB, t. 8, s. 544.

420 Ibidem, s. 551.

421 Ibidem, s. 594.

422 VL, t. 10 , s. 70.

${ }^{423}$ Ibidem, s. 79.

$24000 \mathrm{zt}^{422}$

$34000 \mathrm{zlp}^{423}$ 
Na mniejsze kwoty opiewały zastawy:

- w 1442 r. oddano starostwo sandomierskie za

2700 grzywien $^{424}$

- w 1520 r. starostwo bieckie za

10000 grzywien $^{425}$

A już nieznaczne tylko świadczenia uiszczano za przyznaną ekspektatywę, jak przystoi na zadatek ${ }^{426}$. Nieraz informacja ogranicza się do podania faktu sprzedaży pro certa summa ${ }^{427}$. Czasami dane źródłowe są częściowe: dowiadujemy się o sprzedaży urzędu na raty, znamy wysokość jednej raty, ale nie wiemy, na ile rat suma sprzedażna została rozłożona ${ }^{428}$. Nie jesteśmy też $w$ stanie rozwikłać takiej informacji: wydzierżawiono dwa pisarstwa ziemskie łącznie $\mathrm{z}$ dwoma starostwami niegrodowymi na lat $10 \mathrm{za}$ rocznym czynszem $4100 \mathrm{zl}^{429}$. Jaka częsć z tej kwoty należała się z tytułu pisarstw, a jaka z tytułu starostw?

Charakterystyczne przy tym, że zestawione liczby, dotyczące urzędów cywilnych, stanowią kwoty uiszczane na rzecz króla. Mniej posiadamy danych o cenach urzędów przy transakcjach alter alteri. Jedną wzmiankę zawdzięczamy Hartknochowi: za godność podskarbiego koronnego zapłacono w 1668 r. 900 aurei $^{430}$; dwie dalsze - W. Paluckiemu: za województwo pomorskie łącznie ze starostwem skarszewskim zapłacono w $1758 \mathrm{r}$. $100000 \mathrm{zlp}$, za kasztelanię sandomierską w 1637 r. $-50000 \mathrm{zlp}^{431}$. Według informacji J. Kitowicza, za godność instygatora skrzynkowego płacono 50-100 czerwonych złotych ( $w$ zależności od województw i stron), za stanowisko instygatora securitatis $15-30$ grzywien ${ }^{431 a}$. Niewątpliwie, pilna kwerenda może liczbę przykładów znacznie zwiększyć.

W ogóle informacje o sumach uzyskiwanych za sprzedawane urzędy są niepewne: nikt się tym nie chwalił; co więcej, nieraz wprost zatajano podobne transakcje. Dopiero z chwilą wprowadzenia pensyj (etatów) sprawa staje się jasna. Ale z tym zjawiskiem, jak wiemy, spotykamy się dopiero u zmierzchu szlacheckiej Rzeczypospolitej.

${ }^{424}$ S. Kutrzeba, Starostowie..., s. 335.

425 Ibidem, s. 336.

426 Tak określa to świadczenie trafnie J. Bardach, Czolobicie..., s. 309. Tenże informuje o jego wysokości (w konkretnym wypadku $100 \mathrm{zł}$ ); jest więc on rz̨̧du nieporównanie mniejszego niz cena urzędu.

427 W. Palucki, Studia nad uposażeniem..., s. 22, przyp. 65.

428 W. Czapliński, Sprzedawanie urzédów..., s. 56.

429 Acta Tomiciana, t. 14, nr 529.

430 M. Ch. Hartknoch, o. c., 1678, s. 279: ...ut factum est an. 1668, cum illustris dominus Krasinius, thesaurarius Regni, officium suum venderet illustrissimo domino Andreae in Racibor Morstino, referendario Regni nongentis aureis. W wydaniu drugim położono kropkę nad i: nongentis aureis acceptis, co też utrzymano w edycji z $1697 \mathrm{r}$.

${ }^{431}$ W. Palucki, Studia nad uposażeniem..., s. 110, 145. Cena kasztelanii sandomierskiej miała wynosić w 1507 r. 200 grzywien, ibidem, s. 146.

${ }^{4312}$ J. Kitowicz, o. c., s. 185-186. 
W wypadkach świadczeń niepieniężnych niełatwo o jakąkolwiek próbę ich szacunku. Trudno też do ceny urzędu wliczać formalne lapówki, brane przez dostojników państwowych. Tak np. za Jana Kazimierza województwo podlaskie otrzymał Paweł Warszycki, a dał za nie kanclerzowi 1000 czerwonych złotych; $z$ okazji rozdawnictwa starostw biorą kanclerz i podkanclerzy po 1000 złotych i więcej ${ }^{432}$.

\section{Rentowność urzędów}

Zebrane informacje o cenie urzędów, zawierające cyfry absolutne, nie są wielomówne. Nie poprawi tego stanu rzeczy sprowadzenie ich do wspólnego mianownika. Interesujące byłoby dopiero ustalenie stosunku między płaconą kwotą kapitałową a dochodem, jaki dawał nabywany urząd. Tymczasem, jeśli wiadomości o cenie urzędu są tak fragmentaryczne, to jeszcze gorzej przedstawia się sprawa dochodów związanych z pełnioną funkcją. Ograniczenie się do stwierdzenia, że jakieś stanowisko było dość intratne ${ }^{433}$, nie wychodzi poza mało użyteczny ogólnik. Być może, szczegółowa analiza pozwoli choćby z pewnym przybliżeniem ustalić dochodowość urzędu, choć zapatrujemy się na takie możliwości dość sceptycznie ze względów, które podaliśmy wyżej: nawet gdybyśmy byli poinformowani o dochodach $\mathrm{z}$ samego urzędu i nadanych $w$ związku $z$ nim tenut, nie będziemy znali nigdy wysokości obwencyj, uczciwych i łotrowskich, a one górowały nad dochodami legalnymi. Jedyny konkretny przykład, jakim dysponujemy w tej chwili podał W. Czapliński. Według tej informacji, starostwo wareckie przynosiło rocznie 40000 zlp, kupiono je zaś za $130000 \mathrm{zlp}^{434}$. Niebezpieczną byłoby rzeczą wysnuwać $\mathrm{z}$ jednostkowego faktu jakieś wnioski ogólniejsze. Jest możliwe, że brak oficjalnego biura sprzedaży urzędów, jak i fakt niejawności tych transakcji uniemożliwił w ogóle wytworzenie się jakiejś ceny rynkowej; przynajmniej gdy chodziło o transakcje $z$ królem. Zresztą już tzw. Rady Kallimachowe przewidywały nadawanie urzędów najwięcej dającemu ${ }^{435}$, a więc nie $w$ jakiejś stałej proporcji do dochodów związanych $\mathrm{z}$ daną godnością. Jak wiemy, ten właśnie zalecony przez Kallimacha sposób praktykowano w pewnym okresie wobec podskarbiostwa koronnego. Może więc raczej nie należałoby mówić o proporcji, lecz dysproporcji.

${ }^{432}$ W. Pałucki, Studia nad uposażeniem..., s. 23, przyp. 70. Z drugiej strony, nie można ich brać pod uwage przy rozpatrywaniu kwestii wartości urzędu.

${ }^{433}$ Literackie przystanki, s. 18.

${ }^{434}$ W. Czapliński, Sprzedawanie urzędów..., s. 55.

${ }^{435}$ Fideles ministros, qui ea (officia) licitentur, habeto; ob. też W. Pociecha, Bona..., s. 380. 
Musiała natomiast powstać jakaś ekonomicznie uzasadniona cena przy sprzedaży alter alteri, która zapewne uwzględniała panującą stopę procentową.

Stała taryfa pojawila się dopiero $\mathrm{z}$ chwilą wprowadzenia pensyj. Od tego momentu znamy wysokość rocznych dochodów urzędnika, przynajmniej legalnych. Taryfę odnośnie do stopni oficerskich ustaliła konstytucja z $1784 \mathrm{r}$.

Wysokość jej równa się czteroletniej gaży ${ }^{436}$, tzn. że inwestowany kapitał zwracał się przez pobieranie pensyj $\mathrm{w}$ ciągu czterech lat. Nie zbadaliśmy uzasadnienia gospodarczego tej stawki. Nie wiemy też, czy ona stanowiła novum. Za takim ujęciem przemawia tych kilka przykładów, które udało się nam zebrać. Szczęsny Potocki zapłacił za tytuł generała artylerii $60000 \mathrm{zlp}$, tymczasem uposażenie tego wysokiego oficera wynosiło według komputu i płacy wojska koronnego z 1776 r. $30000 \mathrm{zlp}^{437}$. Tym samym więc zaplacono w tym wypadku gażę dwuletnią. Według informacyj ks. Kitowicza, cena urzędu instygatora skrzynkowego wynosiła 50-100 czerwonych złotych, przeciętna zatem 75 . Lafa jego wynosila 8 czerwonych złotych. Wkład zatem zwracał się dopiero w ciągu 10 lat. Takież wyliczenie dla instygatora securitatis (cena urzędu 15-30 czerwonych złotych, przeciętna -22 , lafa - 4) daje wynik $5,5^{438}$. W ten sam sposób obliczony mnożnik dla starostwa wareckiego wynosi 3,25. Są to zatem wszystko wielkości różne; budzą one najpoważniejsze wątpliwości. Ilość zestawionych cyfr jest tak mała, że nie nadaje się do ujęcia statystycznego, a tylko takie przedstawiałoby dla historyka jakąś wartość. Dopiero ustawa z 1784 r. wprowadza stałą proporcję. Sądzić można, że przestrzegać jej miano zarówno w wypadku sprzedaży ex parte regis, jak też przy transakcjach alter alteri. Nie jesteśmy w stanie powiedzieć, czy ją faktycznie respektowano. Zresztą ze zrozumialych względów (likwidacja państwowości polskiej) rzecz ta nie przedstawia poważniejszego interesu badawczego.

\section{Ocena instytucji}

Współcześni zdawali sobie sprawę z ujemnych stron instytucji. Dowodem na to są narzekania szesnastowiecznego plebana: jeśli urzędy $i$ pierwsze miejsca za pieniedzmi idq, tam nie dziw, że ludzie sa chciwi i lakomi $i^{439}$. Świadczy o tym i terminologia dawna. Krzycki pisał o mercatus regina $e^{440}$.

${ }^{436}$ VL, t. 9, s. 11-12; por. T. Korzon, Dzieje wojen..., t. 3, s. 113 . W związku z tym przepisem pozostaje niewątpliwie sankcja $w$ razie wyrządzenia krzywdy $w$ fortragowaniu. Winni odpowiadać będą przed Komisją Wojskową $i$ tam karani będq zaplaceniem ukrzywdzonemu czteroletniej gaży na awans, który utracil, VL, t. 9. s. 61, Ob. też K. Górski, Historia piechoty, s. 127.

${ }^{437}$ VL, t. 8 , s. 867.

${ }^{438}$ J. Kitowicz, o. c., s. 188-189.

${ }^{439}$ J. Kochanowski, Wróżki, [w:] Dziela polskie, opr. J. Krzyżanowski, wyd. 4, Warszawa 1960, s. 733.

${ }^{440}$ W. Pociecha, Bona..., t. 2, s. 482 , przyp. 160. 
Przeciwko praktykom Bony występował Modrzewski: an non multo vitiosor est (magistratus) cum pecunia contenditur. Fieri enim non potest, ut qui per largitionem adepti sunt honores, non velint ex eis questum facere ${ }^{441}$. Zachodzi zatem - jego zdaniem - obawa, że osoba, która nabyła urząd za pieniądze, będzie potem starala się odbić inwestycję kosztem administrowanej ludności. Tak się też rzeczywiście działo: pisarze na komorach celnych, nabywający stanowiska od kolegów, srożyli się nad ludnością, by wydobyć $\mathrm{z}$ niej popłacone sumy ${ }^{442}$.

Współcześni skarżą się na fakt, że sprzedając urzędy, monarcha robi to $\mathrm{z}$ krzywda zasłużonych. Sprzedaże dokonywane przez Bonę potępial Krzycki; dzięki nim bowiem godności otrzymują homines indigni ${ }^{443}$. Podobnie argumentuje głos na sejmie z 1652 r.: $i$ inszych non bene meritos, sed bene nummatos promowujqc $i$ zalecajac, a cnota $w$ chudej substancji non nummata non habet honorem ani $u$ dworu, ani $w$ sqdzie ${ }^{444}$. Pieniądz zatem bierze górę nad cnotą. Później zwraca się uwagę na to, że pieniądz wypiera ludzi zdolnych. Tak argumentowała deklaracja Stanisława Augusta $\mathrm{z} 1783$ r.: jak szkodliwa jest dla wojska $z$ dawna wprowadzona wolność sprzedawania szarż wojskowych, skoro o awansie nie decyduja zdolności, lecz majątek ${ }^{445}$. Panoszą się też rzeczywiście pasożytnictwo i nieudolność - stwierdza Kukiel ${ }^{446}$; na stopniach generalskich rozpierały się przeważnie jednostki liche, bez żadnej wartości wojskowej - konstatuje tenże autor ${ }^{447}$. Dochodziło nawet do tego, że bogacz kupował szarżę dla nieletniego syna czy niemowlęcia, a zdolny, lecz niezamożny nie mógł stanowiska otrzymać - pisze T. Korzon ${ }^{448}$. Wzwyczajona sprzeda $\dot{z}$ szar $\dot{z}$ $w$ wojsku obojga narodów przez takowa zmiane officyerów mięszala $w$ awansach dobry porządek, uzasadnia swe postanowienia konstytucja z $1784 \mathrm{r}^{449}$, a więc uniemożliwiała należytą gospodarkę osobową ${ }^{450}$. Na oba te negativa zwraca uwage konstytucja z 1793 r. Ustęp jej, zatytułowany Warunek względem przedazy szarż $i$ urzędów, stwierdza: zważajac, $\dot{z} e$ używanie czeste przedaży rang wojskowych $i$ urzędów cywilnych zaslugom $i$ zdatności czyni pokrzywdzenie ${ }^{451}$.

441 W. Voisé, o. c. [patrz: przyp. 103], s. 19.

${ }^{442}$ M. Nycz, o. $c .$, s. $98-99$.

${ }^{443}$ W. Pociecha, Bona..., t. 2, s. 482, przyp. 160.

${ }^{444}$ Cytuje W. Czapliński, Sprzedawanie urzędów..., s. 60.

445 K. Górski, Historia plechoty, s. 124. Ob. też T. Korzon, Wewnętrzne dzieje ..., t. 4, s. 293 , 301; tenże, Dzieje wojen..., t. 3, s. 176; M. Kukiel, Zarys..., s. 127.

${ }^{446}$ M. Kukiel, o. c., s. 125.

${ }^{447}$ M. Kukiel, $Z$ dziejów..., s. 14.

${ }^{448}$ T. Korzon, Dzieje wojen..., t. 3, s. 113.

${ }^{449}$ VL, t. 9, s. 11-12.

${ }^{450}$ M. Kukiel, Zarys..., s. 113.

${ }^{451}$ VL, t. 10, s. 232. 
Sprzedawalność szarż oficerskich prowadziła niejednokrotnie do nadużyć. Informuje o tym konstytucja z 1793 r. Powolana komisja do badania etatów miała stwierdzać: czy nie wzial dawniej jakiego stopnia w wojsku bez oplaty, nie przedal go, a powtórnie bez oplaty czy nie wszedl na jaki stopien $^{452}$. Rzeczywisty toczył się handel szarżami przez ludzi niesumiennych.

$\mathrm{Z}$ tych wszystkich wad, podkreślanych przez współczesnych, uznamy za trafnie uchwycone tendencje do eksploatacji administrowanej ludności oraz upośledzenie ludzi zdolnych. Niewątpliwie też nie było zjawiskiem korzystnym zapewnienie pierwszeństwa do urzędów osobom zamożnym, bez względu na ich kwalifikacje osobiste. Oczywiście ten zarzut odpada, gdy chodzi o niskie stopnie hierarchii administracyjnej (woźnych). Tutaj nawet sprzedaż uzależniono od przynależności do pewnego kręgu ludzi, którzy niejako mają naturalną ekspektatywę na daną godność. Tak np. stanowiska instygatorów skrzynkowych $w$ Trybunale nabywali, pisze ks. Kitowicz, ,pospolicie” palestranci ${ }^{453}$.

Prawda, drogą kupna nieraz nabywali stanowiska ludzie o właściwościach moralnych kompromitujących, historia poczytuje ich wręcz za zdrajców ${ }^{454}$. Bardzo ujemną stroną był również ,handel” stopniami wojskowymi. Ale czy źródłem tych wad w administracji jest sprzedawalność urzędów? Te wszystkie negativa występują również w reżimach, które nie znają omawianej instytucji. Nadużycia władzy, branie łapówek, w ogóle działalność przestępcza urzędnika, czy na jej pograniczu stojące postępowanie, mające na celu zapelnienie osobistego trzosa, znają również kodeksy karne innych epok. Przypomnijmy wreszcie, z jak surową krytyką spotkały się urządzenia Trybunału Koronnego. Nie znano tam sprzedawalności godności sędziowskich, były one bowiem obieralne przez sejmiki, co więcej, doczasowe; te dwie zasady pociągały za sobą jak najfatalniejsze następstwa: niefachowość, frymarczenie sprawiedliwością ${ }^{455}$.

Sprzedawalność urzędów miała i swoje dobre strony.

Istnieli już wspólcześnie jej chwalcy. Kupcząca godnościami świeckimi i duchownymi Bona znalazła swoich laudatores w osobach ochmistrza swego dworu, Wolskiego, i ochmistrza młodego Zygmunta Augusta, Piotra Opalińskiego ${ }^{456}$. Oczywista, pochwały takie można kłaść na karb zwykłego w kręgu dworzan pochlebstwa. Władcy zawsze, a więc i królowie, narażeni są na niebezpieczeństwo aprobaty swych poczynań, choćby najbardziej szkodliwych, ze strony ludzi bez skrupułów, którzy pragną zarobić na wszystkim. Udzielanie pochwał osobistościom wysoko stojącym jest jednym $z$ latwych sposobów nabijania swej kiesy.

\footnotetext{
${ }^{452}$ Ibidem, s. 77.

${ }^{453}$ J. Kitowicz, o. c., s. 185.

${ }^{454}$ Por. tu ocenę omawianej instytucji przez W. Czaplińskiego, Sprzedawanie urzędów..., s. 60.

455 O. Balzer, Geneza Trybunalu Koronnego, Warszawa 1886, s. 343-346.

${ }^{456}$ W. Pociecha, Bona.., t. 2, s. 482, przyp. 160.
} 
Sprzedaż urzędów stanowiła dodatkową możliwość dochodów dla skarbu królewskiego, który w stosunkach polskich świecil szczególną pustką ${ }^{457}$. Według relacji posła francuskiego, Ludwika Maria miała $\mathrm{z}$ tego tytułu 200000 écus czyli około $600000 \mathrm{zh}^{458}$. Nie wiemy, ile wynosiły zarobki monarchy $\mathrm{z}$ tego tytułu. Wydaje się wszakże, że ten sposób opodatkowania warstwy, która miała faktyczny monopol na państwowe godności i ciągnęła olbrzymie dochody, legalne i nielegalne, z piastowanych urzędów, a żadnych podatków nie uiszczała, nie został wykorzystany w stopniu należytym. Na przeszkodzie poważniejszemu wykorzystaniu tego źródła dochodu stal wspomniany wyżej zakaz tworzenia nowych urzędów, pociągający obok tylu innych następstw także $\mathrm{i}$ finansowe. Jak wiemy, magnateria zawarowała sobie, że królowi nawet umniejszyć nie wolno prowentów urzędów dawnych.

Ciekawą informację o funkcji, jaka przypadła sprzedawalności urzędów, zawierała konstytucja z 1784 r., zajmująca się funduszem inwalidowym oficerów i wojskowych. Według niej, officyerowie zaś, którzy by w nadgrodzie lat wyslużonych $w$ wojsku wolność przedania swej szarży pozyskali, pod żadnym pretekstem do mieszczenia się na funduszu inwalidowym należeć nie $\operatorname{mog} q^{459}$. Tym samym więc kwota otrzymana ze sprzedaży stopnia oficerskiego, zastępuje inwalidzką rentę. Jak z cytowanego tekstu wynika, chodzi w nim nie o szarżę kupioną, lecz wysłużoną.

Charakterystyczne też, że w r. 1793, w jednym akcie uregulowano i sprzedawalność stopni, $\mathrm{i}$ odprawę przyznawaną wojskowym w związku $\mathrm{z}$ redukcją armii, przeprowadzona na skutek dokonanego rozbioru kraju ${ }^{460}$. Okazuje się, że prawo sprzedaży rangi za czteroletnią gażę stanowiło zabezpieczenie dla tych, którzy nie zostali pomieszczeni w kompucie aktualnym ${ }^{461}$. Znowu więc stwierdzić można rolę szczególna sprzedawalności: oficer, który sobie wysłużył wolność przedania, miał zapewnioną niejako emeryturę, którą stanowiła kwota sprzedażna ${ }^{462}$.

\section{Zestawienie wyników}

Sprzedawalność urzędów cywilnych i wojskowych w Polsce przedrozbiorowej musi być uznana za pewnik. Nie sposób jej nie uznać za instytucję legalną. Regulowało jej życie prawo zwyczajowe. Stąd wywodzi się niejasność

${ }^{457}$ Por. W. Czapliński, Dawne czasy..., s. 150.

${ }_{458}$ Tenże, Sprzedawanie urzędów..., s. 57. Zdaniem W. Czaplińskiego, informacja ta wydaje się prawdopodobna.

${ }^{459} \mathrm{VL}$, t. 9, s. 11-12.

${ }^{460}$ VL, t. 10, s. 189-190.

461 Ibidem.

${ }^{462}$ Nie znależliśmy wzmianki, która by informowała, czy oficer, który już nabył szarżę przez wysługe piętnastoletnia albo drogą kupna, a zginął na wojnie, przenosił swoje prawo na spadkobierców, czy też powstawal vacal, którym swobodnie dysponowała władza. 
i chwiejność praktyki. Działalność ustawodawcza sprowadza się do formułowania zakazów sprzedaży, z którymi nie liczył się nikt. Dopiero pod sam koniec Rzeczypospolitej wystąpi zdecydowana tendencja do likwidacji sprzedawalności. Stanisław August deklaracją z 1783 r. zniósł w ogóle sprzedawalność stopni wojskowych. Ale i ten zakaz okazał się przedwczesny. Przesłanką bowiem jego było zastąpienie poglądu prawnoprywatnego na urzędy przez ich koncepcję prawnopubliczną. Toteż rok później pojawił się przepis, który ujął w karby samą instytucję, ograniczając ją w znacznym stopniu. Mianowicie uzależnił on prawo do sprzedaży zarówno po stronie sprzedawcy (pelnienie funkcyj przez przeciąg 15, później 10 lat), jak i prawo kupna po stronie nabywcy (określone pierwszeństwo do awansu). Ustalał też cenę sprzedażną w wysokości czteroletniej gaży. Tak uregulować można było sprzedawalność $w$ okresie, w którym wypłacano już stałe pensje ze skarbu. Na tym etapie utrzymały się stosunki w Polsce aż do trzeciego rozbioru.

Sprzedawalność urzędów, powstała w warunkach feudalnych, przy górowaniu elementów prawnoprywatnych, przyczyniła się niemalo do wytworzenia klimatu niepraworządności. Monarchia polska nie potrafiła jej zwalczyć, ani ujać $w$ swe ręce i wykorzystać dla celów publicznych, jak to miało miejsce gdzie indziej. Gros dochodów związanych z urzędami przejęła góra feudalna - możnowładcy. Oni byli najbardziej zainteresowani w utrzymaniu istniejącego stanu rzeczy. Wspaniałe fortuny, które gromadzili, tworzyły się kosztem olbrzymich sprzeniewierzeń grosza publicznego.

\section{Porównanie sprzedawalności urzędów polskiej $\mathrm{z}$ francuską}

Przedstawiane czytelnikowi studium niewątpliwie nie jest wyczerpujące. Autor sam zdaje sobie sprawę $\mathrm{z}$ jego niedoskonałości. Wykazuje ono olbrzymie wprost luki źródłowe, których na tym etapie nie dało się zapelnić. $\mathrm{Na}$ skutek tego ogólna charakterystyka instytucji $\mathrm{z}$ pewnością nie jest ostateczna. Analityczne opracowania poszczególnych zagadnień moga przynieść dane, które zmienią w szczególach, być może nawet $w$ rysach zasadniczych omawianą instytucję sprzedawalności urzędów w Polsce.

Trudno więc pokusić się o porównawcze potraktowanie zagadnienia, o wyczerpujące zestawienie polskiej sprzedawalności urzędów ze sprzedawalnością w innych krajach, takich zwłaszcza jak Francja, które już dysponują dostateczną liczbą monografii, poświęconych vénalité des offices. Wydaje się atoli, że już dziś można poczynić następujące obserwacje.

1. Status prawny sprzedawalnych urzędów był w obydwu krajach - tak to dziś widzimy - identyczny. Traktowano je za nieruchomości, które 
podlegały wszelkim przepisom, dotyczącym immobilia. Mogły przeto być przedmiotem kupna-sprzedaży, dzierżawy, zastawu, dożywocia itd.

2. Sprzedawalność urzędów utrzymała się w obydwu krajach aż po koniec XVIII w.; we Francji aż do rewolucji, w Polsce - do trzeciego rozbioru. Jeśli wysiłki poczynione przez monarchię absolutną ku likwidacji tej instytucji nie dały rezultatu, nic dziwnego, że nie były uwieńczone powodzeniem takież poczynania ostatniego króla polskiego.

3. Podobnie jak we Francji, ogarnęla polska sprzedawalność zarówno urzędy cywilne, jak i stopnie wojskowe. Natomiast - i to cecha wyraźnie różniąca polską instytucję - nie objęła ona stanowisk sędziów sądów najwyższych (Trybunału Koronnego i Radomskiego), które pozostały zawsze wybieralne. Tym to charakterystyczniejsze, że przy urządzeniu Trybunału oglądano się na parlamenty francuskie. W nich zaś, jak wiadomo, sprzedawalność uchodzi za typową.

4. Sprzedawalność w Polsce nie wyszła aż po sam koniec poza fazę vénalité occulte. $\mathrm{Z}$ wszystkimi ujemnymi następstwami dla instytucji rozwijającej się $w$ takich warunkach. Zawsze trąci ona nielegalnością, trudno odróżnić cenę urzędu od lapówki czy platnej protekcji. Ale to niewątpliwie sytuacja legalna. Dopiero u samego zmierzchu państwa wychodzą ustawy, które ją regulują dość dokładnie, ustalając nawet cenę sprzedawanych szarż.

5. Wskutek niejawności polskiej magistratuum mercatura nie doszło $\mathrm{u}$ nas do przemiany jej $\mathrm{w}$ instytucję dziedziczną. Wszakże podobieństwo $\mathrm{z}$ tym urządzeniem daje ius communicativum. Prawnie dotyczyło ono tylko beneficjów sine iurisdictione. Czy jednak tak było bez wyjątku?

6. Ponieważ król polski nie miał prawa tworzenia nowych urzędów, nie powstawały ich niezmierzone krocia, jak to miało miejsce we Francji, gdzie je monarchia mnożyła w nieskończoność, ze względów wyłącznie fiskalnych. Nie znaczy to jednak, żeby w Polsce nie było zbędnych stanowisk. Były nimi wszystkie urzędy honorowe. A już $w$ armii mamy do czynienia z niewątpliwą hipertrofią szarż oficerskich, rozwijającą się kosztem stanu liczebnego armii.

7. Urzędy w Polsce były tanie. Prawda, że podaż ich była mała. Ale i popyt na nie nieduży, zważywszy na niezamożność kraju. Poza nieliczną warstwą, która mogła sobie pozwolić na kupno urzędów, większość, nawet szlachty, o nich marzyć nie mogła. To był próg nie do przekroczenia.

Jeśli we Francji kapital lokowany w urząd oprocentowany był na 5 czy nawet $4 \%$, to $w$ Polsce stanowił on nieznaczny wklad $w$ porównaniu z krociowymi wręcz sprzeniewierzeniami, które umożliwiało posiadanie urzędu. Niewątpliwie urzędy podrażała w pewnym stopniu konieczność dawania lapówek, bez których niełatwo było pozyskać jakąś dochodową dignitas. 
8. Sprzedawalność w Polsce nie odegrała tej spolecznej funkcji, jaką pełniła we Francji. Tam dzięki vénalité des offices burżuazja sięgnęła po władzę. Dysponując kapitałami i ciesząc się poparciem króla w postaci bardzo licznej noblesse de robe, obsadziła ona wszystkie stanowiska do najwyższych włącznie. Ona rządziła krajem, podczas gdy arystokracja ograniczała się do uświetnienia dworu królewskiego. W Polsce wszystkie stanowiska kupowała wyłącznie magnateria. Tylko ona dysponowała odpowiednimi środkami, tym samym miała ona faktyczny monopol na urzędy. To była faktyczna przeszkoda w dojściu do urzędu szaraczka, choć prawnie zagwarantowany miał równy dostęp.

Prawda, że magnateria licytowała się, ubiegając się o urzędy, ale była to licytacja $w$ ograniczonym kręgu. Ustawowy zakaz nadawania urzędów wyższych w jeden dom krępował ją w stopniu poważnym.

9. Choć we Francji sprzedawalność objęła gros urzędów, choć dzięki przemianie jej w dziedziczność ograniczała ona w znacznym stopniu absolutną władzę królewską, nie objęła ona stanowisk naczelnych w państwie, o charakterze czysto politycznym, które (według terminologii używanej w Polsce) nazwalibyśmy ministeria status. „Les grans vésirs” podlegali stale dyskrecjonalnej władzy monarszej. W Polsce kupione raz urzędy, choćby najwyższe, były dożywotnie. Każdy minister był samodzielnym, przed nikim nieodpowiedzialnym szefem swojego działu administracji. Monarcha $\mathrm{z}$ chwilą nadania godności tracił na nich wszelki wpływ, nie mogąc ich z urzędu zdjąć. Stąd to, rozumiejąc tragizm sytuacji, Jan Kazimierz (nie przesądzamy, w jakim stopniu odegrały tu rolę podszepty Marii Ludwiki) usiłował wprowadzić privatae submissiones, co jednak wyraźnie wykluczały pakta zredagowane dla jego następcy, widząc w tym - słusznie - niebezpieczeństwo dla warcholstwa arystokracji.

10. We Francji jawna sprzedawalność nie wykluczała fachowości kadr. Zamożnych kandydatów na urzędy było zbyt wielu, by monarchia nie mogła wybrać sobie $z$ nich elementu dobrego pod względem fachowym. Natomiast szczupłe grono osób, z których rekrutowali się polscy urzędnicy, nie dawało żadnych gwarancyj pod tym względem. Niefachowość jest od pewnego okresu regułą. Obsada stanowisk hetmańskich wylącznie przez wyjątkowe miernoty - nie mówiąc już o kwalifikacjach moralnych - w ciągu ostatnich stu lat niepodległej Polski jest tego najlepszym dowodem. Nie lepiej też przedstawiała się sprawa ze stanowiskami generalskimi - jak o tym świadczy casus generała artylerii, Szczęsnego Potockiego. Galeria podskarbich-przeniewierców jest nazbyt liczna. Niektórzy z nich otwarcie uprawiali rozbój, co nie pozbawiało ich stanowisk.

11. Dziedziczność urzędów, powstała we Francji w ostatniej fazie ich sprzedawalności, była gwarancją pewnej niezawisłości kadry urzędniczej wobec absolutnego monarchy. Tej niezawisłości urzędnika polskiego było 
już i tak za dużo. Sprzedawalność tworzyła więc dodatkowy czynnik anarchii polskiej: Polonia confusione regitur.

12. Monarcha francuski prowadził określoną politykę wobec urzędów. Przez ich inflacje sprawil, ze dochody, jakie dawał handel nimi, nie przechodziły do szkatuły prywatnej, lecz do kasy państwowej. Takiej świadomej polityki finansowej trudno dopatrzeć się u królów polskich. Niewątpliwie $\mathrm{i}$ oni ciągnęli korzyści $\mathrm{z}$ tego procederu. Jednakowoż gros pieniędzy, przelewanych $w$ związku $\mathrm{z}$ transakcjami, nie docierało $\mathrm{w}$ ogóle do kasy królewskiej, lecz ginęlo po drodze, wsiąkając m. in. w formie lapówek. Nie dawała też polska sprzedawalność monarsze stalych opłat w postaci analogicznej do paulette. Nadmiar szarż wojskowych nie wychodzil na korzyść skarbu: było to wyłącznie źródło korzyści dla oficerów kosztem uszczuplenia kadr żołnierskich, a tym samym osłabienia wartości bojowej armii.

13. W rezultacie jawna sprzedawalność, jaką wprowadzila monarchia francuska, okazala się dla państwa o wiele korzystniejsza niż tajna czy póljawna tylko, rozwinięta w Polsce.

Rzeczpospolita szlachecka stanowiła nie tylko w czasie bezkrólewia acephalus status ${ }^{463}$. Bezglowe państwo nie posiadało też innych organów, przede wszystkim zdrowej, urzędniczej kadry. Natomiast jego organy trawienne rozrosly się do gigantycznych rozmiarów. Rak prywaty stoczyl państwowość naszą $w$ calości.

${ }^{463}$ Określenie to zawiera denuncjacja śmierci Augusta II, VL, t. 6, s. 578. 



\section{Gwarancje osobiste w Polsce przedrozbiorowej*}

Niełatwo jest przedstawić zasadnicze linie rozwojowe tych instytucyj, które składają się na tzw. gwarancje osobiste, a tym bardziej dać syntetyczny rzut oka na ich ewolucję zbiorową. Trudności wynikają już $z$ tego faktu, że dzieje prawa prywatnego budza u nas małe zainteresowanie, a w szczególności historia obligacyj. Jedynie niektóre zagadnienia zostały w sposób dostateczny zbadane. Co więcej, nawet problemy, które doczekały się opracowania monograficznego, zostały po większej części zanalizowane tylko dla okresu średniowiecza. Epoka nowożytna leży niemal kompletnie odłogiem.

Wspomniane monografie, poświęcone prawu prywatnemu, zajmuja się przede wszystkim prawem ziemskim, to znaczy tym, którym rządzila się szlachta. Jak się wydaje, ono stanowi oryginalny twór miejscowy. Życie prawne społeczeństwa miejskiego znajduje się pod przeważającym wpływem prawa niemieckiego. Jego dzieje w Polsce mogłyby stanowić interesujący przedmiot niejednego studium. Ale praca ta jest jeszcze niemal w całości do zrobienia. Podobnie jest zresztą i z prawem wiejskim. Na wsiach Sakson również znalazł pełne zastosowanie. Wszakże w czasach nowożytnych wpływ dworu na rozwój prawa, nawet w dziale zobowiązań, stał się znaczny.

Dodajmy jeszcze, że zużytkowane przez nas monografie, jak i zresztą obszerna synteza (P. Dąbkowskiego) pochodzą z początku XX w. Można żywić poważne wątpliwości co do tego, czy odpowiadają one dzisiejszemu poziomowi wiedzy.

$\mathrm{Z}$ tymi zastrzeżeniami spróbujemy naszkicować podane w tytule zagadnienie. Zanim jednak do niego przejdziemy, przypomnimy pewne podstawowe rysy obligacyj średniowiecznych.

* Przedruk z: Zeszyly Naukowe Uniwersytetu Łódzkiego 1965, Ser. I, z. 42, s. 55-65. 
Po pierwsze, podstawowe dla prawnika rozróżnienie osób i rzeczy jest społeczeństwu średniowiecznemu obce. Człowieka - jednostkę fizyczną traktuje się jako rzecz; tym samym może on być przedmiotem prawa.

Po drugie, obligacje nie wyróżniają się zdecydowanie od praw rzeczowych, jak to jest dzisiaj. Wynikają $\mathrm{z}$ nich zobowiązania nie tylko dla kontrahentów, ale wiążą one $\mathrm{i}$ osoby trzecie, często $w$ znacznej liczbie. Innymi słowy, $\mathrm{z}$ punktu widzenia prawa ważna jest nie jednostka, lecz grupa.

Po trzecie, prawo cywilne i prawo karne stanowią jedno. Nietrudno sobie wyobrazić, jakie to pociągnęło za sobą następstwa dla stosunków zobowiązaniowych. Niewykonanie umowy spotyka się z taką samą sankcją, jak przestępstwo; w grę wchodzi w obydwu wypadkach odpowiedzialność osobista, ujęta bardzo surowo. Tym samym dłużnik, który nie zwraca należności wierzycielowi, jest uważany za przestępcę i tak jak on traktowany.

Wspomniane cechy średniowiecznego prawa odgrywają szczególną rolę $\mathrm{w}$ tej właśnie dziedzinie, która jest przeđmiotem naszego zainteresowania, tzn. gwarancyj osobistych.

Ramy chronologiczne niniejszego szkicu rozciągają się faktycznie od XIV w. (ze stuleci poprzednich liczba źródel prawnych jest zbyt nikła) aż do końca XVIII w. Dla obligacyj jest to niewątpliwie epoka przejściowa. Prawda, jest ona dość długa. Ten fakt wszakże nie może nas zdumiewać, gdy zważymy, że zajmujemy się okresem prawa zwyczajowego. W tym czasie wypracowują się nowe koncepcje prawne, które znalazly swój wyraz ostateczny w wielkich kodyfikacjach XIX w. One to usunęly rysy średniowieczne omawianych przez nas instytucyj. Sytuacja polityczna sprawiła, że nowe ujęcia przyszly do nas wraz $\mathrm{z}$ ustawodawstwem zaborczym.

Badany przez nas okres nie tylko cechuje się powolnością rozwoju. Ewolucja postępuje nierównomiernie, przebiega niejednolicie w rozmaitych regionach. Co więcej, nawet w tym samym okręgu występują równocześnie sposoby rozwiązań przeciwstawne. Jeden wierzyciel zadowala się jeszcze gwarancjami typu średniowiecznego, drugi żąda już zabezpieczenia nowoczesnego. Jeśli więc pragnie się przedstawić zasadniczy kierunek ewolucji, należy tego dokonać raczej w porządku logicznym, aniżeli chronologicznym. Chronologia absolutna prowadzilaby siłą rzeczy do chaosu, w którym instytucje dawne i nowe kłębiłyby się w taki sposób, że nie dałoby się ich nijak rozwiklać. Zamiast więc wyjaśnić proces historyczny, zaciemniłaby go zupełnie. 
Używamy pospolicie wyrażenia gwarancja osobista (sureté personnelle, persönliche Sicherheit), odpowiedzialność osobista. Tymczasem jest to niewątpliwie wieloznacznik, który posiada inne znaczenie $w$ średniowieczu, inne w dobie nowożytnej. Średniowieczna gwarancja osobista pociąga za sobą odpowiedzialność osobą w ścisłym tego słowa znaczeniu: człowiek odpowiada swym ciałem jako obiekt fizyczny; wyobrażano też sobie taką gwarancję, przy której jednostka odpowiada swoją duszą, swoimi walorami moralnymi. Biorąc na siebie gwarancję osobistą, człowiek średniowieczny wystawiał na ryzyko swoje ciało albo swoją duszę, albo obie te wartości równocześnie. Jeśli zobowiązaniu nie stanie się zadość, straci swoją głowę, swoją szyję czy rękę, albo też pewne wartości spoleczne niematerialne, jak wolność, względnie - zważywszy na religijny charakter myślenia średniowiecznego - swoją duszę, swoje zbawienie wieczne; rycerz ponadto mógł utracić swoją wiarę lub cześć.

Prawo nowoczesne nie dopuszcza w ogóle możliwości dysponowania wspomnianymi wartościami ludzkimi: ani ciało człowieka, ani jego wolność, wiara lub dusza nie mogą być przedmiotem transakcyj. Człowiek nowoczesny może zaciągać zobowiązania ważne $\mathrm{z}$ punktu widzenia prawa tylko w stosunku do własnego majątku. To mien i e rękojmi - pisze trafnie P. Dąbkowski - jest obciążone odpowiedzialnością, a nie jego osoba. Jeśli nawet ktoś zaciąga zobowiązanie na swoją duszę czy honor, to ma ono wartość tylko w porządku moralnym. Prawo nowoczesne nie tylko nie toleruje gwarancji cielesnej; ono ją będzie ścigać swymi sankcjami. - Tak więc gwarancja osobista kojarzy się z czymś innym w umyśle mediewisty, a z czymś innym w pojęciu prawnika nowoczesnego. Wina leży po stronie nieprecyzyjnej terminologii, która jednemu określnikowi przypisuje różne desygnaty.

Mimo to - trzeba zauważyć - obie te gwarancje osobiste, średniowieczną i nowoczesną, łączą rysy wspólne. Mianowicie i jedna, i druga dają wierzycielowi zabezpieczenie jego pretensji. Ich zatem funkcja, gospodarcza i prawna, jest ta sama. Co więcej, związane są one ze sobą genetycznie. Nowoczesne gwarancje osobiste weszly w miejsce gwarancyj osobistych średniowiecznych. Innymi słowy, odpowiedzialność materialna, majatkowa wyparła $w$ prawie cywilnym odpowiedzialność osobistą $\mathrm{w}$ ścisłym słowa znaczeniu.

\section{5}

Nasuwa się wszakże następujące zastrzeżenie. Omówione przejście od gwarancyj osobistych średniowiecznych do gwarancyj osobistych nowoczesnych, które - jak wiemy - są $w$ istocie nieosobiste, lecz materialne, nie jest równoznaczne ze zniesieniem całkowitym odpowiedzialności fizycznej człowieka 
w życiu prawnym. Utrzymuje się ona $w$ dalszym ciągu $w$ prawie karnym, a usunięta została tylko $\mathrm{z}$ prawa cywilnego. Ale prawo karne oddzieliło się od prawa cywilnego, $\mathrm{z}$ którym złączone było $\mathrm{w}$ średniowieczu, i stało się domeną prawa publicznego. Jesteśmy więc świadkami dwóch zjawisk odbywających się równocześnie: zanikaniu odpowiedzialności osobistej średniowiecznej $\mathrm{w}$ prawie cywilnym towarzyszy wydzielenie się prawa karnego $\mathrm{z}$ prawa prywatnego. Ta separacja stanowi niewątpliwe dobrodziejstwo dla prawa cywilnego. Uwolnione od przymierza $\mathrm{z}$ prawem karnym nabiera ono lekkości, nie uznaje żadnej sankcji cielesnej człowieka. Ta odpowiedzialność cielesna pozostaje właściwa tylko prawu karnemu.

Stwierdzając ten ważki proces historyczny, nie chcemy twierdzić, jakoby wszystkie cechy „karne” zostały obligacjom odjęte jednym pociągnięciem. Jeszcze długo utrzymuje się w nich myśl o zemście. Gdy już nawet karze się dłużnika tylko materialnie, miażdży się go dodatkowymi kosztami, które niejednokrotnie pozostają $w$ rażącej dysproporcji do długu. Długo też, bo aż do końca XVIII w., więzi się niewyplacalnych dłużników. Co prawda, pozbawienie ich wolności nie ma już na celu kary; uwięzienie staje się środkiem presji. Dłużnik wykonujący swe zobowiązanie odzyskuje natychmiast swoja wolność. Stwierdźmy, że ślady takiego ujęcia zna jeszcze dzisiejszy polski kodeks postępowania cywilnego (art. 1053).

\section{6}

Nieobca jest nam doktryna Karola von Amiry, który wyróżnia pojęcia długu i odpowiedzialności (Schuld przeciwstawiano Haftung). Polscy historycy prawa opowiadają się za nią chyba bez wyjątku. Nie zamierzamy jej tutaj kwestionować. Wszakże w badanym przez nas czasie odpowiedzialność dłużnika jest już rzeczą zwykłą. Zadomowiła się ona do tego stopnia w zwyczaju prawnym, że gwarancje osobiste, udzielane przez osoby trzecie, stwarzają tylko dodatkowe zabezpieczenie wierzyciela. Mimo to musimy stwierdzić pewne rysy zobowiązań, które najłatwiej wyjaśnić dawnym oddzieleniem długu i odpowiedzialności. Tym mianowicie tłumaczymy występowanie obok rękojemstwa za dług cudzy, tzw. rękojemstwa własnego (Selbstbürgschaft).

Do gwarancyj osobistych pierwszego okresu (tzn. okresu odpowiedzialności osobistej w znaczeniu ścisłym) zaliczymy: rękojemstwo, będące instytucją o charakterze najogólniejszym, utratę życia, środki zwrócone przeciw wolności w dwu wariantach: (1) zobowiazania sub servitute oraz (2) załoge, lajanie, przekleństwo i przysięgę. 
W okresie następnym (wyłącznej materialnej odpowiedzialności zobowiązanego) zachowały się tylko rękojemstwo i przysięga. Obok nich rodzi się nowy sposób gwarancji, zakład (vadium), rodzaj kary konwencjonalnej, umownej lub nakładanej przez władzę.

Rękojemstwo, istniejące od czasów niepamiętnych, jest pierwotnie zastawem osoby. Rękojmia (fideiussor) odpowiada tylko swoim cialem, jego majątek nie jest objęty zobowiązaniem. W dalszym rozwoju, jak wiemy, odpowiedzialność rękojmi stała się tylko majątkowa.

Ślady dawnej odpowiedzialności osobistej, cielesnej, sq widoczne w zobowiązaniach sub collo. Wierzyciel, zawierający tego rodzaju umowę, jest uprawniony do zabicia dłużnika, który nie wywiązuje się ze zobowiązania, bez narażenia się na odpowiedzialność karną czyli - co wychodzi na jedno - bez konieczności płacenia główszczyzny. Umowy takie pojawiają się tylko wyjątkowo w końcu średniowiecza: spotyka się je na Rusi w XV w. Być może, stały się takie postanowienia formułkami stylistycznymi. Jest bowiem rzeczą charakterystyczną, że w wielu wypadkach przewiduje się równocześnie odpowiedzialność majątkową dłużnika: se obligavit sub omnibus bonis ipsius et privatione colli. Być może, tylko ta pierwsza gwarancja ma znaczenie faktyczne. Dodajmy jeszcze, że nie znamy żadnego wypadku, w którym by wierzyciel rzeczywiście ze swego prawa do życia dłużnika korzystał.

Pierwotny charakter odpowiedzialności przejawia się też w zobowiązaniach sub servitute. Dłużnik stanu niższego, jego żona i dzieci stają się niewolnikami czy - później - poddanymi wierzyciela. Wierzyciel mógł ich sprzedać lub oddać w zastaw. Postanowienia tego rodzaju spotyka się jeszcze w XVI w.

Gwarancje, do których przechodzimy teraz, związane są ściśle z pojęciem czci rycerskiej; są to załoga i lajanie. Dłużnik, który popadł w zwłokę, jest zobowiązany udać się na żądanie wierzyciela do jego domu, później ad castrum regis. W ten sposób pozbawia się go wolności, w sposób zresztą, który nie uwlacza jego czci. Wszakże ten charakter osobistej kary zanika prędko. Akcent padać będzie coraz mocniej na ekonomiczne następstwa załogi: dlużnik musi udać się do oberży. Koszty pobytu w tym lokalu skłonić go mają do szybszego wypelnienia zobowiązania. Co więcej, żeby wzmocnić tę presję, ustala się z góry, ilu towarzyszy wejdzie razem z nim w załogę; nawet określa się liczbę koni, z którymi należy się stawić. Dalszym krokiem wynikającym z przesunięcia się odpowiedzialności osobistej na majątkową, będzic zaloga rękojmi, czy nawet załoga wierzyciela! Tu już aż nadto ewidentne, że nie pozostało $w$ instytucji już nic $z$ dawnej sankcji osobistej pozbawienia wolności. Załogę poświadczają źródła XIII w.; zanika ona ostatecznie $w$ drugiej polowie XVI stulecia.

Łajanie również jest związane $\mathrm{z}$ pojęciem honoru rycerskiego. Jak się wydaje, jest ono pochodzenia zachodniego. Pierwsze o nim wzmianki pochodzą z XIV w. Instytucja zanika również $w$ XVI w. 
Niewykonanie zobowiązania bywało też zagrożone przekleństwem. Ślady jego w źródłach pisanych są nikłe. Jego funkcje przejęła przysięga. Krzywoprzysiężcę spotka surowa kara ze strony potęg nadziemskich. Ten sposób gwarancji występuje najczęściej w umowach zawieranych przed organami kościelnymi, jak i w stosunkach międzynarodowych.

\section{8}

W czasach nowożytnych wszystkie te gwarancje osobiste albo zanikają, albo ulegają przemianom. Jedna tylko utrzymuje się bez zmiany: przysięga - $\mathrm{z}$ racyj, których nietrudno się domyślić. Zobowiązania sub collo, sub servitute tracą moc $\mathrm{z}$ punktu widzenia prawnego. Załoga stała się sposobem wywierania presji majątkowej, a zaginęła jeszcze w XVI w. W tym samym stuleciu wyszło ze zwyczaju łajanie. Rękojemstwo, stając się odpowiedzialnością za cudzy dług, przeszło w odpowiedzialność majątkową.

Wspomnieliśmy wyżej o nowym sposobie gwarancji: zakładzie (vadium). W przeważającej liczbie wypadków jest on narzucany przez organy władzy (starostę, sąd) w tym celu, by zmusić jedną stronę do dokonania czegoś lub wstrzymania jej od kroków nieprzyjaznych wobec drugiej. Wszakże odpowiedzialność, jaką wprowadza, jest natury czysto majątkowej: winny naruszenia zakładu będzie zmuszony do zapłacenia stronie pokrzywdzonej pewnej sumy pieniężnej. Jest atoli charakterystyczne, że wysokość zakładu równała się główszczyźnie szlachcica lub plebejusza. Pierwotnie uważano go więc widocznie za wykup głowy winnego. Później jednak ten związek zostanie zapomniany. Ale zakład utrzyma stale znamię surowej sankcji, ponieważ $\mathrm{z}$ reguły wynosi on podwójną wartość przedmiotu sporu.

Gwarancyj osobistych nie można zestawiać ze średniowiecznymi. W średniowieczu rola ich była ogromna. To nie była tylko instytucja prawa cywilnego. Pojawiały się one we wszystkich dziedzinach życia prawnego. Niewątpliwie także w prawie prywatnym. Ale obok tego w postępowaniu cywilnym i karnym, we wszystkich jego fazach; w prawie karnym; w działalności organów administracyjnych, $\mathrm{z}$ okazji zawiązywania stosunków międzystanowych; również w życiu międzynarodowym.

Tak szerokie zastosowanie gwarancyj osobistych thumaczy się latwo niedorozwojem państwa, brakiem należytych jego organów egzekucyjnych. Wiadomo przecież, że wykonanie wyroku stanowiło niegdyś problem, który wyjątkowo tylko dawał się rozstrzygnąć. Zależało ono, praktycznie rzecz 
biorąc, od dobrej woli strony, która przegrała proces. Tę wolę trzeba więc było umocować, albo ją zastąpić. Rola ta przypadła gwarancjom osobistym.

Ponieważ państwo nowoczesne dysponuje już dostatecznymi środkami przymusu, usuwa ono powoli $\mathrm{w}$ cień gwarancje osobiste $\mathrm{z}$ całych dziedzin życia prawnego. Ich ostatnim i w końcu jedynym schronieniem stanie się prawo cywilne; przynajmniej gdy chodzi o życie prawne wewnątrz państwa. Zmniejsza się też ich liczba: w praktyce utrzyma się tylko rękojemstwo. Przysięga, opierająca się o porządek nadnaturalny, nie może ulec transformacji, ale zaniknie w życiu świeckim.

\section{0}

Mówiliśmy o dużej roli gwarancyj osobistych. One rozszerzają pole stosunków gospodarczych; łagodzą surowe następstwa zadłużenia. Dzięki nim dłużnik unika niewoli czy zmiany w poddanego. Co więcej, umożliwiaja $\mathrm{mu}$ one zatrzymywanie $w$ ręku jego wlasnego majątku. Być może, że przyczyniały się także do zbliżenia się różnych klas społecznych: jednostki należące do różnych stanów występowały jako gwaranci za siebie samych. Dzięki rękojemstwu dochodzi do pewnej, acz względnej, wolności poddanych: moga oni zmienić miejsce pobytu pod warunkiem przedstawienia dawnemu panu wystarczających rękojmi. Rola postępowa rękojemstwa czy zakładu w prawie karnym jest wyraźna: strony spór wiodące zaciągają zobowiązanie, że nie będą uciekać się do zemsty prywatnej.

\section{1}

Pierwotnie jednostka, zaciągając zobowiązanie, stwarza obowiązki dla swoich krewnych, swego rodu czy rodziny. Obok więc gwarancyj dobrowolnych istnieją również gwarancje naturalne, powstające $\mathrm{z}$ mocy prawa przez działalność osoby trzeciej. Istnieją usiłowania zniesienia odpowiedzialności rodzinnej już w XIV w., wszakże utrzymuje się ona jeszcze znacznie później.

Odpowiedzialność ze zbiorowej przechodzi $w$ indywidualna, najpierw $w$ dziedzinie prawa cywilnego. Natomiast $w$ prawie karnym utrzymuje długo swój charakter kolektywny. Ale i tu się ją ogranicza, przede wszystkim do osób żyjących w niedziale. Wszakże odpowiadają one tylko majątkowo. Podobnie jest i z odpowiedzialnością spadkobiercy.

Odpowiedzialność zbiorowa osobista w znaczeniu ścisłym utrzymuje się odnośnie do przestępstw, które nazwalibyśmy politycznymi (zdrada, crimen laesae maiestatis, herezja). Dwie pierwsze zbrodnie przestały za sobą pociągać odpowiedzialność zbiorową dopiero w r. 1791. 
Zwalcza się także odpowiedzialność członków rodu. Ustawodawstwo czternastowieczne usiłuje ograniczyć vendettę jedynie do samej osoby winnej, $\mathrm{z}$ wyłączeniem jej krewnych (reum temptare et inspicere debebit, iustum vero non debebit impedire, statut mazowiecki 1377 r.). W ten sposób toruje się droge reakcji nowoczesnego państwa.

Długo utrzymuje się odpowiedzialność karna pewnych jednostek terytorialnych: opoli, wsi i miast. Opole, obejmujące kilka wsi, płaci główszczyznę za trupa znalezionego na jego terytorium. Poprzez zwolnienia immunitetowe odpowiedzialność ta zanika w XIV w. - Zaznaczmy, że jest ona zawsze odpowiedzialnością majątkową.

Ostatnie ślady podobnej odpowiedzialności wsi i miast datują się z XV w. Wszakże w miastach utrzymuje się odpowiedzialność osobista w ścisłym słowa znaczeniu jeszcze znacznie dlużej. Skazuje się na śmierć i wykonuje wyroki na radnych, lawnikach i starszych cechów z powodu nieopanowania zamieszek, w których zginął szlachcic. Podobne tumulty powodują uwięzienie radnych miejskich. Wypadki takie znamy jeszcze w XVIII w. Kiedy miasto zostanie obłożone banicją, wszyscy jego mieszkańcy tracą zdolność do działań prawnych. To przykre następstwo znosi się dopiero w końcu XVIII w.

Widać więc, że kolektywna odpowiedzialność za przestępstwa nie wygasła nigdy w całości. Co więcej, jak się wydaje, odradza się ona $w$ dobie nowożytnej w „państwach" szlacheckich. Panowie wprowadzają ją w swoich wsiach, by skutecznie walczyć z rozbojami. Jest to jedno świadectwo więcej wtórnego osłabienia państwa, które nie potrafiło opanować feudalizmu i zapewnić pokoju wewnątrz kraju.

\section{2}

Od rękojmi wymaga się tych samych kwalifikacyj, co od innych osób, wchodzących $w$ stosunki zobowiązaniowe. Ale żąda się od nich jeszcze więcej: by byli godni zaufania, by postępowali sine fraude et dolo. Rękojmia winien być sufficiens, a więc posiadać pewien majątek, zwłaszcza nieruchomy, ale także sklep czy warsztat. Nieruchomość winna leżeć w ziemi, w której mieszka wierzyciel.

Od rękojemstwa nie są wykluczone kobiety. Niejednokrotnie w charakterze rękojmi występują sędziowie czy rozjemcy, a więc osobistości o charakterze oficjalnym czy półoficjalnym.

Podział społeczeństwa na stany stwarzał dla gwarancyj osobistych zagadnienia szczególne. W wypadku rękojemstwa dobrowolnego przynależność rękojmi do innego stanu niż ten, z którego pochodzil wierzyciel, nie budziła zainteresowania prawa: wierzyciel broni sam najlepiej swych interesów. By zapobiec trudnościom, które mogły powstać $\mathrm{w}$ razie egzekucji, $\mathrm{z}$ góry 
zastrzega on sobie prorogatio fori. Gdy jednak chodzi o rękojemstwo wymagane przez sąd, może szlachcic $w$ sporze $z$ plebejem odmówić wejścia w proces, jeśli mu się nie przedstawi rękojmi-szlachcica. W dobie nowożytnej potrzebna jest zgoda pana na rękojemstwo poddanego, jeśli ono przekracza pewną kwotę.

Żydzi będący dlużnikami ex delicto przedstawiają jako gwarantów chrześcijan, i to nawet spośród osobistości znakomitych. Natomiast nie stają się oni nigdy rękojmiami w interesie chrześcijan.

Od rękojemstwa wykluczeni są ci, którym sąd zabronił się zadłużać, np. ojcowie żyjący $w$ niedziale. $Z$ innych przyczyn - kler zakonny. Jest rzeczą ciekawą, że król nigdy nie podejmuje się rękojemstwa, lecz zleca te zadania swoim urzędnikom. Nie istnieją zatem, żeby się uciec do określenia dzisiejszego, gwarancje finansowe państwa.

W epoce odpowiedzialności majątkowej gwarancja ciąży na wszystkich dobrach rękojmi. Wyłączone są $\mathrm{z}$ niej zarówno posag żony, jak i wiano. Zobowiązania panów nie powinny - według statutów Kazimierzowskich - obciążać ich poddanych.

Aż do początków doby nowożytnej utrzymuje się przekonanie, że dlużnik, przedstawiając wierzycielowi rękojmię, solvit. Przy takim zapatrywaniu jest rzeczą widoczną, że nie powstaje żaden stosunek zobowiązaniowy między nim a wierzycielem. Jedynie tworzy sį̨ odpowiedzialność rękojmi wobec wierzyciela. W tej sytuacji, gdy dłużnik spłaca swój dług, czyni on coś, do czego nie jest zobowiązany, tym samym nie uwalnia przez to rękojmi. Wszakże taki pogląd zwalcza się już w XIV w.

Ponieważ istnieje prawnie tylko jed no zobowiązanie, rękojmi, jest ono siłą rzeczy niezawisle, nie pozostaje $w$ żadnym związku $z$ pierwotnym długiem, który już wygasl. Wierzyciel przeto może domagać się od rękojmi, by uregulowal swe zobowiązanie natychmiast, rękojmia może też przystąpić do zaplaty $z$ wlasnej inicjatywy. By temu zapobiec, dorzuca się do umowy zastrzeżenia, które zakazują takiej zapłaty bez zgody dłużnika.

Jeśli wierzyciel pozwie do sądu dhużnika, ten korzysta - jeśli się wolno tak wyrazić $-z$ beneficium discussionis: odeśle po prostu powoda do rękojmi. Czasem nawet taki pozew dhużnika przez wierzyciela przyprawi ostatniego o stratę rękojmi.

Niejednokrotnie dłużnik zobowiązuje się sam zostać rękojmią za własny dług (Selbstbürgschaft). W ten sposób, jak należy sądzić, tworzy się nowy pogląd o bezpośredniej odpowiedzialności dłużnika za jego własny dług. Powoli staje się on powszechny: należy się domyślać tej odpowiedzialności 
dlużnika, nawet gdy w umowie brak odpowiedniego zastrzeżenia. $\mathrm{Z}$ początkiem doby nowożytnej odpowiedzialność dłużnika za dług jest faktem dokonanym. Pociąga to za sobą poważne następstwa. A mianowicie, odpowiedzialność osobista dłużnika (w sensie średniowiecznym) utrzyma się jeszcze w epoce nowożytnej, choć taż sama odpowiedzialność rękojmi wygasa już w całości.

\section{4}

W epoce, z której zachowały się przekazy źródłowe, rękojmia zobowiązuje się dostarczyć wierzycielowi dłużnika żywego czy martwego, vivum vel mortuum (Gestellungsbürgschaft). Ten rodzaj zobowiązania ulega jednak zanikowi; utrzyma się dłużej jedynie w postępowaniu karnym.

Wierzyciel domaga się teraz nie zemsty, lecz zaspokojenia swej pretensji pieniężnej. Żąda przeto od rękojmi, by wywarł presję na dłużnika, presję, która by go skłoniła do zapłaty. Rękojmia, dotychczasowy przyjaciel dłużnika, zawiedziony przezeń, przystępuje do działania: on się zaczyna mścić; miażdży dhużnika wszelkimi dostępnymi sobie środkami ad hospicium in obstagium subintrare aut aliqua dampna facere, non solventis in destructionem - stwierdzają statuty Kazimierzowskie. Przeciwko nadużywaniu presji występuje już ustawodawstwo czternastowieczne. Rękojmi wolno tylko wziąć zastaw u dhużnika albo zająć nieruchomość, by ją przekazać wierzycielowi bez interwencji sądu.

Czasem odpowiedzialność gwaranta jest ujęta inaczej: odpowiada on tamquam debitor principalis. Ponieważ dlużnik stał się odpowiedzialny za dług, ponieważ rękojmia stał się dłużnikiem głównym, role ich obydwu pomieszały się zupełnie, o czym świadczy terminologia źródel, które mówią o obydwóch, że ręczą (fideiubent). Odtąd dług wygasa już przez czyjekolwiek świadczenie dhużnika czy rękojmi. Wszakże wierzycielowi nie wolno jeszcze pozywać dłużnika przed sąd; odpowiedzialność jego pozostaje w fazie, żeby się tak wyrazić, obligatio naturalis. Ale i ta ma już duże znaczenie dla odpowiedzialności rękojmi. Niegdyś była ona bezpośrednia, skoro była jedyna i wyłączna. Obecnie pozostaje $w$ zawieszeniu aż do terminu płatności, przewidzianego w umowie. Dopiero w tym momencie nabiera mocy obowiązującej.

Jak długo odpowiedzialność rękojmi jest wyłączna, różni się ona od dhugu. Rękojmia doprowadza dłużnika do rąk wierzyciela lub do sądu, zajmuje jego mienie, by je wręczyć wierzycielowi. Skoro tych czynności dokonal, staje się wolny od odpowiedzialności, nawet gdyby dlużnik nie 
zaspokoił wierzyciela w części czy w całości. Rękojmia staje się odpowiedzialny majątkowo dopiero wtedy, gdy nie wypełni swego zadania. Ale wówczas odpowiedzialność jego nie sięga wyżej niż wynoszą aktywa dłużnika. Kiedy rękojmia wystąpi tamquam debitor principalis, jego odpowiedzialność staje się pełna. $\mathrm{W}$ ten sposób pokrywa się ona $\mathrm{w}$ końcu $\mathrm{z}$ wysokością dhugu.

\section{6}

Rękojemstwo było w zasadzie aktem darmym. Krewni byli obowiązani pomagać swoim krewnym. Z drugiej strony, dłużnik winien jest rękojmi dobrą wiarę. $Z$ tej zasady wypływają następstwa, których nie zawsze zastrzegano wyraźnie w umowach. Rękojmia zobowiązuje się sub dampno. Dłużnik nie powinien dopuścić, by wierzyciel go niepokoił. Jeśli rękojmia poniesie na skutek rękojemstwa jakąś szkodę, dłużnik winien ją wynagrodzić, zwrócić wszelkie powstałe koszta, fideiussores indempnes reddere. Czasami ta odpowiedzialność dłużnika idzie dalej: zobowiązuje się on wobec rękojmi sub omnibus bonis ipsius et privatione colli. Rękojmia pozwany przez wierzyciela przed sąd domaga się intercesji dłużnika głównego (recipe ad principalem), ale na nią musi wierzyciel wyrazić swą zgodę. Tej zgody może odmówić, co się zdarza jeszcze w XV w.: nihil scio de te, nisi omne bonum - odpowiada wierzyciel dłużnikowi głównemu - sed asto termino super [...] fideiussorem meum. $\mathrm{Z}$ czasem beneficium discussionis staje się prawem absolutnym rękojmi. Z drugiej strony, dłużnik może domagać się od rękojmi informacji o jego zamiarach, przede wszystkim w toku procesu. W przeciwnym razie rękojmia straci wszystkie prawa do odszkodowania.

\section{7}

W wypadku wielości rękojmi, odpowiadają oni bądź manu coniuncta, bądź manu divisa, pro parte rata. Pierwszy sposób odpowiedzialności jest dawniejszy. Jego należy się domniemywać, gdy nie ma innego postanowienia. Rękojmie zaspokajają wierzyciela wszyscy razem, wszyscy wstępują w załogę, wierzyciel jest zobowiązany pozwać ich wszystkich przed sąd. Jeśli pozwie jednego tylko rękojmię, ten może odmówić wdania się w spór.

W miejsce takiego ujęcia wchodzi z czasem inne: wystarczy, by jeden rękojmia zaspokoil wierzyciela, by wierzyciel jednego tylko rękojmię pozwal do sądu. Innymi słowy, dotychczasowa odpowiedzialność ręką pospólną przechodzi w odpowiedzialność solidarną.

Rękojemstwo pro parte rata jest późniejszej daty i znajduje rzadziej zastosowanie. 
Jest rzeczą jasną, że rękojemstwo zbiorowe ręką pospólną nie stwarzało żadnych roszczeń dla poszczególnych rękojmi. Problem rodzi się dopiero $\mathrm{z}$ chwilą wytworzenia się odpowiedzialności solidarnej rękojmi. Wówczas to rękojmia, który zaspokoił ze swego majątku wierzyciela, zgłasza swe pretensje do współrękojmi. Może $\mathrm{z}$ nim wszakże wystąpić tylko wtedy, gdy działał $\mathrm{z}$ ich upoważnienia, lub co najmniej wezwał ich do sądu.

Rękojemstwo ręką podzieloną nie stwarza w ogóle zagadnienia wyrównywania pretensji między rękojmiami.

W okresie odpowiedzialności osobistej w ścisłym znaczeniu, zgon rękojmi pociągał za sobą wygaśnięcie rękojemstwa, podczas gdy śmierć dłużnika nie wywoływała w stosunku rękojemczym żadnych następstw. Gdy odpowiedzialność stała się majątkowa, przechodzi ona na dziedziców rękojmi. Rękojemstwo wygasa nieraz jakby za karę, mianowicie gdy wierzyciel żąda zaspokojenia od dhuznika głównego zamiast od rękojmi. Zgaśnięcie rękojemstwa następuje też przez zrzeczenie się ze strony wierzyciela.

Zwyczajnie rękojemstwo wygasa przez zaspokojenie wierzyciela przez rękojmię. Przez długi czas, tylko przez niego. Dłużnik zaspokajający wierzyciela nie uwalnia swego rękojmi, chyba żeby to robił poprzez niego. W późniejszej dobie dłużnik główny może również zaspokoić wierzyciela bezpośrednio, z wszelkimi skutkami prawnymi. Wszakże wierzyciel musi formalnie zwolnić rękojmię $\mathrm{z}$ odpowiedzialności; zwolnienie to nie następuje więc automatycznie. W końcu oświadczenie wierzyciela o zwolnieniu rękojmi nie jest wymagane. Tym samym więc wygaśnięcie zobowiązania głównego pociąga za sobą wygaśnięcie rękojemstwa.

Jeśli zobowiązanie polegało na non facere, ustalano czasokres trwania rękojemstwa; po jego uplywie wygasało ono automatycznie.

Znano także sposoby nadzwyczajne wygaśnięcia stosunku rękojemczego, np. przez wydanie listów królewskich.

Dodajmy jeszcze, że rękojemstwo mogło ulec zawieszeniu przez moratorium udzielone dłużnikowi.

Przedstawiony szkic rozwojowy gwarancyj osobistych pozwala na wysnucie trzech ostrożnych wniosków: 
$1^{\circ} \mathrm{W}$ omawianej przez nas epoce, od XIV do XVIII w., zanikają gwarancje osobiste $w$ ścisłym znaczeniu slowa. W ich miejsce wchodzą tzw. gwarancje osobiste, które w istocie oznaczają odpowiedzialność majątkową gwaranta.

$2^{\circ}$ We wskazanym okresie mamy do czynienia ze zjawiskiem indywidualizacji stosunków prawnych. Prowadzi ono powoli do zaniku gwarancyj naturainych o charakterze kolektywnym.

$3^{\circ}$ Dokonuje się rozdział między prawem cywilnym i prawem karnym z wszystkimi następstwami dobroczynnymi dla prawa prywatnego: nie uznaje ono więcej odpowiedzialności osobistej pierwotnej.

Te wszystkie przemiany oczyściły pole dla ustawodawstwa nowoczesnego, opierającego się na nowych koncepcjach prawnych. Znalazły one swój ostateczny wyraz w wielkich kodyfikacjach XIX w., wśród których na pierwsze miejsce wybija się niewątpliwie Code civil. Rozbiory kraju uniemożliwily Polakom stworzenie własnych ustaw, odpowiadających nowym poglądom. Na ziemie nasze wprowadzily nowoczesne kodyfikacje państwa obce. 



\section{La preuve en droit polonais du Moyen Age et des Temps modernes*1}

L'étude se restreint à une partie de la Pologne, celle de la "Couronne», en laissant de côté le droit de la Lithuanie. Le Grand-Duché, uni à la Pologne vers la fin du XIV ${ }^{c}$ siècle, garda son indépendance à beaucoup d'égards, dans le domaine juridique en particulier ${ }^{2}$.

Le procès polonais ne se rapportait qu'à la noblesse. Les plebei, donc les bourgeois et les vilains, ont reçu, dès le moyen âge, le ius Theutonicum, d'origine saxonne. Ce droit, demeurant toujours coutumier, fut influencé, dans une certaine mesure, par le droit polonais. Néanmoins, ses traits originaux saxons restèrent toujours prédominants. Puisqu'un rapport concernant le droit saxon est prévu dans le programme, nous ne voulons pas empiéter sur ce terrain ${ }^{3}$.

Il faut constater une certaine uniformité du procès polonais durant toute l'époque envisagée. Il garde constamment son caractère médiéval. La Renaissance et le droit romain effleurèrent à peine le procès de Pologne. Ce n'est qu'à partir du milieu du XVIII ${ }^{\mathfrak{c}}$ siècle que la modernisation $\mathrm{du}$ droit commence à se manifester. Jusqu'à ce moment, on entrevoit, non sans difficulté, la distinction du procès en matière civile de celui en matière pénale. Les partages mirent fin à l'évolution originale du procès.

Ceci dit, on est loin d'affirmer qu'il n'y a eu aucun développement dans le système des preuves. Notons, en premier lieu, la disparition des ordalies, méconnues déjà des statuts de Casimir le Grand (milieu du XIV siècle), mais le duel judiciaire fut pratiqué, maintes fois, après cette date. Signalons aussi un certain renouveau de l'examen aquae frigidae dans de nombreux procès, très en vogue aux $\mathrm{XVII}^{\mathrm{e}}$ et $\mathrm{XVIII}^{\mathrm{e}}$ siècles, intents contre les sorcières. Ils furent formellement supprimés en 1776, mais on en relève encore des exemples plus tard.

* Przedruk z: Recueils de la Société Jean Bodin, t. 17: La preuve, Bruxelles 1965, s. 591-594.

1 Résumé du rapport présenté à la session de la Société Jean Bodin.

${ }^{2}$ Cf. J. Deveike, infra, p. 595 et ss.

${ }^{3}$ Cr. G. Buchda, supra, p. 519 et ss. 
Bien que la Formula processus (1523) modérât, dans une certaine mesure, le formalisme des preuves, elle laissa intacts les principes médiévaux du procès. L'accroissement du rôle des témoins oculaires et celui de la preuve écrite se laissent sentir. Cette dernière devient de règle pour les affaires importantes, surtout relatives aux immeubles. La preuve par les cojureurs s'éclipse; ils se maintiennent toutefois jusqu'à la fin.

Le procès d'inquisition fut introduit devant les tribunaux des villes et dans les juridictions seigneuriales. Cependant, la noblesse résiste, non sans succès, à son application dans les procès contre elle-même. Une sorte d'enquête (le scrutinium) apparaît vers la fin du $\mathrm{XVI}^{\mathrm{e}}$ siècle; son champ d'action demeura, du reste, restreint. Au déclin de l'ancienne république nobiliaire, le procès oral fut remplacé par le procès littéral, mais devant certaines juridictions seulement.

Parmi les preuves, une seule prime: l'aveu, qui rend superflues les autres. Sous l'influence du droit allemand, on adopte la torture, qui ne fut supprimée qu'en l'an 1776. Parmi les preuves irrationnelles, sont à mentionner celle par l'eau bouillante, par l'eau froide, par le fer rouge et par le duel. Le serment, prouvant, pour la plupart, le fait négatif, était prêté sur la croix ou sur l'évangile. Un mode nouveau apparaît, dans les sources, au milieu du XV siècle, le serment sur le soleil, réservé d'abord à la noblesse. Remarquons l'existence d'un serment moins solennel, recipere super animam, dans les litiges de moindre importance. Le serment lui-même garde toujours le caractère du jugement de Dieu, puisque celui qui le prête peut aisément se tromper dans la prononciation des mots préétablis.

Le terme testes était employé dans deux acceptions: des cojureurs - testes qui sciunt - et des témoins au sens exact du mot - testes qui fuerunt praesentes - Les cojureurs se maintiennent jusqu'au XVIII ${ }^{c}$ siècle. Le serment propre, ainsi que celui des compurgateurs, furent prêtés en présence de l'adversaire et pour lui seulement. En son absence, cette preuve fut considérée comme superflue et le fait comme ètabli.

Le nombre des témoins varia selon la gravité du crime. Un personnage d'importance vaut plusieurs témoins; on en arrive à une équation: 1 prince $=1$ évêque $=2$ castellans $=6$ témoins ordinaires.

Il y a des témoins privilégiés tels l'huissier du tribunal, l'abbé-confesseur. Le témoignage reste longtemps facultatif; en 1496, il devient obligatoire, en matière pénale pour le moins.

L'utilisation des experts, bien développée dans les villes, est connue, à ce qu'il paraît, seulement dans les litiges relatifs aux limites entre les biens-fonds. On convoque alors les "vieux" du voisinage.

Pour les coupables pris en flagrant délit, il existe un procès très raccourci. On connaît également son prolongement, une perquisition effectuée dans les formes prescrites par la coutume, permettant d'indiquer le coupable nanti de la chose volée. 
On observe l'accroissement continu de l'application de la preuve par écrit, surtout de l'acte public. Ainsi, pour s'en assurer la disposition, on enregistre les actes privés devant les tribunaux jusqu'à ce que la pratique réitérée et générale emportât la conviction que cette forme solennelle était indispensable pour la validité de l'acte. Elle devient de règle pour toutes les dispositions relatives aux biens nobles.

Les preuves ne sont pas toutes du même rang. Celui-ci varie, du reste, avec le temps. En cas d'égalité des preuves proposées - l'habitude se maintient jusqu'au XVIII ${ }^{e}$ siècle - c'est le negans non affirmans propior est ad probandum. La règle n'est pas de rigueur, elle connaît maintes exceptions. Il existe même des situations où l'accusé n'est point admis à se disculper; il est condamné à la suite d'une simple assertion de l'accusateur. 


\section{Recepcja prawa niemieckiego w Polsce i na Litwie*}

Dwa były ośrodki promieniowania kulturalnego w średniowieczu: Rzym

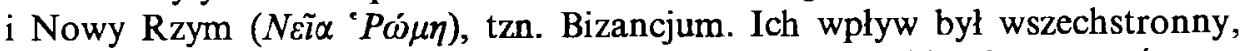
przejawil się także m. in. w dziedzinie prawnej, przybierając postać tzw. recepcji praw.

Źródłem ich były dwa najwyższe, a powszechnie uznawane autorytety średniowiecza: duchowny i świecki, kościól i cesarstwo. Kompetencje ich nie zostały nigdy rozgraniczone. Zresztą kościół ówczesny był ścis̉le związany $\mathrm{z}$ państwem. Ze względu na religijny charakter kultury średniowiecza, rola kościoła byla doniosła. Zrozumiała przeto była waga chrystianizacji kraju. Pociągała ona za sobą ,zupełny przewrót we wszystkich sferach życia prawnego"!.

Ponieważ organizacja świecka, jak i złączona z nią organizacja kościelna, rozbite były na dwa odłamy, ośrodki promieniowania występowały w liczbie podwojonej: rzymski i bizantyjski kościól, rzymskie i bizantyjskie cesarstwo. Tam, gdzie sięgały instytucje cesarstwa lacińskiego, rozprzestrzeniało się i prawo kanoniczne kościoła rzymskiego ${ }^{2}$. Gdzie panowały kanony obrządku wschodniego, tam za wzór służyło prawodawstwo cesarstwa greckiego ${ }^{3}$. Jest to zasadniczy podzial ówczesnej Europy na dwa prawne kręgi kulturowe: katolicko-rzymski i ortodoksyjno-grecki.

Pierwszy obejmuje cały zachód europejski i północ; drugi - wschód i bałkańskie południe. Linię orientacyjną, dzieląca Europę na te dwie strefy, uwidacznia zalączona mapka 1 . Jak $\mathrm{z}$ niej widać, przedziela ona świat słowiański, $i$ to $w$ ten sposób, że Słowianie wschodni i poludniowi ulegli wpływom bizantyjskim, zaś Słowianie zachodni - rzymskim ${ }^{4}$.

* Przedruk z: Sprawozdania z Czynności i Posiedzeń Naukowych Lódzkiego Towarzystwa Naukowego 1966 , t. 20 , nr 9, s. $1-9$.

${ }^{1}$ M. F. Wladimirskij-Budanow, Obzor istorii ruskawo prawa, s. 93.

${ }^{2}$ Do rzymskich kodylikacji nie można nie zaliczyć dzieła Justyniana, choć powstało ono w Konstantynopolu. Renesans studiów nad tą kodyfikacją, tak istotny dla rozwoju europejskiego prawa $w$ późnym średniowieczu, dokonał się na Zachodzie (we Włoszech).

${ }^{3}$ Por. W. Abraham, Powstanie organizacji Kościola lacińskiego na Rusi, t. 1, Lwów 1904, s. 39; S. Kutrzeba, Kilka uwag o recepcji w prawie, odb. z Ksiegi Pam. ku czci L. Pinińskiego, Lwów 1936, s. 7.

${ }_{4}^{4}$ Takie było następstwo nie uwieńczonej powodzeniem misji apostołów greckich Cyryla i Metodego. 


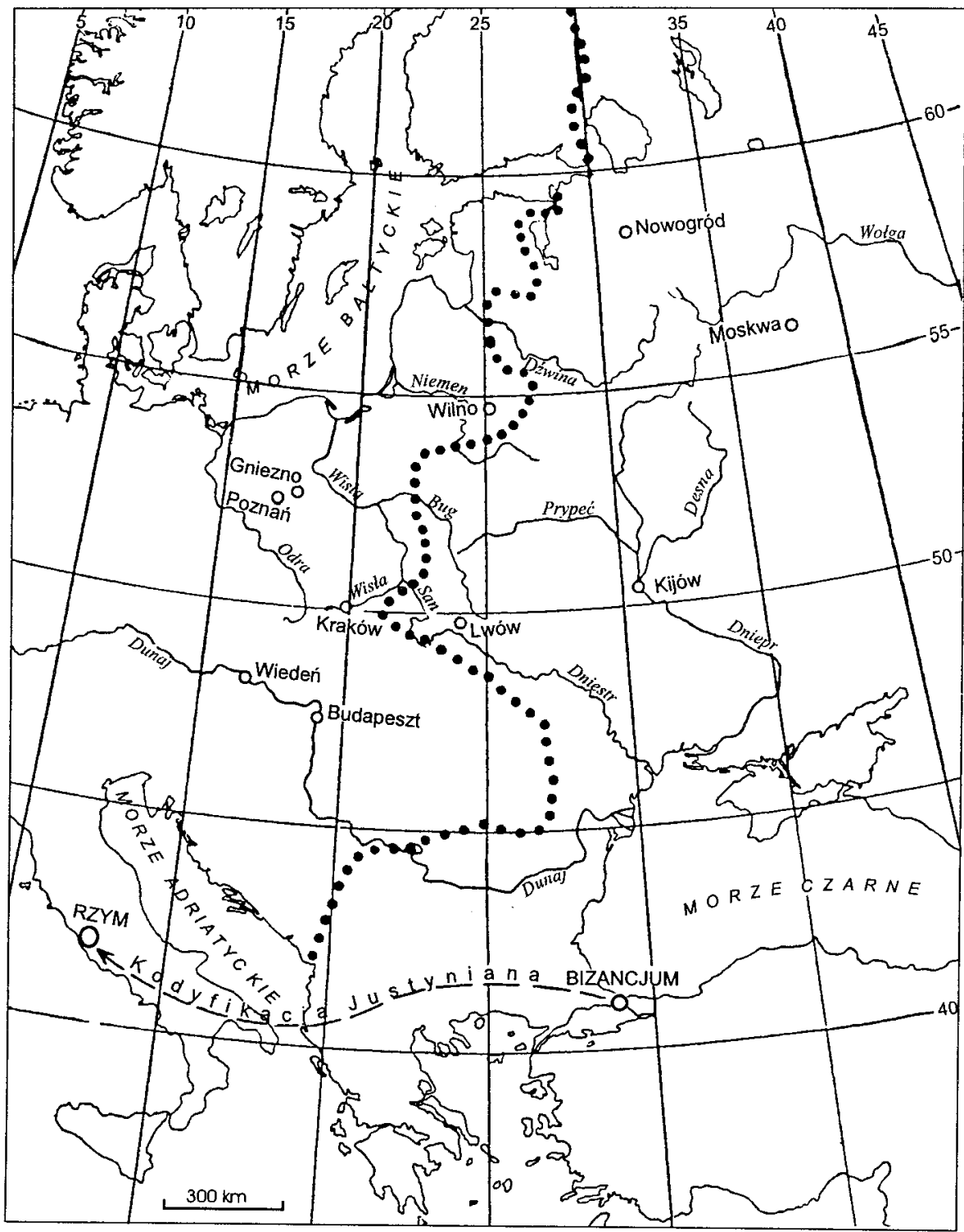

Mapka 1: Granica wpływów Rzymu i Bizancjum 
Tym samym Polska znalazła się w zasięgu i prawa rzymskiego, i prawa kanonicznego łacińskiego. Wraz $\mathrm{z}$ ustaleniem się katolickiej organizacji kościelnej, recypowano także jej prawo, acz nie calkowicie, jak to dawniej przyjmowano ${ }^{5}$. Natomiast mimo pewnej penetracji rzymskiego prawa ${ }^{6}$, do jego recepcji nie doszlo w Polsce nigdy. Co więcej, jego znaczenie wyraźnie zmalało od końca XVI w., tak że w końcu polskie prawo ziemskie - prawo szlachty - w odróżnieniu od sąsiednich Niemiec, oparło się zwycięsko obcej kodyfikacji ${ }^{7}$. Inna rzecz, że mu to nie wyszło na dobre.

Pokazany prosty obraz dwu stref prawnych zamącony zostal przez dodatkowe zjawisko, które wystąpiło już w średniowieczu, a nie przestało działać jeszcze długo w dobie nowożytnej. Mianowicie Europa Środkowa znalazla się pod dodatkowym wplywem prawnym idącym z Zachodu. Obok prawa kanonicznego i rzymskiego penetrować tu zaczęło równocześnie ius theutonicum, prawo niemieckie. Objęło ono swym zasięgiem i Polskę. Co charakterystyczne, przenikanie jego na wschód nie zatrzymało się na granicy kręgu rzymskiego, lecz ją przekroczyło na znacznych obszarach.

Podkreślaliśmy wyżej, jak to wpływy kulturalne szły w parze $z$ wpływami politycznymi. Z krajów zamieszkałych przez Słowian zachodnich najbardziej na wschód jest wysunięta Polska. Ona tymczasem po zjednoczeniu się w XIV w. zaczyna poszerzać swe dzierżawy na wschodnich swych rubieżach, wchłaniając plemiona ruskie. Kazimierz Wielki podporządkowal sobie bezpośrednio Ruś Czerwoną i zhołdowal Moldawię. pochód prawa niemieckiego'. Pod tym względem jeszcze donioślejszy był fakt zawarcia przez Polskę unii z Wielkim Księstwem Litewskim ${ }^{10}$. Litwa przestała być pogańska. Jagiełło przyjmując chrzest od duchownych łacińskich, tym samym podporządkowal swój kraj wpływom idącym z Zachodu.

5 Por. J. Matuszewski, Ustawy de illegitima prole, „Sprawozd. PTPN", nr 72, 1964, s. 209-210, oraz KH, t. 72, 1965 , s. 955-956.

' $\mathrm{S}$. Kutrzeba, Il diritto romano in Polonia fino alla fine del secolo decimoottavo, Roma 1936, s. 62-69; R. Taubenschlag, Einflüsse des römischen Rechts in Polen, Mediolani 1962, s. 7 nn.

${ }^{7}$ L'influenza di questo diritto su quello polacco non è stata, in linea generale, troppo rilevante", Kutrzeba, Il diritto..., s. 70-73; tamże wypowiedź Rojzjusza o niechęci Polaków do stosowania prawa rzymskiego, s. 77.

${ }^{8}$ Z. Kaczmarczyk, Polska czasów Kazimierza Wielkiego, Kraków 1964, s. 61 nn., 163-165, oraz załączone tamże mapki po s. 16 i 32.

${ }^{9}$ R. F. Kaindl, Geschichte der Deutschen in den Karpathenländern, t. 1, Geschichte der Deutschen in Galizien bis 1772, Gotha 1907; tamże załączona mapka. Oczywiście nie wyklucza to, by prawo niemieckie nie pojawiło się sporadycznie na Rusi już wcześniej, s. 32-33; tak też F. Taranowskij, Obzor pamiatnikow magdieburskawo prawa zapadno-russkich gorodow litowskoi epochi, Warszawa 1897, s. 17; A. Jakowliw, Das deutsche Recht in der Ukraine und seine Einflüsse auf das ukrainische Recht im 16.-18. Jahrhundert, Leipzig 1942, s. 11.

${ }^{10}$ R. Roepell, Utber die Verbreitung des Magdeburger Stadtrechts im Gebiete des alten polnischen Reichs ostwärts der Weichsel, Abhandlungen der Histor.-Phil. Gesellschaft in Breslau, 1. 1, Wrocław 1857, s. 244. 
Państwo litewskie $\mathrm{z}$ końca XIV w. składało się w dużej mierze $\mathrm{z}$ terytoriów ruskich (por. mapka 2).

Tym samym polączenie się Litwy z Polską poddało $i$ te ruskie tereny bezpośrednim wpływom polskim, $\mathrm{m}$. in. także $w$ dziedzinie prawnej. Za wzorem polskim - zarówno na Litwie, jak i w jej ruskich dzierżawach - rozprzestrzeniać się poczęla lacińska organizacja kościelna (arcybiskupstwo w Haliczu, 1374 r. - przeniesione później do Lwowa, biskupstwa huckie, kijowskie, wileńskie i żmudzkie) i polski ustrój administracyjny (podział na województwa i kasztelanie), ale też przeniesione zostało - co nas tu interesuje szczególnie - prawo niemieckie" .

Już dawno temu podkreślano związek między pojawieniem się prawa niemieckiego na Litwie a unią tego kraju z Polską ${ }^{12}$. Dowodzi tego jaskrawo zestawienie następujących dat: unia krewska 1385 r., chrzest Litwy 1386 r., lokacja Wilna na prawie niemieckim $1387 \mathrm{r}^{13} \mathrm{~W}$ ciągu XV i XVI w. duża liczba miast litewsko-ruskich otrzymała prawo magdeburskie (Kijów, Kowno, Czernichów, Starodub, Kozielsk, Perejasław, Bracław, Kaniów, Kamieniec Podolski, Kowel, Łuck, Proskirów, Żytomierz, Połock, Shuck, Witebsk, Mińsk, Grodno, Wołkowysk, Brześć Lit., Nowogródek, Włodzimierz, Troki, Turzyska, Kamieniec Lit., Mozyrz, Pińsk, Dzisna, Narwa, Mohylew) ${ }^{14}$. Śladem jego są zachowane archiwalia niektórych miast ${ }^{15}$.

Podkreślmy fakt, że prawo niemieckie nie przekroczyło granic państwa litewskiego. Nie znamy żadnego miasta na wschód od nich leżącego, które by recypowało prawo magdeburskie ${ }^{16}$. Tak więc sukcesy polityczne państwa polsko-litewskiego oznaczały równocześnie zwycięski pochód prawa niemieckiego. Polsko-litewska Rzeczpospolita szlachecka okazała się czynnikiem rozprzestrzeniającym urządzenia prawa magdeburskiego ${ }^{17}$.

"Ibidem, s. 244; szczegóły u Abrahama, pozycja cytowana w przyp. 3.

12 M. F. Wladimirskij-Budanow, Niemieckoje prawo $w$ Polsze $i$ na Lilwie, S. Peterburg 1868, s. 6; Taranowskij, Obzor, s. 18; I. Jaworski, Studia nad ustrojem miast na prawie niemieckim w Wielkim Ksiestwie Litewskim $w$ dobie jagiellońskiej, Rocz. Prawniczy Wileński, R. 5, Wilno 1931, s. 1; Jakowliw, op. cit., s. 2, 13.

${ }^{13}$ P. Dubiński, Zebranie praw, przywilejów... miastu stolecznemu Wilnowi laskawie nadanych, 1788; Jaworski, Studia, s. 4.

${ }^{14}$ Zestawienie daje Roepell, Über die Verbreilung, s. 267-301, oraz S. Wyslouch, Poslugi komunikacyjne $w$ miastach $W$. Ks. Litewskiego na prawie magdeburskim do polowy XVI w., s. 67-78. Najpehniejsze zestawienie miast $z$ magdeburgia z podziałem na stulecia daje Jakowliw, op. cit., s. 12.

15 Zestawienia dokonal A. Halban, Zur Geschichte des deutschen Rechtes in Podolien, Wolhynien und der Ukraine, Berlin 1896, s. 2-14; ob. też recenzje tego dzieła: A. R., Bibl. Warsz. 1897 , t. 4 , s. 543-549.

${ }^{16}$ Kaindl silnie podkreśla, że nie znano prawa niemieckiego w Moskwie i Nowogrodzie, mimo, że byli tam Niemcy, op. cil., s. 96.

${ }^{17}$ S. Kutrzeba, Historia ustroju Polski w zarysie, t. 2: Litwa, Lwów 1914, s. 97, 100. 


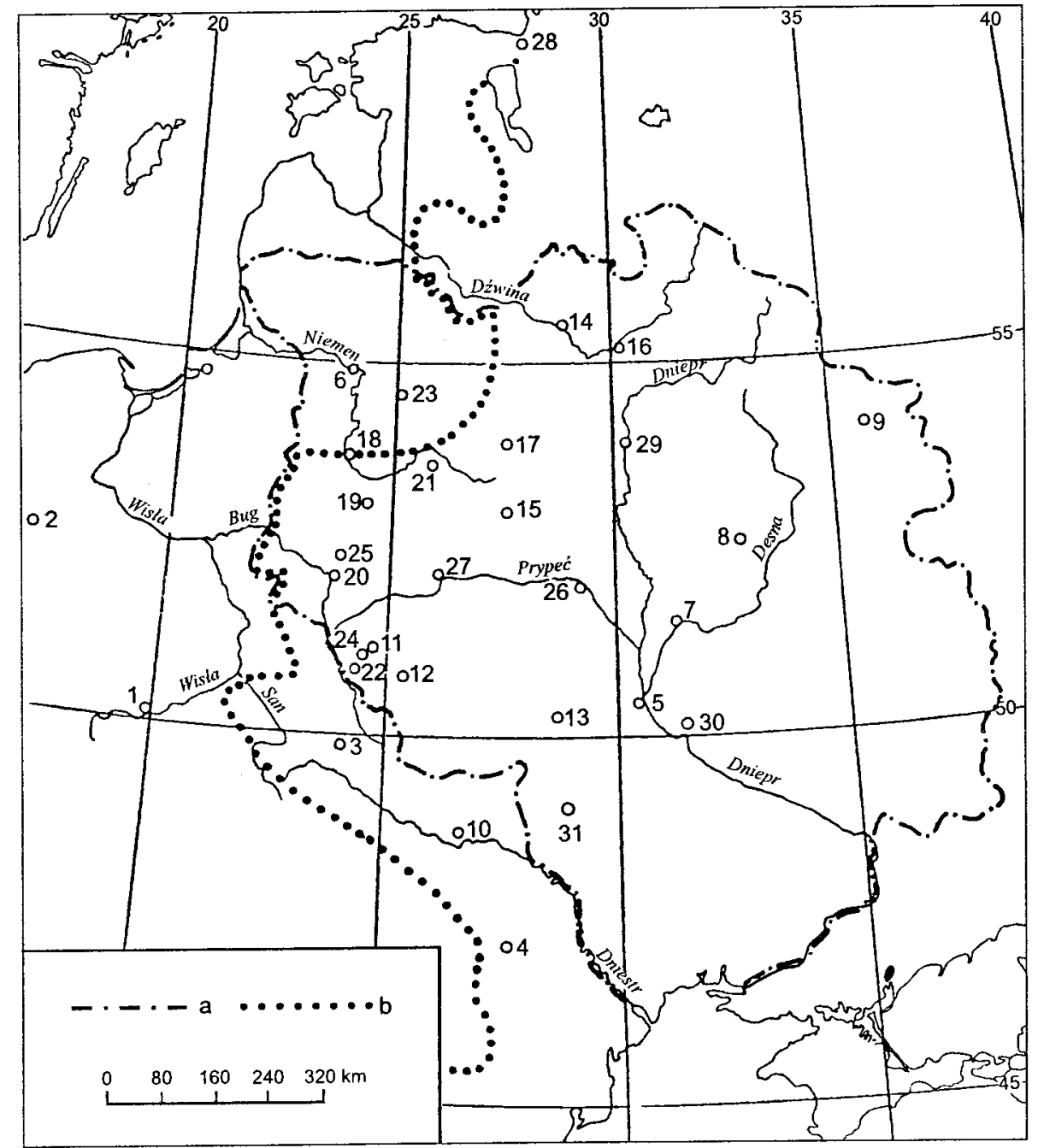

Mapka 2:. Granica Wielkiego Księstwa Litewskiego, 1462 r. [wg: Atlas istorii SSSR, cz. I, Moskwa 1949, karta 16], oraz granica wpływów Rzymu i Bizancjum

a. - granica Wielkiego Księstwa Litewskiego (1462 r.); b. - granica wpływów Rzymu i Bizancjum; 1 - Kraków; 2 - Poznań; 3 - Lwów; 4 - Jassy; 5 - Kijów; 6 - Kowno; 7 - Czernichów; 8 - Starodub; 9 - Kozielsk; 10 - Kamieniec Podolski; 11 - Kowel; 12 - Luck; 13 - Żytomierz; 14 - Połock; 15 - Słuck; 16 - Witebsk; 17 - Mińsk; 18 - Grodno; 19 - Wolkowysk; 20 - Brześć Litewski; 21 - Nowogródek; 22 - Włodzimierz; 23 - Troki; 24 - Turzysk; 25 - Kamieniec Litewski; 26 - Mozyrz; 27 - Pińsk; 28 - Narwa; 29 - Mohylew; 
Jest rzeczą charakterystyczną, że po odłączeniu ziem małoruskich od Rzeczpospolitej i wcieleniu ich do państwa moskiewskiego, władcy jego utrzymują prawo niemieckie $w$ mocy ${ }^{18}$. Co więcej, na polecenie jednego $\mathrm{z}$ nich dokonuje się thumaczenia tego prawa na język rosyjski ${ }^{19}$.

Od drugiej połowy XVIII w. obserwujemy zmierzch prawa niemieckiego. $\mathrm{Na}$ Litwie skasowano ustrój miejski oparty na prawie magdeburskim w r. $1776^{20}$. W Rosji zniesiono je ostatecznie w r. $1831^{21}$.

W literaturze naukowej akcentowano już wielokrotnie, że prawo niemieckie wiązało się początkowo $\mathrm{z}$ kolonizacją niemiecką, ale prędko się od niej oderwało i nadawano je ludności czysto polskiej. $Z$ analogicznym zjawiskiem mamy do czynienia $w$ państwie litewskim. Prawo niemieckie szerzyło się tam $w$ miastach bez ludności niemieckiej, albo $\mathrm{z}$ minimalną tylko jej ilościq̨ ${ }^{22}$. Nadawano je miejscowej ludności miejskiej, ruskiej i polskiejej. W ten sposób prawo niemieckie przekroczyło świat chrześcijan lacińskich.

Prawo niemieckie odegrało zasadniczą rolę pod każdym względem ${ }^{24}$, tworząc odrębne systemy ustrojowe $\mathrm{e}^{25}$. Niewątpliwie wywoływało ono pewne trudności, zwłaszcza przy jego zaprowadzaniu ${ }^{26}$ napotykało na opory ${ }^{27}$, ale ostatecznie ustaliła się nowa organizacja miasta nowoczesnego na zasadach prawa magdeburskiego ${ }^{28}$.

W państwie litewsko-ruskim nie czerpano bynajmniej wzoru dla prawa niemieckiego bezpośrednio z Niemiec. Dostarczała go Polska. Było to zatem polskie prawo niemieckie ${ }^{29}$.

Wladimirskij-Budanow wyrażał niegdyś pogląd, jakoby prawo niemieckie okazało się na Litwie w calej pełni szkodliwe, jakoby upadek miast w tym rejonie mial właśnie swoje źródło w ustroju samorządowym, zorganizowanym

${ }^{18}$ Halban, Zur Geschichte..., s. 49; Kaindl, Geschichte..., s. 35. O dużym wptywie recypowanego prawa niemieckiego na prawo miejscowe - Jakowliw, op. cit., s. 19.

${ }^{19}$ Halban, Zur Geschichte..., s. 50; Kaindl, Geschichte..., s. 276; por. też uwagi Jakowliwa, op. cit., s. 65 .

${ }^{20}$ Przechodza one zatem na prawo ziemskie, Kaindl, op. cit., s. 93-94; przy prawie magdeburskim utrzymano jedynie 11 miast, S. Kutrzeba, Historia źródel dawnego prawa polskiego, t. 2, s. 206.

${ }^{21}$ Halban, Zur Geschichte..., s. 50; Kaindl, op. cit., s. 94-95.

${ }^{22}$ Im bardziej na wschód, tym mniej kolonistów niemieckich, stwierdzał przed z górą stu laty Roepell, op. cit., s. 244; ob. też Halban, op. cit., s. 18; Kaindl, op. cit., s. 96.

${ }^{23}$ Kutrzeba, Historia ustroju..., t. 2, s. 99.

${ }^{24}$ Wyslouch, op. cit., s. 170.

${ }^{25}$ Ibidem, s. 156, 170.

26 Ibidem, s. 77 .

${ }^{27}$ Ibidem, s. 179.

${ }^{28}$ Ibidem, s. 181.

29 Wladimirskij-Budanow, Niemieckoje prawo..., s. 6; Bibl. Warsz. 1872, t. 1, s. 482; Kutrzeba, Historia ustroju..., t. 2, s. 97, 100; Taranowskij, Obzor..., s. 17; Jaworski, Studia..., s. 1-2; Jakowliw, op. cit., s. 2. 
według prawa magdeburskiego. Te jego wywody zbił już kiedyś Pawiński ${ }^{30}$. Trudno byłoby również dzisiaj uznać je za słuszne. W swoim czasie prawo magdeburskie bynajmniej nie przeszkodziło wspaniałemu rozwojowi Mohylewa ${ }^{31}$. Po prostu miasta litewsko-ruskie podzieliły i pod względem ekonomicznym los miast całej Rzeczpospolitej ${ }^{32}$.

Stwierdzając podobny rozwój miast polskich i litewsko-ruskich, musimy zaznaczyć, że prawo niemieckie nie odegrało pod każdym względem takiej roli na Litwie, jak w Polsce. Mianowicie dla stosunków polskich charakterystyczne było rozciągnięcie prawa niemieckiego na wies $^{33}$. Tymczasem w państwie litewsko-ruskim nie ma prawie ani jednego dokumentu nadającego prawo niemieckie we wsiach ${ }^{34}$. Ten proces gospodarczy, który na wsi polskiej odbywal się pod formą lokacji na prawie niemieckim, nosił tu nazwę reformy włócznej.

Prawo niemieckie w Polsce to nie tylko ustrój miasta $\mathrm{i}$ wsi, lecz również prawo prywatne i karne. W Polsce recypowali je wszyscy plebeje. Oporna natomiast wobec niego była szlachta. Wskutek tego doszło do pokrycia się podziału stanowego $\mathrm{z}$ podległością systemom prawnym: stan rządzący (szlachta) rządził się prawem polskim, stany upośledzone (mieszczanie i chłopi) - prawem niemieckim. Ponieważ na Litwie wsi nie urządzono według prawa niemieckiego, chłopi litewscy nie podlegali niemieckiemu prawu prywatnemu. Nie było więc ono tu ogólnoplebejskie, lecz tylko mieszczańskie. Co więcej, respektowano je również w sądownictwie ziemskim ${ }^{35}$.

${ }^{30}$ Streszczenie polemiki zawiera Bibl. Warsz. 1872, t. 1, s. 472-474, 478, 483; późniejszą obszernq polemike na ten temat przedstawia Jakowliw, op. cit., s. 60-62.

${ }^{31}$ H. Lowmiański, Struktura gospodarcza Mohylowa w czasach pomiary wlócznej, RDSG, t. 8, 1939, s. 43; por. też bardzo cenne obserwacje S. Wysloucha, Uwagi o przyczynach rozwoju Mohylewa w XVI i XVIII wieku, Wiadomości Studium Historii Prawa Litewskiego USB, t. 1, Wilno 1938, s. 344-362 i 364-366; przenikanie prawa magdeburskiego uchodzi dziś za prawidlowe zjawisko, jako pewnego rodzaju etap w rozwoju życia miejskiego, O. S. Kompan, Miasta Ukrajiny $w$ druhij polowyni XVII st., Kyjiw 1963 (praca nie była nam dostępna, jej tezę znamy z recenzji M. Horna, drukowanej w RDSG, t. 26, Poznań 1965, s. 132-135); ob. też trafne $w$ tym wypadku ujęcie Jakowliwa, op. cit., s. 55-56.

32 Jaworski, op. cit., s. 26; Jakowliw, op. cit., s. 57, 63.

${ }^{33}$ Kaindl, op. cit., s. 11, 17, 242-243.

${ }^{34}$ Wladimirskij-Budanow, Niemieckoje prawo..., s. 6. Obserwacji tej nie odniesiemy do Rusi Czerwonej, wcielonej do Królestwa przez Kazimierza W.

${ }^{35}$ A. Halban, Zur Geschichte des deutschen Rechtes in den Gebieten von Tschernigow und Poltawa (Archivalischer Reisebericht), ZRG, Germ. Abt., 1. 19, 1898, s. 5, 9-10; tenże, Zur Geschichte des deutschen Rechtes in Podolien..., s. 52; Kaindl, op. cit., s. 55. Zdaniem Jakowliwa, na Ukrainie stosowano prawo niemieckie we wszystkich sądach, wiejskich i miejskich, nie wylączając najwyższego, wojskowego (op. cit., s. 7, 45), tak że doszło do pomieszania wsi na prawie niemieckim, polskim i ruskim (s. 51). Wskazana tu pewna ostrożność ze względu na to, że do statutów litewskich przeszły pewne elementy prawa niemieckiego; por. niżej przyp. 37 . 
Prawo niemieckie w Koronie, prawo - powtarzamy - wszystkich plebejów, miejskich i wiejskich, obowiązywało długo jako prawo zwyczajowe. Wczesne spisanie tego prawa $w$ Saksonii sprawilo, że w tej nowej postaci przedostało się ono do Polski, stając się u nas ius scriptum. Od samego początku XVI w. pojawiły sie jego druki. 1 te wersje drukowane zdobywaja sobie moc wiążącą: Laski 1506, Jaskier 1535, Szczerbicz 1581. A już Bartlomiej Groicki przez swoje dziełka - prace o charakterze czysto prywatnym - stał się wręcz kodyfikatorem prawa niemieckiego. W ustalonej przezeń wersji przemieniwszy się w gedrucktes Recht, rozprzestrzenilo się prawo niemieckie ,na całym obszarze ziem polskich, aż do wschodniej granicy" ${ }^{36}$. Tymczasem stan szlachecki posługiwal się nadal, aż do rozbiorów, prawem zwyczajowym.

Stosunkom koronnym nie odpowiada sytuacja, jaka wytworzyła się na Litwie. Dokonano tu redakcji statutów już w 1529 r. Ta kodyfikacja byla reformowana parokrotnie $(1566,1588)$. Zresztą czerpała ona pewne elementy z prawa polskiego, jak też - wyjątkowo zresztą - ze Zwierciadla Saskiego ${ }^{37}$. $\mathrm{W}$ państwie litewsko-ruskim nie przeciwstawiało się zatem $\mathrm{zw} \mathrm{y} \mathrm{zajowe}$ prawo ziemskie drukowa nemu prawu plebejskiemu ${ }^{38}$.

Wprowadzone w miastach litewsko-ruskich prawo niemieckie przyniosło ze sobą nie tylko nową organizację miejską, lecz także prawo sądowe, cywilne i karne ${ }^{39}$. Toteż w wyrokach powoływano się najczęściej na Speculum Saxonum ${ }^{40}$, często na Ius municipale, na Porzqdek Groickiego czy Saxon Szczerbicza ${ }^{41}$.

Uprzytomnijmy sobie również, że recepcja prawa niemieckiego w Polsce oznaczała w pewnym stopniu i recepcję prawa rzymskiego, zważywszy na to, że polscy pisarze prawni przejęli wraz ze Zwierciadlem Saskim wytworzoną w Niemczech glosę, silnie romanizującą ${ }^{42}$.

Czym jest wszakże recepcja? Dzisiejsza doktryna traktuje recepcje prawa rzymskiego na zachodzie Europy jako swoisty proces unaukowienia prawa

\footnotetext{
${ }^{36}$ Kutrzeba, Historia źródel..., t. 2, s. 282.

${ }^{37}$ Por. tu Taranowskij, Obzor..., s. 1; O. Balzer pisał o pokaźnej ilości elementów prawa niemieckiego, Prof. Piekosiński $i$ "Statuty litewskie» (1907), Przygodne slowa, Lwów 1912, s. 189, 192; w tym duchu też Jakowliw w oparciu o pracę N. Maksimejki, op. cit., s. 8, 19; Natomiast Kutrzeba mówi tylko o wyjątkowych przejątkach z niego, Historia źródel..., t. 2, s. $71 \mathrm{n}$.

${ }^{38}$ Jakie wnioski można wysnuć dla wsi polskiej z tej obserwacji, że wieś litewsko-ruska nie znała prawa niemieckiego?

${ }^{39}$ Zauważmy, że w swym cennym studium Władimirskij-Budanow świadomie pominął zagadnienie prawa sądowego, Niemieckoje prawo..., s. 7.

${ }^{40}$ Halban, Zur Geschichte des deutschen Rechtes in Podolien..., s. 95.

${ }^{41}$ Ibidem, s. 98.

${ }^{42}$ Taranowskij, Obzor..., s. 1, 14; Halban, Zur Geschichte..., s. 99; Kaindl, op. cit., s. 53; ob. też Kutrzeba, Il diritto..., s. 74 i n.
} 
(Verwissenschaftlichung des Rechtes) ${ }^{43}$. Czy więc i na zjawisko polskiej recepcji prawa niemieckiego nie należy patrzeć podobnie? Zauważmy, że już w 1899 r. niemiecki badacz, Schwind, dość sceptycznie odnosił się do przejęcia prawa niemieckiego na ziemiach litewsko-ruskich. Jego zdaniem, po prostu w konkretnym wypadku ,zur Findung und Begründung irgend eines Urteiles eben alles herangezogen wurde, was an Sätzen des objektiven Rechtes dem judicierenden bekannt war"44. Dla rozstrzygnięcia tego problemu niezbędne są studia nad stosunkiem prawa niemieckiego do prawa rodzimego ${ }^{45}$. Zdajemy sobie dobrze sprawę $\mathrm{z}$ tego, że nie rozwiążemy tego zagadnienia nigdy bez pomocy kolegów radzieckich ${ }^{46}$.

Praca przedstawiona na posiedzeniu Wydzialu II LTN $w$ dniu 20 stycznia $1966 r$.

${ }^{43}$ W. Trusen, Anfänge des gelehrten Rechts in Deutschland. Ein Beitrag zur Geschichte der Frührezeption, Wiesbaden 1962, s. 3, 9; tamże wstęp J. Bärmanna, s. VI; H. Baltl, ZRG, Germ. Abt., t. 94, 1964, s. 436-438; B. Rehfeldt, Rezeption in Schweden, ZRG, Germ. Abt., t. 95, 1965 , s. 323. Ujęcie syntetyczne zagadnienia dał H. Coing, Römisches Recht in Deutschland, IRMAE, Mediolani 1964, s. 12 nn. Ob. też: J. Baszkiewicz, Prawo rzymskie i prawo kanoniczne w kulturze politycznej Polski XIII i XIV stulecia, [w:] Historia kultury średniowiecznej w Polsce, t. 1, Warszawa 1963, s. 76; A. Vetulani, ibidem, t. 2, Warszawa 1964, s. 58. Zauważmy, że w odniesieniu do strefy prawa bizantyjskiego już Wadimirskij-Budanow skonstatował, że recepcja jego była došć swobodna: Obzor istorii russkawo prawa, wyd. 4, S. Peterburg-Kiew 1905 , s. 94.

${ }^{44}$ Schwind, HZ, t. 83, 1899, s. 143. Podobny wniosek możemy wysnuć z wypowiedzi Kaindla: „...man entfernte sich immer mehr vom ursprünglichen Geiste der deutschen Rechte”, op. cit., s. 53.

${ }^{45}$ Schwind, op. cit.; Kaindl powołuje się na następujący wypadek z 1474 r.: sołtys wsi Lipica ma wydawać wyroki według prawa magdeburskiego; gdyby wszakże nie dało się stosować, może się uciec do prawa polskiego, op. cit., s. 53-54. Tenże autor zna wypadki posługiwania się prawem ziemskim $w$ miastach, jak $i$ prawem magdeburskim $w$ sądach ziemskich, ibidem, s. 55.

${ }^{46}$ Przed kilkunastu laty występowaliśmy przeciwko nacjonalistycznemu pojmowaniu prawa niemieckiego, $O$ biskupstwie lubuskim, CPH, t. 2, Poznań 1949, s. 77; prowadzi ono do absurdu, którego ofiarą padł Taranowskij; według niego, prawo nie mi eckie było środkiem polonizacji ziem ruskich, Obzor, s. 18. Podkreślmy też, że jeszcze w 1942 r. reformę włóczną na Litwie określał Jakowliw jako „Einführung der deutsch-polnischen Agrarreform”, op. cit., s. 17 oraz s. 60. 


\section{Poddani ekscypowani*}

Klauzule renuncjacyjne są rzeczą pospolitą $w$ aktach średniowiecznych. Wytłumaczyć je latwo niepewnością stosunków prawnych. Nie zaniknęly one i w dobie nowożytnej. Co więcej, rozrastają się one u nas do olbrzymich rozmiarów. Prywatne dokumenty, dotyczące tzw. transakcyj chłopami, nie stanowią tu wyjątku ${ }^{1}$. O tych klauzulach pisano już niemało ${ }^{2}$. Nie chcielibyśmy się dłużej nad nimi zatrzymywać. Zrozumiałe ich znaczenie w dobie rozpanoszenia się szlachty. W pieniackim społeczeństwie rabulistyka prawna święciła swoje triumfy.

Obok klauzul renuncjacyjnych występują często inne formuły, które nazwać wolno rezerwacyjnymi. I na nie zwrócono już uwagę $w$ nauce. Samiśmy zajęli się niedawno rezerwacjami w dokumentach nadających prawo niemieckie ${ }^{3}$. Niniejszy artykul zamierzamy poświęcić klauzulom rezerwacyjnym, występującym we wspomnianych aktach transakcyj chłopami.

Interesujące nas klauzule rezerwacyjne ujmowano bądź negatywnie, bądź pozytywnie. W pierwszym wypadku alienator poddanego stwierdza: nihil

* Przedruk z: Zeszyty Naukowe Uniwersytetu Lódzkiego 1966, Ser. I, z. 44, s. 167-177.

${ }^{1}$ Oto przykład renuncjacji-giganta: a iure terrestri, districtu suis propriis recedendo, appelationibus sive motionibus, exceptionibus, dilationibus, termino pro maiori, verae vel simplici infimitatibus, bello, conventioni Regni generali vel particulari, literis regalibus, legationibus, absentiae a Regno, aurae pestiferae, statutis, laudis, laudatis et in futurum quomodolibet laudandis, poenae trium et ter trium marcarum, et generaliter omnibus iuribus, remediis et coloribus, de iure vel consuetudine fieri solitis, quibus nitti et se defendere contra praemissa potest, renuntiando, nullosque defectus praesenti inscriptioni et citacioni ex ea emanatae obiiciendo, et penitus nihil iuris remediorum sibi in auxilium contra praemissa assumendo sub amissione suae totius causae; quibus omnibus praemissis se benevole ipse nobilis Adam Popowski submisil; Transakcje chlopami w Rzeczypospolitej szlacheckiej (w. XVI-XVIII), wyd. J. Deresiewicz, Warszawa 1959, nr 95, r. 1572; ob. też ibidem nr 96, 97 . Z tej samej publikacji wszystkie późniejsze cytaty, o ile nie zaznaczono czegoś innego.

${ }^{2}$ Literature zestawia J. Matuszewski, Motywacja ignorancyjna w dokumentach prawa niemieckiego, Studia historica w 35-lecie pracy nauk. H. Lowmiańskiego, Warszawa 1958, s. 171 i nast.

${ }^{3}$ Ibidem, s. 176. 
omnio iuris, dominii, proprietatis et heroicae potestatis sibi et suis successoribus ad eosdem subditos reservando et excipiendo ${ }^{4}$, lub po polsku: nic a nic sobie, ani dla sukcesorów moich nie ekscypując, ani wymawiając (nr 648, r. 1783), albo: sobie nic a nic nie zostawujac żadnego poddaństwa i $z$ bydlem ( $\mathrm{nr} 724$, r. 1644).

Sam sens takiej klauzuli jest jasny. Przeniesienie poddaństwa dokonuje się w sposób bezwarunkowy i absolutny. Dotychczasowy właściciel (czy jego spadkobiercy) nie będzie rościł żadnych praw do alienowanego chłopa; wszelkie pretensje w przyszłości zostają $\mathrm{z}$ góry wyłączone. Rola tych klauzul jest więc taka sama jak formuł renuncjacyjnych. I jedne, i drugie maja na oku interes nabywcy, chronią go przed ewentualną natarczywością nielojalnego kontrahenta.

Inne całkiem zadanie przypadnie klauzulom rezerwacyjnym, ujętym pozytywnie, w rodzaju: excepto Alexio, Olech dicto, brassatore, filio eiusdem Iacobi, quem sibi et suis posteris [...] pro necessitate sua reservat $(\mathrm{nr} 15$, r. 1573), czy: excepto uno filio seniore [...], quem idem recognoscens pro se [...] reservat ${ }^{5}$, lub: excepta Catherina, eiusdem Malecz filia, quam sibi ipse nobilis [...] reservat et a donatione praesenti excipit ${ }^{6}$; eorumque liberos reservando et excipiendo ( $\mathrm{nr} 625, \mathrm{r} .1762)$; salva [...], reservata et praecustodita proprietate (nr 610, r. 1746).

W tekstach zredagowanych po polsku wygląda ta klauzula następująco: zachowuje $i z$ poddaństwa nie wypuszcza (nr 718, r. 1636); zostawuje $w$ wieczne poddaństwo (nr 517, r. 1722); ekscypuje zaś sobie tejże kobiety córkę $w$ szóstym roku, imieniem Maryjanne, która sie powinna zostać na gruncie $^{7}$; których sobie zostawuje i wymawiam (nr 361, r. 1787).

Przenosząc więc subditatura chłopa $\mathrm{i}$ - automatycznie - jego rodziny, bo cała lącznie stanowila jednostkę gospodarczą ${ }^{8}$, pan dotychczasowy wyjmuje $\mathrm{z}$ transakcji któreś $\mathrm{z}$ dzieci, jedno lub kilka, i zastrzega je dla siebie. Jeśli przy negatywnej klauzuli rezerwacyjnej brano w rachubę interes nowego pana, przy pozytywnej sytuacja przedstawia się odwrotnie: dotychczasowy właściciel zachowuje sobie jakieś prawa poddańcze.

Przeciwstawność obydwu klauzul, negatywnej i pozytywnej, nie jest wszakże tego rodzaju, by nie mogły one wystąpić w jednym akcie równocześnie: nihil sibi [...] ad eundem subditum reservando aut excipiendo [...], exceptis [...] liberis natu maioribus (nr 311, r. 1634); nihil sibi iuris, dominii, proprietatis et heroicae potestatis ad eundem subditum reservando seu excipiendo

${ }^{4} \mathrm{Nr} 659$, r. $1640 ; 408$ akt 2, r. $1641 ; 722$, r. $1644 ; 120$, r. $1740 ; 692$, r. 1755.

${ }^{5} \mathrm{Nr} 15$, r. $1573 ; 381$, r. 1599 ; podobnie nr 283 , akt 2, r. $1606 ; 289$, r. 1620 ; 29, r. 1624; 559 , r. $1626 ; 658$, r. $1640 ; 661$, r. $1641 ; 170$, r. 1761 .

6 Nr 392, r. 1624; podobnie nr 422, r. 1647 ; 664, r. 1645.

7 Nr 684, r. 1745; por. też nr 648, r. 1783; 454, r. 1787.

8 J. Matuszewski, Chlopska glówszczyzna cywilna w Polsce, CPH, t. 16, z. 1, 1964, s. 199-20I. 
[...], exceptis liberis iam natis (nr 658, r. 1640); lub po polsku: pracowita Anne, wdowe, [...] poddanq wlasnq mojq, te ze wszystkim, co tylko jej jest, już to sprzętami $i$ inwentarzem wszystkim, jaki ma, nic a nic sobie, ani dla sukcesorów moich nie ekscypując, ani wymawiajac, oprócz syna jej, Antoniego (nr 648, r. 1783). We wszystkich tych wypadkach rezerwacja negatywna dotyczy całości dokonanej transakcji, pozytywna - jakiegoś wylączenia szczególnego, które zbywca sobie zastrzegl, np. wyłączył z transakcji dla siebie jednego syna.

Terminy: excipere, reservare, zachować, zostawiać, ekscypować, wymawiać są tu niewątpliwymi synonimami. Akt może zresztą bez nich się obejść. Przenosząc własność nad poddaną, zastrzega pan krótko: non autem liberos eius, [...] non autem illius posteros (nr 322, r. 1635).

Powołane wyżej rezerwacje pomieszczano w aktach transakcyj rodziną chłopską. Ale pojawią się one również przy innej okazji, mianowicie przy zbyciu nieruchomości szlacheckich.

Wiemy, że chłop okresu refeudalizacji, poddaństwa wtórnego czy zaostrzonego - jak chcą niektórzy - stanowił przynależność do gruntu, particula fundi, $\mathrm{z}$ którym był związany ${ }^{9}$, należał do inwentarza dóbr ${ }^{10}$. Alienacja wsi w niczym nie zmienila jego sytuacji prawnej. Zostawal on wciąż poddanym, ktokolwiek bylby właścicielem włości, Skąmpski czy Twardowski.

Ten związek poddanego ze wsią jest dla współczesnych oczywisty. Nabywca gruntu nabywa eo ipso siedzących na nim pracowitych: puerum [...] circa emptionem eorundem bonorum acquisitum (nr 592, r. 1720). Dlatego stanowić on może podstawę wyroku sądowego: quapropter eosdem privignos, videlicet Nicolaum et Stanislaum, fundo bonorum Niemczyn applicandos esse declarat (nr 676, r. 1740, s. 608); ideo iudicium praedictam laboriosam Reginam una cum liberis fundo cedendam existimat ( $\mathrm{nr}$ 676, r. 1740, s. 609). Poddany dzieli zatem losy wsi, w której mieszka. Życie wszakże stwarzało od tej reguły wyjątki. I tu więc otwierało się pole do wprowadzenia klauzul rezerwacyjnych pozytywnych.

${ }^{9}$ W. Hejnosz, Stanowisko prawne ludności wieśniaczej w zbiorze praw sqdowych A. Zamojskiego, RDSG, t. 5, Lwów 1936, s. 81.

${ }^{10}$ Por. akt z 1762 r. dotyczący poddanego nie należqcego do inwentarza dóbr turostowskich (nr 624); ob. też tekst następujący: czego [odebrania poddanego] possessores bonorum bronić nie powinni, poniewaz chlop ten $w$ inwentarzu dóbr tych nie jest im poddany ( $\mathrm{nr} 59, \mathrm{r} .1715$ ). Sądzić wolno, że to samo stwierdza akt z 1561 r.: były właściciel wsi donuje zbiega, subditum et nativum suum proprium de villa Jeziorki, quem sibi acceperat ante venditionem et resignationem eorundem bonorum (nr 3). Widocznie nie wpisał go już pan do inwentarza wsi. 
Sprzedaż wsi dokonuje się: exceptis saltem subditis suis infrascriptis (4 synów kmiecych), quos sibi reservavit ${ }^{11} ; 2$ nativos et subditos [...], quos sibi circa venditionem villae [...] in inscriptione capitaneali castrensi Gnesnensi reservaverat (nr 375, r. 1590); subditum suum, circa resignationem per eum bonorum villae et hereditatis [...] exceptum ${ }^{12}$; subditos certos in actu resignationis bonorum [...] reservatos et exceptos ${ }^{13}$; circa resignationem praefatae sortis villae Wyskoć [...] una cum aliis subditis et ex bonis Wyskoć receptum (nr 671, r. 1725); laboriosos [...] pro se, recognoscente, perpetuis temporibus exceptos et sibi aplicatos ac incorporatos ( $\mathrm{nr} 606, \mathrm{r} .1743$ ); quam sibi [...] relinquerat et specifice excepit ( $\mathrm{nr} 655$, r. 1589).

Polskimi odpowiednikami tych określeń są czasowniki: ekscypować ${ }^{14}$, wymawiac $^{15}$, zostawiać (nr 358, r. 1785), lub równocześnie występujące w jednym akcie verba: wypisać, wylaczyć, ekscypować (nr 452, r. 1786). Jako rzeczownika używa się terminu ekscepcja (nr 683, r. 1742). Za określenia przymiotnikowe służą: wyjety i wylączony (nr 523, r. 1787), czy wymowny ${ }^{16}$.

Praktycznie do tego samego wyniku prowadzi nadanie przez nabywcę wsi sprzedawcy poddanych, zamieszkalych w kupionej osadzie (nr 292, r. 1621), choć akt o ekscypowaniu nie wspomina. Podobnie przy alienacji wsi czy jej części in vim reemptionis; zbywca może libere recipere dwóch poddanych $\mathrm{z}$ rodzinami (nr 251, r. 1568). Nie inne też, jak wolno sądzić, znaczenie donacji poddanego ante dimissionem villae et hereditatis (nr 246, r. 1565).

Terminy, którymi się posługiwano zarówno przy transakcjach chłopami ${ }^{17}$, jak i przy alienacjach nieruchomości, nie stanowią jakichś określeń technicznych. Strony ekscypowaly też sobie czy wymawialy pastewniki ${ }^{18}$. Na inne zastrzeżenia również tych wyrażeń się używa ${ }^{19}$. My wszakże - tak chyba zawsze postępuje historyk - awansujemy termin ekscypować na oznaczenie chłopów wyjętych $\mathrm{z}$ gruntu przy jego alienacji.

${ }^{11} \mathrm{Nr} 531$, r. 1567 ; podobnie nr 597, r. 1724.

$12 \mathrm{Nr} 287$, r. 1618 ; podobnie nr 711 , r. $1625 ; 44$, r. $1677 ; 597$, r. $1688 ; 340$, r. $1732 ; 213$, r. $1760 ; 350$, r. $1776 ; 666$, r. $1675 ; 662$, r. $1642 ; 664$, r. 1645.

${ }^{13} \mathrm{Nr} 300$, r. 1631 ; podobnie nr 555, r. $1599 ; 558$, r. $1623 ; 311$, akt 2, r. 1634; 721, r. $1643 ; 38$, r. $1643 ; 419$, r. $1647 ; 681$, akt 2 , r. $1741 ; 211$, r. $1754 ; 93$, r. 1793.

${ }^{14} \mathrm{Nr} 140$, r. 1791, Materialy do dziejów chlopa wielkopolskiego $w$ drugiej polowie XVIII wieku, wyd. J. Deresiewicz, t. 1 Wrocław 1956, s. 272, t. 3, 1957, s. 79.

${ }^{15} \mathrm{Nr} 20$, r. $1590 ; 686$, r. $1746 ; 87$, r. 1780.

${ }^{16} \mathrm{Nr} 113$, r. 1713; ob. té̇ $\mathrm{nr} 114$, r. $1722 ; 645$, r. 1783. Takie znaczenie dla ostatniego przymiotnika przyjmuje już wydawca, s. 106, przyp. 2. Nie znają go w tym sensie ani Linde, ani SW, choć oba te słowniki zawierają hasła wymówić i wymówiony.

${ }^{17}$ Por. nasze zastrzeżenia co do kwestii dzielenia rodziny poddańczej, Chlopska glówszczyzna cywilna, wyżej: 158-159.

18 Materialy, t. 2, Wrocław 1956, s. 69.

$19 \mathrm{Na}$ przykład jest chlop $w$ inwentarzu runowskim do zaplacenia mnie rezerwowany, $\mathrm{nr} 686$, r. 1746 . 
Sprzedając wieś, ekscypuje zwykle zbywca osobę określoną imiennie ${ }^{20}$. Wyjątkowe są wypadki, w których nie podaje się konkretnego poddanego: po parobku jednemu z każdej wsi, a sześć ich jest przedmiotem alienacji (nr 358, r. 1785). Zastrzeżenie dotyczy najczęściej jednostki, ale niejednokrotnie rezerwuje się więcej osób: 5, 9 czy nawet 22. Czasem liczba ekscypowanych jest nieznana (nr 350, r. 1776).

Fakty ekscypowania poddanych przy sprzedaży nieruchomości są rzeczą nierzadką. Bierze się je w rachubę w kontraktach: $\ddot{z}$ ponieważ $w$ kontrakcie przedażnym nie jest dolożona ekscepcyja ludzi (nr 683, r. 1742); dokonując donacji chłopa, stwierdza darczyńca: prawem poddaństwa na wieczność ustepuje $i$, jako z przyszlego dóbr odrezygnowania wyjętym i wylaczonym będzie, przyrzekam (nr 528). Najwidoczniej obawiano się tego, by ewentualny nabywca gruntu nie występował $w$ przyszłości $z$ pretensjami o zwrot poddanego.

Stwierdzając powszechną praktykę ekscypowania chłopów, nie możemy jednak nie podkreślić, że było to zjawisko $w$ istocie wyjątkowe. $Z$ reguly sprzedaż obejmowała alienację równoczesną wszystkich poddanych. I tak być musiało. Postępując inaczej, naruszałby pan swoje obowiązki wobec poddanych ${ }^{21}$. Chłop mial prawo do gruntu. Samowolne odebranie jego stanowiłoby oczywiste bezprawie ${ }^{22}$. Co więcej, nie tylko wzgląd na interes poddanych kierowal zbywcą. Nie znalazłby on kupca na wieś złożoną z samych deserta. To rzecz zrozumiała.

Ponieważ chłop tkwił $w$ inwentarzu majątku, pomniejszenie tego inwentarza musiało być podane do wiadomości nabywcy, który musiał znać aktywa i passywa kupowanej wsi. Nowy pan musial się zgodzić na wyjęcie; gdyby mu takie postępowanie nie odpowiadało, odstąpiłby po prostu od umowy. Rzeczywiście, cesja poddanego przed zbyciem majątku dokonuje się w obecności nowej pani - Małgorzaty Brzechwiny, nihil ad praemissa contradicendo (nr 246, r. 1565).

Co więc skłaniało do robienia tych wyjątków? Dlaczego zbywca ekscypował sobie poddanego? Dlaczego nabywca wsi na to się godzil? Niestety, dokumenty, z którymi się zapoznaliśmy, zachowują pod tym względem. milczenie. Poszukajmy więc odpowiedzi na nurtujące nas pytanie na innej drodze. Zapytajmy, jakich poddanych wyjmuje się $\mathrm{z}$ dotychczasowego związku $\mathrm{z}$ gruntem.

Ekscypowani zostają: ogrodnik i krawiec (nr 251, r. 1568), kowal (nr 597, r. 1688; nr 340, r. 1732), kolodziejczyk ${ }^{23}$, rybak (nr 711, r. 1625),

\footnotetext{
${ }^{20}$ Oczywiście z żoną i dziećmi, por. wyżej s. 288.

${ }^{21}$ J. Rafacz, Ustrój wsi samorzqdnej malopolskiej $w$ XVIII wieku, Lublin 1922, s. 84.

22 Ibidem, s. 101-102.

${ }^{23}$ Materialy, t. 1, s. 272.
} 
cieśla (nr 311, akt 2, r. 1634; nr 340, r. 1732), ciesielczyk (nr 93, r. 1793) ${ }^{24}$, owczarz (nr 11, r. 1713), zwany też gregis pastor (nr 606, r. 1743). W akcie z 1631 r. występują: szewc, owczarz, cymbalista i serbin ( $\mathrm{nr} 300)^{25}$; w dokumencie z $1590 \mathrm{r}$. na dziewięciu wymówionych rodziców mamy 2 mielcarzy, 1 krawca, 1 cieślę i 1 syna kuśnierza, przypuszczalnie będącego również kuśnierzem ( $\mathrm{nr} 20$ ). Na dużą liczbę, bo aż 22 wyłączonych $\mathrm{w}$ transakcji z 1786 r., składają się: 2 lokaje, 1 forszpan, 1 foryś, 1 włodarz, 3 chłopcy, 2 dziewczyny, 2 dziewki, 2 kuchcików, 1 chałupnik, 3 komorników, 3 parobków i 1 średniak (nr 452) ${ }^{26}$. W r. 1743 wyjęci zostali 2 famuli agrestes (nr 606), w r. 1760 - puer (nr 213), w 1785 r. - parobcy (nr 358).

Czasem nie określa się bliżej zajęcia ekscypowanego, wiemy tylko, że chodzi o syna kmiecia czy ogrodnika (nr 531, r. 1567). A może ostatni jest też ogrodnikiem? Jedyny w swoim rodzaju zawód wykazuje laboriosus Mathias: jest on studiosus (nr 721).

Nie ma natomiast bliższych określeń przy ekscypowanych poddankach. Jest to zrozumiale: w owych czasach kobiety na wsi nie miały wyuczonego zawodu. Akty ograniczają się więc do stwierdzenia, że chodzi o pracowitą, o kobietę czy o poddaną lub dziewkę ${ }^{27}$.

Zestawienie powyższe upoważnia nas do pewnych obserwacyj ogólniejszych. Przede wszystkim stwierdzić należy, że ekscypowani poddani to $\mathrm{z}$ reguly nie chłopi-gospodarze, $w$ stanie rolniczym, ale rzemieślnicy (mielcarz, krawiec, cieśla, kuśnierz, kowal, kołodziej, szewc) albo oddani jakimś zawodom specjalnym (pastuch, owczarz, cymbalista, ,serbin"), a wreszcie służba dworska (lokaje, forszpan, foryś, kuchciki, chłopcy) czy służba folwarczna (włodarz; tutaj może zaliczyć by też należało chałupników, komorników, parobków i średniaka aktu z 1786 r. (nr 452)). Do służby dworskiej czy folwarcznej należą też wedhug wszelkiego prawdopodobieństwa dziewki, dziewczyny $i$ inne pracowite kobiety. Calkiem wyjątkowe stanowisko w tym gronie zajmuje studiosus.

${ }^{24}$ Wedhug wydawcy jest to nazwisko.

${ }^{25} \mathrm{Ci}$ sami poddani występują w akcie z 1633 r., nr 306, Z lączności obydwu dokumentów wydawca zdawał sobie dobrze sprawę, por. s. 272, przyp. 1, a mimo to nie rozwiązał wszystkich określeń w sposób identyczny: rzeczownik cymbalista został raz oddany mała literą (a więc ma to być zawód), raz dużą (a więc przezwisko). Poddany Barlłomiej raz zwie się Rzaniak, to znów Rzamak. Nie wiemy, co to serbin. Wydawca drukuje ten wyraz dużą literą, ale wtedy ów poddany zwałby się Wit Przytocki Serbin; czy to nie za dużo, jak na prostego rodzica? Zważmy, że istniał instrument muzyczny, zwany serby (Linde). Serbin byłby więc muzykiem wyspecjalizowanym w grze na serbach, tak jak cymbalista - w grze na cymbałach. Tym bardziej to prawdopodobne, że i cymbalista, i serbin występują równocześnie; stanowiliby więc obaj niejako wiejską kapelę.

${ }^{26}$ Por. tu J. Deresiewicz, Kilka uwag o poddaństwie $w$ zwiqzku $z$ transakcjami sprzedaży chlopów, KH, t. 60, nr 3, Warszawa 1953, s. 87, przyp. 21.

${ }^{27} \mathrm{Nr} 38$, r. $1643 ; 114$, r. $1722 ; 681$, akt 2, r. $1741 ; 606$, r. $1743 ; 350$, r. 1776 , 645, r. 1783 
Czy pan zatem nie ekscypowal sobie poddanych przy boku jegoż jako $i$ na folwarkach zostajacych [...] osadzonych $i$ w sluzbie na gruncie tamże znajdujących się (nr 452)? Takie rozwiązanie wydaje się naturalne. Wyjęcie kmiecia, którego głównym zajęciem i źródłem utrzymania było rolnictwo, pociągałoby za sobą duże trudności. Bo albo pan wyłączałby równocześnie zagrodę stanowiącą warsztat pracy ekscypowanego, albo też pozbawiałby go tego gospodarstwa. Pierwszy wypadek do pomyślenia wówczas tylko, gdy do sprzedawcy należała wieś sasiednia; przesuwałby on wtedy kmiecia wraz $\mathrm{z}$ jego zagrodą $\mathrm{z}$ jednego folwarku na drugi. Pozbawienie chłopa gospodarstwa (wypadek drugi) stanowiłby jakieś jaskrawe bezprawie ${ }^{28}$, na które pracowity gotów odpowiedzieć zbiegostwem.

Ten szczególny charakter poddanego ekscypowanego, jego nierolniczy zawód, thumaczy łatwo dojście do porozumienia między nabywcą wsi a pozbywcą. Ich interesy nie musiały być z sobą sprzeczne. Gdy w r. 1590 sprzedawca wymawia sobie Wojtka kuszmierzewego, rodzica z Dobiszewka (nr 20), domyślać się wolno, że ten ekscypowany poddany jest również kuśnierzem. Wyraźnie taką sytuację stwierdza akt z $1754 \mathrm{r}$. Przy sprzedaży wsi Kruczyn zostaje w niej chalupnik Szymon, kolodziej; u niego Antoni, Kolodziejczyk, którego sobie [...] Stanislaw Grabski [...] ekscypuje $e^{29}$. Najwidoczniej nabywcy jeden rzemieślnik starczy; poduczony kołodziejczyk może odejść bez straty dla niego. Co więcej, być może, nowy pan nie znalazłby dla niego drugiego warsztatu pracy, nie mógłby więc wykonać swego obowiązku dostarczenia poddanemu sposobu do życia ${ }^{30}$, tym samym byłby drugi rzemieślnik dla niego balastem. Ten kawałek chleba zapewnić mu pragnie zabierający go ze sobą dawny pan $^{31}$.

Dla usunięcia wszystkich niejasności związanych z ekscypowaniem kmieci, pomocne byłyby dla nas wiadomości o dalszych losach pracowitych, wyjętych z dotychczasowego związku ze wsią. Niestety, informacje przejrzanych przez nas aktów są ubogie. Dokumenty ograniczają się do stwierdzenia, że sprzedawca rezerwuje sobie poddanego pro se (nr 38, 93, 681, akt 2), sibi (nr 531, 44), którego przy sprzedażym sobie wymówil (nr 686), sibi aplicatos ac incorporatos (nr 606). Takie informacje nie poszerzają $\mathrm{w}$ niczym naszej wiedzy. Coś więcej da nam dokument mówiący, że ekscypowanych rzemieśIników, kowala i cieślę, sprzedawca ad alia bona sua hereditaria transportare

\footnotetext{
28 Por. wyżej s. 291.

29 Materialy, t. 1, s. 272.

${ }^{30}$ J. Rafacz, Ustrój, s. 84.

31 Według J. Rafacza, poddany poszedł za panem, do którego się przywiązał, Ustrój, s. 97.
} 
disposuerit (nr 340). O poddanych, wyjętych przy sprzedaży dóbr Goniczki, wiemy, że przebywaja in bonis Ksiażno et aliis (nr 606). Czy dobra te stanowią własność zbywającej wspomniane Goniczki Psarskiej?

Duża liczba ekscypowanych jest przedmiotem dalszych transakcyj ${ }^{32}$. Parokrotnie przechodzą oni na rzecz kogoś z rodziny, syna ${ }^{33}$, zięcia (nr 300, r. 1631) czy bratanka (nr 671, r. 1725). Czasami - i to rzecz zastanawiająca - tradowani zostają nowemu wlaścicielowi wsi ${ }^{34}$ czy jego żonie (nr 655, r. 1589). W rzeczywistości zostają więc dalej w majątku, w którym siedzieli dotąd! Możemy więc powtórzyć za J. Deresiewiczem, że w takim wypadku: „sprzedaź ziemi i poddanych objęta była różnymi aktami prawnymi" ${ }^{35}$. Ale $\mathrm{w}$ takim razie, jaki byl sens praktyczny takiego ekscypowania? ${ }^{36}$

Wyjątkową, a przez to szczególnie cenną wiadomość zawiera dokument nr 597. Według niego, pewien kowal, ekscypowany r. 1688, został przez dzieci sprzedawcy zamieniony w r. 1724 na myśliwczyka. Przez blisko 40 lat zostawał on u swego dawnego pana czy jego spadkobierców, a dopiero po tym długim okresie wrócił do wsi, w której mieszkał pierwotnie. Zważywszy na jego wiek podeszły, zadamy sobie pytanie, czy nie wrócił on do swoich dzieci lub jakichś bliskich na emeryturę. Tym to prawdopodobniejsze, gdy zważymy na jego trudny zawód. Być może, z tego samego powodu wrócił do dawnego majątku w r. 1755 laboriosus Marcin, ekscypowany w r. 1727 (nr 693); w tym wypadku uiszczono zań główszczyznę cywilną.

Zdarza się, że wymowna poddanka dokonuje zbiegostwa (nr 645, r. 1783). Jeden jedyny raz ekscypowanie cieśli prowadzi do zwolnienia $\mathrm{z}$ poddaństwa (nr 20, r. 1590$)^{37}$. W innym wypadku ekscypowani poddani sq przedmiotem darowizny, dokonanej przez syna sprzedawcy; wszakże zastrzega on co do nich dożywocie dla babki (nr 419, r. 1647). Czy nie była to już racja pierwotnej rezerwacji? Wyraźnie czasowe ekscypowanie poświadcza jedna informacja: te zaś Michaline, komornice, ekscypuje sobie do uslug ciotki mojej do roku od daty $d z$ isiejszej $j^{38}$. Czy wróciła ona potem do dawnej wioski?

Tak niewiele wyłuskaliśmy wiadomości z publikacji Deresiewicza. A przy tym nie wolno nie zwrócić uwagi na szczególny charakter tego źródla.

${ }^{32} \mathrm{Nr} 375$, r. $1590 ; 287$, r. $1618 ; 558$, r. $1623 ; 311$, akt 2 , r. $1634 ; 397$, r. $1636 ; 666$, r. $1675 ; 44$, r. $1677 ; 606$, r. $1743 ; 213$, r. $1760 ; 350$, r. $1776 ; 93$, r. 1793.

${ }^{33} \mathrm{Nr} 20$, r. $1590 ; 662$, r. $1642 ; 140$, r. 1791.

${ }^{34} \mathrm{Nr} 555$, r. $1599 ; 340$, r. $1732 ; 211$, r. $1754 ; 452$, r. 1786 . Także możliwość w akcie z r. 1625 , nr 711 .

${ }^{35} \mathrm{KH}, \mathrm{t} .60$, nr 3, s. 87.

${ }^{36} \mathrm{~W}$ wypadku z r. 1732 cesja poddanych na rzecz nabywcy została odwolana, ale nowy pan extraditiones prolongat, por. J. Deresiewicz, Handel chlopami $w$ dawnej Rzeczypospolitej, Warszawa 1958, s. 5-8, gdzie zawarte ,handlowa” interpretacja aktu.

${ }^{37} \mathrm{Z}$ taką możliwością liczył się S. Szczotka, Zwalnianie chlopów z poddaństwa w województwie krakowskim w latach 1572-1794, CPH, t. 3, 1951, s. 261.

${ }^{38}$ Materialy, t. 3, s. 79. 
Zawiera ono tylko akty transakcyj chłopami, one jedynie znalazły się w wykorzystywanym przez nas zbiorku. Dowiadujemy się więc $z$ nich o takich tylko ekscypowanych, którzy stali się przedmiotem "handlu". W jakim stopniu wiadomości te są reprezentatywne?

Niektóre teksty podają, jak się technicznie przeprowadzało to ekscypowanie. Nie zawsze poddani odchodzili od razu za swym dotychczasowym panem, jak to miało miejsce w wyżej powolanym akcie z $1732 \mathrm{r}$. (nr 340). Ignacy, rezerwowany 16 lipca $1780 \mathrm{r}$., pozostaje na gruncie do św. Wojciecha, jak się domyślamy, roku następnego. I wtedy dopiero ma zostać wydany za pierwszq rekwizycyjq (nr 87). W innym wypadku zastrzeżeni parobcy odebrani zostali rok później, za rewersem (nr 358, r. 1785-7). Wolno wnosić, że ten odstęp czasu umożliwiał ukończenie dawniejszych robót i przygotowanie nowego warsztatu pracy na innym miejscu.

W jednym wypadku nabywca nie wydal ekscypowanej dziewczyny, thumacząc się tym, że wyszła u niego za mąż. Powołując się więc na zasadę uxor sequitur conditionem mariti oraz na zakaz konsystorza gnieźnieńskiego, uiścił za nią główszczyznę cywilną (nr 681, akt 1, r. 1741).

\section{5}

Prawo ekscypowania jest wyjątkiem od reguly zwiazzania chlopa-poddanego z gruntem. Czym je uzasadnić? Być może, tak przeinaczone zostało w dobie nowożytnej średniowieczne prawo wychodu kmiecia ze wsi w liczbie ograniczonej ${ }^{39}$. Do takiego poglądu skłaniałby przytoczony wyżej akt, ekscypujący po jednym parobku z każdej z sześciu alienowanych wsi. W ten sposób w dobie poddaństwa wtórnego wzmożone prawa pańskie $\mathrm{i} w$ tej materii znaleźć mogły swój wyraz.

Ale rzecz ująć można inaczej. Zauważyliśmy, że w masie wypadków ekscypowaniem objęto rzemieślników, czyli ludzi związanych z dworem pańskim, a nie $\mathrm{z}$ jego folwarkiem. To nie byli chłopi pańszczyźniani ${ }^{40}$. Ich stosunek do majątku był dość luźny, wiązała ich $\mathrm{z}$ nim tylko władza pańska. Tu leżało sedno sprawy.

W okresie zaostrzonego poddaństwa nielatwy byl do pomyślenia trwały stosunek obligatoryjny umowy o pracę między chłopem a panem. Świadczą o tym liczne akty powzdań chłopów-rolników ${ }^{41}$. Podobnie, jeśli szlachcic poszukiwal lokaja albo kołodzieja czy cieślę; wynajmujący swe ushugi fachowiec musiał się zgodzić na stworzenie stosunku rzeczowego, na przyjęcie

\footnotetext{
${ }^{39}$ S. Kutrzeba, Historia ustroju Polski $w$ zarysie, wyd. 8, s. 172.

40 Por. obserwację J. Rafacza o ekscypowaniu kucharza, Ustrój, s. 97.

41 W. Dworzaczek, Dobrowolne poddaństwo chlopów, Warszawa 1952, s. 43-60.
} 
poddaństwa ${ }^{42}$. Ten stosunek rzeczowy nie przestawal jednak pełnić tej samej funkcji, jaka $w$ innych systemach prawnych tworzą obligacje ${ }^{43}$. Jeśli wiẹc pan-kontrahent sprzedawał swoją wieś, zmieniał w istotnym punkcie warunki umowy $\mathrm{z}$ kontrahentem-rzemieślnikiem. Przed taką jednostronną zmianą stosunku należało rzemieślnika chronić, tym samym stworzyć możliwość uchylenia ujemnych następstw rzeczowego stosunku, poddaństwa. Temu celowi służyło ekscypowanie. Dzięki niemu wyłączono rzemieślnika z majątku, któremu rzeczowo podlegal. Przez wymówienie zdobywal on sobie swobodẹ udania się tam, gdzie pragnąl wejść w nowy stosunek pracy, albo utrzymywał zobowiązania zaciągnięte wobec dotychczasowego swego pana. W pierwszym wypadku ze względu na wspomnianą cechę prawa ziemskiego, skłonnego uznać tylko stosunki rzeczowe $\mathrm{z}$ chlopami, nowy kontrakt ubrany zostanie w szaty subditatura. Dawny pan, o ile nie zachowa fachowca u siebie, przeniesie heroica potestas na innego szlachcica; rzemieślnik stanie się poddanym nowego dworu.

Formalnie rzecz biorąc, mamy $w$ tym wypadku do czynienia $\mathrm{z}$ ekscypowaniem poddanego i $\mathrm{z}$ dokonaną nim transakcją, powodującą przeniesienie węzła poddańczego. Materialiter jest to locatio-conductio operarum. Zawierał ją rzemieślnik dość swobodnie. Dobrowolnie stał się pracownikiem u dawnego pana wsi. Gdy ten majątek sprzedal, odchodził wraz $z$ nim, bądź by u niego dalej pracować, bądź też by znaleźć dla siebie nowe miejsce pracy.

Szczególny charakter ma wyjęcie chlopca, który jest studiosus, czy wypadek, w którym przewiduje się libertację. W takich razach wyłącznym celem ekscypowania było, by objęci nim subditi w obce nie przeszli poddaństwo ${ }^{44}$.

Czy więc nie dokonywano ekscypowania więcej w interesie poddanych aniżeli dla korzyści pańskiej? ?5 $^{45}$

Przedstawione ujęcie stosunku poddaństwa rzemieślników jako zewnętrznej szaty treści obligatoryjnej pozwoli nam na wysunięcie dalszego wniosku: ekscypowanie poddanych i transakcje nimi nie upoważniają w żadnym razie do wysunięcia tezy o handlu chlopami ${ }^{46}$.

${ }^{42}$ Dalecyśmy od twierdzenia, że kontrakt był absolutnie niemożliwy, por. S. Kutrzeba, Historia, s. 300, ale jak latwo przedzierzgał się on w stosunek rzeczowy: siedzący za kontraktem chłop narobił dhugów, przez to już stawał się poddanym (nr 361, r. 1787)! Być może, należałoby w miejsce nie obowiązującej u nas zasady Stadtluft macht frei ukuć inną, charakterystyczną dla wsi polskiej: Dorfluft macht eigen.

${ }^{43} \mathrm{Ta}$ rola stosunku rzeczowego występuje wyraźnie w wypadkach przyjęcia poddaństwa na pewien tylko czas, jak też gdy chłop oddawał się w zastaw, W. Dworzaczek, Dobrowolne poddaństwo, s. 55-6. O pewnej swobodzie wieśniaka świadczą też okres̉lone terminy, w których te powzdania $z$ reguły się odbywają, ibidem, s. 60 .

${ }^{44}$ Por. S. Szczotka, Zwalnianie, s. 265.

${ }^{45}$ Por. tu J. Rafacz, Ustrój, s. 96.

${ }^{46}$ Por. nasze uwagi w artykule Chlopska glówszczyzna, s. 187-189. 


\section{La proles illegitima et le ius terestre polonais*}

Le droit canon introduisit dans les systèmes juridiques européens le concept des enfants illégitimes. Par la suite, la distinction des enfants nés dans le mariage et de ceux nés hors mariage devint d'une importance capitale pour leur statut juridique. Les enfants illégitimes étaient frappés d'une déchéance qui n'était connue, autrefois, ni des droits germaniques, ni des droits slaves.

L'Eglise justifie le châtiment infligé aux enfants par le péché de leurs parents. Elle punit, dans la personne des enfants, le commerce illicite des parents qui ne se sont pas soumis à sa volonté. Or, il n'existe pas dans le cas du matrimonium putativum. Par conséquent, de cette union naissent des enfants légitimes, bien que nés hors mariage. Les deux notions: la légitimité des enfants et leur naissance dans le mariage (descendance nuptiale) ou hors du mariage (descendance non nuptiale), ne se recoupent pas.

Le droit canonique s'en tient à ces trois possibilités. N'y a-t-il pas, dans d'autres systèmes, une quatrième modalité encore, celle où la descendance, née dans le mariage, n'est cependant pas dite légitime? Les enfants nés dans le mariage morganatique en sont un exemple classique (descendance nuptiale illégitime). Ils sont alors victimes des dispositions du droit dit "public», toute réserve étant faite sur cette distinction assez anachronique au Moyen-Age. Cependant des mobiles d'ordre "privé» purent entraîner la même conséquence, comme l'atteste le Miroir de Saxe (Landrecht, livre I, art. 37).

On en est donc arrivé au tableau suivant:

\begin{tabular}{cccc}
\multicolumn{2}{c}{$\begin{array}{c}\text { parents } \\
\text { mariés }\end{array}$} & \multicolumn{2}{c}{ parents } \\
non mariés \\
enfants & enfants & enfants & enfants \\
légitimes & illégitimes & illégitimes & légitimes \\
(règle) & (exception) & (règle) & (exception)
\end{tabular}

* Przedruk z: Revue d'histoire du droit français et étranger 1966, t. 44, s. 242-247. 
Comment se peut-il que le droit, reconnaissant le nariage comme légitime, n'estime pas, en même temps, sa descendance légitime? Cette éventualité, il faut le souligner, est étrangère au droit canon. Si celui-ci désapprouve l'union, il y met les entraves dont il dispose, les impedimenta prohibentia; s'il ne l'admet pas, il l'annule a l'aide des impedimenta dirimentia. Ainsi l'harmonie juridique est établie: tous les enfants nés dans le mariage (descendance nuptiale) sont légitimes, tous les enfants nés hors mariage (descendance non nuptiale) illégitimes. La seule exception, relative à la descendance du mariage putatif, ressort à la logique pure et simple: il n'y a pas de tache originelle dans ce cas.

Il en est autrement dans le droit civil. L'Etat médiéval et, longtemps encore, celui de l'époque moderne reconnaissent, dans toute l'Europe, la compétence du législateur spirituel et de la justice ecclésiastique dans le domaine des sacrements, par conséquent, dans celui du mariage. Les sentences, énoncées par la cour de l'Eglise, sont légales, elles lient le tribunal séculier qui ne peut pas se permettre de les invalider ad spiritualia. Par contre, il n'admet pas toutes les conséquences de la légitimité, reconnue par l'Eglise, ad temporalia (droits de succession, appartenance à la classe privilégiée). L'anomalie mentionnée (descendance nuptiale illégitime) n'est donc qu'une résultante du conflit de deux lois, la canonique et la civile. Elle prouve, au demeurant, la souveraineté du pouvoir séculier qui n'attribue pas une valeur absolue aux saints canons.

Il est donc évident que le législateur laïque statue uniquement sur la quatrième modalité, les trois premières étant réglées, tout particulièrement, par l'Eglise. Cinq lois, échelonnées sur trois siècles, se sont occupées, en Pologne de cette matière $(1505,1578,1633,1658,1768)$. Elles concernent uniquement la noblesse, et son ius «terrestre». Sauf la première, latine, toutes sont rédigées en polonais.

La première, promulguée par le roi Alexandre I, vient rénover la bulle de Grégoire XI, condamnant les articuli reprobati du Miroir de Saxe. Les articles 10 et 11 de la bulle reproduisent, on le sait, exactement le Sachsenspiegel (Landrecht I, art. 37). Or, il n'en est pas de même quant aux prescriptions, insérées dans le statut d'Alexandre, au moins pour la dixième. Celle-ci omet, simplement, l'adverbe violenter, ce qui en altère, entièrement, les dispositions. Dans le droit saxon, le fait de violence justifiait la sanction prévue par le coutumier. Puisqu'elle était intervenue, tous les enfants issus de l'union contractée par la suite entre celui qui avait usé de violence et sa victime, même ceux qui naîtraient après la célébration du mariage (descendance postnuptiale), demeuraient illégitimes. Selon la variante du statut polonais, tout commerce charnel, perpétré avant le mariage, entre le solutus et la soluta, même sans qu'il y ait eu violence, entraîne des suites analogues. Toute union volontaire, qu'elle soit stable ou passagère, est ainsi 
interdite. Cette omission de l'adverbe est-elle voulue ou non par le roi polonais?

Notons le bien: la prétendue régle du Miroir de Saxe fut désavouée par le prince polonais. Elle n'a donc, dorénavant, aucune force de loi.

Cependant le précepte fut réintroduit par la loi de 1578: statuimus ut ex talibus uxoribus, antea concubinis, liberi procreati in nullis bonis haereditent, neque ullam praerogativam nobilitatis habeant, dit-elle en substance'. Voilà ce qui est surprenant. Sa teneur concorde exactement avec la règle modifiée du Miroir, insérée dans le statut d'Alexandre. Comment expliquer la tenacité du législateur? En 1505, il condamnait la disposition du Miroir, attaquée auparavant par le Saint-Siège, en l'altérant de telle sorte qu'elle correspondait littéralement, à la rédaction de 1578 !

A signaler encore que l'acte de 1505 fut réimprimé dans le Commune inclyti Regni Poloniae Privilegium de Jean Laski, 1506. Ce dernier contient, dans sa seconde partie, le Speculum Saxonum dans sa version latine. Aussi, l'article incriminé (Landrecht, I, 37) y figure-t-il pour la seconde fois: en effet, cette fois-là, on y parle du viol! Cette seconde partie concerne les roturiers, citadins et vilains. Nous voyons que son texte est resté inchangé. La première partie du Commune Privilegium concerne la noblesse; la disposition y subit une altération importante. Une seule explication du phénomène paraît ici plausible: la règle s'est déja introduite dans la pratique, elle a été coutumièrement pratiquée par les nobles. Le roi l'a condamnée sous i'influence, semble-t-il, de Jean Laski, chancelier du royaume et futur archevêque de Gniezno. Celui-ci, en sa qualité d'ecclésiastique, combattait la consuetudo nobiliaire qui allait à l'encontre des préceptes canoniques. Pour y mieux parvenir, il allégua que cette coutume provenait du droit saxon, droit qui, en Pologne, était réservé aux plébéiens.

Ses efforts restèrent, d'ailleurs, vains. Dans sa forme la coutume devint loi en 1578. Elle se maintint durant deux siècles.

Dans l'intervalle, deux "constitutions» se sont occupées, elles aussi du problème en question. L'une, de 1633 , se borna à rappeler la validité de la loi précédente. L'autre, de 1658 , suspendit l'application de la règle durant la guerre contre les Suédois. Il est fort symptomatique que même cette suspension provisoire provoqua une véhémente protestation de la noblesse, ce qui prouve combien la question était brûlante. A la Diète de 1659 , on finit par faire supprimer l'article, qualifié de subreptice. La nouvelle rédaction de la loi fut établie et reconnue, seule, officielle. L'article incriminé n'y figure pas. Au surplus, le Sejm interdit de le reproduire dans les temps à venir. Aussi, la collection des lois polonaises du XVIII ${ }^{\mathrm{e}}$ s., les

'Nous reproduisons, ici, la traduction latine, excutée par un juriste de la fin du XVII siècle, Nicolas Zalaszowski. 
Volumina Legum, ne le contient-elle pas. Or, l'auteur réussit à en établir le texte d'apres les rédactions imprimées antérieures a l'injonction de 1658 .

La disposition de 1578 ne fut supprimée, définitivement, qu'en 1768.

D'apres les lois polonaises, la proles illegitima englobe toute la descendance postnuptiale, née dans le mariage légitime reconnu aussi bien par l'Eglise que par l'Etat, malgré l'hostilité de ce dernier. Les "constitutions» justifièrent leur attitude par la haute tenue morale exigée de la noblesse: le couple se discrédite par le commerce illicite anténuptial. Il est évident qu'elles vont, toutes, à l'encontre du droit canonique. Un tel empêchement au mariage reste étranger à celui-ci. La bulle papale condamna les articles du Miroir, moins rigoureux puisque rédigés dans un sens plus étroit que le précepte polonais, en leur objectant le manque de distinction: non distinguendo, prout canones distinguunt. A plus forte raison, pourrait-on adresser le même grief a la législation polonaise. Certes, ce n'est pas la morale chrétienne, catholique, qui la motive, puisque l'Eglise en est la gardienne par excellence. La raison de cette attitude du législateur polonais est donc à rechercher ailleurs.

Rappelons-nous qu'en Pologne on ne reconnaît que la noblesse paternelle. Par conséquent, le noble qui épousait une roturière l'anoblissait et leurs enfants étaient nobles. La bassesse de la condition de la mère ne jouait aucun rôle. La loi n'était donc pas, par principe, antidémocratique.

Cependant la noblesse redoutait les mésalliances de fortune. Elle n'admettait pas que de jeunes seigneurs terriens pussent épouser des jeunes filles non dotées. Qu'elles soient nobles ou non, qu'importe, pourvu qu'elles soient aisées! Puisque les jeunes font, parfois, des imprudences, c'est à la famille et, pratiquement, au père, de consentir à l'union ou de la prohiber. C'est lui qui surveille les intérêts collectifs du groupe familial. Si la jeune fille se marie en dépit de son interdiction, elle sera privée de sa dot, en vertu de la loi contre les rapts de séduction (un raptus sans violence). Mais il était beaucoup plus difficile d'écarter un fils, et de le priver de ses droits à la succession. Celui-ci pour éviter toute complication, attendait, simplement sa majorité ou encore, par mesure de précaution, le décès de son père. Entre-temps, il vivait en concubinage, ce qui ne le déshonorait aucunement. C'est ce qu'une jeune fille ne pouvait pas se permettre, sous peine d'exhérédation. Devenu maître du village, le fils était libre d'épouser son amie. Ainsi passait-il outre à l'interdiction du pere défunt. Grâce à la législation de la proles illegitima, l'intervention de la famille devient possible. Celle-ci laisse l'insubordonné tranquille jusqu'a sa mort, mais après celle-ci, malheur à sa postérité! on objectera alors à la veuve le commerce illicite qu'elle avait eu avant le mariage, ce qui entraînera l'illégitimité de tous les enfants, même postnuptiaux. Non nobles, ils ne seront pas admis à la succession des biens-fonds; ils seront, tous, chassés du manoir, y compris leur mère, iure caduco. 
Une solution inhumaine est contraire à la doctrine de l'Eglise. C'est pour engager les parents naturels à contracter mariage que l'Eglise promulgua la loi, relative à la légitimation par vertu du mariage subséquent (favor matrimonii). Selon les préceptes civils, l'union, dans les mêmes conditions, est formellement prohibée: elle encourra des sanctions sévères. Tous les enfants, anté- et postnuptiaux demeureront à jamais illégitimes, le père décédera donc sans hoirs (du point de vue du ius "terrestre»). Les suites graves du commerce illicite anté-nuptial sont indélébiles.

L'attitude des deux législations, canonique et civile, est donc toute différente. Cette dernière lutte contre les mariages imprudents des fils de famille: elle les entrave, en comptant sur l'autorité paternelle, tout d'abord; sur la vigilance intéressée de la famille, par la suite. Il n'y a qu'une solution pour le jeune homme ayant une petite amie: c'est de l'abandonner et d'épouser une autre femme qui plaise à la famille.

La loi polonaise reflète le souci primordial de la noblesse. Elle est obsédée par la crainte permanente de la banqueroute. Celle-ci, il fallait l'empècher à tout prix, même au prix d'une mésalliance. Pourvu que le jeune agri possessor cherche sa femme parmi les filles aisées!

La postérité illégitime est soumise aux incapacités civiles. Elle n'hérite pas de la noblesse de son père; de plus, elle est privée de ses droits à la succession. Dans cette règle - c'est là son trait caractéristique - c'est la deuxième infériorité que les lois mettent au premier plan. Pour le reste (nom de famille, succession aux meubles), le statut juridique de l'enfant reste imprécis.

Ainsi les deux infériorités mentionnées ci-dessus résument, en définitive, toute la législation ancienne en cette matière. Leur but est d'empêcher les mariages des jeunes hommes, contractés contre le gré de leurs parents, d'interdire au séducteur d'épouser la fille séduite, au cas où elle n'apporte pas de dot. En apparence, c'est le commerce sexuel anténuptial qu'on vise, en le rendant irréparable. En fait, on veut la prohibition du mariage désapprouvé par la famille. Les intérêts de cette dernière prennent, décidément, le dessus sur les velléités de l'individu. Ils vont même plus loin que le respect du mariage, reconnu par le droit canon.

De toute évidence, les dispositions concernant les enfants postnuptiaux illégitimes diffèrent, entièrement, de la légitimation par mariage subséquent. Nous n'y insisterons point. Les historiens les ont confondues, toutes les deux. L'erreur, une fois glissée dans la littérature (Bröcker, 1797), fut reproduite, par la suite, par plusieurs auteurs. Elle s'éternisa grâce a l'ouvrage de synthèse de Dąbkowski. Il fallait donc la rectifier, au préalable.

Dąbkowski, imitant ses prédécesseurs, parla de la légitimation par mariage subséquent des enfants anté- et postnuptiaux, en s'appuyant sur les mêmes lois citées par nous. Certes, c'est là un concept erroné. Il va 
à l'encontre de l'interprétation philologique des textes, d'une part, de l'autre, il est contredit par la carence de la légitimation per subsequens matrimonium en droit séculier - nous y reviendrons tout à l'heure. Finalement, cette explication est intrinsèquement illogique. La légitimation des enfants anténuptiaux est aisée à comprendre. Celle des enfants postnuptiaux présume leur état illégitime depuis la naissance jusqu'a une certaine date de la légitimation que personne ne précise. Personne n'indique, non plus, le pourquoi de la légitimation des enfants postnuptiaux. Ce n'est pas le sacrement du mariage qui pourrait être pris en considération, comme c'est le cas pour les enfants anténuptiaux, puisque le mariage précédait la naissance. Dans ces conditions, l'idée de la légitimation des enfants postnuptiaux n'est aucunement acceptable. Elle est le fruit de l'effort des historiens aux prises avec les dispositions des lois polonaises et la doctrine savante, imprégnée des notions romaines et canoniques. Tout essai de les concilier reste vain. Aucun accomodement n'est possible. Les deux institutions: la légitimation par mariage subséquent des droits romain et canonique et l'illégitimité des enfants postnuptiaux, produit du droit féodal, demeurent irréductibles.

Par contre, l'institution en question ressemble, beaucoup, au mariage morganatique. Celui-ci, ainsi que les lois polonaises relatives à la proles illegitima, reconnaît l'existence des enfants postnuptiaux illégitimes. Ils diffèrent, néanmoins, sensiblement. Le mariage morganatique était fondé sur l'Unebenbürtigkeit. La proles illegitima polonaise s'inspira, pour une grande part, d'un motif analogue. Cependant, elle mit un accent tout particulier et, en dernière analyse, décisif sur l'infériorité économique de l'épouse. Ainsi on écarta de la famille de noblesse terrienne toute femme non aisée, fût-elle roturière ou d'extraction noble. On l'élimina avec toute sa descendance, même postnuptiale, en alléguant son inconduite avant le mariage.

Signalons, encore, que les enfants nés en disparagium sont nobles, pour le moins: ce qualificatif est refusé a la proles illegitima polonaise. Finalement, - c'est une différence non moins importante - le concept de mariage morganatique se restreint, pratiquement, à la plus haute noblesse (der hohe Adel); i'institution étudiée concerne toute la noblesse terrienne, même la plus humble.

La législation, écartant de l'héritage les enfants postnuptiaux, pouvait encore moins admettre la postérité anténuptiale à la succession des biens nobles. Aussi ne reconnut-elle, jamais, la legitimatio per subsequens matrimonium. Le fait est attesté par Dresner (début du $\mathrm{XVII}^{\mathrm{e}}$ siècle): etsi iure canonum illegitima proles per subsequens matrimonium legitimetur, [...] et per consequens in bona succedat parentum, tamen iure Regni contrarium disponitur. $\mathrm{La}$ règle fut maintenue, encore, par la loi de 1768 . Sur ce point, la noblesse polonaise resta intraitable jusqu'aux partages du pays. 


\title{
Die angebliche Aufnahme des Sachsenspiegels Landrecht I 37 in das Polnische Landrecht*
}

\begin{abstract}
Certum vero, hodieque in Polonia et Silesia, Polonici Regni quondam parte, passim Saxonici iuris summam esse auctoritatem: exteris populis maiore veneratione Germanica prosequentibus, quam ipsis Germanis**
\end{abstract}

Das Gesetz von 1768 lautet wie folgt:

„Erläuterung der Constitutionen de illegitima prole

(1) Die Rechte unserer Kronlande und des Großherzogtums Litauen gründen sich auf die göttlichen Gesetze und sind zu keinem andern Zwecke abgefasst, als da $\beta$ in allen vorkommenden Fällen die Gerechtigkeit aufrechterhalten werde;

(2) Da nun das Kirchenrecht die Nachkommenschaft aus einer durch die Copulation legitimierten Ehe $^{1}$ als echt anerkannt und dafür gehalten wissen will;

(3) die Constitutionen von 1578 Vol. $2^{\text {do }}$ fol. 971 und 1633 Vol. $3^{\text {tio }}$ fol. 812 aber diesen Fall nicht erläutern, sondern sich, wie es scheint, nach dem Artikel des Sachsenspiegels in tenore: Quicunque cognoverit publice uxorem etc. bequemen;

(4) und sogar die noch nach der Copulation erzeugte Nachkommenschaft von der Erbfolge in den Gütern und von den adelichen Vorrechten ausschließen wollen;

(5) gedachter Artikel aber per Sedem Apostolicam Romanam und durch unseren Vorfahren, den König Alexander, in dem Statute vom Jahre 1505 Vol. $1^{\text {mo }}$ fol. 340 verworfen worden;

(6) so haben wir mit Übereikunft aller Stände, in Erläuterung gedachter Constitutionen von 1578 und 1633 und mit Erneuerung des Statuts unseres Vorfahren, des Königs Alexander, aus dem Jahre 1505, hiedurch festgesetzt;

* Przedruk z: Wiener Archiv, Bd. 5, Studien zur Geschichte Osteuropeas, III Teil, Graz-Köln 1966, s. 112-129.

** H. Conringii, De origine iuris Germanici liber unus, cap. XXXI, ed. 4, Helmestadi 1695, S. 193

${ }^{\prime}$ Copulation ist hier als Eheschließung zu verstehen (vgl. libri copulatorum). Der Sinn der Originalwendung ist: die Nachkommenschaft ex matrimonio legitimo. 
(7) daß die Nachkommenschaft beiderlei Geschlechts, adlichen Standes, welche aus der durch die Copulation festgestellten Ehe, seit Abfassung obgedachter Constitutionen erzeugt sind, von itzt ab in den Vermögen sowohl ihrer Eltern, als auch der nahen Anverwandten erben sollen..."2.

Der Sinn dieses Gesetzes ist klar: In bezug auf die Unechtheit der adligen ehelichen Nachkommenschaft ${ }^{3}$ hätte sich der polnische Adel bisher nach dem Sachsenspiegel gerichtet.

\section{1.}

Mit dem Ius Theutonicum haben wir in Polen seit dem Mittelalter zu tun. Es tritt zu Beginn des 13. Jahrhunderts hervor ${ }^{4}$.

Dies in Polen erscheinende Recht hat zweifache Bedeutung5. Erstens bedeutet es ein neues Agrarsystem, das durch die deutschen Kolonisten mitgebracht wurde (erbliche Rechte des Bauern, Freiheit der Person, Zinszahlungen usw. $)^{6}$. Die Literatur darüber ist unübersehbar ${ }^{7}$. Damit wollen wir uns hier nicht befassen. Wir vermerken nur, da $\beta$ die neue Erscheinung sich schon im 13. und in den folgenden Jahrhunderten weit verbreitet hat ${ }^{8}$. Schließlich, schreibt der Posener Meister K. Tymieniecki,

${ }^{2}$ Volumina Legum [weiterhin: VL], Bd. 7, Petersburg 1860, S. 807-8. Das Original ist polnisch verfaßt. Wir bedienen uns hier der Übersetzung von Friedrich Benjamin Bröcker. Er war Königl.-Preuss. Ober-Accise-und Zollrat, Iustitiarius bey der Direction zu Kalisch, auch JustizCommissarius und Notarius publicus im Departement der Südpreussischen Regierung zu Posen, s. seine Beyträge zur Kenntniss des pohlnischen Rechts. Berlin 1797, Bd. 1, S. 59. Bröcker, wie er selbst angibt, war des Polnischen kundig, ebenda S. V. Wir haben die Übersetzung an manchen Stellen etwas verbessert.

${ }^{3}$ Wir unterscheiden die eheliche und echte, d. h. legitime, von der ehelichen unechten, d. h. illegitimen Nachkommenschaft.

${ }^{4}$ K. Tymieniecki, Historia chlopów polskich, Bd. 1, Warszawa 1965, S. 381, 386, 401 Anm. 19,415 .

${ }^{5}$ K. Tymieniecki, Prawo niemieckie w rozwoju spolecznym wsi poskiej, Kwartalnik Historyczny [weiterhin: KH] 37 (1923) S. 38-9. Hinsichtlich der Terminologie: Ders., Historia chlopów, S. $427,478 \int f ., 481$.

${ }^{6}$ B. Ulanowski, Wieś polska pod wzgledem prawnym od wieku XVI do XVIII, Rocznik Akademii Umiejejtności 1893/94, Kraków 1894, S. 123; K. Tymieniecki, Historia chlopów, S. 426.

${ }^{7}$ Vgl. H. F. Schmid, Polens geschichtliche Beziehungen zu Deutschen und Tschechen in polnischer Schau, Blick nach Osten, 2 (1949), S. 68 f. Dazu auch M. Bloch, Un problème de contact social: la colonisation allemande en Pologne, Annales d'histoire économique et sociale 6 (1934), S. 593-8; M. Friedberg, Kultura polska a niemiecka, Bd. 1, Poznań 1946, S. 176-82; J. Matuszewski, O biskupstwie lubuskim, Czasopismo Prawno-Historyczne [weiterhin: CPH] 2 (1949) S. 76-81, 78 Anm. 4-5. AuBer der dort angeführten Literatur noch H. F. Schmid, Zur Geschichte der Bedeutungsentwicklung westslawischer Lehnwörter für Institutionen der lateinisch-germanischen Kultur, In: Streitberg-Festgabe, Leipzig 1924, S. 331-5; letztens auch das Hauptwerk von K. Tymieniecki, Historia chlopów, S. 393.

${ }^{8}$ K. Tymienicki, Historia chlopów, S. 386, 486. 
darf es nicht als übertrieben betrachtet werden, da $\beta$ diese Erscheinung in mancher Hinsicht einen hundertprozentigen Erfolg errang'.

Das lus Theutonicum hat zweitens auch einen anderen Sinn: Es führte neue Normen, nämlich das deutsche Privat-, Straf- und Prozeßrecht ${ }^{10}$ sowie die deutsche Gerichtsorganisation ${ }^{11}$, ein. Für den Rechtshistoriker ist das keineswegs weniger beachtenswert ${ }^{12}$.

Dazu ist folgendes zu erwähnen: Der deutsche Charakter der genannten Umwandlung der Agrarstruktur ist mehr als fraglich. Mit Recht betonte W. Maas die verblüffende Ähnlichkeit der Lage der deutschen Kolonisten mit der die den Bauern in Frankreich die Loi de Beaumont gewährte ${ }^{13}$. Es handelt sich hier also um eine internationale Erscheinung ${ }^{14}$, die in Polen durch die deutsche Kolonisation vielleicht beschleunigt wurde ${ }^{15}$.

${ }^{9}$ Ebenda, S. 364.

${ }^{10}$ H. F. Schmid, Die rechllichen Grundlagen der Pfarrorganisation auf westslawischem Boden und ihre Entwicklung während des Mittelalters, Zeitschrift für Rechtsgeschichte [weiterhin: ZRG] Kan. Abt. 49 (1929), S. 383.

i1 M. Bobrzyński, $O$ zalożeniu wyższego $i$ najwyższego squdu prawa niemieckiego na zamku krakowskim, In: Rozprawy i Sprawozdania z posiedzeń Wydzialu Historyczno-Filozoficznego Akademii Umiejętności 4 (1875), S. 119; M. Friedberg, Kultura polska, S. 256-7; B. Ulanowski, Wieś, S. 154; K. Tymieniecki, Historia chlopów, S. 468, 502-3, 512, 515.

${ }^{12}$ K. Tymieniecki betrachtet das erste Problem als das wichtigere, vgl. seine [Rezension zu:] Marian Friedberg: Kultura polska i niemiecka, I, II, Poznań 1946, KH 55 (1948), S. 74, das zweite als sekundär, Historia chlopów, S. 372. Er betont, die Rechtsänderungen hätten sich nicht auf einmal und nicht im ganzen vollzogen; die Aufnahme des deutschen Prozeßrechts war nicht vollständig, Historia chlopów, S. 500-3; er sieht jedoch die Auswirkung des deutschen Rechts in den Dörfern, S. 512. Von der Anwendung des deutschen Strafrechts unter den Bauern B. Ulanowski, Wies, S. 165; er stellt fest, daB sich die Dorfgerichte auf Groickis Werk berufen haben, S. 155.

13 W. Maas, "Loi de Beaumont" und Ius Theutonicum, Vierteljahresschrift für Sozial- und Wirtschaftsgeschichte 32 (1939), S. 225. Früher schon K. Tymieniecki, Prawo niemieckie, S. 41-50; vgl. auch dessen Historia chlopów, S. 427, sowie M. Friedberg, Kultura polska, S. 176-82.

${ }^{14} \mathrm{DaB}$ die durchweg an der Oberläche bleibenden westlichen Einflüsse auf diese Vorgänge zwar sprachlich und sachlich vielfach deutsches Gepräge trugen, in ihrem Wesen aber Erscheinungsformen eines zumindesten das gesamte Abendland erfaßten Bewegung waren [...] $\mathrm{DaB}$ eine gleiche Wertung auch das viel komplexere Geschehen der Entstehung städtischer und ländlicher Siedlungen "zu deutschem Recht» erheischt, ist eine Erkenntnis, der sich auch die deutsche Wissenschaft auf die Dauer kaum wird verschließen dürfen", H. F. Schmid, Polens gesch. Beziehungen, S. 68-9; ein „europäisches internationales Siedlungsrecht", K. Kroeschell, ZRG Germ. Abt. 85 (1955), S. 309; ,die mittelalterliche deutsche Ostbewegung [...] war Siedlung und sie war Ausbreitung westlicher Verfassungs-, Rechts- und Wirtschaftsformen in deutschem Gewande nach dem Osten", W. Schlesinger, Die geschichlliche Stellung der mittelalterlichen deutschen Ostbewegung, Historische Zeitschrift [weiterhin: HZ] 183 (1957), S. 530; „denn die Kolonisation ist kein deutsches, sie ist kein slawisches, sie ist kein mitteleuropäisches Problem. Sie ist ein Phänomen des europäischen Mittelalters", F. Graus, Deutsche und slawische Verfassungsgeschichte?, HZ 197 (1963), S. 302.

is W. Schlesinger, Die geschichtliche Stellung, S. 532, 535. 
Dagegen hat das Ius Theutonicum im zweiten Sinne unbestritten das Gepräge deutschen Geistes. Das, was die Kolonisten mitgebracht haben, war tatsächlich echt deutsches Recht.

Während das Ius Theutonicum im ersten Sinne unter dem Druck der wirtschaftlichen Kräfte immer mehr zurückging, so daß es später zur sogenannten sekundären, der verschärften Leibeigenschaft $\mathrm{kam}^{16}$, blieb es im zweiten Sinne bis zu den Teilungen Polens in $\mathrm{Kraft}^{17}$.

Bis zur Kolonisationszeit unterlag die ganze polnische Bevölkerung, auch die bäuerliche, der polnischen Gerichtsorganisation und dem polnischen Landrecht ${ }^{18}$. An diesem Sachverhalt hat das deutsche Recht anfangs nichts geändert. Es war zunächst - dem Personalitätsprinzip gemäß - nur Recht der deutschen Kolonisten ${ }^{19}$. Nach und nach erfaßte es aber die ganze

${ }^{16}$ Über die Zurücknahme der gewährten Freiheiten vgl. K. Tymieniecki, Historia chlopów, S. 429. Als erstes Merkmal dieses für die Bauern ungünstigen Prozesses möchten wir diese Klauseln der Lokationsurkunden betrachten, die die Herrenrechte vorbehalten, da der Aussteller das deutsche Recht nicht kannte; vgl. dazu J. Matuszewski, Motywacja ignorancyjna w dokumentach prawa niemieckiego, In: Studia Historica w 35-lecie pracy naukowej Henryka Eowmiańskiego, Warszawa 1958, S. 175-6. Diese Klauseln erscheinen schon Ende des 13. Jh.s und halten sich bis zum Anfang des 15. Jh.s, ebenda, S. 168-9, 177.

${ }^{17}$ Sogar länger, s. A. Halban, Zur Geschichte des deutschen Rechtes in Podolien, Wolhynien und der Ukraine, Berlin 1896, S. 54.

${ }^{18}$ K. Tymieniecki, [Rezension zu:] Adam Vetulani: $W$ sprawie prawa chlopskiego w Polsce feudalnej, Państwo i prawo, Nr. 10, S. 618-32. Warszawa 1956. In: Roczniki Historyczne [weiterhin: RH] 24 (1958), S. 403; Ders., Historia, S. 486, 491, 517.

${ }^{19}$ Wir lassen das ganze äußerst schwierige demographische Problem beiseite. Die deutschen Historiker sind geneigt, das Ausmaß der deutschen Kolonisation zu übertreiben, die polnischen hingegen sind bestrebt, es aus Furcht vor dem germanischen Drang nach Osten zu vermindern. Natürlich läßt sich die Sache nie statistisch erfassen und endgültig entscheiden; vgl. die letzten Versuche S. Trawkowskis, der die deutsche Bevölkerung in Schlesien zu Anfang des 14. Jh.s auf 15-20\% der Gesamtbevölkerung schätzt: $W$ sprawie roli kolonizacji niemieckiej $w$ przemianach kultury materialnej na ziemiach polskich $w$ XIII wieku, Kwartalnik Historii Kultury Materialnej 8 (1960), S. 187. Für unsere Frage ist das sonst nicht wichtig. Es ist evident, daß die Besiedlung nach deutschem Recht und die Besiedlung mit deutschen Kolonisten scharf zu trennen sind; so schon R. Koebner, Dans les terres de colonisation: Marchés slaves et villes allemandes, Annales d'hist. écon. et soc. 9 (1937), S. 547; J. Matuszewski, O biskupstwie lubuskim, S. 77. Die erste gestattet nicht, Schlüsse bezüglich der Germanisierung des Landes zu ziehen, vgl. M. Bobrzyński, $O$ zalożeniu, S. 112; K. Kadlec, Introduction à l'étude comparative de l'histoire $d u$ droit public des peuples slaves. = Collection de manuels publiée par l'Institut d'études slaves, 3. Paris 1933, S. 233; W. Schlesinger, Die geschichtliche Stellung, S. 533; S. Trawkowski, Zur Erforschung der deutschen Kolonisation auf polnischem Boden im 13. Jahrhundert, Acta Pol. Hist. 7 (1962), S. 88; K. Tymieniecki, Historia chlopów, S. 361, 364, 412, 418. In den Ostteilen des damaligen Königreichs Polen ist es überhaupt zur „Verpflanzung des deutschen Rechts ohne deutsche Kolonisation" gekommen, A. Halban, Zur Geschichte [...] Podolien, S. 131; vgl. ebenda, S. 17-18. Die These von C. Redlich: „wer deutsches Recht erhielt, verlor damit formell und im Laufe der Zeit auch faktisch seine slavische Nationalität', Nationale Frage und Ostkolonisation im Mittelalter. = Rigaer Volkstheoretische Abhandlungen, H. 2, Berlin 1934, S. 52, ist unhaltbar. - Wir verzichten hier auf die Beschreibung der technischen 
polnische Stadt ${ }^{20}$ und Dorfbevölkerung ${ }^{21}$. In der Zeit seiner größten Verbreitung, zu Lebzeiten Kasimirs des Großen ${ }^{22}$, wurde das deutsche Recht offiziell anerkannt $(1356)^{23}$. Mit der Zeit hat sich der Rezeptionsprozeß weiter vertieft. Im 15. Jahrhundert wurde in vielen Fällen das deutsche Recht ganzen Güterkomplexen urkundlich verliehen ${ }^{24}$. Um die Wende zum 16. Jahrhundert - wir verzichten hier auf Nuancen ${ }^{25}-$ kann die Evolution als abgeschlossen betrachtet werden. So ist das fremde Recht nach einigen Generationen zum Recht aller Plebejer geworden, auch das der Plebejer polnischer Nationalität. Der berühmte Jurist Groicki hat bestimmt nicht grundlos geschrieben: „alle Stadtbewohner und das Bauernvolk in der

Neuigkeiten, die im Zusammenhang mit der Kolonisation des deutschen Rechts auftreten, vgl. S. Trawkowski, $W$ sprawie roli, S. 188-197.

${ }^{20}$ S. Kutrzeba, Historia źródel dawnego prawa polskiego, Bd. 2, Lwów 1926, S. 203; H. F. Schmid, Das deutsche Recht in Polen, In: Deutschland und Polen. Beiträge zu ihren geschichtlichen Beziehungen, München u. Berlin 1933, S. 67.

${ }^{21}$ B. Ulanowski, Wieś, S. 123; S. Kutrzeba, Historia źródel, Bd. 2, S. 319, 321; H. F. Schmid, Das deutsche Recht, S. 67; W. Schlesinger, Die geschichtliche Stellung..., S. 533; vgl. auch W. Abraham, Zawarcie malżeństwa w pierwolnym prawie polskim, Lwów 1925, S. 277-8.

${ }^{22}$ M. Patkaniowski, Polityka miejska Kazimierza Wielkiego, Sprawozdania Akademii Umiejętności 43 (1938), S. 87; F. Bujak, Życie gospodarcze Polski za czasów Kazimierza Wielkiego, Wiadomości Historyczno-Dydaktyczne 2 (1934), S. 166.

${ }^{23}$ So schon J. Laski, Akta Aleksandra, hrsg. v. F. Papée, Kraków 1927, Nr. 303, S. 514; diese Meinung ist heute die herrschende, s. S. Kutrzeha, Historia źródel, Bd. 2, S. 205.

${ }^{24} \mathrm{~F}$. Bujak, Ogólny zarys historii osadnictwa niemieckiego na zachodnich ziemiach Polski, Kraków 1945, S. 48.

${ }^{25}$ Das deutsche Privatrecht wurde nicht überall zugleich mit der neuen Wirtschaftsform eingeführt. Übrigens wurde es auch nach der Einführung nicht immer angewandt: es gibt sogar Beispiele seines Rückgangs zugunsten des polnischen Rechts, was durch die Statuten Kasimirs des Großen bezeugt wird [plures sunt nostri milites, ius Theutonicum habentes in multis ipsorum villis ex nostra aut predecessorum gracia eis facta, et tamen, iure Theutonico obmisso, secundum ius Polonicum se regunt in quibusdam. Król. art. 62; dazu R. Hube, Prawo polskie w 14. wieku. Ustawodawstwo Kazimierza Wielkiego, Warszawa 1881, S. 152; M. Handelsman, Prawo karne $w$ statutach Kazimierza Wielkiego, Warszawa 1909, S. 102-3; A. Winiarz, Prejudykaty w statutach Kazimierza Wielkiego, KH 9 (1895), S. 200; R. Grodecki, Wole i Igoty, In: Studia poświęcone [...] Bujakowi, Lwów 1931, S. 63; Z. Wojciechowski, Das Ritterrecht in Polen vor den Statuten Kasimirs des Großen, Breslau 1930, S. 121 Anm. 54; K. Tymieniecki, Sqdownictwo w sprawach kmiecych a ustalanie sie stanów na Mazowszu pod koniec wieków średnich, Poznań 1922, S. 171]. Diese Fälle werden gern durch die polnischen Wissenschaftler betont, K. Tymieniecki, Prawo niemieckie, S. 39; M. Friedberg, Kultura polska, Bd. 1, S. 214-5; zuletzt sprach G. Labuda noch von Städten, die wieder ,,unter das Joch" des polnischen Rechts zurückgekommen sind; derselbe Rückgang in Dörfern wird durch ihn als verhältnismäßig häufig bezeichnet, vgl. Miasta na prawie polskim, In: Studia Historica..., Warszawa 1958, S. 188, 193. Wenn auch die Beobachtungen in Einzelfällen richtig sind, ist Vorsicht bei deren Verallgemeinerung geboten, und zwar im Hinblick auf das Endresultat: die Aufnahme des deutschen Rechts. 
Polnischen Krone werden seit zweihundert Jahren und noch weiter nach dem deutschen, Magdeburger Recht geurteilt"26.

Eine nationale Opposition gegen das übernommene deutsche Recht im 15. Jahrhundert (Ostroróg) blieb ohne irgendeine praktische Auswirkung ${ }^{27}$. Es gab noch im folgenden Jahrhundert einen Versuch - es war der einzige - das deutsche Recht abzuschaffen ${ }^{28}$, die sogenannte Kodifikation Śliwnickis. Sie war ebenfalla erfolglos ${ }^{29}$. Das deutsche Recht hat allen Angriffen standgehalten und ist in Polen auch weiterhin geltendes Recht geblieben.

An diesen Rechtszustand hatte man sich so gewöhnt, daß spätere Änderungen des deutschen Rechts in Deutschland auch in Polen eingeführt wurden, und zwar meistens infolge privater Initiative polnischer Juristen. Die Romanisierung des Rechts in Deutschland wurde durch die Aufnahme der Glosse in den Sachsenspiegel und ins Weichbildrecht auch in Polen vollzogen $^{30}$. Ja sogar die bekannte Reform des deutschen Strafrechts durch Karl V., die Peinliche Halsgerichtsordnung, wurde auch in Polen anerkannt. B. Groicki hat die CCC nämlich in sein Werk Dieses Verfahren ist den kaiserlichen Gesetzen entnommen, welche Carolus $V$ in all seinen Reichen verkünden liess aufgenommen (1559); diese private Arbeit wurde praktisch in den Gerichten des deutschen Rechts als Rechtsquelle benutzt ${ }^{31}$. „Groicki hat also durch eine Übersetzung ein in Polen neues Recht eingeführt und dessen Rezeption auf das wirksamste vollzogen", schrieb Lothar Dargun ${ }^{32}$.

Es mu $B$ dahingestellt bleiben, warum das deutsche sächsische Recht eine so günstige Aufnahme in Polen und anderen slavischen Ländern gefunden hat. Im allgemeinen stand es doch nicht viel über dem durchschnittlichen Niveau der mittelalterlichen nichtentwickelten Rechtssysteme, stellte $\mathbf{O}$. Balzer fest ${ }^{33}$. Verdankt es seine Karriere nicht vielleicht dem Umstand, daß es so früh schriftlich niedergelegt wurde $^{34}$ ?

${ }^{26}$ B. Groicki in der Vorrede zu seinem Porzqdek sqdów $i$ spraw miejskich prawa majdeburskiego w Koronie Polskiej (1559), Warszawa 1953, S. 3; vgl. auch L. Dargun, O źródlach prawa miast polskich $w$ wieku szesnastym, Teil I, Rozprawy Akademii Umiejętności, Wydział Historyczno-Filozoliczny 22 (1888), S. 3; Teil II, Rozprawy AU 25 (1891), S. 122; A. Vetulani, $W$ sprawie prawa chlopskiego w Polsce feudalnej, Państwo i Prawo 11 (1956), 2, S. 624, 626-8.

${ }^{27}$ L. Dargun, $O$ źródlach, Teil I, S. 4.

${ }^{28}$ L. Dargun, Die Reception der Peinlichen Halsgerichtsordnung Kaiser Karls V. in Polen, ZRG Germ. Abt. 10 (1889), S. 172.

${ }^{29}$ J. Dworzaczkowa, $Z$ historii projektu kodyfikacji Macieja Śliwnickiego, CPH 6 (1954), 1, S. 181; S. Russocki, Przyczynek do historii projektu kodyfikacji Macieja Śliwnickiego, CPH 7 (1955), 1, S. 225-6.

${ }^{30}$ L. Dargun, $O$ źródlach, Teil I, S. 4.

${ }^{31}$ K. Koranyi [Einführung zu:] Groickis, Porzqdek, S. XI. Groicki hat auch gleichzeitig einige andere kaiserliche Konstitutionem eingeführt, S. Kutrzeba, Historia źródel, Bd. 2, S. 281-2; vgl. auch H. F. Schmid, Das deutsche Recht, S. 76.

${ }^{32}$ L. Dargun, Die Reception, S. 197; vgl. auch A. Vetulani, $W$ sprawie, S. 628.

${ }^{33}$ O. Balzer, O Niemcach w Polsce, KH 1911, S. 445.

${ }^{34}$ A. Vetulani, $W$ sprawie, S. 626. 
Im 13. und 14. Jahrhundert, gleichzeitig mit der Einführung des deutschen Rechts, bildeten sich in Polen die Stände ${ }^{35}$. Die beiden parallel laufenden Prozesse haben eine merkwürdige Rechtsspaltung der Bevölkerung Polens in zwei Gruppen herbeigeführt. Für die eine Gruppe, den Adel, besteht das polnische materielle und formelle Recht sowie die polnische Gerichtsorganisation $^{36}$. Die zweite, wesentlich zahlreichere Gruppe der Leute plebeiae conditionis, Städter und Bauern, untersteht dem deutschen Recht und der deutschen Gerichtsorganisation ${ }^{37}$. Infolgedessen ist das einheimische, polnische Landrecht zu Adelsrecht geworden ${ }^{38}$ und die polnischen Landgerichte zu Adelsgerichten ${ }^{39}$. Die Plebejer in iudicio [terrestri] standi ius non habent, schrieb M. Kromer ${ }^{40}$. Der obere, adlige Stand, der im Besitz der politischen Macht war, hat sein eigenes Rechtsleben erworben. Das niedere Volk hingegen wurde an das fremde, rezipierte deutsche Recht verwiesen ${ }^{41}$. Darüber beklagte sich Ostroróg: Praeterea aliud nobiles ius habent, aliud plebei; unum Polonicum, aliud Theutonicum ${ }^{42}$. Richtig hat auch Kromer wahrgenommen: (Kasimir der Große) nec ipsos modo Theutonos iure suo Saxonico seu Magdeburgensi uti permisit, sed suis quoque Polonis, nobilitate excepta, id indulsit ${ }^{43}$. Diese Tatsache ist auffallend.

Sie ist begleitet von einer anderen Erscheinung: Das polnische Landrecht, also das Adelsrecht, ist im Grunde stets Gewohnheitsrecht geblieben. Das Plebejerrecht dagegen - hauptsächlich der Sachsenspiege $1^{44}$ - war ius scriptum,

${ }^{35}$ Auf den Zusammenhang wies schon H. F. Schmid, Das deutsche Recht, S. 71-3, hin.

${ }^{36}$ A. Vetulani, $W$ sprawie, S. 619.

${ }^{37}$ Nach der Schätzung von W. Kula gab es in Polen im 16. Jahrhundert $90 \%$ Plebejer und $10 \%$ adlige, Stan $i$ potrzeby badań nad demografiq historycznq dawnej Polski (do poczqıłów XIX wieku), Roczniki Dziejów Społecznych i Gospodarczych 13 (1951), S. 71. Diese Prozentsätze haben sich ungefähr gehalten: im 18. Jahrhundert $8 \%$ Adlige nach T. Korzon, Wewnętrzne dzieje Polski za Stanislawa Augusıa, Bd. 1, Kraków 1897, S. 321. Die Nobilitas ist also zahlreicher als in anderen Ländern.

38 „Mit polnischem Landrecht wurde der Ritterstand bewidmet”, schrieb B. Groicki, Porzq̨dek, S. 23; vgl. auch K. Tymieniecki, Sqdownictwo, S. 133, 136. Darf man aber vom „ritterlichen Landrecht” im Jahre 1237 sprechen, S. Trawkowski, Zur Erforschung, S. 89, N. 44 ?

${ }^{39}$ K. Tymieniecki, Prawo niemieckie, S. 59; Ders., Historia chlopów, S. 486, 491; H. F. Schmid, Das deutsche Recht, S. 73.

${ }^{40}$ M. Kromer, Polonia sive de situ, populis, moribus, magistratibus et republica Regni Polonici libri duo (1578), hrsg. W. Czermak, Kraków 1901, S. 62.

${ }^{41}$ Die Gegenüberstellung des deutschen Rechts und des (polnischen) Landrechts bei K. Tymieniecki, Historia chlopów, S. 489-91, 507, 512.

${ }_{42}$ J. Ostroróg, Monumentum pro Reipublicae utilitate, hrsg. T. Wierzbowski, Warszawa 1891, Kap. XXVI.

${ }^{43}$ Dieser Satz ist zitiert von B. Groicki, Porzqdek, S. 17, ebenfalls von Conring, a. a. O., S. 192.

${ }^{44}$ S. Kutrzeba, Historia źródel, Bd. 2, S. 203-4; H. F. Schmid, Das deutsche Recht, S. 76. 
und zwar in besonderem Sinne: so wie es in den Werken polnischer Juristen festgehalten war.

Es bestanden also in Polen gleichzeitig zwei Rechtssysteme, das polnische für den Adel, das deutsche für das niedere Volk. Dieser Zustand hat sich bis zu den Teilungen Polens nicht geändert. Als die Zeit moderner Kodifikationen kam, war Polen nicht mehr unabhängig ${ }^{45}$.

Natürlich ist das deutsche Recht in Polen nicht unverändert geblieben, es hat sich in der neuen Heimat gewissermaßen polonisiert ${ }^{46}$. Wir beschränken uns hier auf ein Beispiel: Groickis Übersetzung der CCC ist ziemlich frei. Er hat die strengen Strafen der Kodifikation, da sie dem polnischen Geist fremd waren, vielfach gemildert; er hat weiter in seiner Arbeit Institute eingeführt, die dem deutschen Vorbild überhaupt nicht bekannt sind. Sein ProzeBrecht verdankt mehr den römisch-kanonischen Regeln als den deutschen der Halsgerichtsordnung ${ }^{47}$. Dieser Jurist hat sich nicht gescheut, bei seinen Arbeiten nicht nur aus der Praxis der Krakauer Schöffen ${ }^{48}$, also eines deutsch organisierten Gerichts, sondern auch aus der der polnischen Landgerichte zu schöpfen ${ }^{49}$. Die Polonisierung des Ius Theutonicum hat sich in so beachtlichem Umfange vollzogen, $\mathrm{da} \beta$ wir von einem polnischen deutschen

${ }^{45}$ Den Kodifikationsversuchen des letzten polnischen Königs blieb der Erfolg versagt, siehe S. Borowski, Kodeks Stanislawa Augusta, Warszawa 1938; die Kodifikationskommission des Vierjährigen Reichstags (1788-1792) konnte ihre Arbeit nicht fertigbringen, J. J. Litauer, Polskie komisje kodyfikacyjne, Gazeta Sądowa Warszawska, Warszawa 1928, S. 621-3.

${ }^{46}$ So schon M. Wiśniewski, Historia literatury polskiej, Bd. 2, Kraków 1840, S. 387-8; O. Balzer, KH 1911, S. 446; A. Vetulani, $W$ sprawie, S. 630; K. Tymieniecki, Historia chlopów, S. 419; vgl. auch die Handbücher von P. Dąbkowski, Prawo prywatne polskie, Bd. 1, Lwów 1910, S. 19; S. Kutrzeba, Historia ustroju Polski w zarysie. Korona, 8. Aufl, Warszawa 1949 , S. 82; J. Bardach, Historia państwa i prawa Polski, Bd. 1, 2. Aufl. Warszawa 1964, S. 488. Vom Einfluß des polnischen Rechts auf das sog. Schlesische Landrecht K. Koranyi, Podstawy średniowiecznego prawa spadkowego, Lwów 1930, S. 117-8; diese These wurde von H. F. Schmid gebilligt in der [Rezension zu:] Karol Koranyi: Podstawy średniowiecznego prawa spadkowego, Pamiętnik Historyczno-Prawny 9/2, 230 S., Lwów 1930, ZRG 51 (1931) $=64$. Germ. Abt. S. 776; vgl. auch K. Kolańczyk, Studia nad reliktami wspólnej wlasności ziemi w najdawniejszej Polsce, Poznań 1950, S. 466. Ist man berechtigt mit H. F. Schmid zu behaupten, daß das westeuropäische Recht die Bedeutung der Unterscheidung des ererbten und erworbenen Gutes von Haus aus nicht kennt? War diese Unterscheidung im polnischen Recht von so entscheidendem Wert, wie man das in den Handbüchern behauptet?

${ }^{47}$ L. Dargun, Die Reception, S. 173.

${ }^{48}$ K. Koranyi [Einführung zu:] Groickis Porzqdek, S. 6.

${ }^{49}$ K. Koranyi [Einführung zu:] Groickis Artykuly prawa majdeburskiego, Warszawa 1954 , S. IV-V; Ders., [Einführung zu:] Groickis Obrona sierot $i$ wdów, Warszawa 1958, S. VII. 
Recht sprechen können ${ }^{50}$. In den letzten Jahrhunderten der Adelsrepublik treten als Rechtsschöpfer die Grundherren sowie die Dorfgemeinden hervor. Die deutschen Rechtselemente werden also immer mehr verdrängt. Trotzdem wird das deutsche Recht stets in Dörfern (sowie in Städten) als geltendes Recht angewandt ${ }^{51}$.

\section{4.}

Das rezipierte deutsche Recht hat mit der Zeit polnische Normen aufgenommen. Der Einfluß des polnischen Rechts auf das deutsche ist unverkennbar. Wir stellen uns hier eine andere Frage: Ist nicht auch das polnische Landrecht, also das Gewohnheitsrecht des Adels, durch das geschriebene plebejische deutsche Recht beeinflußt worden? Diese Frage hat schon H. F. Schmid, „, der gründlichste Kenner des deutschen Rechts in Polen",52, aufgeworfen, als er 1933 schrieb: „Ein Problem, das noch der Lösung harrt, liegt in der Frage, welchen Einfluß das deutsche Siedlungsrecht in Polen und im Litauischen Reich auf die Entwicklung des polnischen und litauischen Landrechts geübt hat" 53 .

Eine bejahende Antwort ist in bezug auf Schlesien gegeben worden ${ }^{54}$. Dasselbe gilt auch für das Königliche Preußen ${ }^{55}$. Eine bejahende Antwort hat auch Halban gegeben, der die Anwendung des deutschen Rechts durch außerstädtische, landrechtlich organisierte Gerichte feststellte; dies bezog

${ }^{\text {so }}$ Schon B. Groicki schrieb: ,soll dieses Recht billigerweise nicht deutsches, sondern polnisches Stadtrecht genannt werden", Porzqdek sqdów, S. 24; dazu auch L. Dargun, Die Reception, S. 173; A. Kraushar, Pierwsza ksiażka prawnicza polska z wieku XVI, Warszawa 1905, S. 8; M. Patkaniowski, Krakowska rada miejska w średnich wiekach, Kraków 1934, S. 152; M. Friedberg, Kultura polska, S. 214-5. Was die deutsche Gerichtsorganisation angeht, so wurde sie ,in vieler Hinsicht fast bis zur Unkenntlichkeit umgeformt”, M. Bobrzyński, O zalożeniu, S. 109, 119.

${ }^{\text {st }}$ Wir möchten der Meinung Bujaks nichts zustimmen, daß das deutsche Recht in Polen nicht viel Grundsätze des deutschen Rechts in sich hätte, Ogólny zarys, S. 32; ebenda Versuche, die Rolle des deutschen Rechts zu vermindern, S. 48-9.

${ }_{52}$ K. Tymieniecki, Historia chlopów, S. 379, 393; zur wissenschaftlichen Objektivität dieses österreichischen Historikers, ebenda, S. 417 Anm. 4.

${ }^{53}$ H. F. Schmid, Das deutsche Recht, S. 77; früher schon A. Halban, Zur Geschichte des deutschen Rechtes in Podolien, S. 135, zuletzt auch K. Tymieniecki, Historia chlopów, S. 365 Anm. 14. Auf andere Fragen in diesem Zusammenhang verweist G. Ullrich in der [Rez. zu:] R. Kotzschke: Die Anfänge des deutschen Rechtes in der Siedlungsgeschichte des Ostens (Ius teutonicum). = Berichte über die Verhandlungen der Sächsischen Akademie d. Wiss. zu Leipzig, phil.-hist. Klasse, 93 Bd., 2 H., Leipzig 1941, ZRG 64 (1944) = 77. Germ. Abt. S. 425.

${ }^{s 4}$ Z. Wojciechowski, L'État polonais au moyen-âge, Paris 1949, S. 233-4; J. Bardach, Historia państwa, S. $278,577$.

ss S. Kutrzeba, Historia źródel, Bd. 2, S. 38-9. Diese Beobachtung schon bei M. Kromer: eodem quidam cum nobilitate iure et iisdem legibus utitur, Polonia, S. 20. 
sich jedoch auf entfernte Gebiete Kleinrußlands ${ }^{56}$. Trifft das auch auf das polnische Kernland zu?

Das scheinen schon die Iura Sigismundina zu behaupten, ein Entwurf des 16. Jahrhunderts, der das deutsche Recht, wie schon hervorgehoben, ausmerzen sollte, der aber nie geltendes Recht geworden ist ${ }^{57}$. Dort heißt es: $u t$ [...] plures eius [iuris Saxonici] inique observaciones iuri militari Regni nostri irrepserint ${ }^{58}$. Dieser Meinung war auch Theodor Ostrowski, ein Jurist des 18. Jahrhunderts ${ }^{59}$.

Das Problem ist nicht einfach. Zur Aufnahme des deutschen Rechts in das polnische Landrecht ist es gesetzmäßig bestimmt nie gekommen. Geschah das also gewohnheitsrechtlich? Sollte das geschriebene, sächsische Recht wieder Gewohnheitsrecht geworden sein? Hätte der maßlos hochmütige polnische Adel es überhaupt zugelassen, daß er nach Vorschriften behandelt werde, die für Plebejer galten? Hätte er es nicht als eine Beleidigung seines hohen Standes empfunden?

Eine endgültige Antwort, besonders wenn sie negativ sein sollte, müßte sich auf ein gründliches Studium aller vorhandenen Land- und Grodbücher stützen $^{60}$. Ist dies überhaupt durchführbar? Es wären über 10.000 Bände, alle dicke Folianten, die sich in polnischen Archiven befinden, durchzublättern. Dazu fehlen noch die Repertorien. Es sei noch bemerkt, daß es schon strittig ist, ob sich gerade das polnische Institut der Landbücher auf nationalslavischer Grundlage oder unter dem Einfluß des deutschen Rechts herausgebildet hat ${ }^{6 !}$.

Unser Vorhaben ist viel bescheidener. Wir beabsichtigen festzustellen, ob die Regel des polnischen Landrechts, von der das Gesetz von 1768 spricht und die das Familienrecht betrifft, dem Sachsenspiegel entnommen wurde.

Für den Gesetzgeber des 18. Jahrhunderts ist das nur eine Vermutung (wie es scheint). Ist sie überhaupt einigermaßen begründet?

${ }^{56}$ A. von Halban, Zur Geschichte des deutschen Rechtes in den Gebieten von Tschernigow und Poltawa (Archivalischer Reisebericht), ZRG, Germ. Abt. 19 (1898), S. 5, 9-10; Ders., Zur Geschichte des deutschen Rechtes in Podolien, S. 52; dazu noch A. Jakowliw, Das deutsche Recht in der Ukraine und seine Einflüsse auf das ukrainische Recht im 16.-18. Jahrhundert, Leipzig 1942, S. 88, 130.

57 Vgl. oben Anm. 29.

${ }^{58}$ Iurium constitutionumque Sigismundinarum proposita a Mathia Sliwnicio descriptio, hrsg. A. Z. Helcel. Kraków 1859, S. 1.

s9 T. Ostrowski, Prawo cywilne albo szczególne narodu polskiego, Warszawa 1784, Bd. 1, S. 29.

${ }^{60}$ Dieses Argument schon von A. Halban vorgebracht, Zur Geschichte des deutschen Rechtes in Podolien, S. 135.

${ }^{61}$ R. Hübner, Grundzüge des deutschen Privatrechts, Leipzig ${ }^{5} 1930$, S. 237; vgl. hier J. Matuszewski, Aqua abrenuntiationis, CPH 4 (1952), S. 224 Anm. 21. [s. Pisma wybrane, t. I, s. 152 , przyp. 21]. 


\section{5.}

Das Gesetz von 1768 beruft sich auf das Statut König Alexanders von 1505, das es erneuert (Punkt 6), sowie auf die Konstitutionen ${ }^{62}$ von 1578 und von 1633, die es erläutert, aber in Wirklichkeit außer Kraft setzt. Für unsere Erwägung ist das Gesetz von 1633 bedeutungslos, da es nur die Konstitution von 1578 erneut in Kraft setzt. Es sind daher zwei Gesetze zu prüfen, das von 1505 und das von 1578 .

Die erwähnte Behauptung im Gesetz von 1768 gestattet uns zwei Schlüsse zu ziehen: Erstens, das erneuerte Gesetz von 1505 und die abgeschaffte Konstitution von 1578 müssen sich inhaltlich decken; zweitens, der Standpunkt des polnischen Gesetzgebers hat sich im Laufe eines Jahrhunderts völlig geändert. Was man anfangs, 1505 , beseitigte, wurde 73 Jahre später, 1578 , wieder eingeführt.

Im Statut von 1505 übernimmt der polnische König die päpstliche Bulle Gregors XI., die die 14 Artikel des Sachsenspiegels reprobierte. Dieser Schritt ist bestimmt den Einflüssen der Kirche zu verdanken. Sind wir aber berechtigt, auf Grund dieses Statuts zu behaupten, daß alle Regeln, die die Bulle von 1374 verbannte, im polnischen Landrecht noch anfangs des 16 . Jahrhunderts Geltung hatten? Wurden damals in Polen die Gottesgerichte im Gerichtsverfahren immer angewandt? War das Rechtsurteil durch den Zweikampf abzuschaffen? Das ist kaum anzunehmen! Diese sowie andere Tatbestände, die in den 14 Artikeln angeführt sind, darf der Historiker nicht als in Polen bis dahin geltendes Recht betrachten, soweit das anderswo nicht bewiesen ist. Wir verzichten hier auf die Überprüfung aller Rechtsnormen der Bulle und beschränken uns auf zwei Artikel, die gerade die Unechtheit der ehelichen Nachkommenschaft behandeln, das heißt auf die Artikel 10 und 11 .

\section{6.}

Im Punkt 3 des Gesetzes von 1768 wird der Artikel Quicunque cognoverit publice uxorem des Status von 1505 erwähnt. Er ist uns wohl bekannt. Es ist der 11. Artikel der berühmten Articuli reprobati. Er ist im genannten polnischen Statut so abgefaßt: Quicumque cognoverit publice uxorem alicuius, vivente marito, si post mortem mariti illius talis eam ducat in uxorem, numquam ex ea prolem legitimam generabit ${ }^{63}$.

${ }^{62}$ Die Substantive statutum und constitutio werden anfangs promiscue gebraucht (noch bei Laski), später wird Konstitution zur Bezeichnung eines vom Sejm-Reichstag beschlossenen Gesetzes.

${ }^{63}$ VL, Bd. 1, Petersburg 1859, S. 342. 
Es handelt sich hier um den Fall, da verheiratete Eltern unechte Kinder zeugen. Diese Vorschrift wird so begründet: Es war bekannt, daß der Vater mit der Mutter geschlechtlich verkehrte, als sie noch mit einem anderen Mann ehelich verbunden war. Eine solche Regel läuft dem kanonischen Recht zuwider. Deswegen ist diese Regel des Sachsenspiegels von Papst Gregor XI. verdammt worden ${ }^{64}$. Der polnische König stellte sich auf den gleichen Standpunkt und hat diese Vorschrift auch verworfen.

Die im Jahre 1768 außer Kraft gesetzte Konstitution von 1578 lautet: Cum saepissime accidat, quod nonnulli contra mandatum Divinum non cum legitimis uxoribus, sed cum concubinis, quas postea in matrimonium ducunt, habitant, statuimus, ut ex talibus uxoribus, antea concubinis, liberi procreati in nullis bonis hereditent, neque ullam praerogativam nobilitatis habeant ${ }^{65}$. Hier ist also nicht die Rede von Geschlechtsverkehr mit einer verheirateten Frau, wie im vorigen Fall. Zwar handelt es sich ebenfalls um verheiratete Eltern, die unechte Kinder zeugen, aber dies geschieht aus einem anderen Grunde: die Nachkommenschaft ist deswegen unecht, weil ihre Eltern von der Eheschließung intim verkehrten.

Die polnische Vorschrift von 1578 ist demnach viel breiter als die des Sachsenspiegels. Jeder längere, also öffentlich bekannte intime Verkehr mit der zukünftigen Ehefrau, auch wenn sie nicht verheiratet war, wird zum Nachteil für die zukünftigen ehelichen Kinder. Es ist durchaus verständlich, daß die Kirche diesen Standpunkt des polnischen Rechts verwarf, um so mehr, weil sie das schon mit den entsprechenden Regeln des Sachsenspiegels tat.

Für unser Problem ist eines wichtig: Die zwei Casus, der des 11. Artikels der Bulle und der des polnischen Gesetzes von 1578, stimmen nicht überein ${ }^{66}$. Hat also der Gesetzgeber von 1768 die beiden Vorschriften mißverstanden und sie irrtümlich nebeneinander gestellt? Oder hat er vielleicht nur den unrichtigen Artikel der reprobierten Bulle zitiert? Es ist dort nämlich noch ein anderer vorhanden, der sich ebenfalls mit den ehelichen unechten Kindern beschäftigt, und zwar der Artikel 10.

Er lautet: Quicunque cognoverit aliquam feminam, si postea ducat eam in matrimonium, nunquam ex ea poterit prolem legitimam generare. Die ehelichen Kinder werden hier unecht, weil ihre Eltern schon vor der Eheschließung

${ }^{64}$ Der letzte Herausgeber des Sachsenspiegels, K. A. Eckhardt, zitiert eine Vorschrift, die sich im Decretum Gratiani befindet. Die Änlichkeit der zwei Fassungen ist nur oberflächlich; dem Kirchenrecht war der Begriff der ehelichen und trotzdem unechten Nachkommenschaft völlig fremd.

${ }^{65}$ Das Original ist polnisch. Die lateinische Übersetzung besorgte M. Zalaszowski, Ius Regni Poloniae, Warszawa 1741, Bd. 1, S. 569; eine deutsche hat Bröcker beschafft, a. a. O., S. 36.

${ }^{66}$ Dieses Mißverständnis hat man schon betont, W. Dutkiewicz, Uwagi nad dzielem "Prawo polskie prywatne przez Piotra Burzyńskiego", Warszawa 1873, S. 30. 
geschlechtlich verkehrten. Das ist also genau derselbe Fall, den die Konstitution von 1578 behandelt, mit dem einzigen Unterschied, daß der Ausdruck Konkubine im Artikel 10 nicht verwendet wird. Mithin handelt es sich hier um jeden intimen Verkehr, auch wenn er nicht längere Zeit dauerte. Man kann aber fragen, ob die zwei Bestimmungen nicht auf gleiche Weise ausgelegt wurden.

Somit hätten wir das Vergehen des Gesetzgebers von 1768 geklärt, er hat sich lediglich im Incipit des zitierten Artikels geirrt. In Wirklichkeit decken sich die Konstitution von 1578 und der 10. Artikel des Status von 1505. Die Zusammenstellung beider Artikel im Jahre 1768 scheint demnach begründet zu sein. Dadurch entsteht aber nun eine neue Schwierigkeit.

\section{7.}

Nach Artikel 10 des Statuts von 1505 kann das Ehepaar keine echten Kinder zeugen, wenn der Mann mit der Frau, als diese noch ledig war, also vor der Eheschließung, geschlechtlich verkehrte; nach Artikel 11 kommt es zu demselben Resultat: Die eheliche Nachkommenschaft wird unecht im Falle von vorehelichem Verkehr mit einer verheirateten fremden Frau. Der zweite Fall ist doch evident. Wenn der intime Verkehr mit einer Ledigen so schwerwiegende Folgen nach sich zog, so mußte doch der Verkehr mit einer verheirateten Frau zumindest ebenso hart geahndet werden. Man konnte doch nicht für den zweiten Fall einen Vorteil schaffen, da hier der Versto $B$ gegen das Gesetz bedeutend schwerwiegender war. Der Artikel 11 ist also überflüssig; seinen Tatbestand brauchte man nicht besonders hervorzuheben, da ihn die Vorschrift des Artikels 10 völlig erfaßt.

Eine derartige Redaktion wäre noch in der Bulle zu verstehen: sie hätte eine Gradation eingeführt. Nach dem Kirchenrecht bildet nicht nur der voreheliche Geschlechtsverkehr eines Ledigen mit einer Ledigen, sondern auch eines Ledigen mit einer verheirateten Frau - wenn Sonderbedingungen nicht hinzukamen, die das impedimentum dirimens mit sich brachten - keinen Grund, die späteren ehelichen Kinder für unecht zu erklären. Dagegen muß im Sachsenspiegel eine solche Fassung aus den oben angeführten Gründen als unangepaßt betrachtet werden. Hätte das Eike von Repkow nicht wahrgenommen? Darf man dem hervorragenden und scharfsinnigen Rechtskenner eine solche Ungereimtheit zumuten? Ist vielleicht der Sachverhalt im polnischen Statut nicht richtig? Vergleichen wir also den ursprünglichen Text der Bulle mit dem in Polen verfaßten Text, der von König Alexander bestätigt worden ist. 
Der Artikel 11 wiederholt genau die Originalfassung der päpstlichen Bulle; sie ist auch dieselbe im Sachsenspiegel: Swo se enes mannes wif behuret openbare, [...] nimmt he se dar na to echte, echt kint ne vint he nimmer bi $e r^{67}$. Der 10. Artikel dagegen hat einen anderen Inhalt: Quicumque cognoverit violenter aliquam mulierem, si postea ducat eam in matrimonium, nunquam ex ea poterit prolem legitimam generare ${ }^{68}$. Er ist also erweitert um das nicht unwichtige Adverb violenter. So wird auch die Vorschrift im Sachsenspiegel verfaßt: Wer [...] mait adir wip notzoget, nimmt her se dar nach zu der e, elich kint gewinnet her nimmer bi ir ${ }^{69}$. Dieses Wörtchen ändert jedoch den ganzen Sinn der Vorschrift. Auch hier wird das Ehepaar unechte Kinder zeugen, aber aus einem völlig anderen Grunde: der Vater hat die Mutter vor der Eheschließung vergewaltigt.

Der articulus reprobatus in der Fassung des polnischen Statuts von 1505 ist also verzerrt. Er weicht erheblich vom Originaltext ab. Die zwei Casus, der in der originalen Bulle - er deckt sich mit dem des Sachsenspiegels - und der im polnischen Statut, sind ganz verschieden. Der Sachsenspiegel kennt zwei Unechtheitsgründe der ehelichen Nachkommenschaft, die begangene Vergewaltigung und den intimen Verkehr mit einer verheirateten Frau zu Lebzeiten ihres Gatten. Die beiden Casus behandelt auch die päpstliche Bulle von 1374. Nach dem polnischen Landrecht verursacht, der Konstitution von 1578 zufolge, jeder längerdauernde voreheliche intime Verkehr den erwähnten Nachteil für die Kinder. Und gerade diese Regel - anstatt jener des Sachsenspiegels und der päpstlichen Bulle - wird durch polnischen König 1505 verworfen.

Somit erübrigt sich jeder Vorwurf gegen Eike. Er hat im Artikel Landrecht I 37 von zwei ganz verschiedenen Fällen gesprochen, hat sich also nicht geirrt, seine Redaktion ist einwandfrei. Die päpstlichen Juristen haben die Vorschrift des Sachsenspiegels wortgetreu wiederholt. Die Verunstaltung hat sich erst in die polnische Fassung der später verworfenen Artikel eingeschlichen. Sie entstand infolge der Weglassung des Adverbs violenter. Wie konnte es dazu kommen? Kam sie zufällig oder absichtlich zustande? Wir werden nun versuchen, das Statut Alexander I. nach den Quellen zu überprüfen.

${ }^{67}$ Sachsenspiegel, hrsg. v. K. A. Eckhardt.

${ }^{68}$ Bullarum, privilegiorum ac diplomatum Romanorum pontificum amplissima collectio [...] opera et studio Caroli Coquelines, tomus III, pars 2 a Gregorio X ad Martinum V, scilicet ab anno 1271 ad 1431, Romae 1741, N ${ }^{\circ} 19$ S. 361; richtig auch G. Homeyer, Johannes Klenkok wider den Sachsenspiegel. = Abhandlungen der Königl. Akademie der Wissenschaften zu Berlin 1855. Berlin 1855, S. 426.

${ }^{69}$ Sachsenspiegel (Landrecht), hrsg. v. Cl. Frhr. v. Schwerin, eingel. v. H. Thieme, Stuttgart 1962. 
8.

Das Statut von 1505 haben wir nach den Volumina Legum von Ohryzko zitiert $^{70}$. Diese Ausgabe ist bekanntlich nicht immer zuverlässig, sie ist eine Wiederholung der Ausgabe der Piaristen von $1732^{71}$, die, wie wir feststellten, denselben Text enthält. Der Filiation ist also weiter zu folgen. Die Piaristen haben sich für ihre Ausgabe alter Drucke bedient. In unserem Fall haben sie das Commune inclyti Regni Poloniae Privilegium von 1506 ausgewertet. Es zeigt sich, daß der Text in diesem Werk ebenfalls gleichlautend ist ${ }^{72}$.

Das genannte Commune Privilegium ist ein Werk von Johann Laski; er war damals polnischer Reichskanzler und wurde später Erzbischof von Gnesen und Primas von Polen. Welcher Urkunde hat Laski seinen Text entnommen, oder mit anderen Worten: Wie sah das Original des Gesetzes von 1505 aus? Das können wir heute leider nicht mehr feststellen. Im polnischen Hauptarchiv ist die Originalhandschrift nicht vorhanden. Nachdem das Statut von 1505 im Druck erschienen war, legte man der Originalhandschrift offenbar keinen großen Wert bei, und das wurde ihr zum Verhängnis, denn sie ist verschwunden. Somit ist die Möglichkeit des weiteren Quellennachweises ausgeschlossen.

Zwei Vermutungen können wir hier anstellen. Entweder wurde das Adverb violenter schon im Original des Statuts weggelassen, oder es geschah erst bei der Drucklegung durch Łaski. Im zweiten Falle wäre die Unterlassung dem geistlichen Verfasser zuzuschreiben. Aber auch im ersten Falle ist mit dessen Tätigkeit als Reichskanzler zu rechnen. Beide Male erscheint Laski als der Schuldige, der den Text per omissionem gefälscht hätte.

Eine solche Handlungsweise des Reichskanzlers dürfte uns nicht erstaunen. Er hat nämlich auch eine andere Vorschrift, die er ebenfalls in Commune Privilegium abdruckte, und zwar das Judenprivileg, so abgeändert, daß es in der gedruckten Fassung den heiligen Kanones entsprach ${ }^{73}$. Ist es demzufolge nicht angebracht, mit einem ähnlichen Schritt auch bei der gedruckten Wiedergabe der Articuli reprobati in den Normen über die illegitima proles zu rechnen? Die Vorschrift des Sachsenspiegels über die Unechtheit der ehelichen Kinder läuft dem kanonischen Recht gewiß zuwider, deswegen wurde sie durch den Papst verworfen. Somit würde eine getreue Wiedergabe der Bulle vom kirchlichen Standpunkt aus auch in Polen willkommen sein. Aber, wie wir wissen, ging das polnische Landrecht in bezug auf die

${ }^{70}$ Petersburg 1859.

71 Leges, statuta, constitutiones, privilegia Regni Poloniae, Magni Ducatus Lithuaniae, omniumque provinciarum annexarum, hrsg. v. J. Załuski u. S. Konarski, Bd. 1, Warszawa 1732.

${ }^{72}$ Commune inclyti Regni Poloniae Privilegium, fol. CLXXIIII verso.

${ }^{73}$ S. Kutrzeba, Slowo o statucie wielkopolskim Kazimierza Wielkiego, In: Ksiega pamiqtkowa ku czci... W. Abrahama, Bd. 1, Lwów 1931, S. 6-7. 
illegitima proles viel weiter als der Sachsenspiegel, es widersprach in noch größerem Umfang den Kanones. Infolgedessen bot sich die günstige Gelegenheit, dem Papst die Verwerfung nicht nur der sächsischen, sondern auch der polnischen Praxis zuzuschreiben, was durch die ,unschuldige" Unterlassung des Adverbs violenter leicht zu erreichen war. Würde denn der Prälat so etwas nicht als pia fraus betrachten ${ }^{74}$, ebenso wie beim Judenprivileg?

Wenn wir diese Vermutung fallenlassen, so müssen wir mit einem bloßen Zufall rechnen. Ein schlampiger Setzer hat das Wort ausgelassen, beim Korrekturlesen wurde der Fehler übersehen und so hat er sich verewigt. Dies alles ist nicht unmöglich. Sollte aber die Übereinstimmung des Artikels 10 der Łaski-Fassung mit dem Gesetz von 1578 gleichfalls durch Zufall zustande gekommen sein? Das gibt zu denken. Läßt sich unser Verdacht gegen Łaski nicht besser begründen?

9.

Das Commune inclyti Regni Poloniae Privilegium ist zweiteilig. Der erste Teil enthält das polnische Landrecht und daher auch die oft zitierten Articuli reprobati. Der zweite Teil, der die nichtadlige, plebejische Bevölkerung betrifft, hat die Libri duo iuris civilis Maydemburgensis et provincialis Saxonici cum tertio libro iuris feudalis zum Gegenstand ${ }^{75}$. Während der erste Teil lediglich die verworfenen Artikel des Sachsenspiegels übernimmt, um sie gleich abzulehnen, enthält der zweite Teil den ganzen Text des Sachsenspiegels einschließlich der Articuli reprobati ${ }^{76}$. Diese Sachlage gibt uns eine günstige Chance, den in Frage kommenden Artikel 10 nochmals zu prüfen. Er ist hier verfaßt, wie folgt:

Nemo hanc in uxorem ducere debet, quam defloravit.

Quicunque alterius uxorem stupraverit, aut feminam vel virginem violaverit, et si postmodum ipsam legittime ducerit, pueros tamen legittimos cum ipsa nunquam acquirit $t^{77}$.

Der Text ist hier richtig. Er entspricht genau dem Original des Sachsenspiegels.

Der polnische Reichskanzler zitiert also in seinem Werk zweimal denselben Text des Spiegels. Zum zweitenmal im nichtadligen Recht; und hier stimmt

${ }^{74}$ Über dieses Problem vgl. H. Fuhrmann, Die Fälschungen im Mittelalter. Überlegungen zum mittelalterlichen Wahrheitsbegriff, HZ 197 (1963), S. 537, 589-90; K. Bosl (Diskussionsbeitrag), ibidem, S. 566-7.

${ }^{75}$ Commune inclyti Regni Poloniae Privilegium, nicht foliiert.

${ }^{76}$ So schon Z. Kaczmarczyk, Historia państwa $i$ prawa Polski do roku 1795, Bd. 2, Warszawa 1957, S. 30.

${ }^{77}$ Commune [...] Privilegium, fol. CCVII. 
der Inhalt mit dem des Originals genau überein. Das erstemal, im Landrecht, weicht dieser Text von der Originalbulle sowie vom Sachsenspiegel ab. Wurde der Text hier nicht absichtlich gefälscht? Hatte der berühmte polnische Jurist all diese Unstimmigkeiten wirklich nicht bemerkt, zumal er doch im zweiten Teil des Commune Privilegium eine Marginalglosse abdruckte, die sich auf den ersten Teil bezieht? ${ }^{78}$ Der Herausgeber hat demnach beide Texte gleichzeitig im Auge gehabt. Trotzdem hat er im Adelsrecht die veränderte Fassung beibehalten! Sind wir noch weiter berechtigt, von Zufall zu sprechen? Ist der Verdacht gegen den geistlichen Reichskanzler noch nicht genügend begründet? Ist seine Redaktion nicht ein geschicktes Machwerk?

Die Originalhandschrift des Statuts von 1505 ist, wie wir wissen, verschollen. Sie wurde durch den Laski-Druck 1506 ersetzt und dieser ist offiziell anerkannt worden. Somit wurde die Regel des Sachsenspiegels dem polnischen Adel in der Laski-Fassung bekannt. Es ist jedoch ausdrücklich darauf hinzuweisen, daß diese Regel durch den polnischen König - wie früher durch den Papst - verworfen worden ist. Laski wollte also die Ablehnung der polnischen Regel offensichtlich der höchsten Autorität, dem Papst, zuschreiben.

\section{0.}

Wenn wir dem als offiziell anerkannten Commune Privilegium von 1506 - oder sogar dem königlichen Statut von 1505 - einen praktischen Wert beimessen wollen, so müssen wir annehmen, daß die genannte Vorschrift über die Unechtheit der ehelichen Kinder im polnischen Landrecht schon vor diesen Jahren Geltung gehabt hatte. Das heißt, die in den beschriebenen Ehen gezeugten Kinder (Art. 10 der Bulle in der Fassung des polnischen Statuts) wurden durch den Adel als unecht betrachtet. Da wir kein derartiges Gesetz vor 1505 kennen, wäre seine gewohnheitsrechtliche Entstehung anzunehmen, was auch sehr wahrscheinlich ist. Leider läßt sich diese Vermutung auf keine Weise belegen. Die einschlägigen Gerichtsakten dieser Periode bieten in dieser Hinsicht keinerlei Anhaltspunkte. Und wie verhielt sich die Sache zwischen 1505 und 1578?

Wir verfügen hier über einige Quellennachweise. Der polnische Adel kämpfte schon 1550 um die gesetzliche Einführung der 1505 verbannten Regel. Der König hat aber dieser Forderung nicht entsprochen. Daraufhin beklagten sich die Nobiles ${ }^{79}$. Auf diese Weise ist der Quellennachweis entstanden.

\footnotetext{
${ }^{78}$ Ebenda.

${ }^{9}$ Articuli in Conventu Piotrcoviensi anno 1550 od wszego stanu rycerskiego ad exequendum dane. $=$ Scriptores rerum Polonicarum 1, hrsg. J. Szujski, Kraków 1872, S. 45.
} 
Weiterhin wurden auf den Reichstagen von 1555, 1556/57 und 1558 stets Proteste erhoben gegen das fremde Recht (unter anderem gegen die bullae paparum), das von den Bischöfen in das Statut (Laskis?) aufgenommen worden war und auf Grund dessen geistliche Gerichte die „schlecht geborene Nachkommenschaft" als standesgleich anerkannten ${ }^{80}$.

Daraus kann man schließen, daß das polnische Gewohnheitsrecht über die Unechtheit der ehelichen adligen Nachkommenschaft spätestens im 15. Jahrhundert entstand. Der die Interessen der Kirche tatkräftig vertretende geistliche Reichskanzler wollte es abschaffen. Um dies zu erreichen, hat er den Articulus reprobatus im Statut von 1505 oder bei der Drucklegung 1506 einfach gefälscht. Der Adel kämpfte jedoch weiter, um seinem Standpunkt Geltung zu verschaffen. Was um die Mitte des 16. Jahrhunderts nicht gelang, ist 1578 zustande gekommen. In diesem Jahre wurde die Forderung des Adels schließlich erfüllt. Seitdem ist die erwähnte Vorschrift zwei Jahrhunderte lang in Kraft geblieben. Sie wurde erst 1768 abgeschafft.

Es ist bezeichnend, daß 1658 das Gesetz zeitweilig, durante bello mit Schweden, außer Kraft gesetzt wurde. Ein Jahr später wurde diese Konstitution für nichtig erklärt ${ }^{81}$.

\section{1.}

Im Punkt 3 des Gesetzes von 1768 beruft man sich, wie wir wissen, auf den Sachsenspiegel. Diesem Rechtsdenkmal sollte die polnische Regel über die Unechtheit der ehelichen Kinder entnommen sein. Die Analyse der in Frage kommenden Vorschriften führt zu folgendem Schluß: der Artikel Quicunque cognoverit uxorem, auf den die Konstitution von 1768 hinweist, stimmt mit der polnischen Regel von 1578 nicht überein. Die polnische Regel dagegen entspricht dem Artikel 10 des Statuts von 1505. Dieser Artikel ist aber gefälscht; er stimmt weder mit der päpstlichen Bulle noch mit dem Sachsenspiegel überein. Diese Regel, die es im polnischen Landrecht gab, ist dem Sachsenspiegel gänzlich fremd geblieben. Von einer Aufnahme des Ssp. Landrecht I 37 in das polnische Adelsrecht kann demnach keine Rede sein. Die Regeln des Sachsenspiegels und die des polnischen Landrechts weichen sachlich voneinander $\mathrm{ab}$.

${ }^{80}$ Dzienniki sejmów walnych koronnych za panowania Zygmunta Augusta, Króla polskiego, W. X. Litewskiego, 1555 i 1558 r.w Piotrkowie zlożonych, Hrsg. v. T. Fürst v. L(ubomirski), Kraków 1869, S. 200, 235; Diariusz sejmu walnego warszawskiego z roku 1556/7, hrsg. v. S. Bodniak, Kórnik 1939, S. 34-5.

${ }^{81}$ VL 4, S. 514, 585 art. 3. Der vollständige Druck der Konstitution von 1658 befindet sich in der Bibliothek der Polnischen Akademie der Wissenschaften in Gdańsk, NI 94 Nr. 29-30. 
Aber auch formell ist von der Aufnahme des Sachsenspiegels in das polnische Landrecht schwer zu sprechen. Im polnischen Gesetz, dem Statut Königs Alexander I. aus 1505, wird vom Spiegel tatsächlich gesprochen, aber nur im Zusammenhang mit der Verwerfung der Sachsenspiegelvorschrift. Die Abschaffung der Rechtsnorm begründet auf keinen Fall die These von der Rechtsaufnahme.

Eine Aufnahme von Normen des Sachsenspiegels wäre auch von dem adligen Gesetzgeber nicht zu erwarten gewesen. Angesichts der Rechtsspaltung der Bevölkerung Polens nach Ständen - der Adel und das polnische Landrecht einerseits, die Plebejer und das deutsche Recht andrerseits - ist mit einem Einfluß des Plebejerrechts auf das Adelsrecht kaum zu rechnen. Die erste offizielle Nachricht über die Aufnahme der Sachsenspiegelregel erscheint erst im Gesetz von 1768. Aber auch hier wird sie als vermutlich bezeichnet. Diese Vermutung jedoch, wie wir Festgestellt haben, entbehrt jeder Grundlage. Sie beruht einfach auf einem Irrtum. Warum hat der Gesetzgeber von 1768 die unwahre Behauptung vorgebracht? Was hat ihn zur Erwähnung des Sachsenspiegels veranlaßt?

\section{2.}

Die polnische Regel von der illegitima proles hat das kanonische Recht aufs schärfste verletzt. Sie widersprach auch den neuen, demokratischen Tendenzen der Aufklärungszeit. Die früheren Bestrebungen, sie aufzuheben (1505) oder nur vorübergehend außer Kraft zu setzen (1658), wurden wieder aufgenommen. Der polnische Adel war jedoch gegen jede Neuerung und verhinderte jede offene Reform, z. B. 1766 die kühne Kodifikation von A. Zamojski. Um eine Neuerung einzuführen, mußte man vermeiden, den Adel zu kränken.

Wir lesen im Gesetz von 1768, daß die eingeführte Vorschrift nur eine Erläuterung der Konstitutionen von 1578 und 1633 ist. Wie wir wissen, sind diese zwei Gesetze tatsächlich aufgehoben worden. Das war die erste Cammouflage des Gesetzgebers. Es wird weiter von der Erneuerung des Statuts Alexanders I. von 1505 gesprochen. Wiederum wird dem Adel versichert, da 3 man kein neues Gesetz statuiere, sondern lediglich auf altes Recht zurückgreife ${ }^{82}$.

Die Pille blieb aber noch immer bitter. Um deren Verschlucken zu erleichtern, hat sich der Gesetzgeber - Verfasser des Gesetzes von 1768 war höchstwahrscheinlich der Bischof Mlodziejowski - eines geschickten Kniffs

${ }^{82}$ Nach dem Prinzip: altes Recht - gutes Recht, vgl. S. Estreicher, Kultura prawnicza w Polsce XVI wieku. Kultura Staropolska, Kraków 1932, S. 65, 82, 116; s. auch H. Fuhrmann, a. a. O., S. 542 . 
bedient. Er hat den polnischen Nobiles einfach eingeredet, sie befolgten das Recht der Plebejer, den Sachsenspiegel ${ }^{83}$ - und die Pille wurde diesmal glatt geschluckt.

So ist die alte Regel des polnischen Landrechts über die Unechtheit der ehelichen adligen Kinder, gegen die schon Laski Anfang des 16. Jahrhunderts vergebens kämpfte, deren nur vorübergehende Außerkraftsetzung 1658 nicht die Zustimmung des Adels fand, 1768 endlich abgeschafft worden. Die rückständige Regel ist den Strömungen der Aufklärungszeit zum Opfer gefallen.

Die Norm war aber eine rein polnische Schöpfung. Die Behauptung, sie sei aus dem Sachsenspiegel entlehnt worden, ist völlig unbegründet.

${ }^{83}$ Dieser Kunstgriff wurde von den Zeitgenossen (1777) auch anderswo angewandt, P. Burzyński, $O$ prawie bliższości w dawnej Polsce, Rozprawy i Sprawozdania Akad. Umiej. 6 (1877), S. 29-30. 


\section{Poenas tollere*}

Z nadania Wlodzislawa Odonica dla biskupstwa poznańskiego „ludzie przynależni do tego kościoła nie byli obowiązani na wezwanie zjawiać się lub odpowiadać wobec kogokolwiek z nich (urzędników książęcych), lecz tylko wobec swoich własnych panów: biskupa, prałatów i kanoników, $\mathrm{z}$ wyjątkiem trzech spraw, za które ludzie kościola będą sądzeni przez sędziego książęcego lub królewskiego. Jeśliby jednak skazani zostali na kary pieniężne, znosić je będzie nie sędzia książęcy, lecz kościelny, do którego ktokolwiek będzie należał".

Takiej informacji dostarcza nam Kronika Wielkopolska w thumaczeniu latynisty-klasyka, prof. K. Abgarowicza ${ }^{1}$. Co znaczy w tym kontekście zwrot: „znosić kary pieniężne? Chyba równa się to kasowaniu, unieważnianiu nałożonych kar, uwalnianiu od nich. Wszakże przy takiej wykładni tekst staje się niejasny.

Znajomość problematyki immunitetowej, do której wyżej cytowany tekst się odnosi, prowadzi do innego rozumienia inkryminowanego miejsca Kroniki, odmiennego calkiem od tego, jakie sugeruje cytowane thumaczenie. Wiemy $\mathrm{z}$ dotychczasowych badań, że od początku XIII, a może nawet od końca XII w. wystawia się w Polsce dokumenty, przelewające jurysdykcję na rzecz immunizowanej instytucji kościelnej, biskupstwa czy klasztoru ${ }^{2}$. Zgodnie $z$ fiskalnym podejściem średniowiecza do wymiaru sprawiedliwości, przekazaniu sądownictwa towarzyszy przelanie poboru kar sądowych: penam de iudicatis percipientes ${ }^{3}$, omnia iura alia dicto domino abbati cedent (nr 492, r. 1280).

* Przedruk z: Kwartalnik Historyczny 1967, t. 74, z. 2, s. 361-363.

' Kronika Wielkopolska, Warszawa 1965, s. 212.

2 Z. Kaczmarczyk, Immunitet sqdowy $i$ jurysdykcja poimmunitetowa $w$ dobrach Kościola w Polsce do końca XIV wieku, Poznań 1936, s. 73; J. Bardach, Historia państwa i prawa, t. I, wyd. 2, s. 179-180.

${ }^{3}$ KDWP, t. 1, nr 367, r. 1258. Ponieważ ograniczamy się $w$ zasadzie do materiału wielkopolskiego, dla uproszczenia będziemy podawali w nawiasach numery Kodeksu Dyplomatycznego Wielkopolski. 
Immunitet sądowy nie obejmuje wszakże od razu wszystkich spraw ${ }^{4}$. Książęta zastrzegają sobie niejednokrotnie wlasny wymiar sprawiedliwości w ważniejszych sprawach, określanych jako causae magnae (nr 433), casus graves ( $\mathrm{nr} 298)$, causae lub sententiae principales ( $\mathrm{nr}$ 492), causae difficiles (nr 367), causae sanguinis (nr 606, 424); w jednym wypadku zastrzegł sobie książę sprawy o kłusownictwo 5 .

Interesujące są losy kar w wypadku rezerwatów książęcych. $Z$ reguly - $\mathrm{i}$ to znowu charakterystyczne dla zapatrywania na charakter fiskalny ówczesnego sądownictwa ${ }^{6}$ - mimo że wyroki wydawać będzie sąd książęcy, instytucja obdarzona przywilejem nie będzie pozbawiona dochodów, związanych $\mathrm{z}$ zastrzeżonym wymiarem sprawiedliwości. Grzywnę pieniężną (iudicatum, pena, pena pecuniaria, placationes, mulcta) podzieli się między księcia ratione dominii $\mathrm{i}$ jednostkę immunizowaną $\mathrm{w}$ rozmaity sposób: whadca zabierze $2 / 3 \mathrm{kary}$, pozostała $1 / 3$ przypadnie opatowi (nr 492, r. 1280); książę i instytucja kościelna biorą po polowie (nr 81, r. 1213; nr 592, r. 1231 ; nr 174 , r. 1234 ; nr 234, r. 1242; nr 608, r. 1268; Kuj. maz., s. 188, nr 14 r. 1255), albo też książę kontentuje się 1/3 grzywny, ustępując $2 / 3$ uprzywilejowanemu (nr 433, r. 1268; 606, r. 1266; 424, r. 1267). Nieraz zaznaczano, że podział kar między księcia i obdarowanego odbywa się z wyłączeniem urzędników książęcych (Kuj. maz., s. 188 nr 14$)^{7}$.

Znamy też inne rozwiązania: niższe kary pobierać będzie pan immunitetowy w całości: si autem solucio ad penam duodecim marcarum excrescerit et supra, cum duce ipsam dimidiet (nr 174, r. 1234) ${ }^{8}$; arcybiskupowi gnieźnieńskiemu przyznaje się pełny wybór kar in castellatura Gnesnensi et in villis, in quibus suas locaverit curias (ibidem).

Wreszcie, mimo uczestnictwa księcia w wymiarze sprawiedliwości, całość kar pójdzie na rzecz obdarowanego nawet $\mathrm{w}$ sprawach glównych (nr 284, r. $1250^{\circ}$; nr 292, r. 1251 ; nr 298, r. 1251; nr 711, r. 1293; Kuj. maz., s. 188, nr 14 , nr 367 , r. $1258^{10}$ ).

${ }^{4}$ Skłonniśmy przy tym twierdzić, że nawet omnimoda libertas nie obejmowała nigdy całkowitego zwolnienia sądowego. Por. L. Lysiak, Sqdownictwo królewskie w sprawach chlopskich do polowy XVI w., CPH, t. 17, 1965, z. 2, s. 14-15.

${ }^{5}$ Kuj. maz., s. 188 , nr 14.

6 Jaskrawym dowodem jest ewolucja znaczeń słowa poena; wedhug Du Cange'a: tributum, onus agris vel personis impositum; Niermayer notuje: cens, fermage.

Z. Kaczmarczyka.

${ }^{7}$ Przewodnikiem po cytowanych dokumentach było dla nas wspomniane w przyp. 2 dzieło

${ }^{8}$ Por. tu K. Tymieniecki, Przywilej biskupstwa poznańskiego z roku 1232 na tle rozwoju immunitetu w XIII w., Poznań 1934, s. 8.

${ }^{9}$ Brzmienie powtórzono wiernie w akcie z 1252 r., nr 303.

${ }^{10}$ Tak też $w$ przywilejach mazowieckich dla biskupstwa poznańskiego z 1350 r., nr 1300,1301 . 
Przykładów powołaliśmy liczbę wystarczająca, a łatwo by ją powiększyć dokumentami $z$ innych dzielnic ${ }^{11}$. Znając je, zapytamy, czy takiego właśnie sensu nie należy wiązać $\mathrm{z}$ zwolnieniem, o którym nas informuje Kronika Wielkopolska.

R. Grodecki sądził, że interesujący nas tekst zaczerpnął autor Kroniki z autentyku z 1232 r., nieznacznie tylko przestylizowanego, który się do naszych czasów nie dochowal ${ }^{12}$. Do innego wniosku doszedł K. Tymieniecki. Jego zdaniem, immunitet $w$ tych ramach, jak to podaje Kronika, jest na ową wczesną datę niemożliwy ${ }^{13}$, wiadomość musi być podrobiona ${ }^{14}$. Ostatni badacz wykazal też, skąd zaczerpnąl ów kompilator swoją wiadomość: nie z aktu z 1232 r., lecz z dokumentu z 1252 r. Równocześnie stwierdza, że przejęcie tekstu nie było dosłowne, brzmienie jego autor dowolnie zmieniał ${ }^{15}$. Argumentacja ta nie wywołuje żadnych wątpliwości, przesądza też sprawę ostatecznie $^{16}$. To osiągnięcie jest istotne dla interpretacji zakwestionowanego przez nas zwrotu.

Zestawmy oba teksty ${ }^{17}$ :

1252

ita tamen, quod mulcta(m) quam pro huiusmodi delictis infligenda rationabiliter viderimus, ipsorum domini percipiant integre pleno iure ${ }^{18}$.
Kronika Wielkopolska

... nec tamen poenas pecuniales, si ad ipsas condemnarentur, iudex ducalis tollere debeat, sed ecclesiasticus, cuius homo fuerit, ipsas tollet ${ }^{19}$.

Jest rzeczą nieulegającą wątpliwości, że autor Kroniki Wielkopolskiej zwrot aktu z 1252 r.: mulctam percipere oddal wyrażeniem: poenas pecuniales tollere.

${ }^{11}$ Odrębne zagadnienie to podzial kar między immunizowanego pana a jego sẹdziego prywatnego (np. nr 433, 606, 2037), jak też podział kar między dwu seniorów.

${ }_{12}$ R. Grodecki, Przywilej menniczy biskupstwa poznańskiego z r. 1232, Poznań 1921, s. 29.

${ }^{13}$ K. Tymieniecki, op. cit., s. 20.

${ }^{14}$ Ibidem, s. 15.

is Ibidem, s. 22-23.

${ }^{16}$ Wobec dyskusji R. Grodecki - K. Tymieniecki nie zajęła zdecydowanego stanowiska B. Kürbisówna, która referuje poglądy wspomnianych badaczy jako równoważne: Kronika Wielkopolska, s. 213, przyp. 290.

${ }^{17}$ Integralne zestawienie obydwu tekstów dał K. Tymieniecki, op. cit., s. 21 .

${ }^{18}$ KDWP, nr 302; zwrot ten jest niemal dosłownym powtórzeniem wyrażenia aktu z 1237 r., nr 203; por. tu K. Tymieniecki, op. cit., s. 19; Z. Kaczmarczyk, op. cit., s. 212, 215.

${ }^{19} \mathrm{MPH}$, t. 2 , s. $557-558$. 
Ten wynik upoważnia nas do poprawienia zakwestionowanego tłumaczenia w sposób następujący: ,jeśliby nawet ${ }^{20}$ (i w tych wypadkach zastrzeżonych) skazani zostali na kary pieniężne, pobierać je będzie nie sędzia książęcy, lecz kościelny, do którego ktokolwiek będzie należał"21. Przy takiej interpretacji tekst staje się zrozumialy, a przy tym odpowiada temu, co wiemy o współczesnym stanie immunitetu sądowego w Wielkopolsce ${ }^{22}$.

Jeśli thumacz niewłaściwie oddał sens omawianego zdania, wynikało to stąd, że znaczenie czasownika tollere $=$ pobierać jest niezwykłe dla łaciny klasycznej. Ale już w języku poklasycznym tollere znaczy również erhalten (Menge). W lacinie średniowiecznej uxorem tollere znaczy eine Frau nehmen (Habel-Gröbel), argentum tollere- für den eigenen Gebrauch aufheben, reservieren (Haas-Kienle); teloneum, exactiones tollere- prendre, exiger, lever (Niermayer). Stąd to zgromadzone przez Du Cange'a substantiva utworzone od wspomnianego czasownika tollere: tolta, toltura, tollementum oznaczają taille, exactio, quae per vim sit; iniusitia, ius sumendi a subditis res, praesertim ad victum necessarias, absque praesenti solutione pretii earum. Po polsku w tych kontekstach oddamy verbum przez pobierać, a tolta $\mathrm{i}$ jej synonimy przez pobór.

Nie chcemy wszakże negować możliwości innych znaczeń dla laciny średniowiecznej - Niermayer wyróżnia ich sześć. Poenas tollere przełożyć należy przez auf sich nehmen, erleiden (Haas-Kienle), a advocatos tollere wprost $\mathrm{w}$ znaczeniu klasycznym destituer (Niermayer).

Omówiony przykład jest ostrzeżeniem przed rozumieniem tekstu średniowiecznego przy pomocy Forcelliniego. Taki sposób postępowania prowadzić musi nieraz do zupełnego wypaczenia myśli autora źródła. Do tego stopnia lacina średniowieczna odbiegła semantyką od łaciny klasycznej.

Nie znamy dokładnie daty powstania Kroniki Wielkopolskiej; historycy kladą ją bądź na koniec XIII w., bądź dopiero koło połowy XIV w. ${ }^{23}$ Wiemy, że autor jej wyrażenie dokumentu-wzoru mulctam percipere oddał przez poenas tollere. Kiedy te zwroty stały się synonimiczne? W przejrzanych przez nas wielkopolskich dokumentach trzynastowiecznych - niewątpliwie daleko nam do ich wyczerpania - nie napotkaliśmy ani razu na wyrażenie drugie. Nie znaleźliśmy go też w przewertowanych (zresztą dość pobieżnie) aktach małopolskich; w ich formułach egzempcyjnych znajduje zastosowanie zwrot (penas) recipere ${ }^{24}$. Dopiero w przywileju dla klasztoru jeżowskiego

${ }^{20}$ Thumacz stawia w tym miejscu: ,jednak".

${ }^{21}$ Tak już rozumiał zwrot K. Tymieniecki, op. cit., s. 9. Zaznaczam, że thumacz tylko jeden raz oddał po polsku słowo tollere. Czyżby wyczuwał nieskładność swojej interpretacji?

${ }^{22}$ K. Tymieniecki, op. cit., s. 11; Z. Kaczmarczyk, op. cit., s. 56-57.

${ }^{23}$ B. Kürbisówna, op. cit., s. 20-26.

${ }^{24} \mathrm{CDP}$, t. 3, nr 33, r. 1256; KDMP, t. 2, nr 481, r. 1275; częściej spotykamy inne zwroty: solucione capitis... pertinente, $\mathrm{KDKK}, \mathrm{t} .1$, $\mathrm{nr} 40$, r. 1254; pecuniaria pena... reservata, KDMP, t. 2, $\mathrm{nr} 446, \mathrm{r} .1255$; sed omne iudicium et pena consequens cedat fratribus, ib., $\mathrm{nr} 472, \mathrm{r} .1264$. 
z 1334 r. (nr 1131) czytamy: w razie zabójstwa dokonanego między ludźmi klasztornymi prepositus nominatus loci totam intergraliter penam tollet homicidii; $\mathrm{w}$ razie sporu między chłopem klasztornym i obcym poddanym prepositus tantum mediam partem pene accipiet. Jest rzeczą niewątpliwą, że redaktor aktu używa tych zwrotów zamiennie. Czyżby wolno było tę obserwacje wykorzystać dla datacji Kroniki Wielkopolskiej?25

${ }^{25}$ Tollere $\mathrm{w}$ znaczeniu „pobierać" występuje sporadycznie już w 13. w.: ad tollendum tercium denarium nostrum, KDWP, t. 1, nr 436, r. 1268; omnem quoque fructum iudiciorum [...] abbas tollet, CDP, t. 1, $\mathrm{nr} 66, \mathrm{r} .1286$; fratres duas partes tollent, si vero [...], unam partem recipere teneantur, KDKM, nr 39, r. 1289; ob. też przykłady w PmrlUB, nr 447, r. 1289; nr 466, r. 1290 ; nr 487 , r. 1292 , jak i DKM, s. 299 , nr 15 , r. 1300 ; ZDM, t. 1 , nr 14, r. 1303; KDWP, t. 2, nr 919, r. 1308. W 14. i 15. w. używa się często dwóch synonimów równocześnie: tollere et percipere, KDWP, t. 2, nr 1182, r. 1338; tollere et recipere, ZDM, t. 2, nr 517, r. 1438, nr 570, r. 1441; tollere et levare, KDWP, t. 3, nr 1797, r. 1382; ZDM, t. 3 , nr 747, 749, r. 1446; levare et recipere, ZDM, t. 2, nr 577, r. 1441; nieraz nawet i trzech: habere, tollere, recipere, ZDM, t. 4, nr 1113, r. 1394; tollere, lavare et percipere, ZDM, t. 2, nr 529, r. 1439; CDP, t. 2, cz. 2, nr 593, r. 1454. Pobiera się zresztą nie tylko kary i czynsze, ale także duos boves [...] recipiat atque tollat, KDWP, t. 3, $\mathrm{nr} 1873, \mathrm{r} .1388$, czy glandines recipere et tollere, $\mathrm{ZDM}, \mathrm{t} .1, \mathrm{nr} 235, \mathrm{r} .1399$. 


\section{Ecclesia incastellata*}

Nos éminents collègues ont insisté, dans leurs exposés, sur un fait qui semble d'importance frappante. L'Europe du $\mathrm{IX}^{\mathbf{c}}$ au $\mathrm{XI}^{\mathrm{e}}$ siècle et plus tard encore, se distingue par ses châteaux-forts. «C'est l'époque des châteaux-forts» dit M. Lemarignier. M. Vercauteren parla de la politique castrale des grands. J. Bardach, lui-aussi, marqua l'importance du problème. Le phénomène est commun à l'Europe toute entière; il prit une extension beaucoup plus large que le système féodal, remarqua un des interlocuteurs. L'observation parait pertinente.

Nous avons donc affaire à un réseau de castra, de forteresses de l'époque. Ils sont construits soit en pierre, soit en bois. Quel que soit le matériel utilisé pour les construire leur fonction reste partout la même: ils assurent la défense du pays et servent comme moyen de gouverner. Le castrum est l'assise de la structure étatique médiévale.

Un chroniqueur français du $\mathrm{X}^{\mathrm{c}}$ siècle parla d'un manteau blanc des églises dont s'est couverte sa patrie, en ce temps-là. Il est certain qu'en Pologne le nombre d'églises, même un siècle plus tard, n'était pas aussi élevé qu'en France. Cependant l'accroissement du réseau paroissial - dont M. Kloczowski vient de parler - ne saurait se passer des édifices du culte. Aussi se sont-ils formés, en conséquence, deux réseaux distincts, celui des castra et celui des églises. L'un affecté au culte, l'autre aux besoins militaires et politiques. Ces deux réseaux, lä̈que et ecclésiastique, demeuraientils séparés, dés le début, l'un de l'autre?

Dans les sources polonaises du $\mathrm{XIII}^{\circ}$ siècle on mentionne les ecclesiae incastellatae, des églises transformées en castella. Ainsi apparaît le rôle militaire des édifices, affectés, par principe, au culte. Bien sûr, nous sommes loin de nier leur rôle cultuel, les sentiments religieux du Moyen Âge ne peuvent être contestés. L'église, tout d'abord, était un lieu de culte. Elle demeurait cependant susceptible d'être transformée, au besoin, en forteresse.

N'est-il pas surprenant que ce caractère secondaire de l'église semble attirer l'attention des contemporains? Pour désigner l'édifice, les Slaves empruntèrent, simplement, au latin médiéval, le substantif castellum, en le

* Przedruk z: L'Europe aux $I X^{e}-X$ siècles, Warszawa 1968, s. 451-452. 
transformant pour l'adapter à leur système phonétique. D'où le tchèque: kostel, le polonais: kościól. Avons-nous besoin d'une preuve encore plus convainquante? Pouvons-nous procurer un témoignage plus évident qu'une donnée linguistique?

S'il en est ainsi - le fait paraît incontestable, puisqu'il est attesté, au surplus, par les sources écrites - on peut se demander, si le système des églises privées (Eigenkirchen), des églises appartenant aux seigneurs, en propre, ne doit pas son origine, pour une part au moins, aux besoins militaires de l'époque. L'église privée - source de revenus pour les laïques; certes. De plus, c'était aussi, un bourg potentiel. Si le seigneur la construit, s'il la dote, il le fait, sans conteste, dans un dessein religieux, "pro redemptione animae suae». Il construit, en même temps, un abri qui le protegera lui-même, ainsi que sa famille et son entourage.

Le réseau séculier des castra serait donc secondé par un réseau sacral, celui des églises. Ce dernier paraît complémentaire, quant à son rôle militaire. Ne serait-il pas possible de scruter le problème de plus prés?

En abordant une analyse détaillée, on se heurte à des difficultés. Les renseignements, très épars, du reste, relatifs à des ecclesiae incastellatae, n'apparaissent qu'au moment où l'institution est condamnée à l'extinction. Cela arrive, d'ailleurs, assez fréquemment, dans les études médiévistes. Nous sommes, il est bien entendu, à l'époque coutumière. La naissance de l'institution et son évolution échappent, pour la plupart, à nos investigations, puisque les sources ne s'en occupaient pas. Ce n'est qu'au moment où l'Église commence à lutter contre la mala consuetudo de l'incastellation des édifices du culte que cette dernière se dévoile aux yeux du chercheur. L'apparition de l'institution coïncide donc avec sa disparition.

Faute de certitude, les conjectures sont admises. Je me permets donc d'attirer l'attention sur deux faits. Vers la fin du XIII' siècle et au début du XIV ${ }^{e}$ siècle, la propriété privée des églises fut substituée, en Pologne, par l'institution nouvelle, le ius patronatus, droit de patronage - et j'ai dans l'esprit, l'oeuvre magistrale de H. F. Schmid, Grundzüge der Pfarrorganisation auf westslawischem Boden. En même temps l'Eglise fulmine contre les ecclesiae incastellatae qu'elle condamne à la disparition. Cette coïncidence est-elle due au hasard? Voilà la question que je me pose et que je ne suis pas à même de résoudre. 


\section{Morbus comitialis czyli kaduk*}

\section{1.}

W 1966 r. ukazala się rozprawa habilitacyjna H. Olszewskiego pt. Sejm Rzeczypospolitej epoki oligarchii 1652-1763. Prawo - praktyka - teoria - programy. Dzieło niewątpliwie imponujące, świadczące o rozległości horyzontów autora, dobrej znajomości źródel i oczytaniu w literaturze. Wszystko to stanowi najlepsza rekomendację. Nie bez racji ocenia się autora jako badacza dojrzałego i nowatorskiego, jeśli chodzi o metodę badań $^{1}$, podkreśla się oryginalność ujęć, a zwłaszcza szerokość widzenia problemów ${ }^{2}$, jak też - co istotne - wyłamywanie się z formalizmu dogmatycznego ${ }^{3}$. W swym obszernym dziele przypomniał Olszewski wiele rzeczy znanych, ale też wydobył na światło dzienne kwestie nowe, stworzył wlasne koncepcje, dając nauce polskiej opus magnum - pisze znakomity znawca epoki ${ }^{4}$. Walory omawianej pracy pozwalaja ją zaliczyć do grupy najbardziej wartościowych dziel powojennych na temat polskiego parlamentu i parlamentaryzmu okresu przedrozbiorowegos. Otwiera ona przy tym nowe możliwości badawcze

Co prawda, kompetentni badacze nie szczędzą jej też uwag krytycznych. Podkreśla się niejasność pewnych sformułowañ ${ }^{7}$, potrzebę skrótów ${ }^{8}$. Choć autor przedarł się przez pokaźną liczbę diariuszy sejmowych (przeszło 600) ${ }^{9}$, to jednak słabo wykorzystal archiwalia niemieckojęzyczne ${ }^{10}$. Stwierdza się

* Przedruk z: Przegląd Historyczny 1969, t. 60, s. 161-173.

1 R. Laszewski, Cz P-H, XIX, 1967, z. 2, s. 180.

2 J. Bardach, Sejm szlachecki doby oligarchii, KH, LXXIV, 1967, z. 2, s. 365.

3 W. Duski, por. Z. Szczaska, Sejm Rzeczypospolitej epoki oligarchii, KH, LXXIV, 1967, z. 4 , s. 1145 .

4 W. Czapliński, Sejm Rzeczypospolitej epoki oligarchii, Cz P-H, XIX, 1967, z. 2, s. 172, 180.

5 J. Bardach, op. cit., s. 365; Wl. Czapliński, op. cit., s. 180; R. Laszewski, op. cit., s. 186.

${ }^{6}$ W. DHuski, KH, LXXIV, 1967, z. 4, s. 1145.

${ }^{7}$ W. Czapliński, op. cit., s. 176.

8 Tamże, s. 180.

9 Tamże, s. 172. Por. H. Olszewski, Sejm Rzeczypospolitej epoki oligarchii 1652-1763, s. 272 , przyp. 56 .

${ }^{10}$ Wl. Czapliński, op. cit., s. 173; J. Seredyka, KH, LXXIV, 1967, z. 4, s. 1143. 
opuszczenia istotnych pozycji monograficznych - polskich i obcych ${ }^{11}$. Razi też statyczność ujęcia zagadnienia ${ }^{12}$. Niektóre ustalenia szczególowe nie dadzą się utrzymać; nie brak też pomyłek i błędów ${ }^{13}$, pewne fragmenty rozważań nasuwają wątpliwości ${ }^{14}$. Istnieją ważne problemy, których autor nie widzi, np. znaczenia króla ${ }^{15}$, funkcji magnaterii i szlachty ${ }^{16}$, czy zwłaszcza roli państw obcych w utrzymaniu wad polskiego ustroju ${ }^{17}$. Stawia się mu też zarzut dużej zależności od wielkich poprzedników (Kutrzeba, Konopczyński), do czego się - co gorsza - nie przyznaje ${ }^{18}$. A przy tym od Konopczyńskiego zarazil się nieusprawiedliwionym pesymizmem ${ }^{19}$. Wadą wydaje się też brak porównania polskiego sejmu z sejmami innych narodów ${ }^{20}$, to zaś, co $w$ tej mierze zostało zrobione, budzi zastrzeżenia ${ }^{21}$.

Dzielo przedstawia nam szczegółowo funkcjonowanie sejmu w latach 1652-1763, uwypukla wyraziście niedołęstwo organizacyjne naszej szlachty, która nie potrafiła zapewnić zwyczajnego regulaminu porządkowego swojej naczelnej reprezentacji. Toteż sejm, będący organem, do którego należała najwyższa władza w państwie (s. 36), którym - jak mówiono - Rzeczpospolita stoi (s. 27, 32), który miał być unicum malorum anthidotum (s. 31, 32), był niewątpliwie organem impotentnym. Jeśli ta centralna instytucja miała pokaźnie umniejszać skutki rozbicia machiny państwowej, spowodowanego instytucją sejmików ${ }^{22}$, to funkcje tego naczelnego organu życia państwowego sparaliżowane były przez liberum veto ${ }^{23}$. Tę dawną wypowiedź o paraliżu sejmu polskiego powtarza i sam autor: w omawianym okresie został sejm zerwany w 37 wypadkach na 73 (s. 76), przez 25 lat nie wydal ani jednej konstytucji (s. 376) ${ }^{24}$. Jak mogło nasze państwo $\mathrm{z}$ tak źle pracująca władzą naczelną sprostać i wewnętrznym trudnościom, i naporowi zewnętrznemu

"I J. Bardach, op. cit., s. 371 n.; Wl. Czapliński, op. cit., s. 173; J. Seredyka, op. cit., s. 1144.

${ }^{12}$ Wl. Czapliński, op. cit., s. 174; Z. Wójcik, KH, LXXIV, 1967, z. 4, s. 1143.

${ }^{13}$ WI. Czapliński, op. cit., s. 173, 179; R. Laszewski, op. cit., s. 181 nn., 186.

${ }^{14}$ B. Waldo, Nieznane konstytucje sejmu warszawskiego z $1658 \mathrm{r} ., \mathrm{Cz}$ P-H, XIX, 1967, z. 2 , s. $115-117$.

${ }^{15}$ W. Czapliński, op. cit., s. 176-178.

16 J. Seredyka, KH, LXXIV, 1967, z. 4, s. 1144.

${ }^{17}$ Wl. Czapliński, op. cit., s. 176.

${ }_{18}$ Tamże, s. 172.

${ }^{19}$ Tamże, s. 174. Czy wolno jednak posunąć się do twierdzenia, że Olszewski idzie drogą Konopczyńskiego?

${ }^{20}$ WL. Czapliński, op. cit., s. 174. Przed tym zarzutem broni go St. Russocki, KH, LXXIV, 1967, z. 4, s. 1144. Autor zresztą świadomie unikał komparatystyki (por. s. 12, przyp. 16).

21 J. Bardach, op. cit., s. 370.

${ }^{22}$ O. Balzer, $Z$ zagadnień ustrojowych Polski, SHPP, t. VI, z. 2, Lwów 1917, s. 67; tenże, $Z$ zagadnien ustrojowych Polski. Nowe spostrzeżenia i uwagi, Lwów 1920, s. 12, 42.

${ }^{23}$ O. Balzer, $Z$ zagadnień, s. 27.

${ }^{24}$ Ostatnio zetknęliśmy się $z$ inną przenośnią: „skleroza struktur społecznych”. Por. B. Leśnodorski, Cz P-H, XIX, 1967, z. 2, s. 238. 
sąsiadów rosnących $w$ siłę dzięki modernizacji urządzeń państwowych? Toż to anarchia odgórna! Trudno $\mathrm{z}$ tą charakterystyką sejmu przedstawioną przez autora polemizować. Toteż pođzielając jego negatywną opinię o polskim sejmie, przy opublikowanych już tylu tak pełnych i fachowych ocenach, zamierzamy skierować swoją uwagę na pewne tylko wypowiedzi autora, na drobne nieraz niedociągnięcia, które zakradły się do omawianej pracy, szpecąc ją niepotrzebnie.

\section{2.}

Korektę drukarską przeprowadzono wyjątkowo niestarannie. Erratom, zestawionym przez autora, daleko do wyczerpania wszystkich tego rodzaju potknięć (np. na s. 384 zecer wyrzucił wiersz i w jego miejsce wstawił obcy, tak że zdanie dla czytelnika stało się zupełnie niejasne). Znaczna liczba blędów zakradła się do cytatów łacińskich ${ }^{25}$. Tej laciny jest zaś niemało, ponieważ zainteresowania autora rozciągają się, jak wiemy, na stulecia silnie makaronizujące. Niewątpliwie i tu wiele usterek trzeba położyć na karb nieuwagi zecerskiej:

1. „Dochód $\mathrm{z}$ danin, których exaction po województwach [...] non practicabatur"' (s. 381, przyp. 149); ma być: exactio.

2. „(marszałek) szemrzącym imponabat silentium" (s. 191); ma być: imponebat.

3. „Drudzy rectius sententies” (s. 412); ma być: sentientes.

4. „Na zathumienie wolnego głosu senoras tanquam in sylvis voces concitavit" (s. 413); ma być: sonoras.

5. Nihil ominus (s. 47); ma być: nihilominus.

6. In practicabilis (s. 402); ma być: inpracticabilis.

7. Ex usu vocis lebere (s. 421); ma być: libere.

8. Per mutuam comunicatione (s. 402); ma być: communicationem.

9. Secundus leges (s. 400, przyp. 68); ma być: secundum leges.

10. Ma być irritum et inanae (s. 36, przyp. 7) zamiast: inane.

11. „Bo póki my hos patriae turbantos non removebimus” (s. 424); ma być: turbantes.

12. Salvum [...] regressum reliquendo (s. 432); ma być: relinquendo.

13. Scito activitatem (s. 182); ma być: sisto activitatem, jak jest na s. 314 .

14. "Więcej sobie senatusconsilia pozwalają, aniżeli comperit legi" (s. 247): ma być chyba: competit ${ }^{26}$.

${ }^{25}$ W. Czapliński, op. cit., s. 180.

${ }^{26}$ Znaczenie czasownika comperio podane przez M. Plezię nieodpowiednie do kontekstu; natomiast na competo $\mathrm{z}$ datiwem przytoczono moc przykładów, które dają sens: należeć, przysłuchiwać. 
15. „...marszalek stosować się ma ad antiquas leges et usitates praxes" (s. 190); ma być usitatas praxes, skoro niżej na tejże samej stronie spotykamy wyrażenie: usitatae praxes. Wszakże na innej stronie (s. 378) czytamy znowu: „...relacje uchwal sejmu i sejmików, regulowana przez antiquas mores et usitates"; ma być zapewne: per antiquos mores et usitatos.

16. Adam ubies (s. 284, przyp. 99); ma być: Adam, ubi es? jest to aluzja oczywista do znanego wersetu Pisma św.: Vocavitque Dominus Deus Adam, et dixit ei: Ubi es? (Gen. 3. 9). $\mathrm{Nb}$. podobne niedopatrzenia występuja w tekstach staropolskich, silnie latynizujących.

17. „By konstytucyje u marszałka [...] nie były rejterowane ani czytaniem, ani pisaniem" (s. 196). O jakąż tu chodzi rejteradę? Po pewnym namyśle dochodzimy do wniosku, że obawiano się, by konstytucje nie były reiterowane!

18. Co to sa "deputacje de remis" (s. 293, 300)? Przecież nie o wiosła tu chodzi. Okazuje się po bliższym przyjrzeniu, że mimo łacińskiego przyimka de wcale to nie tekst laciński. Chodzi tu o deputowanych do sądów sejmowych, których - jak to autor sam stwierdza - określano niezbyt ściśle (po polsku!) jako „,deputowanych do remiss” (s. 299).

Jeśli więc autor wykazuje w erratach tak niewinne omyłki, jak tygodni zamiast tygodni (s. 414), to czyż nie należałoby raczej poświęcić więcej uwagi zwrotom obcojęzycznym, stanowiącym $\mathrm{z}$ natury rzeczy szczególne pole popisu dla zecera? Pewności co do propozycji korektowych nie ma czytelnik we wszystkich wypadkach. Robiąc je „z głowy”, bez zaglądania do oryginałów, można się potknąć. Tym bardziej gdy, jak w naszym wypadku, ma słabe oczytanie $w$ źródłach siedemnasto- i osiemnastowiecznych. Łatwo bowiem wtedy o gafę. $Z$ góry za nią przepraszamy: prosimy jednak o obciążenie nią nie nas, lecz autora, który winien był wszystkie niedociągnięcia pousuwać.

Czasami wszakże sytuacja jest groźniejsza. Pewnych wyrażeń nie byliśmy w stanie rozszyfrować, nie wiemy więc, jaką poprawny tekst ma postać, tym samym przyznajemy, że wypowiedzi w ogóle nie rozumiemy.

19. Nie wiemy, co to są adicta patronum, albo też zwrot: dummodo patronus magnus scerscat (s. 82).

20. Nie rozumiemy, co znaczy: pro hoc sola cove (s. 393).

21. „Zaczym abyś Uprzejmość Wasza materias tractandorum [...] suggere i nam comunicare raczyl”' (s. 43, przyp. 33). Czy to ma być suggerere (od suggero) czy sugere (od sugo)?

22. „Kiedy manum libemus oraz amori nostro litamus” (s. 142). Nie uprzytamniamy sobie, dlaczego tu raz coniunctivus (?), raz indicativus. 
Zresztą w całym ustępie, w którym ten zwrot występuje, przestankowanie nie wydaje się nienaganne.

23. Czy w oryginale jest rzeczywiście: circumfierunt (s. 82)?

24. Co to znaczy: in ancessu (s. 402) ${ }^{27}$ ?

25. Nie rozumiemy następujących cytatów: „aby województwa inscorsiosas sessionibus obrały między sobą kogo ad connotanda sufragia [...], aby stary marszałek gemitatos otrzymal canes" (s. 211, przyp. 147).

26. „Aby sesyje acoque w senatorskiej jako i poselskiej izbie o ósmej [...] zaczęte do czwartej z pohudnia contennaretur" (s. 277, przyp. 66).

W pewnych wypadkach moglibyśmy wystąpić z propozycjami korektowymi; ale wahamy się co do innych, wolimy więc je zachować dla siebie. Musielibyśmy bowiem robić dalsze poszukiwania, a to nie jest nasze zadanie, zadanie czytelnika. To właśnie rola habilitanda. Tu mógł wykazać talent szperacza i wnikliwego interpretatora, który żadnemu słówku nie przepuści, ale każdą trudność rozwiąże i gotowy produkt poda czytelnikowi. Tego tymczasem wysilku zrozumienia źródel u autora nie widać zupełnie. Zrozumial je w $90 \%$ i tym się zadowolił; o resztę niech się czytelnik martwi. Być może, zestawione wyżej błędy występują w rękopisach, ale to winien był wydawca zasygnalizować. Przy najlepszej woli, czy można wszystkie wskazane potknięcia kłaść na karb zecerskich błędów?

$\mathrm{Z}$ pewnością nie są nimi następujące wypadki:

27. Na paru stronicach czytamy o władzy czy kompetencjach regis soli (s. 28, 217, 155, 162). Czyżby kojarzyć naszego monarchę z królem-słońcem? Ale dlaczego $w$ takim razie dativus? Co ma znaczyć zwrot: ,[proces] osłabiania władzy królewskiej jako regis soli'? Okazuje się, że we wszystkich podanych przypadkach autor chcial postawić wyrażenie rex solus w genetivie, i zrobił to blędnie, deklinując: regis soli zamiast jedynie poprawnego: regis solius $^{28}$.

28. Posel jest nazywany „panem swojego prawa”. Odpowiednik laciński tego polskiego zwrotu brzmi: dominus (domini) iuris suae (s. 6, 29, 264, 267 , por. też streszczenie rosyjskie s. 452 i francuskie s. 458). Ma być oczywiście dominus iuris sui! $!^{29}$

29. Zwrotu morbus comitialis używa autor raz w neutrum, zatem ma on postać: morbum comitiale (s. 453,459 ), to znów w masculinum (morbus,

\footnotetext{
${ }^{27}$ Rzeczownika ancessus brak i w Forcellinim i u Plezi.

${ }^{28}$ Ten sam błąd fleksji u K. Grzybowskiego, Teoria reprezentacji w Polsce epoki Odrodzenia, Warszawa 1959, s. 204.

${ }^{29} \mathrm{Na}$ ten jaskrawy błąd zwrócił uwagę W. Czapliński, op. cit., s. 179.
} 
s. 437). W lacinie klasycznej był to rzeczownik rodzaju męskiego, w łacinie średniowiecznej bywa i masculinum, i neutrum. Ale czy nie należało na jedną postać się zdecydować? A i tam, gdzie autor postawił go w rodzaju męskim (morbus), nie potrafil $\mathrm{z}$ tym rzeczownikiem deklinacji drugiej uzgodnić przymiotnika deklinacji trzeciej, wynikiem czego morbus comitiale (s. 437) zamiast jedynie dopuszczalnego morbus comitialis!

Nieraz wprowadzono przestankowanie takie, żeby czytelnik prostego tekstu nie rozumial:

30. „Abyście [...] ludzi maturi consilii et rerum experientia polentes [poprawnie: pollentes] wyprawili" (s. 52).

31. „Uchodząc periculum rozerwania, zjazdu tego" (s. 395). Po usunięciu w obydwu przypadkach przecinków teksty stają się zupełnie jasne.

32. Należałoby też poprawić i uzupełnić przestankowanie długich cytatów na s. 39 i 430.

To wszystko nie zecerskie wyczyny, obciążamy nimi wyłącznie konto autora. Zdajemy sobie sprawę $\mathrm{z}$ nieuchronności błędów, ale czy nie są one zbyt częste, jak to już krytycy podnieśli? ${ }^{30}$ Zestawienie powyższe - nie jest ono $\mathrm{z}$ pewnością kompletne - dowodzi dużego niedbalstwa, tym samym świadczy niedobrze i o warsztacie, i o metodzie pracy autora, a przede wszystkim zdradza brak należytego przygotowania filologicznego. A bez filologii historyk prawa, jak w ogóle historyk średniowiecza, staje częstokroć bezradny.

I w tekście polskim, pochodzącym od autora, spotykamy wyrażenia, na które trudno się zgodzić, np. „,szlachta dzierżawcza” (s. 258), co ma oznaczać szlachtę-dzierżawców. Nie rozumiemy też zupełnie, skąd się wziął stosunek odwrotnie proporcjonalny między liczbą konstytucyj regulujących sprawy prywatne a liczbą tychże konstytucyj poświęconych materiom publicznym (s. 377). W naszym rozumieniu zagadnienie proporcjonalności jakiejkolwiek nie wchodzi tu $w$ rachubę, nie ma zatem mowy i o stosunku odwrotnie proporcjonalnym.

Wydaje się, że autor pomieszał intytulację dokumentów $\mathrm{z}$ arengą (s. 42, $47,69)$. Bo jak inaczej wytłumaczyć jego wypowiedzi, iż arenga była zależna od godności adresata, i że dla tego celu posługiwano się urzędowym tytularzem. A jak w ogóle $w$ arendze, w rozumieniu, jakie jest przyjęte u dyplomatyków, mogła się znaleźć wiadomość o liczebności sejmiku (s. 69)?

Autor uważa gaże 500-600 złp, wypłacane posłom, za „wcale pokaźne” (s. 49). A tymczasem skromnie one wyglądaja w stosunku do kwot wyplacanych posłom wojskowym, siegających od 30 do 69 tys. złp (s. 56)!

${ }^{30}$ W. Czapliński, op. cit., s. 180. Inaczej J. Bardach, który utrzymuje, że błẹdy są rzadkie (op. cit., s. 371). Por. jeszcze błędy zecerskie (?) na s. 279, 331, 396, przyp. 46; s. 397, przyp. 52. 
Wskażmy wreszcie na wypowiedzi i sformułowania dość nieprecyzyjne ${ }^{31}$. I tak np. dwukrotnie wspomina autor o dekrecie kondyktowanym dla Brühla (s. 181, 325). Niewątpliwie idzie tutaj o fałszywy wywód szlachectwa polskiego, o którym pisal Wl. Konopczyński ${ }^{32}$; wyrobiono go zaś w trybunale przez condictamen, czyli zmowe $e^{33}$. Czy więc $w$ tych warunkach ujemna ocena dziela jako monografiii ${ }^{34}$ nie jest uzasadniona?

\section{6.}

$Z$ podanej przez nas wyżej charakterystyki funkcjonowania sejmu wynikać ma, zdaniem autora, powiedzenie: „Polacy cierpią na sejmową chorobę" (Poloni comitiali morbo laborant, s. 30). Ale jaka jest treść wypowiedzi? Autor powtarza ją zarówno w wersji rosyjskiej (Poljaki stradajut sejmowoju bolezniju, s. 453), jak i francuskiej (les Polonais souffraient le mal de diète, s. 459). Jeśli w tym pomniejszeniu, jakie stanowi streszczenie obcojęzyczne, pomieścil autor ten zwrot, widocznie traktuje go jako istotny dla charakterystyki naszego sejmu. Czytelnik też odnosi wrażenie, że nieuleczalną chorobę, która przeżarty był polski parlamentaryzm, nazywali współcześni morbus comitialis ${ }^{35}$.

Charakterystyczne jednak, że autor, który tylokrotnie swoje wypowiedzi umacnia cytatami źródłowymi, w wypadku gdy idzie o chorobe sejmową, nie podaje żadnego. Dowiadujemy się odeń tylko, że w uszczypliwy sposób wyraził się o sejmie w 1569 r. biskup Karnkowski, że krytykowano tę instytucję w latach wojny domowej 1606-1609 i później, że mnogie specula gromiły panoszącą się w czasie obrad prywatę i nadużycia (s. 30), że malała efektywność zgromadzeń sejmowych, aż doszło do zamarcia ustawodawstwa (s. 30-31). Te fakty niewątpliwie świadczą o zwyrodnieniu instytucji. Toteż nie bez racji Konopczyński pisał o instytucjach i regułach polskich, które ,jak ciężka choroba toczyły ciało Rzeczypospolitej”" nierządu sejmowego" ${ }^{17}$. Czy na tym więc polega choroba sejmowa?

${ }^{31}$ Np.: „Naszym zdaniem problem jest bardziej złożony i nie wydaje się, by można było bez zastrzeżeń uważać veto $\mathrm{w}$ jego najbardziej skrajnej i brzemiennej postaci za wykwit nierówności wśród feudałów", albo: „Teoria liberum veto i zrywania sejmów to jeden z najbardziej perfidnych składników ideologii demokracji szlacheckiej w warunkach dominatu magnackich koterii".

${ }^{32}$ W. Konopczyński, Dzieje, t. II, s. 242.

${ }^{33}$ Por. SPPP, t. II, nr 2943 (1441).

${ }^{34} \mathrm{KH}$, LXXIV, 1967 , z. 4, s. 1144; za monografię poczytuje ją autor (s. 12).

${ }^{35}$ Tak właśnie St. Russocki, Parlament Rzeczypospolitej $w$ dobie upadku, Kultura, nr 9 (194), z 21 lutego 1967.

${ }_{36}$ Wl. Konopczyński, Dzieje Polski nowożytnej, t. II, s. 304.

${ }^{37}$ Tamże, s. 95. 
Zważmy jednak, że wyrażenie to, według informacji autora, pojawia się jeszcze w XVI w., a więc w okresie, gdy wady funkcjonowania sejmu nie były jeszcze tak jaskrawe. Co więcej, dla tej doby pisze się o wysokiej moralności politycznej szlachty polskiej, ocenia się dodatnio wyniki ówczesnego parlamentaryzmu, skoro sejmy dochodziły $\mathrm{z}$ szeregiem uchwalonych konstytucji ${ }^{38}$. A tymczasem brak choćby jednego cytatu $z$ doby wyraźnej degeneracji naszego parlamentu. Kto to wyrażenie ukul, co przyczyniło sie do jego wczesnego zamarcia?

\section{7.}

Zacznijmy analizę od oryginalnego: comitiali morbo laborare. W lacinie klasycznej słowo laborare ma dwa znaczenia: pracować i cierpieć. W sensie drugim notujemy zwroty takie: morbo, febri, pestilentia, utero laborare. Wyraz zostal zatem zaczerpnięty z laciny klasycznej. A może cały zwrot morbus comitialis również jest jej znany?

U Forcelliniego spotykamy taką wskazówkę: morbus maior, comitialis, sacer i objaśnienie włoskie mal caduco; a więc jest to klasycznej łacinie właściwy idiom, oznaczający padaczkę, epilepsję. Stąd też wywodzi się to określenie, iż - jak podaje Forcellini za Pliniuszem - w wypadku gdy ktoś na zebraniu ludowym dostał ataku tej choroby comitia dissolvi ac in alium diem diferri necesse erat. To samo znaczenie poświadcza obficie Thesaurus ${ }^{39}$. I ten sens jest powszechnie znany; powtarzaja go szkolne słowniki laciny klasyczneje ${ }^{40}$, podaja go też encyklopedie ${ }^{41}$.

8.

A jak rozumiano ten zwrot $w$ średniowieczu? Punkt wyjścia stanowić będzie dla nas Izydor ze swymi Etymologiami. Oto, co tam czytamy: Ipse est et morbus comitialis, id est maior et divinus, quo caduci tenentur [...]

${ }^{38}$ J. Siemieński, Polska kultura polityczna wieku XVI, [w:] Kultura staropolska, Kraków 1932, s. 151. Por. też St. Kutrzeba, Historia ustroju Polski w zarysie. Korona, wyd. VIII, przejrzał i uzupełnil A. Vetulani, Warszawa 1949, s. 223. W. Olszewski stwierdza poglębiajacy się upadek kultury politycznej wśród reprezentantów szlacheckich mas od polowy XVII w. (s. 318).

${ }^{39}$ Thesaurus linguae latinae, vol. III, Lipsiae 1907-1912, kol. 1798-9. W tym samym znaczeniu występuje i przysłówek comitialiter. Tenże słownik podaje inne jeszcze wyjaśnienia omawianego zwrotu: ideo comitialis dictus, quod in comitio primum, nescio quis, hoc morbo arreptus est, kol. 34. Polskę porównuje się w XVI w. z republikańskim Rzymem, stąd comitia awansowały na odpowiednik naszego sejmu. Por. St. Estreicher, Kultura prawnicza w Polsce XVI wieku, [w:] Kultura staropolska, s. 92.

${ }^{40}$ F. Gaffiot, Dictionnaire illustré latin-français: morbus comitialis, epilepsie.

${ }^{41}$ E. Seidl, Real-Encyklopädie der klassichen Altertumswissenschaft, t. XXXI, 1933, kol. 277-8, nie mówiąc już o Malej Encyklopedii Kultury Antycznej, Warszawa 1966, s. 576. 
Comitalis autem dictus, quod apud gentiles cum comitiorum die cuiquam accidisset, comitia dimittebantur ${ }^{42}$. W pelni zatem potwierdza się utrzymanie sensu antycznego. To samo znaczenie zwrot ten ma w slowniku medycznym z ok. 700 r. gdzie pod epylempsia czytamy: ...hanc passionem alii morbum comitialem dixerunt, [...] sive quod divinum morbum comitialem dicunt ${ }^{43}$; tamże dalej: Geran noson, hoc est sacerdotalem morbum, ipse est et morbus comitialis $^{44}$.

U Ducange'a pod haslem morbus zestawiono moc określeń powiązanych $\mathrm{z}$ imionami świętych: a dlatego zaś w ten sposób rozmaite choroby określano, quod eorum curatio ab iis potissimum exorabatur. Dalej ida morbi z przydawkami odimiennymi: Naepolitanus, Persicus, Romanus, Ambianensis. Wreszcie z przydawkami pospolitymi: calidus, iniquus, magnus, grossus, regius. Wszakże brak odrębnego hasła morbus comitialis. Ale pod hasłem morbus obscurus czytamy: maladie obscure, epilepsia, comitialis morbus; pod hasłem morbus pulcher: ex adverso apellatur morbus comitialis. A więc to klasyczne znaczenie utrzymuje się nadal ${ }^{45}$. Wykazuje je też Novum Glossarium $^{46}$.

Slownik laciny średniowiecznej M. Plezi zestawia dla polskiej laciny dwa teksty: [ex vini immoderato usu sc.] multi comitiali morbo laborant - pisze autor De institutione regii pueri libellus anonymus w $1502 \mathrm{r}^{47}$ Drugą wzmiankę zawierają Acta capitulorum pod data 1533 r.: Honorabilem Iohannem de Paczina, vicarium perpetuum Cruswiciensem, morbo epilepsis comitiali, quem caducum dicunt, [...] laborantem a sacris exercendis et ingressu ecclesie [...] esse suspensum ${ }^{48}$. W obydwu zatem wypadkach sens klasyczny utrzymuje się dalej ${ }^{49}$. Nie inne jest też znaczenie tego wyrażenia u Mączyńskiego: „Morbus maior idem qui comitialis, wielka niemoc (231, d/34), sacer morbus, świętego Walentego niemoc, aliter comitialis, wielka

${ }^{42}$ Isidori Hispalensis episcopi etymologiarum sive originum libri $X X$, recognovit W. $\mathrm{M}$. Lindsay, Oxonii 1911, t. 1, lib. 4, cap. 7.

${ }^{43}$ Glossae medicinales, ed. J. L. Heiberg, Det kgl. Danske Videnskabernes Selskub. Historisk-filologiske Meddelelser, IX, 1, Köbenhavn 1924, s. 31.

${ }^{44}$ Tamże, s. 37.

${ }^{45}$ Zauważmy, że w średniowieczu przymiotnik comitialis wiąże się też z rzeczownikiem comes, np. comitialis potestas i.e. comitis; poświadcza ten sens Ducange, jak i Niermeyer.

${ }_{46}$ Novum Glossarium Mediae Latinitatis ab anno 800 usuque ad annum 1200, wyd. F. Blatt, Hafniae 1963.

${ }^{47}$ H. Zeissberg, Kleinere Geschichtsquellen Polens im Mittelalter, Archiv für österreichische Geschichte, t. LV, Wien 1877, s. 144. Autorstwo traktatu przypisują niektórzy badacze Maciejowi Drzewickiemu (por. Nowy Korbut, t. II, s. 146.).

${ }^{48}$ Acta capitulorum nec non iudiciorum ecclesiasticorum selecta, ed. B. Ulanowski, vol. III, pars I, Kraków 1908, s. 327.

${ }^{49}$ Rozumie go też dobrze tłumacz wzmiankowanego dziełka pedagogicznego $O$ wychowaniu królewicza, E. Jędrkiewicz, który cytowany zwrot oddaje przez: „wielu cierpi na epilepsję". Por. J. Skoczek, Wybór pism pedagogicznych doby Odrodzenia, Wrocław 1956, s. 32. 
niemoc, padaczka (36 3, a/27); świętego Walentego albo wielka niemoc, morbus comitialis alias herculeus" $(66, \mathrm{~b} / 35)^{50}$.

Nie inaczej Cnapius: „Kaduk, choroba rzucająca, wielka niemoc [...], morbus comitialis [...], morbus caducus, epilepsia, morbus sacer, herculeus". Tamże nawet: „Kaduk cierpiący epilepticus, comitialis homo”. Knapiusz podaje również wyjaśnienie Pliniusza, które zacytowaliśmy wyżej ${ }^{51}$. Wreszcie u samego kresu XVIII w. jezuita ks. Jan Bohomolec, pisał: „Gdy kaduk kogo rzucil, zaraz zrywano sejmy; dlaczego choroba ta nazwana sejmowa, morbus comitialis" 52 .

Pod piórem Polaków zatem do końca Rzeczypospolitej jedno posiada omawiany zwrot znaczenie: morbus comitialis to epilepsja, czyli padaczka, albo po staropolsku, z lacińska, kaduk!

\section{9.}

Jak oddawano morbus comitialis po polsku? W Slowniku staropolskim epilepsja to choroba wielka, padająca, padaczka (ostatnie określenia stanowią oczywiście kalkę lacińskiego morbus caducus). Wyżej podawaliśmy identyczne wyrażenie używane przez Mączyńskiego: świętego Walentego niemoc, wielka niemoc. Knapiusz dodaje do tych terminów: „choroba rzucająca". Charakterystyczne jednak dla ostatniego leksykografa, że mimo, iż comitia wyjaśnia przez sejm, comitialis przez sejmowy, comitialis homo będzie u niego: „kaduk cierpiący, comitialis morbus; kaduk, choroba" 53 . Takie same zestawienia podaje Linde. I dopiero J. Bohomolec użył wyrażenia: choroba sejmowa, wszakże w znaczeniu - i tylko $w$ tym znaczeniu - padaczki. Jest to znowu ewidentna kalka językowa bez zmiany sensu wyrażenia!

Skąd więc H. Olszewski wpadł na to, żeby pewne wady, i to niewątpliwe, w organizacji polskiego sejmu, nazwać „chorobą sejmową”, czyli - acz $z$ tego sobie sprawy nie zdaje - padaczką albo epilepsją?

so J. Mączyński, Lexicon Latino-Polonicum ex optimis Latinae linguae scriptoribus concinnatum, Regiomonti 1564.

${ }^{51}$ Thesaurus Polono-Latino-Graecus, Cracoviae 1621.

52 J. Bohomolec, Diabel w swojej postaci albo o upiorach, guslach, wróżkach, losach, czarach, cz. II, Warszawa 1777, s. 195.

${ }^{53}$ Thesauri Polono-Latino-Graeci, t. II: Latino-Polonicus, Cracoviae 1668; powtórzono w późniejszym wydaniu: Thesauri Polono-Latino-Graeci..., tomus secundus: Latino-GermanoPolonicus, Posnaniae 1754. 
10.

Jednym $\mathrm{z}$ wielkich badaczy polskiego parlamentaryzmu, poprzedników H. Olszewskiego, był Wladysław Konopczyński. Autor niewątpliwie z niego korzysta $^{54}$, czego oczywiście nikt mu nie weźmie za złe. $Z$ niego zaczerpnąl tytul rozdziału: Inter maiestatem et libertatem ${ }^{55}$. Czyżby i stamtąd pochodzilo wyrażenie: choroba sejmowa?

Charakterystyczne dla Olszewskiego, że powołując zwrot: Poloni comitiali morbo laborant, „Polacy cierpią na sejmową chorobę", nie podal żadnego cytatu źródłowego. Skąd go więc zaczerpnąl? Cytując głos Karnkowskiego, powołuje się na B. Leśnodorskiego ${ }^{56}$. Tam wszakże jest wyraźne odesłanie do Konopczyńskiego Liberum veto ${ }^{57}$. W dziele ostatnim rzeczywiście dopatrywać się musimy źródła pierwszego akapitu Olszewskiego na stronie 30. Cały zespół zdań zaczerpnąl on bezpośrednio czy pośrednio z tej monografii.

W niej istotnie Konopczyński zatytulowal jeden ustęp Choroba sejmowa ${ }^{58}$; co więcej, stawia nawet diagnozę tej „sejmowej choroby" 59 . W wersji francuskiej rzecz pojawia się ponownie. Jeden ustęp nosi tytuł: Le morbus comitialis $^{60}$. Podając cytowany wyżej zwrot laciński, stwierdza tenże historyk: ...il n'est pas douteux qu'un élément pathologique ait existé, en Pologne, dans le développement de l'organisation politique [...] Nous pouvons, croyons-nous, contribuer à établir le diagnostic du „,mal des diètes”. W jego rozumowaniu szło o instrukcje sejmikowe typu: „na nic nie pozwalać" i liberum veto ${ }^{61}$. Konopczyński zastanawia się też nad przyczynami niepowodzenia $w$ walce contre la maladie de la Diète ${ }^{62}$.

Jest rzeczą oczywistą: dla Konopczyńskiego morbus comitialis to choroba sejmu; przyjął więc on znaczenie całkiem odmienne od tego, w jakim używali tego wyrażenia Polacy $w$ dobie przedrozbiorowej. Wydaje się, że wspomniany uczony nie podejrzewal nawet sensu tego wyrażenia, właściwego zarówno łacinie klasycznej, jak i infima latinitas.

${ }^{34}$ Por. wyżej ustęp 1.

ss U W. Konopczyńskiego rozdział zatytułowany: Między majestatem $i$ wolnościq. Por. Dzieje, s. 167.

${ }^{56}$ B. Leśnodorski, Sejm polski „zlotego wieku”, Państwo i Prawo, t. XVI, 1961, s. 652

57 Wl. Konopczyński, Liberum veto. Studium porównawczo-historyczne, Kraków 1918, s. 242

st Tamże.

59 Tamże, s. 243.

${ }^{60}$ L. Konopczyński, Le liberum veto. Étude sur le développement du principe majoritaire, Paris 1930, s. 186.

${ }^{61}$ Tamże, s. 192-193: jest to odpowiednik wersji polskiej s. 243-244.

${ }^{62}$ WI. Konopczyński, Le liberum veto, s. 189. 
Stwierdziliśmy wyżej, że w dobie przedrozbiorowej bez wyjątku morbus comitialis znaczył padaczkę, epilepsję. Jak Konopczyński wpadł na to, żeby temu zwrotowi nadać tak inne, sprzeczne ze źródlami znaczenie? Poszukajmy tekstów, na których oparł się znakomity badacz. Podaje on ich dwa: diariusz sejmu lubelskiego z 1569 r. i dzieło Hartknocha z $1678 \mathrm{r}$. Oto, co podaje pierwsze źródło: Biskup płocki, Myszkowski, zabierał głos najpierw w sprawie unii, a potem, „O executia, nie wątpie że król Jego Mość się do tego przyłoży, jedno przychodźmy co rychlej do końca. Wszak to vulgare proverbium u cudzoziemców, iż: Poloni comitiali morbo laborant. Dosyć by pijanym ludziom sprawować tak, jako my dhugo sprawujemy, a nie obacznie. Jam Polak, mam bracie, których dolega egzekucja, a wolę, aby koniec byl. Zmiłujmy się sami nad sobą i nad koroną polską"63.

Zajmując się zrywaniem sejmów (comitia sine fructu dissolvuntur), pisze o tym zagadnieniu Hartknoch, co następuje: Non debet autem hoc nobis mirum videri, quod Comitia aliquando sine fructu dissolvuntur, cum hoc in tanta nuntiorum terrestrium multitudine, tantaque populi Poloni libertate evitari vix possit. Powołuje się dalej na surowa krytykę polskiego sejmu, wyrażoną przez Warszewickiego, której jednak nie chce przytaczać, i dodaje: Alii hic argutias quaesiverunt, satisque false turbas illas notarunt ${ }^{64}$. Sic Ioannes Franciscus Commendonus, Cardinalis et Pontificis Romani ad Ordines Poloniae post obitum Sigismundi Augusti legatus, acute dixisse fertur: Poloniam laborare morbo comitiali, teste Povodovio in Panegyrico ad Stephanum Regem et Senatum tempore comitiorum ipso die s. Stephani habito ${ }^{65}$. Autorstwo wypowiedzi przypisuje się więc nuncjuszowi Commendoniemu. On jest tu winien.

W przytoczonych dziełach Konopczyńskiego i Olszewskiego brak dalszych źródel, które by poświadczaly rozpowszechnienie tego powiedzenia. Ten negatywny wynik poczytamy za miarodajny. Przecież H. Olszewski powołałby takiego autora, który umacnia jego tezę. Ze swej strony nie zamierzaliśmy

${ }^{63}$ Dniewnik ljublinskawo sejma 1569 goda, S. Pieterburg 1869, wyd. W. Kojałowicz, s. 238.

${ }^{64}$ M. Christophorus Hartknoch, Respublica Polona duobus libris illustrata, Francofurti et Lipsiae 1678, s. 456. Według nieco zmienionej wersji wydania drugiego, brzmi ostatnie zdanie następująco: Alii hic argutias tolerabiliore instituto quaesiverunt (De Republica Polonica libri duo, Jenae 1687, s. 732). W wydaniu trzecim (Lipsiae 1698) odnośny passus znajduje się na stronach $687-688$.

${ }^{65} \mathrm{~W}$ wydaniu drugim następuje jeszcze taki passus: Alias iam argutias dictam ob rationem omitto. Praesertim autem ipsi cordatiores Poloni hoc improbant, quod sero ad consilia multi conveniant, s. 732 . 
robić kwerendy uzupełniającej. Zachęceni wszakże wypowiedzią Hartknocha ${ }^{66}$, zapoznaliśmy się z podanym przezeń dzielem Krzysztofa Warszewickiego De optimo statu libertatis libri duo, Cracoviae 1598. Autor ten niezwykle surowo ocenia nasz sejm: burzliwość i przeciagganie obrad, ich bezowocność, brak rozeznania, zmienność postanowień, prywatę, próżność posłów, ich obżarstwo i opilstwo, krzykliwość i klótliwość, przekupstwo i warcholstwo ${ }^{67}$. Wreszcie dodaje: Multa illi (Germani) quidem de Polonis dicunt et dixerunt, sed non probant aut probarunt peraeque universa, ut mos gentium nationumque est omnium, vicinos suos traduxisse. Quid enim? an et morbo comitiali laborare nos continuo non affirmant, obliti, quod eorum imperii comitia, multo maiorum quam nostra causa fuerunt tragoediarum? Cum Norimbergensia - rusticanum, Ratisponensia - bellum Smalcaldinum sit subsecutum, ut in tot exemplis pauca proferantur ${ }^{68}$.

Dysponujemy więc jedną wypowiedzią o morbus comitialis więcej.

Przyjrzyjmy się zestawionym wyżej wersjom. Jest ich w gruncie rzeczy dwie. Wedhug pierwszej powiedzenie: Poloni comitiali morbo laborant stanowi vulgare proverbium cudzoziemców (bp Myszkowski) lub tylko Niemców (Warszewicki). Według drugiej - złośliwy dowcip: Poloniam laborare morbo comitiali ukul nuncjusz papieski, Commendoni.

Charakterystyczne, że Hartknoch, znając oba poglądy, pomija pierwszy milczeniem. Dla niego widocznie autorstwo kardynała wydaje się prawdopodobniejsze. Oczywiście między tymi dwoma poglądami nie ma jakiejś zasadniczej sprzeczności, jeden nie wyklucza drugiego. Pierwszy siła rzeczy jest niemal nie do sprawdzenia. Gotowiśmy zresztą wierzyć zapewnieniom i Myszkowskiego, i Warszewickiego, że takie powiedzenie krążyło wśród cudzoziemców. Co do drugiego, dojście do źródła, które by stwierdzało zgryźliwą wypowiedź nuncjusza, nie jest latwe ${ }^{69}$. Bezpośrednim informatorem

${ }^{66}$ Wygląda ona następująco: In turbas et tumultus Comitiorum Regni generalium, et in ipsos nuncios terrestres, acerbius, quam civem decel, invenitur Christophorus Varsevicius in lib. I de Opt. Statu Libertatis, idque sub persona Ociessii, Regni Poloniae Cancelarii supremi, quem ibidem introducit loquentem. Sed ea hic recensere nolo, ne - licet sint aliena - recensendo tamen mea facere videar (loc. cit.).

${ }^{67}$ K. Warszewicki, De optimo statu libertatis, s. 46, 52, 88, 90, 91-94, 97-99; por. T. Wierzbowski, Krzysztof Warszewicki 1543-1603 i jego dziela. Monografia historyczno-literacka, Warszawa 1887 , s. 216.

${ }^{68}$ K. Warszewicki, op. cit., s. 96.

${ }^{69} \mathrm{Nie}$ zawiera co do tego żadnej wskazówki St. Kot, Rzeczpospolita Polska w literaturze politycznej Zachodu, Kraków 1919, s. 1-17. Zaznaczmy, że ostatni autor zna wspomnienia Grazianiego. 
Hartknocha jest Powodowski. Odnosimy wrażenie, że Hartknoch mial w ręku panegiryk Powodowskiego, na który się powołuje. Niestety i ta wiadomość jest nie do sprawdzenia. Jedyny drukowany i zachowany panegiryk tegoż autora napisany zostal na śmierć króla Stefana. Nie o ten tutaj chodzi. Zresztą nie zawiera on podobnej wzmianki ${ }^{70}$.

Powodowski miał słyszeć ową wypowiedź z ust Commendoniego. Znowu musimy wierzyć na słowo. Jest bowiem rzeczą oczywistą, że dyplomata tej klasy nie zostawił złośliwej wypowiedzi na piśmie. Przemawiając w 1573 r. w sejmie polskim użył on co prawda zwrotu: Haud levi morbo affectam Rempublicam esse et vos praedicare soletis, et res ipsa ostendit ${ }^{71}$. Wszakże idzie tam o sectarum varietas, o haereses ${ }^{72}$. I na tym dociekania nasze się kończą.

Wszystkie trzy wypowiedzi co do jednego są zgodne: zwrotem omawianym posługiwano się $w$ ostatnich dziesiątkach XVI w. Ani Konopczyński, ani - co ważniejsze - Olszewski nie stwierdzili, by to powiedzenie krążyło później. Nie zawierają go Adagia Polonica Knapskiego ${ }^{73}$. Nie wykazują też zbiory przysłów Adalberga, Kolberga czy Bystronia. Podkreśla się w nich tylko hałaśliwość posiedzeń sejmowych czy sejmikowych ${ }^{74}$, względnie nietrzeźwość posłów ${ }^{75}$. Podobnie charakteryzuje sejm polski Descriptio Status Poloniae sprzed $1707 \mathrm{r}^{76}$ Literatura publicystyczna XVII-XVIII w. jakby wspomnianego powiedzenia $w$ ogóle nie znała. Stwierdzamy to oczywiście $\mathrm{z}$ zastrzeżeniem: donec probetur contrarium.

${ }^{70}$ Na pogrzebie Stephana, Wielkiego Króla Polski etc. Kazanie X, w Krakowie 1588. Por. A. Bialecki, Powodowskiego kazanie na pogrzebie Stefana Batorego, Przegląd Homiletyczny', R. V, 1927, s. 118-124.

"Illustrissimi et reverendissimi domini D. Io. Francisci Commendoni, S.R.E. Cardinalis, Apostolicae Sedis per Germaniam et Poloniam de latere legati, Oratio ad Senatum equitesque Polonos in Castris habita, apud Varsaviam VIII Aprilis 1573; druk niepaginowany.

${ }^{72}$ Por. analogiczną wypowiedź w Pamiętniku: „co możniejsi obywatele, znaczniejsza część Senatu, dotknięci zarazą już jawnie na dobra kościelne rzucać się zaczęli" (op. cit., s. 47).

${ }^{73}$ Knapiusz, Thesaurus, t. III, Cracoviae 1632.

${ }^{74}$ „Ej, Polacy aby'ście wiedzieli Czarci Sejmu nie chcieli”. „Kłótnia [krzyk, hałas] jak na sejmie [sejmiku]" por. S. Adalberg, Ksiega przyslów, przypowieści $i$ wyrażeń przyslowiowych polskich, Warszawa 1889-1894: O. Kolberg, Przyslowia, [w:] Dziela wszystkie, t. LX, Warszawa 1967, s. 190. Ostatnie powiedzenie przytacza również J. Bystroń; tenże dodaje następne: ,jak mężatka bez czepka, tak sejmik bez zwady kuso pono wygląda; stare to przyklady" (Przyslowia polskie, Kraków 1933, s. 126).

75 ,Źle to w polskim świecie, gdy na sejmiku opój brydnie plecie" (O. Kolberg, op. cit., s. 332.$)$.

${ }^{76}$ St. Kot, Nationum proprietates, Extract from „Oxford Slavonic Papers”, vol. 7, s. 116: comitia-convitia (poprawilibyśmy tu najchętniej na convicia - wrzaski, głośne spory, kłótnie; podobna poprawka do tekstu Olszewskiego na s. 193). 
Czy posługujący się tą wypowiedzią ludzie z końca XVI w. uprzytamniali sobie sami klasyczne wyrażenia: morbus comitialis - epilepsja? Z zestawionych powyżej materiałów słownikowych, jak i przytoczonych tekstów szesnastowiecznych nie może to ulegać wątpliwości. Nie zawahamy się też co do stwierdzenia, że sens klasyczny zwrotu znal doskonale Commendoni. Taką łaciną operujący nuncjusz, jak tego dowodzi tekst powołanego wyżej przemówienia, nie mógł wprost nie widzieć tego, co znajduje się w każdym elementarnym słowniczku lacińskim. Nie mógł nie znać go też wyższy duchowny polski, biskup Myszkowski, z tej samej racji. Nie mógł nie rozumieć sensu wyrażenia i Powodowski; był to według współczesnych najuczeńszy mąż swego wieku, języki starożytne znał doskonale, po łacinie wygłaszał kazania przed królem ${ }^{77}$.

Trudno też twierdzić, że sens klasyczny zwrotu obcy był Warszewickiemu. Ucznia uniwersytetu bolońskiego, wieloletniego sekretarza biskupa poznańskiego, autora wielu traktatów lacińskich ${ }^{78}$, trudno wprost posądzać o nieznajomość właściwego sensu potocznego w jego czasach wyrażenia. Kontekst ten przemawia za tym, iż dobrze je rozumial.

Rozumiał zwrot właściwie i Hartknoch. Nie bez racji stwierdza on, że legat papieski wyraża się acute, że są to argutiae, a charakterystyka posiedzeń sejmowych dokonana została false. Tenże autor zestawia wspomnianą wypowiedź Commendoniego $\mathrm{z}$ ostrą naganą, jakiej nie szczędzi naszemu sejmowi Warszewicki, który acerbius, quam civem decet, invehitur. Tenże Hartknoch stwierdza (pod koniec XVII w.), że institutum (sejm) było tolerabilior aniżeli argutiae.

Posługując się wspomnianym zwrotem, wszyscy współcześni zdawali sobie sprawę, że mówią o epilepsji. A że kojarzono tę chorobę z sejmem, wynikało to $\mathrm{z}$ latwej gry słów. Morbus comitialis - to tyle co morbus comitiorum. Tu więc źródło asocjacji i złośliwości. Sugerował ją łaciński idiom! Tkwiącą w powiedzeniu dwuznaczność odczuwali dobrze współcześni. Dlatego to Warszewicki paruje cios stwierdzeniem, iż identyczny zarzut można stawić pod adresem Reichstagu (dodajmy od siebie: i każdego innego wspólczesnego posiedzenia stanowego); tym się tłumaczą również podane wyżej wypowiedzi Hartknocha o złośliwym dowcipie Commendoniego ${ }^{79}$.

${ }^{77}$ A. Glinka, Hieronim Powodowski teolog polemista XVI wieku, Nasza Przeszłość, t. XIII, 1961, s. 84.

${ }_{78}^{7}$ Por. Nowy Korbut, t. III, s. 376 nn.

${ }^{79}$ Drastyczność wypowiedzi Commendoniego powiększal fakt, że ostatnia żona Zygmunta Augusta, Katarzyna Austriaczka, cierpiała na wielką chorobę. Por. Pamiętnik Komendoniego, wyd. J. U. Niemcewicz, [w:] Zbiór pamiętników historycznych o dawnej Polsce, t. I, Lipsk 1838, s. 69, 75; Por. też R. Źelewski, PSB, t. XII, s. 214 n. 
Mówiąc o morbus comitialis, stwierdzono tym samym, że Polacy (Polska, sejm) chorują na epilepsję. Jakież zachowanie się na sejmie upoważniało do podobnej charakterystyki? Bolączką sejmu polskiego według poglądu biskupa Myszkowskiego było przedłużanie posiedzeń: „jako my długo sprawujemy, aby koniec był",80, „narzekał na długie Sejmy, iż się sami ubożymy, a co rychlej perswadowal, aby się koniec uczynil" "'. To samo wynika i z innych wypowiedzi: „aby było to prędko" (biskup krakowski - Padniewski) ${ }^{82}$; „,czemuż dalej nie przystępujecie do inszych rzeczy i długoż tego będzie” (biskup kujawski - Karnkowski) ${ }^{83}$. Tenże stwierdza dalej: „Moskiewski zwojuje Litwę, potem się będziemy uniować, kiedy nie będzie z kim"84. Wreszcie arcybiskup Uchański: „Zatem rozumiem temu, iż prędzej będzie po sejmie, niźli się ludzie nadziewają, acz nie mogę rzec, aby mogło być do Wielkiejnocy, alećby podobno było prędzej, będziemyż li o tym mówić"85. W końcu: „Potem wszyscy zwolili na pierwsze vota, jedno pan kanclerz mówił: acz na czas narzekamy, ale ja to jedno baczę, żeśmy go nie darmo trawili, a trawiliśmy go z pożytkiem Rzeczypospolitej"86.

Według Myszkowskiego, posłowie sprawują się jak pijani. Dla Warszewickiego znowu cechą charakterystyczną sejmów niemieckiego i polskiego jest ich bezsilność i niemożność hamowania $\mathrm{zła}^{87}$. Stąd to następstwem Reichstagu były i wojna chłopska, i wojna szmalkaldzka.

W żadnym wypadku nie idzie ani o liberum veto, ani o zrywanie sejmów. Ta treść zresztą mieścić się w przytoczonych wypowiedziach nie mogła. W 1569 r. czy w ogóle do końca XVI w. liberum veto nie było chorobą naszego parlamentu. To jeszcze okres, w którym nawet dobre strony działalności naszego sejmu wyraźnie brały górę ${ }^{88}$. Nawet i sejmiki zachowują się jeszcze wówczas przykładnie ${ }^{89}$. Sens, jaki przypisal zwrotowi

${ }^{80}$ Por. wyżej przyp. 63.

${ }^{81}$ Zrzódlopisma do dziejów unii Korony Polskiej $i W$. X. Litewskiego, cz. III: Diariusz lubelskiego sejmu unii. Rok 1569, Poznań 1856, s. 122.

${ }^{82}$ Dniewnik, s. 236.

83 Tamże, s. 237.

${ }^{84}$ Zrzódlopisma, s. 122.

${ }^{85}$ Tamże, s. 121.

${ }^{86}$ Dniewnik, s. 239 n.

${ }^{87}$ Rebus infectis comitia dissolvuntur, K. Warszewicki, op. cit., s. $97 \mathrm{nn}$. Charakterystyke Warszewickiego daje B. Leśnodorski, Polski Makiawel, [w:] Studia z dziejów kultury polskiej, Warszawa 1949 , s. $257-279$.

${ }^{88}$ Por. wyżej przyp. 38. Odnośnie Commendoniego zauważmy, że to on na wieść o zaprzysiężeniu przez Henryka Walezego praw i wolności różnowierców zawolał: „Nic nie znaczy prawo, gdy jednomysilnie od wszystkich ogłoszone nie było" (Pamiętnik, s. 161).

${ }^{89}$ J. Siemieński, op. cit., s. 151 , gdzie stwierdza się, że nie zdarzały się jeszcze wówczas na sejmikach krwawe burdy. 
H. Olszewski, jest niewątpliwie anachroniczny. Że krążyły kąśliwe wypowiedzi o naszym sejmie szesnastowiecznym, nie może nas zdumiewać: o każdej instytucji można zawsze coś złośliwego powiedzieć. Tym bardziej o zgromadzeniu stanowym. Tutaj wybieg polemiczny polskiego Makiawela wydaje się nam szczególnie zręczny.

Modernistyczny sens wypowiedzi Poloni morbo comitiali laborant przejął H. Olszewski od Konopczyńskiego. Ten zaś powtórzył go prawdopodobnie za Kojałowiczem, który thumacząc diariusz lubelskiego sejmu z 1569 r. na rosyjski, napisal dosłownie: Poljaki stradajut sejmowuju boljeznju .

Współcześni historycy w ogóle nie wyczuwają, jak się zdaje, dwuznaczności wypowiedzi. Biorą idiom laciński literalnie. I tylko tak. Co więcej, przypisują mu treść taką, której nie miał u ludzi XVI-XVII w. Jest to zatem co do sensu anachronizm. W ten sposób klasyczny zwrot: morbus comitialis (epilepsja) awansowal na oznacznik skrajnej wady polskiego parlamentaryzmu.

Charakterystyczne jednak, że Konopczyński, który lansuje to znaczenie w monografii, nie poshuguje się nim w swojej syntezie. Natomiast podnosi je do rangi szczególnej $\mathrm{H}$. Olszewski. U niego to jakby żywy zwrot, określający Polaków doby nowożytnej. Nie podał jednak żadnych przykładów, które by jedynie miały dla nas znaczenie decydujące.

Historycy nasi $-\mathrm{z}$ dawniejszych: Czacki' ${ }^{91}$, Balzer ${ }^{92}$, Konopczyński, z nowszych: Olszewski, Bardach i Seredyka ${ }^{93}$ - porównują nasz parlament $\mathrm{z}$ paralitykiem. Trudno równocześnie zestawić go $\mathrm{z}$ epileptykiem. Jeśli tego rodzaju porównania mają $w$ ogóle jakiś walor, trzeba się zdecydować na wybór jednego z nich. Paralityk to człowiek unieruchomiony, bezwładny ${ }^{94}$. Epilepsja nazywała się po lacinie morbus herculeus, a po staropolsku chorobą rzucająca. Objawy tych dolegliwości są - przynajmniej w oczach laika - całkiem inne.

Zgryźliwe powiedzenie nuncjusza papieskiego: „Polska choruje na epilepsję", wykorzystujące grę słów nie rozumianą przez Kojałowicza, przejęte w tym niewłaściwym znaczeniu przez W1. Konopczyńskiego, awansowało u H. Olszewskiego do jakiejś podstawowej charakterystyki polskiego parlamentu. Nie znając właściwego sensu wyrażenia, $H$. Olszewski propaguje je w streszczeniach obcojęzycznych, przyczyniając się jeszcze bardziej do

\footnotetext{
${ }^{90}$ Dniewnik, s. 238.

91 Opinię Czackiego podajemy za Konopczyńskim, Liberum veto, s. 272 n.

${ }^{92}$ Por. wyżej przyp. 22.

${ }^{93}$ J. Bardach, op. cit., s. 365; J. Seredyka, KH, LXXIV, 1967, z. 4, s. 1144.

${ }^{94} \mathrm{O}$ bezwładności, paraliżu sejmu pisze ostatnio J. Bardach, loc. cit.
} 
osławienia i tak już osławionego polskiego sejmu. A przecież zlośliwości kardynalskiej nie należało powtarzać bezkrytycznie! ${ }^{95}$

Co gorsze, ta zgryźliwa wypowiedź o Polakach zyskuje sobie prawo obywatelstwa wśród nieświadomych jej dwuznaczności historyków. Oto, co pisze ostatnio jeden $\mathrm{z}$ recenzentów dzieła Olszewskiego: „Jest to bowiem okres, kiedy wyksztalcone w pełni instytucje szlacheckiego parlamentaryzmu zaczęły zdradzać objawy owej morbus comitialis (choroby sejmowej), która była symptomem kryzysu całego ustroju",\%.

$\mathrm{Na}$ powyższych uwagach moglibyśmy zamknąć naszą marginalną wypowiedź o dziele H. Olszewskiego. Zapoznajmy się wszakże jeszcze ze streszczeniami obcojęzycznymi. Uwagi swoje ograniczymy zresztą tylko do tekstu francuskiego.

Robi on wrażenie najfatalniejsze. Dla $\mathrm{H}$. Olszewskiego byłoby lepiej, gdyby się to thumaczenie nie ukazalo. Ono go kompromituje. Co więcej, nie tylko jego samego! Oto, co wyczyta czytelnik frankofon, który nie zna ni w ząb języka polskiego, któremu oryginalne dzielo jest w ogóle niedostępne, który więc, siłą rzeczy, wyrobi sobie opinię o wartości dziela tylko na podstawie tego właśnie streszczenia.

Przede wszystkim stwierdzi, że tłumacz nie bardzo włada językiem francuskim (l'oeuvre jest rzeczownikiem rodzaju żeńskiego, w streszczeniu zaś: un grand oeuvre; cadence u Francuza bynajmniej nie oznacza kadencji). Co więcej, skonstatuje bardzo slabą znajomość laciny, ale już nie u thumacza, lecz u autora, który nie zdecydował się, czy morbus czy morbum. Przekona się, że H. Olszewski nie zna lacińskiej fleksji (regis soli), że obce mu są też podstawowe zasady lacińskiej syntaksy (morbus comitiale, dominus iuris suae). A już szczytem wszystkiego literalne thumaczenie lacińskiego idiomu i uczynienie $\mathrm{z}$ fałszywego, doslownego thumaczenia leitmotivu calego dziela (przy tym ze streszczenia - jak zresztą, dodajmy, i z oryginału - nie widać, że autor kontynuuje bląd dawniejszych historyków). A co ten czytelnik francuski pomyśli sobie o polskim historyku, który stwierdza, że na 70 sejmów zerwano „tylko" 37. Czegóż ci Polacy jeszcze chcą? A taki jest dla Francuza sens zdania: ...en résultat de cette pratique ce n'est que 37 qui furent rompus sur le nombre général de 73 des diètes ouvertes en période de 1652 à 1763 (s. 460), sprzeczny zresztą wyraźnie z poprawną wypowiedzią autora drukowaną jednocześnie $w$ tekście polskim. Do tego wszystkiego ta propaganda epilepsji, jako choroby, na którą Polacy chorują! Jeśli więc

${ }^{95} \mathrm{O}$ analogicznym zarzucie por. H. Olszewski, op. cit., s. 148, przyp. 113.

96 J. Bardach, loc. cit. 
résumé ma dawać caractère orientable (s. 456) dzieła H. Olszewskiego, to robi to w sposób najniefortunniejszy. Ono wychodzi jeszcze gorzej niż jest w rzeczywistości.

Pojawił się niedawno krytyczny glos cudzoziemca o streszczeniach obcojęzycznych dodawanych do prac polskich ${ }^{97}$. Trudno uwag jego nie uznać za słuszne. Ale trzeba $z$ podanych tam obserwacji wysnuć wniosek, raz na zawsze: albo dobre streszczenie, albo wcale. Szkoda będzie na pewno mniejsza, jeśli w braku właściwego thumacza rzecz się ukaże bez streszczenia. Niewątpliwie, wydawca opatrując pracę $H$. Olszewskiego podobnym resumé wyrządzil mu dużą krzywdę. A na to autor z pewnością nie zashugiwal.

${ }^{97}$ R. F. Leslie, Acta Poloniae Historica, KH, LXXIV, 1967, z. 1, s. 135-136. 


\title{
Pieniądz ważony*
}

\author{
Nous sommes ainsi faits que rien ne nous entraîne plus \\ loin, ni plus haut que les bonds de nos erreurs. \\ M. Maeterlinck, La vie des abeilles, VII, 7.
}

Należność reguluje się kruszcem w dwojaki sposób: można metal ważyć lub liczyć wybitymi z niego krążkami - monetami. Te dwa rozwiązania wynikają niejako $z$ natury rzeczy, można by więc nie zajmować się nimi z powodu ich oczywistości. Jednak problem „ważenia" i ,liczenia" wzbudził zainteresowanie historyków. Zwrócili oni mianowicie uwagę na to, że wspomnianych dwu sposobów zapłaty używano - przynajmniej w XIII w. - w różnych sytuacjach: moneta-pieniądzem „liczonym" regulowano należności mniejsze; kruszcem-pieniądzem „ważonym" płacono sumy większe ${ }^{1}$. Być może, to samo zagadnienie traci na aktualności dla wcześniejszego średniowiecza. W literaturze podkreślano duże trudności wydzielania $w$ tym okresie $^{2}$ sfery ,na wage" i „na sztuki”.

Posługiwanie się pieniądzem ważonym było następstwem ograniczonej wydajności ówczesnych mennic. Nie były one w stanie wyprodukować takiej ilości monet bitych, która byla potrzebna dla wielkich operacji pieniężnych. Niełatwo też było mało wartościowymi monetkami "wyliczać" większe

* Przedruk z: Liber Iosepho Kostrzewski octogenario a veneratoribus dicatus, Wroclaw 1968 , s. $526-532$.

' A. Malecki, Grzywny karne w dawnej Polsce $i$ najdawniejsza nasza grzywna mennicza, Biblioteka Warszawska, R. 53, t. 220, 1893, s. 173, przyp. 1; M. Gumowski, O grzywnie i monecie piastowskiej, RA WHF, t. 51, 1908, s. 281; R. Grodecki, Przymus używania bieżqcej monety krajowej w Polsce Piastowskiej, WNA, t. 10, 1923, s. 9-10, 14; tenże, Przyczynek do dziejów pieniqdza w Polsce XIII w., WNA, t. 19, 1937, s. 25; R. Kiersnowski, Glówne momenty rozwoju środków wymiany na Pomorzu wczesnofeudalnym, Wiad. Archeol., t. 23; 1956, s. 242; tenże, Pieniqdz kruszcowy w Polsce średniowiecznej, Warszawa 1960, s. 393, 423. Ostatni autor nazywa pierwszą wymianę obrotem drobnicowym, Pieniqdz, s. 436, 467.

${ }^{2}$ R. Kiersnowski, Pieniq̨dz, s. 363. Względność podanego rozróżnienia wynika też z dalszych obserwacji: podział grzywny na wiardunki, szkojce i denary dotyczy jej ciężaru; ibid., s. 319; mówi się też w źródłach o denarowej ilości złota (denariatas auri), które należy ważyć (s. 317), jak i o sprzedawaniu soli za denary (sal, quod per denariatas venditur), ibid, przyp. 2. 
kwoty ze względów czysto technicznych ${ }^{3}$. Wskażmy wreszcie na tak charakterystyczne dla średniowiecza, a przy tym trwałe rozróżnienie monety liczalnej ${ }^{3 \mathrm{a}}$ i monety rzeczywistej.

Tych rozumowych przesłanek używano dla tezy o posługiwaniu się w średniowieczu pieniądzem „ważonym”. Słuszność jej potwierdzają inne argumenty. Płacąc kruszcem, uciekać się musiano z konieczności do wag. Używanie ich poświadczają zabytki ikonograficzne. Co więcej, konkretne egzemplarze wag i odważników znaleziono we wczesnośredniowiecznych skarbach. Zachowały się też one ze stuleci późniejszych ${ }^{4}$.

W tej sytuacji wolno byłoby przejść nad sprawą do porządku dziennego. Pogląd wydaje się mocno uzasadniony. Wszakże historyk zdaje sobie sprawę z zawodności rozumowań choćby najpoprawniejszych, zna też trudności interpretacji źródeł materialnych, „niemych"s. Nic więc dziwnego, że pragnie dowieść swej tezy o posługiwaniu się pieniądzem „ważonym" na podstawie źródeł pisanych. One dopiero będą dla niego stanowić dowód $w$ pelnym tego słowa znaczeniu. Takiego też dowodu źródeł "mówiących" chciał dostarczyć nauce historyk par excellence - R. Grodecki.

3 R. Kiersnowski, Wstẹp do numizmatyki polskiej wieków średnich, Warszawa 1964, s. 184-185.

3. W terminologii francuskiej przeciwstawia się monnaie réelle określeniu monnaie de compte. O kwocie „liczalnej" pisał kiedyś A. Malecki, Grzywny karne, s. 175.

4 J. Żurek, Wczesnodziejowe systemy odważania na ziemiach polskich w świetle materialu wykopaliskowego $i$ dokumentów, WA, t. 16, 1939 (reedycja 1948), s. 387, i tamże tabl. 72; M. Gumowski, $O$ grzywnie, s. 324; tenże, Najstarsze systemy wag w Polsce, Studia Wczesnośredniowieczne, t. 2, Warszawa-Wroclaw 1953, s. 35; S. Suchodolski, Grzywna i stopa mennicza w Polsce w XI-XII w., Wiad. Numizm., t. 4: 1960, s. 17; R. Kiersnowski, Pieniqdz, s. 362, 365, 383, przyp. 55, 372 i ibid., przyp. 26 (wątpliwości co do przykładu powołanego w przyp. 45 do s. 379), s. 366 , przyp. 11. Nie powohujemy się tu na znajdowane często w skarbach siekańce, A. Gupieniec, Skarb monet wczesnośredniowiecznych z Laska, Prace i Materiały Muzeum Archeologicznego i Etnograficznego w Lodzi, nr 1, Lódź 1956, s. 141-142; T. R. Kiersnowscy, Wczesnośredniowieczne skarby srebrne z Pomorza. Materialy, Polskie Badania Archeologiczne, t. 4, Warszawa-Wroclaw 1959 (zestawienie alfabetyczne miejscowości); J. Slaski, S. Tabaczyński, Wczesnośredniowieczne skarby srebrne Wielkopolski: tamże, t. 1; H. Różańska, Wczesnośredniowieczny skarb srebrny z miejscowości Trójca, pow. Opatów, Materiały Wczesnośredniowieczne, t. 5, Warszawa 1960, s. 275; Inventaria Archaeologica, fasc. 1, pl. 10; par A. Abramowicz, A. Gupieniec, M. Młynarska, Lódź 1958, nr 7-13 (por. też V. Hatz, Hamburger Beiträge zur Numismatik, N. F. Hamburg, t. 4, 1959, s. 347); T. R. Kiersnowscy, Dalsza część skarbu ze wsi Stójkowo, pow. Kolobrzeg, Wiad. Arch., t. 25, 1958, s. 234. Można by mniemać, że je również ważono, podobnie jak sztabki, placki czy łomy kruszcu - tak sądził H. Lowmiański, Podstawy gospodarcze, s. 219; takiego zdania jest też A. Gupieniec, który opisuje skarb z Rudy, zawierający $7 \mathrm{~kg}$ siekańców, zawartych w glinianym naczyniu - Przewodnik po dziale numizmatycznym Muzeum Archeologicznego w Lodzi, 1, Lódź 1954, s. 70. Tymczasem R. Kiersnowski, Glówne momenty, s. 237-238, wyraża pogląd, że siekańce liczono $\mathrm{w}$ handlu drobnicowym w braku denarów, więc były to bezpośrednie jednostki wymiany.

s Por. H. Lowmiański, Kwart. Hist., t. 68: 1961, s. 496. Niebezpieczeństwo szczególne przedstawiaja wnioskj wysnute $z$ obserwacji negatywnych; tenże, Podstawy gospodarcze formowania 
Przekazów pisemnych zachowało się niewiele ${ }^{6}$, przy tym nie podają bezpośrednio wiadomości nas interesującej. Temu zaradzić miała inwencja badacza. R. Grodecki znalazł, jak mu się zdawało, przekaz pośredni w znanych średniowieczu ekscepcjach non numeratae pecuniae. Ta jego argumentacja uchodzić musi za chybioną. Przeciwko niej wystąpiliśmy już przed laty trzydziestu. Ponieważ wspomniana ekscepcja jest formułką zaczerpniętą niewątpliwie $\mathrm{z}$ rzymskiego systemu prawnego, na jej podstawie - rozumowaliśmy - nie wolno wysnuwać wniosków o stosunkach pieniężnych, panujących w Polsce trzynastowiecznej ${ }^{7}$. Protest nasz zostal nie dostrzeżony lub zlekceważony. R. Grodecki wrócił później do swego „,dowodu" gorsza, mimo przypomnienia naszego stanowiska po wojnie ${ }^{9}$, przejąl go w swej pięknej syntezie R. Kiersnowski ${ }^{10}$.

Nie chcielibyśmy tu powtarzać dawnej argumentacji. Być może wymaga ona szerszego rozwinięcia. Nie tutaj na nie miejsce. Jednak swoje stanowisko podtrzymujemy w dalszym ciągu, odmawiając rozumowaniu R. Grodeckiego jakiejkolwiek mocy dowodowej.

Zdajemy sobie dobrze sprawę $\mathrm{z}$ tego, że odrzucenie argumentu R. Grodeckiego nie świadczy jeszcze o tym, by sama jego teza o rzeczywistym posługiwaniu się w średniowieczu pieniądzem „ważonym” była nieprawdziwa. Ileż to faktów zajść musiało w minionych czasach, których nie uwiecznil żaden zapis. Niewątpliwie nie istnieją one dla historyka, ale badacz nie będzie twierdził, że ich w ogóle nie było. $Z$ braku zapisu, informującego o ważeniu pieniędzy, nie należy bynajmniej wysnuwać wniosku, że kruszcu rzeczywiście przy transakcjach nie ważono. Sami zresztą jesteśmy przekonani o trafności hipotezy Grodeckiego, zważywszy na argumenty zestawione wyżej. Ale czy w polskich tekstach średniowiecznych nie ma rzeczywiście bezpośredniej wzmianki o „ważeniu" pieniędzy"? Zapoznajmy się z ciekawym

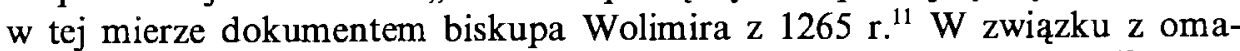
wianą kwestią zwrócono już nań uwagę dawniej (M. Gumowski) ${ }^{12}$. Jego głosu widocznie Grodecki również nie dostrzegl. Przyjrzyjmy się więc temu aktowi bliżej.

sie państw slowiańskich, Warszawa 1955, s. 218-219. M. Gumowski, O grzywnie, s. 279, widział sprzeczność między wykopaliskami a zapisami kronikarskimi i treścią dyplomów.

${ }^{6}$ Tak dla wczesnego średniowiecza R. Kiersnowski, Pieniq̨dz, s. 365, 426, 449.

7 J. Matuszewski, Immunitet ekonomiczny $w$ dobrach Kościola w Polsce do roku 1381, Poznań 1936, s. 157, przyp. 6, s. 156; por. też przeciwstawienie pecunia pensata i pecunia numerata, DWPK, t. 1, nr 254; R. Hube, Pisma, t. 2, s. 435, 437.

${ }^{8}$ R. Grodecki, Przyczynek, s. 26.

${ }^{9}$ J. Matuszewski, Motywacja ignorancyjna $w$ dokumentach prawa niemieckiego, [w:] Studia Historica w 35-lecie pracy naukowej Henryka Lowmiańskiego, Warszawa 1958, s. 178, przyp. 39.

${ }^{10}$ R. Kiersnowski, Wstep, s. 184-185.

$"$ Dokumenty kujawskie i mazowieckie przeważnie z XIII w., AKH, t. 4, wyd. B. Ulanowski, Kraków 1887, s. 204, nr 33.

${ }^{12}$ M. Gumowski, $O$ grzywnie, s. 344. 
Wystawca aktu stwierdza, że niejaki rycerz Marcin z Baranowa sprzedal swą wieś Sbleriz scholastykowi włoclawskiemu, mistrzowi W., za 29 grzywien argenti usualis in pondere Cuiaviensi ${ }^{13}$ et pellibus vulpinis. Ow miles zeznal przed oltarzem w obecności biskupa i kapituly kruszwickiej: se undecim marcas de parata pecunia recepisse, residuum - videlicet decem et octo marcas - L., archidiaconus noster Crusviciensis, in Crumena nobis presentavit. Quam manibus nostris, coram omnibus predictis, eidem militi exhibuimus et pensari iussimus in instanti. Predictus vero miles in recompensacionem supradicte pecunie accepte promisit...

$\mathrm{Z}$ dyplomu wynika wyraźnie, że należną kwotę zaplacono w części gotówką, częścią - jak się domyślamy - w kruszcu, który został zważony (pensari iussimus); tak trafnie wyłożył rzecz M. Gumowski. Stwierdzając to, nie analizowaliśmy jeszcze naszego dokumentu w całości. Mianowicie nie jest dla nas całkiem jasny zwrot: residuum - videlicet decem et octo marcas - L., archidiaconus noster Crusviciensis, in Crumena nobis presentavit.

Wedhug indeksu dołączonego do wydawnictwa, Crumena jest lacińską nazwą wsi Kromnów, leżącej w województwie mazowieckim, w powiecie sochaczewskim. Biskup zatem wraz z całą kapitułą musiałby się udać do tego Kromnowa, by tam asystować przy umowie między wspomnianymi: rycerzem Marcinem a scholastykiem włocławskim. Wydaje to się zastanawiające, pomijając już fakt, że nie widzimy żadnej przyczyny, dla której transakcja podwłocławską wsią, jak sądzić wolno, miałaby się odbywać w dalekim Kromnowie. Sprawa staje się tym kłopotliwsza, że w tej wskazanej przez wydawcę (Ulanowskiego) osadzie, według informacji Slownika geograficznego, nie było kościoła. Wieś należała do parafii w Brochowie. Akt sprzedaży majątku nie mógł się zatem odbywać przed kromnowskim oltarzem!

Tych wszystkich trudności unikamy, uciekając się do innej lekcji źródła. Naprowadza nas na nią składnia. Przy interpretacji Ulanowskiego - Crumena - Kromnów - zaimek względny quam zacytowanego wyżej tekstu trzeba odnieść, jak się wydaje, do bardzo oddalonej parata pecunia, podczas gdy logicznie wiąże się on nie $\mathrm{z}$ tą gotówką, lecz właśnie $\mathrm{z}$ pozycją następną, owym residuum, z którym znowu nie zgadza się ów pronomen gramatycznie. Rozwiązanie proponujemy proste: Crumena poczytamy nie jako nomen proprium, lecz jako appellativum, crumena. Taki rzeczownik zna łacina klasyczna. Forcellini daje wyjaśnienie następujące: ...est sacculus e bracchio aut collo dependens, vel ante pectus, vel in tergum: in quo pecunia reponitur; saccocia, borsa. Gaffiot thumaczy ten rzeczownik przez: bourse, argent ${ }^{14}$, a Haas przez: Geldbeutel,

${ }^{13}$ W odróżnieniu od ogólnopolskiej grzywna kujawska zawierała tylko 36 groszy (ogólnopolska $48 \mathrm{gr}$ ), a waga wynosila tylko $150 \mathrm{~g}$ (ogólnopolska $200 \mathrm{~g}$ ), M. Gumowski, $O$ grzywnie, s. 306, 309, 344; R. Grodecki, O tzw. grzywnie kujawsko-mazowieckiej, odb. z WNA, t. 16, 1934, s. 58; zob. też B. Suchodolski, Grzywna i stopa mennicza w Polsce w XI-XII w., Wiad. Numizm., t. 4, 1960, s. 17.

14 F. Gaffiot, Dictionnaire illustré latin-français, Paris 1934. 
übertr. Kasse, Geld ${ }^{15}$. To samo znaczenie Geldbeutel, Börse podaje Mittellateinisches Glossar $^{16}$. Co ważniejsze, zna go i polska lacina średniowieczna. W materiałach prof. Plezi znaleźliśmy na to przykłady z XV i XVI w. ${ }^{17}$ Byłby to zatem odpowiednik Gallowego saccus $^{18}$, jak i tobolize z Najstarszego zwodu prawa polskiego ${ }^{19}$.

Po tej korekcie, która wydaje się istotna dla właściwego, pełnego rozumienia tekstu, dajemy thumaczenie następujące: Biskup Wolimir stwierdza fakt złożenia oświadczenia przez Marcina z Baranowa. Rycerz ów zeznal, iż ,...otrzymał 11 grzywien w gotówce; resztę - mianowicie 18 grzywien - przedłożył nam (biskupowi) archidiakon nasz kruszwicki w sakiewce; tę (sakiewkę) w obecności wszystkich wspomnianych (osób) własnymi rękoma wręczyliśmy temu rycerzowi i kazaliśmy natychmiast zważyć. Wspomniany zaś rycerz w zamian za wspomniane otrzymane pieniądze obiecał..."

A zatem należną za wieś sumę 29 grzywien wypłacono sprzedawcy częściowo gotówką (parata pecunia ${ }^{20}$ ) - monetą bitą i skórkami lisimi ${ }^{21}$ (nie znamy stosunku tych dwu środków płatniczych do siebie), częściowo kruszcem, przechowywanym w sakiewce, którą odważono przed wręczeniem jej sprzedawcy ${ }^{22}$.

${ }^{15}$ H. Haas, R. v. Kienle, Lateinisch-deutsches Wörterbuch, Heidelberg 1952.

${ }^{16}$ E. Habel, Mittellateinisches Glossar, 2. Aulf., Paderborn 1959.

${ }^{17}$ Statuty Kazimierzowskie używają rzeczownika pera, art. 74 i 105, Polskie statuty ziemskie $\mathrm{w}$ redakcji najstarszych druków (syntagmata) wyd. L. Lysiak i S. Roman, Wrocław-Kraków 1958. Korektura Taszyckiego, trawestując odnośne miejsce statutów, wprowadza termin crumena, SPPP, t. 3, s. 190 , § 769.

${ }^{18}$ Tunc rex Largus de collo pallium extraxit, illudque clerico pauperi pro sacco pecunie porrexit, Anonima tzw. Galla Kronika, wyd. K. Maleczyński, Kraków 1952, s. 52, w. 7; cytuje R. Grodecki, Poczqtki, s. 25.

19 "Syne tobolize adir syne butel”, Najstarszy zwód prawa polskiego, wyd. J. Matuszewski, Warszawa 1959, art. 12, ust. 8 i 10.

${ }^{20}$ Parata pecunia wedlug Forcelliniego preparata, pronta, alla mano, paratus nummus argenti. W polskiej lacinie średniowiecznej klasycznego przykładu dostarczają statuty Kazimierzowskie w artykułach, w których przeciwstawia się grze na kredyt grę za gotówkę: „ut deinceps nullus terrigena noster [...] non ludat taxillos ad prestanciam, sed tantummodo pecunia pro parata", Król., art. 72; "quod ludus taxillorum pro parata pecunia exerceatur et non ludant ad prestandum", ibid., art. 140; por. tu R. Hube, II, s. 196; T. Satumik, O pravu soukromem u Slovanü, s. 202; Z. Kaczmarczyk, Monarchia Kazimierza Wielkiego, t. 1, Poznań 1939, s. 94; tak też R. Grodecki, Mincerze w wcześniejszym średniowieczu polskim, RA WHW, t. 63, 1921, s. 19. Czymś innym jest pieniądz obiegowy; według R. Grodeckiego na to pojęcie używano określeń: pecunia numerata, numerata quantitas, moneta currens, Poczqtki, s. 28, argentum manuale, Mincerze, s. 31, Jak się wydaje, trudno te wszystkie terminy uznać za synonimy. Dodamy ze swej strony moneta usualis, przeciwstawioną moneta falsa, KDW, t. 1, nr 608.

${ }^{21}$ Nieshuszne zatem zdanie A. Maleckiego, jakoby nigdy nie mówiło się o gatunkach zwierząt, których skórkami płacono (Grzywny, s. 156); por. też odnośne artykuły statutów Kazimierza W.

${ }^{22}$ Zanotujemy u Du Cange'a: „crumenia sunt proprie fragmenta auri”. 
Przy takiej wykładni zrywamy z pomyslem dokonywania aktu prawnego przed oltarzem nie istniejącego kościoła w Kromnowie. Równocześnie dostarczamy pisanego, dokumentowego dowodu, którego tak pożądal R. Grodecki, na fakt posługiwania się w średniowiecznej Polsce pieniądzem ważonym. Przytoczony przez zasłużonego badacza argument pośredni, opierający się na swoistym rozumieniu ekscepcji non numeratae pecuniae, polega $w$ istocie na nieporozumieniu. Tymczasem tekst przytoczony daje nam bezpośrednie oparcie dla trafnej tezy: większe wynoszące kilkadziesiąt grzywien sumy uiszczano $w$ drugiej połowie XIII w. monetą ważoną ${ }^{23}$ (w naszym wypadku niemal w wysokości $2 / 3$ ceny sprzedażnej). Tak przynajmniej dzieje się w stosunkach ziemskich.

Podtrzymujemy zatem tezę R. Grodeckiego o posługiwaniu się w XIII w. pieniądzem ważonym i uznajemy ją za w pełni dowiedzioną. Wystąpić musimy wszakże stanowczo przeciwko wnioskom tego uczonego co do stosunków prawnych $w$ ogólności, co do urządzenia regale menniczego w szczególności. Nie da się utrzymać jego zdanie, że używanie czystego srebra zarówno $w$ stosunkach $\mathrm{z}$ państwem, jak i w transakcjach prywatnych bylo prawnie niedopuszczalne ${ }^{24}$. Nie do utrzymania jest również pogląd, jakoby zapłata pieniądzem ważonym dawała podstawę do zerwania wykonanej już umowy ${ }^{25}$. Tezy te wysnul znakomity historyk również $z$ tej samej ekscepcji non numeratae pecuniae. Niefortunne zrozumienie klauzuli - pecunia non numerata to pieniądz ,nie liczony”, a zatem „ważony” - doprowadziło R. Grodeckiego do takiej interpretacji źródeł i do takich wniosków, które po odrzuceniu błędnej podstawy wnioskowania zawisają w próżni.

Co gorsza, wszystkie jego konkluzje przejął bez zastrzeżeń R. Kiersnow$\mathrm{ski}^{26}$. Zostały one uwiecznione $w$ opracowaniu syntetycznym. Tym bardziej zasługują na zdecydowaną refutację. Być może, uda nam się wrócić do tych zagadnień na innym miejscu.

${ }^{23}$ Przykłady literackie na ważenie zestawia M. Gumowski, $O$ grzywnie, s. 281-282, 284.

${ }^{24}$ R. Grodecki, Przymus, s. 5-6, 9-10; tenże, Przyczynek, s. 26. Autor zresztą zdanie to później ścieniował; Przyczynek, s. 25-26. Ale i w tym wypadku interpretacja tekstu, na którym się oparł, nie wydaje się bezsporna.

${ }^{25}$ R. Grodecki, Przymus, s. 13-14, 21.

${ }^{26}$ R. Kiersnowski, Wstepp, s. 184-185; J. Bardach natomiast pisze o nieskuteczności zakazu postugiwania się srebrem, przy czym poczytuje używanie kruszcu za wyraz monetarnej anarchii (Historia państwa i prawa Polski, t. 1, wyd. 2, Warszawa 1964, s. 266). 


\section{Kto to był serbin?*}

Zajmując się poddanymi ekscypowanymi, stawiliśmy domysł, że serbin, występujący w akcie z 1631 r., ,byłby muzykiem, wyspecjalizowanym w grze na serbach, tak jak cymbalista - w grze na cymbałach. Tym bardziej to prawdopodobne, że i cymbalista, i serbin występują równocześnie; stanowiliby więc obaj niejako wiejska kapelę"1. Przypuszczenie to szło po myśli naszego zapotrzebowania; twierdziliśmy bowiem w powołanym artykule, że ekscypowani poddani byli nie chłopami-rolnikami, lecz ludźmi wykonującymi funkcje nierolnicze, takie, których wykonanie w bardziej rozwiniętych stosunkach prawnych zapewnia umowa najmu usług, locatio-conductio operarum. - To przypuszczenie zamienia się obecnie w pewnik.

Przyznajemy, że występując ze wspomnianym przypuszczeniem, nie zauważyliśsmy wcześniejszego wytłumaczenia rzeczownika serbin. Mianowicie wydawca Liber chamorum, natknąwszy się na to slowo, podal następujące wyjaśnienie: „W milicjach pańskich tego okresu bywały oddziały tzw. Serbów. Był to przeważnie żywioł polski, głównie spośród ludzi luźnych"2. Tym samym więc utożsamia prof. Dworzaczek serbinów z Serbami, przy czym przypisuje im jakieś wojackie funkcje, skoro każe im służyć w milicjach pańskich. A zatem nasz domysı o serbinie-grajku byłby nietrafny; albowiem, kto by tworzył oddziały wojskowe $z$ samych grajków, muzykujących na instrumencie smyczkowym. Wyjaśnienie prof. Dworzaczka skłoniło nas do ponownego rozpatrzenia kwestii.

Terminu serbin nie zna żaden $\mathrm{z}$ dawniejszych słowników języka polskiego. Nie zawiera go ani Mączyński, ani Cnapius, ani Linde, ani Slownik jezzyka polskiego Orgelbranda (1861), ani też Slownik warszawski ${ }^{3}$; obcy on także Slownikowi gwar polskich Karlowicza (1907). Jedynie SEJP Brücknera podaje, co następuje: „Serbin (Sarbin) - osobnik ze szczepu Serbów. Od

* Przedruk z: Rozprawy Komisji Językowej Lódzkiego Towarzystwa Naukowego 1968, t. 14 , s. $123-124$.

1 Por. wyżej s. 292, przyp. 25.

2 Liber generationis plebeanorum (Liber chamorum), cz. 2, Wroclaw-Warszawa-Kraków 1963 , s. 18 , poz. 6 , przyp. 1.

${ }^{3}$ W SW pojawiają się serbowie (nie serbinowie!) jako muzykanci grający na serbach; przykład wszakże zaczerpnięto z pism J. I. Kraszewskiego. 
Serbów bałkańskich przychodzili do nas w 16. i 17. w. gęślarze z gęślami, Serbowie z serbami, i przygrywali, w końcu tylko chłopom"4. W myśl tego wyjaśnienia byliby to - zgodnie z naszym domysłem - znowu nie wojacy, lecz grajkowie.

Określnik serbin wiążemy $\mathrm{z}$ instrumentem smyczkowym, zwanym serbami. Robi to również W. Dworzaczek ${ }^{5}$. Ten charakter instrumentu potwierdza Linde, dowodzą go też wypowiedzi autora Liber chamorum: niejaki Jedliński, który „na serbach grawa””, potem „,przystał beł za skrzypka” (nr 739); inny znów, Rębicki, „skrzypkiem beł na serbach” (nr 1663). Niewątpliwie więc skrzypki $\mathrm{i}$ serby to jakieś bratnie instrumenty.

Wspomniany instrument występuje wraz $\mathrm{z}$ cymbałem: niejaki Jeżowski „na serbach grawał", a jego brata, Jana, „dał bel wyuczyć na cymbale Wolski" (nr 754). Według tego świadectwa, byłyby to zatem jakieś komplementarne instrumenty, tworzące wiejską kapelę. Ta obserwacja wzmacnia w pewnym stopniu stawiony przez nas domysł.

W tymże samym Liber chamorum pojawia sie rzeczownik serbin: Albiszowski „starszy za serbina u ślachty służał. Służeł ab anno 1632 u sługi Dominika książęcia też za serbina, lat miał 34" (nr 6); Szymowski ,służel w krakoski ziemi u p. Krasowskiego Piotra za serbina" (nr 2096). Jest to więc ktoś ze szlacheckiej służby, a nie - jak twierdzi wydawca Liber chamorum - wojak $\mathrm{z}$ pańskich pocztów.

Następny cytat, zaczerpnięty $z$ tegoż samego wydawnictwa, dowiedzie, że wiązanie serbina-grajka $\mathrm{z}$ serbami-instrumentem nie może ulegać wątpliwości: niejakiego Lipnickiego „dał beł p. Jarosz Gomoliński uczyć na serbach [...] Kilkanaście lat beł u niego za serbina" (nr 1127). Zatem serbin jest muzykiem, grającym na serbach. Nasz domysı okazuje się pewnikiem.

Nie chcemy przesądzać tego, skąd się wziął w Polsce instrument zwany serbami; nie zajmujemy się też zagadnieniem, czy rzeczywiście serbowie służyli w milicjach pańskich. W przykładach, którymi operujemy, serbinami są wyłącznie chłopcy miejscowi. Trepka nie potwierdza tezy, jakoby w pierwszej połowie XVII w. wywodzili się oni $z$ serbskiej imigracji. Nasze ustawodawstwo siedemnastowieczne traktuje wędrujących po Polsce Serbów jako podejrzanych włóczęgów ${ }^{6}$.

4 A. Brückner, Slownik etymologiczny jezyka polskiego, Warszawa 1957, s. 481, 485.

Dzieło cytowane w przyp. 2., cz. 2, s. 74, poz. 739, przyp. 2.

" „Przechowanie Wolochow y Serbow”: 14. „Wiele rzeczy szkodliwych dzieje się w państwach naszych za przechowaniem Wołochow y Serbow nieosiadłych y lożnych"; dlatego to konstytucja zakazuje przechowywania ich "pod wina, która jest w prawie o przechowaniu cyganów uczyniona", Volumina Legum, t. 3, s. 468 (r. 1624). 


\section{Potestas heroica*}

W cennej publikacji źródłowej prof. J. Deresiewicza (Transakcje chlopami $w$ Rzeczypospolitej szlacheckiej) pojawiają się często zwroty, zawierające wyrażenie potestas heroica. Zaskakujący na pierwszy rzut oka przymiotnik oddaje w tym kontekście W. Dworzaczek przez rycerski ${ }^{1}$, J. Deresiewicz przez szlacheck $i^{2}$. Orzechowski proponowal thumaczenie wladza pańska, choć uznaje równocześnie omawiane określenie za niezupełnie jasne ${ }^{3}$. Jaki jest więc jego desygnat?

Zwrot występuje w calej grupie kontekstów, w których zbywca przenosi potestas heroica na nabywce nieruchomości:

[1] ...se subditum cum omni iure, dominio et proprietate ac heroica potestate, quae sibi ad eundem subditum in hactenus serviebant et competebant [...] dedit, donavit, inscripsit et in perpetuum resignavit, hoc idem ius suum ad eundem subditum, sibi in hucusque serviens, in personam eiusdem generosi [...] cedit et transfundit (nr 55, r. 1701) 4

Nieraz użyje go pisarz parokrotnie:

[2] ...iuri, dominio, proprietati et heroic ae pot est a ti ipsius, recognoscentis, realiter et effective subdidit, subiecit et incorporavit cum eiusmodi totali iure, dominio et proprietate et heroica potest at e, quaecunque sibi in hucusque ad eundem subditum serviebant et competebant [...], dedit [...], omneque ius, dominium, proprietatem ac heroicam potest a tem [...] transposuit (nr 38, r. 1643).

* Przedruk z: Slavia Occidentalis 1968, t. 27, s. 133-142.

1 W. Dworzaczek, "Dobrowolne" poddaristwo chlopów, Warszawa 1952, s. 25, 46, 106.

2 J. Deresiewicz, Sprzedaż chlopów, Wiedza i Życie 24, 1957, s. 352.

${ }^{3}$ K. Orzechowski, $O$ wladztwie pana feudalnego wobec uzależnionych od niego chlopów, CPH, t. 12 , z. 2 , 1960 , s. 228-229.

4 Wszelkie cytaty, o ile nie zaznaczono czegoś innego, z publikacji J. Deresiewicza, Transakcje chlopami w Rzeczypospolitej szlacheckiej ( $w$. XVI-XVIII), Warszawa 1959. Podobne zwroty w aktach $\mathrm{nr} 31$ (1628 r.), 33, 41, 42, 400, akt 1, 401, 411, 412, 144, 414, 416, 107, $425,189,47,49,153,679,600$, akt 2, 589, 606, 744, 161, 745 (r. 1745). 
Innym razem jest bardziej lakoniczny:

[3] ... iuri, dominio et heroicae potestati [...] subdit et incorporat (nr 44, r. 1677) .

Obok tego pozytywnego sformulowania wystapi odmienne. W pewnej grupie aktów ujmuje się klauzulę negatywnie. Zbywca stwierdza, że nie zachowuje sobie żadnej władzy nad poddanym:

[4] ...nihil iuris, dominii, proprietatis ac hero ic a e potest at is ad eundem subditum pro se [...] iam amplius reservando et excipiendo ${ }^{6}$.

Nierzadkie są też akty, w których obie te klauzule, pozytywna i negatywna, pojawiają się równocześnie. I to albo najpierw idzie formula pozytywna, a po niej negatywna:

[5] ...cumque omni iure, dominio, proprietate ac heroica potestate, quaecunque sibi ad eosdem subditos hucusque competebat, nihil omnino iuris, dominii, proprietatis ac he ro ic a e po tes t a tis ad eosdem subditos [...] reservando et excipiendo [...], omneque ius, dominium et iurisdictionem transfundit .

Albo też klauzula negatywna poprzedza pozytywną:

[6] ...nihil sibi [...] iuris, dominii, proprietatis, heroica eque potest a tis et hereditatis [...] reservando [...], cum omni et integro iure suo suprascripto, sibi ad eos ex vi hereditatis servienti et competenti [...] dedit. (Nabywca ma odtąd prawo dysponowania nimi) heroicamque potestatem, prout verum, legitimum et proprietarium dominum spectat et concernit, super eis extendendi ( $\mathrm{nr} 669$, r. 1725).

Przytoczyliśmy wyżej tekst, w którym interesujący nas zwrot wystąpil trzykrotnie. Powolajmy jeszcze jeden akt tego rodzaju szczególnie charakterystyczny:

[7] ...cumque omni ac totali iure, dominio, proprietate ac heroica sua quacunque po test a te, quae sibi in hucusque ad eundem subditum suum $[\ldots .$.$] serviebant et competebant, nihil omnino iuris, dominii, proprietatis ac$ heroicae potestat is ad praefatum subditum suum [...], sibi, recognoscenti, reservando et excipiendo [...], dans et concedens ipsi (nabywcy) plenariam facultatem et omnimodam potestatem subditum praetactum [...] tenendi, habendi, possidendi et in suos [...] beneplacitos usus libere

${ }^{5}$ Zwłaszcza dla kancelarii wschowskiej charakterystyczny jest zwrot: in ius, dominium ac heroicam potestatem [...] dedit ( $\mathrm{nr}$ 163, r. 1747); Zob. też $\mathrm{nr}$ 165-168, 170-172, 174-175. Kancelaria gnieźnieńska posługuje się formułą: cum omni ac totali iure, dominio et proprietate ac heroica potestate (nr 563, r. 1636); ob. też 564-565, 570-571; identyczna zresztą i w kancelarii kościańskiej, nr 107, r. 1650.

${ }^{6} \mathrm{Nr}$ 51, r. 1686; zob. też nr 22 (1599 r.), 25, 26, 141, 28, 142, 30, 657, 316-317, 35, $105-106,658,177,36,720,722-723,179,726,726$ akt 2, 727, 145, 666, 45, 667-668, 50, 62, $67,671,120,342,343,610,211-213,698$ (r. 1765). Wyjątkowo spotykamy zwrot: nihil sibi in eodem subditos... iuris, dominii, proprietatis reservando, immo se omni heroica potestate, in eos sibi serviente, exonerando ( $\mathrm{nr} 656, \mathrm{r} .1620$ ).

${ }^{7} \mathrm{Nr} 48$, r. 1684; ob. też ib. 659 (r. 1640); 660,662, 573, 181; akt 1, 181; akt 2, 663, $665,575-577,145,147,149-151$. 
convertendi, nec non dandi, donandi, alienandi, ad labores et obsequia convertendi, et ius, heroicamque potestatem ac omne dominium pro natura iuris donatorii in ipsum exercendi ${ }^{8}$.

W jednym wypadku pisarz aktu użył omawianego określenia aż cztery razy (nr 578, r. 1650)!

Wyrażenie heroica potestas pojawia się bardzo często w aktach transakcji poddanymi; w niektórych pisarz posługuje się nim dwukrotnie czy więcej. $\mathrm{Z}$ przytoczonych kontekstów widać, że jest ono synonimem takich rzeczowników, jak: ius, dominium, proprietas (akty 1-7), iurisdictio (akt 5), hereditas (akt 6). Wszystkie one określają wladzę pana nad poddanym, jego zwierzchność feudalną, tę moc, którą rozciąga szlachcic-posesjonat nad chłopem-poddanym (akty 6-7), albo którą przenosi na innego seniora (akty 1-6).

Pomieszanie określeń oznaczających wlasność (proprietas) i władzę (iurisdictio) czy równocześnie jedno i drugie (dominium, ius) tlumaczy się łatwo panującymi w owych czasach stosunkami. Konfuzja terminów świetnie charakteryzuje ustrój, w którym uprawnienia natury prywatnej zlały się $\mathrm{z}$ władzą o treści publicznej. Ale co robi w tych kontekstach hereditas? Dlaczego władza pańska zwać się ma heroicznq̨? Żeby te trudności rozstrzygnąć, zestawimy dalsze teksty.

\section{II}

Obok zwrotu potestas heroica pojawia sie nieraz inny - potestas herilis: [8] ...cum omni ac totali iure, dominio, proprietate, iurisdictione et her o ic a po te st a te, quae sibi in hucusque ad ipsum serviebant et competebant, nil sibi [...] iuris, dominii, proprietatis, iurisdictionis ac herilis pot es $t$ a $t$ is ad eundem subditum reservando et excipiendo [...] dedit [...], dans et concedens ipsi [...] plenariam facultatem et omnimodam potestatem subditum eundem tenendi, habendi, possidendi, dandi, donandi, alienandi, ad labores et obsequia convertendi et ius, he ro ic am que pot es ta te $m$ ac omne dominium [...] in eum exercendi (nr 583, r. 1668).

Zapoznawszy się z powyższym tekstem, nie będziemy mieli żadnych wątpliwości co do tego, że można stawić znak równości między potestas heroica a potestas herilis. Ten wynik upoważni nas do uwzględnienia tych wszystkich aktów, które wspominają tylko o potestas herilis ${ }^{9}$. Tym bardziej że i ta potestas figuruje w takich samych kontekstach, jak wyżej potestas heroica.

[9] ...cum omni iure, dominio et proprietate, he ri lique sua potestate, quae sibi in eum hactenus competebat ${ }^{10}$.

${ }^{8} \mathrm{Nr} 575$, r. 1649; ob. też nr 579-580, 582, 584 (r. 1670) - kancelaria gnieźnieńska.

${ }^{9} \mathrm{Nr} 553$ (1594 r.); nr 554, 392, 559 (r. 1626).

${ }_{10}$ Nr 562, I. 1629; ob. też teksty powołane przez W. Dworzaczka, „Dobrowolne” poddaństwo, s. 145 , przyp. 18 . 
Ta potestas herilis wystapi nieraz obok iurisdictio: [10] ...ex iurisdictione et potestate sua herili ${ }^{11}$.

Również niełatwo ich ze sobą nie identyfikować. To zrównanie znowu iurisdictio i potestas upoważni nas do wzięcia pod uwagę aktów, w których mowa tylko o iurisdictio herilis ${ }^{12}$. Nie pogardzimy też wyrażeniem superioritas herilis (nr 532, r. 1571), czy nawet subditio herilis, zwłaszcza gdy wystąpi w następującym kontekście:

[11] ...de omni superioritate, potestate et subditione sua herili, iurisdictioneque sua (nr 378, r. 1595).

A warto dorzucić i zwrot:

[12] ...totamque iurisdictionem herilem ac auctoritatem ( $\mathrm{nr} 526$, r. 1559; nr 530, r. 1566).

Do grupy synonimów, oznaczających władzę pańską, dodać więc wolno potestas herilis, iurisdictio herilis, superioritas herliis, subditio herilis i auctoritas. A czy wyczerpaliśmy już $\mathrm{z}$ nimi wszystkie określenia?

\section{III}

Jeśli za identyczne treściowo poczytujemy potestas heroica i iurisdictio herilis $\mathrm{z}$ jej paru wariantami, to wszakże stwierdzić musimy, że w bardzo wielu aktach transakcyj żadne $\mathrm{z}$ nich się nie pojawi:

[13] ...quia ipsi de omni, integroque iure suo hereditario, quod ad laboriosos

[...] ad diem hodiernam, vigore recognitae per eundem laboriosum Thomam

[...] subditionis, habito [...], cedunt et condescendunt, nihilque sibi [...]

iuris, dominii et proprietatis reservando et excipiendo (nr 677, r. 1740) ${ }^{13}$; [14] ...cum omni iure, superioritate ac iurisdictione sua (nr 204, akt 2, r. 1589) ${ }^{14}$.

I to nas nie zadziwi. Występujące tu synonimy wystarczą dla jasności operacji prawnej zupełnie. Jak obojętna dla czynności prawnej była taka czy inna formula świadcza dwa akty z 1722 r.:

nr 584 nr 595

...nihil sibi iuris, dominii, proprietatis et hereditatis ad laboriosum [...] reservando. ...nihil sibi iuris, dominii, proprietatis et hereditatis, heroicaeque potest at is [...] reservando. nr 558 .

${ }^{11} \mathrm{Nr} 553$, r. 1594; podobnie w akcie z 1623 r.: in iurisdictionem, herilemque potestatem,

${ }^{12} \mathrm{Nr} 526$ (r. 1559); 528, 530, 545, 549, 557 (r. 1622).

${ }^{13}$ Zob. też nr 700 (r. 1569); 701-702, 705, 712, 712, akt 2, 713-717, 724, 596, 597 (akty 1-2), 742, 682, 695 (r. 1758).

14 Zob. też nr 205 (r. 1589); 267-269, 376, 272, 275 (r. 1594), z drobnymi zresztą odmiankami. 
Kto by odważył się na podstawie tych dwu różnych redakcji mówić o innej treści jednej i drugiej transakcji?

$\mathrm{Z}$ przytoczonych aktów wynotujemy ius hereditarium i superioritas. $\mathrm{W}$ literaturze zwracano uwage na dalsze określenie: ius supremum ${ }^{15}$. Z przejrzanych aktów wyłowiliśmy jeszcze takie, jak proprietas ad laboriosum (nr 671, r. 1725), ius proprietarium (nr 146, r. 1697), prawo wlaścicielstwa (nr 354, r. 1782), quaevis competentia (nr 661, akt 1, r. 1641), czy nawet propinquitas (nr 566, r. 1637; nr 729, r. 1690).

Ta władza pańska dawała panu pożytki pewne. Stąd nieraz pamięć o nich znajdzie swój wyraz w aktach:

[14a] ...omne ius, dominium et proprietas, utilitates, usus, fructus, herilis potestas (nr 554, r. 1599) ${ }^{16}$.

Stosunek: pan - chłop, oglądany od strony poddanego stanowił poddaństwo, subditio; wynikały $\mathrm{z}$ niego dla pracowitego servitia ( $\mathrm{nr} 531$, r. 1576), obsequia (nr 730, r. 1690), usluga (nr 734, r. 1724). Zestawiono je z poprzednimi:

[15] ...subditatus, obedientiae, dierum labores ${ }^{17}$,

i wszystkie transferowano na nabywcę. Praktycznie te dwa punkty patrzenia - odgórny (w oczach szlachcica) i oddolny (w oczach poddanego) - mieszały się również. Stąd $\mathrm{w}$ jednym szeregu idą terminy:

[16] ...superioritas, potestas, subditio hereditaria, iurisdictio qualiscunque (nr 380, r. 1596)

Język aktów akcentuje więc raz zwierzchność pańską, to znowu podległość poddańczą albo pożytki, jakie pan z pracowitych ciagnie lub też obowiązki ciążące na poddanych. Jakimkolwiek by pisarz posłużył się zwrotem, rzecz omawiana jest stale ta sama: przenosi się prawa pańskie, prawa seniora, władzę jaśnie pana nad poddanym. $\mathrm{Z}$ pewnościa zasadnie pomieścił je wszystkie w swoim zbiorku J. Deresiewicz.

Taka promiscuitas terminologiczna nie świadczy oczywiście dobrze o wyszkoleniu prawniczym pisarzy i stron, które się jej dopuszczają. Jakiejś precyzji prawniczej, dystynkcji pojęć prawnych doszukiwać się u nich daremnie ${ }^{19}$.

${ }^{15}$ K. Tymieniecki, Przyjecie prawa zwierzchniego w r. 1575, RH, t. 1 Poznań 1925, s. 288-289.

${ }^{16} \mathrm{~W}$ akcie z $1588 \mathrm{r}$.: proventus, ususfructus, $\mathrm{nr} 549$.

${ }^{17}$ Subditatus wystąpi w aktach: nr 607 (r. 1743); 625 (r. 1762); 636, akt 1, r. 1778; subditura - nr 731, r. 1690.

18 Por. też wyżej akt 11.

19 Stanowczo nie wolno zbyt rygorystycznie podchodzic do owych klauzul. Wyraźną daje nam przestroge akt z 1567 r.: Dzierżanowski otrzymał kmiecia w zastaw; już przez ten krok stal się ów chlop cmetho suus. Z swej strony tenże zastawnik owego kmiecia conducit et arendat wlaścicielowi, Gutowskiemu, za trzy grzywny na trzy lata; równocześnie przenosi na niego wszelkie prawa: cum omni iure, dominio et proprietate, $\mathrm{nr} 248$. 


\section{IV}

Jeśli ogólny sens przytoczonych klauzul jest jeden i ten sam, spróbujmy doszukać się jakichś semantycznych odcieni terminów, których się w nich używa. Rozumiemy, jak nam się wydaje, dobrze treść słów: proprietas czy dominium, superioritas, iurisdictio czy auctoritas, subditatus czy obsequia. Jakie zabarwienie zawieraja w sobie potestas heroica czy iurisdictio herilis? Poszukajmy w aktach źródłowych odpowiedzi na postawione pytanie.

Podobnie do przytoczonego wyżej zwrotu pozytywno-negatywnego, zawierającego wzmiankę o potestas heroica (akt 5), zacytować możemy klauzulę następującą:

[17] ...cumque omni ac totali iure, dominio et proprietate ac hereditaria sua quavis potestate [...], nihil omnino iuris, dominii, proprietatis, iurisdictionis ac hereditariae potest at is ad eosdem subditos suos [...] reservando [...], dando et concedendo... plenariam facultatem et omnimodam potestatem subditos eosdem [...] habendi, possidendi, dandi, donandi, alienandi, ad labores et obsequia convertendi et dominium pro natura iuris donatorii sui ipsius exercendi (nr 586, r. 1687).

W akcie z 1624 r. zwalnia się poddanego de subditione et potest a te sua herili, a równocześnie przekazuje się go nowemu panu iureque perpetuo hered i t a rio [...], nullum ius her ed i t a ri u m sibi [...] reservando (nr 392). A jakżeż symptomatyczna redakcja następujących aktów kościańskich:

[18] ...cumque omni iure, dominio, proprietate et heroica potestate (nr 107, r. 1650),

[19] ...nihil sibi [...] iuris, dominii et heredit ariae potes ta tis reservando (nr 108, r. 1690),

[20] ...nihil sibi [...] iuris, dominii, proprietatis et heroicae potes tatis [...] reservando (nr 109, r. 1690),

[21] ...nihil sibi [...] iuris, dominii, proprietatis et he reditariae po tes t at is [...] reservando (nr 110, r. 1690).

Czyż tu przymiotniki heroicus i hereditarius nie występuja alternatywnie? A zważmy jeszcze na daty ostatnich trzech aktów: wszystkie one wystawiono w jednym roku!

Bardzo też symptomatyczne zestawienie dwóch dokumentów z 1629 r., związanych $\mathrm{z}$ sobą rzeczowo i dlatego opublikowanych przez wydawce pod jedna pozycją:

[22] ...subditum et nativum suum, cum omni iure, dominio et proprietate, hereditariaque, quae sibi ad diem hodiernam in eum competebat, potestate (nr 561, akt 1). 
[23] ...subditum et nativum suum cum omni iure, dominio et proprietate, he roicaque, quae sibi ad diem hodiernam in eum competebat, potestate (nr 561, akt 2) 20 .

Wreszcie dokument transakcji z 1720 r. przekazuje:

[24] ...hero icamque potest a tem eundem subditum [...] gerendi, gubernandi [...], po te st a te $m$ heredit a ri a m super ipso extendendi (nr 593).

Prawda, substantivum hereditas może się pojawić także o b o k wyrażenia heroica potestas:

[25] ...nihil iuris, dominii, proprietatis, hereditatis, heroicaeque potest at is ad eundem laboriosum lacobum [...] reservando [...], cum omni iure, dominio, proprietate et subditatu ex vi hereditatis ad eosdem habito et competenti (nr 599, r. 1724).

Wszakże zapoznanie się $\mathrm{z}$ całym kontekstem pokazuje i w tym wypadku wyraźną skłonność, czy nawet manierę pisarzy kancelaryj grodzkich i ziemskich do posługiwania się pleonazmami. Czemuż nie miałyby jej ulec $\mathrm{i}$ owe dwa wyrażenia? Pomieszczenie ich więc obok siebie nie zmusza nas bynajmniej do przeciwstawienia ich sobie. Tym bardziej że $w$ tejże samej kancelarii, w tym samym roku wystạpi klauzula, która już tego pleonazmu zawierać nie będzie:

[26] ...nihil iuris, dominii, proprietatis, heroicaeque potestatis ad laboriosum Clementem [...], subditum nativum et hereditarium [...] reservando ( $\mathrm{nr} 598$, r. 1724$)^{21}$.

A jakżeż wymowny akt z 1720 r., zawierający taki zwrot: totum ius et integrum hereditarium super laborioso [...], po którym idzie: potestas heroica, a dalej: omnimoda absoluta heroicaque potestas, poczem nizjej: potestas hereditaria, dominium hereditarium et proprietarium (nr 593).

Dodajmy jeszcze, że i pan nazywa się dominus hereditarius ${ }^{22}$, również jego ius jest hereditarium ( $\mathrm{nr} 591$, r. 1720); dzierży on chłopa titulo hereditario ${ }^{23}$, stąd jego władza jest potestas hereditaria ${ }^{24}$. A i poddany nazywa się subditus suus proprius et hereditarius (nr 593), czy subditus nativus et hereditarius ( $\mathrm{nr}$ 596, r. 1724). Podnieśmy wreszcie fakt, że subditio he rili s cytowanego wyżej dokumentu (akt 11) odpowiada subditio hereditatis dyplomu z 1590 r. (nr 593). Akt z 1725 r. stwierdza, że omne ius suum, dominium, proprietas, he ro ic aque potest as wraz z subditatus, obedientiae, dierum labores przysługują panu vigore naturalis hereditatis ( $\mathrm{nr} 670$ ).

${ }^{20}$ Autor indeksu związal mylnie przymiotnik heroica $\mathrm{z}$ poprzedzającym go rzeczownikiem proprietas.

${ }^{21}$ Identycznie w akcie z 1731 r. nr 600 .

${ }^{22} \mathrm{Nr} 706$, r. $1595 ; 180$, r. $1644 ; 146$, r. $1697 ; 344$, r. $1751 ; 169$, r. 1752.

${ }^{23} \mathrm{Nr} 566-568$, r. $1637-1638 ; 411-412$, r. $1644 ; 157$, r. $1729 ; 111,729-731$, r. 1690 ; ex $v i$ hereditatis, $\mathrm{nr} 598, \mathrm{r} .1724$.

${ }^{24} \mathrm{Nr} 108,110$, r. $1690 ; 117$, r. $1730 ; 593$, r. $1720 ; 201$, r. 1723. 
Wykazaliśmy wyżej, że można stawić znak równości między przymiotnikami heroicus i herilis. Ostatnie teksty pozwalają na dalsze zrównanie znaczeniowe adiektiwów: heroicus, herilis, hereditarius. Nie bez racji napisał notariusz aktu z 1564 r.: ius totum hereditarium seu herile (nr 527). Skąd ta konfuzja? Zanim wyjaśnimy jej genezę, zestawmy polskie odpowiedniki owych łacińskich określeń władzy pańskiej.

Akty zredagowane $w$ języku polskim sprawią nam tu zawód. Raz, że interesującą nas rzecz oddadzą wtrętem łacińskim:

[27] ...nic sobie [...] do tego chlopa nie zostawujqc dominii (nr 587, r. 1699). [28] ...jakom już dal, darowal et cum iure ac dominio praesentibus rezygnowal (nr 740, r. 1739).

[29] ...i pominionego pracowitego Andrzeja ex nunc za wlasnego poddanego przyznaje $i$ odtqd żadnej pretensyi quovis excogitato titulo tak ratione subditatus, jako też $i$ inszej do tego pracowitego Andrzeja rościć, czynić sobie nie bede ${ }^{25}$.

Druga trudność wynika $\mathrm{z}$ lakoniczności owych aktów zredagowanych po polsku. Podczas gdy formularz laciński osiągnął nieraz postać tasiemca, rojącego się od pleonastycznych wyrażeń, teksty polskie cechuje zdumiewająca lakoniczność. Prawda, i akty łacińskie zostały nieraz ujęte również krótko w rodzaju:

[30] ...nihilque praetensionis intuitu eiusdem laboriosi habere declarat ( $\mathrm{nr} 636$, akt 2, r. 1778),

czemu odpowie tekst polski:

[31] ...nic sobie [...] nie zostawujqc o poddaństwo pretensji (nr 633, r. 1777); lacińskiemu wyrażeniu:

[32] ...nihil sibi iuris, dominii [...] restare (nr 734, r. 1724), odpowiadać będzie polskie:

[33] ...nic sobie do niego prawa nie zostawujac ( $\mathrm{nr} 640$, r. 1781).

Krótkie klauzule, lacińskie i polskie, możemy z sobą zestawić i uznać za paralelne; dla długich okresów lacińskich takiego samego polskiego odpowiednika brak. Mimo to możemy wskazać na polskie określenia władztwa pana-seniora. Wystąpią w tym charakterze prawo i państwo (nr 581, r. 1657) ${ }^{26}$ wlasnośc $^{27}$, prawo ${ }^{28}$, wladza, jurysdykcja i poddaństwo ${ }^{29}$ lub

\footnotetext{
${ }^{25} \mathrm{Nr} 685$, r. 1745 ; podobnie nr 689, r. 1748.

${ }^{26}$ Por. nasz artykul $O$ państwie i Państwie, CPH, t. 10, z. 2, 1958, s. 81; patrz w niniejszym tomie s. $403-426$.

${ }^{27} \mathrm{Nr} 708$, r. $1595 ; 734$, r. $1724 ; 605$, r. $1740 ; 630$, r. 1775.

${ }^{28} \mathrm{Nr} 708$, r. $1595 ; 634$, r. $1778 ; 653$, r. 1791.

${ }^{29} \mathrm{Nr} 732, \mathrm{r} .1723$.
} 
tylko poddaństwo ${ }^{30}$. Akt z 1694 r., przekazujący nabywcy ,mielcarza Wojciecha, rodzica $^{31}$ drobnińskiego", przelewa równocześnie prawo dziedziczne $e^{32}$, jurysdykcje dziedzicznq (nr 112, r. 1694).

To prawo dziedziczne poczytamy bez wahań za odpowiednik lacińskiego ius hereditarium, tak często występującego $w a^{a k t a c h}{ }^{33}$. Nierzadko też czytamy o dobrach dziedzicznych (nr 590, r. 1719). Jest to niewątpliwy derywat od dziedzic. Wszakże strzeżmy się przypisania mu prawniczego sensu rzymskiego spadkobiercy. Dziedzic - to właściciel ziemski, szlachcic-posesjonat, jaśnie pan. To znaczenie wyrazu było powszechne jeszcze w Polsce międzywojennej. Ma ono zaś starą, przedrozbiorową metrykę. Akty transakcyj dowodzą, jak ono było powszechne ${ }^{34}$. Znamienne jednak, że uszło ono uwagi współczesnych. Knapski objaśnia rzeczownik dziedzic tylko w sensie prawa spadkowego, spadkobierca; podobnie i Linde. Wydobywa je dopiero Stownik Warszawski, a cala gamę cytatów podal Stownik Staropolski prof. S. Urbańczyka. Ale i w ostatnim zbiorze, wbrew oczywistej przewadze: dziedzic 'pan, feudał', położono na pierwsze miejsce dziedzica-'spadkobiercę'.

\section{VI}

Ten polski termin dziedzic odpowiada idealnie średniowiecznemu rozumieniu substantivum heres: właściciel ziemski, pan, senior (Niermeyer) ${ }^{35}$. Uzyskujemy w ten sposób grupe odpowiedników:

heres - dziedzic,

hereditarius - dziedziczny, 'przynależący do dziedzica'.

Ale i herus średniowiecznej łaciny posiada sens identyczny: pan, dziedzic. Nie bez racji przymiotnik herilis oddaje Mączyński (149 verso) przez

${ }^{30} \mathrm{Nr} 724$, r. $1644 ; 747$, r. $1770 ; 139$, r. $1786 ; 523$, r. $1787 ; 651$, r. $1789 ; 140$, r. 1791 por. też wyżej akt 31 .

${ }^{31}$ Ustaliliśmy sens tego rzeczownika w artykule Rodzic $i$ rodziczka, CPH, t. 16, z. 1, 1964, s. $321 \mathrm{nn}$. i patrz w niniejszym tomie s. 185-192. Rzecz uznał za udowodnioną językoznawca, S. Urbańczyk, Jezyk Polski, t. 44, 1964, s. 178. Tymczasem A. Mączak nawraca do dawnej interpretacji, według której rodzicami nazywano członków rodzin chłopskich, Dzieje gospodarcze Polski do 1939 r., (praca zbiorowa: B. Zientara, A. Mączak, I. Ihnatowicz, Z. Landau), Warszawa 1965 , s. 241.

${ }^{32} \mathrm{Nr} 152$, r. $1710 ; 687$, akt 2, r. 1746.

${ }^{33}$ Zestawienie aktów $w$ indeksie.

${ }^{34} \mathrm{Nr} 119$, r. $1736 ; 651$, r. 1789.

${ }^{35}$ Opieramy się na materiałach słownikowych, dostarczonych nam przez prof. M. Plezię. Stąd i hereditas oznacza własność ziemską przede wszystkim, dziedzinę. Na określenie spadkobiercy używa się raczej rzeczownika successor, także sequax. W błąd wprowadza zatem Slownik lacińsko-polski J. Maqczyńskiego, według którego heres oznacza na ogół spadkobiercę. Widać na tym przykładzie, jak sens klasyczny słowa potrafił przesłonić autorowi najczęstsze rozumienie jemu współczesne. 
pański $i^{36}$. Stąd wladza pana nad poddanymi będzie władzą dziedzica, potestas, iurisdictio herilis. Pojawia się więc druga grupa odpowiedników:

herus - dziedzic,

herilis - dziedziczny, 'przynależący do dziedzica'.

Co więcej, pod wpływem germańskiego herro - pan, łacina średniowieczna przypisała takież znaczenie rzeczownikowi heros. Wedhug Klugego, słowo to ,scheint aus dem Verhältnis der Untergebenen zu ihrem Brotherrn hervorgegangen in Nachahmung von mlat. senior (frz. seigneur, ital. signore)" ${ }^{37}$. Tak rozumiano je i w Polsce, jak o tym świadczy Mączyński: heros - znamienity człowiek, zacny i niepospolity pan, który wielkimi cnotami jest obdarzon. Jeśli heros jest jaśniepanem dziedzicem, to heroicus oznaczać będzie cechę wlaściwą temu rzeczownikowi. W tym sensie używa omawianego przymiotnika Mączyński: heroicus - pański, zacny. Osiągamy więc trzecią grupę odpowiedników:

heros - dziedzic,

heroicus - dziedziczny, 'do dziedzica przynależący'.

Łacina polska postawiła znak równania między heres, herus, heros. Nie tylko nie różnią się one niemal brzmieniem. Ich sens jest identyczny. W następstwie tego pochodzące od nich przymiotniki: hereditarius, herilis, heroicus, przybrały takież same znaczenie: dziedziczny, pański. By uniknąć wszelkich nieporozumień $w$ ich rozumieniu, należałoby oddać owe terminy we współczesnej polszczyźnie przez feudał i feudalny, czy senior i senioralny. To jest sens właściwy ${ }^{38}$.

\section{VII}

Za naszym pojmowaniem rzeczy świadczą inne jeszcze konteksty. Wiemy, że pan włości był zawsze szlachcicem - nobilis; ta warstwa miała bowiem monopol na grunty. Przynależny do tego stanu był osobą szlachetna - taką, która dotrzymuje danego przez siebie słowa. Stąd waga verbum nobile. Spopularyzowała je w naszej świadomości poezja (A gdzie jest nobile verbum?) i muzyka (Verbum Nobile). Występuje ono niejednokrotnie w aktach transakcyj chlopami (nr 57, r. 1714; nr 160, r. 1742); raz pojawi się ono w postaci verbum nobile et militare (nr 32, r. 1629). Jeśli dał je ktoś $\mathrm{z}$ arystokracji, bylo to verbum senatorium ( $\mathrm{nr} 156$, r. 1723). Ale obok podanych wyrażeń zanotowaliśmy też verbum heroicum (nr 340, r. 1732). Jest to - oczywiście - słowo szlachcica, jaśniepana dziedzica.

\footnotetext{
${ }^{36} \mathrm{~W}$ materiałach prof. M. Plezi znajdujemy wypis z 1450 r.: tota curia her il is cum area et pomorio, SPPP, t. 2, s. 596.

${ }^{37}$ F. Kluge, Etymologisches Wörterbuch der deutschen Sprache, 17. Aufl, Berlin 1957.

${ }^{38}$ Linde daje cytat ze Skrzetuskiego, z klórego wynika, że używała tego terminu kancelaria królów polskich po tytułach prowincyj, czego zaniechano po śmierci Zygmunta Augusta.
} 


\section{VIII}

Przymiotniki hereditarius, herilis, heroicus, które wywodzimy od heres, herus $i$ heros $^{39}$, w umyslach naszych lacinników 16-18 w. skojarzyły się $\mathrm{z}$ substantivum heres. Ta dzika po części etymologia zawdzięcza swe powstanie podobieństwu zewnętrznemu rzeczowników, od których zostały utworzone. Poparcie znakomite zdobyła ona sobie w semantyce: wiążą się one wszystkie $\mathrm{z}$ pojęciem dziedzica, pana, feudała, seniora, właściciela nieruchomości. Stąd jego władza stanowić będzie potestas heroica czy hereditaria lub herilis. Ona go uprawnia do tego wszystkiego quodque dominum hereditarium et proprietarium, super subdito suo proprio et hereditario dominium habentem, spectat et concernit ( $\mathrm{nr} 593$, r. 1724) ${ }^{40}$.

${ }^{39}$ Por. tu wątpliwości K. Orzechowskiego, l. c.

40 Niemiecka łacina zna wyrażenie iurisprudentia heroica, H. Conrad, Deutsche Rechisgeschichte, 1966, t. 2, s. 211 . 



\section{O próbie nowej systematyki źródel historycznych*1}

(G. Labuda, Próba nowej systematyki i nowej interpretacji źródel historycznych, Studia Źródłoznawcze, t. 1, Warszawa 1957, s. 3-48).

1. Sprecyzowanie tematu. 2. Czym jest źródło? 3. Tradycja, 4. Podziały dotychczasowe. 5. Cel klasyfikacji. 6. Warunki klasyfikacji. 7. Kryterium. 8. Omówienie tabelki. 9. Ocena studium.

Obszerny, bo 48 -stronicowy in $4^{\circ}$ artykul prof. G. Labudy, drukowany przed dziesięciu laty, nie wywołal szerszej dyskusji ${ }^{1 \mathrm{a}}$. A przecież to - że się tak wyrazimy - programowy numer Autora, który jako jeden $\mathrm{z}$ dwu redaktorów, otwiera nim nowo powstałe czasopismo - Studia Źródłoznawcze. Prof. Labuda ,nie czując się na siłach doprowadzić poruszone tu zagadnienie do sformułowań ostatecznych", poddaje go „pod szerszą dyskusję". Zachęceni tym wezwaniem, pragniemy podzielić się swymi spostrzeżeniami na omawiany temat, również bez ambicji jego ostatecznego rozwiązania.

Tytuł artykułu zapowiada nową systematykę i nową interpretację źródel historycznych. Żeby uprzytomnić sobie miejsce tych zagadnień w historyce, przypomnijmy sobie etapy pracy dziejopisa. Wyróżnia się jej trzy zasadnicze stadia:

* Przedruk z: Studia Metodologiczne 1968, t. 4, s. 17-50. Por. G. Labuda w: Studia Źródłoznawcze 1971, t. 16.

1 Artykułem prof. dra Józefa Matuszewskiego pragniemy rozpocząć dyskusję na temat metodologicznych problemów źródeł historycznych. $\mathrm{Z}$ wieloma sformułowaniami autora Redakcja nie w pełni się solidaryzuje.

1a Por. niżej ustęp 9.

2 Cyfry w nawiasach odsylają do stronic omawianego opus.

3 Modnym dzisiaj określeniem jest źródłoznawstwo, F. Bronowski - B. Krzemieńska, $Z$ zagadnień źródloznawstwa w nauce radzieckiej, Studia Źródłoznawcze, t. 4, 1959, s. 128, ale bynajmniej nie nowym. Nam się wydaje ono kalką niemieckiej Quellenkunde, używanej już przez Bernheima, choć w znaczeniu węższym, heurystyki, E. Bernheim, Lehrbuch der historischen Methode und der Geschichtsphilosophie, Leipzig 1903, s. 227, jak też szerszym przez DablmanaWaitza, Quellenkunde der deutschen Geschichte, 9 wyd., 1931. 

A. Heurystyka
B. Krytyka
a. zewnetrzna
b. wewnętrzna (hermeneutyka);
C. Opracowanie (synteza, konstrukcja) ${ }^{4}$.

Pierwsze zagadnienie poruszone przez Labudę mieści się w ramach heurystyki ${ }^{5}$, drugie stanowi treść hermeneutyki ${ }^{6}$. Czytelnik nie pojmuje, dlaczego połączono w jednym artykule rzeczy tak różne - cząstkę heurystyki (klasyfikacje źródel) z cząstką krytyki wewnętrznej (interpretacją źródel).

Stwierdźmy wszakże od razu, że brak osobnego rozdziału, który by się zajmował interpretacją; nie doczytaliśmy się też wielu wypowiedzi Autora na ten temat ${ }^{7}$. Artykuł poświęcony został $w$ istocie klasyfikacji źródeł. Nadany mu więc tytuł jest niewątpliwie za szeroki. Oczywiście, faktyczne zwężenie zainteresowań badacza winno było się odbić korzystnie na wywodach o systematyzacji.

Zajmując się klasyfikacją źródel, Autor siłą rzeczy zastanowić się musiał nad tym, czym jest źródło (19). Oto dwie jego definicje: 1. „Źródłem - najogólniej biorą c - nazwiemy wszystkie pozostałości materialne i psychofizyczne, będące wytworem, a zarazem odbiciem i częścią procesów przyrodniczych i społecznych w czasie i w przestrzeni" (22). - Ta definicja liczy się ,w znacznie większym stopniu z czynnym dialektycznym charakterem poznania ludzkiego" (21).

A druga definicja „w ścisłym technicznym tego słowa znaczeniu”: „wszystkie pozostałości psychofizyczne i społeczne, które będąc wytworem pracy ludzkiej, a zarazem uczestnicząc w rozwoju życia społecznego, nabierają przez to zdolności odbijania tego rozwoju. Wskutek tych swoich właściwości (tj. wytworu pracy i zdolności odbijania) źródło jest środkiem poznawczym, umożliwiającym naukowe odtworzenie rozwoju spoleczeństwa we wszystkich jego przejawach" (22).

Nie podoba się nam żadna $\mathrm{z}$ tych definicji już choćby od strony czysto stylistycznej, a tym bardziej od strony rzeczowej. Tymczasem druga akceptuje M. Tyrowicz, ponieważ - jego zdaniem - ona „rozszerza wcześniej u nas przyjęta definicję Handelsmana”, który - rzekomo - pominął „cechę

${ }^{4}$ M. Handelsman, Historyka. Zasady metodologii i teorii poznania historycznego, Warszawa 1928, wyd. 2; podobnie S. Kościalkowski, Historyka. Wstęp do studiów historycznych, Londyn 1954.

${ }^{5}$ M. Handelsman, Historyka, $\S 10$.

6 Ibidem, \& 20.

7 Poza marginalnymi uwagami, rozsypanymi tu i ówdzie, pisze o niej Autor na s. 23-26. 
uczestniczenia źródła w rozwoju życia spoleczeństwa i zdolności odbijania tego rozwoju" ". Wzbudzała też ona entuzjazm u B. Miśkiewicza, wedhug którego jest ona „wyrazem postępu teoretycznego i metodologicznego nauki historycznej"'. Zaznaczmy, że C. Bobińska nie godzi się z niezwykle szerokim pojęciem źródła ${ }^{10}$ a logik zgłosił poważne zastrzeżenia co do wartości cytowanej wyżej definicji ${ }^{11}$; trudno nam ich nie podzielać. Definicje są wręcz ciemne i chaotyczne. Czy nie lepiej posługiwać się taką, jaką dał Handelsman czy Kościalkowski? ${ }^{12}$ Ale nie przywiązujmy wagi do nieprecyzyjności powołanych definicji. Omnis definitio... Być może dalsze wypowiedzi Autora wyjaśnią nam, czym w jego rozumieniu jest źródło.

Prof. Labuda zastanawia się nad ,istotą" źródła $\left(10^{25} ; 20,24,47\right)$, nad tym, czym jest ono „w swej formalno-realnej istocie” (19). Uczyliśmy się kiedyś, jak to pytanie o istotę czegoś jest dość nieokreślone. Nie godzą się myśliciele na to, jak „,istotę” zdefiniować. Wolelibyśmy więc opuścić to pole filozoficznych dociekań o istocie $w$ ogóle, jak też o istocie procesu historycznego (26), czy w szczególności o istocie źródła. Chyba i Autor nie dość swobodnie się w nim porusza, skoro za istotę źródła uważa raz to, że jest narzędziem poznania przeszłości (37), na innym zaś miejscu istotą dla niego jest to, że źródło „musi odbijać działalność ludzka pośrednio i bezpośrednio, gdyż inaczej nie mogłoby być źródłem calkowitym". Zostawiając kwestię istoty źródła niewyjaśnioną, przejdźmy do określeń Autora bardziej konkretnych, orzekających, czym są źródła.

Wszystkie źródła są rzeczami (14, por. też s. 28); na to zgoda absolutna ${ }^{13}$. Źródło jest pozostałością po człowieku (46), pozostałością psychofizycznej działalności człowieka (20). I na to trudno się nie godzić, acz nasuwają się tu pewne zastrzeżenia ${ }^{14}$. Ale stwierdzając to, Labuda nie wnosi absolutnie nic nowego do dotychczasowego dorobku metodologów historii; to jest elementarz każdej tradycyjnej historyki. Gdzież więc tu elementy tej nowej definicji źródła, którą się Autor chełpi (48)?

${ }^{8}$ M. Tyrowicz, Klasyfikacja źródel do dziejów czasopiśmiennictwa i prasy, Prasa Współczesna i Dawna, nr 4, Kraków 1958, s. 49.

${ }^{9}$ B. Miśkiewicz, Wstepp do badań historycznych, Poznań 1963, s. 46.

${ }^{10}$ C. Bobińska, Historyk, fakt, metoda, Warszawa 1964, s. 60, przyp. 3.

11 J. Giedymin, Semantyczne problemy klasyfikacji źródel historycznych, Studia Źródłoznawcze, t. 3, Poznań 1958, s. 195-196.

${ }_{12}$ Por. pozycje przytoczone wyżej w przyp. 4; ob. nadto J. Topolski, $O$ pojeciu $i$ roli wiedzy pozaźródlowej w badaniu historycznym, Studia Metodologiczne, z. 3, 1967, s. 23.

${ }_{13}$ Autor znajdzie się w kłopocie, gdy zajmie się tradycją, por. niżej ustęp 3.

${ }^{14}$ Według Labudy, „powstanie [...] jakiegokolwiek źródła bez udziału świadomości nie jest możliwe" (44). J. Giedymin podniósł zastrzeżenie co do szkieletów ludzi i zwierząt czy innych faktów przyrodniczych, Semantyczne problemy..., s. 187, 191. Poglądy Labudy referuje wiernie B. Miśkiewicz, o. c. Z pewnością lepsze jest określenie W. Moszczeńskiej: „Źródłem historycznym jest to wszystko, ale też tylko to, co $w$ jakiś sposób pozostaje w związku z człowiekiem (społeczeństwem)". Wstepp do badań historycznych, Warszawa 1960, s. 67. 
Źródło jest wytworem człowieka $(26,29)$, źródło jest wytworem spoleczeństwa (27), wynikiem życia społecznego $\left(17^{50}\right)$, pochodzi z płaszczyzny spolecznej (27); jest ono też wynikiem albo wytworem procesu historycznego $(21,24,25)$, wynikiem działalności całoksztaltu procesu historycznego (24). Określenia powyższe skłonni bylibyśmy traktować jako synonimiczne. Ale dopatrzymy się pewnej niekonsekwencji przy czytaniu zdań następujących: czlowiek ,jest podmiotem, twórca procesu historycznego" (27) oraz ",proces historyczny jest twórcą wszystkich rodzajów źródel" (27), i to ma być ten „wlaściwy sens" zdania poprzedniego (27). Czyżby to należało rozumieć tak, że czlowiek tworzy i źródła, i proces historyczny, a stworzony przezeń proces historyczny dalej już wytwarza źródła historyczne, niezależnie od człowieka? Dodajmy jeszcze, że według Labudy sprawcą powstania źródła jest środowisko historyczne (24), a między obiektywnym środowiskiem historycznym a obiektywnym źródłem tkwią jego jednostkowi twórcy (24). Znowu ten cały zbiór wypowiedzi nie robi wrażenia dostatecznie sprecyzowanego; personifikowanie abstrakcji z pewnością nie oznacza posługiwania się językiem konkretnym.

Autor utrzymuje dalej, że źródło jest „częścią (cząstką)” procesu historycznego $(21,22,25)$. Skoro proces historyczny jest twórca źródła, skoro źródło historyczne jest częścią procesu historycznego, to jakoś źródło tworzy samo siebie. Tak to wynika $\mathrm{z}$ wypowiedzi Labudy, acz $\mathrm{z}$ pewnością nie miał on tego na myśli.

Źródło jest nie tylko pozostalością, ale jednocześnie i odbiciem psychofizycznej działalności człowieka (20). Obok tego, że źródło jest samo odbiciem $^{15}$, posiada też ono zdolność odbijania (22), odbija mianowicie w sobie proces dziejowy $\left(19^{54}, 22\right)$, przeszłość (48), poszczególne płaszczyzny procesu historii (48), całokształt procesu historycznego (27), prawidłowość zachodzących przeobrażeń (21). Za Giedyminem przyjmiemy, że odbijanie znaczy to, iż na podstawie obserwacji źródeł można dojść do pewnego poznania przeszłości ${ }^{16}$. To odbicie dokonuje się $w$ sposób pośredni lub bezpośredni (23). Znowu to zwroty wieloznaczne ${ }^{17}$.

Źródło posiada taką właściwość, że ,zawsze prawidłowo odbija proces historyczny" $(23,27)$, w sposób obiektywny $(21,24,48)$. To nam umożliwia poznanie historyczne (48). Dorzućmy jeszcze, że Labuda zna takie źródła, które są syntezą (46). Nie wiemy zupełnie, jaki sens tej wypowiedzi przypisać ${ }^{18}$.

${ }^{15}$ Kilkakrotnie pisze Labuda o odzwierciedlaniu, np. s. 40; raz nawet pojawia się pod jego piórem zwrot: „odbijanie... odzwierciedlania" (42).

${ }^{16}$ J. Giedymin, Semantyczne problemy..., s. 195.

${ }_{17}$ Ibidem, s. 193, przyp. 17, 194; por. też niżej ustęp 8.

${ }^{18}$ Według rozumienia Labudy, takim źródłem-syntezą jest tradycja. Zauważmy, że i wszelkie inne źródła są $w$ wywodach tego uczonego niejako syntezą trzech elementów, materialnego, psychicznego i społecznego. Jak to wszystko rozumieć? 
Labuda wskazuje dalej, do czego źródło shuży (19): wykorzystuje je historyk w swych pracach badawczych do odtwarzania procesu dziejowego (22), służy ono "odtworzeniu rozwoju społecznego" (47). Nota bene: ta cecha źródła, że jest narzędziem poznania przeszłości, awansowała - jak już wiemy - nawet do rangi istoty źródła (37).

Zgromadziliśmy wypowiedzi autora na temat istoty źródel, ich genezy, cech immanentnych i funkcyj, do których służą. Trudno te spostrzeżenia poczytać za nowe. Co gorsza, wszystkie one ujęte jakoś nieprecyzyjnie. O każde ze sformułowań Labudy można by się sprzeczać. A już całkiem nie rozumiemy, o co Autorowi chodzi, gdy utrzymuje, że jego definicja otwiera perspektywy intensywniejszej interpretacji źródeł (48), że ona przezwycięża "dotychczasowy impas powstały na drodze do naukowej klasyfikacji źródel” (19). Czy nie jest to owo „samopocieszanie się”, które profesor Labuda wymawia swoim adwersarzom $\left(10^{25}\right)$.

Do źródeł „sensu strictiori” (47) nie wchodzi tradycja: jest ona bowiem źródłem-syntezą (46). $\mathrm{Z}$ tego powodu wymyka się ona $\mathrm{z}$ trójdzielnego podziału Labudy (45). Historycy przez swoje odczucie ,umieszczali tradycję ustną wśród źródel swego poznania” (13). „Wydaje się, że podstawowym źródłem do odtworzenia życia naszych przodków jest nasze własne życie w ramach współczesnego społeczeństwa, czyli żywa tradycja" (16). Żywy człowiek jest nosicielem tradycji (18), „tradycja, czyli żywy człowiek” (46). Stąd „może on więc [czlowiek] za stą pi ć wszystkie rodzaje źródel z osobna wzięte" (47). Nie chcąc nużyć czytelnika, rezygnujemy z przytaczania dalszych wypowiedzi Autora na temat tradycji. Przytoczone cytaty pokazują, że prof. Labuda rozumie ją $w$ sposób na wskroś oryginalny, całkiem nietradycyjny, zupełnie inny niż to robiono dotąd ${ }^{19}$. Dlatego to zapewne pozbycie się tradycji daje - jego zdaniem - "patent papierowego historyka" (13), skoro ,żywy czlowiek - nosiciel tradycji - odbija bezpośrednio wszystkie płaszczyzny [procesu historycznego] od razu" (46).

${ }^{19}$ Por. np. M. Handelsman, Historyka, s. 45, J. Giedymin, Semantyczne problemy..., s. 191-192; por. też najświeższe uwagi K. Jażdżewskiego, $O$ trwalości $i$ wiarygodności ustnej tradycji historycznej u ludów niepiśmiennych, [w:] Munera archeologica Josepho Kostrzewski [...] oblata, Poznań 1963, s. 7-17, oraz K. Tymienieckiego, Legendy $i$ spór o tradycje historycznq, Studia Źródłoznawcze, t. 10, Warszawa 1965, s. 104-107. 
Przed przedstawieniem własnej klasyfikacji źródel Labuda rozprawia się z systematyzacjami dotychczasowymi. Wszakże - z niewiadomych przyczyn - ogranicza się do tych tylko, które dali historycy niemieccy - J. G. Droysen [1867; 3 wyd., 1882], E. Bernheim [1903], B. Schmeidler [1912]; poświęcił też nieco uwag krytycznych W. Bauerowi [1928], E. Kayserowi [1931], jak i podziałom O. Stolza [1938] i L. Mikoletzkyego [1950]. Z polskich historyków uwzględniony został M. Handelsman $(10-11,14)$. Dlaczego do tych autorów ograniczać się mają „dzieje naukowej klasyfikacji źródeł" (14)? Dlaczego pomijać prace historyków angielskich, francuskich, włoskich i radzieckich? ${ }^{20}$ Tym więcej zdumiewa nas postępowanie Labudy, gdy on sam stwierdza, że historiografia radziecka przeprowadziła wszechstronną krytykę niemieckich klasyfikacji $\left(19^{54}\right)^{21}$.

Rozpatrzone przez Labudę podziały są złe ${ }^{22}$, dlatego Autor je odrzuca (28). Przyczyną ich wad był zarówno związek z poglądami idealistycznymi ich autorów (19), jak i oparcie klasyfikacji na cechach formalnych ${ }^{23}$. „Zarówno system wychodzący z kryteriów formalnych [...], jak i system opierający się na kryterium związków rzeczowych [...] nie dał pożądanego rezultatu" (26). Prof. Labudzie wydaje się, że dowiódl bezspornie (19), iż dorobek dotychczasowy nie wytrzymuje krytyki ${ }^{24}$.

Z zarzutami Labudy jako nieuzasadnionymi rozprawiono się już w literaturze $^{25}$. Krytyka wywodów krytycznych prof. Labudy, przeprowadzona przez logika, wydaje się nam jak najbardziej przekonywająca. Jeśli Labuda stwierdza, że „istnieje nieodparty, dialektyczny związek między źródłami psychicznymi i materialnymi, między pośrednimi a bezpośrednimi, miedzy mówiącymi a niemymi, między pisanymi i niepisanymi itd." (17), temu zdaniu nie zamierzamy przeczyć. Ale ten sam ,nieodparty, dialektyczny związek" istnieje w ogóle miedzy źródłami, jakkolwiekbyśmy je podzielili, a więc także między kategoriami źródeł stworzonymi przez Labudę. Trudno zatem jego zarzut uznać za sensowny. Czyżby bowiem nie należało w ogóle źródeł dzielić?

${ }^{20}$ Autor zresztą cytuje i dzieło Langlois-Seignobos $\left(19^{53}\right)$ i L. W. Czerepnina ( $\left.3^{1}\right)$; ob. też niżej przyp. 24.

${ }^{21}$ Por. tu również Bronowski - Krzemińska, o.c., s. 126.

${ }^{22}$ Obok złych wymienia jeszcze „znacznie gorsze” (14) i „najgorsze” (1545).

${ }^{23}$ Por. J. Giedymin, Semantyczne problemy..., s. 185.

${ }^{24}$ Nie jest również dobry podział Tichomirowa, ponieważ nie wnika „w całą złożoność problematyki" $\left(19^{\text {s4 }}\right)$.

${ }^{25}$ J. Giedymin, Semantyczne problemy..., s. 186, 194. 
Jeśli podziały niemieckich historyków nie są tak złe, jak to nam Autor usiłuje wmówić, to zasługują one $w$ dalszym ciągu na baczną uwage ${ }^{26}$. Wiadomo bowiem, że podziału „zwałów źródeł” (24) dokonywać można $\mathrm{z}$ różnych punktów widzenia ${ }^{27}$. Żadna klasyfikacja nie będzie idealna. Zasadnicza trudność systematyzacji źródeł leży, jak sądzimy, w niemożności przeprowadzenia podziału rozłącznego, który by równocześnie miał znaczenia praktyczne ${ }^{28}$. Z góry domyśleć się możemy, że tej trudności nie uniknie i podział Labudy. Przyjirzyjmy się więc jego systematyce „całoksztaltu źródel" $\left(17^{51}, 43\right)$.

Poglądy Autora na temat klasyfikacji źródeł zgrupować można wokół trzech zagadnień: 1) cel klasyfikacji, 2) warunki poprawnej klasyfikacji, 3) kryterium podziału.

Nie chcemy przywiązywać wagi do jednej wypowiedzi Labudy, polegającej chyba na jakimś nieporozumieniu: tak należy podzielić źródła, „by one odbijały proces historyczny we wszystkich jego przejawach" $\left(19^{54}\right)$. Jak stwierdziliśmy bowiem wyżej, Labuda podal jako cechę immanentną źródła to odbijanie - posługując się terminologią Autora - całokształtu procesu historycznego. Źródła robią to bez względu na to, jak je podzielimy i nawet bez względu na to, czy my je w ogóle podzielimy.

Pominiemy też jego wypowiedź, według której buduje się system źródeł „w celu lepszego rozpoznania istoty źródła" $\left(10^{25}\right)$. Raz, z przyczyny poruszonej już wyżej: nie bardzo wiemy, co to jest ta istota. Ale nawet gdyby ją rozumieć w sensie potocznym, dość zatem nieokreślonym, trudno się godzić z poglądem, że można klasyfikować przedmioty, nie rozpoznawszy przed te m ich istoty. Takie odwrócenie procesu chyba nie wyjdzie wykładowi na dobro.

Przyznajemy się też, że calkiem nie rozumiemy zdania następującego: Systematyka ,wskazuje całokształt zabiegów metodycznych koniecznych dla przywrócenia źródłu jego właściwej wymowy hermeneutycznej” (48). Bo cóż

${ }^{26}$ Referuje je również B. Miśkiewicz i odnosi się do nich krytycznie jako do zbyt skomplikowanych, o. c., s. 48-52; zaś podziały Lelewela i Handelsmana ,muszą [...] ustąpić postępowi metodologicznemu nauki historycznej drugiej połowy XX w.; podział Kościałkowskiego „nie odpowiada współczesnym wymogom historiografii”, ibidem, s. 25.

${ }^{27}$ Por. niżej przyp. 35.

${ }^{28}$ Oto opinia W. Moszczeńskiej: „Jedno i to samo źródło dostarcza danych empirycznych [...] dla zbadania (poznania) wielu faktow i to wielu rozmaitych faktów historycznych. W związku $z$ tym każde źródło historyczne może i musi być rozpatrywane coraz to pod innym kątem widzenia, od innej strony. Zależnie od przedmiotu badania uwaga badacza skupia się na tych lub innych właściwościach czy cechach rzeczy, przy tej lub innej "warstwie» źródła", o. c., s. $67-68$. 
to ten nieszczęsny „całokształt zabiegów metodycznych”, co to ta „właściwa wymowa hermeneutyczna; po co klasyfikacja ma ją przywracać, skoro nie słyszeliśmy nic o tym, by ktoś źródło pozbawił tej właściwej mu wymowy hermeneutycznej.

Klasyfikacja ma zorientować badacza, a tym bardziej studenta „w olbrzymim gąszczu materiału źródłowego" (14); ma znaczenie „dla samej techniki badań historycznych" (11); ma być dobra z punktu widzenia praktyki badawczej (47); „obok walorów ściśle poznawczych ma również walor dydaktyczny" (48). Labuda chce zatem osiągnąć od razu dwa cele: naukowy i dydaktyczny. Zresztą, jego zdaniem, ,systematyka praktyczna żadną miara nie może być przeciwstawiona systematyce naukowej" (11). Temu wymogowi czyni zadość jego systematyka, „która odpowiada zasadniczemu celowi badań historycznych, tj. odtworzeniu rozwoju społecznego" (47), a równocześnie posiada walor dydaktyczny ${ }^{29}$, jest przydatna dla praktyki dydaktycznej (47).

Celem klasyfikacji jest wskazanie, jakie grupy źródeł wchodzą w grę przy rozwiązywaniu poszczególnych zagadnień $(47)^{30}$, a więc - sądzimy - dla badań nad stosunkami ludnościowymi należy się uciec do źródel demograficznych, dla studiów nad rodziną - do źródeł familijnych, dla badań nad państwem - do źródel urzędowych. Na to możemy się zgodzić, choć nie bez pewnych wahan' ${ }^{31}$.

Ale nie podpiszemy się pod następującymi zdaniami: ,Tylko taka klasyfikacja zda egzamin, która [...] poinformuje nas [...], jaka jest wartość - z grubsza biorąc - każdego źródła dla omawianej kwestii" (47); klasyfikacji dokonujemy „w celu lepszej oceny wartości i użyteczności źródła w badaniu” $\left(10^{25}\right)$, czy też, że klasyfikacja „pozwala mu [badaczowi] ocenić stopień subiektywności i klasowe zabarwienie treści źródła" (48). Stanowczo nie! Do źródeł demograficznych zaliczymy spis ludności przeprowadzony najnowocześniejszymi metodami statystycznymi, jak i dawne rejestry parafialne chrztów i zgonów, czy też zestawienia ludności całkiem fałszywe, bo wykazujące martwe dusze. Wartość źródła dla badań nad daną kwestią (47) bynajmniej nie wyniknie $\mathrm{z}$ szufladki, do której je zaliczymy. $\mathrm{Z}$ zaszufladkowania źródła nie wyniknie też ani stopień jego subiektywności, ani klasowe zabarwienie treści. Szufladka: źródła demograficzne zawrze wszystkie

${ }^{29} \mathrm{Na}$ stronie 48 uwagi, na czym ten walor polega; na s. 4 mowa o punkcie widzenia przydatności praktycznej.

${ }^{30} \mathrm{Tę} \mathrm{samą} \mathrm{myśl} \mathrm{zawiera} \mathrm{prawdopodobnie} \mathrm{i} \mathrm{następująca} \mathrm{wypowiedź} \mathrm{Autora:} \mathrm{klasyfikacja}$ ma nas uczyć „o hierarchii wartości i przydatności źródeł w procesie badawczym” (14).

${ }^{31} \mathrm{Nie}$ bardzośmy przekonani zdaniem o roli systematyk dla prac badawczych! Praktycznie historyk, szukając czegoś, nie zagląda do klasyfikacji historycznych, lecz do bibliografii ogólnych czy, najchętniej, specjalistycznych. Orientacje w źródłach zapewnią mu dzieła w rodzaju Historii źródel dawnego prawa polskiego S. Kutrzeby czy przegląd ważniejszych typów żródeł w W. Kuli, Problemy i metody historii gospodarczej, Warszawa 1963, s. 121-171. 
materiały dla demografii historycznej, najlepsze, średnie i złe, nawet oczywiste falsyfikaty. Wyróżnienie tego, co wartościowe, a co bez wartości, przeprowadzi dopiero krytyka! Tę też chyba myśl wypowiada sam Labuda, gdy stwierdza, że dokonanie selekcji źródeł zostaje umożliwione dopiero przez „stanięcie na gruncie konkretnego zagadnienia historycznego" (48). Dlaczego aż tyle żądać od klasyfikacji? ${ }^{32}$ Czy ona sprosta tylu wymogom naraz?

Zacytujemy najpierw zdania, których treści nie bardzo rozumiemy: „systematyka ma nie tylko wyrastać z warsztatu historyka, ale równocześnie celowo i praktycznie ten warsztat organizować" (47), struktura podziału źródeł ma być adekwatna do struktury procesu historycznego (47).

Wyraźna już wypowiedź Autora, gdy wymaga, by podział był konsekwentny ,zarówno z logicznego, jak i psychologicznego punktu widzenia" (11), by był zgodny z logiką (9), „logicznie zwarty” $(14)^{33}$. Nie będzie nim taki podział, w którym ,jedne i te same źródła (list, dokument, rękodzieło, rzeźba itp.) ukazują się po obu stronach linii dzielącej” (9). Nie mogą to być tylko ogólniki (14). - Na te wszystkie wypowiedzi zgodzimy się chyba wszyscy. Ale, dodajmy, nie stanowią one znowu żadnej rewelacji naukowej. A przy tym - stwierdźmy to uprzedzając swoje wywody - wymogowi rozłączności podział Labudy nie odpowiada w stopniu nawet minimalnym!

\section{7}

Dla logiki tradycyjnej kluczem wszelkich podziałów jest kryterium, zasada klasyfikacji. $Z$ pewnością nie jest sformułowaniem zasady podziału definicja źródła historycznego - stwierdźmy za Giedyminem ${ }^{34}$. Zależnie od kryterium spożytkowanego można podzielić źródła na kilka rodzajów ${ }^{35}$.

${ }^{32}$ Przyznajemy, że bardziej odpowiada nam takie rozumienie celu klasylikacji, jakie proponuje S. Borowski. Przede wszystkim przeprowadza ja w celach porządkowych oraz w celu informowania korzystającego o genezie ż́ódła, o środkach technicznych, które należałoby zastosować, aby z nich korzystać, itp. Charakter i klasyfikacja źródel historycznych, Studia Źródłoznawcze, t. 9, 1964, s. 10.

${ }^{33} \mathrm{Na}$ str. 4 pisze Labuda o poprawności względnie zwartości logicznej.

${ }^{34}$ J. Giedymin, Semantyczne problemy..., s. 189.

${ }^{35}$ M. Handelsman, Historyka, s. 44. Zdaniem S. Borowskiego, klasyfikację przeprowadzić można $\mathrm{z}$ rozmaitych punktów widzenia, formy, treści, sposobu powstania, przeznaczenia źródła, zdolności odzwierciedlania procesu historycznego, rodzaju osobliwości poznania, właściwości wnioskowania, Charakter..., s. 7, 9, 10. Przydatność podziału jest zależna od celu wytkniętego przez badacza, i dlatego nie sposób ich wyczerpać, s. 9; tamże konkretne przykłady kryteriów, s. 7-8. 
Zdaniem Labudy, istnieją dwa możliwe kryteria: 1) od strony genezy źródeł oraz 2) w zależności od ich cech formalnych i rzeczowych (26). Cechy formalne - to cechy czasowo-przestrzenne (6); cechy rzeczowe dyktowane są przez samą treść źródła (6), tkwiq̨ immanentnie w źródle (26).

Dotychczasowa systematyka, jak stwierdza Autor, „wyrosła na gruncie metody genetycznej" (6); dotychczasowe podziały posługiwały się kryteriami formalnymi i rzeczowymi (6). A tymczasem - wiemy już - były to podziały złe! „Z pola dyskusji musimy usunąć podział oparty o kryteria rzeczowe” (16). „Ludzą się [...] ci systematycy, którzy wychodząc już to z cech formalnych, już to $z$ cech immanentnie tkwiących $w$ rzeczach, chcieliby stworzyć taki podział źródel, w którym by jedno źródło odstawało w sposób idealny od drugiego" $(14)^{36}$. I dlatego ,można ostatecznie zarzucić próbę klasyfikowania źródel, wychodząc (ą?) z punktu widzenia kryteriów formalnych lub rzeczowych" $(27)^{37}$.

Podział dokonany tylko od strony form a $\mathrm{ln}$ ej nie może dać dostatecznej podstawy dla rzeczowego podziału całokształtu źródeł $\left(17^{51}\right)$. To rzecz

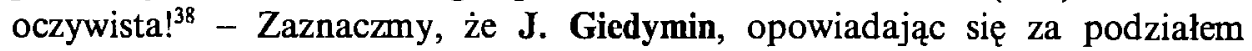
Bernheima, konstatuje, że doskonale da się zbudować poprawne podziały źródel $w$ oparciu o cechy formalne ${ }^{39}$.

Jeśli prof. Labuda odrzuca podział oparty na genezie źródeł, jeśli nie uznaje podziału opartego o formę (tu zalicza podziały chronologiczne i terytorialne) czy systematyki opierającej się na stronie rzeczowej, to jakież proponuje on własne kryterium? Czy nie zapędził się on w jakiś ślepy zaułek? Czytelnik z ciekawością tym bardziej zaostrzoną czeka na takie idealne kryterium, prowadzące do podziału, który zrealizuje cel badawczy i dydaktyczny jednocześnie, doprowadzi do zrozumienia istoty źródła, będzie wyrastał $\mathrm{z}$ warsztatu historyka $\mathrm{i}$ ten warsztat organizowal, będzie wychodził $\mathrm{z}$ cech źródłom immanentnie właściwych, czyli niejako $\mathrm{z}$ wnętrza; kryterium to nie będzie jednocześnie kryterium formalnym. - I tu spotka go zawód.

Przytoczmy najpierw zdania, z którymi nie bardzo wiemy, co począć. Kryterium podziału znajduje Labuda stając ,na gruncie żywego procesu

${ }^{36}$ To zdanie cytuje i nie zgadza się z nim już J. Giedymin, Semantyczne problemy..., s. 194.

${ }^{37}$ Ob. też s. $28,16,47^{135}$.

${ }^{38}$ Jakimś nieporozumieniem wydaje się następująca wypowiedź Labudy: dawniejsi systematycy „obojętnie, czy opierali się na kryteriach formalnych, czy na kryteriach przynależności rzeczowej, usiłowali przeprowadzić klasyfikację, wychodzącą $\mathrm{z}$ cech źródłom immanentnie właściwych, czyli niejako od wnętrza" (47). Wynikałoby z niej, że zarówno formaliści, jak i realiści posługiwali się identycznym kryterium. Równocześnie Labudę dziwi rozbieżność między podziałami formalnymi i rzeczowymi (13-14); nam się to wydaje rzeczą naturalną. Nie przypiszemy też większego sensu tezie, że uwzględnienie jednej tylko strony źródła, już to rzeczowej, już to formalnej, doprowadziło do niezrozumienia istoty źródła (19).

${ }^{39}$ J. Giedymin, o. c., s. 194. Tymczasem według B. Miśkiewicza, oparcie systematyki na założeniach formalnych nie pozwoliło przeprowadzić jasnej klasyfikacji źódel, o. c., s. 51. 
historycznego" $\left(47^{135}\right)$; a na innym miejscu ,same fakty i żywa praktyka badawcza" zostaja przeciwstawione logicznemu rezultatowi dotychczasowych systemów ${ }^{40}$.

Dalej idą już wypowiedzi, których myśl wydaje się nam jasna. Prof. Labuda ,wychodzi z założenia, że porządek do różnych, zmiennych w czasie i przestrzeni typów i rodzajów źródeł, może być wniesiony tylko z zewnątrz" (47). Do analizy nadaje się tylko podzial zbudowany na zasadach formalnych (16); one to moga dać ,jednolitą podstawe zaszeregowania" (16). I niżej: „I dlatego przy [...] klasyfikacji źródel możemy się z pożytkiem posłużyć cechami formalnymi, przyjętymi w dotychczasowych podziałach jako kryterium pomocnicze podziału" (28). Wobec tego ,jako podstawową cechę różnicującą źródła wprowadziliśmy kryterium formalne” (45). Dlaczegóż więc tyle zarzutów pod adresem poprzedników-formalistów? Tym więcej, gdy postępowali logicznie!

Zapoznawszy się z ostatnimi wypowiedziami, czytelnik jest przekonany, że podział Labudy będzie podziałem formalnym. Niech nie ma co do tego najmniejszych złudzeń! Według innej wypowiedzi Labudy, na właściwą drogę naprowadzi nas „genetyczny punkt widzenia, tj. sposób powstawania źródel" (27). Jakież więc ostatecznie stosuje Labuda kryterium, formalne czy genetyczne? Ani jedno, ani drugie! Okazuje się bowiem, że punkt ciężkości klasyfikacji przeniósł się u niego z pytania „do jakiego rodzaju źródeł należy dany zabytek" na pytanie: „o czym dany zabytek mówi” (28). Ależ to kryterium materialne, od którego też się prof. Labuda tak odrzekał!

A może tak należy rozumieć stanowisko Autora: dotychczas stosowane kryteria formalne, materialne i genetyczne były zle, bo stosowano je alternatywnie. Labudy fundamentum divisionis polega na tym, że je wszystkie stosuje równocześnie ${ }^{41}$. Ale czy pozostaje wówczas w zgodzie $\mathrm{z}$ wymogami logiki?

Zło dotychczasowych podziałów polegało na tym, że operowały one kryteriami dwudzielnymi (26) ${ }^{42}$. Tymczasem ,u podstaw podziału dwudzielnego leży koncepcja o zasadniczym przedziale między światem ducha i materii, mianowicie, że istnieją one niezależnie, osobno" (17). - Nie wydaje się nam ta obserwacja trafna. - Labuda wprowadza podział trójdzielny, uzasadniając go następująco.

\footnotetext{
${ }^{40}$ Podkreślmy: były one logiczne!

${ }^{41}$ Również według S. Borowskiego klasyfikacja Labudy oparta jest na kombinacji kryteriów formalnych i rzeczowych, o.c., s. 11 .

${ }^{42}$ Autor zapomnial, że nie wszystkie: przytaczany przezeń podział Droysena jest trójdzielny (6), co go zresztą też w oczach Labudy nie ratuje. Co więcej, E. Bernheim, twórca dwudzielnego podziału, Lehrbuch der historischen Methode und der Geschichtsphilosophie, 3. u. 4. Aufl., Leipzig 1903, s. 230-234, w później wydanym Einleitung in die Geschichtswissenschaft, Leipzig 1905, znanym prof. Labudzie, wyróżnia już trzy rodzaje żródel: 1. Unmittelbare Beobachtung und Erinnerung, 2. Berichte (Tradition), 3. Überreste.
} 
Istnieją trzy płaszczyzny, płaszczyzna stosunków ekonomicznych, płaszczyzna stosunków społecznych i płaszczyzna ideologiczna $(19)^{43}$. „W każdym bowiem źródle są reprezentowane zarówno pierwiastki fizyczne (tj. materialne), jak psychiczne (tj. świadomość) i społeczne (tj. rezultaty oddziaływania człowieka na człowieka w procesie produkcji i współżycia)” (26); „nie wystarczy pod stronę psychiczną podstawić proporcjonalną równowartość fizyczną, ale że w każdym wypadku należy jeszcze podstawić ich proporcjonalną równowartość społeczną" ${ }^{44}$. Innymi słowy: w każdym źródle występują trzy cechy: materialna, psychiczna ${ }^{45}$ i społeczna (polityczna) $(18)^{46}$. Wszakże ilość tych elementów w każdym źródle jest „w innej niejako proporcji" (19); jedne odgrywaja rolę glówną, inne - pomocniczą (27-28) ${ }^{47}$. Podstawą klasyfikacji będzie to, który czynnik wywarł "decydujący wpływ na powstanie źródła” (19), „współczynnik techniczny i intelektualny” (26) czy społeczny (26). Jeśli bowiem, ,nie może być źródła, które by nie odbijało całokształtu procesu historycznego" (27), to nie każde źródło „odbija poszczególne płaszczyzny z jednakową intensywnością" (48). Konkretny proces historyczny „,w płaszczyźnie stosunków ekonomicznych będzie tworzył przede wszystkim źródła o dominującej zawartości elementów fizycznych" (19).

Oto kryterium, które Labuda znalazł ,na gruncie żywego procesu historycznego" $\left(47^{135}\right)$. W wyniku jego stosowania ukazuje się nam podział źródeł na trzy kategorie (Labuda pisze też: „trzy grupy odśrodkowe całoksztaltu źródel” (18)): źródła ergotechniczne, źródła psychotechniczne i źródła socjotechniczne.

Jedno jest pewne przy ocenie tej klasyfikacji: zasady rozłączności nie respektuje ona zupełnie. Wszystkie bowiem źródła są i materialne, i spoleczne, i psychiczne, tym samym wszystkie bez wyjątku należą równocześnie do każdej $\mathrm{z}$ trzech wspomnianych szufladek.

Skoro te same cechy występują we wszystkich źródłach, wyróżnienie kategorii nastąpi $w$ zależności od stopnia intensywności występowania tychże cech. Ale - zapytamy - jak go wymierzyć? Autor stwierdza: „System dwudzielny zawodził dlatego, że nie dało się wykazać, gdzie w poszczególnych grupach źródeł kończy się element fizyczny, a gdzie zaczyna psychiczny" $\left(27^{76}\right)$.

${ }^{43} \mathrm{Na}$ s. 27. wymienia Autor cztery "wspólczynniki procesu historycznego", które są zaangażowane $w$ wytworzeniu źódeł: gospodarczy, społeczny, polityczny $\mathrm{i}$ kulturalny.

${ }^{44}$ Zauważmy, że ostatni element, społeczny, awansował na s. 21 do rzędu podstawowej cechy żródeł.

${ }^{45}$ "Ladunek treści psychicznej" - pisze Autor (15).

46 Oto dalsze wypowiedzi Labudy na ten temat: „Na żadnym etapie swego rozwoju wytwór lub myśl nie może zatracić swego charakteru społecznego" (21); „odblask tego oddziaływania świadomości znajdziemy w źródłach socjotechnicznych" (44). - O źródłach psychicznych i fizycznych por. J. Giedymin, o. c., s. 193.

${ }^{47} \mathrm{Na}$ przykład ,udział świadomości przebija się plastyczniej poprzez źródła ergotechniczne" (44). 
Prawda, system trójdzielny jest bardziej skomplikowany niż dwudzielny $\left(27,27^{76}\right)$. Ale ,teoretycznie biorąc, jest rzeczą możliwą podjąć się ustalenia, $\mathrm{w}$ jakiej proporcji ( $\mathrm{w}$ jakim ilorazie) każda $\mathrm{z}$ wymienionych stron działalności ludzkiej jest zaangażowana w wytworzeniu źródła" (26). Zapewnia nas też Autor, że na podanych przez siebie przykładach pokazał, jak ,z grubsza biorąc, rozróżnienie takie daje pewne wyniki" (26). Tutaj musimy zaoponować. Artykuł przeczytaliśmy uważnie, a nie znaleźliśmy tak niezbędnej ilustracji. Zresztą tego zapewnienia Labudy nie wolno brać całkiem na serio. Autor bowiem zaraz niżej stwierdza: „Jednakże powyższe rozróżnienie [trzech stron: materialnej, psychicznej i społecznej] ma wartość wyłącznie analityczną i nie dało by sięzastosować w klasyfikacji syntetycznej" (26). Tenże badacz na następnej stronie swego ciekawego artykułu pisze: „rozróżnienie ich [elementów przenikających poszczególne źródła] od siebie, nawet $\mathrm{z}$ grubsza biorąc nie jest możliwe" $\left(27^{76}\right)^{48}$.

Czytelnika ogarnia zdumienie. Jak to, Autor wydrukował artykuł, nie zdecydowawszy się na wybór jednej alternatywy? Jeśli rzeczywiście - jak nas Labuda o tym zapewnia - nie da się wydzielić tych elementów nawet „Z grubsza”, to w ogóle na tej podstawie nie można dokonywać systematyzacji źródele ${ }^{49}$. I tak też $w$ istocie jest.

Na tym moglibyśmy zamknąć swoje wywody. Prof. Labuda wywrócił sam swoje fundamentum. Ale wykażmy mu maksimum dobrej woli. Przyjmijmy za nim alternatywę pierwszą: potrafimy wymierzyć ,intensywność poszczególnych płaszczyzn" ${ }^{30}$. Rozpatrzmy praktyczne trudności tej ewentualności.

Gdzie zaszufladkujemy źródło, w którym ładunek poszczególnych elementów wystąpi w 33 i 1/3\%? Gdzie zaliczymy źródło, w którym dwa elementy są równe $(45 \%+45 \%+10 \%)$ ? Daremnie szukamy odpowiedzi na te pytania $w$ artykule.

Spróbujmy scharakteryzować proponowaną przez Labudę klasyfikację. Skłonniśmy uznać ją za genetyczną, przy swoistym zresztą rozumieniu genezy źródła. Ostatecznie nie upieramy się przy tym sądzie. Być może, jest to podział rzeczowy, bo dzieli ze względu na elementy, które każde źródło w sobie zawiera ${ }^{51}$. Prof. Labuda utrzymuje, że wprowadził kryterium formalne, „wyrażające się $w$ pośredniości lub bezpośredniości odbijania procesu historycznego" (45). Niech to zatem będzie klasyfikacja genetyczno-materialno-formalna!

${ }^{48}$ Por. własne obawy Autora co do proponowanego przezeń podziału trójdzielnego (15).

${ }^{49}$ Por. też następującą wypowiedż: „Cechy psychofizyczne i społeczne żródła [...] nie potrafiły jednak dać podstawy klasyfikacji źródel" (27).

${ }^{\text {so }}$ Pomijamy tu jeden szkopul: zdaniem Labudy, „bezustannie ulega zmianie wspólczynnik społeczny każdego faktu historycznego, a z kolei również źxódła" (27).

${ }^{51}$ Por. tu rubrykę tabelki na s. 46: „zawartość, czyli treść źródła historycznego". 
Ale ostatni cytat stanowi dla czytelnika zaskoczenie. Dotąd słyszeliśmy - i tak też rozumiemy tabelkę prof. Labudy na s. 46 - że źródła podzielono ze względu na elementy, które je przenikaja w większym czy mniejszym stopniu, co daje formy: dominującą (materialną, psychiczną i spoleczną) obok wspóldziałającej (materialno-społeczną, materialno-psychiczną i społeczno-psychiczna). $Z$ podanego cytatu wynika, że Labuda stosuje - za dawniejszą literatura $\mathrm{q}^{52}$ - kryterium odbijania pośredniego i bezpośredniego ${ }^{53}$. Czyżby te podziały miały $\mathrm{z}$ sobą się pokrywać? Ale czy to $\mathrm{w}$ ogóle możliwe, żeby podzial trójdzielny (źródła ergo-, socjo- i psychotechniczne) nachodził jakoś na podzial dwudzielny (źródła bezpośrednie i pośrednie)? Labuda trudności nie widzi żadnych, skoro pisze: „decydujemy się na utrzymanie terminów: pośredni i bezpośredni na określenie sposobu odbijania strony materialnej, spolecznej i psychicznej źródła" (28). A więc źródła socjotechniczne odbijają całość procesów w sposób bezpośredni (33), źródla urzędowe - działalność władzy w sposób bezpośredni (39), a źródła ergotechniczne odbijają bezpośrednio stronę gospodarczą produkcji (34), a pośrednio stronę społeczną i psychiczną $(31,39)$.

Być może dla Labudy bezpośredniość oznacza formę dominującą, a pośredniość - formę współdziałającą ${ }^{54}$; ale zapytamy wówczas, po co dublować terminy. Wszakże tego rozumienia nie jesteśmy całkiem pewni. Bo jak z nim zgodzić inną wypowiedź Autora: „W zjawiskach nadbudowy źródła pośrednie z istoty rzeczy odgrywają główną rolę" (38). Albo taki zarzut, robiony Handelsmanowi, że podzielił źródla na pisane - pośrednie i niepisane - bezpośrednie: „nie może być źródel pośrednich lub bezpośrednich [...] Wszystkie źródła [...] muszą być w jakiś sposób bezpośrednio związane z procesem historycznym” $\left(14^{43}\right)$, przy czym Labuda dodaje: „W tym wypadku słuszniej byłoby powiedzieć, że są źródła pośrednio lub bezpośrednio odbijające poszczególne płaszczyzny procesu historycznego" $\left(14^{43}\right)^{55}$. Nie chcąc nużyć czytelnika, nie będziemy powolywać zgromadzonych dalszych wypowiedzi Autora na ten temat. Przyznajemy wszakże: sensu tego konglomeratu zdań nie byliśmy $w$ stanie przeniknąć. Jeśli mieliśmy wyżej kłopot z owym ,ilorazem" wprowadzonym przez Labudę jako fundamentum divisionis, to rzecz tę Autor jeszcze bardziej komplikuje: iloraz ten będzie różny $w$ stosunku do tego samego źródła, w zależności od tego, czy rozpatrujemy źródło bezpośrednio, czy pośrednio. Jak te wszystkie trudności rozwikłać?

${ }^{52}$ Zreszlą rozumiała ona tę bezpośredniość i pośredniość inaczej niż Labuda, np. M. Handelsman, Historyka, s. 44-45.

${ }^{53}$ J. Giedymin, Semantyczne problemy..., s. 193-194.

${ }^{54}$ Tak by wynikało $\mathrm{z}$ wypowiedzi na s. 39 .

ss Mimo tych zastrzeżeń posługuje się sam wyrażeniami: żródła bezpośrednie (34), żródła pośrednie (38). 
Zauważmy, że obok podziału Labudy na trzy kategorie (źródła ergo-, psycho- i socjotechniczne) oraz podziału na dwie kategorie (źródła bezpośrednie $\mathrm{i}$ pośrednie), zarysowują się $\mathrm{w}$ wywodach Labudy inne jeszcze klasyfikacje: dwie dwudzielne oraz jedna czworodzielna. Pierwsza dwudzielna polega na wyróżnieniu 1) podstawowych zespołów oraz 2) takich źródel, „które w gruncie rzeczy nie odgrywają w badaniu historycznym większej roli" $(12)^{56}$. Druga - na podziale źródel na pisane i niepisane ${ }^{57}$.

A tak wygląda jego systematyka czworodzielna: „1) Istnieją więc źródła, które bezpośrednio odbijają rozwój sił wytwórczych (szerzej: stosunków gospodarczych), a pośrednio bazę i nadbudowę; 2) źródła, odbijające bezpośrednio stosunki produkcji (szerzej: stosunki spoleczne), a pośrednio siły wytwórcze i nadbudowę. 3) Są dalej źródła, odbijające bezpośrednio stosunki polityczne, a pośrednio stosunki społeczno-ekonomiczne i kulturalne. 4) Są wreszcie źródła, które odbijaja przede wszystkim poglądy społeczeństwa, a pośrednio stosunki polityczne i całą bazę" (28).

Jeśli w tych warunkach Autor pisze o sobie: „Dowiedliśmy bezspornie, że tradycyjny schemat podziału źródel nie wytrzymuje próby krytyki i musi chyba ustąić nowemu, który na jego miejsce należy zbudować. Podział ten do pewnego stopnia zarysowal się nam na gruncie krytyki dotychczasowych systemów" (19); jeśli Labuda utrzymuje, że jego klasyfikacja „orientuje [...] badacza od razu w środowisku, w którym źródło powstało, pozwala mu ocenić stopień subiektywności i klasowe zabarwienie treści źródła" (48), to jest to czcza przechwałka, której na serio wziąć nie sposób.

Ale nie pomijamy i nuty autokrytycznej Autora. Nie uznaje on swego podziału za doskonały, albowiem wymyka się $\mathrm{z}$ niego jedna kategoria źródel - tradycja (45).

Syntezą długich i często niejasnych, niestety, wywodów jest tabelka, umieszczona na s. 38. Przedstawia ona "calość naszych [Autora] poglądów na podział źródeł historycznych" $(45)^{58}$. Zanalizujmy ją uważnie.

Stwierdźmy od razu, że bez żadnej szkody możemy usunąć z niej rubrykę 3., "nazwa źródła historycznego". Jest rzeczą oczywistą, że klasyfikując jakieś przedmioty, posługujemy się ich nazwami. Jakżeż moglibyśmy postępować inaczej? Toż i zoolog, systematyzujący swoje zwierzęta, poshuguje się ich nazwami.

s6 Wniosek z zarzutu robionego Kayserowi.

57 Por. niżej ustęp 9.

ss Co prawda wedhu L. tabelka jego ma charakter analityczny (45), co zresztą nie przeszkadza mu pisać równocześnie o monistycznym charakterze źródeł „,w ujęciu syntetycznym" (45). 
Zaglądając do tabelki, jesteśmy przygotowani na to, że - zgodnie z zapowiedzią - Autor zawrze w niej wyniki swych dociekań. A tak bynajmniej nie jest. Istnieją $w$ niej rzeczy, których nie ma $w$ tekście; $\mathrm{z}$ drugiej strony brak w niej rezultatów osiągniętych w toku wywodów Labudy.

Tabelka dzieli źródła najogólniej na dwie klasy: nadające się do podziału (rubryka 1), którym przeciwstawione zostają źródła będące syntezą (rubryka 8). Mniemamy, że Labuda tę drugą klasę uznaje za nienadająca się do podziah, skoro jej faktycznie nie dzieli. Można by też sądzić, ze pierwsza klasa źródeł obejmuje źródła nie będące syntezą. Źródłem-syntezą - jak wiemy - jest według Labudy tradycja, czyli żywy czlowiek. Przyznajemy ponownie, że $\mathrm{i} w$ tym kontekście nie rozumiemy $\mathrm{z}$ tego nic. Do pierwszej klasy należą „pozostałości po człowieku”. Ale czyżby tradycja nią nie była?

Być może, źle odczytujemy i interpretujemy tabelkę. Labuda bowiem wie, że i tradycję można dzielić (46). Przy tych wątpliwościach chcielibyśmy poznać kryterium tego podziału, ale daremnie szukamy go w tekście. Tym bardziej umacniamy się w przekonaniu, że nie jest to podzial adekwatny i rozlączny. A brak tych cech wytykal Labuda swym poprzednikom ${ }^{59}$.

Tabela zatem zajmuje się tylko pierwszą kategorią źródeł - tymi, które nadają się do podziału, źródłami historycznymi sensu strictiori, przeciwstawionymi tradycji (47). Możemy więc spokojnie usunąć z dalszych rozważań rubrykę 8. Ale zanim to zrobimy, zanotujmy jeszcze, ze rubryka 7. nie do niej się odnosi, jakby można mniemać z jej pozycji (tak jak rubryka 2 . dotyczy następujących po niej kolumn 4., 5., 6.), lecz również do tych samych rubryk 4,5 i 6.

Pierwsza klasa, źródła sensu strictiori, podzielona została według złożonego kryterium formy dominującej (rubryka 2) i formy współdziałającej (rubryka 7). Żeby wlać treść $w$ to określenie: forma dominująca - zakładamy, że zachodzi ona tam, gdzie pierwiastek dominujący przekracza $50 \%$ wszystkich elementów, bo wtedy tylko dominuje nad innymi wspóldziałającymi formami ${ }^{60}$. W rezultacie tych rozważań wystąpią następujące możliwe kombinacje tych form: trzy formy dominujące (materialna, spoleczna i psychiczna) oraz trzy formy współdziałające (społeczno-psychiczna, materialno-psychiczna i materialno-społeczna). Związek między tymi formami jest stały. Formie dominującej materialnej odpowiada zawsze forma współdziałająca społeczno-psychiczna, dominującej społecznej - współdziałająca materialno-psychiczna, a dominującej psychicznej - współdziałająca - materialno-spoleczna.

\footnotetext{
${ }^{59}$ Por. J. Giedymin, Semantyczne problemy..., s. 185.

${ }^{60}$ Por. jednak zastrzeżenie poczynione wyżej, ustęp 7.
} 


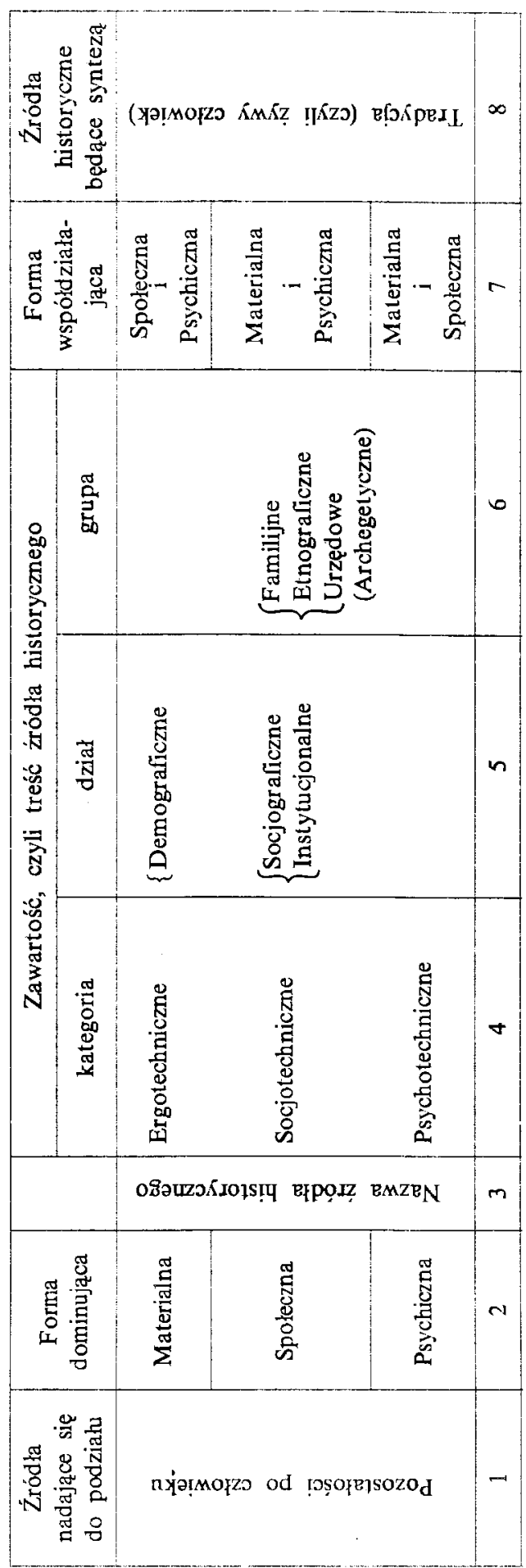


Pragnę zaznaczyć, że w reprodukowanej tu tabelce ścieśniliśmy umyślnie rubryke ,zawartość, czyli treść źródła historycznego" do działu i grupy (rubryki 5-6), nie odnosimy zaś jej do kategorii (rubryki 4), jak to się dzieje w oryginale. Nie możemy bowiem dzielić równocześnie źródel i ze względu na formę, i ze względu na treść. Podział według kilku zasad jest bowiem metodologicznie błędny ${ }^{61}$; logicy nazywają go też mętnym ${ }^{62}$.

Wyjaśniamy jeszcze, że nie protestujemy przeciwko stosowaniu przy systematyzacji źródeł paru kryteriów. Co więcej, z reguły każda systematyka posługuje się wielu kryteriami i posługiwać się nimi musi. Atoli nie może się to dziać jednocześnie: te kryteria odmienne wystąpią przy różnych stopniach klasyfikacji ${ }^{63}$.

Podział zatem Labudy ze względu na ,iloraz”, w oparciu o kryterium formy dominująco-współdziałającej, doprowadzil do wyróżnienia trzech kategorii źródel: ergotechnicznych, socjotechnicznych i psychotechnicznych. Te kategorie dzielą się na podgrupy zwane przez Labudę działami. Co prawda nie wszystkie kategorie uległy temu dalszemu podziałowi; nie uległy mu mianowicie źródła psychotechniczne. Czyżby te kategorie źródeł, ,przy których powstaniu świadomość ludzka odgrywa decydująca rolę" (40), nie nadawały się do dalszej klasyfikacji?

W rubryce „dział” pojawiają się źródła ergotechniczne i socjotechniczne. Pierwsze podzielono na demograficzne i ... nie wiadomo co! Czyżby należało wnosić, że źródla demograficzne wyczerpują całą kategorię źródel ergotechnicznych? Chyba nie tak rzecz Autor rozumie, skoro obie pozycje występuja w różnych kolumnach (4. i 5.). Rzeczywiście okazuje się, że ta luka tabelki powstała przez jakieś niedopatrzenie; możemy ją uzupełnić w oparciu o dane tekstu ${ }^{64}$. Labuda wydziela tam wśród źródeł ergotechnicznych ,te wszystkie zabytki i pozostałości, które odbijają nam bezpośrednio proces produkcji”"65, oraz ,źródla, w których odzwierciedla się proces rozrostu ludnościowego" (31). Pierwsze podzielić można na takie, które odbijają bezpośrednio kulturę materialną, i na takie, których podstawową cechą ,jest pośredni sposób ich przekazania” (31). Z kolei wyróżniono wśród źródeł bezpośrednich kultury materialnej dwa rodzaje: (a) takie, które tworzy produkcja główna „skierowana na zaspokojenie materialnych potrzeb człowieka dla podtrzymania życia ludzkiego na ziemi”, oraz (b) „uboczna

${ }^{61}$ S. Kaczorowski, O niektórych przeksztalceniach podzialu, Lódż 1949, s. 86.

${ }^{52}$ Ibidem, s. 77.

${ }^{63}$ Weźmy choćby na przykład znane klasylikacje zoologów czy botaników. Stąd zasadnie nazywa T. Kotarbiński klasyfikacje spiętrzonymi podziałami logicznymi, Treść i zakres pojecia metodologii, Elementy... wyd. 2, s. 519 (pierwodruk 1956).

${ }^{4}$ Charakterystyczne, że nie dostrzegł tej możliwości B. Miśkiewicz, lecz zostawił w swym podręczniku podział kaleki.

${ }^{65}$ Zwie je też Autor „żródłami ergotechnicznymi, obrazującymi rozwój sił wytwórczych” (31). 
- na zaspokojenie potrzeb wynikających ze spoleczno-politycznego i kulturalnego życia ludzi"' (31).

Drugie podzielił Autor również na dwie grupy: (c) ,jedne powstały w celu zarejestrowania pewnych przejawów i osiągnięć produkcji...", (d) ,drugie stawiają sobie za zadanie opis produkcji w celu przekazania go następnym pokoleniom" (31).

Rozpatrzywszy się $w$ tym podziale, musimy wysunąć przeciwko niemu dwa zastrzeżenia. Raz, że nie wydaje się on nam całkiem jasny. Usilowaliśmy jakoś Autora zrozumieć, ale trud nasz chyba daremny. Jak np. pojąć następujące zdanie, które ma stanowić uzasadnienie dla grupy (d): „Podstawową rolę $w$ tym utrwaleniu odgrywa świadomość ludzka, która dla konkretnych powodów dokonywa takiego czy innego zjawiska $\mathrm{z}$ dziedziny sił wytwórczych i materialnych warunków bytu" (31).

Nie bardzo też wiemy, co tu robi podział na źródła odbijające bezpośrednio proces produkcji oraz takie, które to robią pośrednio ${ }^{66}$. Jeśli to ma być równoznaczne formom dominującej $\mathrm{i}$ współdziałającej, to musielibyśmy stwierdzić, że Autor zagubil się sam. W kategorii "źródla ergotechniczne” znaleźć się bowiem mogły według poprzednich założeń tylko źródła o dominującej formie materialnej (bezpośrednie).

W rezultacie, w oparciu o wywody tekstowe Autora, pozwalamy sobie zaproponować następujące uzupelnienie do tabelki prof. Labudy:

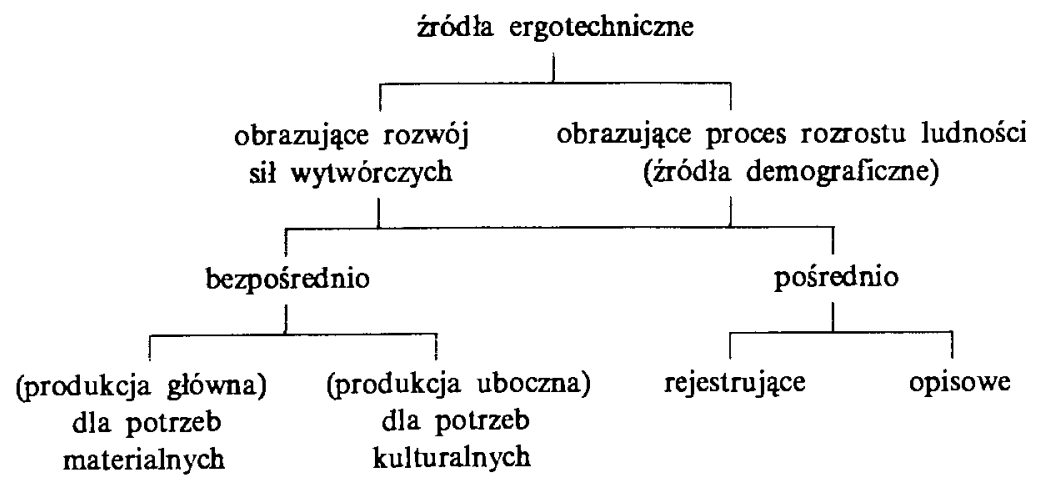

W ten sposób uzupełniliśmy tabelkę w dwóch rubrykach (dział, grupa); ostatni stopień podanego wyżej podziału wyszedl już poza ramy tejże tabelki.

Zastrzeżenie nasze wywołuje też wcielenie źródel demograficznych w całości do ergotechnicznych. Nie jesteśmy w stanie pojąć, dlaczego np. ogloszony przez nas Status animarum parafii Szubin ${ }^{67}$ tutaj ma się znaleźć, a nie w kategorii źródel socjotechnicznych.

${ }^{66}$ Zdaniem Autora, ,rozróżnienie tych dwu typów ma duże znaczenie dla pracy badawczej" (31).

${ }^{67}$ Spis ludności parafii Szubin z $1766 r$., wyd. J. Matuszewski, Studia i Materiały do dziejów Wielkopolski i Pomorza, t. 6, 1960, s. 398-443. 
Źródła socjotechniczne ze względu na treść dzielą się na socjograficzne $\mathrm{i}$ instytucjonalne. Ale jakie tu fundamentum divisionis? Posłuchajmy wypowiedzi Autora: „W obu rodzajach źródeł [socjograficznych i instytucjonalnych] chodzi o wyrażenie treści społecznej przy pomocy czynników działających z płaszczyzny rozwoju sił wytwórczych lub z plaszczyzny świadomości" $(32-33)^{68}$. I dalej: „między źródłami spolecznymi a instytucjonalnymi jest różnica treściowa [jaka?!], ale nie doszukamy się różnicy formalnej" (32). A wreszcie definicja: „Źródłami socjograficznymi nazwiemy takie źródła, które odzwierciedlają bezpośrednio nie tylko ulegające ustawicznej zmianie w toku społecznego podziału pracy stosunki produkcji między ludźmi, lecz także formy wzajemnego współżycia $w$ toku kształtowania się różnego rodzaju wspólnot ekonomicznych, społecznych (rodzinnych), narodowościowych, ideologicznych i innych". „Źródłami instytucjonalnymi zaś takie, które tę samą rolę spełniają wobec instytucji życia społecznego" (34). Przyznajemy: wyraźnej zasady podziału nie widzimy w dalszym ciągu; w obydwu działach znalazły się instytucje spoleczne!

Przechodzimy do dalszej klasyfikacji działów na grupy. Znowu dokonuje jej Autor ze względu na treść, ale jaką? Domyślamy się, że inną niż w rubryce: kategoria. Wedlug tabelki, w ostatniej rubryce (grupie) znalazly się tylko źródła instytucjonalne. Zgodnie $\mathrm{z}$ naszym uzupełnieniem - także źródla obrazujące rozwój sił wytwórczych. Możemy więc zapytać, dlaczego nie uległy podziałowi źródła demograficzne i socjograficzne. Przecież według określenia prof. Labudy wszystko to źródła nadające się do podziału!

Źródła instytucjonalne dzielą się na familijne (dotyczące rodziny), etnograficzne (dotyczące narodu) i urzędowe (dotyczące państwa). Jaka tu zasada podziału? Dlaczego ona tak zaszyfrowana? Trudność dodatkową widzimy jeszcze $w$ tym, że chodzi nam o czasy dawne, kiedy to niełatwo historykowi wyróżnić dokładnie takie instytucje, jak: rodzina, ród, plemię, szczep, państwo, a cóż dopiero naród! ${ }^{69}$ Jaką więc ten podział źródeł instytucjonalnych posiada wartość?

${ }^{68}$ Nieco niżej ujęcie następujące: „Różnicę tę (treści) wyznacza ich pochodzenie już to z płaszczyzny stosunków społecznych, już to z plaszczyzny działania instytucji” (33). Czyżby w rozumieniu Autora płaszczyzna rozwoju sil wytwórczych pokrywała się z płaszczyzną stosunków społecznych, a płaszczyzna świadomości z płaszczyzną działania instytucji?

${ }^{69}$ Autor sam podkreśla trudności w odróżnieniu rodziny i narodu (35); zaznacza też, jak etnografia radziecka śledzi „formy życia narodowego od epoki pierwotnej poprzez takie fazy rozwoju, jak ród, plemię, związek plemion, narodowość [...], naród burżuazyjny i naród socjalistyczny” (36). Równocześnie stwierdza, że „badaniem jej [rodziny] dziejów przeżytkowych zajmuje się glównie nauka etnologii, a częściowo także etnografia" (35). Jak więc wyróżniać źródła familijne od etnograficznych? A dodajmy jeszcze jedno spostrzeżenie Autora: W społeczeństwach bezklasowych ,przednarodowa forma spoleczeństwa zastępuje wielokrotnie funkcje państwa" (38). 
Klasyfikacja ta budzi przy tym jedno ostre zastrzeżenie: zaliczenie organizacji religijnych (Kościola) do instytucji niepaństwowych, wskutek czego odnośne źródla trafiły do grupy źródel etnograficznych (38). Tymczasem praktyka badawcza i dydaktyczna mówi co innego. Ostatni podręcznik państwa i prawa polskiego $w$ obydwu wydaniach poświęca niemało uwagi stanowisku Kościoła w państwie. I chyba nie bez racji! W europejskim średniowieczu Kościół właśnie stanowił najstarszą instytucję prawa publicznego: był już nią w czasie, gdy państwo podlegało jeszcze w pelni normom prawa prywatnego. A tymczasem jego dotyczące źródła nie będa urzędowymi, lecz etnograficznymi. Dlaczego Labuda tak zlekceważyl praktykę badawczą i dydaktyczną, na którą się tylekroć powoluje?

Podnieśmy wreszcie ponownie, że tabelka, która w zamierzeniach Autora przedstawiać miała całość jego poglądów na systematykę źródel historycznych, nie objęła wszystkich obserwacji poczynionych w tekście. Wyżej zwróciliśmy uwage, jak to przez niedopatrzenie, w sposób kaleki, znalazł w niej odbicie podzial źródel ergotechnicznych. Nie uwzględnia ona również podziału źródel magistratywnych na dwa rodzaje: takie, które odnoszą się do regulowania stosunków wewnętrznych, i takie, które odnoszą się do regulowania stosunków między państwami (39).

Zresztą - zanotujmy lojalnie wypowiedź samego Autora - tabelka w samym założeniu nie jest kompletna. Na przykład źródła etnograficzne ze względu na swą rozciągłość i różnorodność wymagają „osobnej i bardziej dokładnej systematyzacji i klasyfikacji" $(38)^{70}$. Etnografia dotychczasowa „nie umiała odróżnić źródel odbijających rozwój narodu w sposób bezpośredni od źródeł pośrednich" (37). Autor daje autorytatywne wskazówki, jak należy to przeprowadzić ${ }^{71}$.

\section{9}

Po tylu uwagach szczegółowych przejdźmy do oceny ogólnej "próby" prof. Labudy. Pisze on bowiem sam: „będzie rzeczą krytyki sprawdzić, czy nam się udało podołać temu zadaniu" systematyzacji źródeł historycznych $\left(47^{135}\right)$.

Opinie o tej próbie, wyrażone dotąd, są na ogól pozytywne. Klasyfikacja Labudy jest interesująca i oryginalna - pisze J. Giedymin ${ }^{72}$; jest to ważne novum $w$ metodologii i źródłoznawstwie historycznym - wyraża się

\footnotetext{
${ }^{70}$ A propos. Nie wiemy, czym w ujęciu Labudy różni się systematyzacja od klasyfikacji.

${ }^{71}$ Klasyfikacji źródeł etnograficznych „można dokonać wyłącznie z punklu widzenia tej płaszczyzny historycznej, która przyczyniła się do jego [działu źródeł etnograficznych] wytworzenia i do rekonstrukcji dziejów, której to z kolei winien on służyć" (39).

72 J. Giedymin, Semantyczne problemy..., s. 195; por. też ibidem, 193.
} 
S. Borowski ${ }^{73}$. A już w oczach ucznia Autora omawiany podział znalazł się w osobnym, końcowym rozdziale, jako ostateczne osiągnięcie metodologiczne, przy czym nie zawahano się sfotografować tabelki Labudy w tym jej surowym - jak stwierdziliśmy - stanie ${ }^{74}$. Również C. Bobińska odsyła do wywodów Labudy, nie wchodząc zresztą sama „w specjalistyczne kwestie systematyzacji źródeł"75. Najbliższa naszemu poglądowi jest W. Moszczeńska. Według niej, ,rozprawa naświetla w sposób instruktywny problem źródła jako faktu historycznego i podkreśla niejednokrotnie, choć w sposób nie zawsze dość jasny i przekonywający, wpływ zalożeń teoretycznych na ujmowanie zagadnień metodologicznych i metodycznych. Polemiczny w całości wywodów charakter może zaciemniać cokolwiek ich treść". Bardzo krytyczne stanowisko mimo częściowego (kurtuazyjnego?) akcesu zajął też A. Nadolski ${ }^{76}$.

Uwagi swoje zakończymy jeszcze jednym konkretnym zarzutem. Wiemy, że dzieło żadne nie powstaje w ciągu jednego dnia, że miesiące czy lata upływają od momentu rozpoczęcia pracy do chwili, w której autor mówi sobie: finis adest operis. Mimo to - taki jest usus naukowy - traktujemy całe dzieło za jedność, która ukazała się w oznaczonym dla publikacji roku. Wiemy też, że poglądy piszącego ewoluują $\mathrm{w}$ toku redagowania tekstu i wgłębiania się $w$ badany problem. Wszakże rzecz oddana do druku stanowi dojrzały, ostateczny pogląd autora, stanowiący wynik jego refleksji. Produkty przejściowe winny być starannie usunięte $z$ pracy. Jeśli więc dostrzegamy sprzeczności w wypowiadanych poglądach, nie liczymy tego autorowi na dobro. Przeciwnie, mówimy wówczas: autor jest niekonsekwentny; na stronie 20 mówi $a$, na stronie 46 - nie- $a$. Tego robić nie wolno. Jeśli autor nie dba o to, by w ostatecznej redakcji wszystko z sobą harmonizowało, kompromituje się. I tu leży paradoks naukowej twórczości: im rzecz dłużej pisana, starannej rozważana, tym bardziej ostateczna redakcja jest harmonijna. Brak jej dowodzi pośpiechu, ten zaś dla naukowej produkcji jest wręcz katastrofalny.

Wykazaliśmy wyżej, jak to prof. Labuda wpadł ze sobą w sprzeczność, utrzymując, że można i że nie można stwierdzić wkładu poszczególnych elementów (materialnego, społecznego i psychicznego) w wytwór, który

\footnotetext{
${ }^{73}$ S. Borowski, o. c., s. 11.

${ }^{74}$ B. Miśkiewicz, Wstẹp do badań historycznych, Poznań 1963, ustęp zatytułowany: Nowa systematyka źródel historycznych, s. 52-55.

${ }^{75}$ C. Bobińska, Historyk, fakt, metoda, Warszawa 1964, s. 69, przyp. 1.; ob. też ibidem, s. 23 , przyp. 7 ; s. 59 , przyp. 2 ; s. 61 , przyp. 4.

${ }_{76}$ W. Moszczeńska, o. c., s. 192-193; A. Nadolski, Uwagi o metodzie publikowania źródel archeologicznych, KHKM 1963, s. 585-588.
} 
nazywa źródłem ${ }^{77}$. Wywrócil tym samym glówną podstawę swego schematu. Oto następna sprzeczność tego samego rodzaju w jego wypowiedziach i podziale na źródła pisane i niepisane.

Źródła pisane „stanowią jeden z najważniejszych zespołów źródłowych" $\left(12^{36}\right)$. Stąd też podzial omawiany jest „bardziej konsekwentny i przejrzysty”, jako że ,istotnie granica między tymi dwoma rodzajami źródeł jest bardzo wyraźna" (15).

Moglibyśmy więc na podstawie zacytowanych wypowiedzi mniemać, że Labuda jest za tym podziałem. Wręcz odwrotnie! I ten podział nie jest lepszy od innych (11), jest on bowiem tylko praktyczny $(11)^{78}$; po wniknięciu w jego systematykę (?) „pokażą się nam trudności nie do przezwyciężenia z punktu widzenia naukowej klasyfikacji”' (15): jak inne źródła posiada ono (pismo) równocześnie cechy pośrednie i bezpośrednie działalności ludzkiej, tj. fizyczne i psychiczne (16), przy tym ,pismo jest nie tylko kryterium podziału, ale także historyczną rzeczywistością" $\left(17^{51}\right)$. W złożoności omawianego podziału ,wprowadzi nas najlepiej punkt widzenia genetyczny" (15); chodzi mianowicie o to, że „pismo jest zmaterializowaną mową, a jeszcze dalej wstecz - zmaterializowanym myśleniem" (16). Omawiany podział dokonany od strony formalnej $\left(17^{51}\right)$ jest na wskroś formalistyczny (15), błędny (16), albowiem istnieje ,nieodparty dialektyczny związek między źródłami... pisanymi i niepisanymi" $(17)^{79}$.

Po tych uwagach, dostatecznie dyskredytujących podział na źródła pisane i niepisane, czytelnik dochodzi do przekonania, że prof. Labuda jest jego zdecydowanym przeciwnikiem. Bynajmniej tak nie jest! „Pismo jako pozostałość związana z mową znacznie lepiej utrwala przeszłość niż jakikolwiek inny rodzaj źródeł” (41 ${ }^{124}$ ); jest ono odbiciem „,realnej rzeczywistości” (42); jest to - zgodnie z Lowmiańskim - „najważniejszy rodzaj źródel historycznych” $\left(41^{124}\right)^{80}$. Zapoznając się z piśmiennictwem w rozwoju historycznym, „możemy stosunkowo dokładnie zmierzyć stopień rozwoju świadomości na każdym etapie historii” (42). I konkluzja: ,nie znaczy to jednak, żebyśmy kwestionowali, iż istotnie źródła można podzielić na takie, które są pisane, i na takie, które sq̨ niepisane. Ten fakt jest bezsporny" $\left(17^{51}\right)$.

Co więcej, prof. Labuda dokonuje sam podziału źródeł pisanych, mimo że one ,sa niewątpliwie najtrudniejsze do posegregowania" $\left(12^{36}\right)$. Okazuje się przy tym, że ta klasyfikacja pasuje świetnie do jego podziału trójdzielnego

${ }^{77}$ Patrz wyżej ustęp 7.

${ }^{78}$ Ze to podzial nie naukowy, lecz czysto praktyczny, pisał już M. Handelsman, Historyka, s. 45. Tak też B. Miśkiewicz, o. c., s. 50, ponieważ to podział oparty na charakterze czysto zewnętrznym żródel, ibidem, s. 24.

${ }^{79}$ Por. tu naszą wypowiedź w ustępie 4.

${ }^{80} \mathrm{Saq}$ jednym z najważniejszych źródeł (16); takiż chyba sens ma wypowiedź: „nie może być żadnego stanu równowagi między źródłem pisanym i niepisanym" $\left(17^{50}\right)$. 
na trzy kategorie, „zgodnie z formalną strukturą procesu historycznego" $(42)^{81}$. Po cóż więc było na nią rzucać takie gromy?

Nam się wydaje ten właśnie podział - wbrew zastrzeženiom Labudy

- uzasadniony. Źródła pisane, w odróżnieniu od reszty, dostarczają historykowi szczególnego, a bezcennego materiału w postaci zdań cudzysłowiowych. Tej cechy tymczasem Labuda nie dostrzega ${ }^{82}$.

${ }^{81}$ Według Labudy, źródła pisane rejestrują rezultaty poznania ludzkiego [1] „w odniesieniu do świata materialnego", [2] „do życia społecznego", [3] "do życia umysłowego jako takiego" (42). Nota bene: ani wzmianki o tym podziale w tabelce! O klasyfikacji źródeł pisanych ob. też S. Kościalkowski, o. c., s. 52-54.

${ }^{82}$ Autor stwierdza tylko, że zabytek pisany „odbija swój etap rozwoju świadomości społecznej" (43). A inne źródla tego nie robią? 


\title{
Terminologia rozpraw metodologicznych*1
}

\author{
Poważnie uprawiać metanauke danej nauki... może tylko \\ ktoś, kto lqczy w sobie wyśrubowanq kulture logicznq \\ $z$ solidnq znajomościq owej nauki \\ Tadeusz Kotarbiński
}

Próba nowej systematyki i nowej interpretacji źródeł historycznych Gerarda Labudy ${ }^{1 \mathrm{a}}$ spotkała się $\mathrm{z}$ żywym odzewem w literaturze ${ }^{2}$. Ostatnio, niemal wspólcześnie, ukazały się trzy prace, które się nią zajęły (podajemy je $w$ porządku chronologicznym): nasza $i$ związany $z$ nią artykuł B. Miśkiewicza (druk ukończony w marcu 1968 r.) oraz dzieło W. Moszczeńskiej (druk ukończony w kwietniu tegoż roku).

W. Moszczeńska zajęła już poprzednio wyraźne stanowisko wobec propozycji Labudy ${ }^{4}$. Obecnie, omawiając ,próby klasyfikacji opartych na nowych zasadach", stwierdza, że systematyka Labudy „budzi te same zastrzeżenia, jakie autor [tj. G. Labuda - J. M.] wysuwał w odniesieniu do systemów dawniejszych, opartych na zasadach tradycyjnych". Wykazuje też, że ,zasada leżąca u jego [tj. podziału G. Labudy - J. M.] podłoża wbrew pozorom nie jest zasada metodologiczną"s. Podkreśla w konsekwencji „połowiczność” wysiłków Labudy ${ }^{6}$.

* Przedruk z: Historyka 1969, t. 2, s. 139-144.

1 Redakcja drukując tę wypowiedź, traktuje ją jako początek dyskusji nad terminologią rozpraw metodologicznych.

${ }^{1 a}$ Studia Źródłoznawcze, t. I, Warszawa 1957, s. 3-48.

2 Por. nasz artykuł, cyt. w przypisie następnym.

3 J. Matuszewski, O próbie nowej systematyki źródel historycznych, Studia Metodologiczne, t. IV, Poznań 1968, s. 17-50; B. Miśkiewicz, W sprawie prób wyjaśnienia i klasyfikacji źródel historycznych, ibid., s. 51-62; W. Moszczeńska, Metodologii historii zarys krytyczny, Warszawa 1968.

- Por. J. Matuszewski, $O$ próbie..., s. 45-46.

5 W. Moszczeńska, op. cit., s. 93. Tamże mocna krytyka definicji źródeł, podanej przez Labude, s. 83-5.

6 Ibid., s. 92. 
Odmienne całkiem stanowisko wobec wspomnianej próby zajął uczeń Labudy - B. Miśkiewicz. Mimo że znal naszą rozprawkę z maszynopisu, uznaje $w$ dalszym ciągu wyniki swego mistrza „za najnowsze osiągnięcie historiografii na ten temat, wynikające $\mathrm{z}$ postępu metodologicznego nauki historycznej. Mam w tym wypadku na myśli - pisze tenże autor - przede wszystkim wykorzystanie założeń materializmu historycznego do poznawania procesów rozwojowych spoleczeństwa"7. Przypisuje też pracy Labudy ,inspiratorskie znaczenie"8. "Stanowi bowiem ona interesującą próbę nowego spojrzenia zarówno na treść jak i klasyfikację źródel"9.

W konsekwencji B. Miśkiewicz nie zmienił na jotę tekstu swego podręcznika dla pierwszego roku studium, rezerwując w nim dla systematyki Labudy osobny rozdział ${ }^{10}$. Jedynie na końcu jego dorzucił akapit $\mathrm{z}$ takim m. in. zdaniem: „Być może też, że niektóre zawarte w nim [tj. w wykładzie Labudy - J. M.] sformułowania ulegną dalszemu udoskonaleniu, szczególnie od strony terminologicznej"11. Przyjrzyjmy się więc językowi rozprawy.

Stwierdźmy od razu, że G. Labuda poshuguje się wyjątkowo nieprecyzyjną, a przy tym bardzo obfitą terminologią. Zestawmy parę dowodów: „proces historyczny" $(23,25,26,27,33,43,45)^{12}$, „cały proces historyczny” $(23,45)$, ,żywy proces historyczny" $\left(47^{135}\right)$, ,proces historyczny jako taki” (23), ,calość procesu historycznego" $(4,24,30)$ czy "dziejowego (24), ,całoksztalt procesu” (25) czy „procesów” (29), „całokształt procesu dziejowego (historycznego)” $(22,23,24,25,27,37,40)^{13}$; ",płaszczyzna historyczna" $(33,39)$ czy ,,plaszczyzna procesu historycznego" $(3,5,34,47,48)$, ,wszystkie płaszczyzny procesu historycznego" $(45,46)$ obok ,,poszczególnych płaszczyzn procesu historycznego" (46) i „,określonej plaszczyzny procesu” (27), „struktura procesu historycznego" (47) obok ,formalnej struktury procesu historycznego" (42); na dodatek: „istota samego procesu historycznego" (26), „rzeczywisty przebieg procesu historycznego" (32), „rzeczywiste życie” (30), ,realne życie społeczne” (33), „obiektywny proces historyczny” $(24,43)$ i „całokształt procesów zachodzących w treści” (37), „proces historyczny we wszystkich jego przejawach” (19).

\footnotetext{
${ }^{7}$ B. Miśkiewicz, W sprawie prób..., s. 53.

"Ibid., s. 51; na dalszej stronie czytamy o ,inspirujących momentach", s. 54.

9 Ibid., s. 51.

${ }^{10}$ B. Miśkiewicz, Wstẹp do badań historycznych, Warszawa-Poznań 1968, s. 100-103.

11 Ibid., s. 103.

${ }^{12}$ Cyfry w nawiasach oznaczają stronice dzieła G. Labudy.

${ }^{13} N$ b. na s. 23 aż trzy razy!
} 
Czy ta mnogość określeń nie da się sprowadzić do jednego: historia. A w takim razie, po co ta wybujała terminologia? Czytelnika ona wręcz zalewa. To wręcz profuzja terminologiczna, chyba karygodna w rozprawie metodologicznej.

A przy tym nie wyczerpaliśmy jeszcze tej terminologii w całości. Obok procesu historycznego występującego $w$ tylu wariantach pojawia się jeszcze druga - jak sądzimy - jego oboczność, mianowicie „plaszczyzna”. Przytaczaliśmy wyżej ,płaszczyznę historyczną" czy „płaszczyznę procesu historycznego”. Poza tym wprowadza autor "plaszczyznę stosunków społecznych" (33 2 razy), „płaszczyznę rozwoju sił wytwórczych” (33), „płaszczyznę instytucjonalną" (33) obok „płaszczyzny działania instytucji” (33), "płaszczyznę życia duchowego" (44), a wreszcie „wszystkie płaszczyzny życia ludzkiego" (45). I te wyrażenia, zbyt nieokreślone, nie przypadają do naszego gustu.

G. Labuda ucieka się z predylekcją do przenośni: „alembik świadomości” (24), „pochód świadomości” (44), „płaszczyzna świadomości” (33), „osad oddziaływania świadomości” (44), „kwant nieoznaczoności” (25), „,stopień nieoznaczoności [faktu jednostkowego] w stosunku do całokształtu procesu” (25), „przesączanie [pozostałości] przez filtr świadomości” (30), „osad społeczny w zabytku” (19), ,,ladunek treści psychicznej” (15). Niektóre z jego metafor szokują czytelnika swą niecodziennością: ,wlewa się potężny strumień źródel” (18); „,...co pozwala nam prześwietlić płomieniem krytyki najbardziej utajone zakamarki świadomości ludzkiej” (26).

Przenośnie - to język literatury pięknej, nie nauki. Czyżby historia jako humanistyczna nauka była na tyle nieścislą wiedzą, że dopuszcza podobne wyrażenia? Wszakże z kompetentnej strony stawiano postulat humanistyki bez hipostaz ${ }^{14}$. Skoro więc G. Labuda pisze o „konkretnościach konkretu" (28), wolelibyśmy, żeby i do nas przemawiał językiem bardziej konkretnym.

Język techniczny autora odbiega nieraz od dotychczasowego. M. Handelsman używa określenia hermeneutyka ( $\dot{\rho} \rho \mu \eta \nu \varepsilon v \tau \imath x \eta ́$ scil. $\tau \dot{\varepsilon} \chi \nu \eta)^{15}$; Labuda wprowadza hermeneuzę (ale przymiotnik hermeneutyczny, s. 48). Może postąpił tak, żeby jej nadać inną treść? Zadaniem hermeneutyki w rozumieniu Handelsmana jest „ustalanie faktu jednostkowego" ${ }^{16}$; Labudy hermeneuza jest też interpretacja - zgodnie z greckim znaczeniem słowa - ale posługuje się ona, w jego rozumieniu, ,metodą genetyczną, inaczej zwaną ewolucyjną" (4). Przypisuje jej wiẹc autor najwidoczniej jakiś walor szczególny, bo nikt metodą ewolucyjną nie ustala faktu jednostkowego.

${ }^{14}$ T. Kotarbiński, Humanistyka bez hipostaz. Próba eliminacji hipostaz ze świata pojeć nauk humanistycznych. Elementy, wyd. 2, Wroctaw 1961; pierwodruk 1952.

${ }^{15}$ M. Handelsman, Historyka. Zasady metodologii $i$ poznania historycznego, Warszawa 1928 , s. $183-201$.

${ }^{16}$ Ibid., s. 201. 
G. Labuda zdradza jakieś młodopolskie skłonności tworzenia neologizmów (archegetyczny, magistratywny). Nie wydają się nam one zręczne. W języku polskim adiektiwów o sufiksie - ywny mamy niemało, lecz zaczerpnięto je wszystkie z laciny, być może nie bez pośrednictwa francuszczyzny: pozytywny, negatywny, selektywny, definitywny, demonstratywny (pomijamy już gramatyczne termini technici: dativus, imperativus itp.). Sa to przymiotniki pochodzenia odsłownego. Dlatego to ani w lacinie, ani we francuskim nie ma (i być nie może) przymiotnika magistrativus, magistratif. Po co więc wprowadzać taki nowotwór $w$ języku polskim wbrew zasadom słowotwórczym języka wzoru, tj. łaciny ${ }^{17}$. Ryzyko tego dziwotworu jest jeszcze dodatkowe: czytelnik gotów go skojarzyć z magistratem, a to już nie szłoby po myśli jego twórcy, dla którego magistratywny znaczy polityczny, urzędowy.

Nauka i technika bardzo często wprowadzają neologizmy, formowane z dwu słów lacińskich (loko-mobila) czy greckich (psycho-patia); nieraz tworzy się hybrydy grecko-lacińskie (auto-mobil, fyto-cyda). Wszakże robiąc to, zwykle tworzy się takie złożenia, których oba człony są zrozumiałe dla przeciętnie wykształconego odbiorcy (przynajmniej w danej dziedzinie wiedzy czy techniki). Automobil jest to więc wehikul, który się sam (àviós rusza (mobilis), tzn. bez zaprzęgu. Temu podstawowemu dezyderatowi nie odpowiada słowo archegetyczny. Labuda informuje czytelnika, że pochodzi ono od $\grave{\alpha} \rho \chi \eta \dot{. ~ J e s t ~ t o ~ w y j a s ́ n i e n i e ~ s ł u s z n e, ~ a l e ~ n i e w y s t a r c z a j a ̨ c e . ~ W ~ j e ̨ z y k a c h ~ e u r o p e j-~}$ skich, czerpiących z dorobku leksykalnego grecko-łacińskiego, postać arche-

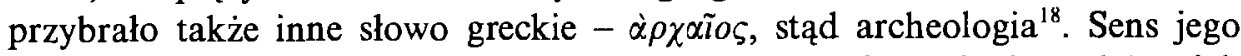
jest inny: 'pierwotny, dawny'. Tymczasem arche- G. Labudy należy, jak sam wyjaśnia, kojarzyć z władzą. Wyłania się więc niebezpieczeństwo, że u nieświadomego tych wariantów leksykalnych i semantycznych czytelnika dojdzie do niewłaściwych skojarzeń.

Co więcej, wskazówka Labudy nie jest ścisła. Archegetyczny pochodzi

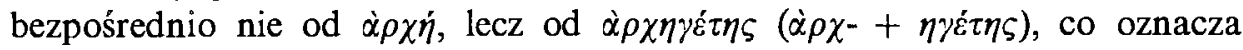
naczelnika, szefa, kierownika. A konia z rzędem, jeśli ktoś, niespecjalista, nie filolog klasyczny, zna sens tego rzeczownika greckiego ${ }^{19}$. Tymczasem ma to być uproszczony znak, zrozumiały dla wszystkich.

Przymiotnik archegetyczny jest $\mathrm{w}$ rozumieniu Labudy synonimem do magistratywny, wyraża on „treść i społeczną formę wykonywania władzy”

${ }^{17}$ Por. tu J. Otrębski, J. Safarewicz, Gramatyka historyczna jezyka lacińskiego, Warszawa 1937, cz. I, s. 254-255.

${ }^{18}$ W tym samym znaczeniu używa się w języku rosyjskim terminu archeografia. F. Bronowski, B. Krzemińska, $Z$ zagadnień źródloznawstwa $w$ nauce radzieckiej, Studia Źródłoznawcze, t. IV, Warszawa 1959 , s. 128.

${ }^{19}$ Indagowany przeze mnie klasyk, jak rozumie słowo archegetyczny, nie dał odpowiedzi, która by szła po myśli G. Labudy. A jakie skojarzenia powstaną w umysłach osób, które nigdy nie uczyły się greki, a takich dziś legion? 
(39); my zaś - zgodnie $\mathrm{z}$ etymologią słowa - musielibyśmy zacieśnić jego znaczenie do aktów naczelnika państwa czy w ogóle władz naczelnych. Magistratus tymczasem oznacza urząd w ogóle, niższy czy wyższy, cum czy sine imperio. W konsekwencji trudno by nam było zgodzić się na postawienie znaku równości między obu terminami: lacińskim i greckim.

W tej sytuacji proponujemy skreślenie obydwu sugestii. Starczy nam zupelnie polski, bezpretensjonalny określnik: urzędowy, którego zresztą i Labuda używa najczęściej. Będziemy więc mówili o źródłach urzędowych, tj. takich, których producentem jest jakikolwiek urząd. Postępując tak, nawiązujemy do starej polskiej tradycji ${ }^{20}$. Nie widzimy żadnej potrzeby zrywania $\mathrm{z}$ nią. Postęp $\mathrm{w}$ nauce nie polega na formowaniu nowych terminów, obcojęzycznych, na stare pojęcia.

Zauważmy dalej, że terminologia zasadniczego podziału Labudy na źródła ergo-techniczne, socjo-techniczne i psycho-techniczne jest również niefortunna. Dlaczego wszystkie źródła mają być jakoś (ergo-, socjo-, psycho-) techniczne? Człon utożsamiający tych złożeń determinatywnych, technika, w dzisiejszej polszczyźnie (jak zreszta i innych wspólczesnych językach) tak swą wartością odbiegł od swego greckiego prawzoru, takiego nabrał specyficznego „technicznego" sensu, że trudno wprost wiązać go $\mathrm{z}$ humanistyczną nauka, $\mathrm{i}$ to tak par excellence humanistyczną, jaka jest historia. Złożenie psychotechniczny - jak to autor kompetentnie wyjaśnia - oznacza w jego języku calkiem coś innego niż w psychologii; ma ono mianowicie uwydatniać "dynamiczny charakter oddziaływania psychiki na otaczającą rzeczywistość" (40). Zauważmy, że i określnik socjotechniczny ma $w$ zastosowaniu Labudy inne znaczenie niz $w$...socjotechnice ${ }^{21}$. Nie lepiej przedstawia się sprawa i z terminem socjograficzny; socjografia zajmuje się problematyką badawczą czasów współczesnych (4), ta zaś w omawianym artykule nie wchodzi w rachubę.

Zapytujemy: po co wprowadzać do nauki historii terminy $z$ innych gałęzi nauk, gdzie już posiadają swój ściśle określony sens „techniczny”, i przy tej okazji zmieniać ich znaczenie? Czyżby dotychczasowy zasób leksykalny historyka był tak ubogi, żeby narzucał tę konieczność? Czy nie będzie rzeczą prostszą zrezygnować z proponowanych terminów i zastąpić je członem dystynktywnym tych złożeń: (źródła) materialne, społeczne i psychiczne. Niewątpliwie brzmi to mniej uczenie, ale o ileż więcej zrozumiale! A przy tym pozostają owe terminy w całkowitej zgodzie $\mathrm{z}$ tokiem myśli autora, bo odpowiadają - używając terminologii Labudy - trzem plaszczyznom życia ludzkiego: fizycznej, społecznej i psychicznej $(45)^{22}$.

${ }^{20}$ T. Korzon, Wewnętrzne dzieje Polski za Stanislawa Augusta (1764-1794), t. I, wyd. 2, Kraków 1897, s. 1; przeciwstawiono tu źódłom literackim źródła urzędowe.

${ }^{21}$ Por. A. Podgórecki, Zasady socjotechniki, Warszawa 1966, s. 9 nn.

${ }^{22}$ Por. też tabelkę na s. 46 artykułu G. Labudy. 
Ale nie wyczerpaliśmy jeszcze wszystkich zarzutów pod adresem języka G. Labudy. W artykule jego spotykamy takie zwroty, których sensu trudno się doszukać, np.: „świadomość ludzka, która dla konkretnych powodów dokonywa takiego czy innego zjawiska $\mathrm{z}$ dziedziny sił wytwórczych i materialnych warunków bytu" (31); ,jedynie przez doprowadzenie empirii do najwyższych stopni abstrakcji moment subiektywności może być wyparty nawet $\mathrm{z}$ tych pokładów ludzkiego myślenia” (42); „najlepiej więc wszystkie etapy oddziaływania świadomości na życie społeczne odnajdziemy odzwierciedlone w tych źródłach socjotechnicznych, które obrazują wysiłek ludzki w celu doprowadzenia życia społecznego do stanu zgodności z prawdziwie naukowymi prawami rozwoju społecznego" (44). I szereg dalszych wypowiedzi nasuwa poważne wątpliwości $\mathrm{w}$ ich rozumieniu: „materiał historyzujący zawarty w źródle" (43); ,prawidłowości rozwoju społeczno-gospodarczego [...] stwarzają odpowiednią treść dla rozmaitych form życia" (36) - myśleliśmy, że to akurat odwrotnie, że formy odpowiednie tworzą się dla rozmaitych treści ${ }^{23}$. Nie rozumiemy też, jak to ,forma narodowościowa" wyraża społeczeństwo feudalne (37), zwłaszcza gdy czytamy dalej, że „,w społeczeństwach klasowych - a za takie poczytamy i spoleczeństwo feudalne - forma narodowościowa i narodowa występuje współrzędnie obok instytucji państwa" (38). Na dobitek, na tejże samej stronicy wyróżnia autor trzy formy: przednarodową, narodowościową i narodową (38) ${ }^{24}$.

Albo następująca nieprecyzyjna wypowiedź: „na podstawie powyższej analizy sformujemy więc pewną generalną tezę, że stwierdzenie subiektywności źródła nie tylko nie stoi na przeszkodzie do ustalenia prawidłowości procesu historycznego, ale wręcz przeciwnie $-\mathrm{z}$ chwila gdy zostało stwierdzone - wybitnie pomaga $w$ osiągnięciu tego celu. To, że źródła są subiektywne, że odbijają spoleczeństwo, a w szczególności klasową świadomość swego twórcy, że tworzą niekiedy nieobiektywne fakty [podkr. - J. M.], to wszystko jest również prawidlowością procesu historycznego. Gdyby było inaczej, musielibyśmy zarzucić źródłom nieobiektywność" (25). Obok tych faktów nieobiektywnych wprowadza autor pojęcie „faktów historycznie niebyłych", tworzonych przez ,,idealnie udane falsyfikaty" $(26)^{25}$.

A do tego wszystkiego, „wzorem fizyków”, wypadnie nam wprowadzić pojęcie nieoznaczoności faktu historycznego, gdyż nie jesteśmy w stanie równocześnie obserwować jego obiektywnego ruchu i subiektywnie rejest-

${ }^{23}$ Tak też zresztą $\mathrm{i}$ Labuda gdzie indziej pisze: „służebna rola formy w stosunku do treści" (28); „forma wyraża całokształt procesów zachodzących w treści” (37); „w przedmiotach różnica jakościowa zachodzi wtedy, gdy nie tylko zmieniły one treść, ale w ślad za nią także swoją formẹ" (32).

${ }^{24} \mathrm{O}$ życiu narodowym i przednarodowym także na s. 36.

${ }^{25}$ "Takich falsyfikatów jest zapewne niezmiernie mało" - stwierdza zresztą sam autor (26). 
rującego go wytwórcy” (25). Co prawda, ten „kwant nieoznaczoności” możemy - zdaniem Labudy - eliminować $(25)^{26}$.

Na tym zamykamy swoje uwagi językowe, zastrzegając się, że bynajmniej nie wyczerpaliśmy wszystkich potknięć stylistycznych znakomitego autora ${ }^{27}$. Te zastrzeżenia muszą budzić pewien niepokój w czytelniku. Język bowiem jest naszym jedynym środkiem porozumiewania się i wzajemnego rozumienia. Tymczasem autor nie gardzi jego nieoznaczonością czy nieścisłością i zdradza wyraźną skłonność do zbędnej prolixitas. Zapytujemy więc, niespokojni, czy posługując się takim językiem może historyk spelnić swe ,wysoce intelektualne" (24) zadanie?

Rezerwa B. Miśkiewicza co do strony terminologicznej opus G. Labudy okazuje się uzasadniona. Ale czy $w$ tych warunkach wolno wymagać od studenta, by sobie przyswajał Labudy ,"podział źródeł w ujęciu graficznym”? ${ }^{28}$ Czy student 1. roku jest $w$ stanie to zrobić, i czy w ogóle warto, by to robił? Czy - powtarzamy tu wypowiedź jednego z najznakomitszych współczesnych historyków polskich - czy nie „lepiej już pozostać przy starym Bernheimie"?

Apologia mistrza ma świetne tradycje literackie; dzieło Platona weszło do skarbca literatury światowej. Ale amicus Plato... Nie wolno w żadnym wypad$\mathrm{ku}$ iurare in verba magistri. A w przedstawionych warunkach stanowczo nie wolno utrzymywać, że klasyfikacja G. Labudy stanowi „najnowszy i zarazem najbardziej precyzyjny wykład na temat pojęcia źródeł historycznych" ${ }^{29}$.

${ }^{26}$ Podejrzewamy, że G. Labuda pomieszał kwant, pojęcie fizyki relatywistycznej, z codziennym kwantum, dozą czegoś!

${ }^{27} \mathrm{Na}$ przykład zwrot o zobiektywizowaniu myśli występuje w czterech kolejno po sobie idących zdaniach (40); por. też zastrzeżenia w naszym artykule na s. 28.

${ }^{28}$ B. Miśkiewicz, Wstęp, s. 103 . Tabelka G. Labudy ma szczęście do publikacji: oprócz oryginału reprodukował ją B. Miśkiewicz (2 razy); J. Serczyk, Podstawy badań historycznych (skrypt, wyd. 2, Toruń 1967; nie mieliśmy w ręku wyd. I z 1963 r.) s. 22 - w skróceniu; nasz artykuł, s. 38. Zaznaczmy, że reprodukując tę tabelkę, drukarz odstąpił w naszym artykule od oryginału, usuwając klamrę, przez co zniweczył podział źródeł ergotechnicznych na demograficzne $\mathrm{i}$ nie wiadomo co (por. tu nasze uwagi na $s .40$ i 44).

${ }^{29}$ B. Miśkiewicz, Wstęp, s. 103 . Zaznaczmy jeszcze, że omawiany artykuł G. Labudy stanowi „wynik przemyśleń autora podjętych w związku z wykładami historii historiografii" (3). Tę zatem gałąż wiedzy historycznej autor rozumie inaczej niż inni, por. E. Bernheim, Lehrbuch der historischen Methode und der Geschichtsphilosophie, Leipzig 1903, s. 35; G. Fueter, Geschichte der neueren Historiographie, wyd. 3, München-Berlin 1936; M. Handelsman, Historyka, s. 59-89; M. H. Serejski, Problematyka historii historiografii, [w:] Pamiętnik VII Powszechnego Zjazdu Historyków Polskich, 1948, t. II, Warszawa 1948, z. 1, s. 41-51; tenże, Przeszlość a teraźniejszość, Wrocław 1965, s. 22; R. Przelaskowski, Projekt opracowania Vademecum dziejów historiografii polskiej, Studia Źródłoznawcze, t. IX, Warszawa 1964, s. 137-139. W pół roku po odesłaniu niniejszego artykułu do redakcji ukazało się dzieło J. Topolskiego, Metodologia historii, Warszawa 1968. 



\section{O państwie i Państwie*}

1. Język środkiem porozumienia między stuleciami. Życie wyrazów. Wynikające stąd trudności. 2. Etymologia słowa pan. Odpowiedniki dominus w języku polskim. Sufiks -stwo. 3. Znaczenia staropolskie: a) pańskość, świetność, b) panowanie, c) władza, d) jedynowładztwo, e) godność urzędowa, n) własność, g) majątek feudalny (senioria), b) kasztelania, i) starostwo, województwo, j) prowincja, k) kraj, l) fiscus, m) bogactwo, n) wielcy panowie, o) pan z panią (małżeństwo), p) fatum. 4. Wnioski z poczynionych zestawień. 5. Swiadomość wieloznaczności w literaturze naukowej. 6. Znaczenia słowa państwo w języku współczesnym. Novum semantyczne: Państwo. 7. Oznaczniki Państwa w jezykach europejskich. 8. Namiastki Państwa w dawnej polszczyźnie (królestwo, księstwo, ziemia, Korona, republika, politeja, stan). 9. Awans państwa na Państwo. 10. Wyparcie wyrazów konkurencyjnych. Utrzymanie się państwa jako collectivum. Tendencje języka do wyróżnienia fleksyjnego i składniowego wyrazu w obydwu zastosowaniach.

Car les mots sont des phares, des points de rassemblement. Autour de leur vie ressuscitée, des perspectives infinies s'éclairent et s'animent.

Marc Bloch

Środkiem porozumienia się między ludźmi jest język. I to nie tylko między jednostkami współcześnie żyjącymi, ale i między pokoleniami oddzielonymi od siebie setkami czy tysiącami lat. Źródła pisane to zasadniczy trzon przekazów, na których opiera się historyk ${ }^{1}$. Stąd więc przed każdym badaczem staje problem znajomości dawnego języka. Trudność w rozumieniu mowy dawnej, nawet tego samego języka, którym się historyk współcześnie posługuje, wynika $z$ tej racji, że wyrazy żyja. Wypowiedź tę rozumiemy w dwojakiem sensie: wyrazy zmieniają swą szatę zewnętrzną. Ulegając prawom fonetyki, palatalizują się spółgłoski, dyftongizują samogłoski, dokonują się metatezy, apokopy, synkopy, asymilacje, dysymilacje, przesuwki

* Przedruk z: Czasopismo Prawno-Historyczne 1958, t. 10, z. 2, s. 77-104.

1 Oczywiście nie chcemy odmawiać waloru pozostałościom materialnym dawniejszych stuleci. $Z$ reguly są one jednak mniej wymowne i dopiero zestawione ze źródłami pisanymi pozwalają na dalej idące wnioski. 
itd. Tym zagadnieniem zajmować się nie zamierzamy. To jest dziedzina językoznawców.

Ale obok tego fonetycznego życia wyrazów istnieje życie wewnętrzne, semantyczne. Każdy wyraz ma swoje znaczenie. Ono zaś interesuje zarówno językoznawcę, jak i historyka. Mówiąc, że środkiem porozumienia między pokoleniami jest język, przyjmujemy, iż te skojarzenia, które jawiły się w głowach ludzi żyjących przed tysiącem lat przy wypowiadaniu danych słów, wywołują zbliżone obrazy i w naszych mózgach. Założenie to jest kamieniem węgielnym dziedziny wiedzy, której patronuje Klio. Odrzucenie jego równałoby się pozbawieniu racji bytu historyka. Jego postępowanie bowiem nie różniłoby się wówczas w niczym od twórczości powieściopisarskiej. W naszym więc dobrze rozumianym interesie leży kultywowanie tego dogmatu: pokolenia mogą się między sobą porozumiewać przy pomocy języka.

Oczywiście nie zawsze przychodzi to latwo, i to właśnie $\mathrm{z}$ tego powodu, że sens wyrazu nie jest niezmienny, że w ciągu wieków następuje semantyczna ewolucja wyrazów. Tę więc musimy śledzić, w miarę jak na to źródła pozwalają, zestawiając interesujące nas terminy $w$ ich kontekstach. Ta robota wstępna jest nieodzowna $w$ pracy historyka, bez niej skłonny on będzie przypisywać wyrazowi spotykanemu w tekście sprzed 500 lat taki sens, jaki ma dzisiaj. Postępując w ten sposób, popelni jeden $\mathrm{z}$ kardynalnych grzechów rzemiosła historycznego - grzech anachronizmu. Próbkę filologii jurydycznej - bo w istocie rzeczy historyk nie dokonuje tu innego zadania - usiłujemy przedstawić na materiale słownym, szczególnie interesującym dla historyków państwa; mianowicie przedmiotem analizy będzie substantivum państwo i jego synonimy.

Etymologia slowa jest jasna: powstało ono $\mathrm{z}$ rzeczownika pan przez dodanie sufiksu -stwo. Temat, co do którego etymologii istnieje sporna literatura ${ }^{2}$, oznacza jednostkę, która w szerszym czy węższym zakresie wykonuje władztwo nad inną osobą lub ich grupą, względnie też władztwo nad rzeczą ; ten co rządzi, panuje - jak wyjaśnia $\mathbf{H}$. Ulaszyn ${ }^{4}$. Wszakże

${ }^{2}$ Ob. A. Brücknera, SEJP, 393, 668; ob. też W. Semkowicz, Wlodycy, KH, t. 22, s. 587 i ib., przyp. 2, oraz K. Tymieniecki, Spoleczeństwo Slowian lechickich, s. 120, 165, 169, 197, 198, 216-9, 222, 231. Zabawna etymologia u rocznikarza średniowiecznego; wywodzi ona termin od greckiego pan, stąd thumaczy po łacinie: totum habens, por. B. Kürbisówna, Studia nad Kronikq Wielkopolskq, s. 118, 128; por. niżej ustęp 2.

${ }^{3}$ Taka wykładnia pokrywa się z tym, co na temat żupanów słowiańskich, urzędniczych i nieurzędniczych pisał K. Tymieniecki, Spoleczeństwo Slowian lechickich, Lwów 1928, s. 169; idzie nawet nieco dalej, obejmując także właściciela.

${ }^{4}$ H. Ulaszyn, Polacy czy Polactwo, JP, t. 23, Kraków 1938, s. 144. 
rozróżnienie wladztwa w sensie publicznym od władania w znaczeniu prawnoprywatnym byłoby zupełnie nie na miejscu. Terminologii ówczesnej tego rodzaju dystynkcja jest całkiem obcas ${ }^{5}$.

Odpowiednikiem lacińskim pana jest dominus. Thumaczenie pozdrowienia anielskiego Dominus tecum przez Pan $z$ tobq jest chyba najstarszym na to przykładem. Ale nie jest to jedyny odpowiednik polski. Pan posiada swoje synonimy; zebral już je kronikarz trzynastowieczny: Pan enim iuxta graecam et Slavorum interpretationem dicitur totum habens et iuxta hoc dicitur pan in slavonico maior dominus, licet alio nomine iuxta diversitatem linguarum slavonicarum dicatur gospodzin. Xandz autem maior est quam pan, veluti princeps et superior rex. Omnes autem domini pan appellantur $^{6}$. Te obserwacje kronikarza i my dzisiaj podzielamy. Gospodzin to w stuleciach XIII-XV pan, ale prawie wyłącznie o Bogu ${ }^{7}$. Ksiqdz zarezerwowany został dla władcy najwyższego $\mathrm{w}$ państwie, samego księcia ${ }^{8}$, oraz dla zrównywanych $\mathrm{z}$ nim w owych wiekach duchownych ${ }^{9}$. Tak nazywali ich Czesi i prawdopodobnie pod ich wplywem zwyczaj ten przeszedł do Polaków ${ }^{10}$. Ludzi zaś władających $\mathrm{z}$ jakiegokolwiek innego tytulu, nie wyłączając zresztą ani wspomnianych książąt czy duchownych, czy Boga ${ }^{11}$ oznaczano wyrazem pan.

Sufiks -stwo tworzy: 1) nazwy właściwości, 2) nazwy zbiorowości, 3) nazwy wytworu. Trzecią grupę odczasownikową tworzą zarówno nomina

s Tymczasem w literaturze pojawiają się zakusy w tym kierunku. A. Rutkowska-Plachińska zestawiając polskie i pomorskie wzmianki komesa, wysnuwa wniosek, że w terminie pan-dominus chodziło o element władzy. Przeciwstawia go dalej rzeczownikowi comes-kmieć, w którym rzekomo tkwiło „pojęciowo związanie [...] z własnością ziemską”; "Comes" w źródlach polskich wcześniejszego średniowiecza, SAU, t. 51, 1950, s. 685-6. Do cytowanej w podanym wyżej streszczeniu literatury dodać jeszcze należy (Juliusz Bartoszewicz), Encyklopedia Powsz. Orgelbranda, t. 24 , s. 679 , oraz t. 25 , s. 880 .

${ }^{6} \mathrm{MPH}$, t. 2, s. 468.

${ }^{7}$ F. Slawski, SEJP, t. 1, s. 325; ob. również A. Brūckner, SEJP, s. 393; ob. też A. Babiaczyk, Lexicon zur altpolnischen Bibel 1455, Breslau 1906, s. 122. Zdaniem A. Brücknera, dopiero od $\mathrm{XV}$ w. pan zastapił wyraz gospodzin, l. $c$.

${ }^{8}$ A. Brückner, SEJP, s. 277, por. też H. Likowski, Powstanie godności prymasowskiej arcybiskupów gnieźnieńskich, PH, t. 19, 1915, s. 34-6. W Kazaniach świętokrzyskich księżyc pokojny oznacza syna Bożego, J. Loś, Ksiqdz i jego krewniacy, JP, t. 6, 1921, ob. przyp. nast., stąd tylko przeniesieniem $w$ świat planet jest nazwa księżyca, przeciwstawionego magnus dominus, tj. słońcu, A. Brückner, $l$. $c$.

' E. Klich, Polska terminologia chrześcijariska, Poznań 1927, s. 86-8; J. Loś, op. c., s. 146-53. Nazwanie księży panami było powszechne w całej Europie średniowiecznej, J. Rozwadowski, JP, 7 (1922), s. 64. Zauważmy zesztą, że rzeczownik ksiqdz nie byl określnikiem wyłącznym dla kapłana; obok niego pospolity był pop, ob. A. Brückner, SEJP, s. 430. Jeszcze u Kochanowskiego goniec szachowy zwie się i ksiqdz, i pop, K. N. [itsch], JP, t. 26, s. 30, 78.

${ }^{10}$ Por. pozycje z przypisku poprzedniego.

${ }^{11} \mathrm{Na}$ ostatnie znaczenie przykładu dostarczają psalmy Kochanowskiego: Kto się w opieke poda Panu sivemu. 
acti, jak i nomina actionis, przy czym różnica między nimi bywa nieraz mało uchwytna ${ }^{12}$.

Grupa pierwsza tworzy rzeczowniki oderwane (nomina abstracta) przede wszystkim od rzeczowników, ale także od przymiotników. W pierwszym wypadku produktywność sufiksu jest duża, w drugim o wiele mniejsza. Powstałe tą drogą rzeczowniki są nazwami cech, właściwości, które tkwią w podstawnikach. Mogą się one wyspecjalizować, tworząc pewne ciaśniejsze kategorie znaczeniowe $\mathrm{z}$ mniejszą lub większą konkretyzacją znaczenia. Wówczas wyrazy te oznaczają: a) stany (macierzyństwo); b) godność, władzę, urzędy, tytuły (hrabstwo); c) instytucje (papiestwo), wreszcie d) państwo, terytoria, kraje (królestwo). Granice tych znaczeń są plynne ${ }^{13}$.

Grupa druga oznacza zbiorowiska osób, istot żywych lub przedmiotów. Można w niej wyróżnić dwie podgrupy: a) zbiorowiska jednostek ludzkich (chłopstwo) oraz b) ludzkie pary małzeńskie ${ }^{14}$.

\section{3}

Przyjrzyjmy się, w jakich znaczeniach występuje słowo państwo w dawnej polszczyźnie.

a. In omni gloria sua - we wszystkim państwie, tzn. w całej królewskiej potędze, pańskości, świetności ${ }^{15}$.

b. Już w Psałterzu Floriańskim 144, 13 czytamy: Królestwo twoje, królestwo wszech wieków, a państwo twoje we wsze pokolenie $i w$ pokolenie. Odpowiednik laciński tego wersetu brzmi: regnum tuum regnum omnium saeculorum et dominacio tua in omni generacione et generacione. Państwo jest tu zatem równoznaczne $\mathrm{z}$ dominacio, a więc sluży na oznaczenie wykonywania funkcji pana, władania. Zauważamy, że identycznie thumaczy Psałterz Pulawski, lecz Biblia Leopolity z 1561 r. i z 1577 r. oddaje to słowo przez panowanie ${ }^{16}$. Psałterz Floriański dostarcza nam drugiego jeszcze przykładu na to znaczenie rzeczownika: Blogoslawcze panv wszyczka dzyala yego $w$ kazdem myestze panstwa yego blogoslaw dusza moya gospodna. Podobnie też Pul. 102, 22: Blogoslawcze bogu wszystka dzyala yego, we wszelykyem myeszcze paynstwa yego. Odpowiednik laciński: Benedicite

${ }^{12}$ Z. Klemensiewicz, T. Lehr-Splawiński, S. Urbańczyk, Gramatyka historyczna jezyka polskiego, Warszawa 1955, s. 212.

${ }^{13}$ H. Ulaszyn, Polacy czy Polactwo, JP, t. 23, Kraków 1938, s. 144, Klemensiewicz i in. op. c., s. 208.

${ }^{14}$ H. Ulaszyn, $l$. c.; Z. Klemensiewicz i in. op. c. s. 216.

15 Cytat z Murzynowskiego podany przez E. Ostrowska, JP, R. 32, 1952, s. 7, przyp. 3.

${ }^{16}$ Tłumaczenie niemieckie oddaje regnum przez reich, dominacio przez hirschaft. 
domino omnia opera eius in omni loco dominacionis eius, benedic anima mea domino. I znowu w obydwu wydaniach Biblii Leopolity użyto w tym kontekście słowa panowanie. U Mączyńskiego czytamy: regimen - państwo, panowanie, regiment, $349 \mathrm{c} / 45$, dis, ditis - państwo, dziedzictwo, panowanie, $91 \mathrm{a} / 7$.

c. Państwo oznacza też władzę samą, możność panowania, wykonywania władzy. W tym prawdopodobnie znaczeniu użyto słowa $w$ zakończeniu rękopisu łacińskiego $\mathrm{z}$ roku 1406: mili bosze, bqd tobe panstwo ${ }^{17}$. W tym teź znaczeniu posługuje się wyrazem państwo thumacz statutów Kazimierzowskich: my Kazymyrz [...] pospolv s krolestwa naszego ryczerzmy [...] baczqncz, ysz podlug czasow starosczi $w$ zemyach panstw naschemv poddanich vyelye rzeczy w Szandzech...", co odpowiada lacińskiemu: Kazimirus [...] una cum baronibus nostris [...] considerantes, quod iuxta temporum antiquitatem in terris dominio ${ }^{18}$ nostro subiectis plereque cause in iudiciis... ${ }^{19}$.

Podobnie w thmaczeniu statutu warckiego z roku $1434 \mathrm{w}$ art. 3 czytamy: Orphanitati. - Syroczsthwu dzeczy poth panysthwem naszim doradzicz laskawye zqdayqcz. Niewątpliwie też to znaczenie u Mączyńskiego: dignus potestate ac dominatu omnium rerum - godzien wszelkiego państwa $i$ zwierzchności, $430 \mathrm{c} / 44$; Philarchus, latine amator imperii, lakomy na państwo, trapiqcy sie na panowanie, $297 \mathrm{c} / 45$; imperare - sprawować sie pobożnie $w$ państwie, $179 \mathrm{~b} / 28$; in iurisditione capitanei generalis Poznaniensis - w pana starosty poznańskiego starostwie, poruczeniu, mocy, panstwie $17 \mathrm{a} / 29$; in ditione ac potestate alicuius esse - $w$ państwie a panowaniu czyim być, $430 \mathrm{c} / 41$; de imperio decertatur o panowanie albo o państwo s tobq czinie, 49 a/3. Takież chyba znaczenie przebija w Mammotrekcie pod państwem - sub dicione ${ }^{20}$, czy państwamy - dominacionibus ${ }^{21}$.

W tym znaczeniu używa omawianego terminu niejednokrotnie Historia Aleksandra: Jynszych thesz wyelye vaszych mocznych $y$ nayesznyeyszych waszego panysthwa szaprzely szyq $J$ przysthqnaly $k v$ alexandrowemv szasthapv, ktory ye the $s$ poczeszthnoszczya przyyal I dal ym sznamyenythe panyszthwa, którego łaciński odpowiednik brzmi: Plurimi etiam vestri potentissimi et preclarissimi milites vestrum imperium denegantes se exercitui

${ }^{17}$ Rękopis łac. I, Folio nr 456 ze zbiorów Zahuskiego pisany w roku 1406 przez Gothardus Ade de Creppicze, ofiarowany póżniej do Częstochowy. Zawiera postilla evangeliorum dominicalium rev. mag. Wilhelmi cantoris parisiensis, wykład wiary składu apostolskiego, traktacik beatitudines, A. Brückner, Średniowieczne slownictwo polskie, Prace Filologiczne, t. 5, 1889, s. 35.

${ }^{18}$ Niektóre teksty lacińskie mają oczywisty błąd: domino, O. Balzer, Statuty Kazimierza Wielkiego, Poznań 1947, praefatio.

19 AKP, t. 3, s. 232.

${ }^{20}$ J. Loś, Mammotrekt z 1471 r., MPKJ, t. 5, 1912, s. 57.

${ }^{21}$ Ibidem, s. 47. 
Alexandri iunxerunt, qui eos honorifice recepit, illisque regales prouinicias erogauit...22.

Przytoczmy jeszcze charakterystyczne thumaczenie Biblii Zofii: Gen. 27, 37: Respondit Isaac: Dominum tuum illum constitui et omnes fratres eius servituti illius subiugavi oddane zostało w niej: Odpowiedzial Izak Panem twym jegośm ostawil $i$ wszytkq twojq braciq pod jego państwem $i$ nad wiele wina $i$ oleju jestem gi panem ustawyl. Jasne tutaj, że thumacz zmienil punkt patrzenia: służeniu $\mathrm{z}$ jednej strony odpowiada panowanie $\mathrm{z}$ drugiej; ta zmiana doprowadziła go do takiego wlaśnie tłumaczenia, przy czym oczywiście servitus nie jest równoznacznikiem państwa. Dodajmy, że późniejsza Biblia Leopolity $w$ wydaniach $z 1561$ r. i 1577 r. zawiera takie wyrażenie: wszystkie bracia jego $w$ slużbe mu podal.

W thumaczeniu ortyli magdeburskich czytamy: Myâsta, targy albo wssy, czo lesza pod waszym prawem, tho gest pod waszym posluszenstwem albo panstwem, czy mogq do wasz po prawo chodzycz. Odpowiednik niemiecki: Städte, Märkte oder Dörfer, die unter euren Gerichte liegen, das ist unter euer Obedienz und Herschaft, die mögen zu euch ums Recht kommen ${ }^{23}$.

d. Jeśli państwo oznacza władzę, to również szczególny jej rodzaj może być tym terminem określony. Cnappius podaje obok innych znaczeń: item jednowladztwo ${ }^{24}$.

e. Jeśli Bielski podaje, że król Szydłowieckiemu państwo krakowskie, a Tarnowskiemu województwo ruskie dal, to wyrażenie to może oznaczać również nadanie godności, urzędu kasztelańskiego oczywiście wraz z przynależnym doń okręgiem ${ }^{25}$. Naturalnie mógłby ktoś zarzucić, że nie jest tu bardzo pewne, czy chodziło w tym wypadku o władzę, czy o terytorium kasztelanii, jak bowiem zobaczymy niżej, i to znaczenie słowo państwo posiadało. Wszakże ta rzecz nie ulega natomiast wątpliwości, gdy zestawimy teksty następujące, oba zaczerpnięte z Mączyńskiego: tribunatus - państwo wojskie, hetmaństwo, $463 \mathrm{~d} / 24$; a zwłaszcza: homo inquietus et ad tribunatum spirans $=$ czlowiek niespokojny, a na państwo wojskie czychajacy, $341 \mathrm{~d} / 36$. Być może w tym sensie należy rozumieć glosę polską w Kazaniach gnieźnieńskich: princeps romane milicie $=$ rzimskego panstwa ${ }^{26}$.

${ }^{22}$ Historia Aleksandra w thumaczeniu Leonarda Bonieckiego $\mathrm{z}$ roku 1510, wyd. M. Z. Przygonia Kryński, Prace Filologiczne, t. 9, Warszawa 1914, s. 84, v. 12, 18; tamże przykładów więcej: s. 3 v. $18 ; 47$ v. $15 ; 51$ v. $6 ; 59$ v. $4 ; 61$ v. $18 ; 62$ v. $8 ; 255$ v. $6 ; 256$ v. $3-4$.

${ }^{23}$ Kaluziniacki, Die polnische Recension der Magdeburger Urtheile, Sitzungsberichte der philosophisch-historischen Klasse der kaiserlichen Akademie der Wissenschaften, t. III, Wien 1886 , s. 295.

${ }^{24}$ Cnappius, Thesaurus, s. 667.

${ }^{25}$ Cytat u Lindego, por. niżej, przyp. 79.

${ }^{26}$ W. Nebring, Kazania gnieźnieŕskie, Kraków 1896, s. 86, oraz glosa do Kazań gnieźnieńskich wydania Vrtela-Wierczyńskiego, s. 132, nr 294. 
f. W tekście $\mathrm{z}$ lat $1428 / 29$ dotyczącym zastawu wsi na przeciąg roku, dokonanego przez niejakiego Marcina z Międzyrzecza, czytamy, że zastaw ten dokonał sie cum omnibus utilitatibus, censibus, honoribus ac cultibus ac dominio totali iureque libero, co przethumaczono na język polski: ze wszystkimi

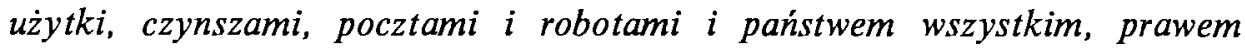
dobrowolnym; w tymże tekście niżej: nichil penitus pro se iuris seu dominii reservantes seu excipientes, nic wszego sobie prawa albo państwa ostawiają $i$ wyjmujac ${ }^{27}$.

W Puł. 104, 20 łaciński tekst: principem omnis possessionis suae oddano przez: postawil gy panem domu swego y kszyezem wszego paynstwa swego ${ }^{28}$. W tym znaczeniu używa słowa Statut ormiański w urzędowym thumaczeniu z 1528 r. w art. 16: Jeśliżby takiemu sludze pan żone dal, a plód między sobq obojej plci rozplodziliby, tedy $w$ takowej rzeczy żona przerzeczonego slugi pospolu $z$ dziećmi ma być $w$ dziedzictwie, a waństwie wiecznem swego pana, a sam tylko przerzeczonym sluga wolność $i$ wypuszczenie ma mieć ${ }^{29}$, odpowiednik laciński: debet esse in hereditate et dominio perpetuo sui domini $^{30}$. W księdze sądowej wsi Zawada czytamy pod. $1624 \mathrm{r}$., że niejaki Maciej Kliś, stolarz, przedal poczqstek swój wlasny [...] po nieboszczyku [...] ojcu swoim [...] Stanislawowi Klisiowi, bratu swemu rodzonemu. Otrzymawszy za to rekompensatę, Maciej stolarz wyrzeka sie tam nic nie mieć państwa, bliskości, tak sam na sie i na potomki swoje ${ }^{31}$. W akcie z 1657 r. dotyczącym darowania siedemnastoletniego „wychowańca” przez Jana Kawieskiego Gabrielowi Sokolnickiemu darczyńca rezygnuje $\mathrm{z}$ wszelkich uprawnień, nic sobie ani potomkom swoim do niego prawa i państwa nie zachowują ${ }^{32}$. To znaczenie słowa państwo utrzymuje się aż po koniec Rzeczypospolitej, R. Hube notuje je jeszcze w konstytucji z $1768 \mathrm{r} .{ }^{33}$ Podane tu zestawienie wykazuje niesłuszność zdania F. Zielińskiego, który przytaczając terminy Długosza na oznaczenie własności, wymienia $\mathrm{m}$. in. dominium, dodając, że

${ }^{27}$ L. Malinowski, Zabytki jezzyka polskiego w rekopisie n. 2303 Biblioteki Uniwersytetu Jagiellońskiego w Krakowie, Prace Filolog. t. 1, Kraków 1885, s. 481-2; ob. też Kryński, Zabytki jezyka staropol., s. 241, oraz H. Safarewiczowa, O staropolskich znaczeniach wyrazu dobrowolny, JP, 1956, s. 8.

${ }^{28}$ W Fl. mamy zwrot: ksqdzem wszego bydla swego.

${ }^{29}$ O. Balzer, Corpus iuris Polonici, t. 3, Kraków 1906, s. 477.

${ }^{30}$ Ibidem, s. 434.

${ }^{31}$ Ksiega sqdowa Uszwi dla wsi Zawady, wyd. A. Vetulani, Wrocław 1957, nr 18; identyczny zwrot $i b .$, nr $30, \mathrm{nr} 35$.

${ }^{32}$ Teksty zaczerpnięto z drukującego się wydawnictwa J. Deresiewicza, Transakcje chlopami, 1959 , s. 523, nr 581. Odpowiednik łaciński w tymże wydawnictwie wygląda następująco: w roku 1699 dokonuje się donacja chłopa, przy czym darczyńca nic sobie ani successoribus meis, do tego chlopa nie zostawujqc dominii $i$ wszelkie praetensiones umarzajac, ib., s. 528, nr 587.

${ }^{33}$ R. Hubego, Pisma, t. 2, s. 407, p. 6; ob. też B. Leśnodorski, Dzielo sejmu czteroletniego, Wrocław 1951, s. 13 . 
„pojęcie w wyrażeniu dominium zawarte było (językowi polskiemu) obce, gdy nie zdołało sobie wyrobić powszechnie przyjętej krajowej nazwy"34.

g. Puł. 104, 20 czytamy: Postawil gy panem domu swego, y kszyczem wszego paynstwa swego, co stanowi odpowiednik lacińskiego principem omnis possessionis suae. Tekst statutów Kazimierzowskich: Statuimus, ut si quis inciderit quercum in bonis alicuius, domino invito [...], pena, que dicitur pyacznadzestha, fertonem illi persolvat, in cuius dominio ${ }^{35}$ sunt incisa. P. II. art. 82 został przetłumaczony przez Świętosława: Dla tego vstawyami, ysz gdiby ktho dap porabyl $w$ gymyenyv drvyego przes panonowey wolye, vynq yasz rzeczona szethmy grziwyen, to gest pyancz groszy przez dwy kwarthynky themv zaplaczycz, w czygem gymyenyv viczal byl... Wszakże $\mathrm{w}$ tegoż casus summarii, art. 83 czytamy: Poramby $w$ dqmb czvcz, wynq gemv oszm grosszow zaplaczy, $w$ czygem paynstwye gest porambyoon.

W rękopisie B I po statutach Kazimierzowskich oraz statucie warckim pomieszczono prawnicze vademecum sporządzone prawdopodobnie przez pisarza polskiej narodowości pod tytułem: Secuntur vocabula libri municipalis provincialis pariter et feodalis etc. Secuntur vocabula bona: [...] Idem feodus panstwo wolne, id est dominium. Et feodus eciam dicitur wolne dobro ${ }^{36}$. Podobnie thumaczenie ortyli magdeburskich: vnd her myt der macht dy her ym behilt seynis erbis noch gutis noch hen wek gegebin hat, co po polsku oddano: a stha moczq, czso sobye zostawyl panstwo swego gymyenya zazywot$h a^{37}$; stamtąd czerpiemy też drugi przykład ap eyn vnelich man vnd seyne kindir adir eyn rechtelos man ir gut adir ir erbe vorkaufin mogin an $d y$ herschaft adir nicht; odpowiednik lacinski: irrequisita potestate dominorum, sub quorum degunt dominio, Magd. Fr., a 155, 2, a w thumaczeniu polskim: besz swych panow, 201, lecz w cap. 18: gynemv panstwu ${ }^{38}$. Jeśliby takie dzieci w panistwie tego to pana nie byli narodzeni - czytamy w przekładzie statutu ormiańskiego z $1528 \mathrm{r}^{39}$ Mączyński daje następujące zestawienia: fines proferre - granice [...] majętności albo państwa swego rozszerzyć, $127 \mathrm{~d} / 57$ - $128 \mathrm{a} / 1$; dominium - państwo, dziedzictwo, 94 a/32. U Cnappiusa zaś

\footnotetext{
${ }^{34}$ F. Zieliński, Liber beneficiorum Dlugosza, Bibl. Warsz. 1872, t. 4, s. 336-7.

${ }^{35} \mathrm{~W}$ niektórych kodeksach oczywiste błędy: dommini, domino, Statuty Kazimierza Wielkiego w opr. O. Balzera, SHPP, t. 19, Poznań 1947.

${ }^{36}$ Kałużniacki, Vocabula iuris provincialis et feodalis, Polnische Glossen aus dem Anfang des XV. Jahrh., Archiv f. Slav. Philologie, t. 27, 1905, s. 268, oraz A. Brückner, Średniowieczne slownictwo polskie, Prace Filolog., t. 5, 1889, s. 35-7.

${ }^{37}$ A. Brückner, Die ,Magdeburger Urtheile", Archiv f. Slav. Philologie, t. 6, 1882, s. 388.

${ }^{38}$ Ibidem, s. 348. Sądzimy, że tutaj też położyć należy zestawienie znalezione w Granariuszu, który może na początku XV w. dostał się do Polski, i który zaopatrzył ktoś w drugim lub trzecim dziesiątku w wykład polski. Rkps. łać. XVI $4^{\circ}, \mathrm{nr} 33$ z Miechowa, pisarz Niemiec nie umiejący po polsku, stąd dziwaczne nieraz formy słów polskich: dominator panuyquczy, dominium pansthwo, A. Brïckner, Średniowieczne slownictwo..., s. 6.

${ }^{39}$ Corpus iuris Polonici, t. 3, s. 478, cap. 2.
} 
czytamy: państwo aliter wlość, majętność pana jakiego ${ }^{40}$. W przypowieściach polskich z 1629 r. zestawionych przez Rysińskiego występuje takie wyrażenie: wlóczy się za nim państwo, by za sarnq ogon (tzn. mało ma gruntów) ${ }^{41}$.

W tych wszystkich wypadkach państwo oznacza mienie feudała - to, które stanowiło podstawę ustroju lennego, włość szlachecką czy magnacką. Jest to zatem dokładny odpowiednik francuskiej seigneurie. Podobny rozwój terminologii spotykamy w Niemczech, gdzie dominium tłumaczy się przez herschaft, co oznacza beschränkte Landeshoheit ${ }^{42}$. Można by przytoczyć dziesiątki przykładów, na które powołują się historycy, pisząc w cudzysłowie o ,państwie” cieszyńskim, orawskim, milickim, suskim, pileckim, muszyńskim i lubowelskim, o ,państwach” Wiśniowieckich, Koniecpolskich, Radziwiłłów itd. ${ }^{43}$ Tą seniorią oczywiście może być też i miasto, stąd u Mączyńskiego: natus est in agro Spirensi - pod pañstwem albo na wlasności Spyrsky sie urodzil, $5 \mathrm{~d} / 13$. W tym też chyba znaczeniu ze względu na rzeczownik pomoeria zwroty Mączyńskiego: fines atque pomoeria dilatare - państwo swoje rozpostrzeć, 124 a/32; pomoeria proferre - państwa swe rozpościerać, rozszerzać państwo swe, 309 a/47.

h. Skoro wadztwo na jakimś terenie nazywało się państwem, to nic dziwnego, że związano je z jednego rodzaju dygnitarzem, którego nazywano krótko panem, mianowicie $\mathrm{z}$ kasztelanem ${ }^{44}$. W dokumentach $\mathrm{z}$ ostatniej ćwierci XIII w. zwie się go castorum dominus czy custodiae dominus - pan bobrowy czy pan stróży ${ }^{45}$. Prędko określa się go przymiotnikiem od grodu, którym włada, np. pan kaliski ${ }^{46}$. Zacytujemy znowu statuty Kazimierzowskie: statuimus, quod Cracoviensis castellanus dumtaxat in tribus locis, videlicet in Cracovia, in Andreow et in Weliczka debet et teneatur sua iudicia pertractare,

${ }^{40}$ Cnappius, Thesaurus, s. 667.

${ }^{41}$ Cytat za Lindem.

${ }^{42}$ Schröder-Künnsberg, Lehrbuch der deutschen Rechtsgeschichte, wyd. 7, s. 610.

${ }^{43}$ Por. artykuły I. T. Baranowskiego, $Z$ dziejów feudalizmu na Podlasiu. Rajgrodzko-Goniq̨dzkie „państwo" Radziwillów w pierwszej polowie XVI wieku, odb. z PH, t. 4, Warszawa 1907, i T. E. Modelskiego, Prawo kreskie w panstwie muszyńskim i lubowelskim, [w:] Ksiega pamiq̨tkowa $k u$ czci O. Balzera, t. 2, Lwów 1925, s. 149, oraz obfite wzmianki w literaturze historycznej, z której wymienimy pewne tylko pozycje bez chęci wyczerpania całości: K. Piwarski, H. Lubomirski, s. 18, 56; M. Gotkiewicz, O plóciennikach w Górnej Orawie, Lud, t. 41, s. 626; Dziewulski, Zaludnienie Ślqska, PZ, 1952, s. 462, 470, 472, 473; W. Czapliński, Dwa sejmy, s. 14; J. Mazurkiewicz, Miasta prywatne pow. lubelskiego a ich dziedzice $w X I X w$. . Lublin 1954 , s. 112; S. Kutrzeba, Akta sejmikowe, s. 241.

${ }^{44}$ Zauważ, że we Francji tout chatellain est dominus, M. David, La souveraineté et limites juridiques du pouvoir monarchique du $I X^{r}$ au $X V^{r}$ siècle, Annales de la Fac. de dr. et des sciences polit. de Strasbourg, Paris 1954, s. 44.

${ }^{45}$ Zestawienie tekstów: F. Bujak, Studia nad osadnictwem Malopolski, Kraków 1905, s. 276.

${ }^{46}$ Kryński, Zabytki jezzkka staropolskiego, s. 42. Określenie pan nie jest zresztą jedyne, w pierwszej połowie XV w. kasztelan bydgoski zwie się grododzierżcą, ib., s. 240, por. niżej przyp. 54. 
P. II. art. 14. W thumaczeniu Świętosława tego artykułu czytamy, że kasztelan tho yest paan cracowsky, ale więcej jeszcze w casus summarii ar. 15: iako paan crakowski tylko ve trzech myesczech ma sandicz, tho gest $w$ Crakowye, $w$ Ondrzeowye a w Wyelicze swoye sandi: a thakesz sandomiesky y gynschi w swoich panstwach na myeszczoch vidanich a nyegyndze sandzicz mayq $q^{47}$. Bardzo pouczające jest też inne zestawienie tychże statutów: Item dum ignoratur, quis commisit homicidii immanitatem, decernimus, quod castellania ${ }^{48}$ de his aliquam non moveat questionem, sed consanguinei et proximiores, co u Świętosława art. 58 oddano przez: tesz gdi nyewyedzecz, ktho maszoboystwo vczinyl wstavyami, abi groczstwo o tho nye rvszalo ktorey skargy, ale przirodzony a blyszy vinngo (s.) nalaszwszy... ${ }^{49}$; tymczasem $\mathrm{w}$ casus summarii czytamy: ... a gdze wanthpyenye gest o mazzoboystwye, iako gdi nyewyedzecz, ktho zabyl, panstwo nye ma kogo gabacz, alye blyszszy acz mogq o glowa rzecz konacz bandq $q^{30}$. Wreszcie trzeci przykład z tychże statutów: Puł. II. art. 55: pro pena homicidii castellanie ${ }^{51}$, in qua homicidium fuerit commissum, w thumaczeniu Suleda brzmi: za wynq maszoboystwa castellany, to gest panystw, w tkorem (s.) maszoboystwa vczynil ${ }^{2}$. W tym znaczeniu używa słowa państwo jeszcze Bielski (koniec XVI w.) ${ }^{53}$. Zaznaczyliśmy wyżej, pod pkt. e, wahania co do rozumienia określenia państwo jako godności kasztelana czy też kasztelanii.

i. Zrównanie pan $=$ kasztelan, państwo $=$ kasztelania , pospolite $\mathrm{w}$ języku polskim ${ }^{54}$, nie wykluczało innego użycia omawianego słowa. $Z$ równą racją można było odnieść je także do innych dygnitarzy i ich okręgów administracyjnych. Rzeczywiście, w szczątku zbioru kazań pochodzących z końca XV w. lub początku XVI w. czytamy: $y$ wyclada thy szlowa s. Cri-(sostomus) et dictus regulus et non rex, bo nyemyal wszystkego krolestwa alye yako powyada tensze doctor s. Crisz(ostom), ysz myal wtem sze krolewstwye nyektore paynstwo yako hodie starowstwo albo woyewocztwo yrzeczom krolykem, ysz myal yakobi pyrwszy vszrząd pokrolv...55.

${ }^{47}$ AKP, t. 3, s. 235.

${ }^{48}$ Niektóre teksty wykazują castellanus, castellani, Statuty Kazimierza Wielkiego, w oprac. Balzera, s. 518.

${ }^{49}$ AKP, t. 3, s. 268.

so Ibidem, s. 241.

sı Niektóre teksty maja castellano, castellanis; ob. warianty w wydawnictwie $\mathrm{O}$. Balzera.

${ }^{52}$ AKP, t. 3, s. 267, art. 55.

${ }^{53}$ Powoluje S. B. Linde, t. 2, s. 628.

${ }^{54} \mathrm{Z}$ rot przysiąg 1400 r. pan kaliski, tj. kasztelan kaliski, Kryński, Zabytki jezzyka staropolskiego, s. 42; dominus lubelski - kasztelan; R. Grodecki, Rachunki wielkorzqdowe z roku 1471, AKH, ser. 2, t. 4, nr 7, Kraków 1951, cap. 17; zwał się on też panem bobrowym, F. Bujak, Studia nad osadnictwem Malopolski, cz. I, RA, t. 47, Kraków 1905, s. 276.

${ }^{5 s}$ K. Czaykowski - J. Loś, Zabytki augustyańskie, Materiały i Prace Komisji językowej AU w Krakowie, t. 2, 1907, s. 318. O dacie zabytku, ibidem, s. 316. Co do ewentualnego okręgu administracyjnego wojskowego, por. wyżej pkt e. 
j. Ale nie tylko okręg administracyjny kasztelana, starosty czy wojewody nazywał się państwem. Tego określenia używano również na oznaczenie części jakiegoś kraju, jego prowincji: populata provincia $=$ spustoszone państwo, Numidia provincia = państwo numidiejskie - czytamy u Mączyńskiego (312 c/48, 176 n/27). Części Polski są też państwami: Exempli causa kiedy po wszystkich państwach koronnych postanawia sie, aby ten, co kupuje pszenice oraz korceby wprawdzie po wszystkich państwach trzeba mieć jednakie... czytamy w pismach politycznych XVII w. ${ }^{56}$

k. Wreszcie państwo jest odpowiednikiem królestwa, księstwa, kraju, imperium. I znowu rzecz ta nie może nas zaskakiwać, skoro jako określnik laciński na oznaczenie księstwa służyło dominium ${ }^{57}$. Dajemy tu kilka zaledwie przykładów, nie chcąc bez potrzeby mnożyć ich w bezlik. W glosach lwowskich $\mathrm{z}$ pierwszej polowy XV w. niemiecki kopista nie umiejący po polsku wciagal je i odczytywal, bardzo niedbale, notując: państwu dominio [...], quomodo eius dominium panstwo sibi szobye obtineret, imperium czeszar$s w_{o}{ }^{58}$. Oto jak thumacza biblie I Par. 18, 3: Eo tempore percussit David etiam Adarezer regem Soba regionis Hemath, quando perrexit, ut dilataret imperium suum usque ad flumen Euphraten. Biblia Zofii z 1455 r.: Tegosz czasu pobyl Dauid krolya Adadezera Sobskego, wloscy Emath, gdy bil vigechal, abi roszirzil swe panstwo aż do rzeki Eufraten. Biblia Leopolity z 1561 r. Tegosz to czasu porazil Dawid Adarezera, krola Soba, krainy Hemath, gdy wyjachal, aby rossyrzyl krolestwo swoje az do rzeki Euffraten. Taż biblia w wydaniu z 1577 r.: aby rozszerzyl państwo swoje aż do rzeki Euffraten. W psałterzu pulawskim $\mathrm{z}$ połowy $\mathrm{XV}$ w. czytamy: Ten ps. powyada, yze xpus chwalyczym szye krolewstwo a paynstwo nyebyeske nade wszystky daye, Pul. 102 arg. W Mammotrekcie lubińskim z roku 1471 spotykamy takie zestawienia: państwo $=$ dominaciones, panstwq $=k s y q s t w a^{59}$, panystwo = imperio, panowal - imperavit ${ }^{60}$. W statucie ks. mazowieckiego, Janusza, z roku 1387 art. 4: Gwalt slyachczyankam przes zemyany gynschego panystwa. Item gdibi czudzozyemyanym a ten, yenzebi nye bil xanzanczi zyemyanin... ${ }^{61}$. W tekście ogłoszonym przez A. Brücknera: quando [...] rebellare volebat romano gdy syq sprzeczyvyla imperio panysthwv ${ }^{62}$. W Rozmyślaniach przemyskich: przetoż mily Cristus rzekl: krolestwo moje nie jest

\footnotetext{
${ }^{56}$ Votum szlachcica polskiego, wyd. Czubek, Pisma polit., t. 2, s. 227.

57 Jeden cytat $z$ wielu: $S i$ aliquis contra dominium nostrum insultum fecerit, quod coloni sepedicte ville dominium nostrum una nobiscum tenebuntur defensare, KDWP, t. 1, nr 289, $1250 \mathrm{r}$.

${ }^{58}$ A. Brückner, Przyczynki do dziejów języka polskiego, Ser. pierwsza, RAU, Wydz. Filolog., t. 47, 1910, s. 358, nr 134.

ss J. Loś, Mammotrekt..., s. 129.

${ }^{80}$ Ibidem, s. 109.

${ }^{61}$ AKP, t. 3, Kraków 1895, s. 312.

${ }^{62}$ A. Brückner, Kazania średniowieczne, RA. WF, t. 25, 1897, s. 182, nr 300.
} 
$s$ tego świata. Jakoby rzekl mily Cristus nienagabamci państwa waszego na tem świecie, bo krolewstwo moje sq wierni moi, ktorzy nie sq $z$ tego swiata ${ }^{63}$. Tamże Epistola, która pisal król Abagarus Jesucristusowi zawiera następujący passus: boć nam miasto niewielkie, ale csne a dobre, a lud jest w nim mqdry a smierny, tako iże $w$ niem obyjdziewa sie dobrze a tobie dam $w$ niem dzierżać państwo wszytko sa $m n q^{64}$. Z Historii Aleksandra datującej się z 1510 r. przytoczymy jako odpowiednik brzmienia lacińskiego quia videbis me in patria tua bella gerentem et regnum tuum meo imperio subiugantem thumaczenie polskie: $y$ sze thy vszrzysz mnye $w$ oczczysznye thwoyey czynyqczego walkq. A twoye panystwo moyey moczy poddane ${ }^{65}$, albo również stamtąd zaczerpnięte thumaczenie: credis itaque imperium Darii subiugare. Athako wyerzasz, yszeby panystwo darrivszowo myal wszyacz ${ }^{66}$. W twórczości Reja spotykamy następujące wyrażenia: Gdyż wiemy iże $v$ nich [aniolów] nic nie platne państwa, Królestwa, zacne księstwa, y ine hetmaństwa ${ }^{67}$. Również Orzechowski wyraża się tak: Królestwo polskie jest jedno z Sarmacyjej państwo wlasnemu królowi... poddane $e^{68}$. W pochodzącym z 1542 r. Sądzie Parysa mówi Parys do Heleny: Bądź pozdrowiona królowa państwa greckiego ${ }^{69}$. W tym też znaczeniu używa niejednokrotnie wyrazu państwo Bielski: Scipio senator rzymski od zwyciestwa africskiego państwa nazwan byl Affricski $i^{70}$. Moc przykładów takiego zastosowania wyrazu przytacza Mączyński: imperium - państwo, $446 \mathrm{c} / 13$; imperium - państwo, cesarstwo, $280 \mathrm{c} / 18,358 \mathrm{a} / 51$, $398 \mathrm{~b} / 36, \mathrm{i}$ in.; imperialis urbs - miasto ku państwu rzymskiemu nalezqce, 383 b/47, 398 b/36; regnum - państwo, 185 d/10, 324 a/53; ius municipale - wlasne prawo, którego królestwa, państwa albo miasta, $178 \mathrm{~d} / 40,237 \mathrm{~d} / 7$. Certat Aegyptus cum feracissimis terris = Królestwo Aegipskie nie da żadnemu państwu naprzód urodzajności, $49 \mathrm{c} / 48$; święte królestwo, państwo albo ksiestwo, $156 \mathrm{a} / 5,315 \mathrm{~d} / 39$; monarchia - jedine państwo, panowanie, księstwo, królestwo, $230 \mathrm{c} / 14$; principatus $=$ ksiesstwo, państwo, $322 \mathrm{c} / 7$; res publica państwa, 234 b/31, 268 a/26; dynastia - państwo, mocarstwo, 98 b/44; państwa-królestwa-ziemie, $260 \mathrm{~b} / 38$; państwa-ksiestwa, 453 a/50. W kazaniu sejmowym Skargi o miłości ojczyzny czytamy: Ta matka (ojczyzna) skupila wam do jednego ciala Rzplitej tak szerokie i zacne narody, a na marginesie: Skupienie tak wielkich państw $w^{71}$. Toż samo znaczenie dość częste również

${ }^{63}$ Rozmyślania przemyskie, s. 779-780.

${ }^{64}$ Ibidem, s. 228, podobnie w tychże Rozmyślaniach, s. 10, 796, 799, 781.

${ }^{65}$ Historia Aleksandra, s. 187.

${ }^{66}$ Ibidem, 45, v. 17; tamze dalsze przykłady: $95^{2-3}, 23$ v. $5,40^{14-15}$.

${ }^{67}$ M. Rej, Wizerunek, 156/X, s. 889 .

${ }^{6 B}$ S. Orzechowski, Quincunx; cytat za Z. Kaczmarczykiem, Typ i forma państwa polskiego $w$ okresie demokracji szlacheckiej. Odrodzenie w Polsce, t. 1, Historia, Warszawa 1955, s. 504.

${ }^{69}$ Cytujemy za J. Losiem, Od "Ty" do „Pan”, JP, R. 3, Kraków 1916, s. 2.

${ }^{70}$ M. Bielski, Żywoty filozofów, 115, 1535 r; podobnie $i b ., 64$.

${ }^{71}$ Cytuje S. Kot, Świadomość narodowa, KH, 52, 1938, s. 22. 
w pismach politycznych XVII w.: Bóg zachowaj, by $i$ poganie korone państwa posiedli ${ }^{2}$.

Cnappius podaje jako odpowiednik państwa następujące wyrazy: satrapia, tetrarchia, despotatus, imperium, ditio, ale również spotykamy u niego zwrot: państwo [...] vicinum: królestwo, nam sub hoc est tanquam sub genere, item... ksiestwo ${ }^{73}$.

Zacytujemy wreszcie instrukcję poselską ziemi dobrzyńskiej z roku 1666: państw, królestw i porzqdnej Rzplitej, każdej na tem stanowieniu świqtobliwych praw $i$ ich konserwacji fortitudo consistit ${ }^{74}$.

I. Zanotujemy też jako osobne znaczenie, w jakim występuje państwo W zespole słów u Mączyńskiego: fiscus, skarb [...] vulgo dominium, państwo, majetność, wlasność, $128 \mathrm{~d} / 15$.

m. Szczególne znaczenie przybiera wyraz państwo w zwrocie następującym: tolle omnes divitias - veszmy wszythky panystwa ${ }^{75}$. W tymże znaczeniu według wszelkiego prawdopodobieństwa występuje w Historii Aleksandra: Wszyszthky rzeczy y panystwa chcesz trzymacz. Pothym wszythky rzeczi beda czyebye dzyerszecz. Odpowiednik laciński: Omnia vis tenere, deinde omnia tenent te vt seruum.

n. Wreszcie państwo występujące jako collectivum. I tak Bielski pisze, że po śmierci Aleksandra tedy go królowie, ksiażęta a państwo do Alexandriey nies $i^{76}$. U Mączyńskiego spotykamy jako równoznacznik senatorius - radne państwo, $382 \mathrm{~b} / 36$.

o. Szczególny wypadek tego collectivum podaje Cnappius: ut jest państwo doma, i. panowie abo pan z paniq ${ }^{77}$.

p. Nie wydaje się jasne oddanie słowem państwo łacińskiego fatum $^{78}$.

${ }^{72}$ Czubek, Pisma, t. 1, s. 216; podobnie ib., t. 1, s. 328, 205, v. 18, t. 2, s. 225, 226.

${ }^{73}$ Cnappius, Thesaurus, s. 667.

74 J. Siemieński, Organizacja sejmiku ziemi dobrzyńskiej, s. 61.

${ }^{75}$ Historia Aleksandra, s. 100 , v. 14-15; podobnie tamże s. 101 , v. 10-1; 178, v. 13.

${ }^{76}$ M. Bielski, Żywoty filozofów, s. 163 (Słownik B) 1535 r.

${ }^{77}$ G. Cnapii e Societate Iesu, Thesaurus Polono-latino-graecus, 1643, s. 667.

${ }^{78}$ Tekst odnośny wygląda następująco: Jako gora tha nye przemyeny myeszczcza szwego, thakyesz ymyq y panyszthwo thwoye (nye) bqdze obyawyono alysz do wnathrznosczy wyekow; odpowiednik laciński: Sicut mons iste non mutabit locum suum, sic nomen et fatum tuum narrabitur usque ad viscera saeculorum, Historia Aleksandra, s. 28, v. 16. Dodajmy tu, że thumacz Historii popełnił nieraz karygodne błędy; przytoczymy tu jeden rażący swą jaskrawością: sedimus in dignitatis solio, descendimus in confinio occidentis oddał thmacz przez ...y szlyszmy w graniczne szloncza szachodv, Historia Aleksandra, s. 61, v. 18. 
$\mathrm{Z}$ powyższego zestawienia widać, w ilu znaczeniach używano w dawnej polszczyźnie słowa państwo. Oparliśmy się tu przy tym nie na pełnym, wyczerpującym materiale źródłowym, lecz na niewielu reprezentantach piśmiennictwa polskiego oraz na słownikach: od Mączyńskiego, 1564, poprzez Knapiusza 1622 r. i Lindego 1807, do tzw. Słownika Warszawskiego ${ }^{79}$. Większość tych znaczeń znana jest dziś tylko małej grupie polonistów czy szperaczy starzyzny.

Niestety nie jesteśmy $w$ stanie badać rozwoju znaczeń substantivum państwo od początku. W zapisach pojawia się ono od XIV w., ale nie ma żadnych podstaw do przyjęcia, by dopiero wówczas pojawiło się ono w naszym języku. Stawić więc jedynie możemy domysł, że wiele ze znanych nam znaczeń wyprzedziło najstarsze zapisy.

Pierwotne znaczenie słowa jest oderwane. Państwo oznacza świetność, pańskość (a), ale także panowanie nad kimś (nomen actionis $\left.{ }^{80}\right)(\mathrm{b})$, czy samą moc, możność panowania, zarówno w znaczeniu publicznym (władza) (c, e), jak i prywatnym (własność) (f). Z czasem następuje konkretyzacja tych pojęć. Ponieważ wladzę wykonuje się na jakimś terytorium, stąd teren, na którym się ona rozpościera, jej zasięg przestrzenny, jest państwem. To terytorium może być różnej wielkości i różnej natury: senioria (g), kasztelania (h), starostwo, województwo (i), prowincja (j), kraj (k) ${ }^{81}$. Państwem może się też nazywać pewna forma ustrojowa (jedynowładztwo) (d), czy jakiś konkretny organ władzy państwowej - fiscus (1). Państwem zwą się też wszystkie przedmioty, które pan posiada, które świadczą o jego pańskości i ją wlaściwie stanowią - bogactwo, grunt $(\mathrm{m})$.

Abstracta przechodzily też do konkretów, otrzymując znaczenie kolektywne. Państwem będzie grupa osób złożona $z$ panów (n), później tylko $\mathrm{z}$ panów i pań (i tak jest w naszym dzisiejszym poczuciu językowym), wreszcie grupa dwuosobowa złożona $\mathrm{z}$ malżeństwa, pana i pani (o) ${ }^{82}$.

$\mathrm{Z}$ zestawienia dokonanego wyżej widać, że państwo było wyjątkowym wieloznacznikiem. Znaczenia przy tym niejednokrotnie się mieszają i krzyżują (charakterystyczny tu przykład cytowany pod pkt. (k), gdzie w jednym

${ }^{79}$ Cnapii Gregorii, Thesaurus Polonolatinograecus, ed. 2, Cracovie 1634; S. B. Linde, Slownik jezyka polskiego, wyd. 2, Lwów 1854 i nn., wyd. fotoofsetowe z 1951 r. O trudnościach w wyzyskaniu Mączyńskiego i thumaczeń staropolskich, por. uwagi J. Kurylowicza, Synonimika $i$ kontekst w Zeszycie próbnym Slownika polszczyzny XVI w., JP, R. 38, 1958, s. 91.

${ }^{80}$ To znaczenie słowa wysuwa na naczelne miejsce H. Ulaszyn, op. c., s. 144.

${ }^{81}$ Według informacji prof. W. Kuraszkiewicza, używanie sufiksu -stwo na oznaczenie terytorium, w którym mieszkał podstawnik, zachodzi bardzo często u Reja. W jego Postylii zanotowano 22 wypadki w rodzaju wyszli z $\dot{Z}$ ydostwa, tzn. z kraju żydowskiego.

${ }^{82}$ H. Ulaszyn, $l$. $c$. 
zdaniu państwo shuży jako odpowiednik lacińskich rzeczowników imperium oraz regales provinciae), tak że w konkretnym wypadku trudno nam nieraz stwierdzić, do której grupy w danym kontekście je zaliczyć.

Wszystkich tych znaczeń byli świadomi językoznawcy, o czym świadcza przytoczone wyżej słowniki polszczyzny. Wiele $z$ nich uchodziło natomiast wiadomości historyków. Wiedzieli oni, że państwo oznaczało własność w rozumieniu prawa prywatnego ${ }^{83}$. Zauważyli też, że oznaczało ono seniorię. Ale niejednokrotnie nie wysnuwano $\mathrm{z}$ tego faktu właściwych wniosków. Ostrożnym trzeba być przede wszystkim ze stawianiem domysłów co do uprawnień feudałów przysługujących im $w$ ich majętnościach, ich praw rzekomo suwerennych, państwowych. Nie ma bowiem żadnego związku przyczynowego między nazwą państwo a faktem, że własność obdarzona była przywilejami książęcymi przenoszącymi „państwowe” uprawnienia książęce na właściciela - jak utrzymuje R. Hube ${ }^{84}$. „Dominium (państwo) niezaprzeczenie oznacza część praw zwierzchniczych, niejako praw majestatycznych przelanych na wlaściciela" - pisze tenże badacz na innym miejscu $^{85}$. Z tym swoim stanowiskiem uczony ten nie byl zresztą odosobniony ${ }^{86}$. Zakres uprawnień feudałów badać trzeba na podstawie konkretnych informacji źródłowych, a nie na podstawie określenia służącego na oznaczenie ich seniorii ${ }^{87}$. Inna sprawa, że szlachta mogłaby w swych ambicjach wykorzystywać fakt wieloznaczności terminu i uzurpować sobie uprawnienia państwowe, choć tego źródłowo nie wykazaliśmy ${ }^{88}$. Zauważmy zresztą, że niektórzy

${ }^{83}$ P. Dąbkowski, Prawo prywatne polskie, t. 2, Lwów 1911, s. 139.

${ }^{84}$ R. Hube, Pisma, t. 2, s. $407-10$.

${ }^{85}$ R. Hube, III, s. 136.

${ }^{86}$ Pan wsi, który w swoje ręce ujął pełną władzę we wsi, wykonywał ją w takim zakresie, jak w państwie władza państwowa. Nieraz też klucz dóbr zwano „państwem", S. Kutrzeba, Historia ustroju, wyd. 8, s. 301. We wsi polskiej nowożytnej widzi też „odrębne niejako państewko" S. Szczotka, Lament chlopski na pany oraz inne narzekania na niedole poddanych polskich, Warszawa 1946, s. 13. Por. też szczególnie jaskrawo sformułowaną tezę o absolutyzmie w „państwach" mających poddanych i panujących, w artykule R. Rybackiej, $O$ slowie „poddaństwo", Nowe Drogi, 1951, z. 6, s. 201.

${ }^{87}$ Jeśli artykuł 19 praw z 1768 r. zapewniał dziedzicom całość dominii et proprietatis, B. Leśnodorski, op. c., s. 13, to w ówczesnych warunkach było jasne, o jakiego rodzaju uprawnienia chodziło. Żadnych wniosków nie możemy wszakże wysnuwać o rozmiarach tych uprawnień na podstawie użytego w konstytucji terminu. Por. również tegoż autora rozdział: Zwierzchnictwo terytorialne czy gruntowe w pracy pt.: Dominium Warmińskie, Poznań 1949, s. $95 \mathrm{nn}$., oraz s. $126-7,16,29,83$.

${ }^{88}$ Jak wiemy - by posłużyć się jednym przykładem - dawność nie pomagała $w$ dawnym prawie polskim przeciwko panującemu, co póżniej rozszerzono na seniorów, P. Dąbkowski, Prawo prywatne polskie, t. 1, Lwów 1910, s. 319-20. Ale czy podstawą tego zrównania była terminologia? 
historycy doskonale zdawali sobie sprawę $\mathrm{z}$ omawianego tu znaczenia państwa-seniorii ${ }^{89}$.

\section{6}

Ta wielość znaczeń słowa państwo w języku staropolskim pozostaje w rażącym kontraście do jego zastosowań w polszczyźnie współczesnej. Używa się go bowiem obecnie tylko $\mathrm{w}$ trzech znaczeniach, jako nomen collectivum:

1. Dla zbioru osób różnej płci, ale chyba z ograniczeniem apostrofy mówcy do słuchaczy: „prosze państwa”;

2. Dla oznaczenia dwojga osób stanowiących parę małżeńską. Mówimy więc o małżeństwie składającym się z pana Zielińskiego i pani Zielińskiej jako o państwu Zielińskich. Ale znowu określnika tego używamy tylko w mowie, choć trochę oficjalnej, dla zaznaczenia respektu czy dystansu. W konwersacji prywatnej raziłaby podobna urzędowość, stąd mówimy krótko: spotkałem Zielińskich. - W obydwu zatem wypadkach państwo używane jest w charakterze tytułu.

3. Terminem państwo oznacza się też dzisiaj szersza zbiorowość najważniejszą, największą osobe prawa publicznego, Państwo, które dla odróżnienia od innych znaczeń, piszemy przez duże p. Nie będziemy precyzowali bliżej tego pojęcia dziś powszechnie przyjętego, pojęcia, którego zakres uświadamiamy sobie wszyscy $z$ dużą dokładnością. Historię tego Państwa wykłada się na wydziałach prawnych, jemu poświęca się osobne wykłady prawa państwowego.

Z obiegowych dziś znaczeń tylko collectiva sq̨ pochodzenia staropolskiego. Natomiast państwo nie było $\mathrm{z}$ całą pewnością w starej polszczyźnie Państwem. Stwierdziliśmy co prawda, że służyło ono dla określenia jakiegokolwiek okręgu terytorialnego, na którym ktoś wykonuje władzę, m. in. także dla oznaczenia kraju, królestwa, księstwa czy prowincji lub mniejszego okręgu administracyjnego, względnie nawet seniorii, ale wszystko są to pojęcia nieostre, jak najbardziej nieprecyzyjne, idące od małego obszaru seniorii czy kasztelanii aż po imperia, ziemskie i niebieskie. Ścisłe prawnicze znaczenie Państwa jest dość późnej daty. Spróbujmy zatem wyświetlić, jakim terminem posługiwała się staropolszczyzna na oznaczenie pojęcia Państwa, i jaką drogą oraz kiedy państwo stało się Państwem. Dla zbadania tego zagadnienia rozejrzyjmy się, jakimi terminami określa się Państwo $w$ innych językach europejskich.

${ }^{89}$ B. Ulanowski, Wieś polska pod wzgledem prawnym od wieku XVI do XVIII, Kraków 1894, s. 12. Por. trafne uwagi Žytkowicza, rec. w KH, R. 63, 1956, nr 1, s. 175. 
Wśród nich wyróżnić można dwie grupy:

I. Te, które stanowią kontynuację języka lacińskiego, a więc języki romańskie. Do tej grupy zaliczają się też języki germańskie, które należąc do świata cywilizacji łacińskiej, zapożyczyły się u łaciny lub też przejęły wyraz poprzez jakiś język romański. Wszystkie one wzięły za punkt wyjścia laciński określnik status, używany przez Rzymian w okresie późnego cesarstwa na oznaczenia Państwa. Stąd pochodzą wl. stato, hiszp. estado, fr. estat, angl. state, niem. Staat, hol. staat ${ }^{90}$.

II. Tej łacińskiej denominacji Państwa przeciwstawiają się generalnie języki slowiańskie, które wytworzyły dla tego pojęcia terminus technicus $\mathrm{z}$ własnego, rodzimego slownictwa: ros. gosudarstwo, serb. drżava, pol. Państwo. Wyjątek stanowi tu czeszczyzna: jej stat jest jednak niewątpliwie przejątkiem $\mathrm{z}$ niemczyzny, może więc nie być brany w rachubę ${ }^{91}$.

Zużytkowanie lacińskiego status na oznaczenie Państwa nie sięga chyba dalej niż wiek XVI. Wprowadził je nie kto inny jak Machiavelli w swym Principe słynnym zdaniem: Tutti li stati, tutti e dominii che hanno avuto et hanno imperio sopra liomini, sono stati e sono o republiche o principati. $\mathrm{Za}$ tym głośnym autorem wyraz już w ścisłym, konkretnym, prawniczym znaczeniu rozpowszechnia się $w$ językach europejskich ${ }^{92}$. Ale dlugo jeszcze uczeni zachodni używali za Bodinem (1576) na oznaczenie Państwa słowa republika. Tak postępuje $\mathrm{m}$. in. jeszcze Kant ${ }^{93}$. We Francji w nowym znaczeniu używa się wyrazu niewątpliwie już za Ludwika XIV (État c'est moi). W Niemczech Staat w znaczeniu res publica nie da się wykazać przed 1677 r., sto lat później już jest identycznego znaczenia co włoskie stato. Ten rozwój semantyczny pozostaje w ścisłym związku z historią absolutyzmu ${ }^{94}$.

W Polsce nie odczuwano dhugo potrzeby konstrukcji pojęcia osoby prawnej prawa publicznego. Nic to dziwnego. Abstrakty są dość obce umyslowości prostej. Zastępowano je osobą władcy, księcia czy króla. O. Balzer stwierdzil, że jeszcze za Kazimierza Wielkiego mieszal się zakres pojęciowy samego państwa i władcy ${ }^{95}$. $\mathrm{Na}$ oznaczenie Państwa wystarczały

${ }^{90}$ Por. E. Gamillscheg, Etymologisches Wörterbuch der französischen Sprache, Heidelberg 1928 , sub verbo.

${ }^{91}$ Co prawda J. Holub podaje: stat, statni, slovensky stat, stany, z lat. status. Stručny slovnik etymologicky, Praha 1937, s. 268. Podobnie V. Machek, Etymologický slovnik jazyka českého a slovenského, Praha 1957. Ale czy rzeczywiście zapożyczenie nastąpiło bezpośrednio?

92 O. Condorelli, Per la storia del nome ,stato" (Il nome „stato" in Machiavelli), Archivio Giuridico, Ser. 4, vol. 5, s. 223-35, vol. 6, s. 77-112. Modena 1923. Ob. też artykuł Stato w Enciclopedia Italiana, vol. 32, Romana 1936, s. 613-4.

${ }^{93}$ Handwörterbuch der Staatswissenschaften, t. 7, Jena 1926, s. 726.

${ }^{94}$ F. Kluge, Etymologisches Wörterbuch der deutschen Sprache, 17. Aufl., Berlin 1957, s. 735.

${ }^{95}$ O. Balzer, Królestwo Polskie, t. 2, Lwów 1919, s. 521; ob. też ib., 516, 517. 
określniki pochodne od władcy danego kraju; od księcia - księstwo, od króla - królestwo ${ }^{96}$, od cesarza - cesarstwo. Mialy one zresztą wzór $w$ języku lacińskim (ducatus, dominium, regnum, imperium). Terminy te wystarczały dlugo. Jeszcze powolowe-poradlne w formie, jaką przybrało w przywileju koszyckim, określa się rzeczownikami łanowe, królestwo ${ }^{97}$. W języku lacińskim używano też niejednokrotnie wyrazu terra, który musiał mieć odpowiednik polski (ziemia), tak jak posiadal odpowiednik niemiecki poświadczony dla stosunków polskich przez Najstarszy Zwód prawa polskiego (land), także w złożeniu landesherr czy herr des landes ${ }^{88}$.

Gdy już zaczęto odróżniać osobę monarchy od Państwa, którym włada, za namiastkę Państwa służyć zacząl najistotniejszy, najbardziej w oczy uderzający symbol władzy królewskiej, korona. Język pozostał zatem dalej przy konkrecie. Wszakże stanowi on o wiele doskonalszy, bardziej postępowy wyraz, bardziej do abstraktu zbliżony, co najważniejsze, różny od śmiertelnego władcy. Jak wykazały studia $\mathrm{O}$. Balzera i $\mathbf{O}$. Solowiewa, przejście do niego jest zdobyczą XIV w. ${ }^{99}$ Raz wprowadzona korona jako namiastka Państwa utrzyma się już na stałe w języku polskim. Z XVII w. pełno dać możemy cytatów mówiących o radosnej Koronie, o żalosnych narzekaniach czy lamencie Korony Polskiej ${ }^{100}$, itd. W pewnych utartych sformułowaniach (modlitwach) utrzymuje się niemal do lat ostatnich. W jakim stopniu pojmowano tę Koronę abstrakcyjnie ${ }^{101}$, nie chcemy tutaj wchodzić. - Dodajmy, że w następnych stuleciach nabrał ów termin nieco odmiennego znaczenia. Po unii z Litwą określano nim pierwszy składnik federacji polsko-litewskiej. $\mathrm{Nie}$ przeszkodziło to zresztą $\mathrm{w}$ posługiwaniu się terminem $\mathrm{w}$ znaczeniu dawniejszym. Korona, jak się wydaje, stanowi pierwszy przykład inwazji terminologii łacińskiej $w$ Polsce $w$ dziedzinie prawa państwowego ${ }^{102}$, ale nie

${ }^{96}$ Już w pierwszym ,pacierzu" thumaczono fiat regnum tuum przez przyjdź królestwo twoje, por. K. Nitsch, Rozbiör jezykowy Ojczenasza, JP, t. 4, s. 148.

${ }^{97}$ O. Balzer, Narzaz, SHPP, t. 11, Lwów 1928, s. 576.

98 SPPP, t. 2, Kraków 1870, art. 11, 12, 15, 28.

${ }^{99}$ O. Balzer, Królestwo Polskie, t. 3, Lwów 1920, s. 143 nn.; A. Soloviev, Corona Regni. Razwitie idei gosudarstwa w slawjanskich monarchijach XIV wieka, Przew. Hist.-Prawny, Lwów 1934, s. 27-48. Co do treści tego wyrażenia zob. J. Dąbrowski, Korona Królestwa Polskiego w XIV w., Wrocław-Kraków 1956, oraz krytyczne uwagi K. Grzybowskiego, Corona Regni a Corona Regni Poloniae, CPH, t. 9, 1957, z. 2, s. 317 nn.

100 Czubek, Pisma polityczne, t. 1, s. 131, 223, 256, 322.

101 Zob. W. Sobociński, RDSG, t. 13, 1951, s. 341.

${ }_{102}$ Oczywiście to pierwszeństwo nie jest absolutne. Już król, ksiqże są pochodzenia obcego, ale bardzo starego, skoro T. Lehr-Spławiński zalicza je do dziedzictwa starosłowiańskiego, Element praslowianski w dzisiejszym slownictwie polskim, [w:] Studia historyczne ku czci Stanislawa Kutrzeby, t. 2, s. 475. Co do etymologii króla por. zestawienie hipotez u J. Birkenmajera, $O$ tytulach: cesarz $i$ król, JP, t. 23, 1938, s. 175-7, oraz T. Lehr-Spławiński, Pochodzenie $i$ rozpowszechnienie wyrazu król $w$ polszczyźnie $i w$ innych jezzykach slowiańskich, Prace polonist. ofiarowane Janowi Losiowi, Warszawa 1927, s. 44-53, oraz A. Brücknera, SEJP, s. 269. 
jedyny. Podkreślmy przy tym jako zjawisko charakterystyczne, że polski jej odpowiednik, wieniec, temu ścisłemu zadaniu terminologicznemu nie służył nigdy, choć król był osobą wieńczoną.

$A$ oto dalsze dowody romańskich wplywów $w$ dziedzinie terminologii ustrojowej. Rzeczpospolita, kalka lacińskiego rzeczownika respublica, często także w brzmieniu lacińskim - republika, oraz politeia - policja. Pierwszy wyraz znany zresztą polskiej łacinie już od dawna, bo za czasów Kadłub$\mathrm{ka}^{103}$, oznaczał $\mathrm{w}$ języku staropolskim - jak zresztą i gdzie indziej - tylko Państwo $^{104}$, a nie - jak dzisiaj $w$ terminologii prawa państwowego - jego formę, przeciwstawną monarchii. Zresztą zgodnie ze swoim znaczeniem wewnętrznym mógł oznaczać także inną pospolitą rzecz, jak gromada wiejska ${ }^{105}$. Drugi wyraz policja, o identycznym zakresie pojęciowym, co respublica jak niegdyś u Cycerona, tak w Polsce u Orzechowskiego ${ }^{106}$ i innych ${ }^{107}$. Politaea - sprawowanie Rzeczpospolitej, państwo, królestwo - notuje Mączyński, 308 b/13. W rozmowie o rokoszu czytamy, jak to przodkowie nasi religiej ś. $z$ policja nie mieszali, nie gmatwali nigdy ${ }^{108}$. Rzeczownik ten nabrał później swoistego ścieśnienia dobrze nam dzisiaj znanego; znowu nie chcielibyśmy się zatrzymywać nad ewolucją jego znaczeń, sumaryczny ich przegląd daje w swym podręczniku S. Kasznica ${ }^{109}$, zdaje się wszakże, że jeszcze $\mathrm{w}$ dawnym znaczeniu używal go w $1817 \mathrm{r}$. prof. Matakiewicz, gdy jako kandydat na profesora filozofii Uniwersytetu Jagiellońskiego powolywał się na to, że na Wydziale Prawa miał lekcje publ. z nauki policji ${ }^{10}$. Charakterystyczne zatem, że Polacy, którzy odczuwali potrzebę abstraktu na oznaczenie Państwa, nie do tego polskiego, znanego sobie terminu się uciekali, lecz woleli zapożyczać wyrazy lacińskie czy greckie. Widocznie termin państwo, obarczony zbyt dużą ilością znaczeń, nie wydawał się adekwatny dla użycia go w tym sprecyzowanym znaczeniu.

${ }^{103}$ Por. zestawienie terminów u K. Grzybowskiego, Corona Regni, s. 330.

104 W tym sensie używal jej Andrzej Frycz Modrzewski, pisząc dzieło pt.: De republica emendanda, 1551, jak póżniej J. Bodin, Les six livres de la République (1576).

${ }^{105}$ Przykład powołuje J. Gerlach, „Nawsie” - wspólna wlasność gromadzka wsi staropolskiej, $\mathrm{CPH}$, t. 4, Poznań 1952, s. 271. Zauważmy, że oba człony tego słowa jeszcze się nie zrosły: Tenże tedy kaplan [...] uznawać to ma, zostawa li w czym winien król rzeczy swej pospolitej czy nie", Orzechowski, Quincunx, s. 248; cytat za Z. Kaczmarczykiem, op. c., s. 504.

${ }_{106}$ W. Voisé, $O$ ideologii spoleczno-ustrojowej Andrzeja Frycza Modrzewskiego, CPH, t. 4, 1952, s. 4, 30, oraz tenże, Frycza Modrzewskiego nauka o państwie $i$ prawie, SHPP, ser. 2, t. 3, 1956, s. 49 .

${ }^{107}$ U Frycza Modrzewskiego oznacza politeja szczególną formę państwa, te mianowicie, w której rządzi większość obywateli, W. Voisé, op. c., s. 119.

${ }^{108}$ Czubek, Pisma, t. 2, s. 125.

109 S. Kasznica, Polskie prawo administracyjne, wyd. 4, Poznań 1947, s. 150-2.

${ }^{110}$ W. Tatarkiewicz, Losy, SAU, R. 52, 1951, s. 119. 
Język łaciński znal wszakże jeszcze jeden termin na oznaczenie państwa - status. W polskiej łacinie spotykamy go dość wcześnie, bo już w przywileju Kazimierza Wielkiego z 1336 r. Czytamy tam, że obywatel krakowski, Hermannus dictus de Ratibor spiskował przeciw Władysławowi Lokietkowi, adversus eundem nostrum genitorem et statum suum ${ }^{111}$. Przytoczymy jeszcze jeden przykład z XVII w.: Kiedyby invalesceret ten terribilis usus sejmy rwać, a ex senatus consultis quasi rempublicam tegere, nie nastapilaby, ale bylaby mutatio status $^{112}$. Wreszcie powołajmy się na znaną konstytucję sejmu z 1768 r., która przeprowadziła bardzo poważne zmiany w kierunku ograniczenia liberum veto. Podzieliła ona prawa na dwie grupy: na materie status i materie ekonomiczne. Do pierwszych, jak podkreśla S. Kutrzeba, zaliczono wiele spraw pierwszorzędnej wagi dla bytu państwa ${ }^{113}$. Jak widzimy, długo wahano się z przetłumaczeniem tego słowa. Odpowiednik polski, stan, był w tylu pojmowany znaczeniach ${ }^{114}$, że pisarze woleli zachować brzmienie lacińskie, żeby nie być źle zrozumianymi. Dopiero $w$ drugiej połowie XVIII w. - Linde notuje jako najstarsze przykłady zaczerpnięte z Monitora Warszawskiego, wychodzącego w latach 1764-1784, oraz z Zabaw przyjemnych i pożytecznych $\mathrm{z}$ lat 1769-1777 - posługiwanie się wyrazem stan na oznaczenie państwa wchodzi w zwyczaj. Jak się wydaje, bodziec do zrównania status = stan dał język francuski ${ }^{115}$, modny wówczas w Polsce. W nim État już od dawna oznaczało Państwo, a nie przeszkadzało temu nic, że słowo to równocześnie używane było $w$ tylu innych znaczeniach. Pod tym wpływem zaczęto liczne zwroty francuskie czy lacińskie: raison d'Etat, coup d'Etat, homme d'Etat, sécrétaires d'Etat, affaires d'Etat, crimina status i in. - oddawać przez: racja stanu, zamach stanu, mq̨̇ stanu, sekretarze stanu, sprawy stanu, zbrodnie stanu, zdrada stanu ${ }^{116}$. Co więcej, nie wahano się nawet powstałej współcześnie konfederacji państw północnoamerykańskich United States przetłumaczyć przez Zjednoczone Stany (Niemcy niedwuznacznie je oddali przez Vereinigte Staaten). $Z$ tego nowego znaczenia słowa stan zdawano sobie współcześnie sprawę: Bohomolec zestawia ze sobą konsyliarz państwa $=$ konsyliarz stanu $^{117}$.

${ }^{111}$ Kod. dypl. Miasta Krakowa, t. 2, nr 375; powoluje ostatnio za Długopolskim J. Baszkiewicz, Powstanie zjednoczonego państwa polskiego, SHPP, Warszawa 1954, s. 420, przyp. 219.

112 W. Czapliński, Rola magnaterii, s. 143.

${ }^{113}$ S. Kutrzeba, Historia ustroju Polski, wyd. 8, s. 344.

${ }^{114}$ Por. Slownik Lindego oraz O. Balzera, Narzaz, s. 363, 366 nn., zob. też często używanie słowa $\mathrm{w}$ znaczeniu $\operatorname{stan}=$ etat wojska, Vol. Leg., t. 10, s. 77, ob. też B. Leśnodorski, op. $c$., s. 234. Por. też zwięzły wykład o stanach publiczno- i prywatno-prawnych u P. Dąbkowskiego, Ksiega alfabetyczna, s. 145-148.

115 A. Gawroński, Szkice jezzkoznawcze, s. 73.

${ }^{116}$ Zauważ, że niemiecki Staatsmann poczytuje za thumaczenie francuskiego homme d'estat F. Kluge, op. c., s. 735. Termin ten zdobył sobie prawo obywatelstwa od roku 1784.

${ }^{117}$ Słownik Lindego pod hasłem: państwo. Zauważ, że A. Brückner pisze: ,stan w znaczeniu rzq̨d późne", SEJP, s. 513. 
Ale $i$ to słowo nie zrobiło kariery państwowotwórczej. Predylekcja do utrzymania brzmienia lacińskiego utrzymuje się stale ${ }^{118}$. Słowo stan, zwłaszcza użyte w liczbie mnogiej (stany) posiada właśnie w języku prawa publicznego ścišle określoną treść: różną od Państwa, identyczną z niemieckim Stände ${ }^{119}$. Trudno przeto było wyrazowi temu zadomowić się w sensie Państwa. Tak, że ograniczył się do wspomnianych wyżej zwrotów. Występował też w ciągu XIX w. w naszym prawie konstytucyjnym: zna go zarówno konstytucja Księstwa Warszawskiego z 1807 r. (Rada Stanu na wzór francuskiego Conseil d'Etat - pisze B. Winiarski ${ }^{120}$ ), jak też i konstytucja Królestwa Polskiego z 1815 r ${ }^{121}$ Poza tymi utartymi zwrotami, które utrzymaly się po dziś dzień ${ }^{122}$, w innych kontekstach, zwłaszcza prawniczych, wahano się $\mathrm{z}$ użyciem wyrazu stan jako równoważnika Państwa. Tak więc na oznaczenie Państwa w języku prawniczym obce wprowadzono terminy: Korona, republika, rzeczpospolita, policja, czy kalkę z obcego - stan. Trawestując więc wypowiedź A. Brücknera, moglibyśmy powiedzieć: „Słowianie $z$ natury anarchiści żadnej nazwy domowej dla panującego (i Państwa) nie wytworzyli, wszystkie są obce"123.

Ostatecznie jednak żaden $\mathrm{z}$ tych obcych terminów nie awansowal na stanowisko terminus technicus. Tę rolę przybrało natomiast polskie państwo. Wydawało się ono z góry predestynowane do odegrania tej roli. Wiemy, że państwo oznaczało władzę, oznaczało również terytorium, na którym się ta wladza przejawia, wraz ze znajdującą się tam ludnością. Zsumowanie tych zakresów winno było logicznie prowadzić do zmiany zakresu terminu: państwo winno było stać się Państwem. Ale dużo czasu upłynęło, zanim język doprowadził do takiego wyniku. Opory w poczuciu językowym były zbyt silne, toż ,zdrada państwa znaczy tyle, co zdrada pana i calej wsi, opuszczenie państwa tyle, co uwolnienie się z związku gromadzkiego" 124 .

${ }^{118}$ Por. Vol. Leg., t. 10, s. 150-60. Również w Konstytucji 3 Maja używa się bądź brzmienia łacińskiego, art. III, lub też w kontekście nastẹpującym: Do tego sqadu należeć będq wystepki przeciwko narodowi i królowi, czyli crimina status, art. VIII. Por. też jeden z projektów okresu Sejmu Wielkiego, w którym kara śmierci grozi szlachcicowi tylko „za występki przeciw stanowi, za występki rozmyślnego zabójstwa", B. Leśnodorski, op. c., s. 156.

119 Konfederacja generalna z $1733 \mathrm{r}$. kładzie pro cardinali iure, zeby przyszly regnant sie do żadnych inter vicinas potentias przeciwnych Stanom i Państwom Rzplitej żadnym sposobem $i$ okolicznościami nie mięszal inıryg, cytuje Z. Radwański, Prawa kardynalne, s. 34. Por. też znany okrzyk: vivat król, vivat sejm, vivant wszystkie stany.

${ }^{120}$ B. Winiarski, Ustrój polityczny ziem polskich w XIX wieku, Poznań 1923, s. 74.

121 Ibidem, s. 112.

122 Zob. kodeks karny z 11 VII 1932 r., gdzie rozdział XVII zatytułowany jest: Zbrodnie stanu. Omawia się w nim zbrodnie przeciwko niepodległości i integralności Państwa Polskiego oraz przeciwko ustrojowi, jak i naczelnym organom.

${ }^{123}$ A. Brückner, SEJP, s. 269.

${ }^{124}$ B. Ulanowski, Wies polska pod wzgledem prawnym od wieku XVI do XVII, Kraków 1894 , s. 12. 
Wpierw popróbowano determinantów obcojęzycznych czy kalk $\mathrm{z}$ obcego. Żaden $\mathrm{z}$ nich wszakże nie przyjął się powszechnie $\mathrm{i}$ na stałe, albo też zmienił swą treść. W tym stanie rzeczy na przełomie XVIII i XIX w. notujemy ważkie przemiany ustrojowe. Znaczenie konkurencyjne słowa państwo w rodzaju państwa-kasztelanii musiało wyjść z użycia wraz z likwidacja dawnych polskich jednostek administracji terytorialnej; seniorie-państwa tracily zastosowanie $\mathrm{z}$ upadaniem systemu feudalno-senioralnego $^{125}$. Stwarzaja się zatem możliwości zużytkowania wyrazu o tak interesującej treści (władza oraz terytorium $\mathrm{z}$ mieszkająca na niej ludnością) jako odpowiednika pospolitego już $w$ tym czasie na Zachodzie określnika status i jego pochodnych. Potrzeba wydaje się tym bardziej paląca, że $w$ Polsce drugiej połowy XVIII w. formuje się nowe pojęcia narodu ${ }^{126}$. Trudno dokładnie stwierdzic moment, kiedy w tym nowoczesnym znaczeniu wyraz zdobył sobie pelne prawo obywatelstwa. Zresztą zjawiska tego rodzaju ścisłej daty rocznej posiadać nie mogą. Stwierdźmy wszakże, że w ostatnich dziesiątkach XVIII w. występują wahania w użytkowaniu wyrazu państwo. Znaja je ostatnie konstytucje Polski przedrozbiorowej - zarówno trzeciomajowa, jak też i grodzieńska. W pierwszej, która zrezygnowała już z rzeczypospolitej ${ }^{127}$, mówi się o krajach polskich, ojczyźnie, ziemi polskiej i o państwach Rzeczypospolitej ${ }^{128}$. Konstytucja grodzieńska nie waha się thumaczyć francuskie État przez państwo ${ }^{129}$, atoli pomieszcza również wyrażenia: państwa Rzeczypospolitej, czy nawet kraje państwa Rzeczypospolitej ${ }^{130}$. Piszący na przełomie XVIII i XIX w. Hugo Kolłątaj wypowiada takie zdanie: król ma państwo albo państwo ma króla ${ }^{131}$. Żadne jednak $z$ jego dzieł $w$ tytule wyrazu państwo nie zawiera. Interesujący się terminologią tego okresu B. Leśnodorski stwierdza, że Rzeczpospolita obejmowała dwa państwa. Niekiedy jednak pojawiało się określenie w liczbie pojedynczej: państwo nasze. W praktyce sejmu szlacheckiego zacieral się ten podział132.

Zwróćmy też uwagę na współcześnie dokonujące się zmiany znaczeniowe podstawnika rozpatrywanego przez nas słowa. W XVIII w., możliwe, że pod wpływem francuszczyzny, tytułem, przez który służba zwraca się do swych państwa staje się prosty pan lub pani. Z początkiem XIX w. ta forma

${ }^{125}$ Zaznaczmy, że w niektórych okolicach określenia w rodzaju „Państwo Szaflary”, „Państwo Sucha i Slemień" jako napisy na słupach granicznych utrzymały się jeszcze w XX w.,

R. Rybacka, O slowie "poddaństwo", Nowe Drogi 1951, z. 6, s. 201.

${ }^{126}$ K. Grzybowski, Dwa nurty polskiej myśli konstytucyjnej, KH, 59, 1952, s. 47.

${ }_{127}$ B. Leśnodorski, Dzielo Sejmu Czteroletniego, Wrocław 1951, s. 438.

${ }^{128}$ Ibidem, s. 240, 438; państwa art. 4 wydają się synonimem prowincyj.

129 Volumina Legum, t. 10, wyd. Z. Kaczmarczyk, Poznań 1952, s. 15.

130 Ibidem, s. 110, 215.

${ }^{131}$ K. Opalek, Hugona Kollqtaja poglqdy na państwo i prawo, Warszawa 1952, s. 187.

132 B. Leśnodorski, Dzielo sejmu, s. 238. 
się upowszechnia ${ }^{133}$, tym samym zatraca się skojarzenie pana z pańskością ${ }^{134}$. I to nie mogło pozostać bez wpływu na odczuwanie słowa państwo. Skoro każdy człowiek jest panem, to i państwem może być terytorium $\mathrm{z}$ całym zbiorem ludzi, którzy na nim mieszkają. $Z$ dawnym terytorialnym pojęciem państwa (pkt. $\mathrm{g}-\mathrm{k}$ ) nie stoi to $\mathrm{w}$ sprzeczności.

Awansując do godności oznacznika najwyższej osoby prawa publicznego, państwo zgodnie ze swoją istotą wykazuje tendencje monopolistyczne, przejawiające się $w$ wypieraniu wszelkich innych odcieni semantycznych tego słowa, jak też i wszystkich innych konkurencyjnych wyrazów. Tak bardzo odbiegające swą treścią w znaczeniu collectivum jako tytułu dla zbioru osób czy przede wszystkim pary małżeńskiej temu monopolistycznemu stanowisku Państwa nie grozilo. Znajdowalo ono przy tym silne oparcie $w$ poczuciu językowym w innych formantach $z$ sufiksem -stwo jak królestwo; oznaczało ono bowiem zarówno parę królewską, jak należący do króla kraj, czy też mieszkańców tego kraju ${ }^{135}$.

W rezultacie tego semantycznego rozwoju, Państwo w języku polskim znalazło się w uprzywilejowanej sytuacji w porównaniu z językami romańskimi. W nich mianowicie słowo état kontynuuje wszelkie znaczenia lacińskiego status; pozostało więc wieloznacznikiem po dziś dzień, tak że dla oznaczenia, iż chodzi o Państwo, pisze się je dużą literą (État $)^{136}$. W języku polskim przeważająca większość dawnych znaczeń słowa państwo wyszła zupełnie $\mathrm{z}$ użycia. Te nieliczne, które się obok Państwa utrzymały, a więc collectiva, tak odbiegają swą treścią, że obawa konfuzji nie zachodzi. Ale mimo to obserwujemy ciekawe zjawisko w języku. Skoro słowo państwo jako collectivum nie dało się wyprzeć przez wladcze Państwo, język usiłuje na innej drodze uwydatnić między nimi różnicę, mianowicie w odmianie i w składni. Mówimy więc dziś o państwie i o Państwie; powiemy też: widzialem państwa Zielińskich. Co więcej, choć w staropolszczyźnie każde państwo,

${ }^{133}$ J. Loś, Od „Ty" do „Pan", JP, t. 3, s. 8-9.

$134 \mathrm{Na}$ ciągłą demokratyzację przymiotników stanowych zwrócono już uwagę w literaturze, por. P. Dąbkowski, Prawo pryw. polskie, t. 1, s. 104, oraz tenze, Ksiega alfabetyczna dawnego prawa prywatnego polskiego, PHP, t. II, z. 3, Lwów 1932, s. 145. W przytoczonym zagadnieniu obserwujemy to samo zjawisko z stanowym rzeczownikiem. Pan i pani - to tytuły zarezerwowane dla szlachty; ludzie stanów niższych mówili sobie przez ty albo przez wy. Ale jak tylko dwóch z braci szlachty choćby tylko troszkę poróżniło się z sobą, wnet zapominali o Waszmości i krzyczeli na siebie przez $t y$, jak proste parobki, J. Loś, op. c., s. 5. Zauważmy, że zwracanie się przez pan, będące kontynuatorem pierwotnego ty, a nie wy, właściwego warstwom ludowym, ib., s. 9-10, znajduje pelną analogię w języku francuskim, gdzie mon seigneur przekształcił się w monsieur.

135 K. Nitsch, Rozbiór jezykowy, s. 148

136 O wieloznaczności słowa état por. ostatnie studium G. de Lagarde, La naissance de l'esprit laique au déclin du Moyen Âge, t. I, 3. éd, Louvain-Paris 1956. Wiadomość o tym czerpiemy z recenzji Jean Chelini, pomieszczonej w Annales ESC, R. 12, 1957, s. 673-4. 
a więc i jako collectivum posiadało rodzaj gramatyczny, dzisiaj państwo otrzymało rodzaj znaczeniowy, państwo przyszli - choć inaczej w języku nieliterackim - Państwo natomiast utrzymuje rodzaj gramatyczny dalej ${ }^{137}$.

Zdajemy sobie dobrze sprawę $\mathrm{z}$ tego, że przedstawiony czytelnikowi artykul jest tylko rozwinięciem i usystematyzowaniem materiałów zebranych w słownikach języka polskiego; niczego więc nowego nie wnosi. Wszakże podane tu znaczenia słowa państwo, jak i jego najnowszy rozwój semantyczny ku Państwu uchodzily dotąd wiadomości prawników ${ }^{138}$. Tę lukę ma niniejszy artykuł zapełnicicis

${ }^{137}$ K. N.[itsch], JP, t. 22, 1937, s. 121-3; zob też. ib., t. 14, s. 31, oraz t. 15, s. 92 . Ob. też J. Karlowicz, Slownik gwar polskich, t. 4, Kraków 1906, s. 30, gdzie przeważnie, acz nie wyłącznie, przykłady na rodzaj gramatyczny. Zanotujmy, że pisarz tej miary, co K. Irzykowski, nie wahał się pisać ,jedno jabłuszko potoczyło sie do nóg, [...] hołd i dań drzew, składane s we mu państwu!", Paluba, wyd. 1957, s. 265.

138 Ob. A. Lopatka, Materialy do nauki teorii państwa i prawa, skrypt, Poznań 1958, s. 17-8.

${ }_{139}$ Dodajmy, że podobnie przedstawia się rozwój odpowiednika rosyjskiego; słowa gosudarstwo zaczęto używać od połowy XIV w. Pochodzi ono od słowa gosudar, które miało to samo znaczenie, co gospodin, gospodar i było używane dla oznaczenia whaściciela niewolników i właściciela gruntu. W takim sensie utrzymało się do XVII w. Od tego czasu ustępuje ono miejsce słowu bojarin, natomiast słowo gosudar zachowało się w słowie gosudarstwo, ale już na oznaczenie państwa, R. Babun, Obszczeje uczenije o prawie $i$ gosudarstwie, Kijew 1925, s. 138. - Powyższą notkę zawdzięczam uprzejmej informacji kol. dra A. Łopatki. M. Vasmer, Russisches etymologisches Wörterbuch, t. 1, Heidelberg 1953, s. 300, podaje jedynie gosudar $=$ Herr Grossfürst, Zar.

Niemniej ciekawe analogie występują w języku czeskim. I tam państwo - państví, ale także w postaci panstvo - posiada wiele znaczeń: świetność - gloria (a), panowanie - dicio (b), władza (c), m. in. także prawo patronatu, własność - dominium (f), senioria (g), margrabstwo - marchionatus Budissinensis (i), kraj, królestwo-monarchia, regnum (k), bogactwo (m), wielcy panowie - barones (n). Nie znaleźliśmy natomiast wypadku, by słowo omawiane oznaczało również grupę małżeńską. Jednym $\mathrm{z}$ najczęstszych jego zastosowań jest sens dominium; przytoczyć moglibyśmy wiele na to przykładów $\mathrm{i}$ to już $\mathrm{z}$ okresu, dla którego dysponujemy tylko jednym cytatem polskim. Ze względu na oszczędność miejsca zacytujemy jeden tekst z 1404 r.: vyznávam, že $k$ tej vsi [...] nejmám žádného práva [...], nežž že ta ves se vším panst vím, se vš́m právem $i$ užtky - jest spravedlivé panstvie těch panen a konventa jich, AČ VII, 609. W przykładzie tym panstwo - własność występuje obok państwa-seniorii. Podkreślmy, że język czeski tłumaczył dominium plenum oraz dominium utile przez panství užtecne i panství plné. - Wszakże czeszczyzna nowoczesna dla oznaczenia Państwa nie sięgnęła do rodzimego terminu, lecz zapożyczyła się u języka niemieckiego (stát). Dzięki temu historycy czescy mogą bez obawy konfuzji posługiwać się $\mathrm{w}$ dzisiejszych pracach słowem panství na oznaczenie seniorii, por. np. Jírásek, Poddani na panství olomouckého biskupstvi v druhé polovině 16 století, 1957. - Podany wyżej tekst zaczerpnęliśmy z materiałów do czeskiego slownika prawnego, gromadzonych przez Instytut Prawa Czeskiej Akademii Nauk. Przeglądnęliśmy również materiały do słownika Gebauera, udostępnione nam dzięki uprzejmości pracowników Instytutu Języka Czeskiego Czechosłowackiej Akademii Nauk w Pradze. 